\title{
De Senaat : Rechtsvergelijkend onderzoek naar het House of Lords, de Sénat, de Eerste Kamer en de Bundesrat
}

Citation for published version (APA):

Knippenberg, E. T. C. (2002). De Senaat : Rechtsvergelijkend onderzoek naar het House of Lords, de Sénat, de Eerste Kamer en de Bundesrat. [Doctoral Thesis, Maastricht University]. Sdu Uitgevers. https://doi.org/10.26481/dis.20020628ek

Document status and date:

Published: 01/01/2002

DOI:

10.26481/dis.20020628ek

Document Version:

Publisher's PDF, also known as Version of record

\section{Please check the document version of this publication:}

- A submitted manuscript is the version of the article upon submission and before peer-review. There can be important differences between the submitted version and the official published version of record.

People interested in the research are advised to contact the author for the final version of the publication, or visit the DOI to the publisher's website.

- The final author version and the galley proof are versions of the publication after peer review.

- The final published version features the final layout of the paper including the volume, issue and page numbers.

Link to publication

\footnotetext{
General rights rights.

- You may freely distribute the URL identifying the publication in the public portal. please follow below link for the End User Agreement:

www.umlib.nl/taverne-license

Take down policy

If you believe that this document breaches copyright please contact us at:

repository@maastrichtuniversity.nl

providing details and we will investigate your claim.
}

Copyright and moral rights for the publications made accessible in the public portal are retained by the authors and/or other copyright owners and it is a condition of accessing publications that users recognise and abide by the legal requirements associated with these

- Users may download and print one copy of any publication from the public portal for the purpose of private study or research.

- You may not further distribute the material or use it for any profit-making activity or commercial gain

If the publication is distributed under the terms of Article 25fa of the Dutch Copyright Act, indicated by the "Taverne" license above, 


\section{De Senaat}





\section{De Senaat}

Rechtsvergelijkend onderzoek naar het House of Lords, de Sénat, de Eerste Kamer en de Bundesrat

\section{PROEFSCHRIFT}

ter verkrijging van de graad van doctor aan de Universiteit Maastricht, op gezag van van de Rector Magnificus, Prof.dr. A.C. Nieuwenhuijzen Kruseman volgens het besluit van het College van Decanen, in het openbaar te verdedigen op vrijdag 28 juni $2002 \mathrm{om} 14.00$ uur

door

ERIK THEODOOR CORNELIS KNIPPENBERG 
Promotor:

Prof.mr. A.W. Heringa

Beoordelingscommissie:

Prof.mr. L.F.M. Verhey (voorzitter)

Dr. K.L.L.M. Dittrich

Prof.mr. E.C.M. Jurgens

Prof.dr. A.F.A. Korsten

Prof.mr. H.R.B.M. Kummeling (Universiteit Utrecht)

O 2002 Sdu Uitgevers BV, Den Haag

Omslagontwerp: Villa Y, Den Haag

Van deze studie is een handelsuitgave verschenen bij Sdu Uitgevers BV onder ISBN 9054093323 
P.M.D.F.F. 
Dankwoord

De waarde van een bijzondere bron van inspiratie is niet in geld uit te drukken.

Hopelijk wel in woorden, Aalt Willem! 


\section{Inhoud}

\section{Hoofdstuk 1 \\ Inleiding}

1.1 Het tweekamerstelsel 1

1.2 Voorlopige probleemstelling $\quad 2$

1.3 Congruentie en symmetrie

1,4 Werkterrein van de Senaat 4

$\begin{array}{lll}1.5 & \text { Probleemstelling } & 7\end{array}$

1.5.1 Nadere afbakening onderzoeksterrein 8

1.5.2 Nadere definie̋ring 9

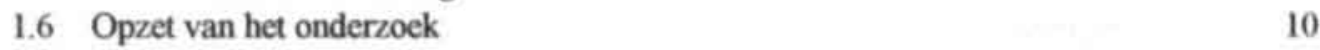

1.7 Het belang van de rede 11

\section{Hoofdstuk 2}

Historische ontwikkeling

2,1 Inleiding 13

$\begin{array}{lll}2.2 & \text { Verenigd Koninkrijk } & 13\end{array}$

2.2.1 De eerste vijf eeuwen 13

2.2.2 De 19e eeuw 15

$\begin{array}{lll}2.2 .3 & \text { De 20e eeuw } & 16\end{array}$

$\begin{array}{ll}\text { 2.2.4 De naoorlogse periode } & 18\end{array}$

$\begin{array}{ll}2.3 \text { Frankrijk } & 20\end{array}$

2.3.1 Les Etats généraux $\quad 20$

2.3.2 De Franse Revolutie 20

2.3.3 De Republiek $\quad 22$

$\begin{array}{lll}2.4 & \text { Nederland } & 25\end{array}$

$\begin{array}{lll}2.4 .1 & \text { Staten-Generaal } & 25\end{array}$

2.4.2 Het Koninkrijk der Nederlanden $\quad 26$

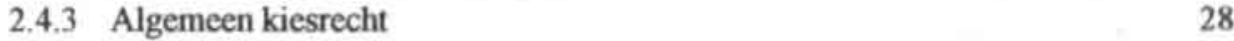

2.5 De Bondsrepubliek Duitsland $\quad 29$

2.5.1 Het Heilig Roomse Rijk 29

2.5.2 De Duitse Bond 30

2.5.3 De Paulskirchenverfassung 31

2.5.4 Pruisen en het Duitse Rijk 31

2.5.5 Weimar 32

2.5.6 Senat oder Bundesrat? $\quad 34$

2.6 Vier trajecten: een nabeschouwing 35 
Inhoud

\section{Hoofdstuk 3}

Verkiezing/benoeming, samenstelling, organisatie

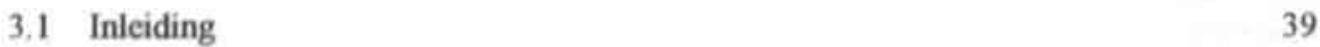

3.2 Groot-Brittanniê $\quad 40$

3.2.1 Benoeming en samenstelling $\quad 40$

3.2.2 Hervormingsvoorstellen $\quad 44$

3.2.3 The Royal Commission $\quad 48$

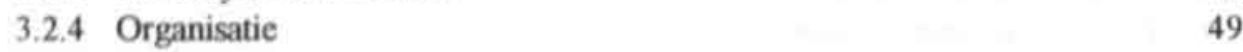

3.3 Nederland 51

3.3.1 Verkiezing en samenstelling 51

3.3.2 Ontbinding $\quad 54$

3.3.3 Organisatic $\quad 56$

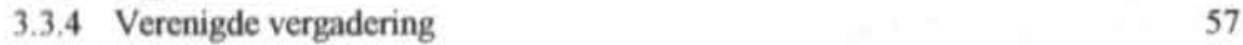

$\begin{array}{llr}3.4 & \text { Frankrijk } & 58\end{array}$

$\begin{array}{lll}3.4 .1 & \text { Verkiezing } & 58\end{array}$

$\begin{array}{ll}\text { 3.4.2 Partijpoliticke samenstelling } & 59\end{array}$

3.4.3 Cumul des mandats 61

3.4.4 Organisatie 62

3.5 Bondsrepubliek Duitsland 63

3.5.1 Benoeming 63

3.5.2 Stemverhouding 64

$\begin{array}{ll}3.5 .3 \text { Organisatic } & 67\end{array}$

$\begin{array}{ll}3.5 .4 \text { Commissies } & 68\end{array}$

$\begin{array}{lll}3.6 & \text { Nabeschouwing } & 69\end{array}$

\section{Hoofdstuk 4}

Groot-Brittanniē, wetgeving en bestuurscontrole

$\begin{array}{lll}4.1 & \text { Inleiding } & 73\end{array}$

4.2 Positionering van het House of Lords 74

$\begin{array}{lll}4.2 .1 & \text { Salisbury Convention } & 74\end{array}$

4.2.2 The Parliament Acts 75

$\begin{array}{ll}\text { 4.2.3 Partijpolitieke- en werkverhoudingen } & 77\end{array}$

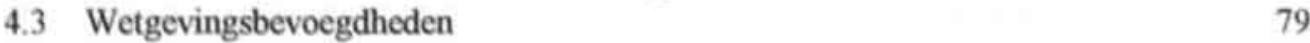

$\begin{array}{lll}\text { 4.3.1 Public Bills } & 79\end{array}$

$\begin{array}{ll}\text { 4.3.2 Wetgevingstraject Public Bills } & 81\end{array}$

$\begin{array}{lll}\text { 4.3.2.1 First reading } & 81\end{array}$

4.3.2.2 Second reading $\quad 82$

4.3.2.3 Committee stage $\quad 84$

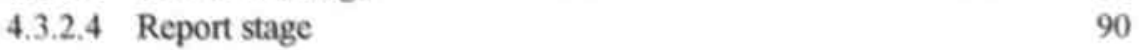


$\begin{array}{ll}\text { 4.3.2.5 Third reading } & 90\end{array}$

4.3.3 Select Committees

4.3.4 Statutory Instruments

4.3.5 Recht van initiatief $\quad 94$

4.4 De praktijk $\quad 97$

4.4.1 Het House of Lords versus Thatcher 97

4.4.2 Het House of Lords versus Blair 99

4.5 Balans wetgevingsfunctie $\quad 103$

4.6 Bestuurscontrole $\quad 104$

4.6.1 Ministeriële verantwoordelijkheid 105

4.6.2 Het (niet wetgevende) pariementaire debat 105

$\begin{array}{lll}\text { 4.6.2.1 General debate } & 106\end{array}$

$\begin{array}{ll}\text { 4.6.2.2 Starred questions } & 108\end{array}$

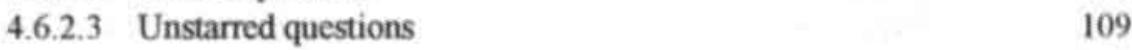

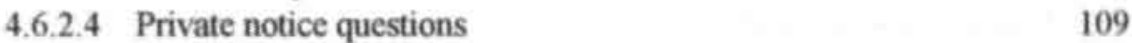

$\begin{array}{ll}\text { 4.6.2.5 Questions for written answer } & 110\end{array}$

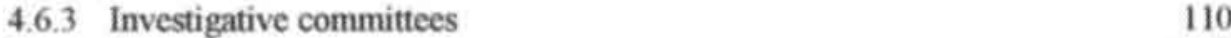

$\begin{array}{lll}4.7 & \text { Eindbalans } & 112\end{array}$

Hoofdstuk 5

Frankrijk, wetgeving en bestuurscontrole

$\begin{array}{llr}5.1 & \text { Inleiding } & 115\end{array}$

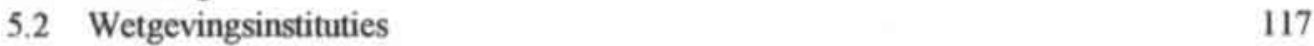

$\begin{array}{ll}\text { 5.2.1 De President } & 117\end{array}$

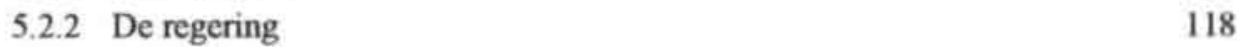

$\begin{array}{lll}5.3 & \text { De wetgevingsprocedure } & 119\end{array}$

$\begin{array}{lll}\text { 5.3.1 Het recht van amendement } & 120\end{array}$

$\begin{array}{lll}\text { 5.3.1.1 Grondwettelijke inperkingrechten } & 121\end{array}$

$\begin{array}{ll}\text { 5.3.1.1.1 Artikel } 40 & 121\end{array}$

$\begin{array}{ll}\text { 5.3.1.1.2 Artikel } 41 & 122\end{array}$

$\begin{array}{ll}\text { 5.3.1.1.3 Artikel } 44 \text { lid } 2 & 123\end{array}$

5.3.1.1.4 Artikel 44 lid $3 \quad 124$

$\begin{array}{ll}\text { 5.3.1.2 Niet grondwettelijke inperkingrechten } & 124\end{array}$

$\begin{array}{ll}\text { 5.3.1.2.1 L'exception d'irrecevabilité } & 125\end{array}$

$\begin{array}{lll}5.3 .2 & \text { De praktijk } & 126\end{array}$

$\begin{array}{ll}\text { 5.3.2.1 La question préalable } & 127\end{array}$

5.3.2.2 La question préalable positive $\quad 128$

$\begin{array}{lll}5.3 .3 & \text { Vaststelling van de agenda } & 129\end{array}$

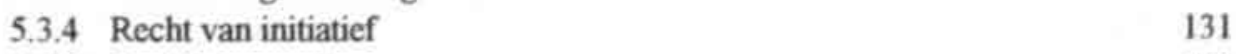

$\begin{array}{ll}\text { 5.3.5 Conflictenregeling } & 133\end{array}$ 
Inhoud

5.3.5.1 Commission Mixte Paritaire

133

$\begin{array}{ll}\text { 5.3.5.2 Dernier mot } & 137\end{array}$

$\begin{array}{lll}5.4 & \text { Bijzondere wetgevingstrajecten } & 138\end{array}$

$\begin{array}{ll}\text { 5.4.1 Grondwetswijziging } & 138\end{array}$

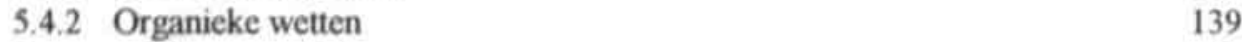

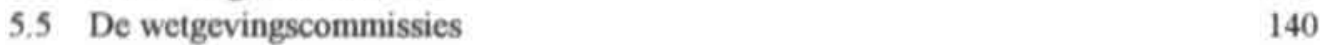

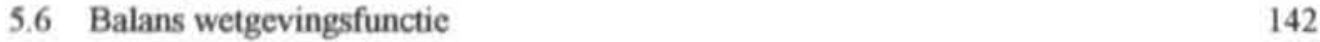

$\begin{array}{llr}5.7 & \text { Bestuurscontrole } & 145\end{array}$

$\begin{array}{ll}5.7 .1 & \text { Inleiding } \\ & 145\end{array}$

5.7.2 De politicke ministerięle verantwoordelijkheid $\quad 145$

$\begin{array}{ll}5.7 .3 \text { Het vragenrecht } & 146\end{array}$

$\begin{array}{lll}5.7 .4 & \text { Vaste kamercommissies } & 148\end{array}$

$\begin{array}{lll}5.7 .5 & \text { Het recht van enquête } & 149\end{array}$

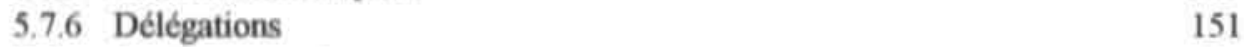

$\begin{array}{llr}5.8 & \text { Balans bestuurscontrole } & 154\end{array}$

Hoofdstuk 6

Nederland, wetgeving en bestuurscontrole

6.1 Inleiding 155

6.2 Achteraan in de rij $\quad 156$

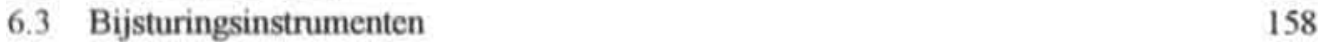

$\begin{array}{ll}\text { 6.3.1. De Novelle } & 158\end{array}$

$\begin{array}{lll}\text { 6.3.1.1 Novellepraktijk } & 159\end{array}$

$\begin{array}{lll}6.3 .2 & \text { Toezegging } & 161\end{array}$

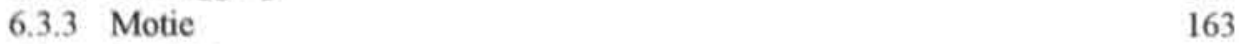

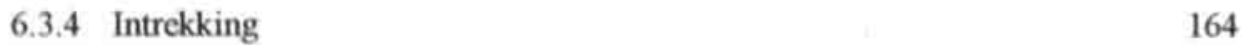

6.4 Het commissiestelsel 165

$\begin{array}{lll}6.5 & \text { Verwerping } & 167\end{array}$

6.5.1 Het veto en de vertrouwensregel 169

$\begin{array}{ll}\text { 6.5.2 Nogmaals het vetorecht } & 173\end{array}$

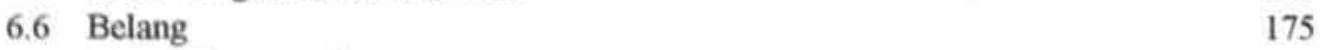

$\begin{array}{lll}6.6 .1 & \text { Tenugzending } & 176\end{array}$

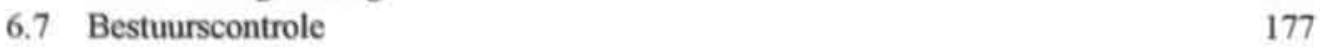

$\begin{array}{lll}6.7 .1 & \text { Inleiding } & 177\end{array}$

$\begin{array}{ll}6.7 .2 \text { Budgetrecht } & 177\end{array}$

$\begin{array}{lll}6.7 .3 & \text { Interpellatie } & 178\end{array}$

$\begin{array}{ll}6.7 .4 & 179\end{array}$

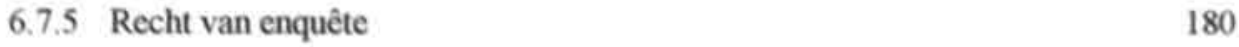

$\begin{array}{llr}6.8 & \text { Balans } & 182\end{array}$ 


\section{Hoofdstuk 7}

Bondsrepubliek Duitsland, wetgeving en bestuurscontrole

7.1 Inleiding

7.2 De Duitse Bondsstaat

7.2.1 Bondsstaat en Bundesrat

7.3 Wetgevingstraject

7.3.1 Erste Durchgang

7.3.2 Partijpolitieke structuren

7.3.2.1 Partijpolitiek, het Land en de Bundesrat 192

7.3.2.2 Partijpolitiek, de Bond en de Bundesrat 194

7.3.3.1 Nogmaals de erste Durchgang 195

$\begin{array}{lll}7.3 .3 .2 & \text { Omzeilen } & 196\end{array}$

7.3.4 Zweite Durchgang 197

$\begin{array}{lll}7.3 .4 .1 & \text { Einspruch } & 198\end{array}$

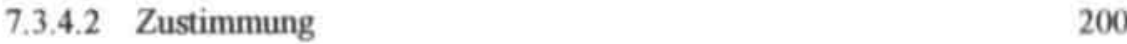

$\begin{array}{lll}7.3 .5 & \text { Wetgevingscommissies } & 201\end{array}$

$\begin{array}{lll}\text { 7.3.6.1 Nogmaals Zustimmung } & 202\end{array}$

7.3.6.2 Art. 84 en 85 GG 203

$\begin{array}{ll}7.3 .7 \text { Vermittlungsausschuss } & 209\end{array}$

7.4 De Bundesrat in Europa 214

$\begin{array}{lll}7.4 .1 & \text { Art. } 23 \mathrm{GG} & 215\end{array}$

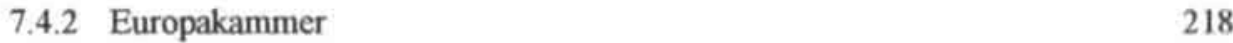

7.5 Gedelegeerde wetgeving en beleidsregels

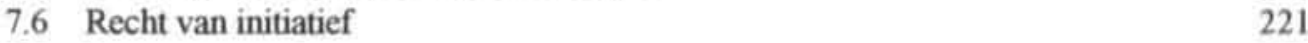

$\begin{array}{lll}7.7 & \text { Bestuurscontrole } & 223\end{array}$

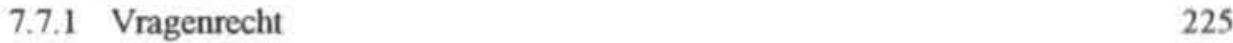

$\begin{array}{llr}7.8 & \text { Balans } & 226\end{array}$

\section{Hoofdstuk 8}

Vergelijkende beschouwingen

8.1 Kies- en benoemingsstelsels $\quad 229$

$\begin{array}{lll}8.1 .1 & \text { Inleiding } & 229\end{array}$

8.1 .2 Kiezen 230

8.1.3 Benoemen 231

8.1.4.1 Partijpolitieke stabiliteit 232

8.1.4.2 Partijpolitieke stabiliteit in relatie tot de eerste parlementskamer 233

8.1.5 Samenstelling 237

8.1.6 Verkiering/benoeming en vertegenwoordiging 239

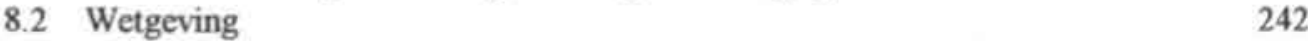


Inhoud

8.2 .1 Inleiding 242

8.2.2 De wetgevingsagenda 243

$\begin{array}{ll}8.2 .3 & \text { Recht van initiatief } 245\end{array}$

8.2.4.1 Commissie algemeen en organisatiestructuur 248

$\begin{array}{ll}\text { 8.2.4.2 Taakstelling senaatscommissies } & 250\end{array}$

8.2.5 Juridische beĭnvloedingsinstrumenten 252

$\begin{array}{lll}8.2 .5 .1 & \text { Vetorecht } & 252\end{array}$

8.2.5.2 Recht van amendement 254

$\begin{array}{ll}\text { 8.2.5.3 Conflictenregeling } 257 & 254\end{array}$

8.2.6 Samenvattend 263

8.3 Bestuurscontrole 263

8.3.1 Inleiding 263

8.3.2 Ministeriele verantwoordelijkheid 264

$\begin{array}{ll}\text { 8.3.3 Ministeriele verantwoordelijkheid? } & 267\end{array}$

$\begin{array}{ll}\text { 8.3.4 Vragenrecht } & 269\end{array}$

$\begin{array}{ll}\text { 8.3.5 Bestuurscontrolerend commissiewerk } & 271\end{array}$

$\begin{array}{lll}\text { 8.3.6 Het recht van enquête } & 271\end{array}$

8.3.7 De senaat en de werking van de politieke ministeriële verantwoordelijkheid 272

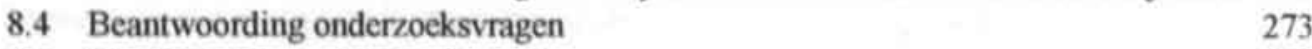

8.5 De Eerste Kamer (obiter dictum) 276

$\begin{array}{lr}\text { Summary } & 279\end{array}$

$\begin{array}{lr}\text { Geraadpleegde literatuur } & 285\end{array}$

$\begin{array}{lr}\text { Curriculum vitae } & 299\end{array}$ 


\section{Hoofdstuk 1}

\section{Inleiding}

\subsection{Het tweekamerstelsel}

'Historisch sind Zweite Kammern institutionalisierte Kompromisse zwischen alten und neuen Legitimitătsūberzeugungen'.' Dit historisch gefundeerde 'compromis' blijkt anno 2001 nog steeds onderdeel uit te maken van vele moderne staatsinstellingen. Momenteel ${ }^{2}$ bevatten de bestanden van de Inter-Parliamentary Union gegevens over 180 parlementaire democratieěn. Daarvan opteren er 67 voor een vorm van bicameralisme. ${ }^{3}$ Ook in veel Europese democratieën worden de (mede)wetgevende taken en de parlementaire bestuurscontrole formeel nog steeds uitgeoefend door twee kamers. ${ }^{4}$ De tweekamerstelsels in Polen, Rocmenie en Tsjechiě ontstonden zelfs pas nadat het ijzeren gordijn definitief geschiedenis was geworden in respectievelijk 1989, 1990 en 1993. In Hongarije wordt de introductie van een tweekamerstelsel overwogen. De parlementen van de democratieên uit Midden en West-Europa bestaan in veruit de meeste gevallen uit twee parlementskamers. Uitzonderingen op die regel worden onder meer gevormd door Denemarken, waar het Landsting in 1953 is afgeschaft en Zweden, waar medio 1973 werd overgestapt op een eenkamer stelsel.

Een voor de hand liggende, zij het uiteraard zeer premature conclusie die uit dit elementaire cijferwerk getrokken lijkt te kunnen worden, is dat tweekamerstelsels in de staatsrechtelijke en politieke constellatie van de meeste West Europese landen geacht worden op enigerlei wijze functioneel te zijn. Anders zou men immers allang, in navolging van Denemarken, massaal zijn overgestapt op slechts één volksvertegenwoordigend orgaan.

De staatsrechtelijke en politieke realiteit is uiteraard heel wat complexer en genuanceerder dan dergelijke conclusies, die slechts gebaseerd zijn op de macht van het getal. Allereerst is daar het gegeven dat de structuur van de ene parlementaire democratie de andere niet is. Binnen West-Europa bestaan immers eenheidsstaten en federaties. Binnen de eenheidsstaten bestaan o.a. semi-presidentiële modellen (Frankrijk), pariementaire meerderheidsmodellen (Groot-Brittanniē) en parlementaire consensusmodellen (Nederland). Ook in de wijze waarop de wetgevende en bestuurlijke instituties van Europese federatieve staten als Zwitserland en de Bondsrepubliek Duitsland functioneren, zijn grote verschillen aan te wijzen. Al deze landen hebben echter een tweekamerstelsel.

Vervolgens moet men zich realiseren dat ook in juridische zin het ene tweekamerstelsel het andere niet is. Leden van de Senaat ${ }^{5}$ worden direct of indirect gekozen voor een periode van bijvoorbeeld vier, of negen jaar. In een andere staat worden leden van de Senaat benoemd voor het leven of krijgen hun zetel zelfs door overerving. De rechten die de Senaat wettelijk

1. S. Schüttemeyer und R. Sturm, Wozu Zweite Kammern?, Zur Repräsentation und Funktionalitut Zweiter Kammem in Westlichen Demokratien, Zeitschrift fïr Parlamentsfragen 1992, p. 517.

2. September 2001.

3. http://www.ipu.org/english/parlweb.htmtb. 10-9-200I.

4. M. Russell, Reforming the House of Lords, Lessons from Overseas, Oxford University Press 2000, p. $22-28$.

5. Telkens wanneer in dit boek in algemene zin gesproken wordt over het tweede volksvertegenwoordigende huis zal de term 'Senaat' gebezigd worden. Voor het eerste volksvertegenwoordigende huis zal in aigemene zin de term 'Volkskamer' gehanteerd worden. 


\section{Hoofdstuk 1}

toekomen met het oog op het formeel te verwezenlijken takenpakket verschillen ook aanzienlijk van land tot land. Het is evident dat een Senaatskamer die slechts de mogelijkheid heeft om een beperkte groep wetsvoorstellen maximaal éen jaar tegen de wil van de parlementskamer met het politieke primaat tegen te houden (Groot-Brittannie)), anders functioneert dan een Senaat die de grondwettelijke bevoegdheid heeft alle wetsvoorstellen definitief weg te stemmen (Nederland) of een tweede parlementskamer die via een conciliatiecommissie in onderhandeling kan treden over vorm en inhoud van een gezamenlijk legislatief eindproduct (Frankrijk en de Bondsrepubliek Duitsland).

Ook zal de mate van invloed die de Senaat op het wetgevingsproces heeft indien deze in vrijwel alle gevallen vanaf het prille begin betrokken wordt bij de ontwikkeling van nieuwe regelgevingvoorstellen (Bondsrepubliek Duitsland), aanmerkelijk kunnen verschillen van de invloed die van een tweede parlementskamer uitgaat op nieuwe wetsvoorstellen die pas in een volledig uitgewerkt stadium voorgelegd plegen te worden (Nederland).

Dan zijn er staten waar de Senaat zijn taken dient te verrichten zonder de hulp van een ambtelijk apparaat, terwijl in andere landen juist sterk geleund kan worden op een hoog gekwalificeerd ambtelijk apparaat. Kortom, samenstelling, werkwijze, taken en bevoegdheden van de Senaat verschillen aanzienlijk van land tot land.

Tenslotte moet ook niet vergeten worden dat het functioneren van de Senaat en daarmee het bestaan van tweekamerstelsels in de allereerste plaats bepaald wordt door politieke processen en niet door regels van staatsorganisatie. De aan of afwezigheid van een sterke partijpolitieke binding bijvoorbeeld heeft ontegenzeggelijk enorme invloed op de wijze van functioneren van senaatskamers in staten met tweekamerstelsels. ${ }^{6}$

\subsection{Voorlopige probleemstelling}

Het totale zover geschilderde plaatje overziend, ontstaat dan een betrekkelijk diffuus beeld van verschillende rechtsstelsels, waarbinnen op geheel eigen wijze veelal twee parlementskamers actief zijn op het terrein van wetgeving en bestuurscontrole.

Mijn belangstelling in dit rechtsvergelijkend onderzoek zal beperkt blijven tot het functioneren van senaatskamers. Meer specifick zal de vraag aan de orde gesteld worden of aan het functioneren van senaatskamers, zoals die die in verscheidene vormen in op westerse leest geschoeide democratische samenlevingen binnen Europa naast de volkskamer vorm gekregen hebben, nog toegevoegde waarde toegekend wordt.

Alvorens deze centrale probleemstelling echter verder uit te werken en het onderzoeksterrein nader af te bakenen, moeten nog een aantal noodzakelijke opmerkingen van inleidende aard met betrekking tot het werkterrein van de tweede parlementskamer toegevoegd worden. Daaraan voorafgaande dient in het kader van dit onderzoek gewezen te worden op relevant

6. Met name in een land als bijvoorbeeld Frankrijk lijkt de wijze van functioneren van de Scenat sterk beinvloed te worden door de politieke kleur van de regering en de Assemblée. Zie daartoe onder meer: J. Mastias et J. Grangé, Les Secondes Chambres du Parlement en Europe Oecidentale, Economica Paris 1987; J. Cluzel, Le Sénat dans la société francaise, Economica Paris 1990; J. Mastias, A Problem of Identity: The French Senat, in: S.C. Patterson and A. Mughan, Senates, Bicameralism in the Contemporary World, Ohio State University Press 1999, p. 162-198.

Zie in algemene zin ook: J. Blondel, Comparative Government, London 1990, p. 243 e.v. 
politicologisch onderzoek naar het functioneren van tweekamerstelsels van de hand van Lijphart.

\subsection{Congruentic en symmetrie}

In een vergelijkend onderzoek naar de werking van democratieenn is Lijphart onder meer tot de conclusie gekomen dat 'incongruentie' in de samenstelling van eerste parlementskamer en Senaat (daarmee doelend op een verschillende methode van verkiezing en/of verschillende vertegenwoordigingsbasis voor de senaatskamer en de eerste parlementskamer) rečle spreiding van wetgevende macht tussen de twee parlementskamers positief beinvloedt.' Recentelijk is die conclusie nogmaals door hem bekrachtigd en verder uitgewerkt". Naast 'incongruentie' benoemt hij dan namelijk tevens zowel de tockenning van grondwettelijke rechten aan de senaatskamer als de aanwerigheid van zgn. 'symmetrie' als belangrijke basisvoorwaarden voor 'powerful' functioneren van tweekamerstelsels. En onder symmetrie verstaat Lijphart: 'Symmetrical chambers are those with equal or only moderately unequal constitutional powers and democratic legitimacy'. ${ }^{9}$ Senaatskamers die te definięren zijn als symmetrisch èn incongruent etaleren volgens Lijphart 'strong bicameralism'. Als schoolvoorbeeld van krachtig bicameralisme benoemt Lijphart de federaties en dan met name die federaties waarin ieder Kanton (Zwitserland) of Staat (Verenigde Staten) evenveel senatoren af mag vaardigen naar de Senaat, los van het inwonersaantal. Ondanks het feit dat het aantal naar de Bundesrat af te vaardigen leden in de Bondsrepubliek Duitland wél gekoppeld is aan de bevolkingsdichtheid der respectievelijke Länder, valt toch ook deze federatie onder de krachtigste categorie. Iets minder krachtig functioneren volgens Lijphart tweekamerstelsels die symmetrie en congruentie als centrale kenmerken bezitten. Als voorbeelden noemt hij onder andere België, Nederland en Italiè. Als asymmetrisch en incongruent en derhalve zwakker ('medium-strength bicameralism') worden in dit kader de tweekamerstelsels van landen als Frankrijk en Spanje geclassificeerd. In die landen is een afwijkende vorm van verkiezing/ vertegenwoordiging voor de senaatskamer gekoppeld aan het bezit van slechts relatief zwakke grondwettelijke instrumenten ter sturing van het legislatieve proces. Ook het tweekamerstelsel van Groot-Brittannië valt formeel onder voornoemde categorie. Lijphart meende het Verenigd Koninkrijk echter in te moeten delen in de nog zwakkere categorie: 'Between mediumstrength and weak bicameralism'. De reden lag voor de hand: 'British bicameralism, although technically incongruent, is demoted by half a point because the upper house is a relic of a predemocratic era ${ }^{10}$ Ronduit zwak bicameralisme tenslotte etaleren, zo blijkt uit het onderzoek, staten met asymmetrische congruente parlementskamers. Voorbeelden in Europa zijn Ierland en Oostenrijk. "De potentiële politieke invloed die senaatskamers in die landen nog

7. A Lijphart, Democracies: Patterns of Majoritarian and Consensus Government in Twenty-One Countries, Yale University Press, New Haven 1984.

8. A.Lijphart, Patterns of Democracy: government forms and performance in thirty-six countries, Yale University Press New Haven 1999, p. 200-215.

9. A. Lijphart 1999, a.w., p. 206.

10. A. Lijphart 1999, a.w., p. 213.

11. A. Lijphart 1999, a.w., p. 212. 
uit kunnen oefenen op het wetgevingsproduct moet volgens Lijphart als gering geclassificeerd worden.

\subsection{Werkterrein van de Senaat}

De Senaat is zich in vrijwel alle West Europese landen gaandeweg (zie hoofdstuk 2) gaan ontwikkelen tot een in meerdere of mindere mate democratisch gelegitimeerd volksvertegenwoordigend orgaan waaraan door de (grond)wetgever de nodige taken op met name wetgevend terrein werden overgelaten. In een samenleving die zich, zeker in de tweede helft van de twintigste eeuw sociaal-economisch in snel tempo ontwikkelde tot een verzorgingsstaat, bleken de taken die de wetgever in beide parlementskamers diende te vervullen, snel in omvang toe te nemen.

In de grootste groep West Europese landen opereert de Senaat in de schaduw van de parlementskamer die als direct gekozen volksvertegenwoordigend orgaan het politieke primaat bezit. De eerste taak van de Senaat betreft, zoals gezegd, met name de heroverweging van wetgeving. De wijze waarop deze heroverweging zich kon manifesteren verschilt aanmerkelijk van staat tot staat. In een land als Italiè bijvoorbeeld, is sprake van een volledige juridische én politieke heroverweging, ${ }^{12}$ terwijl de Senaat in landen als Groot-Brittanniè en Nederland zich toch veeleer lijkt te concentreren op de juridisch dogmatische controle van wetsontwerpen. ${ }^{13}$

Naast de taken uit hoofde van wetgeving kreeg de Senaat in de meeste landen ook een aantal juridische instrumenten in handen om controle uit te oefenen op het bestuurlijk functioneren van de regering. Het aloude budgetrecht, het vragen- en interpellatierecht, het enquêterecht en in een enkel geval ook het recht om de vertrouwensvraag te stellen, alsmede een aantal afgeleide uitingsvormen van voornoemde rechten (beleidsdebatten, semi-zelfstandig onderzoek enz.) kwamen in de loop van de tijd in handen van de Senaat.

Kanttekeningen bij het functioneren van de Senaat binnen voornoemd werkterrein en daanit voortvloeiende twijfels over het bestaansrecht van de tweede parlementskamer zijn er de afgelopen 150 jaar voortdurend geweest. De kritiek was niet alleen afkomstig uit politieke kringen, doch eveneens uit wetenschappelijke hoek. ${ }^{14}$

Een veel gehoord argument betreft de mogelijke doublure van het wetgevingsproces. Waarom wetgevingswerk dat reeds grondig gedaan is door de regering in nauwe samenwerking met de democratisch het best gelegitimeerde parlementskamer nog eens uitgebreid overdoen? Kan een dergelijke activiteit nog wezenlijk surplus opleveren? 'Les secondes Chambres doivent au

12. E.M.H. Hirsch Ballin, De Italiaanse Republick, in: L. Prakke en C.A.J.M. Kortmann (red), Het staatsrecht van de landen der Europese Gemeenschappen, Deventer 1998, p. 438 e.v.

13. Zie voor Groot-Brittannié: B. Thompson, Constitutional \& Administrative Law, Longman, London 1993, p. 173 e.v.

Zie voor Nederland o.a.: N. Cramer. De Eerste Kamer na 1917 in heroverweging in: Postma, A. e.a., Aan deze zijde van het Binnenhof, Sdu 's-Gravenhage 1990, p. 290.

14. Onder andere: P. Carmichael and A. Baker, Second Chambers, A Comparative Perspective, in: The House of Lords, Its Parliamentary and Judicial Roles, Oxford 1999, p. 69: Y. Meny, Government and Politics in Western Europe, Oxford 1993, p.188 e.v; S. Schattemeyer und R. Sturm, Wozu Zweite Kammern?, Zur Repràsentation und Funktionalită Zweiter Kammern in Westlichen Demokratiên, in:Zeitschrift fur Parlamentsfragen 1992, p. 517.536 . 
moins apparaître complémentaire par rapport à l'Assemblée. Un délicat dosage doit être effectué quant à sa spécificité sans pour autant que ses fonctions ne soient altérées. Sans cet équilibre, le bicaméralisme est voué à l'échec'. ${ }^{\text {IS }}$

Vanuit de politiek bleken de bezwaren aangaande het functioneren van de Senaat veelal tenug te voeren tot technieken die, gezien door de bril van regering en regeringspartij(en) in de volkskamer, als bewust beleidsondermijnend of gewoon erg lastig beschouwd werden. Daarbij moet gedacht worden aan het (in de optiek van de regering) bewerkstelligen van serieuze vertraging van het wetgevingsproces, het kapot amenderen van wetsvoorstellen, het (uit oogpunt van beleidsontwikkeling zo hinderlijke) wegstemmen van wetsvoorstellen of het anderszins realiseren van afstel van regelgevingvoorstellen geiniticerd door de regering. Bijzonder sprekend was in dit kader zeker de poging die de Franse President de Gaulle in 1969 ondernam om de macht van een hem regelmatig politick onwelgevallige Sénat verder in te dammen. ${ }^{16}$ Hij schreef daartoe per decreet een referendum uit, gebaseerd op art. 11 van de constitutie uit 1958. ${ }^{17}$ Aan de uitslag van het juridisch kwestieuze referendum verbond 'le plus illustre des Français' zijn politieke leven, zodat Frankrijk in 1969 vrij plotseling afscheid nam van zijn generaal en de positie van de Franse Sénat in het wetgevingsproces formeel onaangetast bleef (zie ook hoofdstuk 2).

De Senaat in de meeste Europese democratieèn lijkt te moeten manoevreren tussen 'doublure' en te grote (politieke) 'bemoeizucht'. Wél eigen accenten toevoegen aan wetgevingsvoorstellen, zodat de 'doublurekritiek' achterwege kan blijven, maar in een mate en op een wijze die recht doen aan de positie van een parlementair wetgevend orgaan dat het politiek primaat niet bezit: 'Zweite Kammern müssen also den Weg zwischen der Scilla der Identităt und der Charybdis der zu grossen Abweichung steuern'. ${ }^{18}$ Concreet kan daarbij ideaaltypisch gedacht worden aan activiteiten die te vatten zijn onder termen als 'revisie' en 'reflexie'. Wetsontwerpen geünitieerd door de regering en behandeld door de Volkskamer worden nogmaals grondig onder de loep genomen door de Senaat en bekeken op onder meer juridisch dogmatische merites en maatschappelijk-politiek belang buiten de 'waan van de dag'. 19

Daarmee zijn echter nog niet alle staatsrechtelijke structuren en politieke invloeden benoemd, die samen het globale 'werkterrein' van de Senaat als wetgever en beleidscontroleur af plegen te bakenen. Van eminent belang in dit kader is immers ook het karakter van het staatsbestel waarbinnen het tweekamerstelsel functioneert en vooral de vraag wie daarbinnen door de Senaat vertegenwoordigd worden. In een eenheidsstaat waar Volkskamer en Senaat op vrijwel identieke wijze gekozen worden door dezelfde groep stemgerechtigden (bijvoorbeeld Italiè en ook Nederland), zullen de afgevaardigden uit de tweede parlementaire kamer duidelijk andere

15. M.Sousse, le bicaméralisme: bilan et perspectives, Revue du Droit Public et de la science politique en France et a l'étranger, Juillet-Août 1997, p, 1332.

16. S. Finer, Comparative Government, An introduction to the study of politics. Harmondsworth 1985, p. 335349.

17. Het referendum werd door de Gaulle uitgeschreven op basis van art.11 Constitution 1958, ondanks het dringende advies van de Conseil d'État om dit niet te doen. Door art. 11 Const. te hanteren zou hij het parlement echter in het geheel niet in de procedure hoeven te betrekken.

18. S. Schuttemeyer und R. Sturm, a.w., p. 519.

19. Zie voor bijvoorbeeld Nederland hiertoe o.a: H. Kummeling. De Eerste Kamer; Chambre de Révolution?, NJB 1990, p. 262; Voor Groot-Brittannic, D. Shell, The House of Lords, a.w., p. 128-156. 
accenten zetten, dan afgevaardigden uit een federatieve staat, waar de Senaat de afzonderlijke landsdelen vertegenwoordigt (Zwitserland of de Bondsrepubliek Duitsland). ${ }^{20}$

Tenslotte moet nog gewezen worden op het voortdurend grote belang in dit kader van partijpolitieke verhoudingen. Een Senaat die qua partijpolitieke samenstelling niet of nauwelijks afwijkt van de verhoudingen dienaangaande in de Volkskamer, zal de revisie- en reflexiewerkzaamheden, alsmede de algemene bestuurscontrole anders aanzetten dan een Senaatskamer die gedomineerd wordt door de oppositie. De Gaulle wilde in 1969 de invioed van de Sénat op het wetgevingsproces verder indammen door er een zuiver adviserend orgaan van te maken, juist omdat dit orgaan gedomineerd werd door politicke tegenstanders. ${ }^{21}$ In het moderne Frankrijk zijn fraaie voorbeelden voorhanden van het belang van partijpolitieke verhoudingen voor het functioneren van de Senaat. Sinds 1981 is, ten gevolge van verkiezingen voor de Assemblée, immers al drie maal sprake geweest van een cohabitation tussen een linkse President en een rechtse regering of andersom. Evenzo vele malen veranderde de opstelling van de (partijpoliticke stabiele) Sénat, de President en regering/Assemblée nationale ten opzichte van elkaar drastisch. ${ }^{22}$

In de Bondsrepubliek woedt momenteel een discussie over de vraag of hervorming van het aldaar functionerende tweekamerstelsel gewenst is. De behoefte tot het voeren van deze discussie is ontstaan omdat de Bundesratmeerderheid de laatste decennia meestentijds oppositioneel samengesteld blijkt te zijn, hetgeen (te) veel 'schipperen' tussen Bundestag en Bundesrat tot gevolg heeft. ${ }^{23}$

Ook voor Groot-Brittannië kan de invloed van partijpolitieke verhoudingen op de wijze van functioneren van de Senaat geillustreerd worden aan de hand van een sprekend voorbeeld. De Labour Party, een partij die zeer kritisch stond ten opzichte van een het bestaansrecht voor het (permanent door de Conservatives gedomineerde) House of Lords, won in 1945 de verkiezingen voor het House of Commons overtuigend. Vanuit een riante absolute meerderheid kon vervolgens door een Labourregering gewerkt worden aan de uitvoering van het verkiezingsmanifest. Onder de gegeven omstandigheden besloot de permanente Conservatieve meerderheid van het House of Lords onder aanvoering van Lord Salisbury om in de toekomst geen al te felle oppositie meer te voeren en in ieder geval regering en House of Commons niet meer hinderlijk in de weg te lopen, waar de realisatie van plannen uit het verkiezingsmanifest in het geding bleek te zijn. ${ }^{24}$

Uit bovenstaande voorbeelden moge tevens blijken dat de globaal geschilderde bandbreedte waarbinnen de Senaat in Frankrijk en Groot-Brittannie̋ (maar ook in andere West Europese democratieěn) zich kwijt van de medewetgevende en beleidscontrolerende taken, allerminst een statisch karakter hoeft te hebben.

Parlementaire controle van het regeringsbeleid door een formeel van de regering onafhankelijke instantie wordt vanuit staatsrechtelijk oogpunt vooral opportuun geacht in staten waar sprake is van duidelijk monisme, zoals in het parlementaire stelsel van Groot-Brittanniē of

20. J. Mastias et J. Grangé, a.w., p. 21-22.

21. Zie S. Finer, a.w., p. 336.

22. Zie daartoe uitgebreid: J-E. Giquel, Le Sénat sous la seconde cohabitation, Revue du droit publie et de la Science Politique en France et a I'Étranger 1996, p.1069-1094. Nadere bespreking volgt in hoofdstuk 5 van dit bock.

23. R. Dolzer und M. Sachs, Das parlamentarische Regienungssystem und der Bundesrat, Entwicklungsstand und Reformbedarf, Berlin 1999, p. 1-138.

24. R. Ivor and D. Welfare, Unfinished Business, Reforming the House of Lords, London 1999. p. 33-35. 
staten waar sprake is van steeds uitgebreider en vrij strakke regeerakkoorden, zoals in Nederland. ${ }^{25}$ Maar ook in zijn algemeenheid is extra controle door een tweede parlementskamer in het kader van een uitgewerkt systeem van 'checks and balances' goed inpasbaar. ${ }^{26}$

\subsection{Probleemstelling}

Een nauwkeurige afbakening van het werkterrein van de Senaat, de kamer die het politicke primaat niet bezit, blijkt niet eenvoudig te geven. Wél kan, zo hebben wij gezien, een bandbreedte aangegeven worden waarbinnen de Senaat zich in de meeste West-Europese democratieèn moet kwijten van haar taken. Omdat de Senaat in het parlement in veel gevallen de tweede viool lijkt te moeten spelen op een wijze die enerzijds geen of niet te veel doublure mag zijn van de werkzaamheden van de Volkskamer en anderzijds niet te veel mag interfereren met het politieke primaat van de 'eerste parlementskamer', steekt de vraag naar de eventuele meerwaarde van tweekamerstelsels ten opzichte van eenkamerstelsels eenvoudig de kop op.

Zeker in een tijd dat 'Europa' zich in juridische zin ontegenzeggelijk snel ontwikkelt, binnengrenzen vervagen en de organisatie van gezamenlijke Europese regelgeving, beleidsuitvoering maar vooral Europese rechtspraak in een stroomversnelling lijkt te zijn terechtgekomen, kan de vraag naar het bestaanrecht van medewetgevende tweekamerstelsels in feite niet langer meer worden afgedaan, met het (meestal onuitgesproken) argument dat het nu eenmaal altijd zo geweest is. Met name in landen als Groot-Brittannié en Nederland, landen die inmiddels kunnen bogen op een ononderbroken bicamerale parlementaire praktijk van zeven c.q. twee ceuwen, heeft een dergelijke attitude met enige regelmaat opgeld gedaan.

Zo kom ik dan definitief uit op de volgende algemene vragen waarop in het kader van dit onderzoek gepoogd zal worden een bevredigend antwoord te formuleren:

- Wordt aan het functioneren van senaatskamers, zoals die in verscheidene vormen in op westerse leest geschoeide democratische samenlevingen binnen Europa naast de volkskamer vorm hebben gekregen, nog toegevoegde waarde toegekend?

Specifieker:

- Wordt aan het functioneren van senaatskamers nog voldoende nut toegekend in het wetgevingsproces en ter controle van het regeringsbeleid om het bestaansrecht van tweekamerstelsels te rechtvaardigen?

- Kunnen deugdelijk democratisch gelegitimeerde senaatskamers hun medewetgevende en bestuurscontrolerende taken effectiever uitoefenen, dan senaatskamers die niet of slechts indirect democratisch gelegitimeerd zijn?

- Kunnen senaatskamers in de hedendaagse parlementaire praktijk nog een rol van betekenis vervullen in het kader van het systeem van 'checks and balances'?

25. In 1992 gaf de de voorzitter van de CDA-fractic in de Nederlandse Eerste Kamer aan een warm voorvechter te zijn van controle van het overheidsbeleid door de Senaat uit oogpunt van het machtsevenwicht. Zie daartoe: Handelingen EK 1991-1992, p. 1383.

26. J. Mastias et J. Grangé, a.w., p. 81-89. 


\subsubsection{Nadere afbakening onderzoeksterrein}

Op dit punt aangekomen is het zinvol het terrein waartoe dit onderzoek zich zal beperken concreter in te gaan kaderen. Besloten is om een rechtsvergelijkende studie te maken van de tweekamerstelsels van Groot-Brittanniē, Frankrijk, Nederland en Duitsland, waarbij expliciet gekeken wordt naar de wijze waarop het staatsrechtelijk kader gehanteerd wordt in de parlementaire politicke praktijk.

De keuze voor juist de vier genoemde West Europese landen lag voor de hand. Voor een eerste reden grijp ik terug naar de resultaten van het reeds gememoreerde vergelijkend onderzoek van Lijphart uit 1999. Daarin kon hij de tweekamerstelsels van ieder der vier door mij gekozen onderzoekslanden in een andere categorie rubriceren, variërend van sterk tot zwak, daarmee doelend op de politicke kracht van het bicameralisme per land. Onderzoekscomponenten die tot deze fraaie indeling geleid hebben waren onder andere: het gehanteerde kiesstelsel, de mate van democratische legitimatie, de wijze van samenstelling van de beide parlementskamers en het bezit van juridische beïnvloedingsrechten. Zonder uitzondering aspecten die ook in mijn onderzock een rol van betekenis zullen spelen.

Vervolgens kan opgemerkt worden dat de staatsinstellingen van de vier landen die het onderwerp van onderzoek zullen worden, zeer divers georganiseerd en gestructureerd zijn. De Bondsrepubliek Duitsland kent een federale staatsstructuur. Frankrijk is een eenheidsstaat, waarin sinds de invoering van de constitutie van de vijfde Republiek in 1958 een stelsel functioneert dat in de literatuur wel wordt omschreven als semi presidentieel. In dit stelsel blijkt zowel op wetgevend als bestuurlijk terrein ook de President van de Republiek een actor te zijn met substantiele rechten. In de eenheidsstaat Groot-Brittannie is het roemruchte 'Cabinet Government' steunend op wisselende parlementaire absolute meerderheden ontstaan. Nederland tenslotte heeft een bestel dat zich juist kenmerkt door de áfwezigheid van automatische parlementaire meerderheden. Consensus is daar dan ook het toverwoord. Door deze variëteit aan stelsels in het onderzoek te betrekken ontstaat een aanmerkelijke verbreding van het onderzoeksspectrum.

Ten derde werd van belang geacht dat de onderzoekslanden met uitzondering van 'thuisland' Nederland te boek staan als politiek toonaangevend binnen Europa.

Een vierde en laatste reden om te opteren voor de vier genoemde landen is van puur opportunistische aard: de Europese kaart wordt ondanks de Schengen akkoorden nog altijd gedomineerd door ontelbare taalbarrières, die ook voor mij lang niet altijd eenvoudig te slechten zijn.

Tenslotte dient hier nog melding gemaakt te worden van het gegeven dat het ook voor Europa en dat met name voor de politieke organisatie van de Europese Unie van belang kan worden inzicht te krijgen in de vraag of tweekamerstelsels meerwaarde hebben ten opzichte van eenkamerstelsels.

Beantwoording van de vraag of een toekomstig Europa behoefte heeft aan een tweekamerstelsel zal echter eerst dan echt actueel kunnen worden indien op enig moment de mogelijkheid van een al dan niet federatief Europa vanuit een solide parlementaire basis voor de politieke leiders van de EU-lidstaten onderwerp van serieuze studie zal gaan worden. Onder andere Jacques Chirac ${ }^{27}$ en Gerhard Schroder ${ }^{28}$ hebben dit thema in 2001

27. Message du Président de la République á l'oceasion de l'ouverture du Forum sur l'avenir de I'Union européenne, Palais de I'Elysée 9-5-2001. 
weliswaar opnieuw aangekaart in hun respectievelijke politieke arena's maar daarmee werd al dan niet onbedoeld tegelijkertijd eigenlijk nog maar eens ten overvloede aangegeven dat de weg naar één Europese (bonds)staat, zo die er al komt, nog lang zal zijn. Wat hier verder ook van komt; in het kader van dit boek zal op geen enkele wijze meer aandacht besteed worden aan het fenomeen bicameralisme in relatie tot een tockomstige staatsstructuur voor de EU.

\subsubsection{Nadere definièring}

De Senaat van de vier onderzoekslanden vertoont naast belangrijke verschillen in werkwijze ook een aantal opmerkelijke verschillen qua samenstelling, zittingstermijnen, en democratische legitimatie. Zo is de zittingstermijn van de leden van de Nederlandse Eerste Kamer gesteld op vier jaar, terwijl de 'Peers' die zitting hebben in het 'House of Lords' grotendeels levenslang benoemd zijn. De benoemingstermijn van senatoren in de Bundesrat kán zich beperken tot een enkele vergadering, doch is in ieder geval formeel gekoppeld aan de levensduur van de 'Landesregierung'. Franse senaatsleden mogen negen jaar blijven zitten, alvorens eventuele herverkiezing noodzakelijk wordt. Ook het aantal leden dat zitting heeft in de Senaat, vertoont per land enorme verschillen: ruim 700 'Peers' in Groot-Brittanuice en bij lange na geen 100 'Mitglieder' in de Duitse 'Bundesrat' en de Nederlandse Eerste Kamer.

De wijze waarop de leden gekozen c.q. benoemd worden is zelfs slechts met de grootst mogelijke moeite vergelijkbaar. Immers, Britse Senaatsleden worden grotendeels benoemd door de Prime Minister. Duitse leden worden als regel 'en bloc' benoemd vanuit de 'Landesregienungen', zodat, afhankelijk van het beleidsonderwerp dat aan de orde is, altijd de meest gespecialiseerde minister uit het Land naar de Bundesrat afgevaardigd kan worden. Franse leden worden indirect gekozen via een bijzonder ingewikkelde procedure die pregnante gevolgen heeft voor de partijpolitieke samenstelling van de 'Sénat' (zie hoofdstuk 3). Nederlandse senatoren tenslotte worden weliswaar formeel nog altijd indirect gekozen, maar in de praktijk beïnvloedt dat gegeven de partijpolitieke samenstelling van de Senaat niet of nauwelijks meer.

De geconstateerde variëteit aan tweekamerstelsels, zowel qua verkiezing/benoeming als qua samenstelling noopt mij ertoe het begrip tweekamerstelsel nader te definièren. De noodzaak tot een nadere definiéring wordt ook gedemonstreerd aan de hand van een uitspraak van het Duitse Bundesverfassungsgericht: 'Nach der Regelung des Grundgesetzes ist der Bundesrat nicht eine Zweite Kammer eines einheitlichen Gesetzgebungsorgans, die gleichwertig mit der ersten Kammer entscheidend am Gesetzgebungsverfahren beteiligt wäre'. 29 'Gleichwertig' is hier het sleutelbegrip.

Het Bundesverfassungsgericht verwijst vervolgens naar bronnen die stellen dat 'es der Beliebigkeit des jeweiligen Autors anheimstellt den Begriffen 'zweite Kammer' und 'Parlament' einen entsprechenden Inhalt beizulegen'. ${ }^{30}$ En dat is precies wat ik nu doe met betrekking tot het begrip tweekamerstelsel: in dit onderzoek wordt gesproken van tweekamerstelsels indien

28. Openingsspeech van Gerhard Schrơder bij de opening van het 5 e congres voor Europese socialistische en sociaal-democratische partijen, Berlijn 7-5-2001.

29. Bundesverfassungsgericht 37,363 ff, 380.

30. K.Reuter. Praxishandbuch Bundesrat, Verfassungsrechtliche Grundlagen, Kommentar zur Geschăftsordnung. Praxis des Bundesrates, Heidelberg 1991, p. 109-110, E. Friesenhahn, Der Bundesrat als Verfassungsorgan und politische Kraft. Zeitschrift für Parlamentsfragen 1974. p. 253. Zie ook: K. Reuter, a.w., p. 1552. 
wetgeving op nationaal niveau slechts tot stand kan komen door middel van de verplichte medewerking in enigerlei vorm (van uitsluitend strikt formeel tot volledig formeel én materieel) van beide parlementskamers aan het wetgevingsproces.

\subsection{Opzet van het onderzoek}

Rest mij, ter afsluiting van het inleidende hoofdstuk, nog aan te geven op welke wijze het onderzoek naar het functioneren van de Senaat in een viertal West-Europese tweekamerstelsels vorm zal krijgen.

Het vervolg van dit boek zal uiteenvallen in een zevental hoofdstukken en een conclusie. In de hoofdstukken $4 \mathrm{t} / \mathrm{m} 7$ ligt het accent op een rechtsvergelijkende studie per onderzoeksland. De bevoegdheden van de Senaat rondom de effectuering van de (mede)wetgevende en de bestuurscontrolerende taakstelling staan daarin centraal. Allereerst zal echter een kort historisch overzicht gegeven worden van ontstaan en ontwikkeling van het House of Lords, de Bundesrat, de Eerste Kamer en de Sénat (hoofdstuk 2). In hoofdstuk 3 wordt uitgebreid aandacht besteed aan de wijze waarop de verkiering c.q. benoeming van de senaatsleden in de vier onderzockslanden gestalte pleegt te krijgen. Tevens zal dan uiteraard bekeken worden op welke wijze de verkiezing/benoeming uit werkt op zowel de samenstelling als de zittingsduur van de Senaat. Tenslotte zal in hoofdstuk 3 ook kort aandacht besteed worden aan de organisatiestructuur van de Senaat in de onderzoekslanden. Wordt de Senaat ondersteund door een ambtelijk apparaat? Zijn er gespecialiseerde commissies in het leven geroepen?

In de hoofdstukken $4 \mathrm{t} / \mathrm{m} 7$ worden de tweekamerstelsels van achtereenvolgens GrootBrittanniě, Frankrijk, Nederland en de Bondsrepubliek Duitsland behandeld.

Zonder daarbij een consequente, strakke en uniforme structuur aan te houden, wordt in deze vier hoofdstukken steeds eerst aandacht besteed aan de wetgevingsgelieerde rechten. Daarbij moet in ieder geval gedacht worden aan: het recht van initiatief, het recht van amendement, het terugzendingsrecht, het recht wetgevingsvoorstellen te verwerpen dan wel bezwaar aan te tekenen, het conciliatierecht en de rechten met betrekking tot herziening van de Grondwet. Op meerdere momenten zal (aan de hand van de gang van wetsontwerpen in de vier landen) in deze hoofdstukken uiteraard tevens stil worden gestaan bij in het oog springende verschillen in het bevoegdhedenpakket van beide kamers en de gevolgen die dit heeft voor het politieke functioneren van de parlementskamers. Met name wordt natuurlijk bekeken of nationale wettelijke regelingen voorzien in een conflictenregeling en zo ja, hoe deze is uitgewerkt.

In het tweede gedeelte van de hoofdstukken $4 \mathrm{t} / \mathrm{m} 7$ wordt de bestuurscontrolerende functie van de Senaat in de vier onderzoekslanden onder de loep genomen. In welke mate is het vragen- en interpellatierecht geincorporeerd en uitgewerkt in de respectievelijke staatsorganisaties? Heeft de Senaat het enquêterecht en wordt daar gebruik van gemaakt? Bestaat er een (formele en/of materièle) vertrouwensrelatie tussen Senaat en regering en zo ja, kan de Senaat die eventuele vertrouwensrelatie dan zelfstandig activeren? Beschikt de Senaat over cen reèel budgetrecht? Naast deze traditionele bevoegdheden ter controle van het bestuur zijn senaatskamers gaandeweg tevens meer tijd gaan steken in zaken als zelfstandig onderzock via daartoe ingestelde commissies (bijvoorbeeld op het terrein van de EU-regelgeving) gevolgd door verdiepend plenair debat van inhoudelijke aard. Ook het belang van deze activiteiten wordt vanzelfsprekend meegenomen. 
In de marge zal tenslotte ook voortdurend meegewogen worden in hoeverre de senaatskamers in kwestie ontbonden of zelfs opgeheven kunnen worden.

Hoofdstuk 8 kan beschouwd worden als de kern van dit boek. In dat hoofdstuk zal de politiekpraktische werking van de rechtstelsels van de vier onderzockslanden op het vlak van het functioneren van senaatskamers thematisch vergeleken worden. In de eerste paragraaf zullen de vier gehanteerde kies- en benoemingstelsels centraal staan. De tweede paragraaf zal handelen over de wetgevende taakstelling van de senaat. Het derde en laatste gedeelte heeft de bestuurscontrolerende praktijk van de vier senaatskamer tot thema.

In de conclusie wordt vanzelfsprekend een antwoord gegeven op op de centrale onderzoeksvragen, zoals geformuleerd in dit inleidende hoofdstuk.

Het bronnenmateriaal is door mij verzameld in Nederland, Londen, Berlijn en Parijs. Allereerst zijn daar natuurlijk de relevante parlementaire stukken. Vervolgens dient melding gemaakt te worden van een substantiele hoeveelheid bronnenmateriaal van secundaire aard. Het betreft dan staatsrechtelijke en politicologische literatuur uit de vier landen.

Tijdens voornoemde bezoeken aan de hoofdsteden van Groot-Brittannie, de Bondsrepubliek Duitsland en Frankrijk heb ik ook van de gelegenheid gebruik gemaakt om met senatoren van gedachten te wisselen over de wijze van functioneren van 'hun' senaatskamer.

Verder worden vanzelfsprekend de beschikbare kwantitatieve gegevens over de mate waarin de Senaat gebruik blijkt te (kunnen) maken van zijn rechten geraadpleegd. Met name op dat terrein is het belang van het Internet nauwelijks nog over te waarderen.

Uiteraard zijn tevens de relevante parlementaire stukken geraadpleegd. Als sluitstuk werd tenslotte ook nog gebruik gemaakt van artikelen uit gezaghebbende kranten der vier onderzoekslanden.

\subsection{Het belang van de rede}

Ruim twee eeuwen geleden, tijdens de turbulente jaren van de, ook uit staatsrechtelijk oogpunt zo belangrijke Franse revolutie, opperde ene Boissy d'Anglas filosoferend over de wijze waarop het nog zo prille tweekamerstelsel in de nieuwe Republiek zou moeten functioneren: 'les Cinq-Cents (de Volkskamer) sont 'l'imagination de la République' et les Ancien (de Senaat) 'la raison de la République'. Het is hoe dan ook interessant om eens te onderzoeken in hoeverre en op welke wijze deze sterk rechtstatelijk gefundeerde visic ook in de 21e eeuw in een aantal West Europese democratieèn nog realiteitswaarde blijkt te bezitten. 



\section{Hoofdstuk 2}

\section{Historische ontwikkeling}

\section{$2.1 \quad$ Inleiding}

Il y a toujours dans un Etat des gens distingués par naissance, les richesses ou les honneurs; mais s'ils étaient confondus parmi le peuple et s'ils n'y avaient qu'une voix comme les autres, la liberté commune senait leur esclavage, et ils n'auraient aucun intènt à la deffendrv, parce que la plupart des résolutions seraient contre eux. La part qu'ils ont à la législation doit done étre proportionnée aux autres avantages qu'ils ont dans l'état; ce qui arrivera s'ils forment un corps qui ait droit d'arnêter les entreprises du peuple, comme le peuple a droit d'arnêter les leurs. (Montesquieu, De l'Esprit des Lois)

De inrichting van de staat in de landen van Europa wordt uiteraard al lang niet meer bepaald door een mengvorm van op elkaar inwerkende monarchale, aristocratische en democratische krachten. De monarchie vervult in West Europa tegenwoordig vrijwel uitsluitend nog ceremoniêle functies, terwijl de aristocratie, met uitzondering van Groot-Brittanniê inmiddels volledig van het overheidstoneel verdwenen is. Toch worden via Montesquieu's visie op de organisatie van de wetgevende macht wel een drietal interessante vragen opgeroepen. Allereerst: als aan een speciale parlementskamer ter behartiging van de belangen van het aristocratische deel van de bevolking op enig moment in de geschiedenis geen behoefte meer was, waarom zijn de vigerende tweekamerstelsels op dat moment dan niet gewoon afgeschaft? En vervolgens: aangezien tweekamerstelsels nog steeds een staatsrechtelijke realiteit zijn; hoe hebben zij zich dan ontwikkeld van aristocratisch bolwerk tot hetgeen zij nu zijn? Tenslotte: verliep die ontwikkeling in de onderzoekslanden op identieke wijze?

Een compact vergelijkend historisch overzicht aangaande de staatsrechtelijke ontwikkeling van het parlementair tweekamerstelsel in de vier onderzoekslanden wordt, in verband met de overzichtelijkheid, hoofdzakelijk gepresenteerd via een gescheiden bespreking per staat (par. $2,2 \mathrm{t} / \mathrm{m} \mathrm{2.5}$ ). In de nabeschouwing zal gepoogd worden enige relevante overeenkomsten en verschillen in rechtsevolutie, alsmede gezamenlijke ontwikkelingslijnen nader te duiden.

\section{$2.2 \quad$ Verenigd Koninkrijk}

\subsubsection{De eerste vijfeeuwen}

Een parlementskamer waar de 'Lord High Chancellor of Great Britain' als 'Speaker' én 'Keeper of the Great Seal' mee debatteert vanuit 'the Woolsack', een indrukwekkende zetel ruim afgezet met wol, 'ten teken van Engeland's grote middeleeuwse welvaart', ' moet wel een lange en rijke historie ten deel zijn gevallen. De wortels van het House of Lords liggen dan ook in de dertiende eeuw. De Engelse koningen uit die tijd plachten regelmatig raadsvergaderingen te beleggen met zowel ridders als burgers uit de steden. Deze raadsvergaderingen, waarin in de loop van de tijd algemene regelgevingvoorstellen voorwerp van

1. O. Hood Phillips", Constitutional and Administrative law, London 1987, p. 160. 
bespreking uit gingen maken, luisterden al snel naar de naam 'parliament' ${ }^{2}$ Tijdens de eerste decennia van de veertiende eeuw ontstond de gewoonte dat de afgevaardigden uit de graafschappen en steden gescheiden gingen vergaderen van de adellijke collega's. Op die wijze werd naast het House of Commons ook het 'Domus Superior' of 'Upperhouse' realiteit. ${ }^{3}$ Hoewel in de loop van de veertiende eeuw duidelijk gesproken kon worden van een zekere institutionalisering van dit tweekamerstelsel, was de enige politicke factor van betekenis in die tijd zonder meer de Koning. Het House of Lords dat rondom het jaar 1500 was samengesteld uit ongeveer 100 leden, bestond uit Lords Spiritual (hogere geestelijken) en Lords Temporal. Deze laatste groep bestond uit graven, baronnen en markiezen met overerfbare titels. ${ }^{4}$ Het automatisme waarmee overerfbare 'Peerages' recht gaven op het lidmaatschap van het House of Lords, kwam op deze wijze tot ontwikkeling. Het aantal Lords Spiritual dat zitting mocht hebben in het Hogerhuis werd structureel behoorlijk verminderd na de roemruchte clash tussen Henry VIII en de paus die weigerde het huwelijk van de Engelse vorst met Catherina van Aragon te ontbinden. Een meerderheid van geestelijken in het Hogerhuis is sindsdien nooit meer voorgekomen.

Halfweg de zestiende eeuw werd duidelijk dat de invloed die de leden van het House of Lords uitoefenden op het wetgevingsproces afbrokkelde ten faveure van de Commons, niet in de laatste plaats omdat de relatie tussen vorst en Hogerhuis in die tijd regelmatig onder druk stond. ${ }^{5}$ Vanzelfsprekende en volledige loyaliteit van de Lords aan de Koning was inmiddels duidelijk geschiedenis geworden. Tijdens de Tudor periode ontstond in feite de klassieke theorie aangaande de Engelse constitutie: een gemengde regeringsvorm waarin de koning het monarchistische element vertegenwoordigde; het House of Lords het aristrocratische en het House of Commons het democratische. Op die wijze werd achteraf voorzien in een theoretische onderbouwing van een in historisch vergelijkend perspectief redelijk genuisloze institutionele ontwikkeling ${ }^{6}$

Minder genuisloos was de Civil-War periode (1649-1660) waarin Engeland het zonder monarch moest stellen en Cromwell een toonaangevende rol speelde. Het Engelse Hogerhuis kwam in die periode 11 jaar lang niet in vergadering bijeen; werd zelfs formeel opgeheven ${ }^{7}$ Op de verdere ontwikkeling van een parlementair stelsel bleek dit alles een heilzame uitwerking te hebben. Na de restauratie in 1660 van Monarchie en Hogerhuis had zich een verdere modificering van de Engelse staatkundige instituties (inperking van de invloed van de monarch en grotere invloed van de Commons op het wetgevingsproces) richting parlementair stelsel voltrokken. De veranderende verhouding Lords-Commons bleek bijvoorbeeld duidelijk uit het gegeven dat amendering van 'financial bills' door het Hogerhuis niet langer getolereerd werd door het Lagerhuis. Een praktijk waar de Lords al snel in bleken te berustten. ${ }^{8}$ Niet vergeten dient te worden dat in die tijd ook de Bill of Rights het licht zag. Daanuit bleek voor

2. F. Longford, A history of the House of Lords, London 1988, p. 28 e.v

3. F. Longford, a.w., p. 31.

4. A. Brown, Parliament 1377-1422, in: R. Davies and J.M. Denton (eds). The English Parliament in the Middle Ages, Collins London 1984, p. 47.

5. F. Longford, a.w... p. 43

6. D. Shell, The House of Lords, London 1992, p. 7.8.

7. Het House of Commons gaf op 19 maart 1649 aan dat het House of Lords beschouwd moest worden als 'useless and dangerous'. Een 'act of parliament' werd dan ook aangenomen 'that from henceforth the House of Lords in Parliament shall be and is wholly abolished and taken away'.

8.

D. Shell, a.w., p. 7-10 
het eerst glashelder dat het parlement inmiddels beschouwd kon worden als een essentieel element in het (overigens ongeschreven) constitutionele raamwerk van Groot-Brittannie.? De geschetste ontwikkeling kon vervolgens anderhalve ceuw lang relatief ongestoord verder evolueren. Daarbij dient wel aangetekend te worden dat de samenstelling van het House of Commons lang sterk aristocratisch getint zou blijven. lets waarin de industriele revolutic en de sterke sociale en economische veranderingen die daarmee gepaard gingen pas structureel wijziging zou brengen. ${ }^{10}$

Wat tijdens de 17 e en 18 e eeuw niet evolueerde was de wijze van benoeming van de 'Peers'. Het koninklijk voorrecht van benoeming bleef volledig intact. Het prerogatief is ook meer dan eens gehanteerd als een belangrijk politiek middel. In 1712 bijvoorbeeld deelde Queen Anne 12 nieuwe overerfbare Peerages uit om er zeker van te kunnen zijn dat het House of Lords in zou stemmen met het Verdrag van Utrecht. ${ }^{11}$

Zo verschoof de (wetgevende) macht in de loop van vijf eeuwen langzaam maar zeker in de richting van een vertegenwoordigend staatsbestel, waarin zowel de Monarch als het Britse Hoger- en Lagerhuis een rol gingen vervullen.

\subsubsection{De 19e eerw}

De overgang van de achttiende naar de negentiende eeuw markeerde een periode van maatschappelijke veranderingen. De impact van de industriele revolutie op de structuur van de Britse samenleving bleek groot te zijn. Daarnaast misten uiteraard ook de ideologische ontwikkelingen ten gevolge van de Franse revolutic en de Amerikaanse vrijheidsstrijd hun invloed op de constitutionele ontwikkelingen in Groot-Brittanniê niet.

De Reform Bill van 1832 voorzag echter op Britse weinig polariserende wijze in aanpassingen aan de nieuwe maatschappelijke realiteit. Het kiesrecht voor de Commons werd uitgebreid naar middenklas groepen uit de (nieuwe) steden. De geografische kaart van stemdistricten werd aangepast in de zin dat de nieuwe verstedelijkte middenklasse een grotere stem kreeg, doch de politieke macht van de plattelandsaristocratie vooralsnog redelijk in tact kon blijven. Dit betekende weer dat de indirecte invloed van de Hogerhuisleden op de landspolitiek via patronage nog decennia lang groot kon blijven. ${ }^{12}$ Zo hadden in het Lagerhuis tussen 1841 en 1847 nog 172 zonen en 27 kleinzonen van Hogerhuisleden zitting. In 1865 waren dat er nog altijd respectievelijk 101 en 15. De zich duidelijk ontwikkelende potentiele suprematie van de Commons (als volksvertegenwoordigend orgaan) op het wetgevingsproces werd op deze wijze nog enige tijd door de aristocratie gereguleerd. ${ }^{13}$ Toch was de weerstand van het House of Lords tegen de Reform Bill groot geweest en stemden de Peers pas in met de veranderingen nadat gedreigd was met massale benoeming van nieuwe leden voor het Britse Hogerhuis door een met de hervormers meewerkende koning. Deze weerstand kwam vooral voort uit de omstandigheid dat het klassiek Britse 'mixed-government'-model (Koning.

9. F. Longford, a.w., p. 96

10. E.A. Smith, The House of Lords in British Politics \& Society 1815-1911, London 1992, p. 2 e.v.

11. O. Hood Phillips', a.w., p. 140,

12. E.A. Smith, a w., p. 116 e.v. Pas na de Reform Act van 1867 zou de invloed van het Hogerhuis op de samenstelling van het Lagerhuis vrijwel gaan verdwijnen.

13. V. Cromwell, Peers and personal networks: the link between the two Houses of Parliament since the midnineteenth century, in: H.W. Blom e.a. (red). Bicameralisme, Tweekamerstelsels vroeger en nu, 's-Gravenhage 1992, p. 383-395. 
Lords, Commons) met aanname van de Bill ten graven leek te worden gedragen. De Koning kwam steeds verder op de achtergrond te staan en over het Hogerhuis werd meer en meer gesproken als een huis van revisie, zoals onder andere bleek uit een commentaar in een gezaghebbende Britse krant: 'It is undoubtedly true, that among the uses of an Upper Chamber ought to be accounted that of checking occasionally the too impetuous flight of popular impulse, and subjecting that which may be but a light or transient caprice, to the test of calm, laborious, and reiterated deliberation'.14

De jaren na 1832 toonden echter aan dat de Britse Senaat goed in staat bleek zich hernieuwd te positioneren. Het House of Commons ging steeds duidelijker de eerste viool spelen in het wetgevingsproces en werd daarbij kritisch doch in eerste instantie niet al te hinderlijk begeleid door de Lords. Het afstemmen van een wetsvoorstel door het Hogerhuis leidde ook niet (meer) automatisch tot de val de regering.

Toonaangevende Hogerhuisleden begonnen zich echter wel zorgen te maken over de status van hun huis: 'The House should be a free, independent House of the Legislature, and that you (collega-Hogerhuisleden) will consider any other more timid or subservient course as at once unworthy of your traditions, unworthy of your honour, and, most of all, unworthy of the nation you serve'. ${ }^{\prime 5}$ Onder invloed van vooral de partijpolitieke ontwikkelingen in de tweede helf van de negentiende eeuw bleek de actualiteitswaarde van Lord Salisbury's woorden vervolgens lang groot. Het ontstaan van moderne strak geleide politieke partijen zorgde voor duidelijke scheidslijnen. Wetsvoorstellen van een door de liberalen gedomineerd Lagerhuis werden 'gereviseerd' door een Conservatief Hogerhuis. Dit betekende dat menig wetsvoorstel de eindstreep niet haalde of werd onderworpen aan de zgn.: 'Referendal theory'. ${ }^{16}$ Wetsvoorstellen die door het House of Commons waren aanvaard werden door de Lords meer dan eens aangehouden tot na de volgende verkiezingen zodat het volk zich via het algemene stemrecht als het ware kon uitspreken over de kwestie.

Their Lordships most militant hours kwamen wellicht tegen het einde van de eeuw toen eerst in 1893 het door de Liberals in het House of Commons aanvaarde wetvoorstel tot zelfbestuur voor de Ieren met grote meerderheid werd verworpen in het Hogerhuis en vervolgens de Lagerhuisverkiezingen van 1895 ook nog eens een solide overwinning voor de Conservatieven opleverde. ${ }^{17}$

\subsubsection{De 20e eeuw}

De serieuze polarisatie die het gevolg was van de geschetste ontwikkelingen trad onverbloemd aan het voetlicht nadat de Liberals de algemene verkiezingen van 1906 bleken te hebben gewonnen. Het leidde er in 1909 zelfs toe dat de begroting door het House of Lords in zijn geheel werd verworpen. ${ }^{18}$ Discussies over het muilkorven van het Hogerhuis laaiden hoog op. De Koning was echter niet genegen om nieuwe (liberale) Peers te benoemen zonder dat eerst de bevolking geraadpleegd werd. De volgende verkiezingen veranderden de machts-

14. In: E.A. Smith, a.w. p. 118. Het betrof een artikel uit de Times van 3 october 1831 .

15. Lord Salisbury in 1868 in het House of Lords.

16. D. Shell, a.w., p. 8 .

17. F. Longford, a.w., p. 118 e,v.

18. En niet zo maar met een nipte meerderheid van stemmen. Uiteindelijk bleken slechts 7 leden van het Britse Hogerhuis hun stem uitgebracht te hebben ter faveure van Lloyd George's budget vooorstellen. Niet minder dan 350 senatoren stemden tegen. 
verhoudingen nauwelijks, waarna het conservatieve Hogerhuis uiteindelijk in 1911, onder dreiging van massale benoeming van nieuwe liberale collega's instemde met de 'Parliament Act' die de invloed van het Hogerhuis op het wetgevingsproces definitief aan banden zou leggen. ${ }^{19}$ Indien het House of Lords in de tockomst niet in zou stemmen met een door de 'Speaker of the Commons' als zodanig gerubriceerde 'Money Bill' (wetsvoorstel van financiẹle aard), zou dit voorstel uiterlijk éen maand later toch kracht van wet krijgen. Overige wetgevingsvoorstellen in formele zin vanuit het House of Commons konden maximaal twee jaar vertraagd worden. Het vetorecht werd de Lords hiermee voorgoed uit handen geslagen. Eén uitzondering op de regel moet hier volledigheidshalve wel vermeld worden: een eventueel wetsvoorstel om een kabinetsperiode te verlengen tot meer dan de toegestane vijf jaar kan ook na 1911 onverkort door een veto van het Hogerhuis getroffen worden. Het moge, afgezet tegen de wettelijke mogelijkheden van vóór 1911 niet meer veel zijn, maar de overgebleven machtsmiddelen werden zeker in den beginne nog met passie en overtuiging gehanteerd door de Lords. ${ }^{20}$

Omdat de Parliament Act van 1911 werd beschouwd als een tijdelijke maatregel, werd in 1917 een commissie bestaande uit 15 Hogerhuisleden en 15 Lagerhuisleden geìnstalleerd die de opdracht mee kreeg te onderzoeken op welke wijze samenstelling en bevoegdheden van het House of Lords nader aangepast zouden kunnen worden aan de moderne tijden ${ }^{21}$ Deze commissie kwam aangaande de wijze van samenstelling van het House of Lords met voorstellen die in essentie bijzonder veel overeenkomst vertoonden met de voorstellen die 83 jaar later (zie hoofdstuk 3) wederom gelanceerd zouden worden. Drievierde deel van het totale aantal Hogerhuisleden zou verkozen moeten worden door middel van indirecte verkiezing via de regio's. De overige Peers zouden benoemd moeten worden door een parlementscommissie. De voorstellen van de Bryce commissie gingen echter verloren in het geweld dat de Eerste Wereldoorlog ook voor Groot-Brittanniè met zich mee bracht.

$\mathrm{Na}$ afloop van de Eerste Wereldoorlog werd de aandacht betreffende het functioneren van het Britse Hogerhuis meer en meer verschoven naar het zo zichtbare gebrek aan democratische legitimatie. Het House of Lords bestond inmiddels, naast enige hoge rechters en cen twintigtal geestelijken, vooral uit een kleine 500 (in hoofdzaak conservatieve) Hereditary Peers. Ook in Groot-Brittanniê werd het in toenemende mate als gekunsteld ervaren dat een uit niet-gekozen leden samengestelde parlementskamer kon beslissen over de vraag of de voortgang van voorliggende wetgevingsvoorstellen al dan niet vertraagd diende te worden (in voorkomende gevallen tot na volgende algemene verkiezingen voor de Commons) ${ }^{22}$ Serieuze pogingen om het House of Lords om te vormen of op te heffen bleven echter uit, niet in de laatste plaats omdat de Conservatieven tijdens vrijwel het gehele interbellum de regeringsmacht konden uitoefenen. Een drietal Private Member Bills die hervorming van het Britse Hogerhuis tot onderwerp hadden, werden tijdens het interbellum (1929, 1933 en 1935) door de zittende regering eenvoudig terzijde geschoven ${ }^{23}$

19. O. Hood Phillips', a.w., p. 140 e.v.

20. De politick zwaar beladen 'home rule bill for Ireland' bijvoorbeeld kon pas kracht van wet krijgen nadat alle denkbare vertragingstechnieken van het House of Lords uitgeput waren.

21. The Bryce Report 1918.

22. D. Shell, a.w., p. 11 .

23. http $/ /$ www. parliament. the-stationery-office.co.uk/pa/ld1997978/ddbrief/ldreform. htm, 30-10-2000. 


\subsubsection{De naoorlogse periode}

Na 1945 ging Labour regeringsverantwoordelijkheid dragen. Het Hogerhuis had zich inmiddels echter vrijwel volledig geschikt in een medewetgevende rol op het tweede plan. Dat van grote partijpolitieke tegenstellingen over het nut van een Hogerhuis in de cerste jaren na de Tweede Wereldoorlog eigenlijk geen sprake was bleek onder meer uit de slotparagraaf van cen 'all-party discussion' uit 1948: 'The House of Lords should continue to play its proper part in the Legislature; and in particular to exercise the valuable functions of revising Bills sent up by the Commons $(. . .)^{2}{ }^{24}$

Hervormingsvoorstellen ingediend tijdens het bewind van de Labourregering konden mede daardoor dan ook een redelijk pacificerend karakter krijgen. De Parliament Act van 1949 (die overigens zonder medewerking van het Hogerhuis tot stand kwam) verkortte de periode dat een door het Lagerhuis aangenomen wetsvoorstel kon worden vertraagd van twee jaar naar één jaar. Over afschaffing of aanpassing van het overerfbare lidmaatschap van het Hogerhuis werd niet gerept. Ook aan zetels van de Lords Spiritual werd niet gezaagd.

Een volgende belangrijke wijziging die in het kader van dit korte historische overzicht over

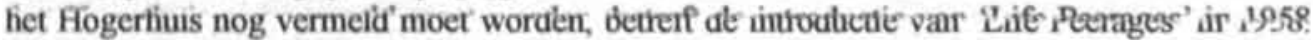
Naast het gegeven dat de democratische legitimatie van het House of Lords volledig ontbrak, kleefde er een belangrijk politiek bezwaar en twee praktische bezwaren aan het benoemingssysteem van Lords, zoals dat al eeuwen lang bestond. Het politieke bezwaar gold het feit dat de 'Hereditary Peers' vrijwel zonder uitzondering met 'blauw bloed' geboren werden. Een gegeven waar de Liberals en de Labour party vanzelfsprekend niet gelukkig mee waren. De praktische bezwaren waren van een andere orde.

In de eerste plaats was het natuurlijk bijzonder goed denkbaar dat de zoon, kleinzoon of achter-achter kleinzoon van een ooit in het Hogerhuis benoemde Lord geen belangstelling bleek te hebben voor het parlementswerk. Dat betekende uiteraard permanente afwezigheid van dergelijke leden. Een tweede nadeel betrof het gegeven dat voor het toch steeds specialisatie vereisende parlementswerk geen 'tijdelijke' (lees: maximaal levenslange) specialisten ingehuurd konden worden. Met de 'Life Peerage Act' van 1958 werd voorzien in een oplossing. Nieuwe Peers waren vanaf dat jaar ook benoembaar voor het leven. $\mathrm{Zij}$ werden vooral gerekruteerd uit de kringen van politici, zakenwereld, vakbond, academici en ambtenarij. ${ }^{25} \mathrm{Na}$ 1958 traden inderdaad verbeteringen op. Peers zonder belangstelling voor het Hogerhuiswerk konden tijdelijk 'leave of absence' vragen. Voor de periode van één of meerdere parlementaire jaren werden deze Peers dan geacht ook niet meer te Westminster te verschijnen. Daarnaast werd door het massaal benoemen van 'Life Peers' veel kennis van zaken in het House of Lords geintroduceerd. Tevens werden vele niet-conservatieve Life Peers benoemd, zodat de enorme getalsmatige dominantie van de Conservatieven in het Hogerhuis enigszins afnam. Een onbedoeld gevolg van de 'Life Peerage Act' tenslotte was de vrij explosieve groei van de groep der zgn. 'Crossbenchers': Peers die een politiek onafhankelijker koers pleegden te varen, dan de Conservatives en de aanhangers van Labour. Crossbenchers achtten zich ook in mindere mate gebonden aan verkiezingsmanifesten ${ }^{26}$

25. J. Griffith and M. Ryle, Parliament, Functions, Practice and Procedures, London 1989, p. 461.

26. J. Griffith, a.w., p. 467. 
Natuurlijk kan ook de Peerage Act uit 1963 niet onvermeld blijven. Tot dat jaar was het voor vrouwen formeel onmogelijk om lid te worden van het House of Lords. Daamaast bleek het eveneens niet mogelijk voor diegenen die via overerfbare titel het recht op een zetel in het Britse Hogerhuis bezaten, om voornoemd recht voor goed op te geven. Dit klemde vooral omdat ambitieuze Hereditary Peers dan nooit een politieke carrière in het House of Commons zouden kunnen nastreven. Ook in Groot-Brittanniê kan immers niemand tegelijkertijd lid zijn van beide parlementskamers. De zaak kwam ten volle in de politieke 'spotlights' te staan nadat Tony Benn, een vooraanstaand lid van het House of Commons (mét aspiraties om ooit regeringsleider te worden), via een sterfgeval in de familie, opgezadeld werd met cen Hereditary Peerage. Ineens raakte hij daardoor zijn Lagerhuiszetel kwijt. Drie jaar later is dan uiteindelijk de wettelijke mogelijkheid geschapen om voor het leven afstand te doen van de 'Peerage'. Naast Tony Benn (die het uiteindelijk heeft weten te schoppen tot lijsttrekker voor Labour) profiteerde bijvoorbeeld ook de Conservatieve Lord Home (die vrijwel direct na aanname van de Peerage Act 1963 regeringsleider werd) ten volle van de formele wijziging. ${ }^{27}$ In 1968 werd een White Paper over 'House of Lords Reform' samengesteld. Daarin werd voorgesteld de Hereditary Peers hun stemrecht in het Hogerhuis te ontnemen. De stemgerechtigde leden van het Hogerhuis zouden in de toekomst nog slechts exclusief en voor het leven benoemd kunnen worden door de Prime Minister. Per saldo zou vooral de invloed van de Crossbench enorm toenemen, indien de plannen werden doorgezet. Uiteindelijk was vooral in het House of Commons te veel oppositie waameembaar tegen de voornemens. ${ }^{28}$

Sindsdien is in Labourkringen een tweetal decennia lang gespeeld met de gedachte het House of Lords dan maar volledig op te heffen. In 1983 werd die voorkeur zelfs opgenomen in het Labour Party verkiezingsmanifest: 'We shall take action to abolish the undemocratic House of Lords as quickly as possible and, as an interim measure, introduce a Bill in the first session of Parliament to remove its legislative powers, with the exception of those which relate to the life of a Parliament'. Labour verloor de verkiezingen in 1983 echter fors en moest nog tot 1997 wachten alvorens zij als New Labour weer eens regeringsmacht mocht gaan uitoefenen. Uit het Labour-verkiezingsmanifest van 1997 werd al duidelijk dat het roer met betrekking tot het bestaansrecht van het House of Lords nogmaals omgegooid was. Het Hogerhuis zou, mits 'more democratic and more representative', haar rol als medewetgevende en het regeringsbeleid controlerende tweede parlementskamer ook in de toekomst mogen blijven spelen. In hoeverre de Labourregering vanaf 1997 de daad ook daadwerkelijk bij het woord heeft gevoegd blijft op deze plaats nog even in het midden. In hoofdstuk 3 zal die problematiek namelijk uitvoerig aan de orde gesteld worden.

27. R. Brazier, Constitutional Practice, Oxford 1988, p. 201-202.

28. Het House of Lords ging akkoord met 251 stemmen vóor en 56 tegen. In het House of Commons stemden echter 270 leden tegen de hervormingsvoorstellen, terwijl slechts 159 leden van het Lagerhuis voor implementering van de voorstellen stemden. 


\section{$2.3 \quad$ Frankrijk}

\subsubsection{Les Etats généraux}

In tegenstelling tot in Groot-Brittanniê waar de ontwikkeling van het parlementaire stelsel werd gekenmerkt door gestage voortgang van het democratiseringsproces in een relatief stabiel politiek klimaat, bleek de staatsrechtelijke ontwikkeling in Frankrijk vooral gekenmerkt te worden door regelmatig optredende politieke instabiliteit.

Tot het revolutiejaar 1789 werden in het centralistisch en absolutistisch geregeerde koninkrijk Frankrijk nauwelijks serieuze pogingen ondernomen om volksvertegenwoordigende organen op enigeriei wijze te betrekken bij het wetgevingsproces. Vanaf de veertiende eeuw tot 1614 liet de Koning zich wel met enige regelmaat (vooral met het oog op het opleggen van belastingen) adviseren door de 'Etats généraux'. Deze Franse Staten-Generaal, waarin de drie standen (geestelijkheid, adel en steden) vertegenwoordigd waren, hebben zeker in de veertiende eeuw ook mogelijkheden gehad om invloed te krijgen op het Franse wetgevings- en beleidsvormingsproces. Onderlinge verdecldheid tussen de standen, beperkte mandaten en in zijn algemeenheid een slechte organisatiestructuur waren er echter debet aan dat de 'Etats généraux' nooit méér geworden zijn dan een relatief onbeduidende semi-adviserende institutie in het absolutistische Frankrijk van het Ancien Régime. ${ }^{29}$ Vanaf 1614 tot 1789 zijn de Franse Staten-Generaal zelfs niet meer in vergadering bijeen geweest.

\subsubsection{De Franse Revolutie}

De Franse constitutionele geschiedenis betreffende de Sénat begint, voor zover van belang in het kader van dit boek, in feite dan ook pas tegen het einde van de achttiende eeuw. De roep om een grondwet werd in deze zowel politick als sociaal zeer turbulente tijd dusdanig groot dat de Koning in 1789 besloot de 'Etats généraux' te laten herleven. Daaruit maakte de revolutionaire burgerlijke 'derde stand' zich al snel los, en proclameerde zichzelf tot 'Assemblée'. Na twee jaar van debat op basis van de gedachten verwoord in de wereldberoemde 'Déclaration des droits de l'homme et du citoyen' ontstond in 1791 de eerste geschreven Franse grondwet waarin democratische aspecten de boventoon voerden. Wetgevende en uitvoerende macht werden vrij strikt gescheiden. De wetgevende macht lag grotendeels ${ }^{30}$ bij de (via censuskiesrecht) gekozen volksvertegenwoordiging die uit slechts één kamer bestond, de 'Assemblée législative'. Tot unicameralisme werd besloten omdat het 'Comité de Constitution' van mening was geweest dat met het creèren van een tweekamerstelsel relatief eenvoudig een nieuw soort aristocratie zou kunnen ontstaan en dàt diende, zo meenden velen in die tijd, vooral voorkomen te worden. De Koning, die de uitvoerende macht zou bezitten, behield met betrekking tot het wetgevingstraject wel een suspensief veto, waardoor wetsvoorstellen waartegen de Koning gekant was maximaal vier jaar tegengehouden zouden kunnen worden. ${ }^{31}$

29. J. Giquel, Droit constititionnel et institutions politiques, Paris 1995, p. 425 e.v.

30. De Koning behield wel de mogelijkheid om wetgevingsvoorstellen van de Assembleé te treffen met een suspensief veto.

31. J-J. Chevaillier. Histoire des institutions et des régimes politiques de la France de 1789 a nos jours, Paris 1991, p. $46 \mathrm{e.v}$. 
Lang heeft de eerste Franse constitutionele monarchie niet stand kunnen houden. De revolutiegeest, de honger naar echte volkssoevereiniteit, maakte handhaving van het koningschap al snel tot een onhoudbare zaak. In 1795 zag een grondwet het licht, waarin de machtenscheiding strikt werd doorgevoerd. De wetgevende macht in de jonge republiek Frankrijk zou gaan berusten bij twee indirect gekozen colleges. De samenstellers van de constitutie hoopten dat op deze wijze de ene kamer een neutraliserende invloed zou hebben op de andere kamer. ${ }^{32}$ Naast de 'Conseil des Cinq Cents' ontstond het 'Conseil des Anciens'. Het eerste Franse tweekamerstelsel, zoals ontworpen in de constitutie van 'I'an III', had in tegenstelling tot het reeds lang bestaande en constitutioneel medegeëvolueerde Britse tweekamerstelsel echter iets kunstmatigs, waardoor nuttig functioneren moeilijk bleek. Reële machtsmiddelen om het beleid van de politiek niet ter verantwoording te roepen uitvoerende macht te kunnen beïnvloeden ontbraken namelijk vrijwel volledig. ${ }^{33}$ De werkverdeling tussen de twee parlementskamers vertoonde overigens veel gelijkenis met de situatie zoals die in Nederland gangbaar zou worden: le Conseil des Cinq-Cents amendeerde of initieerde wetgevingsvoorstellen en le Conseil des Anciens kon die voorstellen vervolgens slechts in zijn geheel aanvaarden of verwerpen $^{34}$

De strikt doorgevoerde machtenscheiding van de constitutie uit 1795 leidde tot een machtsvacuüm dat na de nodige turbulenties uiteindelijk werd ingevuld door Napoleon Bonaparte. In 1799 ontstond een nieuwe grondwet die (althans formeel) tot 1814 dienst zou doen. In die constitutie werd de wetgevende macht complex georganiseerd. Niet éen of twee maar niet minder dan vier organen vormden samen de wetgevingsmachinerie. ${ }^{35}$ Allereerst was daar de 'Conseil d'Etat' die de door de regering, Consul dan wel Keizer gewenste wetgeving voorbereidde ${ }^{36}$ Het 'Tribunat' en het 'Corps législatif' hadden vervolgens slechts het recht om voorstellen tot wet in hun geheel te aanvaarden of te verwerpen. Amendering was niet mogelijk. De 'Sénat conservateur' tenslotte, bekeek of de voorstellen niet in strijd waren met regel en geest van de grondwet. Mocht dit het geval zijn, dan had dit orgaan tot taak de betreffende regelgevingvoorstellen aan te passen. ${ }^{37}$ In de praktijk stond het gehele wetgevingsapparaat volledig in dienst van Bonaparte.

$\mathrm{Na}$ Waterloo en de restauratie van het koningschap ontstond opnieuw een tweekamerstelsel, deze keer echter sterker leunend op het Britse model. Via censuskiesrecht werd de 'Chambre des députés' samengesteld, hetgeen betekende dat ongeveer 90.000 welgestelde Franse staatsburgers van 30 jaar of ouder stemrecht hadden. De andere medewetgevende parlementskamer bestond uit leden die een overerfbaar recht om zitting te hebben op het pluche van de 'Chambre des Pairs' ontvingen uit handen van de Koning. ${ }^{18}$ Bicameralisme kreeg in de Charte van 1814 met name de voorkeur boven unicameralisme omdat na de revolutionaire jaren en de periode Bonaparte zeker ook aangaande het wetgevingsproces behoefte bestond aan structureel verankerde reflexie van serieuzer aard. Van de aristocratische 'Chambre des Pairs' zou

\footnotetext{
32. J-J. Chevailler, a.w., p. 77.

33. J-J. Chevailler, a.w., p. 78.

34. J. Gicquel, a.w., p. 446.

35. J. Gicquel, a.w., p. 447 e,v

36. T. Sauvel, L'Empereur et le Conseil d'État statuant au contentieux, Revue du Droit Politique et de la Science Politique en France et a l'Étranger 1973, p. 1389

37. J. Gicquel, a.w., p. 448.

38. J.J. Chevailler, a.w. p. 140 e.v. De benoeming van Pairs kon ook voor het leven geschiedden, doch van die mogelijkheid werd door Koning Lodewijk XVIII nooit gebruik gemaakt.
} 
als vanzelfsprekend een matigende, regulerende werking uitgaan op het wetgevingsproces, zo was de gedachte ${ }^{39}$ Tijdens de periode $1814-1848$ begonnen langzaam de eerste aanzetten van politicke ministeriele verantwoordelijkheid zichtbaar te worden. ${ }^{40}$

Ten gevolge van de revolutie van 1830 werd besloten het overerfbare lidmaatschap van de 'Chambre des Pairs' maar weer af te schaffen. Het Franse equivalent van de Hereditary Peerage heeft dus 16 jaar stand kunnen houden. Daarvoor in de plaats kwam benoeming voor het leven door de Koning. Deze mocht nieuwe leden slechts kiezen uit limitatief in de wet omschreven categorieèn van 'aanzienlijken'. ${ }^{41}$

$\mathrm{Na}$ het uitroepen van de $2 \mathrm{e}$ republiek in 1848 werd het tweekamerstelsel weer afgezworen. Nodeloze strijd tussen beide kamers zou zo voorkomen worden, was de opinie: 'Or, la lutte en haut c'est l'anarchie en bas, deux Chambres sont donc un principe de désordre' ${ }^{42}$

Naar wat lijkt op een typisch Frans gebruik uit de negentiende eeuw, was ook de constitutie van de $2 \mathrm{e}$ Republick geen lang leven beschoren. Reeds na vier jaar ontstond het $2 \mathrm{e}$ keizerrijk en een daarbij passende grondwet. Dit betekende onder meer, de herintroductie van een tweekamermodel. Naast het gekozen 'Corps législatif' dat wetgeving kon initiëren creserde Lodewijk Napoleon een 'Sénat' bestaande uit 80 voor het leven benoemde leden. Opmerkelijk is het gegeven dat de leden niet uitsluitend gereknuteerd werden vanuit de traditionele kaders. Naast geestelijken en andere rechtsgezinde aanzienlijken benoemde de Keizer ook 'citoyens que l'Empereur juge convenable d'élever à la dignité de sénateur', ${ }^{, 43}$

De Sénat kreeg als belangrijkste taak het toetsen van wetgevingsvoorstellen aan de grondwet. Bij geconstateerde ongrondwettigheid kon de Sénat in principe (met instemming van de uitvoerende macht) eigenmachtig de nodige aanpassingen realiseren. Daarnaast had de Sénat het recht om het Corps législatif te ontbinden. ${ }^{44}$ De organisatie van de staatsinstituties, die in formele zin veel weg had van de situatie ten tijde van Napoleon Bonaparte evolueerde overigens geenszins op gelijke wijze. Vanaf 1860 was duidelijk sprake van een ontwikkeling in de richting van een liberaalparlementaire democratische eenheidsstaat. ${ }^{45}$ Formalisering van de belangrijkste parlementaire tendensen vond plaats in 1870 met de verankering van de politieke ministeriěle verantwoordelijkheid in de grondwet. ${ }^{46}$

\subsubsection{De Republiek}

Belangrijk breckpunt in de ontwikkeling van het Franse tweekamerstelsel vormde het jaar 1875 , toen definitief gekozen werd voor de republikeinse staatsvorm. Vanaf dat moment werd een uit gekozen leden bestaande Sénat, die als medewetgevend orgaan functioneerde naast de (direct via algemeen kiesrecht) gekozen leden van de 'Chambre des députés' een constante staatsrechtelijke en politieke realiteit. In de zich verder ontwikkelende, door partijpolitiek

39. J. Mastias, Titre IV le parlement, Article 24, in: La constitution de la république francaise, Paris 1987, p. 634.

40. J. Gicquel, a.w., p. 450 e.v.

41. J.J Chevailler, a.w., p. 171.

42. Rapport Marrast.

43. J.J. Chevailler, a.w., p. 217.

44. V.A. Ashworth, Le controle de constitutionnalité des lois par le Sénat du Second Empire, Revue du Droit Public et de la Science Politique en France et a I'Êtranger 1994, p. 45.

45. J.J. Chevailler, a.w., p. 221 e.v.

46. C.A.J.M. Kortmann, De Franse Republiek, in: Het staatsrecht van de landen der Europese Gemeenschappen, Deventer 1998, p. 225 . 
gedomineerde, Franse liberaal-democratie bleek bicameralisme goed te kunnen aarden. ${ }^{47} \mathrm{De}$ Sénat was samengesteld uit 225 indirect via departementale organen en gemeenteraden gekozen leden die een mandaat kregen voor 9 jaar, alsmede 75 door de Sénat zelf gekozen leden die onafzetbaar waren. De (bijzonder ingewikkelde) wijze van verkiezing van de Senatoren had tot gevolg dat het Franse Hogerhuis gedomineerd werd door afgevaardigden uit de (in de meeste gevallen erg kleine) gemeenten. De nieuwe rurale elite was enerzijds door en door republikeins gezind, doch anderzijds gekant tegen te rigoureuze veranderingen: 'plus attachée aux réalités de la terre qu'aux spéculations de l'esprit'.

Van eminent belang voor het functioneren van het Franse tweekamerstelsel was het gegeven dat beide Kamers van het parlement (vrijwel) dezelfde rechten toebedeeld kregen. Dit betekende onder meer dat amendering in ieder gewenst stadium van het wetgevingsproces door ieder der Kamers tot de mogelijkheden ging behoren. Het voorstel kon pas kracht van wet krijgen na volledige overeenstemming tussen Sénat en Chambre des députés. Om die overeenstemming te bereiken moest veelvuldig gebruik gemaakt worden van de zgn. 'navette', een pendeldienst tussen de parlementskamers. Vele wetsvoorstellen haalden de eindstreep nooit omdat totale overeenstemming tussen beide parlementskamers (politiek) niet haalbaar bleek te zijn, terwijl in de grondwet geen mogelijkheid was opgenomen tot het eventueel formeren van een conciliatiecommissie. ${ }^{49}$ Deze benuchte periode van het 'bicaméralisme parfait' had ook belangrijke politieke gevolgen op het terrein van de bestuurscontrole. De Sénat beschikte namelijk evenals de Chambre des députés over de mogelijkheid de vertrouwensvraag te hanteren ten opzichte van de regering of individuele ministers. Dat dit recht zeker niet als een dode letter beschouwd moest worden, heeft de Sénat regelmatig geëtaleerd in de periode tot de Tweede Wereldoorlog. ${ }^{50}$ Interessant is het ook nog op te merken dat de Chambre des députés door de President van de republiek slechts ontbonden kon worden na toestemming van de Sénat. ${ }^{51}$ In zijn algemeenheid kan geconstateerd worden dat de politiek relatief instabiele periode van de $3 \mathrm{e}$ republiek ( 95 regeringen) gekenmerkt werd door een groot overwicht van een steeds onevenwichtiger parlement. Het 'bicaméralisme parfait' speelde een duidelijke rol in dit proces.

$\mathrm{Na}$ afloop van de Tweede Wereldoorlog gaf de Franse bevolking via een referendum aan niet verder te willen met de grondwet uit 1875. De vervolgens in het leven geroepen 'Constituante' stelde onder meer voor om het unicameralisme wederom in te voeren. De behoefte aan grotere politieke en bestuurlijke stabiliteit lag ten grondslag aan dit voorstel ${ }^{52}$ Dit eerste grondwetproject werd echter weggestemd bij referendum. Een tweede 'Constituante' had meer succes met haar grondwetsontwerp. In 1946 stemde een (kleine) meerderheid van de Franse kiezers in met de constitutie voor een $4 \mathrm{e}$ Republiek. Daarin was plaats voor twee parlementskamers: de 'Assemblée nationale' en de indirect voor 6 jaar gekozen 'Conseil de la République'. Zoals de naam al doet vermoeden, waren de wetgevende bevoegdheden van het

47. J. Mastias, aw, p. 634 e.v.

48. J-P. Marichy, La deuxième chambre dans la vie politique francaise, Paris 1969, p. 133.

49. J. Gicquel, a.w., p. 470.

50. De Sénat wierp zich vooral tijdens de eerste decennia van de twintigste eeuw regelmatig op als beschermer van het gedachtengoed uit het politieke midden. Dit had tot gevolg dat de kabinetten Briand (1913), Herriot (1925), Tardieu (1930), Laval (1932) en Blum (1937 en 1938) vielen door toedoen van het Franse Hogerhuis.

51. Art. 5 du loi constitutionnel du 25 février 1875.

52. J-J. Chevailler, a.w., p. 510-513. 
nieuwe Franse Hogerhuis echter beperkt. Na aanname van een wetsvoorstel door de Assemblée mocht de Conseil de la République amenderen en adviseren. Aan zowel amendement als advies was de Assemblée op geen enkele wijze gebonden, tenzij een absolute meerderheid van de Conseil de la République via openbare stemming te kennen had gegeven het met de voorstellen van de Assemblée niet eens te zijn. In dat geval was de Assemblée verplicht tot hernieuwde aanname van het wetsontwerp via openbare stemming en met een absolute meerderheid (waarna het wetgevingstraject definitief beëindigd was). ${ }^{53}$ In 1954 werd deze procedure (die in het door parlementarisme gedomineerde Franse staatsbestel niet echt bevredigde) via een grondwetswijziging aangepast. De 'navette' deed haar herintrede, zij het dat tot maximaal honderd dagen na aanname van een wetsvoorstel door de Assemblée nationale 'gependeld' kon worden. Daarna prevaleerde automatisch de visie van de Assemblée nationale. Omdat ook het Frankrijk van de 4e Republiek wederom gekenmerkt werd door grote politieke en staatsrechtelijke instabiliteit ( 25 regeringen in 12 jaar in een tijd dat Frankrijk geconfronteerd werd met belangrijke externe én interne conflicten) ontstaat in Frankrijk het besef dat een stabiel constitutioneel fundament absolute voorwaarde is voor een functionerend staatsbestel. Dat besef ligt ten grondslag aan de teloorgang van de $4 \mathrm{e}$ Republiek en het ontstaan van de 5e Republiek. De door De Gaulle c.s. ontworpen grondwet van 'zijn' 5e Republiek wordt dan ook gekenmerkt door o.a. een aanmerkelijke inperking van de invloed van het parlement ten faveure van de regering en de President van de Republiek. Voor een Sénat met een duidelijk afgebakend takenpakket, bedoeld om een bijdrage te leveren aan de modificatie van een evenwichuger overheid, werd opneuw een plaats in het rranse staatsbestel ingerumd. -

Uiteraard wordt in een volgend hoofdstuk (hoofdstuk 5) uitgebreid aandacht besteed aan de mogelijkheden en onmogelijkheden die de Sénat onder het regime van de 5e Republiek ten dienste zijn gesteld ter effectuering van een evenwichtiger overheidsbeleid. In het kader van dit historische overzicht is het wel van belang hier nog even iets uitgebreider stil te staan bij een (ook reeds in het inleidende hoofdstuk aangehaalde) poging van President de Gaulle uit 1969 , om de invloed van de Sénat aanmerkelijk in te dammen. ${ }^{55}$ Al vanaf het prille begin van de 5e Republick bleek de Franse Hogerhuiskamer haar medewetgevende rechten frequent te hanteren om de plannen van de President en zijn regering te dwarsbomen. Dit was de relatief autoritair regerende De Gaulle ('I'Etat, c'est moi') al snel een doorn in het oog. De openlijke vete tussen de Gaulle en de toenmalige voorzitter van de Sénat, Gaston de Monnerville nam in de loop van de zestiger jaren langzamerhand groteske proporties aan. Daarbij dient men zich te realiseren dat de Franse tweede parlementskamer in meerderheid niet gaullistisch samengesteld was.

In 1968 was de Gaulle het blijkbaar zat en lanceerde voorstellen die in hoofdzaak inhielden dat de Sénat omgevormd zou dienen te worden tot een orgaan met nog slechts adviserende bevoegdheden op het terrein van de wetgeving. Om dit te doen zou natuurlijk wél een grondwetswijziging noodzakelijk zijn. Nu omvat het Franse staatsrecht sinds 1958 ook een mogelijkheid om grondwetswijzigingen doorgevoerd te krijgen zónder medewerking van de parlementkamers. De grondwetgever voor de $5 \mathrm{e}$ Republiek had een dergelijke mogelijkheid in de constitutie van 1958 opgenomen, omdat hoe dan ook voorkomen diende te worden dat

53. F. Goguel, Du Sénat de la Ille à celuit de la Ve, Pouvoirs 1988, p. 5-9.

54. J. Mastias, a.w., p. 636 c.v.

55. De gehele kwestie is grondig en fraai beschreven in: S.E. Finer, Comparative Government, An introduction to the study of politics, Harmondsworth 1985, p. 331-349. 
een of beide parlementskamers semi-permanente 'patstellingen' zoals gebruikelijk ten tijde van de 3e en 4e Republiek zouden kunnen ensceneren. Artikel 11 Constitution 1958 voorzag overeenkomstig die wens in de mogelijkheid dat de President van de Republiek de bevolking rechtstreeks via een bindend referendum mocht consulteren over grondwetswijzigingen aangaande: 'l'organisation du pouvoir public'. Het (in geval van voorgenomen grondwetswijzigingen) normaal gangbare artikel 89 Constitution 1958 zou daarmee volledig omzeild worden. In dat artikel was onder meer opgenomen dat: 'Le projet ou la proposition de révision (de la Constitution EK) doit être voté par les deux assemblées en termes identiques. La révision est définitive après avoir été approuvée par référendum, ${ }^{\text {, }}$.

De Gaulle dacht, gezien de redactie van het artikel, relatief eenvoudig aan te kunnen tonen dat voorstellen tot wijziging van het bevoegdhedenpakket der Franse Sénat onder de paraplu van art. 11 Constitution 1958 voorgelegd mochten worden aan de Franse bevolking. De Conseil d'Etat dacht daar echter anders over. Dit adviserend orgaan achtte de weg via art. 11 onder de gegeven omstandigheden onconstitutioneel. De Gaulle zette echter door. Sterker nog. Via cen en hetzelfde referendum wenste hij niet alleen de Sénat de medewetgevende bevoegdheden te ontnemen. Ook zou de reikwijdte van art. 11 Constitution 1958 uitgebreid mocten worden tot de mogelijkheid voor eventuele amendering van de Grondwet zélf. Tenslotte diende de Franse bevolking zich via één enkel 'oui' of 'non' tevens uit te spreken over de vraag of de voorzitter van de Sénat de aangewezen persoon moest blijven om de functie van President tijdelijk waar te nemen in geval van calamiteiten, zoals overlijden of plotseling ontslag nemen.

Het werd dus 'non'. De Gaulle nam ontslag en de Franse senaatskamer is tot op de dag van vandaag een volledig medewetgevende parlementskamer.

\section{$2.4 \quad$ Nederland}

\subsubsection{Staten-Generaal}

Nu in Nederland in 1998 nog een uitgebreide en heldere dissertatie op de markt is verschenen, die de geschiedenis van de Nederlandse Eerste Kamer tot onderwerp had, ${ }^{57}$ zal ik mij aangaande de ontwikkeling van de Nederlandse senaatskamer vanzelfsprekend beperken tot hoofdlijnen.

In het Bourgondische Nederland van de vijftiende eeuw werden de Staten-Generaal (afgevaardigden uit de provinciale standen) in 1464 te Brugge voor het eerst in gezamenlijke vergadering bijeen geroepen. Hiermee werd door de Graaf van Bourgondiê beoogd noodzakelijke belastingheffingen te kunnen versnellen. ${ }^{5 /}$

$\mathrm{Na}$ het uitbreken van de 80 -jarige oorlog en de daarmee gepaard gaande splitsing tussen het zuidelijke Spaans Nederland en de noordelijke Republiek van de Zeven Verenigde Nederlanden heeft de Staten-Generaal alleen nog in de Noord Nederlandse Republiek (een statenbond) een rol van betekenis kunnen spelen. Gemeenschappelijke aangelegenheden werden aan afgevaardigden uit de autonome provincies voorgelegd. Deze raadpleegden vervolgens hun

57. B. van den Braak. De Eerste Kamer, Geschiedenis, samenstelling en betekenis 1815-1995, Den Haag 1998.

58. R. Wellens, Les Etats-Généraux des Pays-Bas des origines à la fín du règne de Philippe le Beau 1440-1506. Heule 1974, p. 373-377. 
achterban in de Provinciale Statenvergaderingen om dan met hun 'last' terug te keren naar de vergadertafel van de Staten-Generaal. Dat deze wijze van besluitvorming veel tijd in beslag kon nemen moge duidelijk zijn. ${ }^{59}$ Omdat de afgevaardigden voortdurend ruggespraak moesten houden met hun achterban en het ook niet mogelijk was voor de ene stand om de ander weg te stemmen, ontstond er 'geen behoefte aan een tweede kamer naast of binnen de Staten', ${ }^{60}$

Tijdens de periode van de Franse overheersing leerde de zuidelijke Nederlanden het bicameralisme van het Conseil des Cinq Cents en het Conseil des Anciens kennen. In de NoordNederlandse Bataafse Republiek werd tussen 1798 en 1801 kortstondig geëxperimenteerd met een tweekamermodel. ${ }^{61}$

\subsubsection{Het Koninkrijk der Nederlanden}

Bij de totstandkoming in 1815 van de grondwet van de nieuwe eenheidsstaat Koninkrijk der Nederlanden werd vooral door de Zuid Nederlandse adel aangedrongen op het invoeren van een tweekamerstelsel. De positie van vorst en adel behoefde in hun ogen bescherming tegen te grote macht van de volksvertegenwoordiging. Na hevige debatten in een aantal commissies die voorstellen voor de nieuwe grondwet lanceerden, werd geopteerd voor een tweekamerstelsel waarin de leden van de (het 'volk' vertegenwoordigende) Tweede Kamer zouden worden gekozen door provinciale staten, terwijl de Eerste Kamer (Senaat) zou worden samengesteld uit een wisselend aantal $(40-60)$ door de Koning voor het leven benoemde leden. De Senaat kon (in hoofdzaak door de Koning geïnitieerde) formele wetten, nadat deze door de Tweede Kamer waren aangenomen, in zijn geheel aannemen of verwerpen. Het recht van initiatief kreeg de Eerste Kamer niet, evenmin als het recht van amendement. ${ }^{62}$

Belangrijke formele criteria voor de benoeming van de leden waren vermogendheid en levensstijl. De Koning die de Eerste Kamer min of meer beschouwde als zijn persoonlijke werktuig in het formele wetgevingsbedrijf, benoemde de leden geheel naar eigen believen ${ }^{63}$ Deze leden, hoofdzakelijk afkomstig uit de adelstand, waren in de praktijk dan ook trouwe vazallen van de Koning. Zijn wil was wet, hetgeen logischerwijze betekende dat ieder wetgevend initiatief van de Tweede Kamer dat niet overeenkwam met de wensen van de koning, in de Eerste Kamer geen kans maakte. ${ }^{64}$

$\mathrm{Na}$ de afscheiding van Belgie in 1830 veranderde vooralsnog vrijwel niets in de structuur zoals die sinds 1815 voor Tweede en Eerste Kamer had gegolden. Wel werd het aantal leden gereduceerd.

Het beperkt aantal leden, veel absentie (baron van Asbeck bijvoorbeeld kon vijf opeenvolgende jaren niet verschijnen in de Eerste Kamer wegens 'zijnen bijna onafgebroken podagreuzen toestand'), de vaak zeer hoge leeftijd van de voor het leven benoemde leden en het gegeven dat zij slechts als bolwerk voor de troon dienden (en derhalve geen zelfstandige politieke initiatieven dienden te ontwikkelen) zorgden ervoor dat het functioneren van de

59. H.R.B. .M. Kummeling en P. Bovend'Eert, Van Raalte's Het Nederlandse Parlement, Deventer 2000, p. 5.

60. H. de Schepper, De Eerste Kamer in het Verenigd Koninkrijk der Nederlanden, in: A. Postma e.a (red), Aan deze zijde van het Binnenhof. 's-Gravenhage 1990, p. 17.

61. Beide Kamers kwamen voort uit het 'Vertegenwoordigend Lichaam' van de Bataafse Republiek.

62. H. de Schepper, a.w., p. 42 .

63. H. de Schepper, a.w., p. 34

64. H. de Schepper, a.w., p. 49. 
leden van de Eerste Kamer in de periode tot de grondwetsherziening van 1848 gekenmerkt werd door lethargie. ${ }^{65}$ In het zittingsjaar 1836-1837 bijvoorbeeld kwam de Senaat slechts 12 maal voor vergadering bijeen en in het daaropvolgende jaar 14 maal. ${ }^{66}$ De meeste wetsontwerpen werden in feite als hamerstukken door de Senaat geloodst. ${ }^{67}$ Alleen indien de Koning het met de strekking van (reeds door de Tweede Kamer geloodste) wetsvoorstellen niet eens was werd uiteraard actie ondernomen. Het moge dan ook nauwelijks verwondering wekken dat de roep om afschaffing van het tweekamerstelsel toenam. Zover kwam het niet. De grondwetsherziening van 1848 voorzag (naast o.a. politieke ministeriële verantwoordelijkheid) voor de Eerste Kamer in openbaarheid van de vergaderingen en indirecte verkiezing van de senatoren via Provinciale Staten uit de hoogstaangeslagenen der bevolking ${ }^{68}$ Per provincie werd door de statenleden gereknuteerd vanuit de kringen der hoogstaangeslagenen in de grondbelasting, de patentbelasting en de personele belasting. ${ }^{\oplus}$ ledere drie jaar zou eenderde van het totale aantal van 39 leden aftreden. De Nederlandse Senaat was er niet langer slechts als bolwerk voor de troon, doch ook voor de wetgever om: 'overijling te voorkomen en om tijd voor beraad te winnen in ogenblikken van opgewondenheid en verbijsterende driften ${ }^{70}$

De tweede helft van de negentiende ceuw kwam het parlementaire stelsel in Nederland goed tot ontwikkeling. Na een aantal conflicten tussen Koning en Tweede Kamer verminderde ook materieel de invloed van de vorst op het wetgevingsproces snel. De koning probeerde tot ongeveer 1870 nog wel af en toe de Senaat in stelling te brengen tegen hem onwelgevallige wetsvoorstellen. ${ }^{71}$ Met het accepteren door de vorst van de nieuwe staatsrechtelijke en politieke verhoudingen kwam ook aan die praktijk echter een einde. ${ }^{12}$

In 1887 werd het aantal leden uitgebreid en de verkiesbaarheid ook opengesteld voor diegenen die 'gewichtige openbare betrekkingen' bekleden of bekleed hadden. ${ }^{73}$ Tevens werd de mogelijkheid opengesteld voor leden van de Tweede Kamer om initiatiefwetsvoorstellen te komen verdedigen in de Eerste Kamer. ${ }^{74}$

Terwijl tijdens de eerste helft van de negentiende eeuw de verhouding Koning-parlement het centrale element in de ontwikkeling van het parlementaire stelsel in Nederland (en daarmee in de ontwikkeling van de Eerste Kamer) was geweest, verschoof het accent in de tweede helft van de negentiende en het begin van de twintigste eeuw meer en meer naar de (partij)politieke verhoudingen binnen en tussen de parlementskamers. Dit leidde onder meer in toenemende mate tot spanningen en irritaties tussen regering en Tweede Kamer enerzijds en de (regelmatig semi-oppositionele) Eerste Kamer anderzijds. In 1904 kwam het zelfs tot ontbinding

65. G. Beekelaar, Tussen twee revoluticjaren, De Eerste Kamer van 1830 tot 1848, in: A. Postma e.a. (red), Aan deze zijde van het Binnenhof, 's-Gravenhage 1990, p. 88 e.v.

66. Handelingen 1836-1837 en 1837-1838.

67. Handelingen 1835-1840.

68. De keuze voor cen stelsel van indirecte verkiezingen was als politicke deal gekoppeld aan invoering van rechtsreekse verkiezing van de leden der Tweede Kamer.

69. J. Vis, Van ménagerie du Roi tot politiek college, De Eerste Kamer van 1849 tot 1887, uit: Aan deze zijde van het Binnenhof, 's-Gravenhage 1990, p. 163 e.v.

70. Handelingen van de regering en de Staten-Generaal over de herziening der Grondwet 1847-1848.

71. Meest bekende voorbeeld vormde de verwerping door de Eerste Kamer van het wetsontwerp der spoorweg. wet van 1860, hetgeen een kabinetscrisis tot gevolg had.

72. J. Vis, a.w., p. 163 c.v

73. L Prakke, Van links naar rechts, De Eerste Kamer van 1887 tot 1917, in: Aan deze zijde van het Binnenhof, 's-Gravenhage 1990, p. 239e.v.

74. Art. 117 Grondwet 1887. 
van de Eerste Kamer nadat de liberale meerderheid van de Senaat de door de rechtse regering Kuyper ingediende hoger onderwijswet verwierp. ${ }^{75}$

\subsubsection{Algemeen kiesrecht}

De irritaties speelden ook nog door in de discussies rondom de grondwetsherziening van 1922. Daaraan voorafgaande was in 1917 het algemeen kiesrecht grondwettelijk mogelijk gemaakt en werd het lidmaatschap van de Eerste Kamer opengesteld voor iedere Nederlander van dertig jaar of ouder. ${ }^{76}$ Ook had het einde van de Eerste Wereldoorlog iets van het revolutionair élan dat door Europa trok doen overslaan op Nederland. Genoeg om de SDAP te doen besluiten 'arbeiderseisen' te formuleren. ${ }^{17}$ Een van die eisen, de afschaffing van de Eerste Kamer, kreeg een opvallend warm onthaal in het parlement. Zelfs leden van de Tweede Kamer die nu niet bepaald als radicaal te boek stonden, zagen wel iets in het idee om de (in het recente verleden regelmatig politick recalcitrante) Senaat op te heffen. 'Alleen de bodes zouden haar verdwijning betreuren', is dienaangaande een veel geciteerde uitspraak. ${ }^{78}$

De regering zag echter niets in afschaffing van de Eerste Kamer en kwam met suggesties om structuur en bevoegdheden van de Senaat verder te modelleren in de geest van een tijd die verdere democratisering van de staatsinstellingen duidelijk in zich droeg. ${ }^{79}$ Het gevolg was logisch: continuering van het tweekamerstelsel in samenhang met enige aanpassingen betreffende de wijze van verkiezing van de leden der Eerste Kamer. De zittingsdum werd tenggebracht van negen naar zes jaar. Iedere drie jaar zou de helft van de leden vervangen worden. Evenals voor de verkiezing van de leden der Tweede Kamer zou ook voor de verkiezing van de Senatoren gaan gelden dat in de toekomst het stelsel van evenredige vertegenwoordiging bepalend werd. ${ }^{80}$

Een van de belangrijkere gevolgen die de grondwetswijzigingen van 1917 en 1922 (naast relatief stabiele verkiezingsuitslagen) met zich meebrachten, was het gegeven dat de (partij) politieke samenstelling van beide parlementskamers redelijk parallel ging lopen, hetgeen uiteraard een pacificerende uitwerking had op de politieke relatie tussen beide kamers. ${ }^{81}$ Tijdens het interbellum schreef de Nederlandse 'Chambre de réflexion' dan ook niet of nauwelijks aansprekende geschiedenis. Af en toe werd een wetsontwerpje verworpen. Daarbij kan bijvoorbeeld gedacht worden aan zaken als de aankoop van een pand op (what's in a name?) de Kneuterdijk voor de huisvesting van de Raad van State. ${ }^{82}$ Eén uitzondering op voornoemde trend moet volledigheidshalve wel vermeld worden. Een Nederlands-Belgisch traktaat waarin toentertijd zeer gevoelige zaken als het beheer van de Schelde en de aanleg van nieuwe kanalen geregeld zouden worden werd nipt aangenomen door de Tweede Kamer doch tot enthousiasme van menig landgenoot verworpen door de Eerste Kamer. Partijpolitiek

75. B. van den Braak, a.w., p. 146-152.

76. N. Cramer. De Eerste Kamer na 1917 in heroverweging, in: A. Postma e.a. (red), Aan deze zijde van het Binnenhof, 's-Gravenhage 1990, p. 283.

77. N. Cramer, a.w. p. 283

78. J. de Ruwe de, De Eerste Kamer der Staten-Generaal, Gouda 1957, p. 8

79. H.R.B.M. Kumeling en P. Bovend'Eert, a.w., p. $30-33$.

80. N. Cramer, a.w., p. 286-290.

81. N. Cramer, a.w., p. 291 e.v,

82. N. Cramer, a.w., p. 295. 
speelde bij deze beslissing geen rol. Voorstanders van een Eerste Kamer verwezen nog tientallen jaren naar deze zaak ter bepleiting van het nut dezer kamer. ${ }^{83}$

Ook in de eerste decennia na de Tweede Wereldoorlog speelde de Senaat over het algemeen in alle rust en devotie haar rol van heroverweger van wetsvoorstellen. Af en toe een spannende stemming, maar over het algemeen toch vrij braaf de visie van de Tweede Kamer volgend. $^{84}$ De uitbreiding van het aantal leden van 50 naar 75 bracht daarin hoegenaamd geen verandering. Potentieel politiek vuurwerk kan wel voortkomen uit de grondwetsherziening van 1983, waarin de zittingsduur van de Senaat op vier jaar werd gesteld, met gelijktijdig aftreden van al haar leden. Aangezien de leden van de Eerste Kamer wel nog steeds gekozen worden via Provinciale Staten is een vorm van partijpolitieke 'cohabitation' ook in Nederland meer dan pure theorie geworden. Op de rol van 'tweede viool' in het wetgevingsproces die de Eerste Kamer in juridische, maar ook in politieke zin al sinds jaar en dag speelt en waaraan het sinds de tweede helft van de negentiende eeuw in toenemende mate haar bestaansrecht is gaan ontlenen, lijkt dat grosso modo (zie par. 6.5.2) echter nauwelijks invloed te hebben. Toch is tijdens de eerste dagen van de 2 le eeuw door de regering een notitic aan de Tweede Kamer aangeboden waarin onder meer voorgesteld wordt om de situatie zoals die gold vóór 1983 weer te herstellen. ${ }^{85}$ Deze problematiek zal echter niet op deze plaats, doch in par. 6.6.1 verder uitgewerkt worden.

\subsection{De Bondsrepubliek Duitsland}

\subsubsection{Het Heilig Roomse Rijk}

Wie England das parlamentarische Regierungssystem hervorgebracht und Frankreich der Lehre von der Volkssouveränitat Geltung verschafft hat, so kann sich die deutsche Verfassungstradition die Herausbildung eines nur ihr eigentümlichen Staatsorgans zuschreiben: des Bundesrats. ${ }^{86}$

De Duitse Bundesrat is een grondwettelijk verankerd (mede)wetgevend orgaan. In de Duitse staatsrechtelijke literatuur wordt hierover opgemerkt dat sprake is van een institutie die unick is in de wereld. ${ }^{87}$ Vooralsnog in het midden latend of een dergelijk statement daadwerkelijk doel treft, is het in ieder geval zinvol na te gaan in hoeverre structuur en werkwijze van dit federatief medewetgevend orgaan op bondsniveau geworteld zijn in de geschiedenis van de Duitse natie.

In de middeleeuwen kreeg het Heilig Roomse Rijk vorm en ontstond er een Duitse statenbond van honderden naast elkaar liggende zelfstandige gebiedjes en gebieden. Van één grote Duitse nationale staat was in die tijd (in tegenstelling tot onder meer Frankrijk en Engeland waar zich gaandeweg consistente territoriale en staatsrechtelijke eenheden ontwikkelden) absoluut geen sprake.

83. P.J. Oud, Honderd Jaren, Een ecuw van staatkundige vormgeving in Nederland 1840-1940, Assen 1987, p. 252.

84. B. van den Braak, a.w., p. 265.

85. Tweede Kamer 1999-2000, 26976, nr. 1, p. 11-12.

86. D. Wilke und B. Schulte, Der Bundesrat: die staatrechtliche Entwicklung des foderalen Verfassungsorgans, Darmstadt 1990, p. IX.

87. Th. Eschenburg Der Bundesrat 1949-1974, Ein Portrait, 1974, p. 15. 
Vorsten, vrijheren en graven vergaderden, indien dit opportuun bleek, in de optiek van de Keizer. Zo ook in 1663. De Keizer had grote behoefte aan steun vanuit de Duitse statenbond in verband met een dreigende aanval vanuit het Turkse Rijk. De 'Reichstag' kwam echter niet snel tot besluiten zodat zowel de Keizer als talrijke vorsten uit de diverse staatjes vrijwel vijf maanden non-stop vergaderend bijeen waren. Nadat, na ampele besprekingen, uiteindelijk toch de noodzakelijke financièle middelen gegenereerd werden en de vorsten terug konden keren naar hun rijkjes, bleven gezanten achter om de overeenkomst uit te werken. Aangezien er echter voortdurend onopgeloste kwesties bleven bestaan c.q. de kop op staken, ontstond op deze wijze het eerste permanente inter-Duitse (aan last en ruggespraak gebonden) 'wetgevend' orgaan: 'Der Immerwährenden Reichstag'. ${ }^{88}$ Zaken als rijkswetgeving en in het bijzonder rijksbelasting, maakten veelvuldig onderwerp van bespreking uit, waarbij opgemerkt dient te worden dat het in die tijd zeker nog niet het primaire doel van de verschillende partijen was om samen met de Keizer één gezamenlijke wil op rijksniveau te vormen. Veeleer ging het er in de 'Reichstag' om de eigen (semi-federatieve) rechten zo veel mogelijk veilig te stellen.

\subsubsection{De Duitse Bond}

Na de ineenstorting van het Heilige Roopnse Rijk en het intermezzo onder Napoleon Bonaparte ontstond in 1815 de Duitse Bond, waarvan onder meer ook de nodige invloed is uitgegaan op de ontwikkeling van een Bundesratstructuur zoals wij die heden ten dage kennen.

De Duitse Bond kon gekarakteriseerd worden als een statenbond en uitdrukkelijk niet als een bondsstaat. Art 2 van de Weense slotakte: 'In seinem Innern ist die völkerrechtlicher Verein eine Gemeinschaft selbstăndiger unter sich unabhängiger Staaten'. Daarenboven had de Bond geen staatsmacht, niet op wetgevend terrein noch waar het de rechtsmacht betrof. De soevereiniteit van de lidstaten werd in die zin op geen enkele wijze ingeperkt. Wel was het de bedoeling dat de Bond namens de lidstaten verdragen afsloot en in algemene zin optrad als groot-Duitse macht ter verdediging van vrede en veiligheid.

Interessant in het kader van dit boek is het gegeven dat een 'Bundesversammlung' in het leven werd geroepen. Dit orgaan dat met name op het terrein van het civiele recht besluiten mocht nemen die mogelijk gelding kregen in de gehele Bond, vertoonde qua structuur al behoorlijke overeenkomsten met de structuur van de Bundesrat zoals wij die tegenwoordig kennen. Het (in die tijd vooral politick-militaire) gewicht van de staat bepaalde het stemgewicht. Zonder de toestemming van toonaangevende bondsstaten als Pruisen en Oostenrijk kwam dan ook niets van de grond. De gevolmachtigden van één staat mochten de stemmen namens hun vorst of vrijstad slechts in volledige unanimiteit afgeven.

Overigens was de 'Bundesversammlung' voor de heersers (van de politiek bepaald geen cenheid vormende Duitse Bond) in eerste instantie bedoeld om een gemeenschappelijk forum te hebben ter bestrijding van in de negentiende eeuw opkomende tendensen als liberalisme, nationalisme en soevereiniteit voor het volk. ${ }^{89}$

88. K. Reuter, Praxishandbuch Bundesrat, Heidelberg 1991, p. 53.

89. K. Reuter, a.w, p. 56. 


\subsubsection{De Paulskirchenverfassung}

Ten gevolge van de ontwikkelingen die het revolutiejaar 1848 voor de politiek toonaangevende landen van Europa met zich meebracht, zijn ook in de Duitse Bond een tweetal (vrijwel identieke) pogingen ondernomen om de organisatic te moderniseren. De meest in het oog springende poging betrof de zgn.: 'Paulskirchenverfassung'. Daarin werd ter vertegenwoordiging van de verschillende bondsstaten een 'Staatenhaus' in het leven geroepen, dat samen met het democratische 'Volkshaus' de 'Reichstag' zou vormen. Wetgeving kon vervolgens slechts tot stand komen indien daarvoor een meerderheid in beide parlementshuizen te vinden zou zijn. De leden van het Staatenhaus die onafhankelijk van hun moederstaat dienden te functioneren behoorden deels door de regering en deels door de volksvertegenwoordiging gekozen te worden. Met last en ruggespraak zou het derhalve afgelopen zijn. ${ }^{90}$

\subsubsection{Pruisen en het Duitse Rijk}

De politieke realiteit was echter dusdanig dat omstreeks 1850 in de Duitse Bond nog geen ruimte was voor verstrekkende staatsrechtelijke vernieuwingen. Dat zou langzamerhand gaan veranderen met de oprichting van de 'Norddeutschen Bund'. Deze door Bismarck opgerichte bond namelijk, kon na beslechting van het Pruisisch-Oostenrijks conflict beduidend meer dan de voormalige Duitse Bond beschouwd worden als een politieke eenheid. Staatsrechtelijk betekende dit dat de lidstaten delen van hun soevereiniteit overdroegen aan de Bond, die nu dan ook in 'staat' was staatsmacht uit te oefenen. Bij juridische conflicten tussen de rechtsregels van de Noordduitse Bond en een lidstaat gold het adagium: 'Bundesrecht bricht Landesrecht'. ${ }^{91}$

De nieuw opgezette Bondsorganisatie bestond uit een 'Reichstag' van direct gekozen volksvertegenwoordigers, een 'Präsidium' in de persoon van de Koning van Pruisen en een 'Bundesrat'. Een regering op Bondsniveau ontbrak. De macht lag bij het Präsidium, maar vooral bij de Bundesrat, zij het dat zonder de medewerking van Pruisen niets van de grond kon komen. De al redelijk democratisch gelegitimeerde Reichstag mocht mee werken in het wetgevingsproces, maar had nauwelijks macht. ${ }^{92}$ De Bundesrat had via art. 24 van de grondwet zelfs de mogelijkheid om een lastige Reichstag (weliswaar slechts na toestemming van het Präsidium) te ontbinden.

De organisatie van de Bundesrat was ook in de tijd van de Noordduitse Bond en het Duitse Rijk gestructureerd op de inmiddels bekende wijze: leden waren de (vertegenwoordigers van de) vorsten c.q. heersers van de vrijsteden. Er was sprake van gewogen stemrecht waarbij Pruisen de boventoon voerde en grondwetswijzingen zelfs onmogelijk waren zonder medewerking van dat koninkrijk. ${ }^{93}$ Gestemd kon slechts worden per land, waarbij 'dissenting opinions' uit den boze waren. Ook de gezamenlijke vertegenwoordigers konden echter niet naar eigen inzicht beslissen, doch dienden te handelen conform de instructies van hun regering c.q. vorst.

90. Zie art. 96 van de Paulskirchen-Verfassung.

91. Art. 2 Satz 1 van de Verfassung des Norddeutschen Bundes.

92. G. Ziller und G-B Oschatz, Der Bundesrat, Dusseldorf 1998, p. 12-13; K. Reuter, a.w., p. 59 e.v.

93. De 17 stemmen die Pruisen in de Bundesrat toekwamen waren voldoende om een tweederde meerderheid en daarmee een mogelijke grondwetswijziging te allen tijde tegen te houden. 
Omdat ook in het in 1871 ontstane Duitse Rijk de staatsmacht toekwam aan de 'deutschen Fürsten und die Senate der freien Städte in ihre Gesamtheit' en deze verzameling van notabelen door de Bundesrat vertegenwoordigd werd, bleef het belang van voornoemd orgaan tijdens de Keizerlijke periode, zeker formeel, behoorlijk groot. Of, zoals Bismarck het met gevoel voor Pruisische PR placht uit te drukken: 'Das foderative Kollegium übt die Souverănităt des gesamten Reiches aus, denn die Souveränităt ruht nicht beim Kaiser, sie ruht bei der Gesamtheit der verbündeten Regienungen, ${ }^{94}$ Toch zag de staatsrechtelijke en politieke realiteit er aanmerkelijk genuanceerder uit. De Bundesrat kon alle wetsvoorstellen die door de Reichstag aangenomen werden afstemmen. Tevens had zij in tegenstelling tot de volksvertegenwoordiging de mogelijkheid wetsvoorstellen van sancties te voorzien. Afkondiging en uitvoering van wetten behoorden echter expliciet tot de prerogatieven van de Keizer, evenals de verreikende verordeningsbevoegdheid via decreten." Reele ministeriēle verantwoordelijkheid bleck pas na de eerste wereldoorlog (tijdelijk) realiteit te kunnen worden in Duitsland. Een andere kwestie die van grote invloed was op het feitelijk functioneren van de Bundesrat tijdens de keizerlijke periode betrof de (rechts)positie van de Rijkskanselier. Deze persoon die uitvoering gaf aan het Keizerlijk beleid zonder daarvoor (althans tot 1918) overigens enige verantwoording schuldig te zijn aan de volksvertegenwoordiging, drukte een zeer grote stempel op de formeel zo invloedrijke Bundesrat. Als Rijkskanselier was hij namelijk qualitate qua voorzitter met beslissende stem indien de stemmen staakten én had hij zitting in de Bundesrat als gevolmachtigde van Pruisen. ${ }^{96}$ Een en ander had tot gevolg dat de mogelijkheden die de Bundesrat had om de federatieve belangen op Rijksniveau te behartigen geenszins overschat mochten worden en uiteraard vooral dan niet als die federatieve belangen te weinig spoorden met die van Pruisen

Tegelijkertijd moet echter wel onderstreept worden dat het Duitse Rijk in zijn verschijningsvorm een federatieve eenheid vormde, waarin het belang en de invloed van de vorstendommen en vrijsteden op belangrijke terreinen aanzienlijk bleef. De financiêle huishouding van het Rijk bijvoorbeeld werd in hoge mate beïnvloed door overleg tussen de lidstaten, overleg dat plaats vond in het forum dat daarvoor bij uitstek geschikt was: de Bundesrat. ${ }^{97}$

\subsubsection{Weimar}

Als wij de ontwikkeling tot dusverre van de Duitse staat in zijn algemeenheid en van de Bundesrat in het bijzonder overzien, valt op dat democratische tendensen nauwelijks hun invloed hebben kunnen doen gelden. In de Bundesrat werden immers slechts de vorsten van de lidstaten vertegenwoordigd. Regeringen of (voor zover aanwezig) volksvertegenwoordigingen van de aangesloten landen bleven volledig buiten beeld. Dat veranderde na het echec van de Eerste Wereldoorlog en de daarop volgende Novemberrevolutie drastisch. De republick van Weimar ontstond. Gepoogd werd van het oude Duitse Rijk een eenheidsstaat te

94. Rede voor de Reichstag van 19 april 1871.

95. P. Laband, Der Bundesrat, Deutsche Juristen-Zeitung 1911, p. 4.

96. Pruisen kon in de Bundesrat over 17 van de 58 (later 61 ) stemmen vervoegen en had daarmee automatisch de mogelijkheid grondwetswijzigingsvoorstellen definitief te blokkeren, daar hiervoor slechts 14 tegenstemmen nodig waren.

97. M. Seydel, Der Deutsche Bundesrath, in: D. Wilke und B. Schulte (red), Jahrbuch für Gesetzgebung. Verwaltung und Volkswirtschaft im Deutschen Reich 1879, p. 281 e.v. 
maken, waarin 'Die Staatsgewalt vom Volke aus geht' ${ }^{98}$ Dat betekende automatisch dat het politieke belang van de Bundesrat af zou nemen, zo niet geheel zou verdwijnen. In die tijd bleek echter voor het eerst duidelijk dat de 'federatieve' staatsvorm inmiddels toch vrij diep wortel had geschoten. Ook de Bundesrat had zich, als overleg- en beslisorgaan van de lidstaten betreffende bondsaangelegenheden een plaats in het staatsbestel verworven die niet eenvoudig meer weg te denken viel. ${ }^{99}$

Ondanks serieuze pogingen om van Duitsland een gedecentraliseerde democratische eenheidsstaat te maken, bleek voor de grondwet van de nieuwe republiek van Weimar cen bondsstaat toch weer uitgangspunt te zijn, zij het een bondsstaat waarin de invloed van de Länder op het nationale beleid formeel aanmerkelijk gereduceerd was ten opzichte van het recente verleden.

De naam veranderde in Reichsrat, maar de vorm bleef grotendeels dezelfde. Door de Landsregering gevolmachtigde vertegenwoordigers uit de Länder bevolkten de Reichsrat. Die Landsregering kwam tijdens de Weimarperiode overigens wel voort uit c.q. steunde op een Landsparlement dat tot stand was gekomen na algemene en geheime verkiezingen. ${ }^{100}$

Er werd door de gevolmachtigden nog steeds gestemd via gewogen stemrecht, waarbij nu echter het bevolkingsaantal de verdeelsleutel bepaalde. Alle stemmen uit een bepaald land dienden eensgezind afgegeven te worden. Om de invloed van Pruisen in te dammen werd voor dat land een speciale regeling getroffen. ${ }^{101}$

De bevoegdheden van de Reichsrat waren zoals gezegd beperkt ten opzichte van de bevoegdheden van de Bundesrat ten tijde van het Duitse Rijk. De grootste wetgevende invloed was verschoven naar de volksvertegenwoordiging in de Reichstag. De wetgevende taak van de Reichsrat beperkte zich grotendeels tot toestemming of bezwaar aantekenen. In dat laatste geval kon via de Reichspräsident een procedure worden opgestart die uiteindelijk resulteerde in een volksraadpleging over het betreffende wetsvoorstel. Tijdens de jaren van de Weimarrepubliek is het zover echter nooit gekomen. ${ }^{102}$

De machtsovername door Hitler in 1933 betekende het einde van de Reichsrat. Voor overheidsorganen die de Länder vertegenwoordigden was in de nationaal-socialistische cenheidsstaat geen plaats. Het zou gelukkig geen duizend jaar duren voordat de draad weer opgepikt kon worden.

Tussentijds resumerend kan gesteld worden dat Duitsland een staatsrechtelijke ontwikkeling heeft doorgemaakt waarin gaandeweg steeds duidelijker een 'natuurlijke' plaats werd ingenuimd voor de Bundesrat in het wetgevings- en besluitvormingsproces van de federatie als geheel.

Die ontwikkeling heeft er mede zorg voor gedragen dat voor het vanuit internationaal perspectief bezien toch relatief markante instituut Bundesrat plaats ingeruimd kon worden in de staatsstructuur van het naoorlogse democratische Duitsland. Markant met name omdat het

98. Art. 1 Weimarer Reichsverfassung 1919.

99. K. Reuter, a.w., p. 67 e.v.

100. H-H. Lammers, Der Reichsrat, Staats- und Selbstverwaltung 3, 1921-1922, p. 182 e.v.

101. In art. 63 Abs. I Satz 2 van de Weimarer Verfassung was de zgn. 'clausula antiborussica' opgenomen. De helft van de stemmen waar het dichtbevolkte Pruisen recht op had, vielen niet toe aan de landsregering. doch aan Pruisische provinciebesturen. Deze waren bij het uitbrengen van hun stemmen niet gebonden aan de voor het overige geldende eis dat alle stemmen per land gezamenlijk en ecnsgezind uitgebracht moesten worden.

102. K. Reuter, a.w., p. 70 e.v. 
orgaan Bundesrat tot dan toe bepaald niet eenvoudig beschouwd kon worden als een dragende pijler van de parlementaire democratic, terwijl de gedachten van de ontwerpers van de nieuwe grondwet van de 'Bundes Republiek Deutschland' toch onverkort uitgingen naar een krachtige federaal gestructureerde democratie, die in al zijn facetten parlementair gegrond zou zijn. Betreffende het medewetgevende orgaan dat de Länder zou gaan vertegenwoordigen stuitte men daar op problemen. Tot 1918 was de Bundesrat immers (als ondersteunend element voor des keizers politiek) wel vrij krachtig geweest, maar allesbehalve democratisch gelegitimeerd, terwijl de Reichsrat van de Weimarrepublick nu net gekenmerkt werd door een deugdelijke democratische legitimatie in samenhang met een staatsrechtelijk en politiek zwakke positionering in het wetgevings- en besluitvormingsproces.

Vanuit de geschetste ontwikkelingslijnen bleken de discussies in de Parlementarische Rat (die de voorstellen voor een nieuwe grondwet formuleerde) zich dan ook al vrij snel toe te spitsen op de vraag of voor het bepalen van de structuur van een tweede Bondsduitse parlementskamer uitgegaan moest worden van het zgn. 'Senatsprinzip' of van het 'Bundesratprinzip', 103

\subsubsection{Senat oder Bundesrat?}

Voorafgaande aan de aanname van de definitieve versie van Art. 51 GG waarin de samenstelling van de Bundesrat geregeld werd, vond een diepgaande discussie plaats over de vraag of een 'Kamer' die in de bondsstaatconstructie het element 'Land' vertegenwoordigt en uitdraagt, een Senat zou moeten zijn bestaande uit onafhankelijke leden, gekozen door de volksvertegenwoordiging van de Lảnder, dan wel een Bundesrat bestaande uit leden van de Landsregeringen. ${ }^{104}$ De Senat zou bestaan hebben uit ongeveer 50 senatoren die minstens de leeftijd van 40 jaar bereikt moesten hebben. Zij zouden door de Landestag van het betreffende Land gekozen worden voor een termijn die afliep bij de volgende verkiezingen van de Landestag. De gekozen senatoren zouden een afspiegeling moeten vormen van de partijpolitieke verhoudingen in de verschillende Länder. ${ }^{105}$ Een Bundesrat ging bestaan uit ongeveer 45 leden gekozen uit de Landsregeringen door de Landsregeringen. Het aantal leden per Land zou vastgesteld worden naar rato van het aantal inwoners. Alle Bundesratleden afkomstig uit hetzelfde Land zouden slechts unaniem stemgedrag kunnen vertonen in de Bondsduitse senaatskamer. ${ }^{106}$

Interessant zijn een aantal argumenten zoals die gehanteerd werden in de discussie die uiteindelijk geleid heeft tot het verkiezen van de Bundesratvariant boven de Senatvariant: ${ }^{107}$

a. In een bondsstaat is het geheel, zeker als het aankomt op uitvoering van besluiten, afhankelijk van de wil tot samenwerking vanuit de delen. Indien de executieve van de Länder nu via de leden van de Bundesrat actief betrokken zou worden bij het wetgevingsproces van de Bond als geheel, zou de medewerking van een niet te onderschatten machtsfactor in de Lånder op voorhand vrijwel verzekerd zijn.

103. W-R Schenke, Gesetzgebung zwischen Parlamentarismus und Foderalismus, uit: Parlementrecht und Parlementpraxis, Berlin 1989, p. 1485 e.v.

104. Verfassungskonvent Herrenchiemsee 1948.

105. Art. 66 Herrenchiemsee-ontwerp 1948.

106. Artt 66 en 67 Herrenchiemsee-ontwerp 1948.

107. G. Strickrodt, Das Bundesratsmandat, Gebunden und frei, Die Offentliche Verwaltung 1949, p. 321-324. 
b. Door de wijze van benoeming der leden vanuit de regering van de Länder zou de Bundesrat geen (partijpolitieke) kopie van de Bundestag zijn, doch veeleer een orgaan dat door zijn relatieve afstand tot de politieke waan van alle dag een hogere mate van objectiviteit aan de dag zou kunnen leggen ten opzichte van partijpolitieke belangen dan een Senat.

c. Met de benoeming van de leden van de Bundesrat uit de regeringen van de Länder kon ook de daarin aanwezige expertise, alsmede de expertise van het ambtelijk apparaat van de Lănder (m.n. in commissievergaderingen) ingezet worden ter ondersteuning tijdens het wetgevingsproces.

d. Aangezien wetgeving uitgevoerd wordt in de Lănder is een vorm van bemiddeling met betrekking tot de uitvoering (lees het Landsbestuur), zeker bij relatief controversięle wetgeving geen overbodige luxe. De leden van de Bundesrat lijken daartoe geschikt te zijn. Zou geopteerd worden voor de Senatvariant, dan ware het goed denkbaar dat de (door de parlementen van de Länder gekozen) senatoren uit electoraal oogpunt te veel aandacht zouden hebben voor het belang van het Land en niet voor dat van de Bond als geheel. Al deze argumenten lijken met name ingegeven te zijn vanuit doelmatigheidsoverwegingen. De belangrijkste kritiekpunten die tegen de Bundesratvariant werden ingebracht betroffen andere dan doelmatigheidsoverwegingen: er zou geen sprake zijn van voldoende democratische legitimatie nu de leden benoemd zouden worden vanuit de regeringen der Länder en deze grondslag slechts indirect kon leiden naar de werkelijk democratische grondslag van een gekozen Landesparlement. Ook zouden Bundesratleden als leden van de uitvoerende macht der Lănder qualitate qua de voortgang van het wetgevingsproces veelal laten prevaleren boven politiekbeleidsmatige controle (checks and balances).

Na pittige discussies tussen met name de drie grootste Duitse politieke partijen werd uiteindelijk geopteerd voor de Bundesratvariant. Bij dit besluit heeft de 'deutsche Verfassungstradition' een eminente rol vervuld, maar zoals gezegd hebben ook doelmatigheidsoverwegingen sterk meegewogen: 'Es soll der Stärkung des Demokratieprinzips, der Gewaltenteilung, aber auch der Steigerung der Effizienz der staatlichen Aufgabenfüllung dienen', ${ }^{108}$

Zo ontstond in 1949 de Bundesrat in zijn huidige vorm. Een 'Senaat' die een logische plaats heeft gekregen in de Duitse federatieve staatsstructuur. Vanaf 1949 tot 1990 zijn in de samenstelling en organisatiestructuur van de Bundesrat vervolgens geen belangrijke wijzigingen meer doorgevoerd. In dat jaar zijn ten gevolge van de hereniging der beide Duitslanden de vijf Länder van de voormalige DDR toegetreden tot de Bondsrepubliek hetgeen met name tot gevolg had dat de stemverhouding daaraan aangepast diende te worden. Maar daarover meer in het volgende hoofdstuk.

\subsection{Vier trajecten: een nabeschouwing}

Als er iets duidelijk is geworden uit de historische beschouwingen die in dit hoofdstuk zijn opgenomen, dan is het wel dat de staatsrechtelijke ontwikkeling van tweekamerstelsels in de vier onderzoekslanden bepaald niet parallel is gelopen. De gestage vrijwel ononderbroken ontwikkelingslijn van het Britse 'parliament' lijkt nauwelijks vergelijkbaar met het voortdurend gewijzigde 'beleid' (bicameralisme-unicameralisme-bicameralisme enz) dienaangaande 
van de Franse overheden, laat staan met de evolutie van het sterk federatieve, lange tijd nauwelijks democratische gelegitimeerde staatsbestel van de Bondsrepubliek Duitsland. Het nog steeds bestaande benoemingsbeleid voor Britse 'Peers' spoort ook bepaald niet met de (op democratische leest geschoeide) verkiezingsmethoden zoals ontwikkeld in landen als Frankrijk, Nederland en zelfs Duitsland.

Tegelijkertijd kan geconstateerd worden dat Europa ook vroeger allerminst uit elkaar niet te beinvloeden 'eilanden' bestond. De inhoud van de Britse Reform Bill was duidelijk doordrenkt met de gedachten over democratie en volkssoevereiniteit die vanaf 1789 via Frankrijk door Europa trokken. Andersom werd in Frankrijk in 1814 (zij het kortstondig) een tweekamerstelsel naar Brits model geintroduceerd, inclusief overerfbare Peerages. De Nederlandse parlementaire ontwikkeling heeft onder voortdurende invloed gestaan van hetgeen in Frankrijk en (later) Duitsland gebeurde. Het eerste Franse tweekamerstelsel stond model voor het (nog steeds vigerende) Nederlandse. De introductie van de politieke ministeriěle verantwoordelijkheid in 1848 in Nederland kan onmogelijk los gezien worden van de revolutieperikelen die vanuit Frankrijk over West-Europa uitwaaierden. Ook de Duitse democratiseringspoging. inclusief introductie van een tweekamerstelsel, van de 'Paulskirchenverfassung' was een rechtstreeks uitvloeisel van de 'geest' van 1848.

Vanaf het midden van de negentiende eeuw evolueerde het tot dan toe toch in sterke mate als aristocratisch bolwerk van de troon functionerende Hogerhuis van zowel Groot-Brittanniē, Frankrijk als Nederland in de richting van een medewetgevend orgaan, waarvan de gedragingen meer en meer ingegeven en bepaald gingen worden door eigentijdse politiek-ideologische stromingen: conservatisme versus liberalisme, links versus rechts, zij het dat het Britse Hogerhuis verstoken bleef van iedere vorm van democratische legitimatie.

Bezien wij de ontwikkeling van de onderlinge (machts-)verhouding tussen de parlementskamers in de onderzoekslanden iets nauwkeuriger, dan zijn met name voor de drie reeds genoemde eenheidsstaten toch frappante parallellen aanwijsbaar. In zowel Groot-Brittannië, Frankrijk als Nederland werden eind negentiende, begin twintigste eeuw de aanzetten gegeven voor de opbouw van de moderne partijpolitieke organisatiestructuren, die tot op heden gangbaar zijn gebleven. Ten gevolge van de (ten opzichte van het Lagerhuis) afwijkende wijze van verkiezing (indirecte verkiezing en census kiesrecht) c.q. benoeming van Senaatsleden werd het Hogerhuis in alle drie de landen bevolkt door leden met een meestal ${ }^{109}$ 'behoudender' maatschappijvisie dan de collega's van het Lagerhuis. Dit had tot gevolg dat zowel het House of Lords, als de Sénat en de Eerste Kamer in die jaren regelmatig opvallend oppositioneel partijpolitick gestuurd gedrag ten opzichte van regering en House of Commons, Assemblée of Tweede Kamer gingen etaleren, waarbij het hanteren van staatsrechtelijke machtsmiddelen als het verwerpen van wetgevingsvoorstellen (waaronder begrotingen), en het forceren van kabinetscrises niet geschuwd werd. Deze hoogtijdagen van het 'parlementarisme parfait' bleven niet zonder gevolgen. In Groot-Brittanniè ontstond daardoor uiteindelijk de 'Parliament Act' van 1911 die het juridisch instrumentarium dat het House of Lords als medewetgever en bestuurscontroleur nog ten dienste zou staan, drastisch inperkte. In Nederland kroop de Eerste Kamer definitief in zijn schulp nadat een dreigende opheffing rondom 1920 geen doorgang vond. In het superparlementaire Frankrijk van de 3e Republiek duurde

109. De partijpoliticke situatie in 1904 ten tijde van de kamerontbinding door het kabinet Kuyper vormt op deze regel kortstondig een uitzondering. 
het in feite nog tot na de Tweede Wereldoorlog voordat de Sénat als medewetgevend orgaan duidelijk gepositioneerd werd áchter de Assemblée, regering en President.

Reflexie en revisie van wetgeving vanuit een minder gepolitiseerde omgeving dan die van het Lagerhuis lijkt vanaf die tijd in zowel Groot-Brittanniê, Frankrijk als Nederland te worden beschouwd als nieuwe hoofdtaak van de Senaat. ${ }^{110}$

De ontwikkelingslijn van het tweekamerstelsel is daarmee voor zover het de drie eenheidsstaten betreft in grove lijnen geschetst. Het federatieve Duitsland heeft een geheel andere koers gevaren. Tot 1918 nauwelijks beïnvloed door ideeên over machtenscheiding en andere democratiseringsinvloeden, heeft zich met de Bundesrat in de Duitse (staten)Bond (srepubliek) een sterk door Landsregeringen gedomineerd overlegorgaan kunnen ontwikkelen tot medewetgevend orgaan. Dat orgaan werd én wordt ook in het democratische Duitsland beschouwd als stem van de Länder op Bondsniveau, waarmee het tweekamerstelsel zich in de BRD een natuurlijke, niet of nauwelijks uit de staatsorganisatic weg te denken positie lijkt te hebben verworven.

110. Zie ook: M. Wasowicz, Les changements des attributions de la chambre haute des parlements en Europe aux XIXe et au début du XXe siècle, in: H.W. Blom e.a. (red), Bicameralisme, a.w., p. 131-146. 



\section{Hoofdstuk 3}

\section{Verkiezing/benoeming, samenstelling, organisatie}

\subsection{Inleiding}

Electoral systems should be given their proper weight when assessing a country's political system as a whole. Electoral systems should not be looked upon as mere technical details without political consequences. ${ }^{\text {I }}$

Het kiesstelsel, de te hanteren methode om stemmen om te zetten in zetels, staat te boek als een van de belangrijkste elementen van de vertegenwoordigende democratic. ${ }^{2}$ Bevreemden zal deze constatering nauwelijks. Dat de keuze voor een kiesstelsel grote gevolgen heeft voor de wijze waarop al dan niet geregeerd kan worden, is fraai te illustreren aan de hand van de volgende vergelijking: in 1987 behaalden de Britse Liberals en de Social Democrats samen 22.6 procent van het aantal geldig uitgebrachte stemmen bij de algemene parlementsverkiezingen. Dit leverde in het first-past-the-post-systeem slechts 3.4 procent van de beschikbare zetels en een onbeduidend oppositierolletje in het Lagerhuis op. In hetzelfde jaar behaalden de Sociaal-democraten in Finland 24.1 procent van de stemmen, hetgeen hun dankzij een kiesstelsel gebaseerd op evenredige vertegenwoordiging 28 procent van de zetels én regeringsverantwoordelijkheid opleverde. ${ }^{3}$ Kiesstelsels die niet (volledig) gebaseerd zijn op een systeem van evenredige vertegenwoordiging hebben een beduidend grotere mate van disproportionaliteit tussen stemmenaantal en zetelverdeling tot gevolg dan kiesstelsels die dat wel zijn.

Ook kunnen er grote verschillen ontstaan in zetelverdeling in het parlement indien redelijk forse kiesdrempels (BRD) of verkiezing over meerdere kiesrondes (Frankrijk) ingebouwd worden in het vigerende kiesstelsel.

Naar de effecten van kiesstelsels is veel onderzoek verricht. ${ }^{4}$ Vrijwel al die onderzoeken hebben zich echter gericht op de relatie tussen kiesstelsels enerzijds en samenstelling, structuur en/of werkwijze van de politiek belangrijkste parlementskamer anderzijds. Naar de relatie tussen kiesstelsel/benoemingsystemen enerzijds en de positionering van de Senaat tegenover de andere kamer van het parlement en regering anderzijds, is in rechtsvergelijkende zin helaas nauwelijks gericht onderzoek verricht. ${ }^{5}$ En dat, terwijl de verschillen in kiesstelsels/

1. M. Gallagher, Electoral Systems and Voting Behavior, in: M. Rhodes, Developments in West European Politics, London 1997, p. 124.

2. A. Lijphart, Electoral Systems and Party Systems, A study of Twenty-Seven Democracies 1945-1990. Oxford 1994, p. 1.

3. M. Gallagher, a.w... p. 119.

4. Onder andere: A. Lijphart en B. Grofman, Choosing an electoral system, Issues and Alternatives, New York 1984; A. Lijphart, Electoral Systems and Party Systems, a.w.; M. Albrecht, De invloed van het kiesstelsel op de samenstelling van de volksvertegenwoordiging en op de vorming van de regering, dissertatic, Amsterdam 1960; D. Nohlen, Wahlrecht und Parteiensystem, Augsburg 1989.

5. Het betreft hier met name: J. Mastias et J. Grangé, Les secondes chambres du pariement en Europe Occidentale, Paris 1987; H.W. Blom e.a. (red), Bicameralisme, Tweekamersteisels vroeger en nu, Handelingen van de Internationale Conferentie ter gelegenheid van het 175-jarig bestaan van de Eerste Kamer der StatenGeneraal, Den Haag 1992; M. Russell, Reforming the House of Lords, Lessons from Overseas, Oxford $2000 ;$ S.C. Patterson and A. Mughan, Senates, Bicameralism in the contemporary World, Ohio 1999. 
benoemingssystemen betreffende de Senaat in de Europese democratieèn ronduit groot te noemen zijn. Onze onderzoekslanden mogen daarvoor zeker tot voorbeeld dienen. Van deze landen namelijk hanteert Groot-Brittannië nog steeds een zuiver benoemingsstelsel. In de Bondsrepubliek wordt gebruik gemaakt van een afgeleid benoemingsstelsel, gebaseerd op de politieke uitkomst (de regeringsverantwoordelijkheid) van directe verkiezingen. Frankrijk kent evenals Nederland een kiesstelsel waarbij de Senaatsleden indirect gekozen worden. Het Franse kiesstelsel baseert zich daarbij in tegenstelling tot Nederland slechts in zeer geringe mate op het principe van de zuiver evenredige vertegenwoordiging, terwijl in Frankrijk daarenboven per verkiezing maar een beperkt gedeelte van de senaatszetels vacant is.

In dit hoofdstuk wordt de wijze van verkiezing c. q. benoeming van de leden der Senaat in de vier onderzoekslanden per onderzoeksland beschreven en waar nodig al vergeleken. Hoe gaat de verkiezing/benoeming in zijn werk? Ook wordt aandacht besteed aan de vraag hoe de Senaat samengesteld en georganiseerd is. Hoe lang is de zittingstermijn en wat zijn de gevolgen daarvan? Tevens zal in dit hoofdstuk al enige inleidende aandacht besteed worden aan de effecten die vigerende kiesstelsels kunnen hebben op de wijze van (politiek) functioneren van de Senaat. In Frankrijk bijvoorbeeld lijkt een verbinding gelegd te kunnen worden tussen het vigerende kiesstelsel en de vermeend archaïsche benaderingswijze van de Sénat, terwijl in Nederland meermaals gesuggereerd is, dat er wellicht een relatie gesignaleerd zou kunnen worden tussen een in 1983 gedeeltelijk gewijzigd kiesregime en een enigermate gewijzigde politieke cultuur in de opstelling van de Eerste Kamer bij het wetgevingsproces. ${ }^{6}$ Zeker is dat vanuit deNederlandse regering minder dan 20 jaar na dato pogingen ondernomen worden om terug te keren naar het tot 1983 ten behoeve van de Eerste Kamer gehanteerde kiesregime.

\subsection{Groot-Brittannië}

\subsubsection{Benoeming en samenstelling}

Over de spelregels die leiden tot de samenstelling van het Britse House of Lords kunnen wij kort zijn: in alle gevallen is sprake van benoeming der leden op een wijze die (in tegenstelling tot de benoeming van leden van de Duitse Bundesrat) niet terug te voeren is tot enigerlei vorm van democratische legitimatie, of het zou moeten zijn dat de voordracht tot benoeming opgesteld wordt door de zittende Prime Minister. Het betreft dan de benoeming van zowel partijgebonden als onafhankelijke Hogerhuisleden. Het is alleszins mogelijk dat de wijze van benoeming binnenkort partieel gewijzigd zal gaan worden, maar daarover zodadelijk meer.

De formele benoeming van een Lord Temporal (een niet-geestelijk lid van het Britse Hogerhuis) vindt momenteel in ieder geval nog plaats door de Kroon. Benoemingen geschiedden vroeger veelal via een dagvaarding aan het adres van een aspirant-Lord, een zgn. 'Writ of Summons' om te Westminster te verschijnen. De afgelopen decennia vond een (zeldzame) benoeming tot Hereditary Peer plaats via 'Letters Patent', waarin de nieuwe peerage als het ware door de Kroon gecreěerd werd. ${ }^{8}$ Om zitting te mogen nemen in het Hogerhuis moet de

6. Onder andere: A. Postma, De Eerste Kamer timmert aan de weg. Namens 1987, nr. 2, p. 90 e.v.

7. Tweede Kamer 1999-2000, 26976, nr. 1, p. 11-12.

8. R. Brazier, Constitutional Practice, Oxford 1988, p. 198. 
leeftijd van 21 jaar bereikt zijn, ${ }^{9}$ de Peer voldoende solvabel zijn ${ }^{10}$ en niet onvoorwaardelijk veroordeeld op grond van 'treason'."

In het House of Lords kunnen tegenwoordig nog een viertal groepen onderscheiden worden. Allereerst zijn daar de 'Lords Spiritual' of (Aarts)bisschoppen. Lang niet alle Britse bisschoppen hebben een zetel in het Hogerhuis. Maximaal 24 bisschoppen en 2 aartsbisschoppen kunnen tegelijkertijd zitting hebben. Dit impliceert dat de meeste plaatsen ${ }^{12}$ als het ware 'rouleren' tussen de vele bisdommen die Groot-Brittannie rijk is. Indien een bisschop met pensioen moet gaan ( 70 jaar), vervalt de daardoor opengevallen zetel in het Hogerhuis aan de oudste bisschop in functie uit een diocees dat nog geen 'Lord Spiritual' levert. ${ }^{13}$ Inherent aan deze gang van zaken is het toch wel opmerkelijke gegeven dat de meeste bisschoppen ondanks de al vaak gevorderde leeftijd gevoeglijk beschouwd kunnen worden als relatief 'frisse' krachten in een Senaat waar de nodige leden al haast een volwassen leven lang zitting hebben. $^{14}$

Veruit de grootste groep leden van het Britse Hogerhuis was voorafgaande aan de aanname van de 'House of Lords Act 1999' afkomstig uit de rangen van de 'Hereditary Peers'. Deze groep bezit (nog even) het overerfbare op een adellijke titel gebaseerde recht zitting te nemen in het House of Lords. De Peerages stammen uit Engeland en Schotland (vóor 1707). GrootBrittanniē (vanaf 1707) en het United Kingdom (vanaf 1801). ${ }^{15}$

Hereditary Peers waren er ook eind $20 \mathrm{e}$ eeuw nog in vele soorten: hertogen, markiezen, graven en gravinnen, burggraven, baronnen en baronessen. De benoeming werd, zoals reeds gememoreerd, geêffectueerd via een 'Writ of Summons', dan wel de uitgifte van een 'Letter Patent' door de Britse Koning(in). De Prime Minister pleegde jaarlijks, na onder andere advies ingewonnen te hebben bij de leider van de oppositie in het House of Commons, een lijst van kandidaat-Hereditary Peers samen te stellen, waarna benoeming door de Kroon kon plaatsvinden.

Vanaf het aantreden van een nieuwe Labourregering in 1964 is het voor opeenvolgende regeringen min of meer usance geworden geen nieuw overerfbare peerages meer te creèren. Uitzondering op deze ongeschreven regel werd sindsdien nog slechts gevormd door Margareth Thatcher (tegenwoordig zelf als Life Peer lid van het Hogerhuis) die in 1983 meende het initiatief te moeten nemen om toch nog twee nieuwe 'Hereditary Peerages' aan de 785 in die tijd bestaande toe te voegen. ${ }^{16}$

Een Hereditary peerage tot stand gekomen via 'Letters patent' is in de praktijk nauwelijks overdraagbaar aan een vrouw. Dit is dan ook een van de belangrijkste oorzaken geweest voor de vrijwel totale afwezigheid van vrouwen in het House of Lords.

9. Standing Order Nr. 2, 1685. De leeftijdsgrens van 21 jaar is nooit verlaagd. Ook niet nadat de status van volwassene in Groot-Brittanniẽ na wetswijziging niet langer bereikt werd op de $21 \mathrm{e}$, doch op de $18 \mathrm{e}$ verjaardag.

10. Insolvency Act 1986.

11. Forefeiture Act 1870, geamendeerd in de Criminal Law Act 1967.

12. De twee aartsbisschoppen en de bischop van London, Durham en Winchester hebben ambtshalve permanent zitting in het Hogerhuis.

13. F. Bown, Influencing the House of Lords: the Role of the Lords Spiritual 1979-1987, Political Studies 1994, p. 105.

14. D. Shell, The House of Lords, London 1992, p. 30-31.

15. J.A.G. Griffith and M. Ryle, Parliament, Functions. Practice and Procedures, London 1989. p. 458.

16. Onder andere; O. Hood Phillips, Constitutional and Administrative Law, London 1987, p. 159; D. Shell, a.w., p. 33. 
Hoewel sommige ${ }^{17}$ overerfbare zetels ook door vrouwen ingenomen zouden mogen worden ${ }^{18}$, is het aantal vrouwen dat daadwerkelijk een dergelijke zetel in het Britse Hogerhuis 'in her own right' bezit altijd bijzonder klein geweest. ${ }^{19}$

De mogelijkheid om afstand te doen van de verieende rechten bestond (zie ook hoofdstuk 2) tot 1963 eenvoudig niet. ${ }^{20}$ Dat wrong temeer daar in voorkomende gevallen capabele, ambitieuze politici die via geboorte als bijvoorbeeld Earl of Viscount een peerage bezaten, geen ambities richting House of Commons mochten koesteren. Als Hereditary Peer was men qualitate qua lid van het House of Lords en dus nooit lid van het House of Commons. Vanaf 1963 is die regeling echter versoepeld. ${ }^{21}$ Sinds die tijd kan iedere Peer afstand doen van zijn rechten met betrekking tot een Hogerhuiszetel. Geen dode regel trouwens, die 'Peerage Act 1963'. De 14e Earl of Home, Sir Alec Douglas-Home heeft het dankzij de Peerage Act van 1963 linea recta tot Prime Minister geschopt. Hereditary Peers mogen hun rechten als lid van het Britse Hogerhuis uitoefenen vanaf hun 21 e verjaardag. ${ }^{22}$

Onder de (maar liefst) 758 'Peers by succession' die tot oktober 1999 lid waren van het Britse Hogerhuis waren er velen die niets zagen in het bij hun titel horende 'vrijwillige' Hogerhuiswerk, of het eenvoudig te druk hebben met hun leven. Deze Peers hadden de mogelijkheid formeel 'leave of absence' nemen ${ }^{23} \mathrm{Zij}$ gaven dan aan de voorzitter van het Britse Hogerhuis, de Lord Chancellor, te kennen voor de duur van het parlementaire jaar af te zien van alle activiteiten die behoorden bij het lidmaatschap van de Britse Senaat. Hereditary Peers die zonder ooit nog een teken van leven te geven het House of Lords pleegden te mijden, kregen eveneens 'leave of absence'. Al deze Peers werden geacht voor de duur van het parlementaire jaar niet meer deel te nemen aan formele activiteiten van het Hogerhuis.

In 1999 zijn, zoals reeds enige malen aangestipt, grondige wetswijzigingen doorgevoerd aangaande de wijze van samenstelling van het House of Lords. Deze golden met name de groep Hereditary Peers. New Labour had al in het verkiezingsmanifest aangekondigd dat: 'the right of Hereditary Peers to sit and vote in the House of Lords will be ended by statute'. Na de verkiezingsoverwinning van 1997 werd de daad bij het woord gevoerd. In het 'white paper' werd vooralsnog echter niet uitgegaan van totale afschaffing van het recht voor Hereditary Peers zitting te nemen en te stemmen in het House of Lords. ${ }^{24}$ Een voorstel vanuit de Crossbench $^{25}$ om één op de (ongeveer) tien Hereditary Pers als Hogerhuis lid vooralsnog te handhaven in afwachting van verdere (reeds geplande) hervormingen, werd welwillend ontvangen door de regering. Een en ander heeft er uiteindelijk toe geleid dat met ingang van het parle-

17. Indien de pecrage oorspronkelijk gecreêerd werd via cen zgn. 'writ of summons' is voortzetting via de vrouwelijke lijn mogelijk. Een peerage ontstaan via 'Ietters patent from the Sovereign' (de grootste groep) kan uitsluitend aan mannen toevallen.

18. Pogingen om de ongelijkheid op te heffen zijn tot op heden altijd gestrand. Overigens mogen vrouwen hun recht om zitting te hebben in het House of Lords op grond van een hereditary peerage pas uitoefenen sinds de Peerage Act van 1963.

19. In 1998 waren slechts 16 van de 750 overerfbare 'Peerages' in het bezit van vrouwen.

20. Pecrage Act 1963.

21. Zie hoofdstuk 2 .

22. Standing Order nr. 2

23. Standing Order nr. 20. Report from the Select Committee on Leave of Absence, H.L. 60 (1957-8).

24. Modernising Parliament: Reforming the House of Lords, January 1999, Cm4183, Chapter 3, paragraph 2.

25. Het voorstel, gelanceerd door de Convenor van de Crossbenches Lord Weatherhill en onderschreven door de Conservatieven bij monde van Lord Cranborne, wordt tegenwoordig geciteerd als 'the Cranborne/Weatherhill agreement'. 
mentaire jaar 1999-2000 nog 92 Hereditary Peers om zitting en stemrecht hadden in het Britse Hogerhuis. ${ }^{26}$ Inmiddels (september 2001) zijn het er nog 91 . Dit alles dus in afwachting van een (eveneens door de Labourregering te initièren) 'further long-term reform of the House of Lords', die onder meer de totale afschaffing van het fenomeen Hereditary Peerage tot gevolg zal moeten hebben. ${ }^{27}$ Tot die tijd zullen eventueel (ten gevolge van bijvoorbeeld sterfgevallen) nog openvallende Hereditary Peerages overigens niet meer automatisch in handen komen van de erven. Gesloten 'by-elections' waaraan slechts geìnteresseerde leden van de Britse adel mogen deelnemen, bepalen uiteindelijk wie een vacante zetel zal mogen bezet$\operatorname{ten}^{28}$

Nu de omvang van de groep Hereditary Peers zo drastisch is teruggebracht, vormen de 'Life Peers' qua omvang veruit de grootste groep Lords in het Hogerhuis (op 1-9-2001: 592). Life Peers worden evenals de Hereditary Peers benoemd door de Kroon op voordracht van de Prime Minister. Zij worden benoemd voor het leven. Van een overerfbaar recht is hier nooit sprake. $^{29}$

Het creèren van de mogelijkheid om het Britse Hogerhuis verder aan te vullen met 'Life Peerages' bleek om drie redenen uiterst zinvol te zijn. In de eerste plaats omdat ook het Hogerhuis ondanks de beperkingen opgelegd in de 'Parliament Acts' van 1911 en 1949 formeel toch nog altijd vrijwel onverkort medewetgevend orgaan is met een dito work-load. De politieke invloed mag dan sterk ingedamd zijn, dat neemt niet weg dat het praktische legislatieve werk toch gewoon gedaan moet worden. Voor de uitvoering van die legislatieve taken is constante bemanning van de Senaat dan ook een vereiste. In de rangen der Lords Spiritual en de Hereditary Peers viel qualitate qua altijd al een hoge mate van absenteīsme te noteren. Ook kon waargenomen worden dat Hereditary Peers in voorkomende gevallen eenvoudig de intellectuele bagage misten om met vrucht werkzaam te kunnen zijn in het Hogerhuis. ${ }^{30}$ Aan voornoemde bezwaren werd effectief tegemoet gekomen door het rekruteren van grote groepen Life Peers ('working Peers') vanuit de kringen van o.a. het House of Commons. Daarbij dient gedacht te worden aan voormalige MP's (vaker tevens lid van een aftredende regering) die het Westminster-leven nog niet op wilden geven. Politiek belangrijker zijn echter de tot ministers van de zittende regering benoemde Life Peers die het als centrale taak dienen te beschouwen om nieuwe wetgevingsvoorstellen van 'hun ploeg' uit het House of Commons zonder al te veel vertraging door het Hogerhuis te loodsen. ${ }^{31}$ In de literatuur wordt nu en dan geopperd dat het werk- en denkniveau, zoals geëtaleerd door de Life Peers, hoogst waarschijnlijk niet geëvenaard zou kunnen worden door democratisch gekozen senatoren. ${ }^{32}$

In de tweede plaats werd met de introductie van Life Peers de mogelijkheid geopend het Hogerhuis partieel op semi-corporatieve basis te doen samenstellen. Niet slechts afgevaardigden van de adel, maar ook afgevaardigden uit andere maatschappelijke groeperingen zoals

28. House of Lords Act 1999, section 2.

29. Life Peerage Act 1958.

30. D. Shell, a.w., p. 29-64.

31. P. Cowley, and D. Melhuish, Peers' Careers: Ministers in the House of Lords, 1965-95, in: Political Studies, 1997, p. 20-35.

32. B. Thompson, Constitutional \& Administrative Law, London 1993, p. 179 
zakenmensen, vakbondsmensen, wetenschappers, militairen, artsen, advocaten, ambtenaren en journalisten kregen zitting in de Britse senaatskamer. ${ }^{33}$

De derde reden was van partijpolitieke aard. Via benoeming van Peers voor het leven was het mogelijk grotere groepen aanhangers van niet-conservatieve huize toe te voegen aan een tot dan toe voor vrijwel $100 \%$ door Conservatieven gedomineerd Hogerhuis. ${ }^{34}$ Naast Life Peers van zuivere Labour- en Sociaal Democratische huize ontstond er ook een grote groep zgn. 'Crossbenchers', partijpolitick onafhankelijker leden afkomstig uit alle maatschappelijke geledingen, die hun benaming dankten aan het feit dat hun zetels in het Hogerhuis haaks gesitueerd waren ten opzichte van de zetels van de overige leden van het House of Lords.

Als een uitvloeisel van de House of Lords Act 1999 heeft de Labourregering onder Tony Blair maar liefst 180 nieuwe Life Peers (waaronder vele Peers van Labourhuize) benoemd. Deels is dit gebeurd om de belofte uit het verkiezingsmanifest dat geen enkele partij meer zou mogen beschikken over een vanzelfsprekende meerderheid in het House of Lords daadwerkelijk te verwezenlijken. ${ }^{35}$ Deels ook om een voldoende bemanning van de tweede parlementskamer (en de daarvoor werkzame commissies) te kunnen blijven garanderen.

Het House of Lords is niet slechts medewetgevend orgaan maar ook de hoogste beroepsinstantie in het Britse rechtssysteem. Dat heeft onder meer tot directe consequentie dat een twintigtal (waarvan maximaal elf actief rechtsprekende Lords of Appeal in Ordinary ${ }^{36}$ ) voor het leven benoemde 'Law Lords' zitting hebben in het Hogerhuis. ${ }^{37}$ In tegenstelling tot de bisschoppen verliezen deze rechters hun zetel in de Senaat niet bij hun pensioen. Met name de 'gepensioneerde' Law Lords plegen regelmatig nuttige activiteiten te ontplooien op het terrein van de wetgeving en ter verdere juridische uitdieping van het parlementaire debat. ${ }^{38}$

Tenslotte dient nog kort melding gemaakt te worden van een vijftal 'Royal Dukes' die, als lid van het Koninklijk Huis, tot eind 1999 formeel een permanente zetel in het Britse Hogerhuis hadden. Gebruik maken van de rechten die hieraan verbonden waren, deden deze Hertogen niet of nauwelijks, al was het maar omdat op die wijze potentiële politiek controversiěle uitspraken gedaan als lid van het Parlement in ieder geval nooit opgetekend zouden kunnen worden uit de mond van bijvoorbeeld een beoogd troonopvolger.

\subsubsection{Hervormingsvoorstellen}

In hoofdstuk 2 werd reeds kort stilgestaan bij het vanuit politiekstaatsrechtelijk oogpunt zeer markante gegeven dat het ook eind twintigste eeuw nog mogelijk is dat een medewetgevend volksvertegenwoordigend orgaan van een modern West-Europees land als Groot-Brittannië bestaat uit (voor het leven 'or even beyond') door de Kroon benoemde leden, in plaats van uit democratisch gekozen senatoren. Pogingen om het Britse Hogerhuis om te vormen tot een (gedeeltelijk of volledig) democratisch gelegitimeerde tweede parlementskamer zijn er in de loop van de afgelopen eeuw zeker geweest. Reeds in de considerans van de Parliament Act

33. D. Shell, a.w., p. 39-40.

34. Harald Wilson, de Labour Prime Minister regelde in de periode 1964-1970 de benoeming van 78 Life Peers van Labourhuize, 46 onafhankelijke Crossbenchers en slechts 11 Life Lords van Consevatieve huize.

35. 1. Richard and D. Welfare, Unfinished Business, Reforming the House of Lords, Vintage London 1999, p. 103-105.

36. Appellate Jurisdiction Act $1876 \mathrm{en} 1887$.

37. Appellate Jurisdiction Act 1876 en 1877

38. D. Shell, a.w., p. 57-59. 
van 1911 werd de intentie uitgesproken 'to substitute for the House of Lords as it as present exists a second chamber constituted on a popular instead of a hereditary basis' ${ }^{39}$ Tegengas kon echter eveneens genoteerd worden: 'A directly elected Second Chamber, it may be added, would have so much more authority than one built upon nomination, that we may expect rather an addition to, than a subtraction from, the difficulties it creates'. Daarmee werd gedoeld op de hogere politiseringgraad en de effecten die daarvan uit zouden gaan op de verhouding tussen beide pariementskamers. ${ }^{40}$

Zeker tot na de Tweede Wereldoorlog bleef het toch in hoofdzaak bij onvoldragen voorstellen. ${ }^{41}$ Een relatief serieuze poging tot gedeeltelijke hervorming van het Britse Hogerhuis werd ondernomen in $19688^{42}$ Voorstellen werden gelanceerd om de Senaat om te vormen op een dusdanige wijze dat geen enkele politieke groepering meer over een voortdurende automatische meerderheid zou kunnen beschikken. Crossbenchers zouden de partijpolitieke balans in werkbaar evenwicht moeten houden. Uitgewerkte plannen tot afschaffing van de historisch gegroeide benoemingspraktijk ten faveure van enigerlei vorm van 'popular vote' ontbraken vooralsnog echter.

De enige wijziging van betekenis in de samenstelling van het House of Lords is tot vlak voor het einde van de 20e eeuw de Life Peerages Act van 1958 gebleven. Dit kon gebeuren omdat enerzijds de Conservatieven niet ontevreden waren met hun automatische meerderheid in het Hogerhuis en anderzijds opeenvolgende regeringen van zowel Conservative- als Labourhuize een niet democratisch gelegitimeerde (en daardoor politiek relatief zwakke) tweede parlementskamer bepaald niet onpraktisch bleken te vinden.

De getalsmatige Conservatieve kracht in het Hogerhuis heeft uiteraard welhaast vanzelfsprekend tot gevolg gehad dat hervormingsinitiatieven meestal ${ }^{43}$ vanuit het Labour kamp geïnitieerd werden. Het ligt dan ook geheel in die lijn, dat de Regering Blair bij het aantreden in 1997 op basis van haar verkiezingsmanifest (nog maar weer eens) te kennen gegeven heeft, serieus werk te willen maken van de omvorming van het House of Lords tot een eigentijds volksvertegenwoordigend orgaan: 'A process of reform to make the House of Lords more democratic and representative' ${ }^{44}$ De daad bij het woord voegend is, zoals reeds meerdere malen gememoreerd, in 1999 als eerste stap in dat proces van hervorming de House of Lords Bill naar het House of Commons gestuurd. In dat stuk werd slechts voorgesteld om allereerst maar eens de vanuit democratisch oogpunt meest pregnante dissonantie, het HereditaryPeerage, qua uitoefenbare parlementaire rechten aan te passen aan de hedendaagse staatsrechtelijke vereisten. Per saldo zou dat neer moeten komen op verwijdering van een substantieel deel contemporaine Britsparlementaire geschiedenis uit het Britse Hogerhuis. Dat is

39. S, De Smith and R. Brazier, Constututional and Administrative law, London 1998, p. 311.

40. H.J. Laski. The problem of a Second Chamber, uit:Studies in Law and Politics, London 1932, p. 113.

41. De 'Bryce conference' van 1917 suggereerde dat het Hogerhuis samengesteld moest gaan worden uit I/4 benoemde en $3 / 4$ indirect gekozen leden. Tot serieuze juridische afwegingen en politicke haalbaarheid van de gelanceerde voorstellen is het nooit gekomen.

42. House of Lords Reform 1968, Cmnd 3799 (1968).

43. Uitzondering op deze regel vormde het Conservative Review Committee van 1978. Deze commissie stelde voor dat het Hogerhuis voor $2 / 3$ e deel zou gaan bestaan uit gekozen leden en voor $1 / 3 \mathrm{e}$ deel uit benoemde leden.

44. Interview met Tony Blair in Today programme, BBC Radio 4, 30 july 1998, afgedrukt in de Times, 31 July 1998. 
dus inmiddels, met inachtneming van de Cranborne/Weatherhill overeenkomst grotendeels gebeurd. ${ }^{45}$

Veel interessanter is echter de vraag, hoe nu verder? Moeten de leden van het House of Lords in de toekomst gekozen gaan worden? En zo ja, via welke methode? Direct of indirect, 'first past the post' of evenredige vertegenwoordiging? Of kan het House of Lords toch maar beter samengesteld blijven worden uit (op enigerlei wijze) benoemde leden?

Alvorens een poging te ondernemen tot het formuleren van een antwoord op die staatsrechtelijk interessante en politiek verstrekkende vragen, heeft de regering Blair een onderzoekscommissie verzocht de materie nader te onderzoeken. ${ }^{46}$ In dat kader dient op deze plaats volledigheidshalve wel nog gewag gemaakt te worden van een nauwelijks mis te verstane passage uit het White Paper van de regering. In die notitie namelijk, werd aan de Royal Commission het advies meegegeven vooral toch ook oog te blijven houden voor de 'more attractive features of the present House', ${ }^{47}$ daarmee doelend op zowel het Crossbench element als de bij Life Peers (dankzij een sterk door het parlementaire werk ingekleurde conduitestaat) ${ }^{48}$ zo duidelijk aanwezige expertise.

Voorafgaande aan de publicatie van het eindrapport eind 1999, is een levendige discussie over deze thematiek op gang gekomen in constitutioneel/politicologisch wetenschappelijke kringen. ${ }^{49}$ Voor- en nadelen van zowel benoeming als verkiezing zijn daarin uitvoerig belicht.

Het meest evidente en meest geciteerde nadeel van benoeming is uiteraard het democratisch deficit en het daarmee gepaard gaande gebrek aan politieke status. Daar staat tegenover dat het Verenigd Koninkrijk desondanks inmiddels zeker ook de nodige positieve gevolgen van het gehanteerde benoemingsbeleid heeft kunnen ervaren. De waaier aan noodzakelijk geachte expertise kan naar believen verbreed worden. Een mogelijkheid waarvan bijvoorbeeld Tony Blair nimschoots gebruik heeft gemaakt via de benoeming van meer dan 200 nieuwe Life Peers sinds 1997. Vertegenwoordiging van minderheden kan eveneens eenvoudig gerealiseerd worden. Aanwezige expertise (via bijvoorbeeld de Law Lords) hoeft lang niet in alle gevallen partijpolitiek gebonden te zijn ${ }^{50}$ De daar uit voortvloeiende mate van onafhankelijkheid zou de kwaliteit van wetgevingsherziening door het House of Lords in gunstige zin kunnen beïnvloeden. En als sterk politiek getint argument pro-benoemingsbeleid moet ten-

45. I. Richard and D. Welfare, a.w., p. 8-9. Zoals uitgelegd in par. 3.2.1 mogen ten gevolge van de Cranborne Weatherhill overeenkomst (zie noot 25) vooralsnog maximaal 92 Hereditary Peers actief blijven in het House of Lords.

46. Royal Commission of the House of Lords, A House for the Future, Cm 4534, january 2000.

47. Modernising Parliament: Reforming the House of Lords, Cm 4183, january 1999, Chapter 8, paragraph 4

48. I. Richard and D. Welfare, a.w., p. 118

49. Zie daartoe onder andere D. Shell, and P. Gidding. The Future of Parliament, Reform of the Second Chamber. The Hansard Society for Parliamentary Government, London 1999: D. Shell. The future of the Second Chamber, in: The Political Quarterly 1999, p. 390-396: I. Richard, and D. Welfare. Unfinished Business, Vintage London 1999; A. Beattie, Why the Case for Parliamentary Reform in Britain is so weak. in: The Journal of Legislative Studies, Vol.4 1998, p. 1-16; D. Shell, The Second Chamber Question, in: The Journal of Legislative Studies, Vol 4 1998, p. 17-32; P. Riddell, The Second Chamber: In Search of a Complementary Role, in: The Political Quarterly 1999, p. 404-410; P. Archer. The House of Lords, Past, Present and Future, in: The Political Quarterly 1999, p. 396-403; V. Bogdanor, Reform of the House of Lords: A Sceptical View, in: The Political Quarterly 1999, p. 375-381, D. Puttnam, A Democratic and Expert House. in: The Political Quarterly 1999, p. 368-373: L. Mclean, Mr Asquith's Unfinished Business, in: The Political Quarterly 1999, p. 382-389.

50. P. Archer, a.w., p. 398. 
slotte nog vermeld worden dat de superioriteit van het House of Commons nooit in het geding zal kunnen komen. ${ }^{51}$

Als typisch Brits nadeel van een systeem gebaseerd op verkiezing wordt allereerst gewezen op de verhouding tot de belangrijkste (sterk door monistische verhoudingen gedomineerde) parlementskamer. De samenstelling daarvan wordt bepaald via het 'first past the post'-systeem. Verkiezing van het Hogerhuis organiseren via een zelfde systeem zou uiteraard welhaast vanzelfsprekend ook daar zorg dragen voor automatische absolute meerderheden en dát wordt voor een parlementskamer die de politiek-juridische herziening c.q. bijstelling van wetsvoorstellen tot hoofdtaak dient te rekenen, bepaald ongewenst geacht. Verkiezing via een systeem van evenredige vertegenwoordiging gaat echter ook niet. In dat geval zou de democratische legitimatie voor het House of Lords immers beduidend 'zuiverder' uitvallen dan momenteel het geval is voor het House of Commons (gekozen via eenvoudige meerderheid per district). En een dergelijke situatie is absoluut ongewenst volgens het eensluidend oordeel van de doctrine. ${ }^{52}$

Uitgaande van de vooronderstelling dat via een toekomstig verkiezings- dan wel benoemingssysteem zowel legitimiteit, onafhankelijkheid als de ondergeschikte relatic tot het House of Commons gewaarborgd dienen te worden, zonder de legislatieve werkzaamheden te laten verworden tot een doublure, opteren de Britse staatsrechtdeskundigen in hoofdzaak voor een gemengd systeem. ${ }^{53}$ 'Looking to the future, it is arguable that the need to mingle expertise and wisdom with politics will be even greater in the years ahead' ${ }^{54}$ Het grootste gedeelte der senatoren (bijvoorbeeld tweederde van het totaal) zou via een verkiezingssysteem gebaseerd op evenredige vertegenwoordiging een zetel kunnen bemachtigen. Dit dient wel te geschieden door middel van indirecte verkiezing van slechts eenderde deel iedere drie of vier jaar, zodat iedere gekozen senator, naar Frans model, negen of twaalf jaar in functie zal zijn. De indirecte verkiezing zou plaats moeten vinden op regionaal/provinciale basis. Op deze wijze, zo is de gedachte, wordt als het ware een afgeleide gecreëerd van de vertegenwoordigingsgedachte die zo kenmerkend is in federatieve staten met bicamerale parlementaire stelsels. Tevens wordt door de keuze voor indirecte verkiezing via een systeem van evenredige vertegenwoordiging van slechts een gedeelte der zittende senatoren de mate van democratische legitimatie ten opzichte van het House of Commons niet te bedreigend. ${ }^{55}$

De op voormelde wijze gekozen senatoren zouden dan gezelschap dienen te krijgen van benoemde collega's, opdat brede expertise, mede met het oog op het inhoudelijk hoogstaande commissiewerk dat het Britse Hogerhuis af pleegt te leveren, ook in de toekomst altijd gegarandeerd kan blijven. De voordracht tot benoeming zou niet langer geheel in handen moeten zijn van de Prime Minister, doch moeten geschieden via een politiek onafhankelijke commissie. $^{56}$

51. P. Ridell, a.w., p. 406.

52. Zie noot 49.

53. Zie o.a: D. Shell and P. Gidding, a.w.; I. Richard and D. Welfare, a.w.

54. D. Shell, a.w., The Political Quarterly 1999, p. 395.

55. Idem.

56. V. Bogdanor, a.w., p. $380-381$. 


\subsubsection{The Royal Commission}

Het cindrapport van de Royal Commission on the Reform of the House of Lords (The Wakeham Report) kwam tijdens de allereerste maand van het nieuwe millennium uit. De adviezen bleken minder vernieuwend te zijn dan het moment wellicht zou suggereren. Een meerderheid van het House of Lords bestaande uit 550 (of méér) leden zou, zo meende de commissie, gewoon benoemd moeten worden, zij het wel via een onafhankelijke benoemingscommissie. ${ }^{57}$ De overige leden zouden (het aantal afhankelijk van het geprefereerde model), gekozen moeten worden via verkiezingen. De wijze van verkiezing verschilt per model. In model $\mathrm{A}$ worden de resultaten van de meest recente verkiezingen voor het House of Commons voor cenderde van het totale Britse kiesterritorium omgerekend van district naar regio. ${ }^{58}$ Op die wijze worden iedere drie jaar de zetels van 65 'gekozen' senatoren ter beschikking gesteld, zodat het democratisch fundament onder het toekomstige House of Lords uiteindelijk zou bestaan uit 195 van de 550 Hogerhuisleden, zijnde $35 \%$ van het total.

De modellen $\mathrm{B}$ en $\mathrm{C}^{59}$ voorzien in aparte senaatsverkiezingen die in de tijd parallel lopen met de verkieringen voor het Europees Parlement. In beide gevallen zouden de verkiezingen direct zijn en plaatsvinden via een systeem van evenredige vertegenwoordiging. Het grote verschil betreft het kiesterritorium. In model B wordt geopteerd voor vijfjaarlijkse verkiezing van 87 afgevaardigden afkomstig uit eenderde deel van het totaal aantal Britse regio's. Op die wijze kunnen de kiezers dus slechts een maal per vijftien jaar hun stem uitbrengen op de senaatskandidaat van hun voorkeur. Mocht deze periode als te lang worden ervaren dan biedt model $\mathrm{C}$ daarvoor de oplossing. Dat model voorziet namelijk in vijfjaarlijkse verkiezing van 65 senatoren (eenderde van het totale aantal senatoren dat via verkiezing in het House of Lords zitting kan nemen) door de gehele kiesgerechtigde Britse bevolking. ${ }^{60}$ De zittingstermijn voor de gekozen senatoren is ook in dit model gesteld op vijftien jaar.

Twee additionele opmerkingen tenslotte nog over de adviezen van de Royal Commission. De voorstellen dienen, aldus de commissie, uitgewerkt te worden op een wijze die een zekere partijpoliticke balans blijvend garandeert. Verder meent de commissie dat de zittingstermijn voor benoemde en gekozen leden identiek moet zijn. ${ }^{61}$

Sindsdien is het vrijwel twee jaar relatief stil gebleven. In publicaties nadien werd regelmatig geopperd, dat langdurige handhaving van de situatie, zoals ontstaan ten gevolge van de House of Lords Act 1999 geenszins ondenkbaar zou zijn. ${ }^{62}$ Vanuit politiek oogpunt lijkt een dergelijke 'oplossing' ook zeer goed te verdedigen. Een democratisch zeer zwak gelegitimeerde senaatskamer samengesteld uit (hoofdzakelijk) Life Peers zal altijd in de schaduw moeten staan van het House of Commons, hetgeen zowel het Lagerhuis als de regering zeker niet onwelgevallig zal zijn. Via continuering van het benoemingsbeleid kan erop toegezien worden dat het Hogerhuis goed geغ̌quipeerd blijft voor het uitoefenen van zijn onderzoeks- en herzieningstaken. De partijpolitieke balans tenslotte is momenteel redelijk in evenwicht, zodat ook

A House for the future, Report of the Royal Commission on the Reform of the House of Lords, January 2000 , p. 117.

A House for the Future, a.w., p. 122-124.

A House for the Future, a.w., p. 124-127.

A House for the Future, a.w., p. 117.

A House for the Future, a.w., p. 116-117.

O.a.: D. Shell and P. Giddings. The Future of Parliament, a.w., p. 19; V. Bogdanor, a. w., p. 380-381. 
voor Labour het belangrijkste bezwaar tegen een niet op 'popular vote' steunende senaatskamer weggevallen is.

November 2001 bracht de regering dan toch het White Paper 'The House of Lords, Completing the Reform' uit. De belangrijkste adviezen uit voornoemd rapport van de Royal Commission zijn overgenomen in dit White Paper. Concreet stelt de regering voor dat viervijfde deel van een toekomstige Britse senaatskamer vanuit 'the major political parties' benoemd zou moeten worden door een onafhankelijke commissie. 'Its political membership should be broadly representative of the main parties relative voting strengths as reflected in the previous General Election' ${ }^{63}$ De overige 120 senatoren zouden gefaseerd gekozen moeten worden ter vertegenwoordiging van de Britse regio's. Voor zowel de wijze van verkiezing als de termijn van benoeming én verkiezing (beide, aldus de regering, liefst te stellen op 15 jaar) verwijst het White Paper naar de opties zoals uitgewerkt (en hierboven beschreven) in het Wakeham rapport uit 1999.

\subsubsection{Organisatie}

Anno 2000 draagt ook de organisatiestructuur van de tweede Britse parlementskamer nog vele kenmerken uit haar markante historie met zich mee.

De plenaire vergaderingen (ongeveer 150 per zittingsjaar) staan formeel onder leiding van de Lord Chancellor. Deze wordt (mede met het oog op zijn taken als prominente Law Lord) benoemd door de Prime Minister en is tevens lid van de zittende regering. Dit betekent dat de Lord Chancellor niet (zoals de Speaker in het House of Commons), 'onpartijdig' moet blijven. Hij/zij mag zich mengen in het debat en is stemgerechtigd. Bij het staken van de stemmen is zijn stem echter niet van doorslaggevende betekenis. ${ }^{64}$ In deze zin speelt de voorzitter van de Britse Senaat een duidelijk andere rol dan de voorzitters van de senaatskamer in de overige drie onderzoekslanden. In zowel Frankrijk, Duitsland als Nederland wordt de voorzitter van de Senaat gekozen uit haar midden, en wordt geacht onpartijdig zijn leidende en sturende functies uit te oefenen.

Commissievergaderingen (zowel de plenaire vergaderingen als de vergaderingen der Select Committees) worden voorgezeten door de 'first Deputy Speaker' kortweg Lord Chairman. $\mathrm{Hij} / z \mathrm{ij}$ komt voort uit de eigen Hogerhuis gelederen. Via typisch Britse informele overlegrondes wordt een goede kandidaat aangezocht, die vervolgens formeel wordt voorgedragen door de Leader of the House. De benoeming moet vervolgens geaccordeerd worden door het plenum. ${ }^{65}$

De Leader of the House wordt, in tegenstelling tot hetgeen dienaangaande opgemerkt is over de Lord Chancellor, geacht zich wél strikt te beperken tot het uitoefenen van de voorzittersrol. ${ }^{66}$ De Lord Chancellor zal tijdens commissiewerkzaamheden vanaf de Frontbench de belangen van de regering zo veel mogelijk proberen te behartigen.

En dan is er ook nog de 'Leader of the House'. Deze wordt evenals de Lord Chancellor benoemd door de Prime Minister. Ook hij is lid van het kabinet. De 'Leader of the House' heeft, samen met de 'Government Chief Whip' de verantwoording waar de voortgang van 'Govern-

63. http:/www.led.gov.uk/constitution/holref/holreform.htm. 27-11-2001

64. D. Shell, The House of Lords, a.w., p. 93 e.v.

65. D. Shell, The House of Lords, a.w., p. 115.

66. B. Thompson, Constitutional \& Administrative Law, London 1993, p. 173 c.v. 
ment business' in het geding is. Dat maakt hem/haar in de Britse parlementaire constellatie tot een belangrijke en invloedrijke persoon. Hij onderhoudt de contacten met de Chief Whips van de politieke partijen. Hij houdt het regeringsbelang in het oog. Hij adviseert het Hogerhuis over orde- en procedureregels en bewaakt een correcte voortgang van de werkzaamheden.

Dat de positie van de 'Leader of the House' van groot praktisch belang is, hangt niet in de laatste plaats samen met twee typisch Britsparlementaire feitelijkheden. Ten eerste dient men zich te realiseren dat 'Government business' in het House of Lords een formele voorrangsstatus (naar bijvoorbeeld Frans model) ontbeert. In laatste instantie kan altijd het Hogerhuis zelf bepalen welke werkzaamheden wanneer gedaan zullen worden. In de tweede plaats echter laat het Hogerhuis zich tevens leiden, door de conventie dat de regering altijd het recht heeft 'to have its business considered ${ }^{67}$ Het is evident dat in een dergelijke setting voortdurend informeel managen een vereiste is. Dit managen gebeurt in voortdurende wisselwerking en op semi-permanente basis door de Leader of the House, de Chief Whips en de Convenor (leider van de Crossbench). Dit groepje vooraanstaande regeineven in het House of Lords luistert naar de benaming 'the Usual Channels., ${ }^{68}$

De wijze waarop het commissiewerk in het Hogerhuis georganiseerd wordt, verschilt aanmerkelijk van de conventies dienaangaande in het Lagerhuis. Standaard commissiewerk, nodig ter (voor)bespreking van de belangrijkste groep wetgevingsvoorstellen, de zgn. Public Bills, geschiedt in de regel niet in departementale commissies, zoals dat in zowel Frankrijk, Duitsland als Nederland wel geschiedt, doch in een 'Committee of the Whole House'. ${ }^{69}$ Iedere die dag aanwezige Peer (als regel in ieder geval belanghebbende leden van de regering en specialisten van de grotere politicke partijen) kan zijn of haar zegje doen tijdens de plenaire commissievergaderingen, Backbenchers zowel als Frontbenchers. Voor het overige onderzoekswerk maakt de Britse Senaat gebruik van 'Select Committees', die zich (al dan niet op ad-hoc basis) berig houden met specifieke onderwerpen van maatschappelijke importantie. ${ }^{70} \mathrm{Zie}$ daarvoor uitgebreid par. 4.7.3.

Van de 1290 leden die het Hogerhuis voor de inwerkingtreding van de House of Lords Act 1999 telde $^{71}$, participeerden gemiddeld nuim 450 Peers bij minimaal $1 / 3$ deel van de jaarlijkse werkzaamheden ${ }^{12}$ Hiermee had het House of Lords qua mankracht van de vier onderzoekslanden veruit het grootste potenticel. Na de inwerkingtreding van de House of Lords Act 1999 is dat potenticel uiteraard flink teruggelopen, doch daar staat tegenover dat de huidige generatie Life Peers (alsmede trouwens ook de resterende Hereditary Peers) frequenter deel plegen te nemen aan de parlementaire werkzaamheden. Per saldo plegen er dan ook nooit moeilijkheden op te treden ten gevolge van een eventueel gebrek aan mankracht, waar de voortgang van het Hogerhuiswerk in het geding is. ${ }^{73}$

67. J. Griffith and M. Ryle, Parliament, Functions, Practice and Procedures, London 1989, p. 464.

68. J. Griffith, a.w., p. 468 .

69. Standing Order nr. 45 .

70. Standing Order nr. 61, 63-5. Relatief vermaard zijn 'the EC Committee' en 'the Science and Technology Committee'.

71. House of Lords website: http:/www. parliament the-stationery-office.co.uk/pa/d/ldhome.htm, gegevens bijgewerkt tot 2 november 1998.

72. Attendance statistics $1996-97$ session.

73. De gemiddelde 'daily attendance' was tijdens het pariementaire jaar 1999-2000 vrijwel 350. Bron:http:/l www.parliament the-stationeryoffice.co.uk/pa/d199900/1dbrief 10402. htm, 11-10-2001. 
Samenstelling van het House of Lords

\begin{tabular}{|c|c|c|}
\hline & $\begin{array}{l}\text { Voor inwerkingtreding van } \\
\text { de House of Lords Act } \\
1999\end{array}$ & $\begin{array}{l}\text { Na inwerkingtreding van } \\
\text { de House of Lords Act } \\
1999\end{array}$ \\
\hline Archbishops and bishops & 26 & 26 \\
\hline Hereditary Peers & 759 & 91 \\
\hline Life Peers & 505 & 586 \\
\hline Total & 1290 & 703 \\
\hline
\end{tabular}

Bron: http://www.parliament.the-stationeryoffice.co.uk/pa/ldI99900/ldbrief/10410.htm, 11 oktober 2001

\subsection{Nederland}

Art. 51-1 Gw: De Staten-Generaal bestaan uit de Tweede en de Eerste Kamer. Art. 53-1 Gw: De leden van beide kamers worden gekozen op de grondslag van evenredige vertegenwoordiging binnen door de wet te stellen grenzen.

Art. 55 Gw: De leden van de Eerste Kamer worden gekozen door de leden van Provinciale Staten. De verkiezing wordt behoudens in geval van ontbinding der kamer gehouden binnen drie maanden na de verkiezing van de leden van Provinciale Staten.

\subsubsection{Verkiezing en samenstelling ${ }^{74}$}

In Nederland wordt de samenstelling van de Senaat niet zoals in Groot-Brittannië en Duitsland bepaald via benoeming, doch via periodieke verkiezingen. Terzijde zij hier allereerst opgemerkt dat de naamgeving van de Nederlandse Senaatskamer: 'Eerste Kamer', zonder meer markant blijft. Ondanks het gegeven dat in Nederland politiekmaterieel de Tweede Kamer sinds jaar en dag onmiskenbaar de eerste viool speelt, heeft de Nederlandse (grond) wetgever het tot nu toe toch nooit voldoende opportuun geacht, deze historisch gegroeide anomalie te corrigeren. Wel stelt artikel $51 \mathrm{Gw}$ dat de Staten-Generaal bestaan uit: 'de Tweede en de Eerste Kamer', daarmee duidend op het gegeven dat de Tweede Kamer het wetgevingsprimaat toekomt.

In tegenstelling tot de Tweede Kamer wordt de Eerste Kamer indirect verkozen door de leden van Provinciale Staten. De verkiezing van alle 75 senatoren vindt normaliter ${ }^{75}$ eens in de vier jaar plaats en wel binnen drie maanden na de directe verkiezing van de leden van Provinciale Staten. $^{76}$

Hoewel formeel indirect gekozen via Provinciale Staten, verschilt de Eerste Kamer qua democratische legitimatie nog slechts in beperkte mate van de Tweede Kamer. Evenals dat bij de

74. In het in 2000 verschenen proefschrift van F. de Vries handelend over de staatsrechtelijke positie van de Eerste Kamer (Deventer 2000), wordt de problematiek rondom de verkiezingswijze van leden van de Nederlandse senaatskamer uitgebreid en gedegen beschreven. Met het oog op die constatering beperk ik mij hier dienaangaande tot het benoemen van de hoofdpunten.

75. Indien de Eerste Kamer tussentijds ontbonden is geweest, zit een vervolgens nieuw gekozen Eerste Kamer niet de volle periode van vier jaar uit, doch slechts de periode lopend tot drie maanden na de volgende provineiale staten verkiezingen.

76. Art. Q 2 Kieswet. De wijze van verkiezing der Leden van de Eerste Kamer is nader uitgewerkt in de hoofdstukken Q, R, S, T en U van de Kieswet. 
Tweede Kamer het geval is, worden alle leden van Provinciale Staten ineens gekozen via een systeem van evenredige vertegenwoordiging. Van speciale territoriale verkiezingsvereisten is geen sprake. Hoewel de leden van Provinciale Staten per provincie in vergadering bijeen komen voor het uitbrengen van hun stem, worden de leden van de Eerste Kamer tegenwoordig wel gekozen in één landelijk kiesgebied. ${ }^{17}$ De verschillen in legitimatie tussen Tweede en Eerste Kamer hebben dan ook vooral betrekking op de opkomst, die voor de verkiezing van provinciale staten standaard beduidend lager uitvalt dan voor de Tweede-Kamerverkiezingen. Van demografische of sociologische verkiezingsvereisten is in Nederland geen sprake.

De wijze van verkiezing heeft onder meer ook tot gevolg dat een nieuw aantredende Eerste Kamer zich kan beroepen op een iets minder zuiver (opkomst) doch recenter kiezersmandaat dan de Tweede Kamer. Een kiezersmandaat dat daarenboven zorggedragen kán hebben voor aanmerkelijke partijpoliticke verschuivingen. ${ }^{78}$

De formele vereisten voor toetreding tot de Nederlandse Eerste en Tweede Kamer verschillen nict. De leeftijdsgrens voor zowel passief als actief kiesrecht voor de Staten-Generaal is 18 jaar (art. $56 \mathrm{Gw}$ ). Toch ligt de gemiddelde leeftijd van de senatoren nog steeds aanmerkelijk hoger, dan de gemiddelde leeftijd van de volksvertegenwoordigers uit de Tweede Kamer. ${ }^{79}$ Evenals dat voor het Britse House of Lords geconstateerd kon worden, blijken in Nederland ook de nodige oud bewindslieden en oud Tweede-Kamerleden nadien te opteren voor verlenging van hun politicke carrière via de senaatskamer. ${ }^{80}$

Partijpolitiek is de samenstelling sinds 1983 vrijwel volledig conform de verkiezingsuitslag van de laatste Provinciale Staten verkiezingen. Afwijkingen kunnen optreden omdat de Kieswet (art. S 8) lijstencombinaties toestaat. Vanaf 1995 bezette dankzij een dergelijke combinatie een afgevaardigde van regionale partijen en de Groenen één zetel in de Eerste Kamer. ${ }^{81}$ Ten gevolge van het geldende kiesstelsel zijn ook in Nederland via de partijpolitieke lijn duidelijke banden waarneembaar tussen de leden van beide Kamers. ${ }^{82}$ In geen van de andere onderzoekslanden wordt via het kiesstelsel/benoemingsstelsel trouwens een grotere politieke evenredigheid in samenstelling van beide parlementskamers teweeggebracht dan in Nederland.

Tot de grondwetswijziging van 1983 werden de leden van de Nederlandse Eerste Kamer indirect gekozen voor zes jaar. Iedere drie jaar werd via de leden van Provinciale Staten de helft van de senatoren ververst. De wijziging in het kiesstelsel van zes naar vier jaar in één kiesdistrict, gepaard gaande met verversing van de volledige Senaat in één keer heeft, zo lijkt het althans, minimaal tijdelijk gevolgen gehad voor de wijze van functioneren van de Eerste Kamer: vanaf de tweede helft van de jaren tachtig wordt de tot dan toe gebruikelijke politieke

77. Wet van 18 mei 1983 , Stb. 238 .

78. Zie ook: H. Kummeling, De Eerste Kamer: Chambre de Révolution?, NJB februari 1990, p. 261 e.v

79. N. Cramer, De Eerste Kamer na 1917 in heroverweging, in: A. Postma e.a. (red), Aan deze zijde van het Binnenhof, SDU 's-Gravenhage 1990, p. 334.

80. B. van den Braak, De Eerste Kamer, Geschiedenis, samenstelling en betekenis 1815-1995, Den Haag 1998 . p. 343-345.

81. Lijst Kuperus. Bron: Statistiek der verkiezingen 1995, provinciale staten 8 maart, CBS 1995, p. 19

82. Dat hier sprake kan zijn meer dan onschuldige theorie bleek onder meer tijdens de algemene beschouwingen van 1988 in de Eerste Kamer. Geirriteerd door de houding van 'zijn eigen' CDA-fractie in de Senaat gaf Minister-president Lubbers aan dat na het na een eventuele ontbinding van de Eerste Kamer bepaald niet vanzelfsprekend was dat dezelfde senatoren wederom gekozen zouden gaan worden. Wijzigingen op een nieuwe CDA-kandidatenlijst waren immers snel door te voeren. 
pacificatietraditie in de verhouding tussen Tweede en Eerste Kamer meermaals relatief nuw doorbroken ${ }^{83}$ De fractievoorzitter van het Christen Democratisch Appel (in die tijd de vaste regeringspartij in Nederland) in de Eerste Kamer signaleerde dat na de grondwetswijziging van 1983 het verschil in politieke legitimatie tussen Eerste- en Tweede-Kamerleden minder geworden was. Het leek dan ook alleen al daarom logisch dat de Eerste Kamer zich politiek assertiever op zou gaan stellen ${ }^{84}$

Het aantal verwerpingen van wetsvoorstellen nam relatief toe in de eerste jaren na de grondwetswijziging van 1983, Ook ventileerde de Eerste Kamer duidelijker dan voorheen haar ongenoegen over de beperkte tijdspanne (reflectie!) waarbinnen tegen het einde van vrijwel ieder kalenderjaar een pakket aan wetgevingsvoorstellen 'heroverwogen' moest worden. ${ }^{85}$ Tegen het einde van de tachtiger jaren speelden daarenboven ook een tweetal kwesties, waarin verkapt (Harmonisatiewet) dan wel openlijk (AOW) in de Eerste Kamer de vertrouwenskwestie werd gesteld door de betreffende minister. In beide gevallen deed de Senaat vervolgens water bij de wijn, maar liet wel bij monde van haar voorzitter weten zichzelf te beschouwen als een democratisch gelegitimeerd politiek orgaan dat serieus genomen wenste te worden (zie uitgebreider hoofdstuk 6) ${ }^{86}$

Vanaf het einde van de tachtiger jaren werd het weer rustiger in de verhouding tussen de Nederlandse senaatskamer en de regering. Tijdens het laatste jaar van het millennium manifesteerde de Nederlandse senaatskamer zich echter nogmaals duidelijk. Een grondwetsherzieningvoorstel dat de mogelijkheid tot het houden van correctieve referenda mogelijk zou moeten maken, behaalde tijdens de tweede lezing in de Eerste Kamer net niet de vereiste tweederde meerderheid. Hoewel op zich vervelend, zou de politieke schade die zo'n besluit teweeg kan brengen nog wel te overzien zijn geweest, ware het niet dat D66, een der coalitiepartners van de zittende regering Kok II, op voorhand had aangegeven uit het kabinet te zullen stappen indien voornoemde stemming negatief uit zou vallen. Omdat de daad ook bij het woord werd gevoegd deed zich in mei 1999 een situatie voor die uit Nederlands politiek oogpunt toch bijzonder markant te noemen was; een regering kwam ten val ten gevolge van de stemming over een voorstel tot Grondwetsherziening in de Nederlandse senaatskamer. ${ }^{87}$ In politieke zin bleek de storm zich overigens te beperken tot het spreekwoordelijke glas water. ${ }^{88}$ Toch was een en ander voor de regering voldoende aanleiding om het pas sinds 1983 vigerende kiesstelsel voor leden van de Eerste Kamer wederom ter discussie te stellen. In cen regeringsnotitie dienaangaande van de hand van Minister Peper viel te lezen dat het huidige kiesstelsel 'de kans op divergerende meerderheden in de beide kamer vergroot, hetgeen een verhoogd risico meebrengt voor conflicten tussen de Tweede en de Eerste Kamer, waarvoor in ons stelsel geen oplossing bestaat' ${ }^{89}$ Tevens werd in die notitie beweerd dat een in haar geheel gekozen Eerste Kamer gezien zou worden als een meer actuele afspiegeling van de opvattingen van de bevolking, waardoor de kans op divergerende meerderheden en mogelijke conflicten tussen beide kamers vergroot zouden worden. De Minister zou tenugkeer naar het

83. Zie daartoe par. 6.5.2.

84. Handelingen Eerste Kamer, 1989-1990, p. 283 e.v.

85. N. Cramer, a.w., p. 338 e,v. B. van den Braak, a.w., p. 423-424.

86. Handelingen Eerste Kamer 1989-1990, p. 450-468.

87. Handelingen Eerste Kamer 1998-1999. p. 1404

88. Het teruggetreden kabinet Kok II kon relatief eenvoudig gelijmd worden en zat vervolgens gewoon de rit uit.

89. Kamerstukken II 1999-2000, 26976, nr. 1. p. 7-8. 
stelsel van vóór 1983, of een afgeleide daarvan dan ook toejuichen.$^{90}$ De onderbouwing van voornoemde argumenten ontbeerde overigens overtuiging. Dat het vigerende kiesstelsel de kans op divergerende meerderheden in de beide parlementskamers vergroot staat allerminst vast. Via doorrekenen van de verkiezingsuitslagen voor provinciale staten tussen 1987 en 1999 op basis van een volatiliteitindex bleek empirisch eenvoudig aangetoond te kunnen worden dat een dergelijke conclusie zeker niet zonder meer getrokken kan worden. ${ }^{91}$

Dat de Eerste Kamer politiek sterker op de voorgrond zou zijn getreden (via een toename van het aantal novelles en verwerpingen) omdat 'een in haar geheel gekozen Eerste Kamer als een meer actuele afspiegeling van de opvattingen van de bevolking' werd gezien, kon evenmin overtuigend aangetoond worden. Oorzaken van onder andere persoonlijke en partijpoliticke aard, alsmede de vermeende gebrekkiger kwaliteit van wetgevingsvoorstellen speelden hier zeker ook cen belangrijke rol (zie ook hoofdstuk 6) ${ }^{92}$ Of de regeringsnotitie 'Positie van de Eerste Kamer' een vervolg zal krijgen in de vorm van een of meerdere uitgewerkte voorstellen tot grondwetswijziging is momenteel nog niet geheel duidelijk, maar wel erg onwaarschijnlijk. ${ }^{93}$

\subsubsection{Ontbinding}

Dan op deze plaats nog enkele opmerkingen over de formele mogelijkheid tot ontbinding van de Eerste Kamer. Nederland blijkt namelijk het enige der vier onderzoekslanden waar tussentijdse ontbinding überhaupt tot de staatsrechtelijke mogelijkheden behoort. In Frankrijk is tussentijdse ontbinding van de Sénat wettelijk uitgesloten. ${ }^{94}$ In Groot-Brittanniě en de Bondsrepublick is de mogelijkheid van tussentijdse ontbinding uiteraard onverenigbaar met het aldaar gevoerde benoemingsbeleid voor leden van de senaatskamers.

Ook na de grondwetsherziening van 1983 is de mogelijkheid tot ontbinding van de Eerste Kamer gewoon in de grondwet verankerd gebleven (art. $64 \mathrm{Gw}$ ). Het besluit van de grondwetgever om de mogelijkheid tot politieke ontbinding te handhaven, hangt rechtstreeks samen met het gegeven dat de relatie Eerste Kamer-regering althans in theorie ${ }^{35}$ nog steeds gedomineerd wordt door de regels der ministeriële verantwoordelijkheid en de daanuit voortvloeiende vertrouwensregel.. Tijdens de parlementaire discussies rondom de grondwetsherziening van 1983 is de 'politicke ontbinding' overigens wel indringend aan de orde gesteld. Aanname van de motie De Kwaadsteniet had duidelijk gemaakt dat het taken- en bevoegdhedenpakket van de Eerste Kamer ongewijzigd zou blijven. ${ }^{96}$ De indirecte driejaarlijkse verkiezingen via provinciale staten van de helft der senatoren, zou vervangen worden door getrapte verkiezingen van de gehele Eerste Kamer ineens, iedere vier jaar op een tijdstip liggende maximaal drie

90. Concreet werden drie opties voorgesteld: Provinciale Staten uit alle provincies kiezen iedere drie jaar de helf der senatoren; Provinciale Staten uit alle provincies kiezen iedere vier jaar de helft der senatoren, of Provinciale Staten uit de helf van alle provincies kiest iedere vier jaar de helft der senatoren.

91. E. Knippenberg. Reflecties over de positie van de Eerste Kamer heroverwogen, NJB 2000, p. $934-936$.

92. Zie daartoe onder andere: A. Postma, De Eerste Kamer timmert aan de weg. Namens 1987, p. 90-92; H. Kummeling. Preadvies, De Nederlandse Eerste Kamer, Zwolle 1992, p. 33-35; W. Witteveen, Retour afzender: over de terugzendplicht, NJB 2000, p. 932-933.

93. De Eerste Kamer gaf in meerderheid tijdens debatten over dit thema op 6 november 2001 al aan geen enkel wijzigingsvoorstel te zullen steunen. Handelingen Eerste Kamer 2001-2002, p. 176-207.

94. Zoals valt op te maken uit de strekking van de artt. LO 274- LO 278.

95. Zie daartoe uitgebreid de hoofdstukken 6 en 8.

96. Handelingen Tweede Kamer 1974-75, 12.944. 
maanden na de provinciale statenverkiezingen. Het verkiezingsregime voor provinciale staten zélf zou ongewijzigd blijven. Tussentijdse ontbinding van de provinciale volksvertegenwoordiging bleef een onmogelijkheid. De Raad van State wees er terecht op dat het voorgestelde systeem nog slechts aanleiding kon geven tot "een reeks van vrijwel zinledige ontbindingen en verkiezingen'. ${ }^{97}$ De samenstelling van de Eerste Kamer kon grosso modo immers nauwelijks wijzigen.

Naast deze politieke ontbindingsmogelijkheid, wordt binnen het Nederlandse staatsbestel ook, en zelfs frequent, gewerkt met de 'herzieningsontbinding': indien de regering een voorstel tot grondwetswijziging lanceert moet dit, conform art 137 jo $64 \mathrm{Gw}$, na kamerontbinding en daaropvolgende verkiezingen een tweede maal en dan via een gekwalificeerde $2 / 3$ meerderheid in beide Kamers van de Staten-Generaal aangenomen worden. Het momentum voor ontbinding en verkiezing viel uit politiekpraktische overwegingen daarom altijd samen met de politiek belangrijker verkiezingen voor de Tweede Kamer. Dat senatoren dientengevolge de laatste decennia nog slechts hoogst zelden hun mandaat vol gemaakt hebben, werd op de koop toe genomen. Pro forma werden senatoren opnieuw gekozen door provinciale staten in een vrijwel ongewijzigde samenstelling. Tot aan de grondwetsherziening van 1983 kon in ieder geval nog geopperd worden dat de samenstelling van de (twee maal drie is zesjarige) Senaat daardoor gedeeltelijk geactualiseerd zou kunnen worden. Dat argument verviel echter ook met de inwerkingtreding van vierjaarlijkse indirecte verkiezingen voor de gehele Eerste Kamer, zodat vooral na 1983 gepoogd is wijziging aan te brengen in deze onbevredigende gang van zaken. Middels een motie van de D'66er Vis ${ }^{98}$ werd verzocht het tijdstip van ontbinding in Tweede en Eerste Kamer van elkaar los te koppelen, zodat ook de vierjaren zittingstermijn van de Senaat gerespecteerd kon worden. Ter ondersteuning van dit verzoek werd gewezen op de in art. 55 Grondwet uitgewerkte relatie tussen de verkiezing van de Senaat en de uitslag van de provinciale statenverkiezingen. Ook werd gewezen op het feit dat reeds in 1946 sprake is geweest van een precedent. ${ }^{99}$ Ondanks vrijwel kamerbrede steun voor de motie Vis heeft het toch nog even geduurd voordat loskoppeling van beide (ontbindings)verkiezingsdata een feit was. De Raad van State ontraadde die loskoppeling namelijk in eerste instantie omdat dit niet in overeenstemming werd geacht met de ongeschreven bedoelingen van de grondwetgever. ${ }^{100}$ De regering nam het advies van de Raad van State over, zodat de ontbinding van de Eerste Kamer ex art. $137 \mathrm{Gw}$ sindsdien ongetwijfeld beschouwd kon worden als 'politiek volstrekt irrelevant en dus een farce' ${ }^{101}$ De zinloosheid gold, aldus Vis, evengoed voor de politieke als voor de grondwetsherzieningontbinding ${ }^{102}$ Blijkbaar heeft de Grondwetgever zich deze kritiek aangetrokken, aangezien art. 137 lid 3 in 1995 in dier voege is aangepast, dat bij een grondwetsherziening tegenwoordig nog slechts de Tweede Kamer ontbonden hoeft te worden. $^{103}$

Strikt theoretisch is binnen de Nederlandse constitutie ook ruimte voor de mogelijkheid tot opheffing van de Eerste Kamer aanwezig. Hiertoe zal dan uiteraard wel de reguliere grond-

97. Alg. Grondwetsherziening deel IIIa, p. 142.

98. Handelingen Eerste Kamer 1984-1985, nr. 18.179, p. 1213-1214

99. Handelingen Eerste Kamer 1984-1985, p. 1205 e.v.

100. Eerste Kamer 1985-1986, 18.179 nr.89, p. 21-23.

101. J.J. Vis, De ontbinding van het parlement, Groningen 1987. p. 139.

102. Idem.

103. Kamerstukken II, 23575 1994, stb 404. 
wetswijzigingprocedure doorlopen moeten worden, inclusief tweederde meerderheden in beide parlementskamers. Aan de in's en out's van dit gegeven zal in relatie tot het functioneren van bicamerale systemen in de andere onderzoekslanden in hoofdstuk 8 nog enige aandacht besteed worden.

\subsubsection{Organisatie}

De 75 partime senatoren komen tijdens de duur van het parlementaire jaar in de regel één keer per week op dinsdag bij elkaar. Zij moeten minimaal achttien jaar oud zijn en de Nederlandse nationaliteit bezitten. ${ }^{104}$ In tegenstelling tot de Britse collega's kunnen Nederlandse senatoren niet tevens deel uitmaken van de regering ${ }^{105}$ De mogelijkheid tot dubbelmandaten voor senatoren naar Frans voorbeeld (bij bijvoorbeeld provincie of gemeente), wordt door de Nederlandse constitutic niet uitgesloten. ${ }^{106}$ Omdat het lidmaatschap van de Eerste Kamer slechts een partime functie is, blijken op dat vlak overigens nooit problemen te ontstaan.

De leden van de Eerste Kamer vergaderen onder voorzitterschap van een uit hun midden gekozen voorzitter. ${ }^{107}$ Naar goed gebruik komt de voorzitter tegenwoordig vaak voort uit een andere politieke partij dan de voorzitter van de Tweede Kamer. Hij is tevens voorzitter van de verenigde vergadering der Staten-Generaal. ${ }^{108}$ Een topzwaar taken- en bevoegdheden pakket, zoals de collega-voorzitters van de Britse en Franse Senaat hebben, ontbeert de voorzitter van de Eerste Kamer.

De leden van de Eerste Kamer groeperen zich in partijpolitieke fracties ${ }^{109}$ Zoals gezegd betreft het fracties afkomstig uit dezelfde politieke partijen als de fracties van de Tweede Kamer. Substantielle invloed van de politieke partijen op het gehele parlementaire gebeuren ligt dan ook voor de hand. Een conclusie die anno 2001 overigens voor alle vier de onderzoekslanden zonder voorbehoud getrokken lijkt te kunnen worden. Maar daarover in de loop van mijn betoog uiteraard meer.

Ter voorbereiding van de plenaire zittingen van de Eerste Kamer, waarin vrijwel uitsluitend de medewetgevende taken centraal staan, worden, te doen gebruikelijk, commissievergaderingen belegd. Vaste commissies worden, evenals in Duitsland en Frankrijk samengesteld conform de opdeling in ministeriële departementen ${ }^{110}$ Omdat de Senaat in Nederland geen amendementsrecht toekomt, is het commissiestelsel aldaar nooit echt tot wasdom gekomen. Het gros der commissievergaderingen betreft namelijk zgn. 'inbrengvergaderingen' ex art. 44v RvOEK, waar eventuele opmerkingen als regel schriftelijk ingebracht worden. Deze opmerkingen worden dan vervolgens door de griffier in de vorm van een (al dan niet voorlopig) verslag samengevoegd en door de commissievoorzitter verder formeel afgehandeld. ${ }^{111}$

104. Art. 56 Grondwet.

105. Uitzondering op deze hoofdregel geeft art 57-3 Grondwet: in geval van demissionaire status is vereniging van ambten wel tijdelijk toegestaan.

106. Zie bijvoorbeeld art. 13 Gemeentewet.

107. Tot aan de grondwetsherziening van 1983 werd de voorzitter van de Eerste Kamer benoemd door de Kroon, op voordracht van de Tweede Kamer.

108. Art. 62 Grondwet.

109. Art. 23-25 RvOEK.

110. Art. 34 RvOEK.

111. G. Hagelstein, De parlementaire commissies, Serie monografieên Nederlands Parlementsrecht nr. 6, Groningen 1991, p. 374. 
Ondersteuning van een gekwalificeerd ambtelijk apparaat krijgen de Nederlandse parttime senatoren, in tegenstelling tot hun Duitse collega's bij hun werkzaamheden hoegenaamd niet. Zelfs substantiële ondersteuning van fractiesecretariaten vergelijkbaar met de gang van zaken dienaangaande in de Tweede Kamer, is voor de leden van de Eerste Kamer niet weggelegd. Tenslotte op deze plaats nog enige opmerkingen over de mogelijkheid tot het organiseren van verenigde vergaderingen voor beide Nederlandse parlementskamers.

\subsubsection{Verenigde vergadering}

De verenigde vergadering van de Staten-Generaal heeft toch vooral ceremoniële betekenis. Art 65 Grondwet schrijft voor dat jaarlijks op de derde dinsdag van september een verenigde vergadering van beide parlementskamers wordt georganiseerd met als doel het 'door of namens de Koning' geven van een uiteenzetting over de beleidsvoornemens voor het komende kalenderjaar. Ook voor de inhuldiging van een nieuwe Koning (art 32 Grondwet) en de beèdiging van een regent (art 37 lid 2 Grondwet) dienen de Tweede en Eerste Kamer in verenigde vergadering bijeen te komen. Dergelijke bijeenkomsten staan dan onder leiding van de voorzitter van de Eerste Kamer. Tijdens de grondwetsherzieningdebatten van 1983 zijn door de Tweede Kamer pogingen ondernomen om de voorzittershamer van de verenigde vergadering over te hevelen. De Nederlandse Senaat heeft echter altijd consequent voorstellen in die richting van de hand gewezen.

Art 51 Grondwet lid 4 bepaalt dat bij een verenigde vergadering de Kamers als één worden beschouwd. Deze Kamer moet in voorkomende gevallen ook taken verrichten die niet beperkt blijven tot ceremonieel vertoon. In de meeste gevallen betreft het dan de positie van de Koning in ons staatsbestel. Benoeming van een troonopvolger (art 30 Grondwet), minderjarigheid (art 34 Grondwet), benoeming van een regent (art 37 Grondwet) en het buiten staat zijn om het Koninklijk gezag uit te oefenen (art 35 Grondwet) vereisen gezamenlijke besluitvorming door de Staten-Generaal. Daarnaast is ook voor een oorlogsverklaring (art 97 lid 3 Grondwet) besluitvorming via verenigde vergadering vereist.

De Grondwet geeft een limitatieve opsomming van de onderwerpen waarover ter verenigde vergadering besluitvorming plaats kan vinden. ${ }^{1 / 2}$ In de 'proeve van een nieuwe Grondwet' uit 1966 werd voorgesteld beide parlementskamers het recht toe te kennen zelfstandig te bepalen welke onderwerpen aan de verenigde vergadering zouden kunnen worden voorgelegd. Ware dit voorstel overgenomen, dan zou de theoretische mogelijkheid tot opheffing van de Nederlandse Senaatskamer ineens veel reëler zijn geworden. Immers ter verenigde vergadering bezetten de senatoren slechts $1 / 3$ deel van de zetels, niet genoeg om grondwetswijzigingen te blokkeren. ${ }^{113}$

112. H.R.B.M. Kummeling en P.P.T. Bovend'Eert, Van Raalte's Het Nederlands parlement, Deventer 2000. p. 56-61.

113. H. van Maarseveen wees sprekend over de mogelijkheid tot 'geruisloze zelfmoord' in 1971 al fijntjes op deze eventuele consequentie, in: J.M. Kan (red), Een nieuwe Grondwet?, Beschouwingen naar aanleiding van het Eindrapport staatscommissie-Cals/Donner. Zwolle 1971, p. 19 e.v. 


\section{$3.4 \quad$ Frankrijk}

\subsubsection{Verkiezing}

Article 24 Constitution 1958 :

Alinéa I-Le parlement comprend I'Assemblée nationale et le Sénat.

Alinéa 3-Le Sénat est élu au suffrage indirect. Il assure la représentation des collectivités terri-

toriales de la République. Les Français établis hors de France sont représentés au Sénat.

Evenals dat in Nederland het geval is, worden de leden van de Senaat in Frankrijk indirect gekozen. Zo eenvoudig als het Nederlandse kiesstelsel dienaangaande in elkaar steekt, zo ingewikkeld is in wezen echter het Franse systeem.

Laten wij eerst eens in kaart brengen wie het recht hebben om als leden van de kiescolleges per departement de afgevaardigden voor de Franse Senaat te kiezen. In de eerste plaats zijn daar de in het departement woonachtige vertegenwoordigers voor de Assemblée Nationale. Vervolgens de leden van een tweetal bovendepartementale vertegenwoordigende organen ingesteld in het kader van het streven naar verdere decentralisatie, te weten de 'Conseils régionaux' (o.a. infrastructuur) en de 'Conseils generaux' (zorgsector). ${ }^{114}$ Tenslotte de grote groep afgevaardigden vanuit de gemeenteraden. Van de ongeveer 104.000 leden van de kiescolleges voor de Franse Senaat zijn er rondom de 100.000 afkomstig uit de gemeenten. ${ }^{115}$ Volledigheidshalve dient nog gewag gemaakt te worden van de leden van 'le Conseil supérieur des Français de l'étranger', die het recht hebben de senatoren ter vertegenwoordiging van de gebiedsdelen overzee te kiezen. ${ }^{116}$

Terwijl in de Nederlandse provinciale staten de verkiezing van senatoren plaats vindt volgens een systeem van evenredige vertegenwoordiging, is dat in Frankrijk slechts zeer ten dele het geval. Om het beeld zuiver te krijgen, moet eerst helder worden op welke wijze de grootste en venuit belangrijkste groep aspirant-leden van de kiescolleges voor senatoren, de gemeenteraadsleden zélf, hun gedelegeerden voor het kiescollege selecteren.

In gemeenten die niet meer dan 9.000 inwoners tellen (en waarvan de raadsleden gekozen worden via een meerderheidssysteem) geschiedt deze verkiezing via een meerderheidssysteem. Hele kleine gemeenten (tot 500 inwoners) mogen een enkele afgevaardigde kiezen. Dit aantal loopt dan op tot 15 in gemeenten met een inwonertal tussen de 3.500 en 9.000 inwoners. In gemeenten vanaf 9.000 inwoners zijn alle gemeenteraadsleden van rechtswege lid van het kiescollege in hun departement. Daarenboven mogen gemeenten met een inwoneraantal vanaf 30.000 per 1.000 inwoners nog een afgevaardigde voor het kiescollege selecteren. Dit geschiedt via een stelsel van evenredige vertegenwoordiging. ${ }^{117}$

Goed beschouwd betekent dit alles dat afgevaardigden uit de kleinere en kleinste gemeenten altijd exclusief afkomstig zijn uit de gelederen van de plaatselijke politieke meerderheid, terwijl vanuit de grotere gemeenten ook afgevaardigden tot de kiescolleges zullen toetreden die lokale minderheden representeren. Deze ongelijkheid heeft uiteraard gevolgen voor de politieke kleur in de samenstelling van de kiescolleges. Immers, aangezien de politieke wind

114. Ant. L.280. Code electoral. Zie ook: A. Stevens, The Government and politics of France, London 1996, p. 163-168.

115. P. Georges, Droit Public, Paris 1992, p. 114

116. Loi organique nr. 83-499, 17 juin 1983

117. Art. L. 283 a L. 293 Code electorale. 
in de niet geürbaniseerde gebieden traditioneel behoudend centrumrechts waait, zijn het vooral de centrumrechtse partijen die profiteren van het vigerende systeem. Maar er is meer. Vervolgens moeten wij namelijk het aantal afgevaardigden voor de kiescolleges in ogenschouw nemen dat gekozen mag worden door de raden van kleine c.q. grote gemeenten. Opvallend genoeg blijkt dat de grote groep van héél kleine gemeenten (tot 1500 inwoners) die ruim $20 \%$ van de totale Franse bevolking herbergt, meer dan $40 \%$ van het aantal afgevaardigden voor het kiescollege mag toewijzen. Andersom komt een kleine $30 \%$ van de afgevaardigden uit gemeenten groter dan 10,000 inwoners, terwijl in deze groep gemeenten ruimschoots de helft van de Franse bevolking woonachtig is. ${ }^{118}$ Ook hier weer wordt de behoudende centrumrechtse hoofdstroming die de bepalende politieke factor bij uitstek is voor Franse plattelandsgemeenten in niet geringe mate bevoordeeld.

De wijze waarop de kiescolleges per departement te werk moeten gaan, alsmede het aantal senaatszetels dat per departement toegewezen mag worden, benadrukken de beschreven ongelijkheid nog eens. Om met het laatste te beginnen: het aantal senatoren dat per departement afgevaardigd mag worden naar het Palais de Luxembourg is zeker niet evenredig aan de bevolkingsdichtheid. Voor 150.000 inwoners mag het departement één senator afvaardigen. Daarenboven mag per 250.000 inwoners een volgende zetel in de Senaat geclaimd worden. Gevolg: dunbevolkte departementen mogen verhoudingsgewijze meer senatoren afvaardigen. ${ }^{119}$

De verkiezing van de senatoren tenslotte, geschiedt niet voor alle departementen eensluidend. In rurale departementen waar maximaal 4 senaatszetels te verdelen zijn, geschiedt de verkiezing via een meerderheidsstelsel in twee ronden. ${ }^{120}$ In meer dichtbevolkte departementen waar meer dan vier senaatszetels te verdelen zijn ${ }^{121}$ wordt het stelsel van evenredige vertegenwoordiging gehanteerd. ${ }^{122}$ Dit betekent dat de rurale departementen slechts vertegenwoordigd zullen zijn via afgevaardigden van de meerderheidsgroeperingen, terwijl het goed mogelijk is dat vanuit de geürbaniseerde departementen ook de politiek minder dominante groeperingen in de Senaat vertegenwoordigd zullen worden.

\subsubsection{Partijpolitieke samenstelling}

Het moge duidelijk zijn dat de hierboven beschreven praktische uitvloeisels van het vigerende kiesstelsel aanzienlijke gevolgen hebben voor de uiteindelijke samenstelling van de tweede Franse parlementskamer. Het gaat hier niet volledig in zijn werk zoals bijvoorbeeld voor het Britse House of Commons: 'the winner takes it all', maar toch wel dusdanig dat: 'Grand Conseil des petites communes de France' geen al te bombastisch statement lijkt te zijn, waar de Franse Sénat bedoeld is.

De Franse (Grond)wetgever van 1958 heeft er bij het construeren van het ingewikkelde kiesstelsel voor de Senaat bewust voor geopteerd de 'behoudender' elementen uit de samenle-

118. J. Mastias, Titre IV: le parlement, Article 24, Uit: La constitution de la république française, Paris 1987, p. 641.

119. J. Mastias et J. Grangé, Les secondes chambres du parlement en Europe Occidentale, Paris 1987, p. 244.

120. Art. L.294. Code électoral.

121. Art L.279 Code électoral. Slechts in 13 van de 95 Franse departementen overstijgt het aantal te kiezen senatoren het getal 4. Bron: http://cubitus.senat.fr/presentation/livrel/livrel0.html , 26-09-2001.

122. Art. L.295. Code électoral. 
ving te bevoordelen. ${ }^{123}$ Het zal dan ook geen verwondering wekken dat deze 'chambre d'agriculture', zoals Duverger de tweede parlementskamer vier decennia geleden al typeerde, een constante centrumrechtse politieke meerderheid pleegt te herbergen. Ter illustratie: tijdens de verkiezingen van 1998 was 1/3 deel van het totale aantal zetels in het Palais de Luxembourg vacant. Ondanks het feit dat de socialistische regering Jospin zich dat jaar zeker nog mocht verheugen in een behoorlijke mate van landelijke populariteit, vielen vrijwel alle senaatszetels toe aan centrumrechts.

Verdedigbaar is uiteraard het adagium: 'stabilité, prudence, expérience' als politieke constante in een snel veranderende samenleving. Maar het is juist ten gevolge van die veranderende samenleving dat de kritiek op het besproken kiesstelsel toeneemt. Frankrijk werd in 1958, ten tijde van het ontstaan van de Vijfde Republick, inderdaad nog bevolkt door grote groepen plattelanders; groepen die (ook getalsmatig) nimschoots meetelden en: 'quel meilleur corps électoral que celui qui reflète la terre d'où est née la Nation'.124 Meer dan de helft van de bevolking leefde buiten de steden. Tegenwoordig echter wordt het Franse platteland nog maar bevolkt door nim een kwart van de totale Franse bevolking. Genoeg voor de Senaat om apostel van de sociale stabiliteit in Frankrijk te mogen blijven? ${ }^{123}$ Of inderdaad zo weinig dat Jospin met recht zou mogen beweren de Sénat te beschouwen is als een anomalie in de Westerse democratie? ${ }^{126}$

De grondwetgever van 1958 heeft duidelijk grote behoefte gevoeld tot het inbouwen van een maximum aan continuiteit en stabiliteit. Naast de reeds beschreven juridische mechanismen die een stabiele instroom in de Senaat moeten garanderen, wordt er ook nog eens zorg voor gedragen dat uitstroom pas plaats vindt na 9 jaar $^{127}$ Iedere drie jaar wordt via indirecte verkiezingen 1/3 deel van de Franse Senaat vernieuwd. ${ }^{128}$ De laatste keer gebeurde dat op 23 september 2001. Vooral voor de samenwerking tussen beide parlementskamers kunnen de gevolgen van deze lange zittingstermijn aanzienlijk zijn. Een voorbeeld ter illustratie: gemeenteraadsleden die zelf direct gekozen zijn in 1977, kiezen in 1980 voor de vacante senaatszetels hun (in hoofdzaak centrumrechtse) senatoren. In 1981 wordt de socialist Mitterand President van de Republiek. Vervolgens wordt de Assembleé nationale ontbonden en worden nieuwe verkiezingen uitgeschreven die leiden tot een absolute meerderheid voor de socialistische partij in de eerste parlementskamer. Drie jaar na afloop van het (maximaal 5-jarig) mandaat van die Assembleé nationale en een jaar na afloop van het (7-jarig) mandaat van de President zitten eerder genoemde senatoren uit het kamp van de politicke opponent ten gevolge van het vigerende kiesstelsel nog steeds gewoon op hun post in de medewetgevende tweede parlementskamer. ${ }^{129}$

123. M. Sousse, Le bicameralisme: bilan et perspectives, uit: Revue du Droit Public et de la science politique en France et a l'etranger 1997, p. 1337 e.v.

124. M. Debré, Le Monde 21-9-1958.

125. J. Mastias et J. Grangé, a.w., p. 249.

126. NRC Handelsblad, 8-10-1998.

127. Art. L.O275 Code electoral.

128. Art. LO 276 Code electoral. In alfabetische volgorde worden de 95 departementen van Frankrijk in drie tranches onderverdeeld. Steeds aangevuld met enige zetels ter vertegenwoordiging van Franse onderdanen woonachtig in het buitenland en de overzeese gebiedsdelen worden per drie jaar achtereenvolgens 102,103 en 116 senatoren door de kiescolleges uitgeselecteerd. 
Een laatste nog te noemen stabiliserende pilaar van het kiesstelsel voor de Franse Senaat betreft de leeftijdsgrens voor passief kiesrecht. Senator kan men in Frankrijk pas worden vanaf het 35e levensjaar (Assembleé: 23 jaar). ${ }^{130}$ In geen van de andere onderzoekslanden is een dergelijke hoge leeftijdsgrens gesteld. Toch is de gemiddelde leeftijd van senatoren in Frankrijk met 60 jaar, slechts 5 jaar hoger dan de gemiddelde leeftijd van de Nederlandse collega's, die al vanaf hun achttiende levensjaar verkiesbaar zijn.

\subsubsection{Cumul des mandats}

De Franse Senaat telt momenteel 321 leden. ${ }^{131}$ Deze komen in de regel drie maal per week in openbare zitting bijeen. ${ }^{132}$ De leden, die formeel de belangen van de 'collectivités territoriales' dienen te behartigen, stemmen evenals de senatoren uit Groot-Brittanniê en Nederland individueel, zonder last. De banden die de meeste Franse senatoren verbindt met hun 'achterland', blijken overigens wel stevig te zijn. 'Le cumul des Mandats' is in Frankrijk dan ook een politiek begrip met een bijzonder zware lading geworden, waar het de leden van de Sénat betreft. Dit is allerminst onbegrijpelijk indien men de gegevens dienaangaande bestudeert: in 1996 bleken de 321 senatoren samen 413 andere openbare functies te bekleden in de gemeente (213), het departement (167) en de regio (33). ${ }^{33}$ Dat 'Cumul des Mandats', hoewel frequent bekritiseerd, een zeer normaal verschijnsel is in de Franse politieke constellatic komt duidelijk tot uiting in de volgende tabel, waarin slechts de burgemeestersposten van senatoren zijn opgenomen.

Verstrengeling van openbare functies op een dergelijke schaal kan uiteraard niet zonder gevolgen zijn, waar de intensiteit van werken in de Sénat in het geding is (zie hoofdstuk 5).

Senator-burgemeesters in Frankrijk

\begin{tabular}{|c|c|c|c|}
\hline Jaar & $\begin{array}{l}\text { Senator-burgemeesters } \\
\text { absoluut }\end{array}$ & $\begin{array}{l}\text { Senator-burgemeesters } \\
\text { percentueel }\end{array}$ & $\begin{array}{l}\text { totale aantal } \\
\text { senaatszetels }\end{array}$ \\
\hline 1959 & 163 & $52,9 \%$ & 308 \\
\hline 1965 & 148 & $52,3 \%$ & 283 \\
\hline 1971 & 150 & $53,0 \%$ & 283 \\
\hline 1973 & 170 & $60,1 \%$ & 283 \\
\hline 1977 & 152 & $51,5 \%$ & 295 \\
\hline 1978 & 156 & $52,9 \%$ & 295 \\
\hline 1980 & 178 & $58,6 \%$ & 304 \\
\hline 1983 & 181 & $57,1 \%$ & 317 \\
\hline 1986 & 191 & $59,9 \%$ & 319 \\
\hline 1989 & 163 & $50,8 \%$ & 321 \\
\hline 1992 & 171 & $53,3 \%$ & 321 \\
\hline 1995 & 155 & $48,3 \%$ & 321 \\
\hline
\end{tabular}

Bron: Chevalier, F., Le Sènateur Francais 1875-1995, Paris 1997, p. 292.

130. Art. LO 296 Code électoral.

131. Art. LO 274 Code électoral.

132. Art. 32 Règlement du Sénat.

133. F. Chevalier, Le Sénateur Francais 1875-1995, Essai sur le Recrutement et la Représentativité des Membres de la Seconde Chambre, p. 292-303. 


\subsubsection{Organisatie}

De plenaire zittingen van de Sénat worden geleid door een president, gekozen door de senatoren vanuit hun midden, voor een periode van drie jaar. Naast de president worden er ook zes vice-presidenten benoemd, die als vervanger op kunnen c.q. moeten treden, bij verhindering van de senaatsvoorzitter. ${ }^{134}$

Terzijde enige opmerkingen over het goed gevulde takenpakket behorende bij deze functie. De bevoegdheden van de president van de Franse Senaat wordt, evenals dat voor de Lord Chancellor in Groot-Brittanniê het geval is, namelijk zeker niet beschouwd als een sinecure. Naast het geven van dagelijkse leiding aan de beraadslagingen kan hij/zij een aantal rechten uitoefenen die veel verder reiken dan de buitenmuren van het Palais de Luxembourg. Indien Frankrijk, om het even om welke reden, tijdelijk moet functioneren zonder staatshoofd, neemt de voorzitter van de Senaat diens taken waar. ${ }^{135}$ Een andere niet te onderschatten bevoegdheid betreft het recht van benoeming van drie leden van de Conseil Constitutionnel. ${ }^{136}$ De negen leden van dit orgaan die onafhankelijk zijn en voor negen jaar benoemd worden, hebben de in Frankrijk bepaald niet onbelangrijke taak verdragen en wetgeving te toetsen op grondwettigheid. Aangezien bij dergelijke toetsingen zelden sprake zal zijn van een a-politiek gebeuren, is het van eminent belang wie het Conseil Constitutionnel mag samenstellen. De overige zes leden worden aangewezen door respectievelijk de President van de Republiek (drie) en de voorzitter van de Assembleé nationale (drie).

Mocht de President van de Republiek de Assembleé nationale willen ontbinden (regelmatig voorgekomen tijdens nuim 40 jaar Vijfde Republiek), dan dient deze eerst een aantal personen waaronder de voorzitter van de Sénat te consulteren. ${ }^{137}$

Een zelfde procedure dient gevolgd te worden indien de President van de Republiek het nodig acht staatsnoodrecht gebaseerd op art. 16 van de Grondwet te gaan hanteren. ${ }^{38}$

Naast de president en de vice-presidenten bestaat het 'Bureau' van de Franse Senaat nog uit een aantal penningmeesters en secretarissen, allen benoemt voor een periode van drie jaar. ${ }^{139}$ Uitgangspunt voor de wijze waarop de leden van de Franse Senaat zich organiseren is niet de departementale indeling van Frankrijk, doch de partijpolitieke binding. ${ }^{140}$ Vrijwel alle afgevaardigden uit de 95 departementen en de overzeese gebiedsdelen vinden onderdak in de gangbare Franse politieke partijen. Onafhankelijken hebben in verband met commissiewerk ook juridische mogelijkheden om zich te groeperen. ${ }^{141}$ In de praktijk verlopen stemmingen veelvuldig via partijpolitieke scheidslijnen. ${ }^{42}$

De Franse Senaat maakt in verband met de wetgevende taken gebruik van een zestal permanente commissies (zie par. 5.5) waarin al naar gelang het onderwerp. de gebruikelijke voorbe-

134. Art. 3 Alinéa 3 Règlement du Sénat.

135. Art. 7 Constitition 1958 . Tot nu toe is dit twee maal voorgekomen. Een maal na het overlijden van Pompidou en een maal nadat de Gaulle het (plesbicitair) referendum van 1969 had verloren. Hij hoefde formeel niet op te stappen als staatshoofd, maar deed dit toch direct.

136. Art. 56 Constitution 1958.

137. Art. 12 Constitution 1958.

138. De Gaulle maakte gebruik van art. 16 van de constitutie tijdens de Algerije-crisis in 1961.

139. Art. 3 Reglement du Senat.

140. Art. 5 Règlement du Senat.

141. Art. 6 Alinda 4 Règlement du Sénat.

142. M. Sousse, Bicaméralisme, in: Revue du Droit Public et de la Science Politique en France ct a l'étranger, Juillet-Ao0t 1997. p. 1338. 
reidende stadia van het wetgevingsproces worden afgewerkt. ${ }^{143}$ Speciale vermelding verdient de 'Commission Mixte Paritaire' waarin leden van beide parlementskamers zitting hebben. ${ }^{1.44}$ Deze commissie bemiddelt in geval van onenigheid tussen Sénat en Assembleé over inhoud c.q. redactie van wetsontwerpen. Duitsland kent met zijn 'Vermittungsausschuss' een vergelijkbare commissie. In de hoofdstukken 5, 7 en 8 komt het belang van deze commissies voor het Franse en Duitse wetgevingsproces meermaals aan de orde.

Evenals in Groot-Brittannië (Select Committees) is het ook binnen de Franse staatsrechtelijke constellatie mogelijk speciale ad-hoc onderzoekscommissies in het leven te roepen. ${ }^{145}$ Tenslotte dient hier nog melding gemaakt te worden van (de door de Franse senaatskamer bijzonder frequent gehanteerde) mogelijkheid tot het installeren van enquêtecommissies. ${ }^{146}$ Over het praktische functioneren van al deze commissies zal gerapporteerd worden in het kader van hoofdstuk 5 .

\subsection{Bondsrepubliek Duitsland}

\subsubsection{Benoeming}

Artikel 50 GG: Durch den Bundesrat wirken die Länder bei der Gesetzgebung und Verwaltung des Bundes mit.

Artikel 51 Abs. I GG: Der Bundesrat besteht aus Mitgliedern der Regiernangen der Lander, die sie bestellen und abberufen. Sie können durch andere Mitglieder ihrer Regiernangen vertreten werden.

De constitutionele wetgever heeft er bij de formulering van de artt. 50 en 51 GG bewust voor gekozen de Bundesrat exclusief te doen samenstellen uit, hun Land én de Bond als geheel vertegenwoordigende leden: 'Der Bundesrat erscheint sowohl als Representant der Länder, der Landesvölker, aber auch des Bundes sowie des Bundesvolkes. ${ }^{147}$ De Bundesratleden worden benoemd vanuit de Länderregeringen en zij zijn bij stemmingen grondwettelijk verplicht hun keuzes per Land volledig op elkaar af te stemmen. ${ }^{148}$ Dit (historisch verklaarbare)gegeven heeft, zeker bezien vanuit rechtsvergelijkend perspectief, de nodige gevolgen gehad voor werkwijze en functioneren van de Senaat. Alvorens hier in de concluderende paragraaf van dit hoofdstuk alsmede in hoofdstuk 8 verder op in te gaan, is het echter opportuun alle elementen van art. 51 GG nader uit te werken.

Lid van de Landsregeringen in de zin van art. 51 lid 1 GG kunnen slechts diegenen zijn die zitting én stemrecht hebben in het Landeskabinett. ${ }^{149}$ Daartoe behoren in een aantal Länder

143. Art. 7-9 Règlement du Sénat.

144. Art. 12 Règlement du Sénat.

145. Art. 10 Règlement du Sénat.

146. Art. 11 Règlement du Sénat.

147. K. Reuter, Praxishandbuch Bundesrat, Verfassungsrechtliche Grundlagen, Kommentar zur Geschaftsordnung. Praxis des Bundesrates, Heidelberg 1991, p. 112. Zie ter nadere duiding van deze (in hoofdstuk 7 nader uitgewerkte) problematiek tevens: D. Hanf, Bundesstaat ohne Bundesrat?. Die Mitwirkung der Glieder und die Rolle zweiter Kammern in evolutiven und devolutiven Bundesstaaten, Baden-Baden 1999, p. 57-59.

148. Art. 51 Abs. 3 Satz 2 GG.

149. Art. 51 Abs. 1 Satz 1 GG. 
ook staatssecretarissen. ${ }^{150}$ De regering van de Länder kan (en moet) leden van de Bundesrat uitsluitend uit haar midden benoemen. De regeringsleider, de Minister voor Bondsaangelegenheden en de Minister van Financièn van vrijwel alle Länder zijn vaste ('ordentliche') leden van de Bundesrat. Daarnaast zijn in feite alle leden van de Landsregeringen benoemd tot zgn. 'stellvertretenden Mitglieder', afroepbaar indien aan hun expertise behoefte is. ${ }^{151}$ In die zin dringt een vergelijking met de EG-praktijk van qua samenstelling voortdurend wisselende Raden van Ministers, zich cenvoudig op.

Voor commissievergaderingen geldt een afwijkend regime (Art 52 lid 4 GG), waaraan in het vervolg van dit hoofdstuk nog enige opmerkingen gewijd zullen worden.

Het lidmaatschap van de Bundesrat eindigt automatisch indien men (om wat voor reden dan ook) niet langer behoort tot de zittende regering van een der Länder. Leden van demissionaire regeringen blijven lid van de Bundesrat totdat de nieuwe regering geïnstalleerd wordt. Ook kan het lidmaadschap van de Bundesrat becindigd worden doordat de Landsregering een (ontslag)besluit van die strekking neemt ('Abbenufung' Art. 51 lid $1 \mathrm{GG}$ ). Iets dergelijks is overigens nog nooit voorgekomen in de geschiedenis van de BRD. ${ }^{152}$

De wijze waarop beetindiging van het lidmaatschap van de Bundesrat georganiseerd is, heeft interessante juridische en politicke consequenties. De data waarop de algemene Landtagverkiezingen in de 16 Länder van de Bondsrepubliek plaatsvinden liggen in de praktijk verspreid over de gehele vierjarige zittingstermijn van de Bundestag. Dat betekent impliciet voortdurende continuilteit in de werkzaamheden van Duitsland's tweede wetgevingskamer, omdat tegelijkertijd zelden of nooit meer dan enkele leden (en één stemblok) de status 'demissionair' zullen bezitten: 'Der Bundesrat ist verfassungsrechtlich gesehen ein ewiges Organ'. ${ }^{153}$

Tevens betekent dit dat de politieke krachtsverhoudingen regelmatig kúnnen wisselen, zodat wisselende vormen van 'cohabitation' tussen Bundestagmeerderheden en Bundesratmeerderheden allerminst fictie zijn. ${ }^{154}$

\subsubsection{Stemverhouding}

Artikel 51 Abs. 2 GG: Jedes Land hat mindestens drei Stimmen, Lander mit mehr als zwei Millionen Einwohnem haben vier, Lander mit mehr als sechs Millionen Eimwohnem füf, Lander mit mehr als sieben Millionen Einwohnem sechs Stimmen.

Artikel 51 Abs. 3 GG: Jedes Land kann so viele Mitglieder entsenden, wie es Stimmen hat. Die Stimmen eines Landes konnen nur einheitlich und nur durch anwesende Mitglieder oder deren Vertreter abgegeben wenden.

150. Dit geldt ten volle voor Bayern, terwijl in Baden-Wurttemberg slechts die Staatssecretarissen en Staatsraden bedoeld zijn, die ook stemrecht in de Landesregierung hebben.

151. G. Ziller und G-B Oschatz, Der Bundesrat, Dosseldorf 1998, p. 60-61.

152. K. Reuter, a.w, p. 229.

153. G. Ziller und G.B Oschatz, a.w., p. 61 .

154. W. Knies, Der Bundesrat: Zusammensetzung und Aufgaben, uit: Die Offentliche Verwaltung 30, 1977. p. $575 \mathrm{e.v}$

In feite is tijdens de nog jonge geschiedenis van de BRD al vaak sprake geweest van 'oppositionele meerdeheden' in de Bundesrat, hetgeen alleen al om die reden gesprekken over aanpassing van het aantal uit te brengen stemmen per Land, zoals diende te gebeuren ten gevolge van de Duitse eenwording, tot een politiek zeer gevoelig thema maakte. 
Uit de tekst van art. 51 GG lid 3 kan afgeleid worden dat primair het aantal stemmen per Land van belang is in de Bundesrat-structuur. Het aantal leden dat ieder Land afvaardigt, is daaraan ondergeschikt.

De onderlinge afstemming van het stemmenaantal per land is regelmatig onderwerp van felle discussies en polemieken geweest in zowel het Duitse staatsrecht als de Duitse politiek. Moest ieder land evenveel stemmen krijgen of moest het inwoneraantal van de Lănder als criterium gelden en zo ja op welke wijze? ${ }^{3:}$

Staatsrechtelijk heet het dat, omdat het aandeel van de verschillende Länder in de verwerkelijking van de taken van de Bond als geheel per Land verschilt, ook het stemmenaantal mag verschillen, zolang een Land in ieder geval altijd minimaal één stem in het geheel heeft. Strikte gelijkheid van stemmen in alle Lănder (naar voorbeeld van bijvoorbeeld de USA) is altijd principieel afgewezen. ${ }^{156}$

Gepoogd is om de verdeling van het aantal stemmen zo te regelen dat grotere Länder meer stemrecht hadden, doch dat daarenboven vooral sprake was van een verantwoord 'evenwicht' tussen grote en kleine Lănder. Dat het creèren van een dusdanig evenwicht geen eenvoudige zaak bleek te zijn werd duidelijk na het aantreden van de regering Brandt. In het begin van de zeventiger jaren bleek dat de oppositiepartijen in de Bundestag over een meerderheid van én stem in de Bundesrat (21-20) gingen beschikken, terwijl diezelfde oppositiepartijen ook in de Bundesrat zuiver getalsmatig minder dan de helft van de Duitse bevolking bleken te representeren. Dit kon omdat de kleinere Länder (met drie stemmen minimaal), gerelateerd aan inwonersaantallen relatief een te grote 'stem' in het geheel hadden. Een en ander betekende dat het formeel mogelijk was, dat de Bundesrat met de stemmen van die Länder die slechts een minderheid van de Duitse bevolking vertegenwoordigden wetgevingsbesluiten geaccordeerd door een meerderheid van de Bundestag en vallend onder de groep 'Zustimmungsgezetse' (voorstellen tot wet die zonder formele toestemming van de Bundesrat nooit de status van wet in formele zin kunnen verkrijgen), eenvoudig tegen kon houden. ${ }^{157}$

De val van de Berlijnse Muur en de daaropvolgende eenwording van de BRD en de DDR heeft de discussie over de stemverdeling in de Bundesrat wederom doen oplaaien. ${ }^{158}$ Indien de vijf nieuwe 'Oost-Duitse Lănder de hun op basis van bevolkingsaantal toekomende stemmen zouden hebben gekregen, zonder dat nadere wijzigingen in de stemverhoudingen werden doorgevoerd, zou dat betekend hebben dat de vier 'grote' Duitse Lănder hun 'Sperrminorităt' kwijt waren. Onwelgevallige grondwetswijzigingen, waarbij bijvoorbeeld gedacht kan worden aan herschikking van financiële lasten ten gunste van de middelgrote en kleine Länder, kunnen in een dergelijke situatie niet meer tegen gehouden worden door de vier groten: Bayem, Baden-Würtenberg, Niedersachsen en Nordrhein-Westfalen. ${ }^{159}$ Uiteindelijk is ervoor geopteerd om de vier grote Länder ieder een stem extra te doen toekomen, zodat zij op een

155. Zie daartoe onder andere: G. Limberger, Die Kompetenzen des Bundesrates und ihre Inanspruchnahme, Eine empirische Untersuchung, in: Schriften zum Offentlichen Recht, Band 435, Berlin 1982, p. $152-163$.

156. K. Reuter, a.w., p. 214 e.v.

157. K. Reuter, a.w., p. 233.

158. E. Busch, Die Stimmenverteilung im Bundesrat, Ein verfassungsgeschichtlicher Vergleich, in: Zeitschrift fur Gesetzgebung 1990, p. 307-332. Niet minder dan vijf verschillende scenario's hebben onderdeel van de discussies uitgemaakt.

159. J. Jekewitz. Die Stimmenverteilung im Bundesrat nach dem Einigungsvertrag, uit: Recht und Politik, maart 1991, p. 107 
totaal van 69 stemmen er maximaal 24 kunnen genereren, hetgeen ruim voldoende is om de voor grondwetswijzigingen vereiste $2 / 3$ meerderheid te voorkomen.

De vijf nieuwe Oost Duitse Bundeslănder: Brandenburg, Mecklenburg-Vorpommern, Sachsen, Sachsen-Anhalt en Thüringen beschikken sinds het inwerkingtreden van het hernieuwde art. 51 GG op 19 september 1990 samen over 19 van de 69 stemmen in de Duitse Senaat. ${ }^{160}$ Zoals reeds aangegeven, kunnen de stemmen die aan een Land toegekend zijn, slechts geclusterd uitgebracht worden tijdens de plenaire Bundesratvergaderingen. $\mathrm{Zij}$ resulteren per Land dus in een gemeenschappelijk 'Ja', 'Nee' of 'Onthouding'. Een enkel in de plenaire vergadering van de Bundesrat aanwezig lid kan namens zijn Land alle beschikbare stemmen uitbrengen. Andere Bundesrat leden hoeven daarbij niet aanwezig te zijn. De stemmen moeten wel uitgebracht worden door een volwaardig lid en niet door bijvoorbeeld een gevolmachtigde ambtenaar die wel commissievergaderingen van de Bundesrat mag bijwonen. ${ }^{161}$ Vanuit politiek oogpunt bekeken doemen bijzonder interessante vragen op ten gevolge van de grondwettelijke plicht tot geclusterd stemmen per Land. Hoe te stemmen indien de Landsregering is samengesteld uit coalitiepartijen die inzake het wetsvoorstel dat in de Bundesrat ter tafel ligt lijnrecht tegenovergestelde visies uitdragen? En werkt de plicht tot 'einheitlichen Stimmabgabe' per Land wellicht depolariserend uit? Vragen die in hoofdstuk 7 nader uitgewerkt zullen wordèn.

De grondwettelijke plicht tot geclusterd stemmen wordt in het Duitse staatsrecht formeel niet beschouwd als collectieve last tot stemmen volgens instructies vanuit het Land. De Bundesratleden zijn zuiver naar de letter wellicht vrij om zelfstandig hun stemgedrag te bepalen, doch in de praktijk moeten zij dat wel nauwkeurig op elkaar afstemmen ter wille van de plicht van de landsregering om mee te helpen aan de 'Bildung des Bundeswillens' (in art 50 GG valt te lezen dat via de Bundesrat de medewerking van het 'Land' gevraagd wordt bij het wetgevingsproces en niet de medewerking van de afgevaardigden). In de Duitse staatsrechtpraktijk wordt zonder enig voorbehoud uitgegaan van gebondenheid van de Bundesrat-afgevaardigden aan stemopdrachten vanuit de Landsregering (en niet vanuit het Landsparlement!). Echter: 'Rechtlich ist die Landesregienung bei der Ausübung der Weisungsbefügnis zwar autonom. Politisch ist sie es nicht'. ${ }^{162}$ Het collegiale recht van de Landsregering om het stemgedrag van de Bundesrat leden voor te schrijven kan juridisch blijkbaar niet beperkt worden. Politick blijft er uiteraard invloed vanuit de Landsparlementen aanwezig, aangezien het in een vertegenwoordigende democratie nu eenmaal ondenkbaar is dat regeringen volledig hun gang gaan zonder zich ook maar iets aan te trekken van hun 'controlerende' achterban in de volksvertegenwoordigende organen.

De stemopdrachtenpraktijk is overigens flexibeler dan het geschreven woord. Leden van de Bundesrat hebben immers onderhandelings- c.q. afstemmingsruimte nodig en kunnen ook als medewetgever in situaties terechtkomen die ad-hoc beslissingen rechtvaardigen. Een en ander natuurlijk zonder de 'politieke basisvisie' van het Landskabinet te ontkennen. Formeel-juridische sancties staan er overigens niet op (de landsregering niet welgevallig) afwijkend stemgedrag door leden van de Bondsduitse senaatskamer.

160. Art. 4 nr, 3 Einigungsvertrag.

161. K. Reuter, a.w. p. 236 e.v.

162. K. Reuter, a.w., p. 242. 


\subsubsection{Organisatie}

De partijpolitieke organisatie van Bundesrat en Bundestag is identiek. In principe bevolken in Duitsland dezelfde politieke partijen de beide parlementskamers. Uiteraard hebben de frequent voorkomende algemene verkiezingen in Lănder van de BRD een voortdurend (licht) wisselend partijpolitiek spectrum tot gevolg. De mogelijkheid tot getalsmatig opgelegde 'Cohabitation' tussen Bundestagmeerderheid en Bundesratmeerderheid moet daarbij, zoals gezegd, eveneens verdisconteerd worden.

\section{Art. 52 GG: Abs. 1-Der Bundesrat wahlt seinen Präsidenten auf ein Jahr. \\ Abs. 2- Der Präsident beruft den Bundesrat ein. Er hat ihn einzuberufen, wenn die Vertreter von mindestens zwei Lädem oder die Bundesregierung es verlangen. \\ Abs. 3- Der Bundesrat fasst seine Beschlusse mit mindestens der Mehrheit seiner Stimmen. Er gibt sich eine Geschaftsondmung. Er verhandelt offentlich. Die Offentlichkeit kann ausgeschlos- sen werden. \\ Abs. 4-Den Ausschilssen des Bundesnates können andere Mitglieder oder Beauftragte der Regie- rungen der Läder angehören.}

Het zittingsjaar loopt van 1 november tot 31 oktober. ${ }^{163}$ In dat tijdsbestek vinden in de regel ongeveer 15 plenaire vergaderingen plaats (iedere derde vrijdag). Deze zittingen staan onder leiding van een president. Hoewel dat niet met zoveel woorden in de tekst van art. 52 GG opgenomen staat, is het de bedoeling dat de president van de Bundesrat evenals zijn Franse en Nederlandse collega slechts gekozen kan worden vanuit de Senaat. Kandidaten van buiten vallen dus af. Het is al vrijwel direct staatspraktijk geworden dat de president van de Bundesrat slechts voor de periode van één jaar gekozen wordt uit de kring van regeringsleiders van de verschillende Länder. ${ }^{164}$ Sinds 1949 hebben de regeringsleiders van alle bij de BRD aangesloten Länder in keurige volg- en tijdsorde reeds meerdere malen de scepter mogen zwaaien als voorzitter van de Bundesrat.

De benoeming staat in Duitsland voor het overige altijd volledig los van de vraag welke politieke kleur (SPD, CDU of CSU) de nieuwe president heeft. Nadat een president zijn jaar heeft uitgediend wordt hij (wederom voor één jaar) vice-president. Indien de president verhinderd is (bijvoorbeeld om de taken van de Bondspresident waar te nemen op grond van art. 57 GG) kan één der (uit de gelederen der Landesministerpresidenten gekozen) drie vice-presidenten diens taken in de Bundesrat waamemen. ${ }^{165}$ Samen met de vice-presidenten vormt de president van de Bundesrat het 'Prăsidium', dat onder andere tot taak heeft jaarlijks een huishoudreglement voor de Bundesrat op te stellen. ${ }^{166}$

Strikt juridisch is het mogelijk dat de zittende president van de Bundesrat het jaar waarvoor hij benoemd is uitdient, ook al heeft hij in het eigen land (bijvoorbeeld na verloren algemene verkiezingen) moeten terugtreden. In de praktijk hebben zich dergelijke problemen nog nooit voorgedaan. Afzetting van een Bundesratpresident via een motie van wantrouwen is niet mogelijk.

163. $\S 3$ Geschäftsordnung des Bundesrates (GOBR).

164. Tijdens het 'Königsteiner Abkommen' van 13 augustus 1950, nader uitgewerkt in paragraaf 5 GOBR is uitgemaakt dat directe herverkiezing van een zittende President geen praktijk moest worden.

165. §7 GOBR.

166. $\S 8 \mathrm{GOBR}$. 
Bijeenroepen van de Bundesrat is een recht dat exclusief toebehoort aan de president van de Duitse Senaat. De president kan verplicht worden de Bundesrat bijeen te roepen indien de Bondsregering dit wil, of indien twee landen (Reglement van Orde Bundesrat: één land is genoeg!) ${ }^{\text {?67 }}$ dit verzoeken (art 52 lid 2 GG).

Bepaald niet van praktisch belang ontbloot is de zgn. 'Stăndige Beirat'. Dit orgaan van de Bundesrat waarin gevolmachtigde regeringsleden uit alle Länder zitting hebben, komt in de regel een maal per week samen ${ }^{168}$ en heeft tot voornaamste taken, de voorbereiding van de plenaire zittingen en (politick belangrijker) het onderhouden van contacten tussen Bundesrat en Bondsregering. ${ }^{169}$

\subsubsection{Commissies}

Uitzondering op de hoofdregel van art. 51 GG die inhoudt dat slechts leden van de Landsregeringen lid van de Bundesrat kunnen zijn, staat beschreven in art. 52 lid 4 GG: 'Den Ausschüssen des Bundesrates können andere Mitglieder oder Beauftragte der Regienungen der Länder angehören'. In commissies kunnen dus ook gevolmachtigden van de regering zitting hebben, die als zodanig benoemd worden door de regeringen van de Länder. Een regime dat duidelijk afwijkt van hetgeen gebruikelijk is in de overige drie onderzoekslanden. In de praktijk zijn dit in de meeste gevallen ter zake kundige ambtenaren die zelfs geen inwoner hoeven te zijn van het Land waarvoor zij als gevolmachtigde optreden. ${ }^{170}$ Om de 'ordentliche Mitgliedschaft' te verkrijgen volstaat formele benoeming als zodanig door de Landsregering. Beeindigd wordt het lidmaatschap van de commissies door het simpelweg op te geven, of door een besluit van die strekking door de Landsregering. De Bundesrat organisatie kent 14 vaste commissies en de mogelijkheid tot het formeren van ad-hoc 'Sonderausschusse'. De vaste commissies van de Bundesrat komen net zo dikwijls bijeen, als daaraan behoefte is ter voorbereiding van de plenaire zittingen, waar de definitieve stemming over wetsontwerpen plaats zal vinden. ${ }^{171}$ Zoals gezegd bestaat ook in Duitsland een commissie die in geval van onenigheid tussen beide parlementskamers met betrekking tot wetgevingsvoorstellen kan bemiddelen, de zgn. 'Vermittlungsausschuss'. In deze politiek zo belangrijke commissie hebben gespecialiseerde ambtenaren uit de Länder (in tegenstelling tot hetgeen gebruikelijk is in de vaste Bundesratcommissies) echter nooit zitting. ${ }^{172}$

Voor de wijze waarop in het Duitse politiek-bestuurlijke krachtenveld wetsvoorstellen omgezet worden in wetgeving, heeft de regeling van art. $52 \mathrm{Abs} .4 \mathrm{GG}$ in de praktijk grote invloed. $\mathrm{De}$ in Berlijn door het daar op de ministeries aanwezige ambtenarenapparaat uitgewerkte wetsvoorstellen voor de Bond als geheel worden in de Senaat(scommissies) niet louter gecheckt door politici, doch grondig bestudeerd door ambtelijke specialisten, werkend voor het uitvoerend overheidsapparaat der Länder. Enerzijds betekent dat 'gründliche' en technisch hoogstaande wetgevingsinput. Anderzijds wordt materieel de mogelijkheid tot politiek debat in de Senaat toch duidelijk ingekaderd als gevolg van het gedegen veldwerk van de ambte-

169. $\$ 9$ Abs. 3 GOBR

170. $\$ 11$ Abs. 3 GOBR.

171. § 15 GOBR.

172. G. Ziller und G-B. Oschatz, a.w., p. 73. 
narij. ${ }^{1 / 3}$ Vanzelfsprekend kom ik op deze thematiek, met name in rechtsvergelijkende zin, in een later stadium nog terug.

\subsection{Nabeschouwing}

Het is frappant te constateren hoe groot de verschillen in zowel gehanteerde benoemings- c.q. verkiezingmethoden voor de Senaat als de directe gevolgen daarvan in cen viertal moderne West-Europese buurlanden feitelijk zijn.

Allereerst is daar de democratische legitimatie. Vooralsnog is deze vrijwel afwezig in GrootBrittanniè en slechts indirect herleidbaar in de Bondsrepubliek Duitsland. Daarentegen is zij het dominante leidmotief voor het Franse stelsel maar zeker ook voor de regeling in Nederland. De povere democratische legitimatie in Groot-Brittannie is in hoofdzaak historisch verklaarbaar. De Duitse situatie is daarmee slechts zeer ten dele vergelijkbaar. De benoemingswijze van een uit leden der Länder samengestelde Bundesrat kent, zoals uitgelegd in hoofdstuk 2, eveneens historische wortels, doch de beweegredenen van de grondwetgever van 1949 om te kiezen voor benoeming van de senatoren vanuit de Landsregeringen, bleken toch met name gebaseerd op pragmatische gronden. Efficiënt werken vanuit de Länder, mede ten behoeve van de Bond als geheel, leek het beste gegarandeerd te kunnen worden via de uitgewerkte 'Bundesratvariant'. Een halve eeuw later blijkt deze stellingname in het Duitse staatsrecht nog steeds vrijwel onverkort de heersende leer te zijn. ${ }^{174}$

Zou nu gesteld kunnen worden dat conform de momenteel in de westerse wereld heersende conventies dienaangaande, de mate van democratische legitimatie bepalend is voor het politieke gezag van de Senaat? Hooguit ten dele. De Britse Lords hebben door het gebrek aan democratische legitimatie duidelijk verdedigende stellingen moeten betrekken, doch van de Bundesrat kan dit allerminst gezegd worden. De Nederlandse Eerste Kamer is een toonbeeld van democratische fundering. Toch lijkt vooralsnog van die Eerste Kamer niet licht beweerd te kunnen worden dat zij beschikt over groot politiek gezag. Ik kom op deze problematiek met name in het kader van hoofdstuk 8 vanzelfsprekend uitgebreid terug.

Vooral in Frankrijk staat het kies/benoemingsstelsel in directe relatie tot een ten opzichte van de demografie disproportionele partijpolitieke samenstelling van de Senaat. Ook het House of Lords is qua partijpolitieke samenstelling, ondanks de in 1999 doorgevoerde wijzigingen (verwijdering van de meeste Hereditary Peers uit het Hogerhuis) zeker nog geen sprake van een volledig reële afspiegeling van de bevolkingsvoorkeuren. De geconstateerde disproportionaliteit was en is een van de redenen voor de Britse Labour-regering om wijzigingen in het benoemingsstelsel te (blijven) agenderen op de parlementaire agenda. Eventuele wijzigingen in het Franse kiesstelsel zullen in ieder geval art. 24 Constitution 1958 (verkiezing vanuit het departement) als startpunt moeten nemen.

Uiteraard zijn het met name de omvang en kwaliteit van de (in de volgende hoofdstukken te bespreken) taken- en bevoegdheden van de Senaat in de respectievelijke onderzoekslanden, die grote gevolgen kunnen hebben voor de mate waarin de verhouding tussen beide parlementskamers gepolitiseerd kunnen raken. Echter, dat ook van kies- en benoemingsstelsels

173. G. Ziller und G-B. Oschatz, a.w., p. 125.

174. R. Dolzer und M. Sachs, Das parlamentarische Regierungssystem und der Bundesrat, Entwicklungsstand und Reformbedarf, Berlin 1999, p. 7-138. 


\section{Hoofdstuk 3}

politiserende dan wel depolitiserende invloeden uit kunnen gaan valt niet te betwisten. Evident is dit in het geval van Duitsland. Daar zorgt de wijze waarop benoeming van senatoren vanuit de gelederen der Landsregeringen (uitvoerende macht) gestalte krijgt voor duidelijke kanalisering van potentiele politieke invloeden. De Landsparlementen kunnen via de reguliere parlementaire controlemechanismen weliswaar pogen enige invloed uit te oefenen op het gedrag van senatoren, doch deze controle is als regel marginaal. ${ }^{175}$ Hier komt dan nog bij, dat stemmingen in de Bundesrat niet via het individu lopen, doch via het Land als geheel. Het partijpoliticke element krijgt voor de senaatskamer van de Bondsrepubliek derhalve gestalte via de mate waarin de uitvoerende macht van de 16 Länder zich blijkt te kunnen of willen groeperen. De volksvertegenwoordiging van de Länder mag slechts toekijken.

Het politicke debat versterkende invloeden gaan in potentie uit van het verkiezingsstelsel voor de Senaat van Frankrijk. Centrumrechtse meerderheden zijn in de senaatskamer van dat land immers een permanente realiteit, terwijl dat voor de samenstelling van de Assembleé nationale zeker niet geldt.

De organisatiestructuur van de Senaat in de vier staten kent naast vanzelfsprekende parallellen ook de nodige interessante verschillen.

De voorzitter van het House of Lords hoeft niet onpartijdig te zijn. Aangezien het tot zijn takenpakket gerekend wordt dat hij, als lid van de regering, de in wetgevingsvoorstellen gegoten beleidsplannen van het kabinet door de Senaat loodst, is het zelfs expliciet niet de bedoeling onpartijdig te blijven tijdens de plenaire debatten dienaangaande. In Frankrijk, Duitsland en Nederland wordt de Senaatsvoorzitter wel te allen tijde geacht zich onpartijdig op te stellen.

Enorm groot zijn de verschillen in zittingstermijn van de senatoren. Met uitzondering van de Lords Spiritual geldt voor de Britse senatoren nog steeds: 'till death us parts'. Ook Franse senatoren kunnen met hun negenjarige zittingstermijn relatief lang expertise opbouwen en invloed proberen uit te oefenen op het regeringsbeleid in hun land. Continuitteit is daar verzekerd. Juist met betrekking tot die continuiteit lijkt zich een probleem voor te doen voor de leden van de Bundesrat. De meeste leden van de Landsregeringen zijn immers slechts Bundesratlid op afroep. Tevens dient in dit kader niet vergeten te worden dat het Bundesratlidmaatschap volledig afhankelijk is van de duur van regeringsdeelname in het betreffende Land. Dat kan wellicht twintig jaar onafgebroken lidmaatschap van de Duitse Senaat betekenen voor bijvoorbeeld de minister van financiën van Land X. Het kan eveneens betekenen dat het lidmaatschap voor bijvoorbeeld een milieuminister uit Land $\mathrm{Y}$ beperkt blijft tot éen of twee bijeenkomsten. Continuitteit wordt in de senaatskamer van de Bondsrepubliek Duitsland echter wel in hoge mate gegarandeerd via de prominente aanwezigheid van het ambtelijk apparaat der Länder in de senaatscommissies.

Van wezenlijke invloed op de output van de werkzaamheden der senatoren is ook de wijze waarop het vertegenwoordigend orgaan is samengesteld. Zo werd bijvoorbeeld in Nederland rond 1990 een relatie gesignaleerd tussen de grote belangstelling van de Eerste Kamer voor onderwijsvraagstukken en het gegeven dat relatief veel senatoren afkomstig zijn uit de onderwijswereld. ${ }^{176}$ Enigszins generaliserend kan gesteld worden dat de senaatskamers van Groot-

175. H. Koschnick, Der Bundesrat zwischen Landerinteressen, gesamtstaatlicher Verantwortung und Parteipolitik, in Vierzig Jahre Bundesrat, Baden-Baden 1989, p. 81-94.

176. H. Kummeling. De Nederiandse Eerste Kamer, preadvies, de Vereniging voor de vergelijkende studie van het recht van Belgiê en Nederland, Zwolle 1992, p. 39. 
Brittannie, Frankrijk en Nederland redelijk divers zijn samengesteld. Dankzij de Life Peerage Act (en het grotendeels wegsaneren van de groep Hereditary Peers) hebben in het House of Lords leden van allerhande beroepsgroepen zoals zakenmensen, wetenschappers, overheidspersoneel, onderwijsmensen, medici, vakbondsmensen en vooral oud-politici definitief hun intrede gedaan. Ook in de Franse 'chambre d'agriculture' zitten naast afgevaardigden vanuit de land- en tuinbouw en het midden- en kleinbedrijf ook groepen senatoren die oorspronkelijk afkomstig zijn uit andere belangrijke sectoren van het maatschappelijk leven, zij het sterk gecentreerd rondom de semi-overheid. De Duitse Bundesrat tenslotte bestaat qualitate qua uiteraard slechts uit fulltime regeringsverantwoordelijken uit de Länder, met alle gevolgen van dien voor de wijze waarop het politieke debat wordt ingevuld.

Tot slot nog enige korte algemene opmerkingen over de wijze waarop het commissiewerk georganiseerd wordt. Twee zaken springen eruit. Allereerst dat in Groot-Brittanniê en Nederland het werk ten behoeve van de reguliere wetgevingsvoorstellen veelal verricht wordt in een plenaire setting. Voor de 75 leden van de Nederlandse Eerste Kamer is de noodzaak tot het entameren van grootschalig commissiewerk, bij afwezigheid van een recht van amendement, blijkbaar nooit opportuun gebleken. De formele 'inbrengvergadering' voldoet als regel.

Politiek/beleidsmatig interessanter is de situatie in de Bondsrepublick. Daar wordt het uitvoerige en gedetailleerde commissiewerk in de vaste senaatscommissies grotendeels niet door de Bundesratleden zelf, doch door gespecialiseerde ambtenaren in vaste dienst van de Lander verricht. Het kan haast niet anders zijn, dan dat hierdoor de wetgevingswerkzaamheden een totaal ander, veel technischer, uitgewerkt en minder politiek karakter krijgen dan dezelfde werkzaamheden verricht door bijvoorbeeld de Frans-rurale senatoren.

In hoeverre ook deze laatste veronderstelling gestaafd wordt door de praktijk, zal in de volgende vier hoofdstukken, waarin de medewetgevende taakstelling en de bestuurscontrole zoals uitgeoefend door de senaatskamers van achtereenvolgens Groot-Brittanniè, Frankrijk, Nederland en de Bondsrepubliek Duitsland centraal staan, onder meer aan de orde gesteld worden. 



\section{Hoofdstuk 4}

\section{Groot-Brittannië, wetgeving en bestuurscontrole}

\subsection{Inleiding}

De oudste en zeker ook de markantste nog functionerende senaatskamer die besproken wordt in het kader van dit boek is, zoveel is inmiddels wel duidelijk geworden, ongetwijfeld het Britse House of Lords. Ontstaan in een wel héél grijs verleden (zie hoofdstuk 2), lijkt het Britse Hogerhuis zich qua samenstelling en organisatie maar moeizaam aan te kunnen passen aan de vertegenwoordigingseisen die in de twintigste en eenentwintigste eeuw in een democratische samenleving aan een parlementskamer gesteld lijken te mogen worden. Ook nadat in 1999 al grotendeels een einde is gemaakt aan het overerfbare Hogerhuislidmaatschap voor de grote groep Hereditary Peers, blijft Groot-Brittanniê constitutioneel 'zitten' met een medewetgevende parlementskamer, waarvan de samenstelling op geen enkele wijze in verband te brengen is met een volksvertegenwoordigende basis, of het zou moeten zijn dat ieder nieuw lid van het Britse Hogerhuis ook anno 2001 in feite nog steeds benoemd pleegt te worden door de Prime Minister.

Een bespreking van de wijze waarop het Britse Hogerhuis vanuit deze setting uitvoering blijkt te geven aan zijn medewetgevende taken moet onvermijdelijk beginnen bij het 'first-past-thepost' kiesstelsel dat gehanteerd wordt voor de verkiezing van de leden voor het House of Commons. De gevolgen van de keuze voor dit gecombineerde stelsel van verkiezing per district bij eenvoudige meerderheid heeft voor de werking van het gehele parlementaire stelsel in het Verenigd Koninkrijk immers een aantal consequenties gehad die de wijze van samenstelling van het Britse Lagerhuis verre overstijgen en ontegenzeggelijk tevens grote invloed (hebben) doen gelden op de wijze waarop het Britse Hogerhuis dagelijks uitvoering kan geven aan zijn (mede)wetgevende taakstelling.

Ten gevolge van dat kiesstelsel zal welhaast per definitie een van de twee grote politieke partijen, Conservatives dan wel Labour na verkiezingen in het House of Commons beschikken over een absolute meerderheid. ${ }^{\prime}$ De leider van de winnende partij wordt de nieuwe Prime Minister en zal, steunend op een op papier reeds vóór de verkiezingen bestaand 'shadow cabinet', in de meeste gevallen binnen één of twee dagen zijn regeringsploeg rond hebben en aan de slag kunnen gaan. Aan een langere formatieperiode is in de Britse constellatie geen behoefte. De noodzaak tot coalitiebesprekingen is volledig afwezig. De belangrijkste beleidsvoornemens voor de komende zittingsperiode werden daarenboven voorafgaande aan de algemene verkiezingen door zowel Labour als de Conservatives al vastgelegd in het partijmanifest dat aan de kiezer voorgelegd is.

De volledige regeringsploeg bestaande uit de Prime Minister, de Cabinet Ministers, Full Ministers, Ministers of State, Chief Whips, Parliamentary Under-Secretaries en Assistent Whips,

1. Sinds de Tweede Wereldoorlog is het slecht één maal (februari 1974) voorgekomen dat de grootste partij als direct gevolg van algemene pariementsverkjezingen niet kon beschikken over een absolute meerderheid. Labour won 301 zetels van de totaal beschikbare 635 zetels. In 1977 ging een krappe absolute meerderheid voor Labour teloor ten gevolge van verloren by-elections en het overlopen van MP's naar een andere politieke partij. 
in totaal nuim honderd mannen en vrouwen, zijn in het monistische Verenigd Koninkrijk naast lid van de regering ook lid van het Lager- of Hogerhuis. Sinds de Tweede Wereldoorlog is het gebruikelijk dat ongeveer $20 \%$ van de regeringsleden als Life Peer deel uitmaken van het House of Lords. ${ }^{2}$

De partijdiscipline blijkt in het House of Commons enorm groot te zijn. Niet alleen omdat politicke carrières tevens in niet geringe mate mede afhangen van de partijloyaliteit, maar ook omdat binnen de partijorganisatie veel aandacht en geld wordt besteed aan het gestroomlijnd houden van de organisatic. ${ }^{3} \mathrm{De}$ invloed die de leiders van de twee grote politieke partijen hebben op het (kies)gedrag van de MP's is in feite nauwelijks te overschatten. En een van die twee partijleiders is per definitie de regeringsleider. Deze benoemt de leden van zijn kabinet. Zolang de Prime Minister in staat is om zijn partijachterban goed in het gareel te houden blijkt zijn/haar macht over het House of Commons in feite vrijwel onbeperkt. Dit alles stelt het begrip 'Sovereignty of Parliament' dan ook in een apart daglicht. De democratisch gelegitimeerde machtsophoping bij de Britse Prime Minister wordt tegenwoordig wellicht ietwat robuust, maar tegelijkertijd toch ook fraai en kernachtig omschreven als 'elective dictatorship'. ${ }^{4}$

Een en ander heeft grote gevolgen gehad voor de wijze waarop het parlementaire werk in Groot-Brittannic in zijn algemeenheid en de creatie van nieuwe wetgeving in het bijzonder, tot stand komt. Dit geldt natuurlijk tevens voor de inkleuring van begrippen als 'checks and balances' en 'bicameralisme' in de verhouding Regering-Commons-Lords. Met name tijdens achtereenvolgende regeringen onder leiding van Margaret Thatcher en tijdens de huidige regeringen onder leiding van Tony Blair is dienaangaande sprake geweest van een opmerkelijke ontwikkeling, een ontwikkeling die de rode draad zal vormen voor de bespreking van het bevoegdhedenpakket van het House of Lords.

\subsection{Positionering van het House of Lords}

\subsubsection{Salisbury Convention}

Terecht had het House of Lords nog niet eens zo lang geleden een behoorlijke faam als rusten dutplaats voor Conservatieve Britse adel. ${ }^{5}$ De invloed van de Lords, parlementariërs uit het Britse Hogerhuis, kon in de zeventiger jaren van de vorige eeuw, slechts dertig jaar geleden derhalve, volgens toonaangevende leden uit eigen kring nog omschreven worden als: 'arguably less persuasive than a powerful leading article in the Times, or even a good edition of Panorama' ${ }^{6}$

Deze beeldvorming heeft vooral zo duidelijk post kunnen vatten nadat het House of Lords ten gevolge van de aanname van de Parliament Act van 1911 het vetorecht verloor. Vanaf dat moment werden langzamerhand steeds minder politiek sterk in het oog springende Hogerhuis

2. P. Cowley and D. Melhuish. Peers' Careers: Ministers in the House of Lords, 1964-95, in: Political Studies $1997, \mathrm{XLV}, \mathrm{p} .21-35$.

3. De goed betaalde en hoog in aanzien staande functie van Chief-Whip moge tot voorbeeld dienen.

4. Lord Hailsham, Elective Dictatorship. The Dimbleby Lecture, London 1976.

5. R. Brazier. The Second Chamber: Paradoxes and Plans, uit: The House of Lords, Its Parliamentary and Judicial Roles, Oxford 1999, p. 57.

6. Aldus Lord Hailsham in de vermaarde Dimbleby Lecture uit 1976. 
activiteiten waargenomen. Dit proces werd sterk gestimuleerd onder invloed van conventies, waarvan de zelfopgelegde 'Salisbury Doctrine' wel de bekendste is geworden. De strekking en het belang van deze opvallend taaie, anno 2000 nog steeds relevante doctrine werd duidelijk verwoord tijdens Hogerhuisdebatten in 1964: 'our broad guiding nule was, that what had been on the Labour Party programme (Labour was op dat moment de regeringspartij, EK) at the preceding General Election should be regarded as having been approved by the British people. Therefore we passed all the nationalisation bills, although we cordially disliked them, on the second reading and did our best to improve them and make them more workable on Committee stage'. ' Bicameralisme op Britse wijze 'in a nutshell'.

Zoals gezegd wordt ook aan het begin van de 2 le eeuw deze ongeschreven regel van Brits parlementair recht door alle belangrijke politieke groeperingen in het parlement nog steeds beschouwd als een van de fundamenten onder het politiek functioneren van het Britse Hogerhuis. De kern van de wijze waarop het bicameralisme in Groot-Brittannic, onder zowel Labour als Conservative regeringen vorm pleegt te krijgen, ligt in dit citaat verscholen: altijd coöperatief en meedenkend, zelfs in geval meerderheden in Hoger- en Lagerhuis qua politieke visie lijnrecht tegenover elkaar blijken te staan. Daarvan was bijvoorbeeld duidelijk sprake ten tijde van de ouderwets socialistische golven van nationalisering door Labour, ideeên die volledig haaks stonden op het rechts-liberale privatiseringgedachtegoed dat de permanente Conservatieve meerderheid in het House of Lords in die tijd wenste uit te dragen.

Vooral indien een regeringsvoorstel tot wet een officieel onderdeel van het programma uitmaakt waarmee de regeringspartij de laatste verkiezingen heeft gewonnen, zullen oppositionele politieke groeperingen in het House of Lords ook tegenwoordig nog terughoudend zijn in het hanteren van de hun staatsrechtelijk toekomende 'correctie'-rechten: het recht van amendement en het recht de wetgevingsvoortgang te vertragen conform de Parliament Acts van 1911 en 1949. Via de zelf opgelegde 'Salisbury Doctrine' is het niet gebruikmaken van deze rechten tot vertraging van wetgevingsvoorstellen door het Britse Hogerhuis, in geval deze plannen onderdeel uit maakten van het officiële partijprogramma waarmee de laatste algemene verkiezingen gewonnen werden, al sinds ruim een halve eeuw geformaliseerd.

\subsubsection{The Parliament Acts}

In hoofdstuk 2 is het ontstaan van de Parliament Acts van 1911 en 1949 al aan de orde geweest. De belangrijkste groep gewone wetgevingsvoorstellen zijn de zgn: 'Public Bills', wetgevingsvoorstellen geïnitieerd door regering en House of Commons. Deze voorstellen kunnen, indien zij eerst het Britse Lagerhuis passeren, op grond van deze Acts door de Britse senaatskamer maximaal een jaar vertraagd worden. Daama zal de wil van het House of Commons automatisch prevaleren. In de Britse wetgevingspraktijk komt het er op neer dat een wetsvoorstel dat door het House of Lords tijdens de 'second-' of 'third reading' afgestemd wordt, tijdens het daaropvolgende parlementaire jaar automatisch 'Royal Assent' kan krijgen indien het Hogerhuis wederom een negatief oordeel velt én minstens twaalf maanden zijn verlopen sinds de 'second reading' van het gewraakte wetsvoorstel tijdens het vorige parlementaire jaar. ${ }^{8}$ 


\section{Hoofdstuk 4}

Onder de Parliament Acts valt geen 'secondary legislation'. In tegenstelling tot hetgeen in Nederland op dit vlak gebeurt, wordt in Groot-Brittannie̋ regelmatig in raamwetten (de 'Parent Act') opgenomen dat regelgeving die vervolgens tot stand komen op basis van de verleende delegatiebevoegdheid toch eerst formeel het parlement zal moeten passeren, alvorens deze in werking kan treden. ${ }^{9}$ En omdat de Parliament Acts van 1911 en 1949 op dit terrein geen gelding hebben, kán het Hogerhuis in principe met betrekking tot bijvoorbeeld volledig uitgewerkte regelgevingvoorstellen afkomstig van de ministeries in theorie dan wél gewoon beschikken over een absoluut vetorecht. In par.4.3.4 wordt deze problematiek nader uitgewerkt.

In constitutionele zin is vervolgens nog van belang, dat besluiten van het House of Commons om de maximale levensduur van een zittende regering (vijf jaar) te verlengen niet onder de Parliament Acts vallen. Dienaangaande (maar ook alleen dienaangaande) heeft de tweede Britse parlementskamer dus ook in de 2 le eeuw nog steeds de taak van constitutionele waakhond.

Voor het overige kunnen regering en House of Commons, althans in theorie, op termijn ieder willekeurig regelgevingvoorstel (inclusief bijvoorbeeld een voorstel tot afschaffing van het House of Lords) voorgedragen krijgen voor 'Royal Assent'.

Activering van de Parliament Acts van 1911 en 1949 met als gevolg een vertraging van het wetgevingstraject van maximaal 12 maanden, is in de sterk op ongeschreven conventies gegrondveste Bitse staatsrechtelijke constellatie echter hoge uitzondering gebleven. Toch opmerkelijk, omdat zeker ook in Groot-Brittanniè tijdens de parlementaire fases van een wetsontwerp met enige regelmaat maatschappelijke ontwikkelingen manifest worden, die als het ware schreeuwen om een 'time-out'. Zowel het politiek als het maatschappelijk belang van het onderhavige wetsontwerp zouden dan nog eens op hun merites gewogen kunnen worden. De gewraakte Poll-tax uit $1988^{10}$ moge hiervoor tot sprekend voorbeeld dienen. Slechts vijf maal is in de loop van de twintigste eeuw formeel door het Hogerhuis gebruik gemaakt van de uit de Parliament Acts van 1911 en 1949 voortvloeiende vertragingsbevoegdheid: twee maal in 1914, in verband met de lrish Home Rule en een beperking van de wereldlijke invloed van de Kerk van Wales. Vervolgens kon de Parliament Act van 1949 die de mazen uit 1911 nader verfijnde van twee naar maximaal één jaar wetgevingsvertraging voor het House of Lords, pas twee jaar na de eerste 'second reading' in het House of Commons' kracht van wet krijgen. De laatste twee gevallen zijn van redelijk recente datum, de War Crime Bill uit 1991 en de European Parliamentary Elections Bill uit 1998 (waarover later meer). De Parliament Acts van 1911 en 1949 blijken echter niet zo zeer in repressieve als wel in preventieve zin hun functie te vervullen. "De hiërarchische verhouding in het wetgevingsproces tussen het House of Commons en het House of Lords is sindsdien namelijk een duidelijk vaststaand gegeven en een uitgangspunt voor de poli-

9. Standing Order nr. 70 .

10. In 1988 wenste de regering Thatcher een bijzonder impopulaire belastingmaatregel met spoed door het parlement te drukken. Hoewel de maatschappelijke onvrede rondom de voorgestelde maatregelen naar Britse maatstaven gemeten enorme proporties aannam, ging een regeringsgezinde meerderheid in het House of Lords tijdens de behandeling van het wetsvoorstel toch niet verder dan het uiten van felle kritick gekoppeld aan aanname van de Bill, terwijl de behoefte aan 'een pas op de plaats' ontegenzeggelijk zelden zo groot is goweest.

11. M. Rush, The House of Lords: The Political Context, in: P. Carmichael and B. Dickson, The House of Lords, Its Parliamentary and Judicial Roles, Oxford 1999, p. 16 e.v. 
tiekinhoudelijke inkleuring van het bevoegdhedenpakket dat de Britse senatoren in het wetgevingsproces nog rest.

\subsubsection{Partijpolitieke- en werkverhoudingen}

Alvorens over te gaan tot een bespreking van het Britse wetgevingsproces dienen nog enige noodzakelijke algemene opmerkingen gewijd te worden aan zowel de partijpoliticke verhoudingen als de gangbare werkverhoudingen in het Britse Hogerhuis.

Tot 1999 kon er, zoals in het vervolg van dit hoofdstuk nog meermaals naar voren zal komen, gevoeglijk van uitgegaan worden dat stemmingen over controversiěle amendementen in het House of Lords, lopende via de partijpolitieke scheidslijnen, welhaast per definitie automatische meerderheden opleverde voor de Conservatieve partij. Deze partij beschikte weliswaar niet over een permanente absolute meerderheid aan feitelijk ten bchoeve van het Hogerhuis actief zijnde 'working Peers', doch was wel te allen tijde in staat om, indien de noodzaak daartoe zich aandiende, relatief snel een substantieel aantal Hereditary Peers van conservatieve huize als 'stemvee' te mobiliseren. Een voorbeeld: de zér beladen debatten die in 1988 tijdens de commissiefase vooraf gingen aan de stemming over een 'wreking amendement waardoor de uitvoering van de (door de Conservatieve regering Thatcher geëntameerde) PollTax-regelgeving per saldo een vol jaar vertraging op zou lopen (nota bene ingediend door een Backbencher van Conservatieve huize) deed de Conservatieve Chief Whip besluiten zijn 'backwoodsmen' op te trommelen. Deze 'backwoodsmen' zijn Peers die normaliter hoogst zelden deel plegen te nemen aan de werkzaamheden in het Hogerhuis. Zij waren bij dergelijke stemmingen echter wel eenvoudig in staat het verschil te maken tussen voortgang van het wetgevingstraject of een jaar vertraging. In het geval van de Poll-tax werden 317 stemmen uitgebracht tegen het 'wrecking amendment', dat beoogde de individuele betalingsmogelijkheid van de Poll-tax te koppelen aan financiële draagkracht, waarmee het hart c.q. de angel uit het voorliggende wetsvoorstel zou zijn gehaald. Maar liefst 140 stemmen tegen het afgewezen amendement bleken afkomstig te zijn van backwoodsmen. Het staat wel vast dat zonder deze (in hoofdzaak van Hereditary Peers 'in ruste' afkomstige) stemmen de uitslag van de stemming anders zou zijn uitgevallen. ${ }^{12}$

Aanname van de House of Lords Bill van 1999, waardoor 541 van de 633 Hereditary Peers het veld moesten ruimen, heeft in combinatie met de benoeming van meer dan honderd nieuwe Life Peers van Labourhuize ('Tony-Cronies') inmiddels (zie par.3.2.1) zorg gedragen voor een volledig gewijzigde partijpolitieke samenstelling van het House of Lords. Een samenstelling waarbij vanzelfsprekende absolute meerderheden voor één enkele politieke groepering niet snel meer voor zullen komen. Een en ander valt duidelijk af te lezen uit tabel 4.1.

Men dient zich bij het interpreteren van deze gegevens wel te realiseren dat activiteiten voortvloeiend uit het lidmaatschap van het Hogerhuis ook na 1999 nog steeds als semi-vrijwilligerswerk beschouwd moeten worden, waardoor lang niet altijd te voorspellen valt hoe de partijpolitieke verhoudingen op een willekeurige vergaderdag uit zullen vallen. Zeker indien gestemd wordt over amendementen kán dit (zoals de vermelde stemming aangaande de Polltax al aangaf) in partijpolitieke zin van groot belang blijken te zijn. 


\section{Hoofdstuk 4}

Partijpolitieke samenstelling van het House of Lords per 15 oktober 2001

Tabel 4.I

\begin{tabular}{|l|c|c|c|c|}
\hline Partij & Life Peers & Hereditary Peers & Bishops & Totaal \\
\hline Conservative & 172 & 50 & & 222 \\
\hline Labour & 193 & 4 & & 197 \\
\hline Liberal Democrats & 57 & 5 & & 62 \\
\hline Cross Bench & 145 & 31 & & 176 \\
\hline Bishops & & & 26 & 26 \\
\hline Anderen & 20 & & & 20 \\
\hline Totaal & 587 & 90 & 26 & 703 \\
\hline
\end{tabular}

Bron: http://www.parliament.the-stationery-office.co.uk/pa/ld199798/ldbriefldanal.htm, 20 oktober 2001

Participatie op basis van vrijwilligheid betekent onvermijdelijk dat regelmatige en voortdurende uitoefening van de (mede)wetgevende taken door in principe alle leden van het Hogerhuis niet bij voorbaat verlangd kan worden

In het verleden was de gemiddelde dagelijkse opkomst ten behoeve van de Hogerhuiswerkzaamheden in Groot-Brittanniê relatief bescheiden. Met de creatie van Life Peers in 1958 is hierin echter ontegenzeggelijk langzaam maar zeker verandering gekomen (zie tabel 4.2).

Tabel 4.2

\begin{tabular}{|l|c|c|c|c|c|c|c|}
\hline & $\begin{array}{l}1970- \\
1971\end{array}$ & $\begin{array}{l}1975- \\
1976\end{array}$ & $\begin{array}{l}1980- \\
1981\end{array}$ & $\begin{array}{l}1985- \\
1986\end{array}$ & $\begin{array}{l}1990- \\
1991\end{array}$ & $\begin{array}{l}1995- \\
1996\end{array}$ & $\begin{array}{l}2000- \\
2001\end{array}$ \\
\hline $\begin{array}{l}\text { Lidmaatschap } \\
\text { Life Peers }\end{array}$ & 178 & 272 & 319 & 340 & 358 & 371 & 587 \\
\hline $\begin{array}{l}\text { Gemiddelde } \\
\text { dagelijkse } \\
\text { opkomst per } \\
\text { parlementair } \\
\text { jaar }\end{array}$ & 265 & 275 & 296 & 317 & 324 & 372 & 346 \\
\hline
\end{tabular}

Bron: http://www, official-documents.co.uk/document/cm45/4534/4534.htm, 20 oktober 2001

De Life Peers, sinds 1999 veruit de grootste groep senatoren, zijn dankzij hun ervaring, breed expertise terrein en (in het geval van 'former MP's) affiniteit met het métier ontegenzeggelijk te beschouwen als de motor van het House of Lords. ${ }^{13} \mathrm{Via}$ hen is het ook de bedoeling een nadere professionalisering van het Britse Hogerhuis als tweede parlementskamer door te voeren.

De inbreng van de 26 geestelijken moet zeker niet overschat worden. Indien bijvoorbeeld een 'Infant Life (Preservation) Bill' onderwerp van bespreking uitmaakt zal een aantal bisschoppen en kardinalen prominent participeren, maar grosso modo blijven zij toch relatief onzichtbaar én (als groep) machteloos. ${ }^{14}$ De opinie van de 'Lords Spiritual' wordt met name zo nu en

13. J. Griffith., and M. Ryle, Parliament, Functions, Practice and Procedures, London 1989, p. 461.

14. F. Bown, Influencing the House of Lords: the Role of the Lords Spiritual 1979-1987, Political Studies 1994, p. 111 . 
dan geuit, waar de legitimiteit van sociaal-economisch beleid in het geding is. Op die beleidsterreinen willen zij nog wel eens botsen met de regering van de dag. Margaret Thatcher was in 1988 dusdanig verbolgen over de kritische opstelling van de geestelijken in het House of Lords waar haar sociaal-economische politiek in het geding was, dat zij tijdens een openbare toespraak voor een gehoor van prominente Britse geestelijken niet langer weerstand kon bieden aan de behoefte tot duidelijke kapitteling: (....) It is not the creation of wealth that is wrong, but love of money for its own sake. We are all responsible for our own actions. We simply cannot delegate the exercise of mercy and generosity to others' $(. ..){ }^{15}$ De speech werd al snel fameus als 'the Gospel according to Thatcher'.

\subsection{Wetgevingsbevoegdheden}

De ( mede)wetgevende bevoegdheden van het Britse House of Lords beperken zich niet, naar bijvoorbeeld Nederlands model, tot uitsluitend de herziening van regeringsvoorstellen tot wet afkomstig uit het House of Commons. Revisie van deze groep zgn. 'Public Bills' wordt echter wel beschouwd als de belangrijkste wetgevende bevoegdheid van het Britse Hogerhuis. Daarnaast strekken de wetgevende bevoegdheden zich echter ook uit tot het recht van initiatief (Private Member Bills), het checken van 'subordinate legislation', voornamelijk totstandgekomen op basis van delegatie (zie par. 4.3.4) en tenslotte de bevoegdheid tot bespreking en aanname van zgn.' Private Bills'. Bij de bespreking van het Britse wetgevingsproces zullen ontstaan en ontwikkeling van de regeringsvoorstellen tot wet vanzelfsprekend als leidraad dienen. Vervolgens zullen enkele additionele opmerkingen over zowel de rol van het House of Lords bij het lanceren van 'Private Member Bills' als de beoordeling van gedelegeerde wetgevingsproducten onderwerp van bespreking uitmaken. 'Private Bills', die niet door leden van regering en/of parlement aanhangig worden gemaakt $^{16}$, passen niet in het kader van dit boek en blijven derhalve onbesproken.

\subsubsection{Public Bills}

Veruit de meeste aandacht in het kader van (mede)wetgevende activiteiten wordt ook in het Britse Hogerhuis besteed aan beoordeling en revisie van wetsvoorstellen die geïnitieerd worden door de regering. ${ }^{17}$ Deze kunnen geïntroduceerd worden in zowel het House of Commons als in het House of Lords. ${ }^{18}$ De politiek belangrijkste wetsvoorstellen worden als regel eerst besproken in het Lagerhuis. ${ }^{19}$ Hiervoor zijn twee redenen aanwijsbaar. In de eerste plaats de conventie dat wetsvoorstellen met gewicht primair door gekozen volksvertegenwoordigers

15. The Observer 22-5-1988.

16. Via de Private Bill procedure kan bijvoorbeeld ook via formeel initiatief van een gemeente wetgeving tot stand komen die het, in afwijking van de landelijk geldende vereisten dienaangaande mogelijk maakt een nieuwe weg door een plaatselijk bos aan te leggen.

17. De laatste jaren schommelt dit rondom de $90 \%$ van de tijd die door het House of Lords besteed wordt ten behoeve wetgevingsactiviteiten (exclusief Private Bills). Bron: http://www.parliament the-stationeryoffice. co.uk/pa/pabills.htm. 22-11-2001.

18. M. May, Paliamentary Practice, London 1997, p. 465-466.

19. D. Shell, The House of Lords, London 1992, p. 133. 
beoordeeld moeten kunnen worden. Daarnaast wensen de 'Cabinet Ministers' hun nieuwe wetgevingsproducten zo veel mogelijk zélf in het parlement te kunnen introduceren en meer dan driekwart van hen heeft nu eenmaal zitting in de Commons.

Tegelijkertijd is er zeker de laatste jaren een duidelijke tendens waameembaar om meer 'Government Bills' direct in het Hogerhuis te introduceren. Tijdens het parlementaire jaar 1997-1998 bijvoorbeeld werden niet minder dan 15 van de 50 voorstellen tot wet afkomstig uit de regeringskoker eerst behandeld in het House of Lords. ${ }^{20}$ Het betreft hier dan wel de politiek minder controversièle c.q. eenvoudiger voorstellen tot wet. De werkwijze waarbij bepaalde wetsvoorstellen eerst door het Hogerhuis besproken worden, is vooral ingegeven door de grote behoefte aan een meer efficiěnte tijdsplanning. Voornoemde 'minder controversiële c.q. cenvoudiger' voorstellen tot wet kunnen immers door de senatoren inhoudelijk reeds klaargestoomd worden, zodat de parlementariërs in het House of Commons er nog maar relatief weinig tijd aan hocven te besteden. Tijdens periodes dat de politieke wil daartoe in beide pariementskamers aanwezig is, blijken tegenwoordig zelfs wetsvoorstellen met relatief groot politick gewicht af en toe als eerste in het Hogerhuis besproken te worden. Zo besloot de Labourregering onder Tony Blair om tijdens het parlementaire jaar 1997-1998 onder andere de 'Teaching and Higher Education Bill', de 'Human Rights Bill' en de 'Crime and Disorder Bill' eerst door de Lords te laten onderzoeken, bespreken en amenderen. ${ }^{21}$

Desondanks heeft het House of Lords, evenals overigens de senaatskamer in Frankrijk, Nederland en de Bondsrepubliek Duitsland zeker tegen het einde van het parlementaire jaar steevast te kampen met forse tijdsproblemen rondom de afronding van wetsvoorstellen. Het House of Lords moet daarenboven ook nog eens rekening houden met een beslist niet te veronachtzamen formeel staatsrechtelijk fenomeen dat in bijvoorbeeld Frankrijk en Nederland niet bestaat. Ieder wetsvoorstel namelijk dat voorafgaande aan de officiële sluiting van het parlementaire jaar (in de regel eind oktober-begin november van ieder kalenderjaar) nog geen 'Royal Assent' heeft kunnen ontvangen, zijnde de laatste stap van het wetgevingsproces vóor inwerkingtreding, vervalt volledig. ${ }^{22}$ Wil de regering een wetsvoorstel dat, om welke reden dan ook, niet kon worden afgerond voor het einde van het parlementaire jaar toch doorzetten, bijvoorbeeld omdat het een politiek speerpunt betrof, dan zal na herintroductie van het onderhavige voorstel bij een der parlementskamers tijdens de volgende sessie het gehele wetgevingstraject gewoon weer in zijn totaliteit doorlopen moeten worden. Op de gevolgen die voornoemde regel uit het (ongeschreven) Britse staatsrecht zoal kán hebben op de gang van een wetsontwerp kom ik, tijdens de gedetailleerde bespreking van het recht van amendement en de behandeling van de gang van zaken rondom een aantal wetsontwerpen ten tijde van de regeringen Thatcher en Blair, nog uitgebreid tenug.

Het probleem van wetgevingscongestie tegen het einde van het pariementaire jaar bestaat in Groot-Brittanniê reeds enige decennia. Al in 1972 werd het einde van het zomerreces voor de Peers met een volle maand vervroegd in verband met een enorme work-load. In 1976 werd het pariementaire jaar zelfs verlengd, opdat het Hogerhuis via veel avond- en nachtwerk alle belangrijke wetgevingsvoorstellen die dat jaar ingediend waren, nog vór die formele deadline behandeld kon krijgen. ${ }^{23}$ Klachten over de onmogelijkheid kwaliteit te kunnen blijven

20. Bron:http:/www.parliament.thestationeryoffice.co.uk/pa/d199798/dpbstat/stat9802. htm. 4-10-2001.

21. Bron: http:/www. parliament thestationeryoffice.co.uk/pa/d199798/dpbstat9807.htm. 4-10-2001.

22. J. Griffith and M. Ryle, a.w., p. 184

23. D. Shell, a.w., p. 139-140. 
garanderen bij de uitvoering van de wetgevingsrevisie waren als uitvloeisel van die gang van zaken (die sterke overeenkomst vertoont met de 'kerstzittingen' van de Nederlandse Eerste Kamer) niet langer slechts waarneembaar vanuit de oppositie. Nadat het House of Lords in 1980 onder grote druk van de regering als het ware gedwongen werd 246 zojuist door de Conservatieve regering voorgestelde amendementen in één dag volledig te behandelen, lieten gerespecteerde Conservatieve senior Backbenchers in de Handelingen optekeningen dat op deze wijze de functie van wetgevingsrevisie functie door het House of Lords niet mér kon zijn dan een regelrechte aanfluiting. ${ }^{24}$ Hoewel sindsdien regelmatig voorstellen gelanceerd zijn om verbetering in de situatie aan te brengen (vooral op het vlak van het commissiewerk) ${ }^{25}$ bestaan de beschreven problemen, zij het minder geprononceerd, anno 2001 grosso modo nog steeds. De introductie van een groter aantal (nu en dan substantièle) 'Government Bills' in het House of Lords tijdens de eerste helft van het parlementaire jaar, heeft wel enige verlichting te weeg weten te brengen. ${ }^{26}$ Dit bleek ook echt noodzakelijk aangezien in 1998 maar liefst 714 uur door het House of Lords gespendeerd diende te worden aan werkzaamheden ten behoeve van uitsluitend Public Bills in wording. Ter vergelijking: tien jaar eerder in 1988 waren dat 677 uur en twintig jaar voordien in 1978 zelfs slechts 367 uur. $^{27}$

\subsubsection{Wetgevingstraject Public Bills}

\subsubsection{First Reading}

Van de tijd die het House of Lords uittrekt voor (mede)wetgevende activiteiten, wordt tegenwoordig nuim $85 \%$ besteed aan 'Public Bills' en dan, zoals reeds opgemerkt, met name aan de wetsvoorstellen afkomstig van de regering. ${ }^{28}$ Het wetgevingstraject van Public Bills in het House of Lords kent vijf hoofdstadia: Introduction and first reading, second reading, committee, report en third reading. ${ }^{29}$ Met uitzondering van de 'first reading' die in de regel beschouwd kan worden als een zuivere formaliteit kunnen alle stadia tijdrovend zijn. De 'first reading' echter, behelst in feite niet meer dan het voorlezen van de volledige titel van het onderhavige voorstel. Dit ligt ook voor de hand om de eenvoudige reden dat de senatoren in dat stadium nog niet formeel kennis hebben kunnen nemen van het wetsvoorstel ${ }^{30}$ In het hoogst zeldzame geval dat een wetsvoorstel tijdens de afgelopen decennia bij de 'first reading' toch onderwerp van enige bespreking in het House of Lords heeft uitgemaakt, betrof het een bij voorbaat volledig kansloze 'Private Member Bill', afkomstig uit de eigen gelederen.

24. House of Lords Debates, 27-10-1980, 922

25. Bijvoorbeeld via het reeds opstarten van de commissiewerkzaamheden terwijl het wetsvoorstel nog bij het House of Commons in behandeling is.

26. Tijdens de eerste drie jaar introduceerde de regering Blair I respectievelijk $24 \%, 37 \%$ en $30 \%$ van diens wetsvoorstellen eerst in het Hogerhuis.

27. A House for the Future, Royal Commission on the House of Lords, Cm 4534, januari 2000, p. 20.

28. House of Lords Hansard 14-10-1998, 925.

29. E. May, Parliamentary practice, a.w., p. 465.

30. In de twintigste eeuw is het desondanks drie mal voorgekomen dat direct na de 'first reading' oppositie is gevoerd: de Irish Free State Bill (1922). The Government of India Bill (1935) en Licensing Bill (1961).

31. D. Shell, a.w., p. 133-134. 


\subsubsection{Second reading}

Vanaf de 'second reading' speelt het wetgevingsproces in het House of Lords zich onder normale omstandigheden voortdurend af 'on the Floor of the House'. Er dient dan op toegezien te worden dat tussen de verschillende stadia van het proces minimum tijdintervallen in acht genomen worden van ongeveer twee weken. ${ }^{32}$ Tijdens de 'second reading' worden de centrale uitgangspunten en grote lijnen van het regeringsvoorstel tot wet besproken. Het initiatief voor de tweede lezing ligt normaliter bij een lid van de regering die zitting heeft in het House of Lords. Hij/zij licht de regeringsstandpunten toe en leidt de verdediging van het wetsvoorstel.

Reeds in dit nog vrij prille stadium van het heroverwegingsproces in de Britse senaatskamer treden duidelijke verschillen aan het licht in vergelijking met de gang van zaken dienaangaande in het House of Commons. De structureel sterk gepolitiseerde en gepolariseerde politieke verhoudingen in het Lagerhuis zorgen zowel plenair als in de vaste commissies voor een debat via strakke partijpolitieke scheidslijnen. De regie is daarbij te allen tijde in handen van de regering, aangezien een absolute en loyale meerderheid, zoals reeds eerder betoogd, immers welhaast per definitic gegarandeerd is in de Britse politieke constellatie. In het Hogerhuis daarentegen beschikt sinds 1999 geen enkele politieke partij meer over een automatische absolute meerderheid. ${ }^{33}$ Ook voordien echter was er altijd al sprake van een duidelijk van het House of Commons afwijkende politicke cultuur. Peers blijken zich zeker niet ónafhankelijk maar wel degelijk minder áfhankelijk op te stellen van strakke regels en officięle partijstandpunten, dan MP's in het House of Commons dat plegen te doen: 'The House (of Lords, EK) runs its affairs according to good sense rather than by the rule book. The House is a selfregulatory body, which is accustomed to agree on its day-to-day proceedings. Peers should therefore be aware that the democratic and flexible way of managing the affairs depends on the responsibility and restraint of each individual member' ${ }^{34}$ Daar komt bij dat het Britse Hogerhuis een grote groep Cross-benchers en onafhankelijken herbergt. Relatieve vrijheid van handelen is een niet te veronachtzamen gegeven voor de politiek minst belangrijke Britse parlementskamer:'within the terms of standing orders, we (de leden van het House of Lords, EK) have great flexibility in our procedure and are therefore able to conduct our business expeditiously, politely and sensibly. We are not troubled by points of order, nor by the exploitation of time-wasting procedural devices, which are often to be observed in other legislative assemblies. The 'sense of the House' is the decisive factor in the conduct of our business, and in the main this works well' ${ }^{35}$ Tegelijkertijd echter moet natuurlijk wel opgemerkt worden dat regeringen van zowel Labour als Conservative huize op basis van typisch Brits ongeschreven recht altijd in de mogelijkheid gesteld moeten en zullen worden 'to have their business considered, ${ }^{36}$

Vanuit de minder afhankelijke politiek-culturele setting gebruiken de Peers met name de aan het commissiewerk voorafgaande 'second reading' om wetsvoorstellen niet zozeer partijpolitick als wel inhoudelijk kritisch te benaderen, vanuit een allerminst te veronachtzamen niveau aan expertise. De reeds gepensioneerde 'Law Lords' voorzover deze actief blijven in de

Zie tabel 4.1

Tenth Report of the Procedure Committee, House of Lords. Vol. 227, 1970-71

Idem.

J. Griffith and M. Ryle, a.w., p. 468. 
politiek bijvoorbeeld, staan qualitate qua garant voor een respectabele dosis aan juridische knowhow.

De gewoonte om zoveel mogelijk afwegingen van zuiver partijpoliticke aard buiten de deur van het Hogerhuis te houden, wordt zowel door leden van de regeringsgezinde partij als leden van de oppositionele partijen in ere gehouden. ${ }^{37}$ Hoewel de 'second reading' beslist niet bedoeld is om reeds gedetailleerd op de merites van het wetsvoorstel in te gaan, blijkt in dit stadium toch al vaak duidelijk of de Bill tijdens het commissiestadium op onderdelen nog nader geamendeerd zal gaan worden.

Slechts amendementen in relatie tot de grote lijnen van een Public Bill zijn tijdens de 'second reading' toegestaan. Deze worden in de, zoals gezegd relatief gepacificeerde Britse Hogerhuispraktijk waarvoor de Salisbury Doctrine zo richtinggevend is, met betrekking tot vele Public Bills slecht sporadisch ingediend, maar hebben dan uiteraard wel een relatief zwaardere politieke lading, nu de grote lijnen van een voorstel in het geding zullen zijn.

Een amendement tijdens het stadium van de tweede lezing zal als regel gedeponeerd worden in de vorm van óf een 'delaying amendment, of een 'reasoned amendment'. 38 In het eerste geval wordt een verzoek tot uitstel ingediend, meestal voor een termijn die de resterende looptijd van het parlementaire jaar overschrijdt. Bij aanname van een dergelijk amendement zal het wetsvoorstel in kwestie dan ook direct afgevoerd worden. In het frequenter voorkomende geval dat tijdens de 'second reading' tegen de grote lijnen van een wetsvoorstel geageerd wordt via een 'reasoned amendment', motiveert de indiener waarom voortzetting van het wetgevingsproces onder de gegeven omstandigheden niet verstandig zou zijn, dan wel waarom additionele informatie ter beschikking gesteld moet worden alvorens cen afgewogen oordeel over het voorstel gegeven zal kunnen worden. ${ }^{39}$

Een fraai voorbeeld van de politieke lading en dito reikwijdte die een door het House of Lords ingediend 'reasoned amendment' in extreme gevallen kan hebben, speelde ten tijde van de tweede regering Thatcher. In het najaar van 1984 werden door deze regering in het voetspoor van de Local Government Bill voor het lopende parlementaire jaar voorstellen gelanceerd om de 'Greater London Council and the metropolitan counties' op te heffen en te vervangen door (centraal) benoemde bestuurders. De zittende (gekozen) bestuurders functioneerden onafhankelijk van de centrale overheid. Zij werkten ten behoeve van de grotere verstedelijkte gebieden in Engeland én, allerminst onbelangrijk, werden (vooral in het geval van groot-London) gedomineerd door Labour. De doorgaans bijzonder loyale degelijk Conservatieve meerderheid die het Britse Hogerhuis in die tijd nog domineerde, zou zich in principe zonder al te veel moeite achter zo'n voorstel kunnen scharen. Het probleem was echter, dat de regering Thatcher steunend op een grote vanzelfsprekende meerderheid in het House of Commons, veel te hard van stapel wenste te lopen. Vooruitlopend namelijk op zeker geachte aanname (Salisbury Doctrine) van de Local Government Bill waarin deze voornemens aangeboden werden aan beide parlementskamers van het Verenigd Koninkrijk, wilde de regering al direct ná de tweede lezing van dit wetsvoorstel in het Lagerhuis en dus ruimschoot vóór de Bill überhaupt door het House of Lords besproken zou kunnen gaan worden, via overgangsregelingen (die, zo meenden de Lords in meerderheid, niet onder de Salisbury Doctrine vielen) de aanstaande verkiezingen voor de Councils laten schrappen en deze raden alvast tijdelijk laten bemensen 


\section{Hoofdstuk 4}

met door de centrale regering benoemde leden. De Peers waren uiteraard 'not amused'. Hier zou sprake zijn van zuiver staatsrechtelijke malversaties. Het House of Lords, de medewetgevende parlementskamer, de kamer van herziening, zou te zijner tijd nog mogen delibereren over mogelijke afschaffing van de verkiezing van leden voor de grootstedelijke raden, terwijl in materièle zin deze afschaffing reeds lang een feit zou zijn. De uit 1976 stammende theorie van het 'Elective Dictatorship' werd door de senatoren weer eens met verve ten tonele gevoerd. Een en ander leidde uiteindelijk onvermijdelijk tot de indiening én aanname van een 'reasoned amendment' door het Britse Hogerhuis met als belangrijkste gevolg dat pas na het verkrijgen van een 'Royal Assent' voor de nadien te behandelen Local Government Bill tot vervanging van gekozen council-leden door benoemde overgegaan zou kunnen worden. ${ }^{40}$ De kredietwaardigheid van de tweede Britse parlementskamer zijnde een niet democratisch gelegitimeerde kamer voor wetgevingsherziening gedomineerd door conservatieve adel, steeg flink. ${ }^{41}$

Terzijde zij nog opgemerkt dat de stemming negatief uitviel voor de regering ondanks intensieve 'whipping' door regeringswhips. Voor deze vrij unieke gelegenheid liet een meerderheid van het House of Lords haar tot dan toe zeer gebruikelijke behoudende conformistische houding varen: 'One of the principal consequences of this remarkable vote has been to shatter the conventional wisdom on the House of Lords'. ${ }^{42}$

Indienen van een 'reasoned amendment', indien daartoe de ruimte aanwezig bleek, heeft voor het House of Lords in venuit de meeste gevallen echter hooguit symbolische waarde gehad. Door de structurele Labourminderheid in het House of Lords van vóor 1999 werd bijvoorbeeld menig amendement tijdens de 'second reading' in stemming gebracht in de zuivere wetenschap dat succes ten ene male onhaalbaar zou zijn. ${ }^{43}$ Dit om in ieder geval op enig moment blijk gegeven te kunnen hebben van ongenoegen over de grote lijnen van een regeringsvoorstel tot wet. $^{44}$

\subsubsection{Committee stage}

De meest tijdrovende wetgevingsklus voor het Hogerhuis begint in voorkomende gevallen na de tweede lezing, wanneer ook alle details van een wetsvoorstel onder de loep kunnen worden genomen. Dan is het voor iedere individuele Peer mogelijk uiteenlopende amendementen niet meer de grote lijnen betreffende, ter bespreking en beoordeling aan te dragen. Een belangrijke groep wetsvoorstellen is hiervan echter op voorhand uitgesloten, te weten 'Supply-' (begrotingsvoorstellen) en 'Money Bills'. Onder deze laatste groep vallen wetsvoorstellen komende vanuit het Lagerhuis, betreffende: 'the imposition, repeal, remission, alteration or regulation of taxation; the imposition for the payment of debt or other financial provisions of charges on the Consolidated Fund or the National Loans Fund, or on money provided by Parliament or

40. D. Welfare, An Anachronism with Relevance: The Revival of the House of Lords in the 1980s and tts Defence of Local Government, Parliamentary affairs 1991, p.205-219. Ook: D. Shell, The House of Lords and the Thatcher Government, Parliamentary Affairs 1985, p. 17.32.

41. I. Richard and D. Welfare, Unfinished Business, London 1999, p. 66

42. The Times, 2 Juli 1984.

43. London Regional Passenger (Transport)Bill, 1985.

44. D. Shell, The House of Lords, a w., p. 135. 
the variation or repeal of any such charges. ${ }^{45}$ Of voorstellen tot wet onder deze definitic vallen wordt bij twijfel dienaangaande uiteindelijk vastgesteld door de Speaker van het House of Commons. Zijn/haar beslissing is niet vatbaar voor enige vorm van beroep. ${ }^{46}$

Vaststelling van de vraag of het Britse Hogerhuis te doen heeft met een 'Money Bill' is van belang en wel met name, omdat dergelijke wetsontwerpen vallen onder de Parliament Act van 1911. Ten gevolge van deze wet kunnen (reeds door het House of Commons goedgekeurde) wetsvoorstellen die te boek staan als 'Money Bills' namelijk één maand nadat deze zijn doorgestuurd naar het Hogerhuis automatisch kracht van wet krijgen. Het Hogerhuis is daardoor vanaf 1911 in feite volledig buitenspel gezet waar het rijksbudget in het geding is. Het ligt dan ook voor de hand dat de Britse senatoren in de regel niet al te veel tijd en energie in budgetgerelateerde wetsvoorstellen zullen steken. Enige algemene opmerkingen tijdens de 'second reading' volstaan in de meeste gevallen. Bij zeer hoge uitzondering willen dergelijke opmerkingen over de grote lijnen van een 'Money Bill' nog wel eens vergezeld gaan van een 'reasoned amendment just for the sake of argument ${ }^{47}$, maar daar blijft het dan ook bij. De Britse senatoren zijn zich zeer bewust van het feit dat zij rondom 'Money Bills' slechts rituele dansen uit moeten voeren.

Het commissiewerk blijft dus beperkt tot de overige 'Government Bills'. Dit werk gebeur, in tegenstelling tot hetgeen gebruikelijk is in het House of Commons, maar bijvoorbeeld ook in de Franse Sénat, normaliter niet in vaste kamercommissies, doch 'in Committee of the whole House ${ }^{48}{ }^{48}$ In praktische zin is deze frappante werkwijze van een verpletterende eenvoud. Indien de aanwezige Peers op formeel verzoek van de Lord die namens de regering het wetsvoorstel verdedigt ('That the House do now resolve itself into a committee upon the bill'), besluiten over te gaan tot de fase van commissiewerk, verlaat de Lord Speaker de Woolsack en neemt de Lord Chairman de 'voorzittershamer' over vanaf the Chair. Vervolgens zijn alle die dag aanwezige Peers bezig met een commissievergadering.

De belangrijkste oorzaak voor het gegeven dat commissiewerk ten behoeve van het wetgevingsproces in het Britse Hogerhuis zich in hoofdzaak plenair pleegt te voltrekken, gaat schuil in het gegeven dat de Peers semi-'vrijwilligers' zijn. Permanente bemanning van vaste kamercommissies ten behoeve van alle belangrijke beleidsvelden naar voorbeeld van het House of Commons, is in het House of Lords tot nu toe eenvoudigweg getalsmatig niet haalbaar gebleken. Dientengevolge wordt slechts op een zeer beperkt aantal specifieke terreinen gewerkt met speciale 'Select Committees' (zie par. 4.3.3) en prevaleert voor het overige de methode van plenaire inbreng via 'the Whole House'. Tijdens deze plenaire commissievergaderingen is de actieve inbreng van regeringswege natuurlijk gegarandeerd, indien vanuit die hoek de behoefte tot nadere amendering van wetsvoorstellen blijkt te bestaan. Daarnaast plegen zich natuurlijk, alleen al dankzij het gegeven dat de Lords door de macht van het getal (tegenwoordig nuim 700 senatoren) over een waaier aan expertise blijken te beschikken, ook Hogerhuisleden via de partijfracties te verplichten tot actieve begeleiding van het wetsontwerp door onder meer de commissiefase. ${ }^{49}$ Overigens moet hier wel opgemerkt worden dat de commissiefase overgeslagen kan en zal worden, indien er vanuit zowel regeringskringen als van-

45. National Loans Act 1968.

46. E. May, a.w., p. 485 .

47. I. Richard and D. Welfare, a.w., p. 29.

48. Standing Order nr. 45.

49. D. Shell, The House of Lords, a.w., p. 136-138. 


\section{Hoofdstuk 4}

uit de oppositie geen behoefte bestaat tot het indienen van amendementen of moties die verband houden met het voorliggende wetsontwerp. Een situatie die al met al ook tegenwoordig nog met enige regelmaat voor pleegt te komen. Tussen 1970 en 2000 werden bij ruim $55 \%$ van de Government Bills niet zijnde Money of Supply Bills een of meer amendementen ingediend door leden van het Britse Hogerhuis (zie ook tabel 4.3). ${ }^{50}$ Tot op zekere hoogte hoeft het nauwelijks verbazing te wekken dat een aantal voorstellen tot wet in het geheel niet geamendeerd blijken te worden. Ieder jaar passeren namelijk ook een aantal wetsvoorstellen de Britse parlementskamers die simpelweg zo weinig complex zijn dat amendering, om het eens cufemistisch uit te drukken, niet erg voor de hand ligt. De Currency Bill uit 1981 bijvoorbeeld had slechts tot doel de benaming 'new penny' om te dopen tot 'penny'. Een karwei dat voortvarend en zonder nadere amendering door zowel Hoger- als Lagerhuis geklaard bleck te kunnen worden.

Tabel 4.3, waarin de statistische gegevens zijn opgenomen over hantering door het House of Lords van het recht van amendement betreffende regeringsvoorstellen tot wet tijdens het parlementaire jaar 1998-99, kan tot voorbeeld dienen voor de gebnuikelijke handelswijze aangaande amendementen.

De Britse Hogerhuiskamer blijkt in kwantitatieve zin een substantieel aantal wijzigingen doorgevoerd te krijgen in op stapel staande wetgeving. Tijdens één parlementair jaar werden nim 2000 voorstellen tot wijziging, formeel afkomstig uit de gelederen der senatoren uiteindelijk geaccepteerd door regering en het House of Commons. Men dient zich bij het interpreteren van de gegevens uit deze tabel wel rekenschap te geven van het feit dat de nodige amendementen die in het House of Lords worden ingediend in feite afkomstig zijn vanuit regeringskringen. ${ }^{51}$ De behandeling in tweede instantie van een wetsontwerp in het Hogerhuis biedt voor de regering een ideale gelegenheid om politiek, juridisch of maatschappelijk noodzakelijk geachte verbeteringen en aanpassingen doorgevoerd te krijgen. ${ }^{52}$ Overigens hebben vele van deze regeringsamendementen een juridisch-technisch karakter. Dit hangt samen met het gegeven dat ook in het Verenigd Koninkrijk de formele wetgever actief moet zijn onder grote en permanente tijdsdruk, met alle logische gevolgen van dien voor de kwaliteit van het wetgevingsproduct.

Uit tabel $4.3 \mathrm{kan}$ vervolgens nog afgelezen worden dat er veel meer amendementen door het House of Lords worden ingediend, dan er uiteindelijk geīncorporeerd worden in de definitieve wettekst. Tevens blijkt dat relatief weinig stemmingen over amendementen door de regering verloren plegen te worden. Ergo, daar waar de regering (tijdens behandeling in het House of Commons) aangeeft niet gelukkig te zijn met (het karakter van) voorstellen tot wetswijziging gelanceerd door het Hogerhuis, persisteren de senatoren, conform de geest der geldende conventies eenvoudigweg niet langer, zodat de gewrakkte amendementen zonder verdere politieke strijd in de prullenbak plegen te verdwijnen.

50. Bron: Public Bill Office, House of Lords.

51. M. Rush, a.w., p. 18

52. J. Griffith and M. Ryle, a.w, p. 485. 
Tabel 4.3

\begin{tabular}{|c|c|c|c|}
\hline Titel & $\begin{array}{l}\text { Ingediende } \\
\text { amendementen }\end{array}$ & $\begin{array}{l}\text { aangenomen } \\
\text { amendementen }\end{array}$ & $\begin{array}{l}\text { Door de regering } \\
\text { verioren } \\
\text { stemmingen }\end{array}$ \\
\hline Consolidated Fund & 0 & 0 & 0 \\
\hline Consolidated Fund (nr. 2) & 0 & 0 & 0 \\
\hline $\begin{array}{l}\text { Consolidated Fund } \\
\text { (Appropriation) }\end{array}$ & 0 & 0 & 0 \\
\hline Employment Relations & 540 & 373 & 1 \\
\hline $\begin{array}{l}\text { European Parliamentary } \\
\text { Elections }\end{array}$ & 1 & 1 & 1 \\
\hline Finance & 0 & 0 & 0 \\
\hline Food Standards & 190 & 50 & 0 \\
\hline Greater London Authority & 2355 & 887 & 1 \\
\hline House of Lords & 384 & 21 & 4 \\
\hline $\begin{array}{l}\text { Immigration and Asylum } \\
\text { Bill }\end{array}$ & 812 & 407 & 1 \\
\hline Local Government & 158 & 20 & 0 \\
\hline Northern Ireland & 0 & 0 & 0 \\
\hline $\begin{array}{l}\text { Northern Ireland (Location } \\
\text { of Victim's Remains) }\end{array}$ & 15 & 0 & 0 \\
\hline Rating (Valuation) & 8 & 0 & 0 \\
\hline Road Traffic (NHS Charges) & 53 & 1 & 0 \\
\hline Scottish Enterprise & 0 & 0 & 0 \\
\hline $\begin{array}{l}\text { Sexual Offences } \\
\text { (Amendment) }\end{array}$ & 1 & 1 & 0 \\
\hline Tax Credits & 98 & 7 & 2 \\
\hline Water Industry & 54 & 0 & 0 \\
\hline $\begin{array}{l}\text { Welfare Reform and } \\
\text { Pensions }\end{array}$ & 565 & 234 & 8 \\
\hline Totaal & 5234 & 2002 & 18 \\
\hline
\end{tabular}

Bron: http://www.parliament.the-stationery-office.co.uk/pald199899/1dpbstat9903.htm, 23 augustus 2000

Betekent dit nu dat partijpolitieke sentimenten totaal geen rol kunnen spelen in de Britse senaatskamer?

Uit tabel 4.4 kan afgelezen worden dat het aantal ingediende amendementen behoorlijke verschillen vertoont tussen de respectievelijke perioden. In de periode 1974-1977, met Labour aan de macht, hebben de (in hoofdzaak Conservatieve) Lords relatief weinig energie gestoken in het lanceren van aanpassingsvoorstellen. Van de 1859 wetswijzigingsvoorstellen die toch opgetekend konden worden, werden er ook nog eens 400 niet overgenomen door het House of Commons. Geheel conform Britsparlementaire conventies bleef het daar vervolgens bij, zodat de regeringsvoorstellen mooi op tijd hun 'Royal Assent' wisten te verkrijgen. Tussen 1979 en 
Govemment Bills(niet zijnde Money en Supply Bills) in het House of Lords behandeld:

Tabel 4.4

\begin{tabular}{|l|c|c|c|}
\hline Jaargang & Wetsvoorstellen & $\begin{array}{l}\text { Aantal geamendeerde } \\
\text { wetsvoorstellen }\end{array}$ & $\begin{array}{l}\text { totale aantal voorgestelde } \\
\text { amendementen }\end{array}$ \\
\hline $1970-1973$ & 79 & 31 & 2.366 \\
\hline $1974-1977$ & 68 & 49 & 1.859 \\
\hline $1979-1982$ & 82 & 39 & 2.231 \\
\hline $1983-1986$ & 69 & 43 & 3.137 \\
\hline $1987-1990$ & 61 & 38 & 5.181 \\
\hline $1992-1995$ & 59 & 42 & 3.664 \\
\hline $1997-1999$ & 66 & 45 & 4.652 \\
\hline
\end{tabular}

Bronnen: http://www.parliament.the-stationery-office.co. uk/paldpbstat.htm, 23 augustus 2000

D. Shell, The House of Lords, a.w., p. 144.

N.B. De tussenliggende niet in de tabel opgenomen jaren zijn weinig representatief omdat het verkiezingsjaren betrof, waarin om praktische redenen relatief weinig wetsvoorstellen geinitieerd plegen te worden.

1983, de periode waarin beide parlementskamers schier maximale trouw betrachtten ten opzichte van de eerste Conservatieve regering Thatcher, werden 2231 amendementen voorgesteld in het House of Lords. Slechts $6($ !) van deze wijzigingsvoorstellen werden niet geìncorporeerd in de definitieve versie van de wetteksten. ${ }^{53}$ Tijdens de beginjaren van het Thatcherregime werd de tweede Britse parlementskamer blijkbaar efficiënt 'ingezet' (vgl. de Franse Sénat ten tijde van de eerste cohabitation, zie hoofdstuk 5) om noodzakelijk geachte aanpassingen snel doorgevoerd te krijgen.

Tijdens de eerste drie jaar van de regering Blair etaleerde het House of Lords (in afwachting van belangrijke wijzigingen in samenstelling voorzien voor 1999) ook een bijzonder actieve en constructieve meestentijds regeringsvriendelijke werkattitude. De 4652 amendementen die daarvan de voornaamste neerslag vormden, vonden in de bulk der gevallen dan ook moeiteloos hun weg naar de definitieve wetteksten. Als het House of Lords tussen 1997 en 1999 amendeerde, lag het gemiddelde per wet num boven de honderd. Deze enorme productie was mogelijk omdat de regering Blair na haar aantreden in straf tempo veel nieuwe Life Peers van hoofdzakelijk Labourhuize benoemde. Tussen mei 1997 en november 1999 reeds 88. Deze nieuwe Peers toonden vervolgens direct aan loyale én hardwerkende 'Tony-Cronies' te kunnen zijn. ${ }^{54}$

Nadat de wijzigingen in de samenstelling van het House of Lords als gevolg van de House of Lords Bill 1999 een feit waren geworden, is zowel de werk- als de amenderingslust onder de Britse senatoren overigens nogmaals substantieel toegenomen. Tijdens de periode april 1999maart 2001 werden door de 'nieuwe ploeg' niet minder dan 18199(!) amendementen voorgesteld. Daarvan werden er 7080 op de een of andere wijze geincorporeerd in de definitieve wetteksten. ${ }^{55}$ Indrukwekkende aantallen.

53. D. Shell, House of Londs, a.w., p. 148

54. Onder andere: M. Russell, Reforming the House of Lords, Lessons from overseas, Oxford 2000, p. 17: I. Richard, and D. Welfare, a.w., p. 4 e.v.

55. Bronnen:http:/ www. parliament the-stationery-office co.uk/pa/ld 199900/dbrief $10412 \mathrm{htm}, 21-10-2001$. http://www. partiament the-stationery-office.co,uk/pa/d200001//dbrief/2329.htm, 21-10-2001. 
In vergelijking tot de gang van zaken in commissie bij het House of Commons kan geconcludeerd worden dat de Lords bij de uitoefening van het hun toekomende amendementsrecht met weinig procedurele beperkingen rekening hoeven te houden. In de eerste plaats mag iedere aanwezige Peer ongelimiteerd amendementen indienen, zolang deze maar relevant zijn, geen inhoudelijke tegenstrijdigheden vertonen ten opzichte van eerder besluiten en geen extra (en dus ongedekte) financiele lasten tot gevolg kunnen hebben, tenzij alle (regerings)tekenen er op wijzen dat het House of Commons de benodigde extra middelen alsnog zal gaan toewijzen $^{56}$ In de tweede plaats kan de Britse regering in het Lagerhuis wel, doch in het Hogerhuis expliciet niet gebruik maken van het procedurele wapen dat luistert naar de naam 'guillotine'. Indien de debatten rondom ingediende amendementen zich in (een vaste commissie van) het House of Commons blijven voortslepen kan de regering dáár namelijk een tijdslimiet stellen. De parlementskamer heeft vanaf dat moment nog slechts beperkte tijd ter beschikking om de door haar te verrichten taken rondom het wetgevingsproces af te ronden. In het Hogerhuis is een dergelijke formeel gestuurde gang van zaken absoluut ondenkbaar. Als de debatten rondom ingediende amendementen zich nodeloos voort lijken te gaan slepen zal hooguit informeel geprobeerd worden om de 'debaters' via de inspanningen van de Leader en de Chief Whips tot het inzicht te laten komen dat verdere herhaling van zetten zo veel mogelijk voorkomen dient te worden. ${ }^{57}$ Dit proces luistert naar de fraaie benaming 'Usual Channels': 'a wide-ranging process of consultation with members of the House takes place, in an attempt to ensure orderly proceedings on the Floor of the House, without points of order and with minimum discussion or business arrangements in the Chamber, ${ }^{38}$

Mocht desondanks toch maar geen einde komen aan de commissiefase van een wetsvoorstel, dan is het niet aan de Speaker, doch aan de verzamelde vergadering om uiteindelijk te beslissen of acceleratie van het wetgevingsproces via selectie van uitsluitend relevant geachte amendementen wenselijk is. De die dag aanwezige Peers kunnen een dergelijk besluit nemen bij gewone meerderheid. ${ }^{59}$ Tevens is het mogelijk amendementen geclusterd te bespreken, maar dwang daartoe, zoals bijvoorbeeld verankerd in de Franse grondwet, bestaat nooit. Ook hier beslissen bij onenigheid uiteindelijk de die dag aanwezige Peers simpelweg bij gewone meerderheid van stemmen. ${ }^{60}$

Alles overziend, kan opgemerkt worden dat er onmiskenbaar functionele opties voor handen zijn voor de leden van het House of Lords om nadere invulling te kunnen geven aan de hun anno 2000 onder de Acts of Parliament van 1911 en 1949 nog toekomende medewetgevende bevoegdheden ${ }^{61}$ De Britse Hogerhuisleden hebben via nauwelijks in te perken vrijheid van handelen immers nog altijd de beschikking over mogelijkheden van procedurele aard tot vertraging c.q. versnelling van het materiële wetgevingsproces. Strategische indiening én behandeling van eindeloze hoeveelheden amendementen door oppositionele politieke kringen naar Frans voorbeeld (zie hoofdstuk 5), lijkt in het Hogerhuis te Westminster wel hél eenvoudig te ensceneren. De kans dat dergelijke vertragingstechnieken daarenboven beter zouden kun-

56. Zie daartoe de Crime and Punishment Bill, House of Lords Debates 1999-97, 579.

57. D. Shell, The House of Lords, a.w., p. 137.

58. J. Griffith, and M. Ryle, a.w., p. 468.

59. E. May, Parliamentary Practice, a.w., p. 471.

60. E. May, Parliamentary Practice, a.w., p. 473.

61. Zie daartoe ook: M. Rush, a.w., in: P. Carmichael and B. Dickson. The House of Lords, Its Parliamentary and Judicial Roles, Oxford 1999, p. 16-22. 
nen renderen dan in Parijs, is verre van irreěel te noemen, nu 'Public Bills' die niet volledig afgerond zijn voor het einde van het lopende parlementaire jaar immers van rechtswege plegen te vervallen en een geformaliseerde conciliatieprocedure in Groot Brittanniè eenvoudigweg ontbreekt. Ik zal deze problematiek verderop in dit hoofdstuk (par. 4.4.2) verder verduidelijken aan de hand van een berucht geworden Britse praktijkvoorbeeld.

\subsubsection{Report stage}

$\mathrm{Na}$ beeindiging van het commissiewerk wordt ten overstaan van het voltallige Hogerhuis gerapportecrd. In feite is hier sprake van een tussenfase die voor het oog nauwelijks verschilt van de daaraan voorafgaande fase van het wetgevingsproces in het Hogerhuis. De Lord Chairman verlaat the Chair en de Lord Chancellor of een Deputy Speaker ploft op de Woolsack. Vervolgens kan een wetsontwerp, standing order 44 daargelaten ${ }^{62}$, rapporterend en wederom amenderend besproken worden ten overstaan van dezelfde groep Peers, zijnde alle die dag aanwezige Hogerhuisleden. De rapportagefase is vooral bedoeld om de regering, de debatten tijdens de commissiefase gehoord hebbende, de mogelijkheid te bieden tot het indienen van eigen amendementen ter aanvulling c.q. verbetering van het oorspronkelijke wetsvoorstel. Een mogelijkheid waarvan op ruime schaal gebruik gemaakt pleegt te worden. ${ }^{\sigma 3}$ Om eindeloze herhaling van zetten te voorkomen, kent de rapportagefase enige formele beperkingen in de tijd. De meest belangrijke: met uitzondering van de indiener van een amendement mag tijdens deze fase in principe iedere senator slechts één maal het woord voeren over het onderwerp van bespreking. ${ }^{64}$ Terzijde zij nog opgemerkt dat deze 'rapportagefase' overgeslagen kan en zal worden, indien tijdens de voorgaande fase (Committee of the Whole House) van het wetgevingsproces in het Hogerhuis geen amendementen ingediend zijn.

\subsubsection{Third reading}

De derde en laatste formele lezing van het wetsontwerp is welhaast vanzelfsprekend bedoeld om de puntjes als het ware op de i te zetten: onduidelijkheden wegwerken, wetstechnische details aanscherpen en tekstuele toezeggingen (van regeringswege) nakomen, waarna het voorstel, afhankelijk van het formele wetgevingsstadium, richting House of Commons kan gaan, dan wel via Royal Assent kracht van wet zal krijgen.

Toch is ook tijdens deze fase van het wetsproces weer sprake van typische House of Lordskenmerken. In tegenstelling tot hetgeen gebruikelijk is in Frankrijk, maar ook in het eigen House of Commons, mogen de leden van het Britse Hogerhuis zelfs tijdens deze finale fase nog volledig nieuwe amendementen voorstellen. Dit past perfect in de lossere 'at ease' werkattitude die de Lords zich in de loop der tijd eigen hebben gemaakt. In voorkomende gevallen (zie bijvoorbeeld het uitgebreide relaas rondom de 'European Parliamentary Elections Bill van 1998, uitgewerkt in par. 4.4.2) wordt dan ook zeker nog nimschoots gebruik gemaakt van deze mogelijkheid. Enige restrictie is echter wel doorgevoerd: amendementen met betrek-

\footnotetext{
62. Tenzij deze regel uit het reglement van orde via goedkeuring van een verzock van die strekking door de plenaire vergadering terzijde geschoven wordt, kan hetzelfde wetsvoorstel geen opeenvolgende stadia van het wetgevingsproces op dezelfde dag doorlopen.

63. J. Griffith and M. Ryle, a.w., p. 485.

64. E. May, a.w., p. 480 .
} 
king tot onderwerpen die reeds grondig besproken zijn tijdens eerdere fases van het proces, zijn 'not done'. 65 Het Hogerhuis heeft zich daarover in 1988 zeer duidelijk uitgesproken. ${ }^{66}$

De gang van zaken 'in politieke zin' tijdens het gehele wetgevingstraject van 'Public Bills' overziend, kan gesteld worden, dat vanuit een opvallend terughoudende attitude (ten opzichte van het democratisch gelegitimeerde House of Commons) door de leden van het House of Lords aan voorstellen tot wet gewerkt pleegt te worden. De partijpolitieke controverse speelt over het algemeen geen bijzonder prominente rol, zodat het recht van amendement door de Britse senaatskamer eerst en vooral in relatieve harmonie met de regering ingezet pleegt te worden ter verdere verbetering van het wetgevingsproduct. Uitzonderingen op deze regel zijn er (zoals nog zal blijken) af en toe zeker geweest, maar het qua partijpoliticke discipline 'lossere' House of Lords lijkt zich over het algemeen toch goed bewust te zijn van zijn positie op het tweede plan, zoals ontstaan ten gevolge van de Acts of Parliament van 1911 en 1949.

In grote lijnen worden de centrale (regerings)voorstellen tot wet in het Britse House of Lords behandeld op de hierboven beschreven wijze. Als een gevolg van het gegeven dat het moderne wetgevingsmetier zowel in politieke als juridische zin bijzonder veelvormig en complex pleegt te zijn, zal echter ook het Hogerhuis met regelmaat gebruik (moeten) maken van werkprocedures die afwijken van de hierboven geschilderde. Ter vervollediging van het relaas betreffende de (mede)wetgevende bevoegdheden van het House of Lords zal in de volgende subparagrafen in dat kader achtereenvolgens aandacht besteed worden aan speciale wetgevingscommissies, regelgevingvoorstellen gebaseerd op delegatie van wetgevende bevoegdheid en het recht van initiatief.

\subsubsection{Select Committees}

Hoewel de beschreven werkwijze via het 'Committee of the whole House' zoals gezegd, voor de Britse senaatskamer ter nadere uitwerking van alle wetstechnische en politiekbeleidsmatige details van voorliggende onderwerpen voor wetgeving de normale gang van zaken is, blijkt het in de Britse staatsrechtelijke constellatie toch ook voor de senaatskamer niet ongebruikelijk om speciale onderzoekscommissies samen te doen stellen indien daaraan behoefte bestaat. 'The House of Lords has the power to appoint select committees to examine any matter which, in the opinion of the House, requires investigation' ${ }^{67}$

Deze 'Select Committees' zijn in te delen in een drietal categorieèn, te weten de wetgevingscommissies, onderzoekscommissies en huishoudelijke commissies. Deze laatste categorie wordt, bij gemis aan werkelijke relevantie, in dit boek verder onbesproken gelaten. Voor een bespreking van functioneren en belang van de onderzoekscommissies zij verwezen naar par. 4.6.3.

Wetgevingscommissies worden door het Hogerhuis op ad-hoc basis samengesteld, vooral indien politiek gevoelige zaken die niet opgepakt worden door regering en House of Commons

65. E. May, a.w., p. 481.

66. House of Lords Hansard 1988-1989, Volume 504,Column 656-658.

67. E. May, a.w., p. 574 
grondig (voor)onderzoek vereisen voorafgaande aan eventuele derde lezing van een wetsvoorstel. . $^{8}$

Gemiddeld genomen wordt ieder parlementair jaar één dergelijke commissie geïnstalleerd. Sinds begin jaren zeventig is die regelmaat goed herkenbaar geworden. De installatie van meerdere Select Committees tijdens het verloop van éen jaar bleek tot nu toe overigens af te ketsen op personele problemen omdat bemensing immers nog steeds afhankelijk is van de inzet van semi-'vrijwilligers'.

Select commissies zijn er in hoofdzaak ten behoeve van maatschappelijk gevoelige 'Private Member Bills'. Een tekenend voorbeeld hiervan vormde de 'Infant Life (Preservation) Bill', een onderwerp dat (evenals dat in Nederland het geval was) de fracties van de belangrijkste politicke groeperingen sterk intern verdeelde. De regering Thatcher wenste de handen niet te branden aan het onderwerp. In het Britse Hogerhuis werd tijdens twee opeenvolgende parlementaire jaren door Select Committees het abortusdebat levend gehouden, tegelijkertijd vruchteloos pogend om tot een sluitend ontwerp te komen aangaande het maximaal aantal weken van zwangerschap waarbinnen abortus nog toelaatbaar zou zijn. ${ }^{69}$

Onder de categorie wetgevingscommissies vallen ook de zgn. 'Public Bill committees'. Ten behoeve van een aantal politiek minder gevoelige wetgevingsvoorstellen is het voor de regering uit oogpunt van tijdsbesparing bijzonder praktisch indien het juridisch-technische voorwerk door een beperkte groep 'specialisten' al afgehandeld is vóór de 'report stage'. Ook is het mogelijk om gezamenlijke commissies met leden uit beide Britse parlementskamers te doen samenstellen. ${ }^{70}$.

Tenslotte dient bij de bespreking van wetgevingscommissies prominent gewag gemaakt te worden van het bestaan van de 'Delegated Powers and Deregulation Committee'. Deze commissie wordt jaar in jaar uit opnieuw formeel ingesteld, eenvoudig omdat het praktische belang van met name de delegatiebevoegdheden zoals verderop ook nog zal blijken bij de bespreking van de rol van het Hogerhuis ten aanzien van Statutory Instruments, tegenwoordig zo groot is. In Groot-Brittanniè heeft, evenals dat in zo goed als alle moderne op democratische leest geschoeide staten het geval is geweest, delegatie van wetgeving een enorme vlucht genomen. In dat kader wordt semi-permanent onderzoek naar de totstandkoming en kwaliteit van gedelegeerde regelgeving door het parlement als hoogst belangrijk ervaren. Een taak die het House of Lords in het Verenigd Koninkrijk met name het laatste decennium nadrukkelijk naar zich toe heeft weten te trekken.

De commissie stelt zich vooral ten doel voor alle primaire wetgevingsvoorstellen nauwkeurig na te gaan in hoeverre deze een raamwerk leveren voor nadere gedelegeerde regelgeving. Met name wordt ook uitgezocht welke toezichts- en controlemechanismen op de uitoefening van delegatie in de primaire regelgeving vastgelegd zijn. Blijkt formele toestemming nodig van het parlement, alvorens de regeling in werking kan treden? Hoe is de mogelijkheid tot eventueel repressief toezicht geregeld? Zijn er geen (verkapte) mogelijkheden in specifieke delegatiebevoegdheden ingebouwd, waardoor wetgeving in formele zin als het ware nader geamendeerd zou kunnen gaan worden, zonder nieuwe bemoeienis van het parlement? ${ }^{71} \mathrm{De}$ commissie rapporteert haar bevindingen aan het Hogerhuis, dat vervolgens eventueel nood-

68. J. Griffith and M. Ryle, a.w., p. 490

69. J. Griffith and M. Ryle, a.w., p. 487 .

70. E. May, a.w., p. $488-490$

71. http://www. partiament the-stationery-office.co,uk/pa/Id199789/dselect/ddelder.htm, 21-9-2000. 
zakelijke aanbevelingen formuleert en doorsluist richting regering. De regering accepteert deze aanbevelingen, zo is gebleken, vrijwel altijd, hetgeen veel zegt over het aanzien dat de commissie tegenwoordig pleegt te genieten ${ }^{72}$ Bij dit alles dient tevens (nogmaals) aangetekend te worden dat gedelegeerde regelgevingvoorstellen niet onder het regime van de Parliament Acts van 1911 en 1949 vallen en derhalve minimaal in theorie door een absoluut veto van het House of Lords getroffen zouden kunnen worden. Dat het House of Lords op het terrein van wetgevingsdelegatie relatief serieus genomen wordt stoelt dan zeker ook mede op dit formeel juridische gegeven.

Ook in Groot-Brittanniē zijn de primaire wetgevingsproducten, de 'Public Bills', tegenwoordig in de regel raam- of kaderwetten. Nadere regelgeving wordt op grote schaal gedelegeerd aan met name de ministeries. De positie en bevoegdheden van het House of Lords met betrekking tot deze 'Statutory Instruments' wijken op essentiěle punten af van hetgeen daarover beschreven is aangaande het ontstaansproces van de Public Bill. Enige korte complementaire opmerkingen over de rol die het Britse Hogerhuis speelt bij de creatie van regelgeving op basis van delegatie (naast hetgeen reeds opgemerkt werd betreffende de 'Delegated Powers and Deregulation Committee'), zijn ter vervollediging van het geschetste beeld, dan ook wenselijk.

\subsubsection{Statutory Instruments}

Zoals opgemerkt tijdens de bespreking van de reikwijdte van de Acts of Parliament van 1911 en 1949, behoeft secundaire regelgeving tot stand gekomen op grond van delegatiebesluiten in een aantal gevallen impliciet dan wel expliciet ongeclausuleerde goedkeuring van beide parlementskamers. Bepalend daarvoor is de redactie van de 'Parent Act'. Op dit terrein heeft het House of Lords nog steeds het vetorecht: 'That this House affirms its unfettered freedom to vote on any subordinate legislation submitted for its consideration, ${ }^{73}$ De goedkeuring dient, zoals reeds aangestipt, afhankelijk van de tekst van het voorstel tot wet dus expliciet dan wel stilzwijgend te geschieden. In het eerste geval (uiteraard vooral in stelling gebracht bij de zwaardere voorstellen) spreekt het reglement van orde van het House of Lords over 'Affirmative Instruments' ${ }^{74}$ In het tweede (veel voorkomende) geval wordt gesproken over 'Negative Instruments': indien binnen veertig dagen geen 'prayer' ingediend en aangenomen is, waarin verzocht wordt af te zien van het in werking laten treden van de gedelegeerde regelgevingvoorstellen, krijgen deze automatisch kracht van wet.

Alvorens het Hogerhuis diens impliciete dan wel expliciete goedkeuring kan geven, moet advies verkregen worden van het 'Joint Committee on Statutory Instruments'. Deze commissie bestaande uit leden van beide te Westminster zetelende parlementskamers bekijkt of de gedelegeerde regelgeving qua doelstelling, opzet en uitvoering spoort met de juridisch-technische merites van de raam- of kaderwet die er aan ten grondslag ligt. ${ }^{75}$

Indien het Hogerhuis het advies van de Joint Committee gehoord hebbende niet tot goedkeuring over wenst te gaan, zal dit als regel op twee verschillende wijzen geëffectueerd kun-

72. Idem.

73. House of Lords Hansard 1993-94, Vol. 558, Column 356v. Overigens wordt blijkens een in november 2001 uitgebracht White Paper door de regering Blair getornd aan dit vetorecht. Vertragen zou in de toekomst wel nog mogen, verwerpen niet meer.

74. House of Lords Standing Order nr. 72 (2).

75. E. May, a.w., p. $591-592$. 
nen worden, namelijk via amendering door het House of Lords van het noodzakelijke goedkeuringsbesluit, dan wel via het aanhangig maken van een afkeuringbesluit. ${ }^{76}$ In de politieke praktijk blijkt van beide mogelijkheden toch slechts hoogst zelden gebruik gemaakt te worden. ${ }^{77}$ Ook hier spelen ongeschreven conventies weer een belangrijke rol. De Lords plegen zich, in het bewustzijn dat afkeuring van gedelegeerde regelgevingvoorstellen door het parlement beleidsmatig verstrekkende consequenties kan hebben, zeer terughoudend op te stellen bij de hantering van het hun toekomende vetorecht. Het alles of niets principe blijkt gewoon cen andere wijze van afweging te vergen, zoals bijvoorbeeld de senatoren van de Nederlandse Eerste Kamer al zo vaak hebben mogen ervaren.

Slechts cén maal, in 1968, is ooit een 'Affirmative Instrument' afgestemd door een meerderheid van het House of Lords ${ }^{78}$ Dit is echter de spreekwoordelijke uitzondering op de regel gebleken. Sindsdien werd door oppositionele minderheden in het Hogerhuis nog wel cens gepoogd regelgevingvoorstellen tot stand gekomen op basis van wetgevingsdelegatie weg te stemmen, doch dergelijke pogingen zijn altijd vruchteloos gebleken. ${ }^{79}$ Mocht het House of Lords, om haar moverende redenen, in meerderheid toch menen dat een bepaald 'Affirmative' of 'Negative Instrument' in de voorliggende vorm echt niet in werking zou mogen treden of blijven, dan wordt via moties die materieel veel overeenkomst vertonen met 'reasoned amendments' gepoogd de Minister te bewegen tot intrekking van het voorstel c.q. intrekking van de regeling. ${ }^{8 C}$

Ook hier wordt het functioneren van de 'not-elected Chamber' blijkbaar weer in hoofdzaak bepaald door de Britse conventie dat flexibel meedenken te allen tijde usance behoort te zijn. In de beschreven gang van zaken rondom de parlementaire fases van wetsvoorstellen (in wording) stond tot nu toe met name het regeringsinitiatief centraal. De legislatieve activiteiten van het House of Lords beperken zich daartoe, zoals reeds eerder gememoreerd, echter allerminst.

\subsubsection{Recht van initiatief}

Evenals het House of Commons bezit het Britse Hogerhuis het recht van initiatief. Een recht waarvan door de Lords op grote schaal gebruik gemaakt wordt. Ieder lid van het Hogerhuis mag een wetsvoorstel indienen. Loting, zoals in het House of Commons ${ }^{81}$ te doen gebruikelijk is, komt in het Hogerhuis niet voor. Via de 'usual channels' wordt er bij voortduring zorg voor gedragen dat hantering van procedurele regels rondom indiening van cen 'private Member Bill' in het House of Lords tot een absoluut minimum beperkt kan blijven. 'Any member may present a Bill without notice. The first reading is moved immediately on presentation, and is normally agreed to without discussion or dissent'. ${ }^{82}$ Van strakke limitering van de tijd (naar Lagerhuismodel) beschikbaar voor verdere bespreking van het 'eigen' wetsvoorstel in

76. E. May, a.w. p. $589-590$.

77. House of Lords Hansard 1993-94, Vol. 558, Column 356-383.

78. Het betrof de Southern Rhodesia Order 1968, House of Lords Hansard 1967-68, vol. 293, Column 321-598.

79. D. Shell, The House of Lords, a.w., p. 218-219.

80. Zie bijvoorbeeld House of Lords Hansard 1995-96, Vol. 563, Column 923-949.

81. Per parlementair jaar mogen in het House of Commons slechts een beperkt aantal via het lot aangewezen MP's een eigen wetswoorstel indienen. Voor die loting kunnen alle MP's niet zijnde leden van de zittende regering zich inschrijven. 
het Hogerhuis is eveneens geen sprake. De voor een enigszins verantwoorde bespreking blijkbaar noodzakelijke geachte tijdspanne moet eenvoudigweg beschikbaar komen, menen de Lords.

In de meeste gevallen zijn de door Peers gelanceerde 'Private Member Bills' die de eindstreep halen relatief eenvoudige wetsvoorstellen. In de meeste gevallen is de inhoud van deze succesvolle voorstellen politiek tevens weinig controversieel. Het is vooral aan deze twee kenmerken te danken dat ieder parlementair jaar toch nog altijd een of meerdere 'Private Member Bills' afkomstig van Hogerhuisleden het gehele wetgevingstraject met goed gevolg weten te doorlopen ${ }^{83}$

Naast 'Private Member Bills' afkomstig uit eigen huis, moet het House of Lords natuurlijk ook initiatieven tot wet van Back-benchers uit het House of Commons behandelen.

Tabel 4.5

\begin{tabular}{|l|c|c|c|}
\hline & $1996-1997$ & $1997-1998$ & $1998-1999$ \\
\hline $\begin{array}{l}\text { Private Member Bills geìnitieerd door het } \\
\text { House of Commons }\end{array}$ & 15 & 9 & 7 \\
\hline Waarvan Royal Assent & 15 & 8 & 7 \\
\hline $\begin{array}{l}\text { Private Member Bills geïnitieerd door het } \\
\text { House of Lords }\end{array}$ & 21 & 22 & 20 \\
\hline waarvan Royal Assent & 7 & 2 & 1 \\
\hline
\end{tabular}

Bron: http://www.parliament.the-stationery-office.co.uk/paldpbstat.htm, 23 oktober 2001

Zoals duidelijk afgelezen kan worden uit bovenstaande tabel, dient alleen al om kwantitatieve redenen een duidelijk onderscheid gemaakt te worden tussen Private Member Bills afkomstig uit het Hogerhuis en Private Member Bills afkomstig uit het Lagerhuis. De kans dat wetsvoorstellen gelanceerd door MP's de eindstreep halen blijkt immers vele malen groter te zijn. Een conclusie die reeds lang vóór het aantreden van de regering Blair overigens ook al getrokken kon worden. Tussen 1978 en 1990 bijvoorbeeld haalden 121 van de 131 in het House of Commons geïntroduceerde Private Member Bills de eindstreep, hetgeen neerkomt op ruim $90 \%{ }^{84}$ De collegae uit het Hogerhuis zagen in dezelfde periode hun wetgevingsinspanningen voortspruitend uit eigen initiatief beloond met een slagingspercentage van slechts $17 \%{ }^{85}$

De belangrijkste verklaring voor deze grote verschillen is, zoals reeds eerder impliciet aangegeven, gelegen in de factor 'tijd'. Om het puntig te formuleren: het chronische gebrek aan tijd beschikbaar voor wetgevingsdoeleinden in het House of Commons is er debet aan dat slechts Private Member Bills geïnitieerd door MP's uit datzelfde huis vaker wél de eindstreep plegen te halen. Het is namelijk gebleken dat in het House of Commons tegenwoordig gewoon in het geheel geen tijd meer besteed kan worden aan fundamentele bespreking van 'Private Member Billss. ${ }^{86}$ De eenvoudige en politiek weinig controversiêle wetgevingsinitiatieven afkomstig uit het Lagerhuis worden met steun van de regering daarom in de regel

83. D. Natzler, and D. Millar, Private Members' Bills, in: The House of Lords at Work, A Study based on the 1988-1989 Session, Oxford 1993.

84. D. Shell, The House of Lords, a.w., p. 151.

85. Van de 175 door leden van het House of Lords geintroduceerde 'Private Member Bills' die minimaal een 'first reading' doorliepen, kregen er slechts 29 uiteindelijk 'Royal Assent'.

86. http://www.parliament.the-stationery-office.co.uk/pa/ld//dpmbill.htm, 20-9-2000. 
zonder procedurele poespas doorgesluisd naar het House of Lords. De Britse senaatskamer kan zich vervolgens, formeel zelfs niet gehinderd door de Parliament Acts van 1911 en 1949 , kwijten van haar herzieningstaak. Geheel in lijn met de geldende conventies is het, onafhankelijk van de partijpolitieke verhoudingen van het moment in beide parlementskamers niet de bedoeling dat het Hogerhuis deze weinig gecompliceerde en regeringsvriendelijke wetsvoorstellen ter verwezenlijking van politieke doeleinden torpedeert. En aangezien het aannemen van ook maar één enkel amendement door het House of Lords (ten gevolge van het chronische tijdgebrek in het House of Commons) per saldo wel degelijk het einde van het wetsvoorstel zal betekenen, stelt de herzieningstaak hier dan ook erg weinig voor.

Andersom zullen slecht die wetgevingsinitiatieven afkomstig uit het Hogerhuis kans van slagen hebben die én voldoende politiek draagvlak hebben in het House of Lords, om op tijd (uiterlijk 4 maanden voor het einde van het lopende parlementaire jaar) het Lagerhuis te bereiken én absoluut geen besprekingstijd aldaar vergen. Iedere minuut die de MP's tijdens de tweede helf van het pariementaire jaar moeten besteden aan Private Member Bills is simpelweg dodelijk voor het voorstel in kwestie. ${ }^{87}$ In kwantitatieve zin domineren daarom duidelijk de door de regering ondersteunde aanpassingsvoorstellen.

Dit alles wil echter niet zeggen dat via het door het House of Lords uitgeoefende recht van initiatief per definitie nooit wetsvoorstellen met enig maatschappelijk gewicht de eindstreep kunnen halen. Wel degelijk komt ook via die weg af en toe inhoudelijk substantiëlere wetgeving tot stand. Het betreft dan wel vaak zgn. 'all party'-onderwerpen, zoals bijvoorbeeld het belang van wetenschappelijke experimenten in relatie tot dierenbescherming. ${ }^{88}$

De in materieel opzicht écht aansprekende 'Private Member Bills' afkomstig uit het House of Lords, voorstellen met soms verstrekkende consequenties van in hoofdzaak sociaal-maatschappelijke aard, zullen in kwantitatieve staatjes echter vrijwel onopgemerkt blijven. Voorstellen tot legalisering van homoseksualiteit en abortus bijvoorbeeld, werden tijdens de zestiger jaren in eerste instantie als 'Private Member Bill' geïntroduceerd in het House of Lords. De parlementaire en maatschappelijke debatten die daarvan het gevolg waren, leverden tijdens de eerste jaren van politiek debat weliswaar geen tastbaar resultaat op, doch hebben uiteindelijk toch nog relatief snel de weg vrij gemaakt voor de in sociaal-maatschappelijk opzicht blijkbaar erg wenselijke regelgeving op die terreinen. 'It seems that the Upper House is the place for all social reform to be first discussed' ${ }^{89}$ Ook recent blijkt wenselijk geachte regelgeving betreffende maatschappelijk gevoelige onderwerpen vaak aangezwengeld te worden via Private Member Bills afkomstig uit het Hogerhuis. Het verbod op besnijdenis van vrouwen en regelgeving met betrekking tot genetisch gemanipuleerd voedsel zijn twee voorbeelden van die praktijk.

Tenslotte kan over het door Peers uitgeoefende recht van initiatief nog opgemerkt worden, dat indiening van een 'Private Member Bill' soms zelfs uitsluitend bedoeld is om het debat over cen bepaald onderwerp aan te kunnen gaan. ${ }^{91} \mathrm{Na}$ het debat pleegt het voorstel dan vervolgens rap van de Hogerhuisagenda afgevoerd te worden.

87. D, Shell. The House of Lords, a.w., p. $152 \mathrm{e}, \mathrm{v}$.

88. M. Rush. The House of Lords: The Political Context, in: P. Carmichacl and B. Dickson, a. w, p. 20.

89. Lord Gardiner, House of Lords Hansard, Column 251, 23-11-1966.

90. http:/Www. parliament the-stationery-office. co uk/pa/ld199899/dpbstat stat9907.htm. 2-11-2001.

91. D. Shell. The House of Lords, a.w., p. 156. 


\subsection{De praktijk}

Om de reêle werking en reikwijdte van de wetgevende bevoegdheden die het House of Lords formeel ter beschikking heeft ook daadwerkelijk te kunnen duiden, is het zinvol enige Britse parlementaire praktijkvoorbeeiden uit het recente verleden nader uit te werken. Allereerst volgt daartoe nu een bespreking van enkele kwesties die speelden ten tijde van de regeringen Thatcher (1979-1993). Deze brengen, omdat tijdens die periode een gedeeltelijke omslag in de opstelling van het House of Lords ten opzichte van regering en House of Commons plaats heeft gevonden, de werking van het Britse bicamerale partijpolitieke krachtenveld fraa in beeld.

\subsubsection{Het House of Lords versus Thatcher}

Tot het begin van de jaren tachtig van de vorige eeuw stond het House of Lords, zoals aangegeven in de inleiding van dit hoofdstuk, te boek als een anachronisme. De oorzaken daarvoor, de belangrijkste natuurlijk het democratiedeficit, zijn uitvoerig belicht. Door de wijze waarop het House of Lords tijdens drie achtereenvolgende regeringen Thatcher invulling heeft weten te geven aan zijn medewetgevende bevoegdheden, is de beeldvorming rondom het belang van een tweede Britse parlementskamer echter in sterke mate positief beïnvloed. In dat kader wordt sindsdien, schrijvend over het belang van het House of Lords als medewetgevend orgaan, ook wel de term 'anachronism with relevance' gebezigd. ${ }^{92}$

De periode Thatcher was er een van bijzonder sterke overheersing door de Prime Minister. Zowel de regering als de (nuime) Conservatieve meerderheid van het House of Commons liep gedwee aan de leiband van de regeringsleidster. Het 'Elective Dictatorship' vierde hoogtijdagen. Een kritische check van (zeker de politiek gevoeliger) regeringsvoorstellen door de democratisch gelegitimeerde volksvertegenwoordiging in het House of Commons werd in die jaren minder dan ooit als een politiekstaatsrechtelijke realiteit beschouwd. ${ }^{93}$ Ook van het House of Lords werd tijdens de periode Thatcher eigenlijk 'traditiegetrouw' geen al te kritische opstelling verwacht waar beoordeling van regeringsvoorstellen tot wet in het geding was. Immers, een permanente meerderheid van deze 'Revision Chamber' was nog van gekend conservatief adellijke huize. Een conservatieve meerderheid die trouwens tijdens de Thatcherjaren getalsmatig alleen maar verder uitdijde. 'Lords versus people' heette het zeker tijdens de beginjaren van de 'ijzeren dame' dan ook. De gang van zaken tijdens haar eerste regeerperiode (1979-1983) voedde voornoemde beeldvorming nog verder. Terwijl de regering Thatcher beleidsmatig toch direct fel uit de startblokken sprong via onder meer de initiëring van het 'Right to buy' programma, bleef het House of Lords zich als kamer voor wetgevingherziening zeer tenughoudend opstellen. Slechts op het zuiver juridische vlak, waar het Hogerhuis dankzij de permanente aanwezigheid van onder andere de professionele Law Lords altijd al het nodige gezag uit pleegde te stralen, bleek de senaatskamer in staat enige kleine, door de regering om politieke redenen niet gewenste wijzigingen doorgevoerd te krijgen. ${ }^{94}$ Indien

92. D. Welfare, An Anachronism with relevance: The revival of the House of Lords in the 1980s and Its Defence of Local Government, Parliamentary Affairs 1991, p. 205.

93. D. Shell, The House of Lords and the Thatcher Government, a.w., p. 16 c.v.

94. D. Shell, The House of Lords and the Thatcher Government, a.w., p. 21. Het betrof met name aanpassingen in de Criminal Justice Bills van 1980 en 1982. 
door het House of Lords aangenomen amendementen niet geaccepteerd werden door het House of Commons, was dat in de jaren 1979-1983, zoals te doen gebruikelijk binnen de Britse parlementaire verhoudingen, altijd einde verhaal. De vraag of in casu al dan niet sprake was van wetsvoorstellen ter uitvoering van het verkiezingsmanifest (Salisbury Doctrine), speelde daarbij zelfs niet eens een rol.

Het kan dan ook niet echt verwondering wekken dat de oppositionele Labourparty, in zijn verkiezingsmanifest van 1983 opnam, dat afschaffing van het House of Lords zo snel mogelijk ter hand genomen zou dienen te worden, indien deze partij aan de macht zou komen. Slechts 15 jaar later repte Labour (na 18 jaar oppositie weer eens aan de macht) onder Tony Blair in haar verkiezingsprogrammaprogramma echter met geen woord meer over afschaffing. Een opmerkelijk snel en diametraal veranderde zienswijze, waarbij de opstelling van het Hogerhuis in de tussenliggende jaren van voortdurend voortschrijdende Conservatieve regeringsmacht ontegenzeggelijk een grote rol heeft gespeeld.

De regering Thatcher wenste de sterk sociaal verkokerde Britse samenleving begin jaren tachtig steeds sneller en efficiënter om te vormen conform ideeën gebaseerd op een vrijemarkteconomie. Omdat de Britse economie tijdens de eerste helft van de jaren tachtig niet goed draaide, waren in de optick van de regering ook nog eens harde financięle bezuinigingsmaatregelen noodzakelijk. Dit proces van sociaal-maatschappelijke hervormingen gecombineerd met bezuinigingen zou volgens de regering snel gestalte moeten, maar ook kúnnen krijgen, nu parlementaire politieke meerderheden in beide kamers van het toch al zo sterk monistische Britse stelsel immers min of meer gegarandeerd waren. In de Commons bedroeg de Conservatieve meerderheid sinds de laatste verkiezingen maar liefst 146. De lucht, leek tot 1984 in Westminster in feite dan ook volledig onbewolkt Tory-blauw te zijn.

Vanaf die tijd bleck het House of Lords echter ineens in een aantal gevallen toch enige weerstand te willen bieden tegen de al te sterk monistische tendensen in de verhouding regering - parlement. Regelmatig werd ook vanuit de eigen Conservatieve kring oppositie gevoerd tegen de scherpste kantjes van het Thatcher-programma. Vooral waar wetgevingsvoorstellen op het terrein van 'Local Government' en huisvesting in het geding waren, ging het Hogerhuis het spel met enige regelmaat minder gedwee spelen dan in Westminster gebruikelijk was. De Britse (conservatief-adellijke) senatoren wisten zich met de nodige verve in te zetten voor de sociaal 'zwakkeren'. Voor minder gefortuneerde ouderen die de dupe dreigden te worden van het 'right to buy'(coöperatiewoningen)-programma; voor financieel minderbedeelden die even veel Poll-tax zouden moeten gaan betalen als steenrijke landgenoten. Lobbygroeperingen kregen ineens ook oog voor de mogelijkheden tot beïnvloeding van het wetgevingsproces via het Hogerhuis. Op een totaal van 2091 stemmingen die tijdens de drie regeringsperiodes onder Margaret Thatcher plaatsvonden in het House of Lords werden er 156 verloren door de regering, daaronder vele die politiek zeer gevoelige zaken betroffen. ${ }^{95}$ Een aantal van deze stemmingen hadden 'Local Government' en daarmee het rechtstreekse belang van individuele burgers tot onderwerp. 'The Lords caught the mood of the political left as it rediscovered the right of the individual'. 96

Vooral de wijze waarop de (reeds eerder vanuit een andere verband besproken) opheffing van de gekozen 'Greater London Council and the metropolitan counties' gestalte kreeg, bleek een

95. D. Welfare, a.w, p. 205-206.

96. D. Welfare, a.w., p. 206. 
breckpunt te zijn geweest in de opinievorming ten aanzien van de potenticle mogelijkheden van het House of Lords in zijn rol van Kamer van herziening.

De oorzaken voor deze al met al opmerkelijke gang van zaken waren drieledig. Ten eerste was de partijpolitieke samenstelling van het House of Lords in combinatie met de (allerminst stabiele) dagelijkse opkomstgegevens van dien aard dat de stemverhoudingen niet (zoals bij de Commons wel het geval is) per definitie vast kunnen liggen. Een combine van oppositie, Cross-bench en onafhankelijken op een strategisch moment (bijvoorbeeld 's avonds laat), kán verrassende uitslagen bij stemmingen over amendementen opleveren. De tweede, daarmee samenhangende factor, betreft de niet al te strakke organisatiestructuur van zowel het Hogerhuis als geheel, als van de in dat huis werkzame politieke partijen. Geinstitutionaliseerde polarisatie zoals in het House of Commons, is in wezen vrijwel afwezig in het House of Lords. Redelijke argumenten prevaleren in het House of Lords meestal boven ijzeren fractiediscipline. De 'three line whip' komt daar dan ook nauwelijks voor: 'Whipping in the Lords remains essentially low-key. It may be possible to persuade peers, but they cannot be coerced, commanded or bullied. ". Waarmee ik beland ben bij de derde factor, want vooral de wijze waarop de regering tijdens het Thatcher-regime een ideologisch programma van ongekende omvang (privatiseringen, woningpolitiek, restrictie macht vakbonden $\mathrm{enz}$.) door het parlement wenste te jassen, wekte grote wrevel, niet in de laatste plaats omdat zelfs de regeringen Thatcher via het 'first past the post'-kiessysteem in feite slechts steun verkregen hadden van een minderheid van de Britse kiesgerechtigde bevolking van nim $40 \%$. 'Allied with this sense of constitutional unease, there was increasing concern at the quality of legislative scrunity in the Commons. As the government produced ever bulkier legislation - much of it receiving only the barest consideration by MP's - and forced it through on the guillotine, peers perceived a greater need for an effective revising chamber than ever before'. ${ }^{98}$

De vraag of het Britse Hogerhuis tijdens de Thatcherjaren ook écht effectief in heeft weten te springen op die behoefte aan effectievere wetgevingsherziening moet in essentie op deze plaats nog onbeantwoord blijven. Leden uit het politiek oppositionele kamp van de Franse Sénat bijvoorbeeld zullen ongetwijfeld een geheel eigen perceptie van de term 'effective revising' hebben. Aan de grenzen van de Salisbury Doctrine is in ieder geval nooit getornd. Wel hebben de Lords via amendementen in de loop der jaren de aller scherpste kanten van een aantal centrale wetsvoorstellen af weten te halen, ondanks fel tegenstribbelen van regeringswege.${ }^{99} \mathrm{Om}$ te eindigen met een citaat van een MP: 'It is an interesting constitutional situation that gives an unelected chamber a greater influence than the elected chamber to change the minds of the Executive on legislation'. ${ }^{100}$

\subsubsection{Het House of Lords versus Blair}

Het tweede voorbeeld uit de wetgevingspraktijk speelde zich af ten tijde van de eerste regering Blair. De gang van zaken rondom de totstandkoming van de 'European Parliamentary Elections Bill' die hier beschreven zal worden, krijgt met name vrij veel aandacht omdat

97. D. Shell, The House of Lords and the Thatcher Government, a.w., p. 28.

98. D. Welfare, a.w., p. 217.

99. Onder andere: Interim Provisions Act 1984. Housing Act 1988, Local Government and Housing Act 1989. Education Reform Act 1988, Local Government Finance Act 1988.

100. Kenneth Lewis MP, in: Daily Telegraph 17-5-1984. 
daarbij zo fraai ${ }^{101}$ tot uiting komt, wanneer in de Brits-bicamerale wetgevingspraktijk de grens tussen te respecteren politieke conventies enerzijds en het hanteren van staatsrechtelijke mogelijkheden ten behoeve van de wetgevingsrevisie anderzijds lijkt te zijn bereikt.

Zoals wij nog zullen constateren bij de bespreking van de bevoegdheden die de Sénat in Frankrijk toekomen, dienen wetgevingsvoorstellen ook in Parijs in identieke bewoordingen aangenomen te worden door beide parlementskamers. Zolang nog geen sprake is van volledige tekstuele overeenstemming zal tussen de Assemblée nationale en het Palais de Luxembourg een zgn. 'navette' haar werk moeten verrichten, dan wel een 'Commission Mixte Paritaire' ingesteld moeten worden.

In de (gedeeltelijk redelijk identieke) Britse staatsrechtelijke constellatie rondom aanname van wetgevingsvoorstellen is, zij het hoofdzakelijk in theorie, een met de 'navette' vergelijkbare procedure, luisterend naar de veelzeggende naam 'ping pong' mogelijk.

In de loop van het eerste parlementaire jaar dat de regering Blair aan de macht was (derhalve nog in de oude, door Conservatieve Hereditary Peers gedomineerde setting), werd bij de behandeling van de 'European Parliamentary Elections Bill' een fraai staaltje bicameraal politiek tafeltennis op het randje van Britsparlementaire betamelijkheid ten tonele gevoerd. De 'European Parliamentary Elections Bill' had tot doel de verkiezing van de Britse afgevaardigden voor het Europees Parlement in de toekomst te kunnen laten verlopen volgens een stelsel van evenredige vertegenwoordiging. Dit onderwerp was een centraal actiepunt uit het programma waarmee Labour de laatste parlementsverkiezingen gewonnen had en viel als zodanig conform de (nog altijd) gangbare conventies dus onder de Salisbury Doctrine. Het ontwerp werd eerst door het House of Commons behandeld, hetgeen betekende dat de Parliament Acts van 1911 en 1949 zo nodig geactiveerd zouden kunnen worden. Omdat geen grote problemen voorzien werden, had de regering niet al te veel energie gestoken in het stimuleren van de voortgang van het wetgevingstraject. Dit had tot gevolg dat de Bill pas op 20 oktober 1998 zijn 'third reading' in het House of Lords kreeg, ruim éen maand voor het einde van het parlementaire jaar. Tot aan de derde lezing was er ook eigenlijk niets bijzonders gebeurd. Direct bij de opening van de derde lezing in het House of Lords echter, werd een amendement ingediend door de Conservatieve Lord Mackay of Ardbrecknish dat tot strekking had de toekomstige verkiezingen voor Britse afgevaardigden in het Europees parlement te kunnen laten verlopen via gedeeltelijk 'open lijsten': de kiezer zou de volgorde van verkiezing der individuele kandidaten mede moeten kunnen bepalen (voorkeur) en niet verplicht moeten worden om de (in het wetsvoorstel uitgewerkte) lijstvolgorde volgens een strikt 'gesloten lijsten'-systeem, volledig ingekleurd door de partijtop, te accepteren. ${ }^{102}$ Hoewel niet verboden, is het bepaald ongebruikelijk voor het Britse Hogerhuis om dergelijke relatief fundamentele wijzigingsvoorstellen pas tijdens de derde lezing te deponeren: 'the principal purposes on third reading are to clarify any remaining uncertainties, to improve the drafting and to enable the Government to fulfil undertakings given at earlier stages of the bill: ${ }^{103}$

Lord Mackay raakte blijkbaar een politiek gevoelige snaar, ${ }^{104}$ want zijn voorstel werd gesteund door een meerderheid van de die dag aanwezige Peers: 165 stemmen vóór en 140

101. Deze casus wordt ook in de Britse literatuur breed uitgemeten. Zie onder andere: L Richard en D. Welfare, a.w., p. 73-83.

102. House of Lords Hansard 1998, Column 1317, Clause 1.

103. E. May, a.w., p. 481 .

104. Overstappen op een systeem van evenredige vertegenwoordiging ook al was het vooralsnog slechts bedoeld 
tegen ${ }^{105}$ Opgemerkt dient te worden dat enige sturende 'whipping' in conservatieve kringen aan de stemming vooraf ging.

Het House of Commons zag vervolgens niets in het amendement Mackay en stemde het dan ook weg. Terug in het Hogerhuis werd het amendement op 4 november in ongewijzigde vorm door Lord Mackay wederom in stemming gebracht en breed gesteund: 221 stemmen voor en 145 tegen. ${ }^{106}$

Niet alleen dreigde in casu een volledig ingraven achter de eigen linies, doch serieuzer wellicht nog. dreigden de twee belangrijkste ongeschreven conventies die tijdens het wetgevingsproces in Groot-Brittannie al sinds jaar en dag gangbaar zijn in de relatie regeringCommons-Lords, te weten de Salisbury Doctrine en de regel 'that all Government business is considered within a reasonable time', ${ }^{107}$ met voeten getreden te worden. Tevens ontstond een formeel probleem. In tegenstelling tot hetgeen gebruikelijk is rondom de Franse 'navette', zal een regeringsvoorstel tot wet in Groot-Brittannie in zijn geheel verloren gaan indien de ene parlementskamer een amendement dat in relatie staat tot de geest van het voorstel, in ongewijzigde vorm twee maal achtereen verwerpt, terwijl de andere parlementskamer het juist twee maal achtereen omarmt. ${ }^{108}$

Nu duidelijk werd dat de Conservatieve meerderheid in het House of Lords zich in casu niet inschikkelijk wenste op te stellen, kreeg de regering pas goed haast. Het parlementaire jaar zou op 24 november, 20 dagen later, gesloten worden. Indien niet vóór dat moment in identieke bewoordingen aangenomen door beide parlementskamers, zou het wetsvoorstel automatisch vervallen. Dat nu wenste de regering onder de gegeven omstandigheden absoluut te voorkomen. De noodzakelijke extra voorbereidingen die verkiezingen voor het Europees Parlement onder een gewijzigd kiesregime met zich mee zouden brengen, maakten dat de regering in feite ook geen gebruik wenste te maken van de Parliament Acts van 1911 en 1949, waarmee de gehele affaire immers pas twaalf maanden ná de 'second reading' in het House of Commons definitief afgehandeld zou kunnen worden.

De regering bood, na verwerping van het gewraakte amendement, via een enigszins afwijkend geredigeerd wetwijzigingsvoorstel aan, de zaak rondom de gesloten kieslijsten grondig te doen evalueren na afloop van de komende verkiezingen voor het Europees Parlement. Door deze actie werd in ieder geval al het grote procedurele voordeel bereikt, dat nu wederom twee stemmingen over het amendement per parlementskamer toelaatbaar waren, zonder verdere consequenties voor het wetsontwerp in zijn geheel.

Minder dan twee weken voordat het Britse equivalent van 'Prinsjesdag' plaats zou vinden, maakte het aangepaste voorstel voor de derde keer (tijdens de 'third reading' in het Hogerhuis) onderwerp van debat uit. Omdat de gang van zaken steeds nadrukkelijker een vrijwel volledige ontkenning van de gebruikelijke omgangsvormen tussen Commons, Lords en regering in zich droeg, nam de mediabelangstelling enorm toe. Vanuit Labourkringen werd fijntjes geopperd dat voor het amendement-Mackay tijdens geen enkele stemming een meerderheid in

voor de verkiezing van Europarlementariêrs lijkt, zeker voor Consevatieven die dankzij het geldende 'first past the post'-systeem gewend zijn regelmatig én alleen de regeringsmacht uit te kunnen oefenen, geen eenvoudig te accepteren verandering te kunnen zijn.

105. House of Lords Hansard, 1998, Column 1333, 20-10-1998,

106. House of Lords Hansard, Column 288, 4-11-1998.

107. A House for the Future, a.w., p. 39-40

108. E. May, Parliamentary Practice, a.w., p. 471 e.v. 
het Hogerhuis zou zijn gevonden indien, conform de voorstellen die het daarop volgende parlementaire jaar door de regering Blair zouden worden ingediend, slechts de Life Peers hadden mogen stemmen. De (op Hereditary basis stoelende) Conservatieve meerderheid onder aanvoering van Lord Mackay gaf desondanks nog steeds geen krimp. ${ }^{109}$ Nooit eerder vertoond, werd ten derde male gepoogd het gesloten lijstensysteem aangepast te krijgen. Het lijkt allerminst ondenkbaar dat wijlen Lord Salisbury zich inmiddels zo nu en dan in zijn graf had omgedraaid. De kwestie van de open dan wel gesloten kieslijsten had weliswaar geen deel uitgemaakt van het beleidsprogramma waarmee Tony Blair aan de macht was gekomen, maar evenredige vertegenwoordiging bij verkiezingen van juni 1999 voor het Europees Parlement wél. En indien de 'European Parliamentary Elections Bill' niet binnen zeven dagen kracht van wet kon krijgen, werd de kans wel erg klein dat juni 1999 (via de Parliament Acts) toch nog gehaald zou kunnen worden. De commentaren vanuit het regeringskamp lieten steeds minder aan duidelijkheid te wensen over. Lord Williams of Mostyn: 'This House is a revising Chamber. It should not seek to become a dictating Chamber. ${ }^{110}$ 'They (de MP's uit het House of Commons, EK) were elected. None of us was. This is now becoming a wholly improper abuse of power'."' Lord Callaghan of Cardiff: 'When one seeks reasons for its attitude, I believe it is the growth of a self-confessed hooligan tendency in the Conservative Party ${ }^{, 12}$

Het Mackay-amendement werd desondanks ook nu gewoon weer aangenomen door het House of Lords. Op 18 november persisteerde vervolgens ook het House of Commons in zijn visie, zij het dat de tekst van het amendement dat nu ter tafel verscheen, wederom een kleine, hoofdzakelijk formele, wijziging had ondergaan ten opzichte van het oorspronkelijke voorstel. Minder dan één volle dag later, tijdens de laatste werkdag van het lopende parlementaire jaar kregen de leden van het Britse Hogerhuis de laatste kans om het wetsvoorstel alsnog te redden. Lord Garel-Jones: 'Its place and high reputation are also based on the instinct that your Lordships have shown for knowing to what point the elected Chamber can be pushed. I respectfully submit to your Lordships that that point has been reached. ${ }^{113}$

Helaas voor Lord Garel-Jones en de zijnen, maar een ruime meerderheid van het House of Lords meende dat het balletje ten vijfde male terug gekaatst moest worden richting Commons, daarmee het lot van het wetsvoorstel voor dat parlementaire jaar definitief bezegelend. 114

Als een uitvloeisel van dit ping-pong spelletje werden via de Britse pers pittige discussies gevoerd over de verhouding Hogerhuis-Lagerhuis in zijn algemeenheid, over de plaats van een niet gekozen kamer van revisie in een door 'elective dictatorship' gedomineerd staatsbestel, over noodzaak en reikwijdte van de Salisbury Doctrine en last but not least, over de gewenste staatsrechtelijke vernieuwingen betreffende het House of Lords. In politicologisch/ staatsrechtelijke literatuur werd de gang van zaken rondom de 'European Parliamentary Elections Bill' veelzeggend beoordeeld als 'The House going too far'. ${ }^{115}$

109. House of Lords Hansard, Column 1148, 17-11-1998.

110. House of Lords Hansard, Column 1148, 17-11-1998.

111. House of Lords Hansard, Column 1150, 17-11-1998.

112. House of Lords Hansard, Column 1144, 17-11-1998

113. House of Lords Hansard, Column 1348, 18-11-1998.

114. House of Lords Hansard, Column 1357, 18-11-1998.

115. I. Richard I and D. Welfare, a.w., p. 73. 
Ook de epiloog aangaande het door de Lords gewraakte wetsvoorstel was bepaald markant te noemen. De verdedigers van de Elections Bill in de door de regering voorgestelde vorm, hadden al meermaals aangegeven dat verkiezing voor het Europees Parlement via evenredige vertegenwoordiging in 1999 alleen nog doorgezet kon worden (lees: praktisch cen haalbare kaart zou zijn), indien de oppositie na herintroductie van het wetsvoorstel direct bij de opening van het nieuwe parlementaire jaar 1998-1999 niet meer tegen zou werken. Met 'oppositie' werd in casu in materičle zin uiteraard het door de Hereditary Peers gedomineerde Hogerhuis bedoeld.

Al op 15 december bereikte de nieuwe 'European Parliamentary Elections Bill' in de door de regering gewenste vorm (gesloten lijsten) het House of Lords voor een 'second reading'. Lord Mackay of Ardbrecknish hield nog maar eens een vlammend betoog over het zijns inziens bijzonder magere democratische gehalte van verkiezingen via 'gesloten' (door de partij opgestelde) kieslijsten. Vervolgens echter citeerde hij uit 'the Scottish play' van Shakespeare: 'If it were done when 'tis done, then 'twere well it were done quickly', ${ }^{116}$ Vervolgens werd een 'reasoned amendment' ingediend dat duidelijk tot strekking had het wetsvoorstel te torpederen. De stemverhouding was glashelder. 167 voór en 67 tegen. ${ }^{117}$ De 'European Parliament Elections Bill' lag weer in de pnullenbak en kon dankzij dat gegeven nu onder de Parliament Acts van 1911 en 1949 per omgaande ${ }^{118}$ voor Royal Assent worden voorgedragen.

Interessant is het, hier alvast eens op te merken dat de gelijkenis tussen de bedoelingen van de beschreven procedure tijdens de tweede lezing op 15 december 1998 in het House of Lords en de bedoelingen die men in Frankrijk heeft met de procedure die bekend staat als de 'question préalable positive' (par. 5.3.2.2) frappant te noemen is. Een groot verschil gaat wel schuil in het gegeven dat de 'question préalable positive' voor de Franse senatoren tot het courante juridische instrumentarium behoort, terwijl de gang van zaken rondom de 'European Parliamentary Elections Bill' exemplarisch is voor de wijze waarop de parlementskamers en de regering in Westminster niet met elkaar om plegen te gaan.

\subsection{Balans wetgevingsfunctie}

Een ook na doorvoering van de wijzigingen in de samenstelling van het House of Lords medio 1999 nog steeds niet of nauwelijks democratisch gelegitimeerde tweede Britse parlementskamer heeft, waar het de invulling van haar taak als (mede)wetgever betreft, een positie in relatie tot regering en House of Commons, die wellicht het best getypeerd kan worden als: strategisch altruistisch.

Het systeem van benoemingen voor het leven speelt een niet te veronachtzamen rol in het geheel. Aan de ene kant is daar de relatieve vrijheid waarbinnen de noodzakelijke werkzaamheden verricht kunnen worden. Met de 'eigen' partijpolitieke achterban hoeven de Lords bij hun legislatieve afwegingen immers veel minder rekening te houden dan de (van herverkiezing afhankelijke) collega's uit het House of Commons. Tegelijkertijd kunnen de Lords gebruikmaken van de grote mate aan expertise die zij als voor het leven benoemde leden

116. House of Lords Hansard, Column 1309, 15-12-1998.

117. House of Lords Hansard, Column 1338, 15-12-1998.

118. Sinds de 'second reading' van het wetsvoorstel in het House of Commons tijdens het voorafgaande parlementaire jaar, waren inmiddels namelijk al ruim 13 maanden verstreken. 
gaandeweg hebben kunnen opbouwen. Dit alles ook nog eens zonder hinder te ondervinden van al te veel tijdsdruk. Aan de andere kant blijkt het democratie deficit dat inherent is aan de staatsrechtelijke keuze tot benoeming van Hogerhuisleden ook een grote mate van politieke onvrijheid tot gevolg te hebben. Opdat 'de stem van het volk' uiteindelijk altijd zal dienen te prevaleren, zijn de Acts of Parliament van 1911 en 1949 aangenomen. Hetzelfde gedachtegoed ligt ten grondslag aan de 'Salisbury Doctrine'.

Vanuit die politiekstaatsrechtelijke realiteit - grote (amenderings)vrijheden binnen hoge muren - moet het House of Lords zijn belangrijkste legislatieve arbeid verrichten. Een combinatie van ruimschoots aanwezige expertise onder senatoren ${ }^{119}$ en het vermogen tot voortdurende aanpassing aan de politieke realiteit zoals uitgedragen door regering en House of Commons, draagt er zorg voor dat de wetgevingherzieningsfunctie in het House of Lords bij voortduring vruchten af blijft werpen. Het belangrijkste juridische instrument dat de Lords nog rest ter sturing, beinvloeding en vervolmaking van het wetgevingsproces is ontegenzeggelijk het recht van amendement. Dit recht blijkt, in goede samenspraak met de regering van de dag (en dus in de meeste gevallen onafhankelijk van politieke kleur) veel gehanteerd te worden om de kwaliteit van het wetgevingproduct te verbeteren. In die zin kan het Britse Hogerhuis in zijn rol als medewetgever regelmatig (juridisch-maatschappelijk) tastbare successen laten aantekenen in het kader van het legislatieve herzieningsproces.

Belangrijke winst in de publicke opinie behaalde het House of Lords de laatste twee decennia vooral omdat enkele malen met gebnikmaking van zowel het recht van amendement als van procedurele juridische vertragingstechnieken gepoogd is een (zeer bescheiden) bres te slaan in de (nu en dan erg) monistische verhoudingen die het legislatieve werk van parlementskamers en regering in het Verenigd Koninkrijk zowel formeel als materieel zo sterk blijken te domineren.

\subsection{Bestuurscontrole}

Het vrijwel totale gebrek aan democratische legitimatie voor het Britse Hogerhuis is tot op zekere hoogte medebepalend voor de reikwijdte van de bestuurscontrole, uiteraard voor zover deze in praktische zin ook uitgeoefend zou kunnen worden door de Britse senaatskamer. Het juridisch instrumentarium dat beschikbaar is voor het uitoefenen van die controle, beperkt zich in het Verenigd Koninkrijk in directe zin in feite tot het vragenrecht, terwijl in indirecte zin het parlementaire debat en het werk van de speciale onderzoekscommissies een check op kunnen leveren voor het functioneren van het landsbestuur.

Alvorens de praktische werking van deze controle-instrumenten besproken wordt, dient echter eerst aandacht besteed te worden aan de vraag in hoeverre de verhouding regering - senaatskamer in Groot-Brittanniê in algemeen staatsrechtelijke zin mede bepaald blijkt te worden, door het bestaan van enige vorm van politieke ministerièle verantwoordelijkheid ten opzichte van het House of Lords in het Britse constitutionele recht.

119. Bankiers, ingenieurs, diplomaten, juristen, zakenmensen, economen, vakbondsmensen, militairen, politici, academici, onderwijskundigen, wetenschappers,enz, in: N. Balwin. The Membership and Work of the House of Lords, London 1999, p. 46. 


\subsubsection{Ministerięle verantwoordelijkheid}

Het Britse Hogerhuis zal, blijkens reeds lang bestaande ongeschreven constitutioncle conventies, als niet democratisch gelegitimeerde parlementskamer op geen enkele wijze imvloed uit (kunnen) oefenen op de samenstelling van regeringsploegen. Omgekeerd is het zo, dat de regering voor haar (voort)bestaan als zodanig ook op geen enkele wijze afhankelijk gesteld kan worden van het oordeel van het Britse Hogerhuis. Uitspreken van een vertrouwensvotum over het functioneren van de regering door het House of Lords, zowel positief als negatief geformuleerd, is (zoals gesignaleerd in hoofdstuk 2) sinds begin vorige eeuw hoegenaamd nooit meer voorgekomen binnen het Britse parlementaire rechtsstelsel. Ook een facultatieve variant van het positieve vertrouwensvotum naar Frans voorbeeld (hetgeen inhoudt dat slechts de regering zélf formeel bevoegd is om een door de senaatskamer uit te spreken vertrouwensvotum uit te lokken), is in het ongeschreven Britse staatsrecht eenvoudigweg onbekend. Het opzeggen van het vertrouwen in individuele ministers door het Britse Hogerhuis heeft in het Verenigd Koninkrijk evenmin (meer) cen plaats in het constitutionele recht.

De ultieme uitingsvorm van de politieke ministeriele verantwoordelijkheid in de relatic House of Lords-regering is daarmee dus op voorhand volledig weg gevallen.

Maar betekent dit dan ook dat de verhouding regering-House of Lords op geen enkele wijze (mede) bepaald wordt of bepaald kán worden door de politieke ministerięle verantwoordelijkheid? Natuurlijk niet, zij het dat nadere uitgewerkte beschouwingen aangaande die verhouding weinig praktische politieke relevantie zullen hebben: 'while the government is responsible to the Commons because it is ultimately removable by the Commons, it is in effect only answerable to the Lords'. ${ }^{120}$ In het woord 'answerable' ligt uiteraard de kern van de kwestie verscholen. Indien formele vragen gesteld vanuit het House of Lords netjes beantwoord worden door of vanwege de regering, is daarmee de kous af.

Dat een Britse regering onder omstandigheden af zou treden ten gevolge van een negatief uitgevallen stemming in het Hogerhuis (vgl. bijvoorbeeld de Nederlandse 'nacht van Wiegel' uit 1999) is onder de heersende omstandigheden absoluut ondenkbaar. Anno 2002 omvat het constitutionele bestel van Groot-Brittannië op het vlak van de politieke ministerièle verantwoordelijkheid in de verhouding regering-House of Lords dienaangaande ook geen dwingende instrumenten.

\subsubsection{Het (niet wetgevende) parlementaire debat}

'Crucial is the fact that the Government is obliged to define its attitude to the subjects raised in motions or in questions. It is this obligation on Government to state its view, to argue its case, to defend its policy, which is the distinctive feature of parliamentary debate'. ${ }^{121}$ Het lijkt zaak om eerst deugdelijk in kaart te brengen via welke procedures het House of Lords het vragenrecht c.q. de mogelijkheid tot inhoudelijk politiek debat blijkt te kunnen effectueren om onderwerpen onder de aandacht van de regering te brengen en te kunnen bespreken.

In kwantitatieve zin blijken de Britse senatoren te beschikken over een respectabele lijst aan mogelijkheden tot het uitlokken van dat debat: 'Motion for adress','Motion to take note', 'Motion for paper', 'Motions on subordinate legislation' en 'Ministerial statement'. Die lijst

120. D. Shell, The House of Lords, a.w., p. 181.

121. D. Shell, The House of Lords, a.w., p. 179. 
kan dan nog verder aangevuld worden via het vragenrecht. 'Unstarred questions' lokken in feite ook het debat uit. 'Private notice questions' en 'Starred questions' doen dat hooguit minimaal. 'Written questions' complementeren de lijst. Over al deze mogelijkheden volgt hierna een korte uiteenzetting.

\subsubsection{General debate}

Een regeringsnotitie uit $1968 \mathrm{zag}$ in 'the provision of a forum for full and free debate on matters of public interest' een hoofdtaak weggelegd voor het House of Lords. ${ }^{122}$ Inderdaad trekken de Britse senatoren sindsdien vrij veel tijd uit voor het parlementaire debat. Drie vormen zijn met name van belang, te weten 'General debate', 'Debate on committee reports' en 'Unstarred questions'.

Het algemene debat wordt formeel opgestart via een 'Motion for papers'. Dergelijke debatten zijn bedoeld om op verzoek van daartoe in de gelegenheid gestelde Lords onderwerpen met maatschappelijke relevantic te bespreken. Tot een formele standpuntbepaling en stemming na afloop van het debat hoeft het niet te komen. ${ }^{123}$ De algemene debatten vinden plaats op woensdag en duren maximaal of $21 / 2$ of 5 uur, afhankelijk van de afspraak die via 'the usual channels' daarover gemaakt is. De keuze van het te bespreken onderwerp wordt aangedragen door de senatoren zelf. Wiens voorstel wanneer onderwerp van deliberatie uit mag maken, wordt deels bepaald via loting. deels door de politieke groeperingen die in het Hogerhuis zitting hebben. De te bespreken onderwerpen bestrijken het volledige maatschappelijke spectrum: luchtvervuiling, ontwapening, kemenergie, demografische ontwikkelingen, de Britse constitutie, de EMU, Joegoslaviě Hooliganism, Pinochet, het Koninklijk Huis, de jacht, enz.

Deze 'general debates' hebben in de loop der jaren de naam gekregen bijzonder diep te graven en zeer informatief te (kunnen) zijn. ${ }^{124}$ Dit is voor een groot gedeelte te danken aan het gegeven dat in de gelederen van ongeveer 600 (grotendeels oudere) Life Peers bijzonder veel expertise en ervaring schuil gaat. Daar komt bij dat in het House of Lords slechts bij hoge uitzondering pogingen zullen worden ondernomen om de uitkomst van het debat partijpolitiek te sturen. Mocht dit laatste toch gewenst zijn, dan zal een 'Motion for resolution' voorgesteld worden, zodat het debat in een dergelijk geval wél via formele stemming beëindigd zal worden. Labour probeerde bijvoorbeeld in de jaren tachtig na afloop van een algemeen debat over de werkloosheidsproblematiek vergeefs een motie aangenomen te krijgen, die een veroordeling van het regeringsbeleid dienaangaande in zou houden.

Ook regeringsnota's in de vorm van Green en White Papers maken vanzelfsprekend regelmatig onderwerp van debat uit. Dit pleegt te gebeuren op verzoek van de regering en te worden gegoten in de vorm van een 'motion to take note'. ${ }^{23}$

Verder dient melding gemaakt te worden van de 'Ministerial statements'. Politiek zwaarwegende regeringsbeslissingen worden in het kader van het idee van checks and balances door een tid van die regering toegelicht in beide parlementskamers. Omdat het House of Lords in de regel niet wenst te herhalen wat in het politiek belangrijkere House of Commons reeds aan de orde is geweest, zal een dergelijk 'statement' in het Hogerhuis in de meeste gevallen ter kennisgeving worden aangenomen. In een beperkt aantal gevallen zal het afleggen

122. White Paper on House of Lords Reform 1968.

123. The Companion to the Standing Orders 1989, p. 84.

124. M. Rush, a.w., p. 22-23.

125. J. Griffith and M. Ryle, a.w., p. 480. 
van een 'Ministerial statement' in het House of Lords echter gevolgd worden door een debat over het onderwerp. ${ }^{126}$

Zeker sinds het House of Lords tijdens de Thatcherjaren betere contacten met de publicke opinie, media en belangengroeperingen heeft weten te leggen, plegen uitkomsten van het debat vaker dan voorheen door de regering meegenomen te worden bij het entameren van nieuwe beleidsplannen, alsmede bij de evaluatie van (de effecten van) bestaande regelgeving. Een voorbeeld bezuinigingsmaatregelen die de BBC hard troffen, werden uiteindelijk grotendeels ingetrokken (mede) als gevolg van de uitkomsten van een vijf uur durend debat in het Britse Hogerhuis. ${ }^{127}$

Naast politicke overwegingen (publieke opinie) spelen, zoals reeds meerdere malen betoogd, ook overwegingen van inhoudelijke aard cen rol, waar het relatieve succes van het debat in het House of Lords in het geding is. Wellicht ten overvloede maak in dat kader nogmaals gewag van het feit dat ook 'Law Lords' als hoogste rechterlijke instantic in Groot-Brittannic prominent deel uit maken van het ledenbestand van het Hogerhuis. Het is niet ongebruikelijk dat deze leden van het hoogste Britse rechtscollege na pensionering hun energie deels gaan steken in parlementaire werkzaamheden. Voor de kwaliteit van het 'generale debate' bijvoorbeeld, betekent dit welhaast vanzelfsprekend, dat het juridisch-inhoudelijke niveau naar een hoger plan wordt getild.

Indien een 'Select Committee' zulks verzoekt (hetgeen meestal het geval is) zal het House of Lords ook debatingtijd wijden aan de op schrift gestelde uitkomsten van onderzock door zo'n commissie. In veruit de meeste gevallen betreft het hier een bespreking van rapporten opgesteld door de twee permanente onderzoekscommissies het 'Science and Technology Committee' en het 'European Communities Committee' (zie par. 4.6.3).

Ook nu weer geldt dat de uitkomsten van het debat door de regering in de regel serieus plegen te worden genomen, niet in de laatste plaats omdat de in het Hogerhuis aanwezige expertise aangaande onder meer EU-vraagstukken en Wetenschap \& Technologie hoog ingeschat pleegt te worden. Belangrijker nog dan die constatering echter is in dit kader het gegeven dat door het betreffende 'Select Committee' waardevolle informatie verschaft wordt, die anders door de regering niet meegenomen zou kunnen worden ter bepaling van het (toekomstig) beleid, eenvoudig omdat tijd en mankracht daarvoor ten ene male ontbreekt. ${ }^{128}$

Voor een bespreking van de derde hoofdvorm van debat in het House of Lords tenslotte, de 'unstarred questions' zij verwezen naar de volgende paragraaf.

Welke slotconclusie kan er nu getrokken worden, met betrekking tot het politieke en maatschappelijke belang van het debat in het House of Lords? En gerichter, wat kunnen de uitkomsten van dit non-legislatieve debat in het Hogerhuis betekenen voor de verwezenlijking van de tweede hoofdtaak der Britse senaatskamer, te weten de permanente parlementaire bestuurscontrole?

Over de invloed die van het Hogerhuisdebat uit kan gaan op de (toekomstige) standpuntbepaling van de regering kan opgemerkt worden dat dankzij expertise, grondigheid van werken

126. D. Shell, The House of Lords, a.w., p. 179 e.v.

127. House of Lords Hansard, 30-7-1981.

128. M. Rush, a.w., p. 22-23. 
en (relatieve) onafhankelijkheid enige reële invloed onmogelijk ontkend kan worden. Maar om het wel in het juiste perspectief te kunnen blijven zien: 'Ninety percent is puff. ${ }^{129}$

Ter expliciete repressieve controle van het regeringsbeleid is het belang van het debat in het House of Lords overigens verwaarloosbaar klein. Voor zover de senatoren uit het Verenigd Koninkrijk überhaupt middelen in dier voege ter beschikking plegen te hebben, vinden wij die toch eerder terug in het vragenrecht.

\subsubsection{Starred questions}

Als er éen recht is waarvan de publieke opinie meent dat het bijzonder goed tot zijn 'recht' komt binnen de muren van Westminster, dan is dat zonder enige twijfel het vragenrecht. De reden daarvoor gaat echter met name schuil in het House of Commons. 'Question Hour' aldaar, meer in het bijzonder nog de tweewekelijkse 'Prime Minister's Question Time' heeft door de semi-chaotisch ogende dynamiek in een kader van vanzelfsprekende politieke opportuniteit grote vermaardheid verwerven. 'Question Time' in het House of Lords is van een andere, bepaald minder dynamische orde. Daarvoor is een tweetal redenen aanwijsbaar. In de cerste plaats speclt uiteraard een zeer grote rol dat het Hogerhuis slechts een tweederangs politieke arena is. De macht ligt in het House of Commons met als gevolg dat vrijwel alle leden van het kabinet met ook maar enig politiek gewicht eveneens zitting hebben in het Lagerhuis. Als gevolg daarvan wordt de taak van het beantwoorden van de 'starred questions' in het Hogerhuis meestal 'waargenomen' door de 'Lord in waiting', zeg maar de dienstdoende Lord die zitting heeft in de regering. Dat de gemoederen in politieke zin in een dergelijke setting minder snel verhit plegen te raken, zal nauwelijks verwondering wekken. In het verlengde van deze constatering kan ook nog gewezen worden op Standing Order 34: 'Questions to which a star is attached, indicate that they are asked for information only (...)'. Niet interessant dus voor oppositie of Back-bench om ad-rem replicerend snelle politieke punten te kunnen scoren.

In de tweede plaats is het vragenuur in het House of Lords ook anders georganiseerd. Geen Speaker die er snel én beslist ongeveer 20 vragen per dag doorheen jaagt. Geen spervuur aan 'staccato'-vragen voor de regering door zowel Front- als Back-benchers van de oppositie, doch daarvoor in de plaats maximaal vier mondelinge vragen per zittingsdag. Dit heeft tot gevolg dat via verdiepende vervolgvragen toch al gauw een soort inhoudelijke minidebatjes kunnen ontstaan. ${ }^{130}$ Ook bijzonder indicatief voor de gang van zaken in het Hogerhuis is het gegeven dat daar per week slechts een enkele als zodanig formeel geboekstaafde 'topical question' gesteld zal mogen worden. ${ }^{131}$

De vragencultuur binnen het Britse parlementsrecht gaat, zoals reeds opgemerkt in de inleiding van dit onderdeel, echter veel verder dan het stellen van mondelinge vragen tijdens het dagelijkse vragenuur. Naast de 'starred questions' kent het Britse staatsrecht ook de 'Unstarred questions', de 'Private notice Questions' en de 'Questions for Written answers'. ${ }^{32}$

129. D. Shell. The House of Lords, a.w., p. 198.

130. D, Shell. Questions in the House of Lords, in: M. Franklin and P. Norton. Parliamentary Questions, Oxford 1993, p. 150-151.

131. En wel op donderdag. Wie de actuele vraag mag stellen wordt bij loting beslist. Een lid van het House of Lords mag per parlementair jaar maximaal twee maal een 'topical question' stellen.

132. E. May, a.w., p. 438 e.v. 


\subsubsection{Unstarred questions}

Ook buiten het 'question hour' om is het in het House of Lords mogelijk mondeling vragen te stellen aan het adres van de regering. Het betreft dan vragen die aanleiding kunnen geven tot beperkt debat. Afhankelijk van het tijdstip (altijd als laatste agendapunt van de dag) wordt maximaal één tot anderhalf uur uitgetrokken voor het 'debat' over een dergelijke 'Unstarred question'. De vraag wordt door een Peer gesteld in de vorm van een toespraak. Sprekende voorbeelden uit het recente verleden betroffen onder meer het debat over de vraag waarom en onder welke omstandigheden de Chileense generaal Pinochet in Groot-Brittannie was aangehouden, ${ }^{133}$ alsmede de BSE-besmetting van Brits vee. ${ }^{134}$ Echt gedebatteerd wordt er in de praktijk in feite slechts zelden op basis van 'Unstarred questions'. In de regel komt het in wezen neer op het aanhoren door de senatoren van elkanders speeches. ${ }^{135}$ Het gegeven dat 'Unstarred questions' slechts gesteld mogen worden, indien zij vermeld staan op het dagelijkse 'Order Paper', geeft nog eens extra aan dat het hierbij niet gaat om een spontaan inspringen op actuele gebeurtenissen. ${ }^{136}$ De kwestie wordt afgesloten met het antwoord door een vertegenwoordiger van de regering. Nadere reacties betreffende het besproken onderwerp vanuit het Hogerhuis zijn na het antwoord van de regering niet meer toegestaan. ${ }^{137}$

De 'Unstarred question' was vanaf de zeventiger jaren van de vorige eeuw redelijk populair onder de Lords, voornamelijk omdat in principe iedere Back-bencher op deze wijze in staat gesteld kon worden zijn of haar (opvallend veel Baronesses plegen gebruik te maken van de mogelijkheid tot het stellen van een 'Unstarred question') 'ei' in het Huis te deponeren. Tussen 1975 en 1980 werden gemiddeld 43 vragen per parlementair jaar gesteld. ${ }^{138}$ De 'Unstarred question' droeg echter ook sterk bij aan het stoffige imago van het House of Lords in die jaren. Tegenwoordig maken de leden van het Britse Hogerhuis minder gebruik van hun recht tot het stellen van 'Unstarred questions'. In 2001 (22 oktober) nog slechts 13 maal. ${ }^{139}$

\subsubsection{Private notice questions}

Indien actuele gebeurtenissen daartoe aanleiding geven, kunnen de Britse parlementariërs een verzoek indienen tot het stellen van een vraag daarover aan de regering, vreemd aan de orde van de dag. In het House of Lords geeft in eerste instantie de Leader zijn mening over de toelaatbaarheid van een 'Private notice question'. In geval men er niet echt uitkomt aangaande de toelaatbaarheid, beslist uiteindelijk 'the general sense of the House'. ${ }^{140}$ Indien toegelaten, wordt een 'Private notice question' direct aansluitend op de Starred questions én volgens dezelfde procedure gesteld. ${ }^{14}$ Het is expliciet niet de bedoeling dat het stellen van cen 'Private notice question' gevolgd wordt door debat. ${ }^{142}$

133. House of Lords Hansard, 19-7-1999, Column 795 e.v.

134. House of Lords Hansard, 16-10-1996, Column 1744.

135. D. Shell, The House of Lords, a.w., p. 191.

136. Standing Order nr. 38.

137. E. May, a.w., p. 442 .

138. J. Griffith and M. Ryle, a.w., p. 475.

139. http:/www.parliament the-stationery-office.co.uk/pa/ld200001/ldhansrd/pdvn/all-us.htm. 24-10-2001.

140. J. Griffith and M. Ryle, a.w., p. 477 .

141. E. May, a.w, p.439.

142. Standing Order nr. 35. 
Het politieke belang van dergelijke vragen is voor het Hogerhuis nooit erg groot geweest. Zeker sinds het in 1983 ook nog eens onmogelijk is geworden om Private notice questions aan de regering te stellen aangaande actuele onderwerpen waarnaar ook het House of Commons via een soortgelijke procedure bleek te informeren, is de procedure in het Hogerhuis vrijwel volledig in onbruik geraakt. ${ }^{143}$

\subsubsection{Questions for written answer}

Het stellen van schriftelijke vragen door de senaat aan de regering heeft in het Verenigd Koninkrijk een enorme vlucht genomen. Tijdens het parlementaire jaar 1967-1968 stelden de Lords nog slechts 93 schriftelijke vragen aan de regering. Tien jaar later waren dat er al 544 . In 1987-1988 was dit verder opgelopen tot 1405 schriftelijke informatieverzoeken. Tijdens het parlementaire jaar 1997-1998 moest (het ambtelijk apparaat van) de regering Blair maar liefst $5729 \mathrm{keer}$ in de pen klimmen om vragen vanuit het Hogerhuis te beantwoorden. ${ }^{144}$ Dergelijke aantallen zijn sindsdien gebruikelijk gebleven. ${ }^{145}$ De antwoorden van de regering volgen in de regel binnen 14 dagen. Deze worden afgedrukt in de Hansard. $\mathrm{Zij}$ betreffen zeer regelmatig lokale kwesties zoals het gevaar van bepaalde wegen en kruispunten, het sluiten van slachthuizen of de toegankelijkheid van Brits natuurschoon. Maar ook internationale aangelegenheden zoals wapenembargo's of nationale aangelegenheden zoals de abortusproblematick.

Het praktische politieke gewicht van het totale vragenrecht pakket zoals dat de Lords ten dienste staat, dient zeker niet overtrokken te worden. Het partijpolitieke element staat in het Hogerhuis veel minder op de voorgrond bij de uitoefening van het vragenrecht dan in het House of Commons. Hoewel dat aan de inhoudelijk kant voordelen op kan leveren, blijkt het praktische belang van het vragenrecht voor het Hogerhuis toch vooral bepaald te worden door een chronisch gebrek aan reële machtsmiddelen in de (formeel controlerende) verhouding House of Lords-regering: 'because of the absence of any real semblance of power and hence the lack of a genuine or developed sense of ministerial responsibility to the House, questions in the Lords often have the appearance of being mere shadow-boxing '. ${ }^{46}$

\subsubsection{Investigative committees}

Onder de groep 'Select Committees' vallen naast de in par. 4.3 .3 besproken 'Legislative Committees' ook zgn. 'Investigative committees'.147 Deze commissies staan wat verder af van het day to day-wetgevingswerk. Zij onderzoeken onderwerpen die het openbaar belang betreffen. ${ }^{148} \mathrm{Op}$ ad-hoc basis worden daartoe tegenwoordig regelmatig commissies geïnstal-

143. Sinds 1983 legt de regering in dergelijke gevallen via een woordvoerder nog slechts een verklaring af.

144. A House for the future, a.w., p. 20

145. Hetgeen allerminst verwonderlijk is, aangezien de Life Peers 'nieuwe stijl' die het House of Lords sinds 1999 getalsmatig to sterk domineren over het algemeen immers actiever participeren bij de Hogerhuiswerkzaamheden, dan de teruggetreden Hereditary Peers plachten te doen.

146. D. Shell. Questions in the House of Lords,uit: M. Franklin and P. Norton, Parliamentary Questions, Oxford 1993, p. 174.

147. M. Rush. The House of Lords: The Political Context, in: P. Carmichael and B. Dickson, a.w., p. 20.

148. E. May, Parliamentary Practice, a.w., p. 623. 
leerd 'Public Service' (1997-98), 'Stem Cell Research' (2000-2001) en 'Economic Affairs' zijn daarvan drie voorbeelden. ${ }^{149}$

De twee toonaangevende House of Lords-commissies op dit vlak zijn echter: 'the Committee on Science and Technology' en 'the European Union Committee'.

Over de eerste kunnen wij kort zijn. De doelstellingen van deze Hogerhuiscommissie zijn zeer goed vergelijkbaar met die van de Franse 'office parlementaire d'évaluation des choix scientifiques et technologiques'. Als 'joint committee' van beide parlementskamers, adviseert aj de regering op voornoemde beleidsterreinen na eerst zelfstandig grondig onderzoek te hebben verricht. De onderzoeksterreinen varièren van zeer algemeen: 'Priorities for the Science Base (1993)', tot vrij bijzonder: 'Fish stock Conservation and Management (1996); 1 , 50

De veruit bekendste Britse onderzockscommissie is echter de 'European Union Committee'. Deze commissie, opgericht in 1974, ${ }^{151}$ heeft in de loop der jaren behoorlijk naam gemaakt. voornamelijk dankzij veelvuldig en nauwgezet onderzock van (regelgevings)voorstellen afkomstig van de Europese Commissie in Brussel. De officiele, opvallend breed geredigeerde taakstelling voor de Hogerhuiscommissie was oorspronkelijk in 1974 duidelijk ingegeven door de Britse argwaan ten oprichte van 'Brussel': 'to consider Community proposals, whether in draft or otherwise, to obtain all necessary information about them, and to make reports on those which, in the opinion of the Committee, raise important questions of policy or principle, and on other questions to which the Committee considers that the special attention of the House should be drawn', ${ }^{152}$ Een kwart eeuw later zijn beduidend minder woorden nodig om de aan het EU-model aangepaste brede doelstelling van de dynamische Hogerhuiscommisie te verwoorden: 'to consider European Union documents and other matters relating to the European Union', ${ }^{153}$ inclusief regelgeving vallend onder de tweede en derde pijler van de EU.

Het relatieve succes van deze commissie hangt ongetwijfeld voor een niet onaanzienlijk deel samen met het gegeven dat het House of Lords in een tweetal opzichten een beduidend rianter uitgangspositie heeft voor het verrichten van onderzoek naar de gigantische berg EU-regelgevingvoorstellen dan het House of Commons. In de eerste plaats is daar uiteraard (wederom) de factor flexibiliteit. De Peers, werkend op vrijwillige basis in min of meer wisselende settings, zitten nu eenmaal veel minder vast aan strakke tijdschema's dan de collega's uit het Lagerhuis. Dientengevolge zijn de mogelijkheden tot het verrichten van grondig onderzoek en het schrijven van rapporten over de uitkomsten daarvan eenvoudig veel groter. Daar komt bij dat in het House of Commons tot op de dag van vandaag een, met name in Conservatieve kringen zeer serieus te nemen anti Europa lobby actief pleegt te zijn. Sentimenten van dien aard hebben nooit bestaan in het House of Lords, waardoor dit Huis veel geschikter bleek te zijn voor het verrichten van 'onafhankelijk' en enigermate gedepolitiseerd onderzoek naar de verrichtingen in 'Brussel'. ${ }^{154}$

149. http://www.parliament the-stationery-office.co.uk/pa/dd199697/dselect/dscenqs.htm. 24-10-2001.

150. http://www.parliament. the-stationery-office.co.uk/pa/ld199697/dinfo/ldl6sctk/ld16sctk.htm, 21-9-2000.

151. Als 'European Communities Committee'.

152. D. Shell, The European Communities Committee, in: D. Beamish and D. Shell, The House of Lords at Work, aw., p. 248

153. http://www.parliament.the-stationery-office.co.uk/pa/ld199798/dbrief/dscrueu.htm. 21-9-2000.

154. J. Griffith, and M. Ryle, a.w., p. 491. 
De 'European Union Committee' bestaat uit ongeveer 20 Peers. De voorzitter wordt niet als vrijwilliger beschouwd en ontvangt een regulier salaris. Ter nadere ondersteuning van de werkzaamheden van de commissie is al snel de mogelijkheid geschapen tot het installeren van subcommissies op ad-hoc basis. In deze subcommissies kunnen in totaal nog eens ongeveer 50 Peers op vrijwillige basis (en daarom in regelmatig wisselende, flexibele samenstelling) actief zijn. De sub-commissies bestrijken grofweg de centrale beleidsterreinen die ook de vaste kamercommissies van Eerste Kamer, House of Commons, Assemblée nationale of Bundestag als hun onderzoeksterritorium mogen beschouwen. $\mathrm{Zij}$ worden, reagerend op actuele ontwikkelingen, actief. Het initiatief gaat daarbij uit van de voorzitter van de hoofdcommissie. Die scheidt het Brusselse kaf van het koren en bepaalt waar de prioriteiten moeten liggen. Slechts ongeveer een kwart van de EU-documenten die bij de voorzitter ter tafel komen, vinden hun weg naar subcommissies. 'The Subcommittee on Fraud and mismanagement of the Community's finances, the subcommittee on Genetically modified organisms in food' en 'the subcommittee on Enlargement of the EU' zijn drie voorbeelden daarvan uit een nog niet al te grijs EU-verleden. ${ }^{155}$ In 2001 werd, allerminst oninteressant in relatie tot de inhoud van dit boek, onder meer een onderzoek opgestart naar 'the possible role of a Second Chamber and its place in the institutional architecture of the European Union. ${ }^{156}$

Het succes van de 'European Union Committee' is voor een zeker niet onaanzienlijk deel te danken. aan het feit dat er pro-aktief gewerkt pleegt te worden. Ontwikkelingen binnen EG en EU worden nauwgezet en op de voet gevolgd, zodat steeds direct én adequaat ingesprongen kon worden op een voortdurende nationaal-Britse behoefte aan Europagerelateerde informatic. De Britse regering krijgt in de regel noodzakelijke informatie aangereikt met betrekking tot regelgevingvoorstellen van de EC vóór de Raad van Ministers over gaat tot definitieve besluitvorming. ${ }^{157}$ Bij de onderhandelingen tussen de ministers van de EU-lidstaten blijken de uitkomsten van 'European Union Committee'-rapporten dan ook met enige regelmaat sterk richtinggevend te zijn. ${ }^{158}$ Tenslotte moet nog opgemerkt worden dat het EUgerelateerde onderzoekswerk door commissies uit het Britse Hogerhuis mede tot gevolg heeft gehad, dat de Lords bijzonder goed de weg weten te vinden in 'Brussels' en 'Europe', hetgeen het aanzien en de kracht van dit commissiewerk bepaald niet negatief beïnvloed heeft. ${ }^{159}$

\subsection{Eindbalans}

Bestuurscontrole door het House of Lords stelt in politieke zin bijzonder weinig voor. Deze conclusie zal natuurlijk ook nauwelijks bevreemding wekken, aangezien de ministeriële verantwoordelijkheid in de verhouding regering-House of Lords anno 2000 nog slechts een plicht tot antwoorden inhoudt.

De Britse senaatskamer doet echter beduidend meer dan slechts het stellen van vragen. Zij onderzoekt zelfstandig, grondig en professioneel op een aantal specifieke beleidsterreinen. Zij

155. http:/www. parliament the-stationery-office.co.uk/pa/d199798/dbrief/ldscrueu. htm. 21-9-2000.

156. http:/ www parliament.the-stationery-office.co.uk/pa/d199697//dselect/dscenqs.htm. 25-10-2001

157. J. Griffith and M. Ryle, a.w., p. 491.

158. Idem. Uiteraard zijn de uitkomsten van onderzock door de subcommissies zo nu en dan politick van dien aard, dat de regering er zich beslist nict mee wenst te identificeren.

159. D. Shell, The European Communities Committec, a.w., p. 278-281. 
neemt de tijd voor grondig inhoudelijk debat over ieder denkbaar onderwerp dat onderdeel uit kan maken van de politicke agenda Zij bewaart een zekere mate van (politicke) onaflankelijkheid ten opzichte van House of Commons en regering.

Het Britse Hogerhuis is, tevens zijn legislatieve functies in ogenschouw nemend, blijkbaar wonderwel in staat gebleken een formeel nadeel om te buigen tot een praktisch voordecl. Tegenwoordig in feite verstoken van reèle politieke (veto)macht, heeft het House of Lords via de gesignaleerde activiteiten op het gebied van zowel de wetgeving als de bestuurscontrole een aanmerkelijke mate van aanpassingsvermogen aan veranderende omstandigheden ten toon weten te spreiden. ${ }^{160}$ Vanuit een werkomgeving die in partijpolitieke zin beduidend meer (creatieve) ruimte biedt dan in het sterk monistisch functionerende House of Commons het geval pleegt te zijn, is constructief meedenken met de (wetgevings)voorstellen van de regering het vanzelfsprekende credo. Vanzelfsprekend, omdat regering en (de automatische absolute meerderheid van) het House of Commons per definitic het laatste woord kunnen hebben, waar wetgeving in het geding is. Voortdurend dwarsliggen en vertragen via het recht van amendement naar Frans voorbeeld zou voor het House of Lords formeel dan ook eenvoudig suìcidale gevolgen kunnen hebben. Één act of Parliament en én jaar geduld zou daartoe immers volstaan. Het House of Lords heeft er door zijn cooperatief informatieve opstelling, maar zeker ook door zijn regeringskritische attitude op het juiste moment (het doorschietende Elective Dictatorship ten tijde van Thatcher bijvoorbeeld) echter zorg voor gedragen dat zowel in de publieke opinie als in politieke kringen te Westminster het woord 'abolition' in relatie tot het Britse Hogerhuis tegenwoordig niet meer op te tekenen valt. 



\section{Hoofdstuk 5}

\section{Frankrijk, wetgeving en bestuurscontrole}

\section{$5.1 \quad$ Inleiding}

Comme l'ensemble des grandes branches du droit français contemponain, le droit parlementair est devemu, en majeure partie, un droit écrit. La Constitution de 1958 instit elle-mème des proddures assez détaillees, précisées et explicitées par d'autres textes dont le strict respect s impose au Parlement.'

Als iets in dit hoofdstuk (waarin het functioneren van de Franse senaatskamer het centrale onderwerp is) duidelijk zal worden, dan is het wel dat de Franse grondwetgever voor de constitutie van de 5e Republiek het functioneren van het parlement verregaand wenste te reguleren. Een opgave die in het tot dan toe (zie par. 2.3.3) zo sterk parlementaristisch georiēnteerde Frankrijk bepaald niet als een sinecure beschouwd mocht worden. Het eindproduct dat na het referendum van 28 september 1958 in werking kon treden, bevatte een uitgebreid netwerk aan geschreven rechtsregels die het handelen van alle participanten in het wetgevingsproces in hoge mate zou moeten gaan bepalen. Aan een beschriving van de manier waarop de (mede)wetgevende functies in Frankrijk behoren te worden uitgeoefend door de senaatskamer, moet daarom een bondige inleidende uiteenzetting van de wijze waarop het Franse semi-presidentiële stelsel, voorzover relevant rondom de legislatieve taakstelling, in de Grondwet van 1958 vorm heeft gekregen, voorafgaan.

In Frankrijk kunnen meerdere organen een (mogelijke) hoofdrol vervullen tijdens de totstandkomingfase van wetgeving in formele zin. Dit zijn: de President van de Republiek, de regering, de Assemblée nationale, de Sénat en de Conseil Constitutionnel. Wij concentreren ons verder met name op de rol van de eerste vier organen. De (overigens behoorlijk prominente) rol die constitutionele toetsing van wetgeving in formele zin in Frankrijk is gaan vervullen valt, hoe interessant ook, buiten het kader van dit boek en zal in algemene zin verder dan ook vrijwel onbesproken blijven. ${ }^{2}$

De President van de Republiek kan, evenals de Assemblée nationale en de Sénat bogen op een eigen kiezersmandaat. ${ }^{3}$ Indien de partijpolitieke meerderheid van de Franse volkskamer, de Assemblée nationale, alsmede de daarop steunende regering afkomstig zijn uit hetzelfde politieke kamp als de President (in de praktijk centrumrechts of socialistisch), kan deze laatste in de praktijk tevens functioneren als regeringsleider. De (formeel door de President te benoemen $\left.^{4}\right)$ Premier Ministre is in een dergelijke situatie onder omstandigheden ietwat oneerbiedig ook wel te betitelen als 'zetbaas'. Deze situatie deed zich bijvoorbeeld duidelijk voor onder De Gaulle (1958-1969) en Mitterand (1981-1986 en 1988-1993). Een parallel met de wijze waarop de dwarsverbanden tussen executieve en wetgever functioneren in parlementaire

1. R. Chazelle, Le Sénat et le droit parlementaire coutumier, Chroniques cinstitutionnelles, Paris 1988 , p. 711.

2. Evenals trouwens de rol die het Bundesverfassungsgericht dienaangaande in de Bondsrepubliek vervult.

3. Art. 6 lid 1, Constitution $1958 \mathrm{en}$ art. 24 Constitution 1958.

4. Art. 8 lid 1, Constitution 1958.

5. V. Wright, The President and the Prime Minister, subordination, conflict, symbiosis or reciprocal paratism? in: M. Harrison e.a., De Gaulle to Mitterand, Presidential Power in France, London 1993, p. 101-149. 
stelsels als Nederland en Groot-Brittanniē, is onder dergelijke omstandigheden nog redelijk eenvoudig te trekken, zij het dat boven de Premier ministre ook een (politiek gelijkgezind) opper opperhoofd functioneert, dat op geen enkele wijze afhankelijk gesteld kan worden van het vertrouwen van een of beide parlementskamers.

Aanmerkelijk ingewikkelder kan het echter worden indien de Assemblée nationale in meerderheid een andere politieke kleur vertegenwoordigt dan de President. Laat ik alvorens dit te verduidelijken allereerst nog een aantal noodzakelijke weetjes op een rij zetten. Vooralsnog is de zittingstermijn voor het Franse staatshoofd gesteld op zeven jaar. ${ }^{6}$ Verder dient men zich te realiseren dat de President te allen tijde formeel voorzitter is van de ministerraad en zich uit dien hoofde intensief pleegt te bemoeien met het regeringsbeleid.

De leden van de Assemblée nationale hebben slechts een mandaat voor een periode van maximaal vijf jaar. ${ }^{8}$ Daarenboven onderhoudt de regering een sanctioneerbare vertrouwensrelatie met diezelfde Assemblée. ${ }^{9}$ Electorale voorkeuren kunnen uiteraard verschuiven. Het kiesstelsel dat gehanteerd wordt voor de Assemblée nationale leent zich daar ook beduidend beter voor dan het in par. 3.4.1 uitgewerkte kiesstelsel voor de Sénat.

In een dergelijke constellatie kan het voorkomen dat de President, ondanks zijn formele bevoegdheid tot benoeming van de regeringsleider, als uitvloeisel van algemene verkiezingen voor de Assemblée nationale, een regering én een Premier ministre zal moeten gedogen die partijpolitick niet de 'zijne' zijn: 'cohabitation'. Er ontstaat dan een situatie waarin een President die zelfstandig kan beschikken over indringende bevoegdheden op het terrein van wetgeving (par. 5.2.1), zal moeten samenwerken met een regering uit het 'andere' politieke kamp. Zowel ten tijde van Mitterand (1986-1988 en 1993-1995) als momenteel onder Chirac (vanaf 1997) is sprake (geweest) van een dergelijke situatie. Een situatie waarin de Premier ministre, de leider van de executieve, en vanuit die hoedanigheid in het bezit van indringende juridische bevoegdheden ter regulering van het wetgevingsproces in formele zin, plotsklaps (tijdelijk) uit kan groeien tot de meest invloedrijke pion in het geheel. En wat dit alles bezien vanuit de problematick die in dit vergelijkend onderzoek onder de loep wordt genomen extra interessant maakt, is het gegeven dat de partijpolitieke samenstelling van de Sénat (de tweede medewetgevende parlementskamer) onder het huidige kiezersregime gewoon áltijd centrumrechts zal blijven. Die zekerheid staat immers nog steeds overeind.

Pogen kortom, om puntig te beschrijven op welke wijze de President, de regeringsleider en de beide parlementskamers samen plegen te werken in het kader van het wetgevingsproces, vertoont overeenkomsten met de poging: 'to try to nail a pudding to a door' ${ }^{10} \mathrm{Wij}$ zullen dat in dit boek dan ook slechts proberen voorzover noodzakelijk ter verwezenlijking van onze doelstelling: het neerzetten van een beschrijving van positie en functioneren van de Sénat in het Franse wetgevingsproces in formele zin.

Van groot belang voor de wijze van functioneren van het Franse Hogerhuis is dus het gegeven dat de vier centrale wetgevingsinstituties qualitate qua behoorlijk gepolitiseerd zijn. Immers,

6. Art. 6 lid 1, Constitution 1958.

7. Art. 9, Constitution 1958 .

8. Art. LO 121, Code électorale.

9. Art 50 Constitution 1958 .

10. V. Wright, The President and the Prime Minister; subordination, conflict, symbioses or reciprocal paratism? in: M. Harrison c.a., De Gaulle to Mitterand, Presidential Power in France, London 1993, p. 101 
behalve de Conseil d'État (advisering) en de Conseil Constitutionnel (constitutionele toetsing) wordt het gedrag van alle participanten in het Franse wetgevingsproces mede gestuurd vanuit het kiezersmandaat verkregen door partijpolitieke stellingname. In tegenstelling tot de situatic in zowel de Bondsrepubliek Duitsland, als Groot-Brittanniè en Nederland geldt deze constatering in Frankrijk ook afzonderlijk voor het (sinds 1962) direct gekozen staatshoofd.

\subsection{Wetgevingsinstituties}

\subsubsection{De President}

De President van de Republiek benoemt en ontslaat bij decreet de Premier ministre. De overige leden van de regering worden op voordracht van de Premier ministre eveneens benoemd en ontslagen door het staatshoofd. "De bemoeienis van de President met het regeringsbeleid is indringend. $\mathrm{Hij}$ is zoals gezegd voorzitter van de ministerraad en pleegt zich uit hoofde van die functie actief te bemoeien met de gang van zaken ${ }^{12}$ De President is als voorzitter van de ministerraad namelijk actief betrokken bij alle wetsvoorstellen ('projets de lois') die geěntameerd worden vanuit de regering. Aangezien de President zich sinds het referendum van 1962 enerzijds kan beroepen op een eigen kiezersmandaat en hij anderzjds nauw betrokken is bij benoeming en ontslag van ministers is ook om die redenen zijn gezag binnen de ministerraad aanzienlijk te noemen. Wetten worden afgekondigd door de President. ${ }^{13} \mathrm{Op}$ grond van art. 10 Grondwet kan de President ook eisen dat een (reeds door het parlement goedgekeurde) wet, of gedeelten daaruit, nogmaals het parlementaire traject doorlopen. Mitterand maakte tijdens de laatste twee jaar van zijn eerste ambtsperiode, plotsklaps geconfronteerd met een regering van niet-socialistische huize, meerdere keren gebruik van deze mogelijkheid.

De directe invloed van de President strekt zich ook uit tot het parlement, meer in het bijzonder de Assembleé nationale. Dit direct gekozen volksvertegenwoordigend orgaan kan door het staatshoofd vrijwel naar believen ontbonden worden. ${ }^{14}$ Slechts een tweetal restricties zijn aan de uitoefening van dit ontbindingsrecht 'verbonden'. Er dient advies ingewonnen te worden bij de voorzitters van de beide parlementskamers en tot één jaar na parlementverkiezingen volgend op ontbinding ex art. 12 Grondwet is een nieuwe ontbinding wettelijk niet mogelijk. Ontbinding van de Assemblée nationale door de President is meer dan eens voorgekomen tijdens de laatste decennia. De motieven daartoe waren van partijpolitieke aard; het succes van aanwending sterk wisselend: Mitterand heeft in 1981 het momentum van zijn verkiezing tot staatshoofd zeer effectief gebruikt om via ontbinding van de Assembleé nationale ex art. 12 Grondwet en daaropvolgende parlementsverkiezingen de machtsbasis van zijn (socialistische) partij in de belangrijkste parlementskamer aanmerkelijk te versterken. In 1997, na twee jaar presidentschap, meende Jacques Chirac op identieke wijze gebruik te moeten maken van de dan geldende electorale sentimenten, ondanks het gegeven dat het mandaat van zijn centrumrechtse regeringscoalitie formeel nog drie jaar van kracht kon blijven. Een verkie-

11. Art. 8 Constitution 1958.

12. Y. Guchet, La Ve République, Paris 1994, p. 278.

13. Art. 10 Constitution 1958.

14. Art. 12 Constitution 1958. 
zingsoverwinning zou echter niet alleen de positie van zijn centrumrechtse coalitiepartijen versterken, doch tevens garanderen dat voor de volledige vijf jaar die de presidentiële ambtstermijn nog zou duren van parlementaire oppositie in beide parlementskamers nauwelijks nog sprake zou zijn. Ideale vooruitzichten in het licht van de polls. Een dramatische omslag van de electorale sentimenten, direct nadat de ontbinding ex art. 12 Grondwet zijn beslag had gekregen, had echter tot gevolg dat de centrumrechtse machtsbasis van het staatshoofd in de Assembleé nationale verloren ging en 'cohabitation' met een regering van socialistische signatuur onder Jospin onafwendbaar werd. Een situatie die sindsdien voort duurt, aangezien Chirac het nooit heeft aangedurfd om de zittende regering Jospin uit te dagen via een hernieuwde gang naar de stembus.

Een andere bevoegdheid van het Franse staatshoofd, van zijdelings belang in het kader van dit relaas, betreft de benoeming van leden van de Conseil Constitutionnel. De President van de Republick benoemt drie gewone leden van dit orgaan. Daarnaast bepaalt hij wie de voorzitterfunctie zal uitoefenen. Het belang van deze benoemingsbevoegdheid is met name groot omdat de Conseil Constitutionnel zich onder het regime van de 5e Republiek snel ontwikkeld heeft tot een zeer invloedrijk orgaan betreffende de toetsing van wetgeving(svoorstellen) aan de grondwet. De overige zes leden van de Conseil Constitutionnel worden benoemd door de voorzitters van de beide parlementskamers. ${ }^{15}$

Tenslotte dient de mogelijkheid tot het uitschrijven van referenda ex art. 11 Grondwet nog gememoreerd te worden. Het staatshoofd kan besluiten tot het houden van een volksstemming over wetsontwerpen die 'I'organisation des pouvoirs publics' tot onderwerp hebben. In de praktijk wordt, althans voor het modelleren van de zuiver nationale staatsinstellingen, weinig gebruikgemaakt van dit middel, dat regelmatig onderwerp van discussie is geweest (zie par. 2.3.3). De Gaulle heeft ooit op deze wijze rechtstreekse verkiezing van de President van de Republiek mogelijk gemaakt. Ook heeft hij op die wijze, zonder succes, geprobeerd de (hem regelmatig onwelgevallige) Sénat om te vormen tot adviesorgaan.

\subsubsection{De regering}

De regering, met aan het hoofd de Premier ministre, bekleedt een positie in het wetgevingsproces waarbij zij voortdurend twee richtingen uit moet kijken: richting parlement en richting President van de Republiek. De door de President benoemde Premier ministre zoekt normaliter de regeringsploeg bij elkaar. Een en ander is natuurlijk mede afhankelijk van de partijpolitieke situatie van het moment. Ten tijde van 'cohabitation' is de invloed die de President probeert uit te oefenen op de samenstelling van de regeringsploeg natuurlijk nauwelijks vergelijkbaar met de situatie waarin de President een Premier Ministre uit de eigen politieke gelederen kan benoemen. De ministers worden op voordracht van de Premier ministre vervolgens formeel benoemd door de President, met contraseign van de Premier ministre. ${ }^{16}$ Evenals het Nederlandse staatsrecht kent ook het Franse staatsrecht de onverenigbaarheid tussen regeringslidmaatschap en het lidmaatschap van een der parlementskamers. ${ }^{17}$

De politieke ministeriěle verantwoordelijkheid komt tot uiting in art. 49 Grondwet. De Premier ministre vraagt het vertrouwen van de Assembleé nationale bij het aantreden van zijn

15. Art. 56 Constitution 1958.

16. Art. 8 tid 2 jo art. 19 Constitution 1958.

17. Art. 23 Constitution 1958 
regering. Verder kán hij, wederom uitsluitend in de Assembleé nationale, het vertrouwen vragen met betrekking tot de stemming van in behandeling zijnde wetsvoorstellen. ${ }^{18} \mathrm{De}$ Assembleé nationale heeft ook de mogelijkheid om zelfstandig te besluiten tot het in stemming brengen van een motie van afkeuring. Dit recht is wel sterk gereguleerd. ${ }^{19}$

De relatie tussen regering en Sénat, in het kader van dit onderzock van meer belang, wordt formeel ook gedragen door enige vorm van vertrouwensregel, maar wel in sterk afgezwakte vorm: 'le premier ministre a la faculté de demander au Sénat l'approbation d'une déclaration de politique générale' ${ }^{20}$ In de praktijk wenst de regering een dergelijke niet-gesanctioneerde goedkeuringsverklaring uiteraard alleen indien succes op voorhand verzekerd is. Omdat de partijpolitieke samenstelling van het Franse Hogerhuis, zoals wij gezien hebben in hoofdstuk 3, grotendeels vast ligt ten gevolge van het gehanteerde kiesstelsel, maken slechts regeringen van centrumrechtse signatuur gebruik van art 49 lid 4 , om hun 'goede' band met de geachte afgevaardigden van het Palais de Luxembourg enig extra cachet te geven. ${ }^{21}$

\subsection{De wetgevingsprocedure}

De wijze waarop het Britse wetgevingsproces tegenwoordig gestalte krijgt is cen uitvloeisel van de Britse 'Parliamentary tradition': historisch gegroeid en grotendecls nog altijd ongeschreven, maar tegelijkertijd rotsvast verankerd in het hedendaagse staatsrecht. Frankrijk daarentegen kent een geschreven constitutie, die op het vlak van het wetgevingsproces ook nog eens opvallend gedetailleerde instructies blijkt te bevatten. Toch kan ook de tegenwoordige werking van het parlementaire stelsel in Frankrijk onmogelijk worden verklaard zonder voortdurende verwijzingen naar het verleden. De invloed die het typisch Franse 'parlementarisme' van de 3e en 4e Republiek (inclusief 'bicameralisme parfait') gehad heeft op de geest van de vigerende constitutie is onmiskenbaar groot geweest. Geheel in lijn met die constatering is de behoefte van de Franse grondwetgever van 1958 om de invloed van het parlement op de gang van het wetgevingsproces in te dammen aanzienlijk geweest. Uit pragmatisch oogpunt alleszins begrijpelijk, als in aanmerking wordt genomen dat het tijdens het bestaan van de $3 \mathrm{e}$ en 4e Republiek erg vaak welhaast onmogelijk bleek wetsvoorstellen tot wet verheven te krijgen. ${ }^{22}$ De grondwetgever van 1958 introduceerde toch wederom het bicameralisme, zij het met dien verstande dat de rol van de Sénat uiteindelijk ondergeschikt

18. Een regelmatig gehanteerd zwaar middel om wetsvoorstellen aangenomen te krijgen, dat dankzij de te volgen procedure nog aan effectiviteit wint: stelt de regering de vertrouwenskwestie dan wordt het wetsvoorstel geacht te zijn aangenomen tenzij een meerderheid van de leden van de Assmbleé via een motie van afkeuring te kennen geeft een andere mening te zijn toegedaan.

19. Art. 49 lid 2 Constitution 1958 bepaalt dat minimaal $1 / 10$ e deel van het totaal aantal leden van de Assembleé Nationale een dergelijk voorstel moet indienen. Bij de stemming moet het aantal voorstemmers de helft van het totale aantal leden van het Franse lagerhuis overtreffen. De meerderheid van het totale aantal aanwezige parlementariếrs voldoet dus niet. Ook is van belang dat ieder lid van de Assembleé per sessie slechts eenmaal een motie van afkeuring in stemming kan brengen. Frequent gebruik vanuit de oppostie bedoeld als politiek 'protest' blijft ten gevolge van deze procedureregels achterwege.

20. Art. 49 lid 4 Constitution 1958.

21. Vooral tijdens de periode 1974-1981 (Giscard d'Estaing) en de periode 1993-1995 (de laatste twee jaar Mitterand in cohabitation met de centrum-rechtse regering Balladur) was de band tussen regering en senaat dusdanig innig dat art 49 lid 4 Grondwet meermaals geactiveerd werd.

22. J. Mastias et J. Grangé, Les Secondes Chambres du Parlement en Europe Occidentale, Paris 1987, p. 218 e.v. 
diende te zijn aan de rol van de Assemblée nationale: 'bicameralisme inégal'. Daartoe werd dan ook een aantal regels in de nieuwe constitutie opgenomen. Het meest zichtbaar: art. 45 lid 4 Grondwet, waarin de grondwetgever het 'laatste woord' in het wetgevingsproces, zij het onder voorwaarden, toebedeelt aan de Assemblée nationale. Ik kom hier (par, 5.3.6.2) nog uitgebreid op terug. Dat het Franse Hogerhuis ten opzichte van de Assemblée nationale de tweede viool dient te spelen, blijkt tevens uit het gegeven dat de vertrouwenskwestie in relatie tot cen wetsvoorstel ex art. 49 Grondwet slechts kan spelen in het Franse Lagerhuis. De Sénat moet zich, zoals in het vervolg van dit hoofdstuk zal blijken, vanaf 1958 voor haar goed- of afkeuringbeleid betreffende wetgevingsproducten daarom toch weer wenden tot een middel dat in de Franse parlementaire geschiedenis altijd al een vooraanstaande rol placht te spelen: de procedure. Met name in de wijze waarop het recht van amendement door de Franse senaatskamer gehanteerd wordt (zie par. 5.3.1 e.v.), komt dit goed tot uiting.

De omvang van het juridische instrumentarium dat via de constitutie van 1958 en de reglementen van orde van de beide parlementskamers ter regulering van het legislatieve proces ten dienste staat aan de participanten in het Franse wetgevingstraject, is ronduit indrukwekkend. Vooral de regering heeft de beschikking gekregen over veel juridische mogelijkheden die het proces kunnen sturen in de door haar gewenste richting. Centraal element: indamming van het amendementsrecht.

\subsubsection{Het recht van amendement}

In tegenstelling tot de mogelijkheden dienaangaande voor de Nederlandse Eerste Kamer, maar sporend met de situatic in Groot-Brittanniè heeft de Franse Sénat het recht (onderdelen van) wetsvoorstellen van amendementen te voorzien. Enerzijds doordrongen van het feit dat het recht van amendement een plaats heeft in de wortels van de parlementaire democratie, doch zich anderzijds ook ten volle bewust van het gegeven dat wetgevingsprocessen maar beter voltooid kunnen worden, heeft de Franse (grond)wetgever van 1958 een scala aan rechtsregels opgesteld, die het parlementaire recht van amendement sterk moeten reguleren c.q. inperken.

\section{- Art. 44 lid 1 Constitution 1958: Les Membres du Parlement et le gouvernement ont le droit} d'amendement.

Concreet komt het amendementrecht toe aan iedere senator, individueel dan wel partijpolitiek gegroepeerd. Verder kunnen amendementen voortkomen uit de kokers van kamercommissies bij monde van hun rapporteurs en (bepaald niet onbelangrijk) de regering. Tijdens het regime van de IVe Republiek was de regering verstoken gebleven van het recht van amendement. Vanaf 1958 is het echter mogelijk geworden, zonder enige vorm van restrictie, dat de regering wetsvoorstellen amendeert, ook indien het voorstellen ('projets de loi') betreft die direct van haar afkomstig zijn.

Art. 49 Règlement du Sénat regelt zeer nauwkeurig de te volgen procedure bij de plenaire bespreking van ingediende amendementen. Eerst worden de wijzigingsvoorstellen besproken die beogen dat tekstgedeelten volledig geschrapt worden. Vervolgens de amendementen die zich verzetten tegen de voorgestelde tekst. Tenslotte amendementen die tussenvoegingen c.q. toevoegingen beogen. ${ }^{23}$ 
Bestudering van de Franse Grondwet van 1958 leert ons vervolgens dat de grondwetgever de nodige energie heeft gestoken in het formuleren van een aantal mogelijkheden voor de regering om het recht van amendement, voorzover uit te oefenen door de beide parlementskamers, fors in te kunnen perken.

\subsubsection{Grondwettelijke inperkingrechten}

\subsubsection{1}

- Art 40 Constitution 1958: Les propositions et amendements formulés par les membres du Parlement ne sont pas recevables lorsque leur adoption aurait pour conséquence soit une diminution des ressources publiques, soit la críation ou l'aggravation d'une charge publique.

Uiteraard beoogt dit artikel een dam op te werpen tegen misbruik van openbare financiěn. De niet-toelaatbaarheid van amendementen voorgesteld door de Senaat op basis van art. 40 Grondwet wordt, weliswaar mede afhankelijk van de partijpoliticke samenstelling van het moment, relatief frequent ingeroepen door de regering. Het blijkt een breed inzetbaar juridisch instrument te zijn in de politieke strijd tegen onwelgevallige amendering. Wetsvoorstellen die op geen enkele wijze een afname van publieke middelen, dan wel een verzwaring van publieke lasten tot gevolg kunnen hebben, zullen immers niet zo vaak onderwerp van parlementaire behandeling uitmaken. Dit betekent overigens nict automatisch dat de regering op basis van art. 40 Grondwet te pas en te onpas de niet-toelaatbaarheid van amendementen kan inroepen. De Conseil Constitutionnel ziet er dienaangaande op toe dat aanwending slechts mogelijk is indien dit gebeurt 'conforme à la lettre et à l' esprit' van de rechtsregel. Anderzijds heeft de Conseil Constitutionnel ook duidelijk gemaakt dat bezwaren uit het kamp van senatoren tegen het inroepen van de niet-toelaatbaarheid van amendementen op basis van art. 40 Grondwet slechts in behandeling zullen worden genomen, indien op voorhand duidelijk is dat de betreffende wijzigingsvoorstellen niet de financiële grenzen geformuleerd in dat grondwetsartikel overschrijden. ${ }^{24}$

Overigens verloopt de te volgen procedure ex art. 40 Grondwet niet volledig identiek bij de beide parlementskamers. De president van het Franse Lagerhuis (afkomstig uit de gelederen van de regeringscoalitie) onderzoekt namelijk direct ambtshalve of een ingediend amendement wel spoort met de eisen van art. 40 Grondwet. Komt hij, eventueel na advies ingewonnen te hebben bij de vaste commissie van financiën, tot de conclusie dat hiervan geen sprake is, dan weigert hij het betreffende amendement überhaupt in behandeling te nemen. In de Senaat wordt een dergelijke procedure niet gevolgd. Ambtshalve weigering van amendementen op grond van motieven gelieerd aan de financiële huishouding van de Staat, is in het Franse Hogerhuis uit den boze. Alle amendementen worden in ieder geval formeel gedeponeerd. Pas nadat de regering vervolgens gesteld heeft dat een wijzigingsvoorstel de financiële huishouding van de staat raakt en derhalve ingetrokken dient te worden, zal de commissie van financiën de kwestie onderzoeken en niet-appellabel bindend uitspraak doen. ${ }^{25}$ Markant is het gegeven dat deze uitspraak niet gemotiveerd hoeft te worden.

24. Conseil Constitutionnel, 13 januari 1994, nr. 93-329. Zie ook: F, Luchaire, L'Abrogation de la loi Falloux devant le Juge Constitutionnel, Revue du Droit Public et de la Science Politique en France et à I'ćtranger 1994, p. 609-634.

25. Art. 45 Règlement du Sénat. 
Indien de regering het niet eens mocht zijn met de uitkomst van de procedure, kan zij wel altijd nog proberen via de reguliere conflictprocedure (per 'navette' en 'Commission Mixte Paritaire') ex. art. 45 Grondwet (zie par. 5.3.6.1) haar zin te krijgen.

Er wordt door de regering, afhankelijk van de politieke verhoudingen van het moment en het politieke belang van het onderwerp 'onder de hamer' vrij regelmatig gebruik gemaakt van de mogelijkheden die art. 40 Grondwet biedt om onwelgevallige amendementen te weren uit aanhangige wetsvoorstellen. Tijdens het eerste parlementaire jaar van het nieuwe millennium bijvoorbeeld, werd art. 40 Grondwet 69 maal door de regering ingeroepen met het doel amendementen vanuit de gelederen der Sénat te kunnen weren uit de voorliggende wetteksten. In 57 gevallen gebeurde dit dat jaar met succes. ${ }^{26}$

\section{3 .1 .1 .2}

- Art 41 Constitutiont:S'il apparaît au cours de la procédure législative qu' une proposition ou un amendement n'est pas du domaine de la loi ou est contraire á une délégation accordée en vertu de l'article 38, le gouvernement peut opposer l'irrecevabilité.

Kan de regering aantonen dat de senaat wetgevingsvoorstellen wil amenderen op een wijze die buiten het werkterrein van de wetgever in formele zin valt of in strijd is met een door het parlement aan de regering verstrekte delegatiebevoegdheid tot het uitvaardigen van "ordonnances', dan voorciot art. 41 Grondwot in hotzelfdo rochtsgevolg als art. 40 Grondwot, namelijk de ontoelaatbaarheid van het amendement. De uiteindelijke beslissing wordt genomen door de senaatsvoorzitter. Mocht zijn beslissing niet overeenkomen met de wensen van de regering, dan bekijkt de Conseil Constitutionnel de kwestie in laatste instantie en beslist definitief binnen acht dagen. ${ }^{27}$

Tijdens de eerste drie decennia van het bestaan van de 5e Republiek werd art. 41 van de huidige Franse constitutie niet gehanteerd in de Sénat. Ten gevolge van de verkiezingen van 1986 veranderde dat echter in het kielzog van veranderende partijpolitieke machtsverhouding. Wat was er aan de hand? Na vijf jaar van socialistisch bewind onder Mauroy en Fabius werd in 1986 de centrumrechtse regering Chirac geinstalleerd. Deze regering wilde in samenwerking met centrumrechtse meerderheden in beide parlementskamers snel nieuw beleid in wetgeving gaan omzetten. Deze behoefte aan snelheid vond haar oorzaak in het recente verleden. Vanaf 1981 had Frankrijk namelijk voor de eerste keer onder het regime van de 5e Republiek te maken gekregen met de situatie dat zowel de President als de regering van socialistische huize was. Dit had sterke polarisatie van de politieke verhoudingen tot gevolg gehad. Na de parlementsverkiezingen van 1986 die centrumrechts in de Assembleée nationale weer aan de macht bracht, bleven de verhoudingen tussen de centrumrechtse partijen van de regeringscoalitie enerzijds en de linkse oppositie anderzijds onverminderd sterk gepolariseerd. ${ }^{28}$ Als direct uitvloeisel hiervan ging de oppositie in het kader van het wetgevingstraject gebruik maken van obstructietechnicken. Zo bleek het recht van amendement door de oppositie in de Sénat al snel als zuivere vertragingstechniek gehanteerd te gaan worden. De behandeling van een wet aangaande de vrijheid van meningsuiting in de Sénat bijvoorbeeld werd door de

26. http:/www.senat.fr/presentation/livre $3 /$ livre 3 mono.html. 5-5-2001.

27. Art. 41 lid 2 Constitution 1958.

28. Hierbij speelde onmiskenbaar ook de naderende presidentsverkiezing van 1988 een rol. Zowel de zittende (socialistische) President Mitterand als de Minister-President Chirac (RPR) gooiden namelijk hoge ogen in de polls. 
communistische en socialistische groeperingen aangegrepen om een spervuur aan amendementen te lanceren. ${ }^{29}$ Omdat het onderhavige wetsvoorstel niet onder het (financièle) regime van art 40 Grondwet kón vallen, werd door de voorzitter van het Hogerhuis art. 41 Grondwet onder het stof vandaan gehaald. Het resultaat: zestien amendementen werden, omdat zij niet de vereiste relatie tot het wetsvoorstel bleken te bezitten, niet toelaatbaar geacht. En omdat de regering het uiteraard eens was met deze zestien beslissingen, kon de weg richting Conseil Constitutionnel ook niet bewandeld worden.

Zeven jaar later, in het kader van de herziening van de wet Falloux heeft de constitutionele rechter, ook niet blind voor de consequenties van het gebruik van art. 41 Grondwet, zich uiteindelijk pas uitgelaten over de voorwaarden waaronder hij, in geval van eensgezindheid tussen de kamervoorzitter en de regering, toch genegen is de niet-toclaatbaarheidsuitspraak op zijn merites te beoordelen: "la question de recevabilité ait été soulevée et contastée en seance publique' ${ }^{30}$ Als de niet-toelaatbaarheid opgeworpen én betwist werd in openbare zitting kan de Conseil Constitutionnel naar eigen zeggen dus het laatste woord krijgen.

In dat kader is een nadere verfijning van de niet-toelaatbaarheidsproblematick betreffende amendementen gecodificeerd in art. 45 lid 5 van het Règlement du Sénat interessant: 'Il n'y a pas lieu (...) à débat dans le cas d'une exeption d'irrecevabilité soulevée par le gouvernement s'il lui apparait qu'une proposition ou un amendement n'est pas du domaine de la loi ou est contraire à une délégation accordée en vertu de l'article 38 de la Constitution, l'irrecevabilité étant admise de droit lorsqu'elle est confirmée par le président du Sénat'. De mogelijkheid voor indieners van amendementen, niet afkomstig uit het regeringskamp, om het Conseil Constitutionnel te consulteren over een besluit tot niet toelaatbaarheid ex art. 41 Grondwet lijkt daarmee zo goed als dichtgetimmerd te zijn.

Sinds $1986^{31}$ is het overigens praktijk geworden de niet-toelaatbaarheid van amendementen groepsgewijze te beoordelen. De noodzaak daartoe ontstond nadat een groep communistische senatoren niet minder dan 2832 amendementen meende in te moeten dienen ter obstructie van een wetsvoorstel tot flexibilisering van de werktijden. ${ }^{32}$

\section{3 .1 .1 .3}

- Art 44 lid 2 Constitution 1958: Après l'ouverture du débat, le gouvernement peut s'opposer à

l'examen de tout amendement qui n'a pas été antérieurement soumis à la commission.

Deze grondwettelijke bepaling ter regulering van het gebruik van het amendementsrecht door het Franse Hogerhuis (herhaald in art. 49. lid 5 Règlement du Sénat) hoeft in de praktijk vrijwel nooit ingeroepen te worden door de regering, om de eenvoudige reden dat na de opening van het openbare debat in de Sénat (althans door de oppositie) geen nieuwe amendementen met 'gewicht' meer plegen te worden ingediend. ${ }^{33}$ De verklaring hiervoor gaat schuil in de nadere uitwerking van het grondwetsartikel in het Règlement du Sénat: alle amendementen

29. JO, Sénat, Débats 1986, p.2394, 2509-2510, 2594, 2868 en 2873.

30. Conseil Constitutionnel 13 janvier 1994, nr. 93-329.

31. JO, Sénat, Débats, séance du 31 janvier 1986, p. 216.

32. Zie hierover uitgebreider: J-E. Giquel, La lutte contre l'abus du droit d'amendement au Sénat, Revue du droit public et de la science politique en France et a l'étranger, 1997, p. 1351-1374.

33. In de Assembleé Nationale daarentegen werden tijdens de debatten aangaande de wet Falloux maar liefst 2394 amendementen in één keer terzijde geschoven op basis van art, 44 lid 2 Grondwet (Débats Assembleć Nationale, 27 juin 1993, p. 2637). 
die bespreking vragen in het openbare debat moeten door de commissie die het wetsvoorstel onderzoekt en voorbereidt, bekeken kunnen worden op hun merites voordat de openbare discussie over de individuele wetsartikelen plaats zal vinden. ${ }^{34}$

Het effect van art. 44 lid 2 Grondwet moet dan ook vooral als sterk preventief gezien worden. Oppositionele verrassingsstrategieën 'te-elfder-ure', gebaseerd op het amenderingswapen worden op deze wijze immers uitgesloten.

\section{3 .1 .1 .4}

- Art 44 lid 3 Constitution 1958: 'Si le gotvernement le demande, l'Assemblée saisie se prononce par un seul vote sur tout ou partie du texte en discussion en ne retenant que les amendements proposées ou acceptés par le gouvemement.

Als de regering om haar moverende redenen meent dat behandeling per afzonderlijk artikel van een wetsvoorstel, al dan niet gepaard gaande met de bespreking van ingediende amendementen, vermeden dient te worden, kan zij de zgn. 'vote bloqué' proclameren. Wederom een fraai staaltje wetgevingstechnick dat zo kenmerkend is voor het staatsrechtelijk denken van de grondwetgever van 1958. Activering van art. 44 lid 3 Grondwet dwingt de betreffende parlementskamer te stemmen over (een afgebakend gedeelte van) een wetsvoorstel in de vorm zoals dat gewenst wordt door de regering. Alles of niets, waarbij aangetekend moet worden dat (toch niet onbelangrijk) slechts amendementen die gedeponeerd zijn door de regering wél meegenomen mogen worden. De vertrouwensvraag staat formeel volledig los van dit gebeuren, zodat de regering, indien zij dit opportuun acht, de beide volksvertegenwoordigende wetgevingsorganen eenvoudig 'technisch' buitenspel kan zetten. Anderzijds verdraagt frequent gebruik van dit middel zich natuurlijk slecht met het idee van 'checks and balances'. Art. 44 lid 3 Grondwet is tijdens de eerste 50 jaar van het bestaan van de 5e Republiek in de verhouding regering- Sénat al met al toch vrij regelmatig gehanteerd. Tussen 1958 en juni 2000 in totaal 243 maal. In iets minder dan de helft van deze gevallen (110) werd het regeringsvoorstel vervolgens niet aangenomen. ${ }^{35}$ Handig bleek het middel onder meer zijn, indien oppositionele minderheden in de Sénat aanname van een wettekst zo lang als maar mogelijk wensten te bruuskeren. In 1986 werd met gebruikmaking van de mogelijkheden die art. 44 lid 3 Grondwet bood aan een regering die kon bogen op een solide meerderheid in het Hogerhuis maar liefst 27 maal de techniek van de 'vote bloqué' gehanteerd. Op die wijze werden talloze procedurele moties en ontelbare amendementen afkomstig van (eerst) de communisten en (later) de socialisten in één klap van de tafel geveegd ${ }^{36}$ Ook de socialistisch regeringen Rocard en Cresson maakten met enige regelmaat met succes gebruik van de 'vote bloqué' ter kanalisering van ongewenste bemoeienis met de inhoud van wetsvoorstellen van de kant van de centrumrechts georiënteerde Sénat.

\subsubsection{Niet grondwettelijke inperkingrechten}

In de reglementen van orde van de Franse parlementskamers zijn in de vorm van een nadere uitwerking van de reeds besproken grondwetsartikelen gedetailleerde procedureregels opge-

34. Art 20 lid 1 bis Règlement du Sènat.

35. http://www.senat.fr/presentation/livre3/livre3_mono.html. 7-5-2001. In veruit de meeste gevallen (79x) dat de stemming negatief uit viel voor de regering, gebeurde dit in de periode De Gaulle, vóor 1969.

36. Zie o.a.: J-E. Giquel, le Sénat sous la seconde cohabitation, Revue du Droit Public et de la Science Politique en France et a l'étranger 1996, p. 1091 c.v; A. Tardan, le rôle législatif du Sénat, Pouvoirs 1988, p. 98-109. 
nomen betreffende de volgorde en de vorm waarin bespreking van rechtsvragen, overige vragen, amendementen, moties e.d. plaats moet vinden. Vanaf het moment dat de (aan preventief toezicht van de Conseil Constitutionnel onderworpen) reglementen rechtskracht hebben, vormen zij in feite de belangrijkste regulerende bron van het wetgevingsproces. Ook een aantal van déze regels, voor de Sénat gecodificeerd in art. 44 Règlement du Sénat (hier te noemen: RdS), werpen een interessant licht op de wijze waarop het Franse wetgevingsproces vorm pleegt te krijgen.

\subsection{L'exception d'irrecevabilité}

Indien (de redactie van) een wetsvoorstel, dan wel een gedeelte van een dergelijk voorstel volgens een meerderheid van een der parlementskamers dan wel volgens de regering in strijd lijkt te zijn met de grondwet dan wel in tegenspraak lijkt te zijn met een organicke wet of verdrag, kan de wetgevingsprocedure in de betreffende parlementskamer stopgezet worden. ${ }^{37}$ Door zowel de Assembleé Nationale als de Sénat kan een rechtsvraag, gebaseerd op voornoemde strijdigheid per openbaar debat slechts één maal opgeworpen worden. Voornoemde beperking geldt niet voor de regering, noch voor de commissie die het wetsvoorstel behandelt. De wijze waarop de te volgen procedure verder is uitgewerkt, verschilt per parlementskamer op een wijze die duidelijk enig licht laat schijnen op de onderlinge 'bicamerale' verhouding. In de Assemblée nationale moet de 'exception d'irrecevabilité' ex art. 44 lid 2 RdS opgeworpen worden vóór aanvang van de algemene discussie over het betreffende wetsontwerp en kan slechts het voorstel in zijn geheel betreffen. Dat maakt het middel bijzonder zwaar. In het Hogerhuis komt de vraag naar de toelaatbaarheid pas aan de orde na afloop van het debat over de grote lijnen van het wetsontwerp. Daar komt bij dat de 'irrecevabilité' in de Sénat slechts amendementen mag betreffen dan wel de plaats die tekstgedeelten in het wetsvoorstel toebedeeld hebben gekregen.

Het moge duidelijk zijn dat de mogelijkheid tot het opwerpen van de 'exception' in de Assembleé Nationale een ander doel dient, dan in de Sénat. Terwijl in het Lagerhuis de toekomst van het wetsvoorstel in zijn geheel zeer wel in het geding kan zijn, lijkt aanwending van art. 44 lid 2 RdS in het Hogerhuis toch eerst en vooral het bijschaven van details te betreffen. ${ }^{38}$

Overigens kan, niet in de laatste plaats omdat de regering op ieder gewenst moment tijdens de plenaire behandeling van een wetsvoorstel art. 44 lid 2 kan activeren, ook de 'exception d'irrecevabilité' een zeer praktisch wapen zijn tegen de regering onwelgevallig gebruik van het recht van amendement door oppositionele groeperingen. In 1986 werd zo voor het eerst een grote groep min of meer samenhangende amendementen op voorspraak van de regering 'onconstitutioneel' verklaard door de Sénat. ${ }^{39}$

Om het beeld betreffende de direct op inperking van het recht van amendement toegesneden wettelijke mogelijkheden compleet te maken, dient tenslotte nog gewezen te worden op art. 48 lid $3 \mathrm{RdS}$ : amendementen die op geen enkele wijze in verband staan met de behandelde wettekst kunnen eveneens getroffen worden door de 'irrecevabilité'. Het praktisch belang van dit artikel is, in de schaduw van art. 44 lid 2 RdS altijd zeer gering gebleven. ${ }^{40}$

37. Art. 44 , lid 2 du Règlement du Sénat.

38. J-E, Giquel, 1997, a.w., p. 1357 e.v.

39. Het betrof een pakket van 44 amendementen ter obstructie van wetgevingsvoorstellen op het terrein van een werktijdenregeling. De actie werd ondernomen door de communistische oppositie.

40. J-E. Gicquel, 1997, a.w., p.1361. 


\subsubsection{De praktijk}

Het recht van amendement is in de Franse wetgevingsconstellatie blijkbaar een belangrijk politiek strijdmiddel, zo veel is inmiddels al wel duidelijk geworden. Maar het is ook in Frankrijk uiteraard meer dan dat. Het recht van amendement is in feite de juridische vlag voor zowel de onderhandeling als de ontkenning, de correctie, de precisering, de verbetering en de vernieuwing. Hoe gepolariseerd de verhoudingen in de Franse politiek soms ook kunnen zijn, vele amendementen afkomstig uit het Franse Hogerhuis blijken ook dan invloed uit te oefenen op vorm en inhoud van het eindproduct. ${ }^{41}$

Tabel 5.1

\begin{tabular}{|c|c|c|c|}
\hline & $\begin{array}{l}\text { In de Sénat ingediende } \\
\text { amendementen }\end{array}$ & $\begin{array}{l}\text { In de Sénat aangenomen } \\
\text { amendementen }\end{array}$ & $\begin{array}{l}\text { Amendementen van de } \\
\text { Sénat verwerkt in de } \\
\text { definitieve wettekst }\end{array}$ \\
\hline 1981 & 2692 & 887 & 300 \\
\hline 1982 & 4857 & 2525 & 1070 \\
\hline 1983 & 4403 & 2680 & 1138 \\
\hline 1984 & 4752 & 2647 & 1367 \\
\hline 1985 & 4180 & 2551 & 1273 \\
\hline 1986 & 8553 & 905 & 740 \\
\hline 1987 & 4478 & 1222 & 1064 \\
\hline 1988 & 1991 & 826 & 470 \\
\hline 1989 & 4025 & 1987 & 1174 \\
\hline 1990 & 6129 & 1911 & 1155 \\
\hline 1991 & 4736 & 2617 & 1289 \\
\hline 1992 & 5232 & 3316 & 1732 \\
\hline 1993 & 7806 & 1519 & 1331 \\
\hline 1994 & 6913 & 2733 & 2349 \\
\hline 1995 & 6926 & 1968 & 1635 \\
\hline 1996 & 3350 & 1286 & 933 \\
\hline 1997 & 3153 & 1719 & 705 \\
\hline 1998 & 4740 & 2809 & 1390 \\
\hline 1999 & 5556 & 3131 & 1346 \\
\hline
\end{tabular}

Bron: http://www.senat.fir/presentation/ivre3/livre 3 mono.html, 29 ktober 2001

De gegevens in tabel 5.1 maken inderdaad duidelijk dat de Sénat via het recht van amendement voortdurend een zekere rol blijft spelen in het wetgevingsproces. En dat ongeacht de politieke kleur van de regering van de dag. Immers zelf tijdens het eerste jaar dat de regeringen Mauroy (1981-1982) en Rocard (1988-1989) in functie waren, jaren dat polarisatie de verhouding tussen (centrumrechtse) Sénat en de regering sterk bepaalde, vonden toch nog altijd meerdere honderden wetswijzigingvoorstellen hun weg naar de definitieve teksten. Voor de verklaring van het beperkt aantal amendementen in 1986 verwijs ik naar par. 5.3.2.2.

41. J. Mastias, A Problem of Identity; The French Sénat, in: S.C. Patterson and A. Mughan, Senates, Bicameralism in the Contemporary World, Ohio State University Press 1999, p. 177. 
Manipuleren van het recht van amendement door met name de regering gebeurt overigens allerminst uitsluitend via gebnuikmaking van de hierboven beschreven wetsartikelen. De Grondwetgever van 1958 had nog meer in petto.

\subsubsection{La question préalable}

Indien door een der parlementskamers voorafgaande aan de plenaire behandeling van een wetsvoorstel de formele vraag naar de opportuniteit van de betreffende tekst wordt gesteld, kan de Sénat (of de Assembleé) besluiten af te zien van beraadslaging ${ }^{42}$

Omdat het 'sec' verwerpen van een (in veruit de meeste gevallen door de regering geìnitieerd) wetsvoorstel zonder enige vorm van debat, toch beschouwd wordt als een vrij rigide wapen in handen van de Sénat, is het gebruik ervan middels het reglement van orde sinds 1991 stevig gereguleerd. Voordien, en dan met name tijdens de periode 1981-1986, maakte de 'oppositionele' meerderheid in de Sénat zeer regelmatig gebruik van de 'question préalable' om regeringsvoorstellen om puur partijpolitieke overwegingen onbesproken weg te stemmen. In die tijd moest een centrumrechtse senaat immers opboksen tegen een President, een regering én een Assembleé die hun wetgevend handelen pleegden te baseren op het socialistisch gedachtegoed. Het (via gebruikmaking van de 'question préalable') weigeren om in 1981 mee te werken aan wetgeving die nationalisatie van bedrijven mogelijk maakte, moge hier tot kenmerkend voorbeeld dienen. Tijdens de periode 1981-1986 werd de 'question préalable' 65 maal ingeroepen, tegen slechts 36 maal in de 15 jaar daaraan voorafgaande. De Franse 'Chambre de réflexion' werd in die jaren door zowel de Franse regering als de socialistische meerderheid in de Assemblée nationale regelmatig getypeerd als 'Chambre de demolition'. ${ }^{43}$

In 1991 is de regeling rondom hantering van de 'question préalable' in die zin aangepast dat vanaf het moment dat de regering en de rapporteur van de senaatscommissie die het wetsvoorstel aan een vooronderzoek onderworpen heeft, door de Sénat gehoord zijn, nog slechts de betreffende commissie en de regering (vgl. art. 44 lid 2 RdS) de 'vraag' mogen opwerpen. $^{44}$ Ten gevolge van voornoemde regeling liggen partijpolitieke motieven nu veel minder vaak ten grondslag aan het inroepen van art. 44 lid 3 RdS door leden van het Franse Hogerhuis. De vaste kamercommissie immers die het wetsvoorstel in vooronderzoek heeft gehad, ervaart uit dien hoofde al snel een grotere verwantschap met het onderwerp dan de Sénat in zijn geheel. Om nog maar te zwijgen van oppositionele minderheden uit de senaatkamer.

Door de Franse senaatkamer wordt wel nog steeds met enige regelmaat gebruik gemaakt van de regeling ex art. 44 lid $3 \mathrm{RdS}$, indien tijdsdruk tegen het einde van de jaarlijkse reguliere wetgevingssessie als het ware dwingt wetsvoorstellen aan te nemen zonder tijd tot serieus onderzoek, discussie en debat gehad te hebben. Een problematiek die ook de leden van de Nederlandse Eerste Kamer en het Britse House of Lords bijzonder bekend voor zal komen. Illustratief voor de gang van zaken in Frankrijk was bijvoorbeeld een reeds door de Assembleé nationale aanvaard wetsvoorstel tot instelling van een nieuw overheidsorgaan. ${ }^{45}$ Twee dagen voor het einde van de najaarssessie van 1972 werd dit voorstel ingeschreven bij het Bureau van de Franse senaat, waarmee impliciet de veronderstelling werd uitgesproken dat

42. Art. 44 lid 3 Règlement du Sénat.

43. J. Mastias et J. Grangé, a.w., p. 226.

44. Art. 44 lid 3 Règlement du Sénat (na aanpassing ten gevolge van de resolutie van 18-12-1991).

45. Het betrof een 'Conseil supérieur de l'information sexuelle, de la regulation des naissances et de l'éducation familiale'. 
commissiconderzoek door het Franse Hogerhuis en plenaire behandeling inclusief eventuele amendering binnen die twee dagen plaats zou kunnen vinden. Via het stellen van de 'question préalable' werd de regering vervolgens 'verzocht' om het voorstel tijdens de voorjaarssessie van 1973 opnieuw op de agenda te laten plaatsen.

\subsubsection{La question préalable positive}

In art. 44 lid $3 \mathrm{RdS}$ gaat trouwens een interessant en bijzonder karakteristiek gevolg van de wijze waarop het wetgevingsproces in Frankrijk is ingericht, schuil. Een verwerping van een wetsvoorstel via opwerpen van de vraag naar de opportuniteit betekent namelijk lang niet altijd automatisch het einde van de lopende wetgevingsprocedure. In tegendeel; de procedure kan zelfs behoorlijk versneld worden indien het Hogerhuis de 'question préalable' stelt.

In 1986 wijzigde de politieke situatie, zoals gezegd, drastisch voor de Franse senaat. Reguliere parlementsverkiezingen die dat jaar plaatsvonden, zorgden ervoor dat er een centrumrechtse regering geinstalleerd werd die kon steunen op een riante meerderheid in zowel de Assembleé als de Sénat. De socialistische President van de Republiek Mitterand kwam zodoende in een politiek isolement terecht. In een aantal gevallen weigerde hij hem onwelgevallige regeringsvoorstellen die het gehele wetgevingstraject met vnucht hadden doorlopen van zijn noodzakelijke handtekening te voorzien. ${ }^{46}$ De meerderheid van het parlement van 'naar kam wenste eensgezind en 'oijzond̊er voortvarend samen te werken mea de regering. Om ook snel en daadkrachtig te kúnnen werken aan de totstandkoming van niet-socialistische regelgeving (in casu de privatisering van genationaliseerde bedrijven) ging de Sénat de zgn. 'question préalable positive' hanteren: het onderhavige (door Mitterand niet gewenste) wetsvoorstel werd na (verplichte hernieuwde) inschrijving, in het Palais de Luxembourg zo snel mogelijk verworpen, met het expliciete doel de regering ter wille te zijn. Deze op haar beurt hanteerde dan de mogelijkheid om via de 'urgence' ex art. 45 lid 2 Grondwet en daaropvolgende bijeenroeping van een Commission Mixte Paritair (zie par. 5.3.5.1) het wetgevingstraject in een stroomversnelling te brengen. De uitkomst van het beraad in de Commission Mixte Paritaire, waarbij slechts amendementen afkomstig van de regering meegenomen mochten worden, ${ }^{47}$ werd ten spoedigste ter goedkeuring voorgelegd aan welwillende kamermeerderheden in zowel Lager- als Hogerhuis, waarna afkondiging kon volgen zonder formele instemming van de President. ${ }^{48}$

De oppositie in de Sénat heeft indien deze procedure gevolg wordt, geen enkele reële mogelijkheid gehad om invloed uit te oefenen op de kwaliteit van het wetgevingsproduct. Dat de 'question préalable positive' met name in 1986 frequent gesteld is, komt ook duidelijk tot uiting in tabel 5.1. Het verklaart hoe de bulk van de ruim 8500 amendementen die tijdens de commissiefases in de Sénat tijdens dat parlementaire jaar ingediend waren, geruisloos in de prullenbak kon verdwijnen.

46. Een mogelijkheid die hem grondwettelijk toekomt op grond van art. 10 lid 2 Constitution 1958: binnen veertien dagen nadat wetgevingsvoorstellen door beide parlementskamers definitief aangenomen zijn, kan de President eisen dat de gehele wet (of gedeelten daaruit) opnieuw door de Assemblée nationale en de Senat bekeken wordt.

47. Art. 45 lid 3 Constitution 1958.

48. Dat een dergelijke procedure erg snel kan gaan, werd aangetoond in 1986. Mitterand weigerde op 16 juli 'le projet d'ordonnances relatif aux privatisations' te ondertekenen. Desondanks kon de wet minder dan een maand later (6 augustus 1986) toch afgekondigd worden. 
Interessant en tevens illustratief voor de mogelijkheden van de politieke machtshebbers om het wetgevingsproces te plooien, was een geval van hantering van de 'question préalable positive' door de Sénat uit 1995. In dit geval was versnelling van het wetgevingstraject via een uitschakeling van oppositionele krachten binnen de parlementskamer wederom het vooropgezette doel. Hervorming van het stelsel van sociale zekerheden door de centrumrechtse regering stuitte (vanzelfsprekend) op massale protesten bij de socialisten en communisten uit beide parlementskamers. Voor de eerste lezing van het wetsvoorstel in de Assemblée Nationale betekende dat 17 weken van debat en het verwerken van ruim 3000 amendementen. De (in meerderheid regeringsgezinde) Sénat wilde een dergelijk scenario in het Palais de Luxembourg zien te vermijden. De uitkomsten van een snelle voorstudie leerde dat ongeveer de helft van de ingediende amendementen via een combinatie van de artikelen 40 en 41 Grondwet alsmede art. 44 lid 2 RdS uitgefilterd zou kunnen worden. Aangezien dat resultaat niet bevredigend genoeg werd bevonden, besloot de permanente centrumrechtse meerderheid van de Sénat iedere vorm van verdere discussie over zowel het ontwerp als geheel, als de door de Assemblée Nationale ingediende amendementen af te kappen via gebruikmaking van art. 44 lid 3 RdS. Bezien vanuit de idee van het op art. 24 Grondwet gegrondveste bicameralisme als een der bouwstenen voor de balans van Franse parlementaire stelsel, een opmerkelijke stap.

De Conseil Constitutionnel heeft een dergelijke gang van zaken rondom het hanteren van de

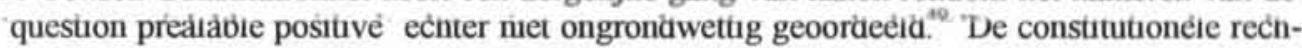
ters maakten dat duidelijk in een beslissing over de toelaatbaarheid van wijzigingen in de omvang van kiesdistricten (ten behoeve van verkiezing voor de Assemblée nationale). De toelaatbaarheid van de 'question préalable positive wordt beoordeeld in samenhang met het gegeven dat de drang tot het deponeren van wetswijzigingvoorstellen door de politieke oppositie in de Sénat in voorkomende gevallen omschreven kan worden als: "usage manifestement excessif du droit d'amendement'. ${ }^{\text {so }}$

\subsubsection{Vaststelling van de agenda}

Art. 48 lid I Constitution 1958: L'ordre du jour des Assemblées comporte, par priorité et dans l'ordre que le gouvernement a fixé, la discussion des projets de loi déposés par le gouvernement et des propositions de loi acceptées par lui.

Une séance par semaine est réservé par priorité aux questions des membres du Parlement et aux réponses du gouvemement'.

In tegenstelling tot hetgeen gebruikelijk is in de andere onderzoekslanden wordt de agenda van de Sénat in materiële zin niet opgesteld door de voorzitter van het Hogerhuis, doch door de regering. Zij bepaalt vrijwel volledig inhoud en volgorde van de te behandelen wetsontwerpen. De Fransen noemen dat 'l'ordre du jour prioritaire'. Daarnaast bestaat formeel ook nog een 'ordre du jour complémentaire', maar de praktijk wijst uit (zoals in het vervolg duidelijk zal worden) dat voor complementaire zaken nauwelijks ruimte overblijft op de senaatsagenda. $^{51}$

Het politieke gewicht dat het recht tot opstelling van de agenda in zich draagt, is in de Franse parlementaire constellatie nauwelijks te overschatten. Het failliet van de $3 \mathrm{e}$ en $4 \mathrm{e}$ Republiek

49. Conseil Constitutionnel, décision du 18 novembre 1986 .

50. J-E. Gicquel, 1997, a.w., p. 1369.

51. Pour mieux connaitre le Sénat, http://www.senat.fr/presentation/livre2/livre2_mono.html. 18-07-2000. 
hing gedeeltelijk samen met gegeven dat het parlement de eigen agenda kon samenstellen. ${ }^{52}$ De regie van het politieke spel, hetgeen het wetgevingsproces nu eenmaal per definitie is, valt sinds 1958 echter (vooral dankzij het gegeven dat de parlementaire agenda door de regering wordt samengesteld) onmiskenbaar toe aan de 'uitvoerende' macht.

De wijze waarop uitvoering kan worden gegeven aan dat recht, lijkt weinig ruimte tot manoeuvreren meer over te laten aan de volksvertegenwoordiging:

De regering bepaalt bij voorrang welke wetsvoorstellen in welke volgorde behandeld zullen worden door de Sénat. Het betreft hier zowel de regeringsvoorstellen als eventuele initiatiefvoorstellen vanuit de beide parlementskamers, inclusief amendementen en sous-amendementen $^{53}$ Wenst de Sénat te intervenièren betreffende een (actueel) onderwerp vreemd aan de orde van de dag, dan is dat onmogelijk zonder voorafgaande goedkeuring door de regering. Hetzelfde geldt indien de leden van het Franse Hogerhuis de volgorde van bespreking van artikelen, amendementen e.d. zouden willen aanpassen. ${ }^{54}$ Mocht de regering van haar kant echter, om haar moverende redenen besluiten de agenda aan te willen passen, dan volstaat een eenvoudige verklaring van die strekking, afgegeven door een lid van de regering. 'Du moment' wordt het onderwerp van onderzoek en/of debat dan gewijzigd. Doordat de regering de voortgang van het parlementaire werk zo strak kan regisseren, is zij natuurlijk goed in staat om de 'navette' (zie par. 5.3.5.1) en indien nodig de Commission Mixte Paritaire efficiěnt in stelling te brengen.

Kan de Sénat dan op geen enkele wijze meer substantiële invloed uitoefenen op de voortgang van de eigen werkzaamheden? Afgaande op de volgorde waarin het parlementaire wetgevingswerk zich dient te voltrekken lijkt die conclusie inderdaad gerechtvaardigd. Indien de prioriteitenagenda het toe laat, is het weliswaar denkbaar dat via de 'Ordre du Jour Complémentaire' een of meerdere initiatiefvoorstellen besproken kunnen worden, doch ook dat gebeurt in de praktijk slechts onder regie van een (welwillende) regering. 55

Betreffende de voortgang van het openbare debat beschikt het Hogerhuis echter via (onder meer) art. 32 lid 2 RdS ondanks alles toch nog over enige eigen (Frans-parlementaristische) inbreng: 'Le Sénat se réunit en séance publique en principe les mardi, jeudi et vendredi de chacque semaine'. En vervolgens in art, 32 lid $4 \mathrm{RdS}$; 'En outre, le Sénat peut décider de tenir d'autres séances à la demande de son président, le gouvernement (...)'. Onder omstandigheden kan het Franse Hogerhuis dus toch de beschikking krijgen over een bescheiden zweem aan discretionaire bevoegdheid ten opzichte van de regering waar de voortgang van de eigen legislatieve werkzaamheden in het geding is.

Ook art. 48 lid 2 Constutution 1958 biedt nog beperkte mogelijkheden voor de Franse senaatskamer, waar het de tijdsbesteding betreft. Een dag per week (de vrijdag) wordt in principe gereserveerd voor het stellen en beantwoorden van kamervragen. Mocht er tijd over zijn, dan kán die anderszins ingevuld worden. Die invulling kan echter, anders dan bij 'l'ordre du jour prionitaire', niet door de regering ingevuld worden zonder voorafgaand inhoudelijk overleg met de Sćnat.

52. F. Goguel, Du Sénat de la IIIe à celui de la Ve, Pouvoirs 1988, p. 5-14.

53. Zie ook Art. 29 lid 3 Règlement du Sénat.

54. Art. 29 lid 5 Règlement du Sénat.

55. De regeringsleider kan het van belang achten (Raymond Barre bijvoorbeeld in 1993) om de banden met de Sénat nader aan te halen. Toelating van senaatsinitiatieven via de 'ordre du jour complémentaire' is daartoe een probaat middel. 
De praktijk heeft inmiddels nimschoots uitgewezen dat de voortgang van de parlementaire wetgevingswerkzaamheden onder het regime van de 5e Republiek allerminst als een statisch gegeven te beschouwen is. Afhankelijk van de politieke kleur van de regering en de meerderheid van het Assemblée nationale worden de beschikbare procedurele vertragingstechnicken met meer of minder passie door de Sénat in zijn geheel, dan wel oppositionele minderheden daanuit gehanteend. Niet alleen wordt dan gestreden over het aantal vergaderdagen per week en de invulling van de vrijdag, voorzover deze niet ingevuld wordt met kamervragen. Ook wordt dan gebruik gemaakt van ieder denkbaar procedureregeltje dat het tempo waarin de werkzaamheden hun beslag krijgen, kan beìnvloeden. ${ }^{56}$ In vertragende zin 0. a. interventies ex art. 36 lid 2 RdS (maximaal toegestane tijdsduur 45 minuten per senator), internumperen ex art. 36 lid 1 RdS (maximaal toegestane tijdsduur 2 minuten per senator) en het afgeven van stemverklaringen ex art. 42 lid $8 \mathrm{RdS}$ (maximaal toegestane tijdsduur 5 minuten per senator). In versnellende zin (en buitengewoon exemplarisch voor de praktische visie van de grondwetgever aangaande de gewenste werking van het Franse parlementaire recht onder het regime van de 5e Republiek) vooral art. $38 \mathrm{RdS}$ : indien op zijn minst twee senatoren met tegengestelde opinies betreffende het onderwerp (amendement, artikel of zelfs de volledige tekst) van bespreking hun zegje hebben kunnen doen, kán de voorzitter van de Sénat besluiten de beraadslagingen af te sluiten. Er is dan nog slechts nimte voor één spreker per politieke groepering om een stemverklaring van maximaal vijf minuten af te leggen, waarna definitieve afsluiting van het openbare debat volgt. Deze regeling, die het parlementaire debat over wetsvoorstellen (zij het met medewerking van de kamervoorzitter) welhaast kan laten verworden tot een technisch een-tweetje, is in het reglement van orde van het Franse Hogerhuis terecht gekomen naar aanleiding van de debatten over een nieuw werktijdenbesluit medio 1986. De Sénat, die in meerderheid gekant was tegen deze voorstellen, hanteerde ieder denkbaar procedureregeltje om de zaak te traineren tot het einde van de lopende zittingsperiode. Vierhonderd amendementen werden daartoe ingediend. Iedere senator die oppositie wenste te voeren tegen het voorstel voerde het woord, zowel aangaande de amendementen als over het voorstel in zijn geheel. Er werd gedelibereerd over het quorum, de agenda, de procedure. Het debat sleepte zich op die wijze ruim 70 klokuren voort, zonder dat inhoudelijk in feite nog iets toegevoegd of afgedaan werd aan het voorliggende wetsvoorstel. ${ }^{57}$ Praktijken die sterk herinnerden aan de hoogtijdagen van het parlementarisme onder het regime van de $3 \mathrm{e}$ en $4 \mathrm{e}$ Republiek, maar vanaf 1986 dus eenvoudig vermeden kunnen worden via hantering van art. 38 RdS.

\subsubsection{Recht van initiatief}

In het fenomeen van de 'ordre du jour complémentaire' zit meestal ${ }^{58}$ het Franse parlementaire recht van initiatief opgeborgen. Deze agenda wordt vastgesteld door 'La Conférence des présidents', een gezelschap dat regelmatig bijeenkomt en bestaat uit de voorzitter en vicevoorzitter van de Sénat, de fractievoorzitters van de politieke partijen en de voorzitters van de

56. Zie onder andere: J. Mastias, Histoire des tentations du Sénat de la Ve République, Pouvoirs 1988, p. 15-34; J-C. Bécane, Le Règlement du Sénat à la recherche du temps maîtrisé, Pouvoirs 1988, p. 79-96.

57. J. Mastias, Histoire des tentations du Sénat de la Ve République, a.w., p. 29.

58. Het komt overigens ook wel voor dat de regering dusdanig geporteerd is van een initiatiefwetsvoorstel dat zij hiervoor plaats inruimt op de 'ordere du jour prioritaire'. 
vaste kamercommissies. Vergaderingen van deze 'conférence' plegen tevens bijgewoond te worden door een lid van de regering. Dit laatste gegeven is niet onbelangrijk. Immers zeker in perioden van politieke détente tussen regering en Hogerhuis kan uitwisseling van prioritaire regeringsverlangens en complémentaire senaatsverlangens vnuchtbaar blijken te zijn. Soepele afhandeling van de 'projets de loi' kan nuimte doen ontstaan voor 'propositions de loi'.

Tabel 5.2

\begin{tabular}{|c|c|c|c|c|}
\hline Jaar & $\begin{array}{l}\text { Proposition de } \\
\text { loi ingediend } \\
\text { door de } \\
\text { Assemblée }\end{array}$ & $\begin{array}{l}\text { Proposition de } \\
\text { loi ingediend } \\
\text { door de Sénat }\end{array}$ & $\begin{array}{l}\text { Proposition de } \\
\text { loi van de } \\
\text { Assemblée tot } \\
\text { wet verheven }\end{array}$ & $\begin{array}{l}\text { Proposition de } \\
\text { loi van de Sénat } \\
\text { tot wet } \\
\text { verheven }\end{array}$ \\
\hline 1981-1982 & 412 & 136 & 1 & $1(0.7 \%)$ \\
\hline $1982-1983$ & 147 & 107 & 4 & $4(3.7 \%)$ \\
\hline $1983-1984$ & 82 & 76 & 3 & $2(2.6 \%)$ \\
\hline 1984-1985 & 99 & 76 & 5 & $3(3.9 \%)$ \\
\hline $1985-1986$ & 142 & 89 & 2 & $0 \quad(0 \%)$ \\
\hline 1986-1987 & 362 & 153 & 4 & $4(2.6 \%)$ \\
\hline $1987-1988$ & 272 & 108 & 18 & $9(8.3 \%)$ \\
\hline 1988-1989 & 366 & 126 & 2 & $1(0.8 \%)$ \\
\hline $1989-1990$ & 197 & 83 & 5 & $2(2.4 \%)$ \\
\hline 1990-1991 & 202 & 84 & 9 & $3(3.5 \%)$ \\
\hline $1991-1992$ & 176 & 97 & 4 & $4(4.1 \%)$ \\
\hline $1992-1993$ & 194 & 57 & 3 & $1(1.7 \%)$ \\
\hline $1993-1994$ & 516 & 129 & 3 & $6(4.6 \%)$ \\
\hline 1994-1995 & 390 & 98 & 10 & $3(3.1 \%)$ \\
\hline 1995-1996 & 442 & 80 & 11 & $4(5.0 \%)$ \\
\hline 1996-1997 & 317 & 91 & 8 & $4(4.3 \%)$ \\
\hline $1997-1998$ & 329 & 107 & 10 & $6(5.6 \%)$ \\
\hline 1998-1999 & 432 & 99 & 9 & $2(2.0 \%)$ \\
\hline $1999-2000$ & 398 & 111 & 12 & $5(4.5 \%)$ \\
\hline $1981-2000$ & $5475(100 \%)$ & $1907(100 \%)$ & $123(2.2 \%)$ & $64(3.3 \%)$ \\
\hline
\end{tabular}

Bron: http:/www.senat,fripresentation/ivre2/ivre227.html, 23-6-2001.

Een sprekend voorbeeld van de gevolgen die politieke détente tussen regering en parlement kan hebben voor de verwezenlijking van initiatiefwetsvoorstellen, bood vooral het jaar 1987. $\mathrm{Na}$ vijf jaar oppositie vanuit het Hogerhuis tegen het beleid van een socialistische regering. trad, zoals reeds eerder gememoreerd, medio 1986 een geestverwante centrumrechtse regering aan die de contacten met de Sénat sterk aanhaalde. Het resultaat: nuim acht procent van het totale aantal door senatoren ingediende initiatiefwetsvoorstellen haalde het staatsblad. ${ }^{59}$ Een aantal dat onder het regime van de 5e Republick tot op heden nooit meer geëvenaard werd.

59. De presidentsverkiezingen van 1988 en de daarmee wederom gepaardgaande wijzigingen in de electorale verhoudingen waren debet aan het gegeven dat deze kwantitatieve verbetering beperkt bleef tot dat ene parlementaire jaar. 
Over de gehele periode blijkt slechts nuim drie procent van de initiatiefwetsvoorstellen ingediend door de Sénat uiteindelijk de eindstreep te halen. Kwantitatief is de status van het recht van initiatief van het Franse Hogerhuis dan ook weinig indrukwekkend te noemen. Beperkingen die de implementatie van dit recht aan banden leggen spelen hierbij vanzelfsprekend een rol, de logistieke plaats op de politieke agenda van de 'ordre du jour complémentaire' voorop. Verder is daar wederom art. 40 Grondwet, waarin bepaald wordt dat initiatiefwetsvoorstellen niet toelaatbaar zijn indien hun aanvaarding een vermindering van publieke middelen en/of een verzwaring van publieke lasten tot gevolg heeft.

Schaart de regering zich niet volledig achter een initiatiefwetsvoorstel, dan is de kans op uiteindelijk succes in feite erg klein. Probaat middel in dat kader blijkt de simpele regeringsweigering om een door de Sénat aangenomen initiatiefwetsvoorstel in te laten schrijven in de agenda van de Assemblée Nationale.

\subsubsection{Conflictenregeling}

\subsubsection{Commission Mixte Paritaire}

Art. 45 lid 2 Constitution 1958: Tout projet ou propasition de loi est examiné successivement dans les deux Assemblées du Parlement en vue de l'adoption d'un texte identique.

Als hoofdregel kan een niet-onaanzienlijk aantal belangrijke voorstellen tot wetgeving in formele zin het Franse staatsblad niet bereiken, indien niet beide parlementskamers in meerderheid hun fiat hebben gegeven aan de tekst in de definitieve vorm. Omdat beide parlementkamers beschikken over het recht van amendement en daarvan ook op grote schaal gebruik plegen te maken ${ }^{61}$, kan dit in theorie eindeloos pendelen van controversiële wetsteksten tussen Assemblée Nationale en Sénat tot gevolg hebben. Geheel in de geest van de Grondwet van 1958 is ook deze mogelijkheid tot het politiek opportuun exploreren van parlementaire rechten door de parlementskamers (als bijvoorbeeld vertragingstechniek) sterk gereguleerd. Het 'bicameralisme parfait', gestoeld op de gedachte dat een tweekamerstelsel alleen dan optimaal kan functioneren, indien de rechten van beide kamers op het terrein van wetgevingsvoorbereiding identiek zijn, is met de teloorgang van de $4 \mathrm{e}$ Republiek eenvoudigweg afgezworen. $^{62}$

Ieder wetgevingsvoorstel dat geïnitieerd is vanuit de regering ${ }^{63}$, wordt na (al dan niet geamendeerde) aanname van de tekst door de Sénat, door de voorzitter niet, zoals te doen gebruikelijk tijdens het regime van de 4e Republiek, naar de Assemblée nationale (terug) gestuurd, doch gaat daarentegen 'sans délai' richting regering ${ }^{64}$ De Premier ministre verzorgt vervolgens de wetteksttransmissie richting Lagerhuis. Een verplichting vanuit de regering tot verzending van het betreffende wetsvoorstel naar de Assemblée Nationale bestaat echter niet, zodat een 'projet de loi' relatief eenvoudig ergens 'tussen' beide parlementskamers kan sneuvelen, althans van regeringswege. Dit laatste gebeurt overigens zelden. Niet alleen is het immers zo, dat de regering via 'l'ordre du jour' al een essentiële stem heeft in de voortgangsmogelijk-

60. Pour mieux connaitre le Sénat, http://www.senat.fr/presentation/livre3/livre3 mono.html.

61. Vanaf 1981 werden door de Sénat in het kader van het wetgevingstraject gemiddeld meer dan 4000 amendementen per jaar gedeponeerd.

62. Zie daartoe uitgebreid: F. Luchaire e.a., La constitution de la république française, Paris 1987, p. 888 e, v.

63. Ook in Frankrijk meer dan $90 \%$ van alle wetgevingsvoorstellen die het stadium van openbare pariementaire behandeling bereiken.

64. Art. 65 lid 1 Règlement du Sénat. 
heden van wetsvoorstellen; ook na aanname door beide parlementkamers van een 'projet de loi' is intrekking daarvan door de regering juridisch immers nog altijd mogelijk.

Art. 42 al. 2 Constitution 1958 bepaalt vervolgens dat de ene parlementskamer het wetsvoorstel zoals aangenomen door de andere parlementkamer tot uitgangspunt moet nemen voor de verdere behandeling c.q. amendering. Indien een der beide Franse parlementskamers van mening zou zijn dat het betreffende wetsvoorstel nog nadere modificaties behoeft en een in die geest nader geamendeerde tekst aanneemt, zal uiteindelijk via de 'navette' gestreefd moeten worden naar een volledig sluitend politiek-juridisch compromis. De reglementen van beide parlementskamers voorzien in een stroomlijning van de discussies rondom de overblijvende strijdpunten ${ }^{65}$ Vooral indien die strijdpunten politiek van aard blijken te zijn, is het zeker niet onmogelijk, zelfs allerminst onwaarschijnlijk, dat via de 'navette' geen oplossing voorgedragen zal worden. In dat geval, ó indien de regering meent dat 'spoed' vereist is, kan de Premier besluiten een 'Commission Mixte Paritaire' samen te laten stellen.

Art. 45 lid 2 Constitution 1958:Lorsque, par suite d'un désaccond entre les deux assemblées, un projet ou une proposition de loi n'a pu ètre adopté apnés deux lectures par chaque assemblée ou, si le gouvernement a déclaré l'urgence, après une seule lecture par chacune d'entre elles, le premier ministre a la faculté de provoquer la réunion d'une commission mixte paritaire changée de proposer un texte sur les dispositions restant en discussion.

'Urgence' is hier een procedurele juridische term: '(...) ou si le gouvernement a déclaré l'urgence (...)', voorziet namelijk (onder andere) in de mogelijkheid voor de regering, bij monde van de Premier ministre, bijeenroeping van een Commission Mixte Paritaire te versnellen. Daarvoor is slechts vereist dat de eerste lezing van een wetsvoorstel in beide kamers reeds heeft plaatsgevonden. Op het eerste oog lijkt een formele urgentieverklaring niet meer te zijn dan éen 'navette' minder, in het kader van het wetgevingsproces. ${ }^{66} \mathrm{Er}$ is echter meer aan de hand. Immers, indien de regering na één lezing in beide parlementskamers via 'l'urgence' een Commission Mixte Paritaire wil laten samenstellen, betekent dit, dat de opinie (inclusief amendementen) van de kamer die als tweede de parlementaire behandeling ter hand heeft genomen, nog slechts punt van verder onderzoek zal kunnen vormen voor een commissie waarin maar een zeer beperkt aantal parlementarièrs zitting mogen hebben. Een uitwisseling van gedachten en (deels) tegengestelde meningen aangaande het wetsvoorstel in behandeling tussen de twee parlementskamers als geheel ('Bicameralisme parfait'), wordt verder onmogelijk.

In de periode 1959-2000 werd 881 maal een Commission Mixte Paritaire samengesteld. In niet minder dan 469 gevallen (53\%) gebeurde dat via 'l'urgence' na slechts één lezing in beide parlementskamers. Interessant is het gegeven dat 'I'urgence' tijdens voornoemde periode maar liefst 392 maal werd uitgeroepen in een fase dat het wetsvoorstel onderwerp van bespreking uit maakte in de Assemblée Nationale. Dit betekent dat de Sénat in $83 \%$ van de genoemde gevallen, bezien vanuit het theoretische oogpunt van een optimale dialoog tussen parlementskamers, vervolgens nog slechts de bevoegdheid toekwam haar visie betreffende het wetgevingsvoorstel voor te leggen aan de leden van de conciliatiecommissie en meer in het bijzonder aan de zeven afgevaardigden van de Assemblée Nationale hierin ${ }^{67}$ Het Franse

65. Voor de Sénat: Art. 42 lid 10 Règlement du Sènat.

66. Journal Officiel, Débats Sénat 1982, p. 3793

67. J-E. Gicquel, le Sénat sous la seconde cohabitation, Revue du droit public et de la science polititque en 
Hogerhuis is, als 'Chambre de réflexion' nooit blij geweest met deze gang van zaken, waardoor de verrijkende invloed die de Sénat op de uitkomst van het wetgevingsproces zou kunnen uitoefenen immers betrekkelijk eenvoudig kan verworden tot een relatief onbetekenend bijrolletje. De Franse senaatskamer sprak meerdere keren uit dat op deze wijze geen recht meer gedaan kon worden aan het gedachtegoed opgeslagen in het grondwettelijk verankerde bicameralisme. ${ }^{\text {os }}$

Een Commission Mixte Paritaire bestaat uit zeven leden van de Assemblée Nationale en zeven leden van de Sénat, aangevuld met zeven 'reserves' uit iedere parlementskamer. ${ }^{69} \mathrm{De}$ plaatsvervangers plegen wel deel te nemen aan de discussies, maar worden uiteraard uitgesloten bij stemmingen over wijzigings- c.q. aanpassingsvoorstellen.

Het is niet ongebruikelijk dat zowel de voorzitter als de rapporteur van de kamercommissie die het wetsvoorstel door het voorbereidende stadium geloodst heeft, zitting nemen in de conciliatiecommissie. Het is echter ontegenzeggelijk usance dat de representanten uit het Hogerhuis die zitting nemen in een Commission Mixte Paritaire zoveel als mogelijk afkomstig zijn uit alle politieke geledingen van de Sénat. ${ }^{70}$ De leden afkomstig uit de gelederen van de Assemblée Nationale worden daarentegen niet benoemd vanuit die afspiegelingsgedachte. Voor het Franse Lagerhuis geldt veeleer dat de afgevaardigden in een samen te stellen conciliatiecommissie ex art. 45 Constitution 1958 het meerderheids- (en regerings-)standpunt behoren te onderschrijven. Op het eerste oog een enigszins verbazingwekkende tegenstelling. De Commission Mixte Paritaire is immers een orgaan dat, rekening houdend met de constitutionele eis tot voortgang van het wetgevingsproces, bedoeld lijkt te zijn om toch uitvoering te kunnen blijven geven aan de gedachte van het bicameralisme. Partijpolitieke disharmonie in de samenstelling van een conciliatiecommissie lijkt dan niet bepaald voor de hand te liggen. Vanuit het gezichtspunt van de Sénat is de Commission Mixte Paritaire, evenals dat bijvoorbeeld voor de gewone vaste commissies geldt, echter eerst en vooral een wetgevingsorgaan en niet, zoals dat voor de Assemblée Nationale het geval is 'een regeringgestuurd beïnvloedingsen arbitrage instrument'?" In de praktijk ontstaan er desondanks tegenwoordig overigens zelden problemen op dit vlak, aangezien beide parlementskamers overeen zijn gekomen dat een regeringsgezinde partijpolitieke meerderheid in toekomstig samen te stellen Commisions Mixte Paritaire altijd gegarandeerd moet zijn.

De laatste drie constateringen indachtig, is impliciet ook al aangegeven dat het grote belang van het activeren van conciliatiecommissies door de Franse regering niet zozeer gestoeld is op enige vorm van bicameraal gedachtegoed, doch veeleer voortvloeit uit een als zodanig ervaren noodzaak om (door de regering als niet-constructief ervaren) wetgevingsbemoeienis van oppositionele minderheden in zowel de Assemblée Nationale als de Sénat te kunnen kanaliseren.

Het eindproduct van een Commission Mixte Paritaire kan vele vormen aannemen. Het voorstel zoals aangenomen door de Assemblée Nationale kan integraal overgenomen worden. Hetzelfde geldt vanzelfsprekend ook voor het oorspronkelijke senaatsvoorstel. Zeker is in ieder geval dat eventuele amendementen afkomstig uit de koker van de commissie slechts

France et a l'étranger 1996, p. 1082.

68. Zie o.a.:Journal officiel Débats Sénat 1981 p. 4563 e.v, 1882 p. 7177,1983 p. 4551,1985 p. 1879.

69. Art. 111 Règlement de l'Assemblée Nationale en art. 12 Règlement du Sénat.

70. Pour mieux connaitre le Sénat, a.w., p. 256.

71. F. Luchaire, La constitution de la république française, Paris 1987, p. 892. 
onderdeel van een eindvoorstel uit kunnen maken, indien deze geaccordeerd zijn door de regering. ${ }^{12}$

In de meeste gevallen komt er een compromistekst tot stand. Tussen 1959 en 2000 is dat voor 545 wetsvoorstellen die daardoor uiteindelijk de status van wet verkregen het geval geweest. ${ }^{73}$ Uit voorliggende kwantitatieve gegevens (zie tabel 5.3) betreffende het parlementaire stemgedrag bij wetsvoorstellen zijn verbanden aantoonbaar tussen de partijpolitieke constellatie tijdens bepaalde legislatieve perioden enerzijds en de mate waarin tijdens diezelfde perioden Commissions Mixte Paritaire werden samengesteld anderzijds. In een aaneengesloten periode van 1958 tot 1981 was sprake van grote centrumrechtse dominantie. Tijdens het presidentschap van achtereenvolgens de Gaulle, Pompidou en Giscard d'Estaing waren zowel de regering als de samengestelde meerderheden in beide parlementskamers van centrumrechtse huize (uiteenvallend in Gaullisten en niet-Gaullisten). Vanaf 1981 echter is, met uitzondering van de periode 1995-1997, nooit meer sprake geweest van een dergelijke relatief coherente partijpolitieke constellatie voor de hoofdrolspelers in het formele wetgevingsproces. Tijdens de periode 1981-1986 diende de socialistische President Mitterand, de eveneens hoofdzakelijk ${ }^{74}$ socialistische regering en de socialistische meerderheid van de Assemblée Nationale zoals gezegd samen te werken met de permanente centrumrechtse meerderheid in de Sénat. Van een vrijwel identiek partijpolitiek scenario was sprake in de periode $1988-1993 .{ }^{75}$ Daarnaast was in de periode 1981-2000 ook nog eens drie maal sprake van cohabitation tussen de President van de Republiek en de regering. ${ }^{76}$

Tabel 5,3

\begin{tabular}{|c|c|c|c|c|}
\hline Periode & $\begin{array}{l}\text { Aantal definitief } \\
\text { aangenomen } \\
\text { wetten }\end{array}$ & $\begin{array}{l}\text { Aangenomen } \\
\text { wetten zonder } \\
\text { tussenkomst } \\
\text { CMP }\end{array}$ & $\begin{array}{l}\text { Aangenomen } \\
\text { wetten via } \\
\text { tussenkomst } \\
\text { CMP }\end{array}$ & $\begin{array}{l}\text { Aangenomen } \\
\text { wetten na } \\
\text { 'dernier mot' }\end{array}$ \\
\hline $1959-1980$ & $\begin{array}{c}1600 \\
(100 \%)\end{array}$ & $\begin{array}{l}1291 \\
(81 \%)\end{array}$ & $\begin{array}{c}247 \\
(15 \%)\end{array}$ & $\begin{array}{c}62 \\
(4 \%)\end{array}$ \\
\hline $1981-2000$ & $\begin{array}{c}1131 \\
(100 \%)\end{array}$ & $\begin{array}{c}572 \\
(51 \%)\end{array}$ & $\begin{array}{c}298 \\
(26 \%)\end{array}$ & $(23 \%)$ \\
\hline
\end{tabular}

Bron: Senat Français http://www.fr/presentation/livre3/livre3_mono.html, 29 oktober 2001

Vanaf 1981 is het aantal wetsvoorstellen dat pas na conciliatie via een Commission Mixte Paritaire het 'Journal officiel' bereikte vrijwel verdubbeld. Nog pregnanter overigens zijn de gegevens aangaande het hanteren van 'le dernier mot' door de Assemblée nationale.

72. Art. 45 lid 3 Constitution 1958.

73. http://www. senat. fr/presentation/livre3/livre3 mono.html. 29-10-2001.

74. Tussen 1981 en 1984 makten ook de communisten deel uit van de coalitieregering onder leiding van Mauroy.

75. Met dien verstande dat de regeringen Rocard, Cresson en Bérégovoy niet meer konden bogen op de luxe van een absolute meerderheid voor de PS in de Assemblée Nationale.

76. 1986-1988: Mitterand (PS)-Chirac (RPR), 1993-1995 Mitterand (PS)-Balladur (UDF), $1997-2000$ Chirac (RPR)-Jospin (PS). 


\subsubsection{Le dernier mot}

Indien de Commission Mixte Paritaire niet in staat is gebleken om een compromistekst te ontwikkelen die voor beide parlementskamers aanvaardbaar is, betekent dat in de Franse staatkundige constellatie allerminst dat het wetsvoorstel de eindstreep niet kan halen. In de constitutie van 1958 is namelijk nog een laatste mogelijkheid opgenomen voor de regering om het wetgevingsresultaat te plooien in de door haar gewenste richting: indien de Commission Mixte Paritaire geen voorstel weet te formuleren dat voor beide parlementskamers acceptabel is, kan de regering besluiten om de Assemblée nationale het laatste woord te geven. Het Lagerhuis beslist dan na een laatste lezing definitief bij gewone meerderheid. Uit bovenstaande tabel blijkt dat met name sinds 1981 frequent gebruik gemaakt is van deze mogelijkheid. Ook onthullend is tabel 5.4 waarin de frequentie waarmee 'Ie dernier mot' ex art. 45 al. 4 Constitution 1958 gehanteerd is, vanaf 1981 wordt uitgesplitst per parlementair jaar.

\section{Tabel 5.4}

\begin{tabular}{|l|c|c|}
\hline Jaar & Dernier mot absoluut & Dernier mot procentueel \\
\hline $1981-1982$ & 10 & $30,3 \%$ \\
\hline $1982-1983$ & 32 & $45,1 \%$ \\
\hline $1983-1984$ & 26 & $29,9 \%$ \\
\hline $1984-1985$ & 26 & $35,6 \%$ \\
\hline $1985-1986$ & 45 & $55,5 \%$ \\
\hline $1986-1987$ & 1 & $2,3 \%$ \\
\hline $1987-1988$ & 0 & $0,0 \%$ \\
\hline $1988-1989$ & 8 & $34,8 \%$ \\
\hline $1989-1990$ & 20 & $31,8 \%$ \\
\hline $1990-1991$ & 19 & $27,5 \%$ \\
\hline $1991-1992$ & 16 & $27,6 \%$ \\
\hline $1992-1993$ & 16 & $22,5 \%$ \\
\hline $1993-1994$ & 0 & $0,0 \%$ \\
\hline $1994-1995$ & 1 & $1,4 \%$ \\
\hline $1995-1996$ & 0 & $0,0 \%$ \\
\hline $1996-1997$ & 1 & $3,0 \%$ \\
\hline $1997-1998$ & 14 & $31,1 \%$ \\
\hline $1998-1999$ & 11 & $22,0 \%$ \\
\hline $1999-2000$ & 16 & $29,0 \%$ \\
\hline
\end{tabular}

Bron: Senat Français http://www.fr/presentation/ivre3/livre mono.html, 29 oktober 2001

Tijdens de periode 1981-1986 stond de (ten gevolge van het vigerende kiesstelsel structurele centrumrechtse meerderheid van de) Sénat, zoals reeds meermaals gememoreerd, partijpolitiek tegenover regering en (de meerderheid van de) Assemblée nationale. Tussen 1988 en 1993 moest door het Franse Hogerhuis ten tweede male samengewerkt worden met de socialisten in regering en het Lagerhuis. Vanaf 1997 tenslotte regeren de socialisten onder Jospin wederom. Tijdens voornoemde perioden stijgt het aantal 'dernier mots' (nog) altijd explosief. Blijkbaar is de inkleuring van het constitutioneel verankerde bicamerale 
gedachtengoed in Frankrijk erg afhankelijk van de partijpolitieke situatie van het moment. Indien de kleur van de politieke meerderheid in beide parlementshuizen verschilt lijkt de praktische positionering van de 'chambre de réflexion et révision inégale' binnen de constitutioneel toegestane bandbreedte immers sterk te eroderen ten opzichte van de situatie waarin beide Kamers door centrumrechts gedomineerd worden. Anderzijds blijft natuurlijk ook overeind staan, dat wetgeving in formele zin in Frankrijk nog altijd grotendeels tot stand komt via de reguliere procedures in twee parlementskamers.

\subsection{Bijzondere wetgevingstrajecten}

\subsubsection{Grondwetswijziging}

Art. 89 lid I Constitution 1958: L'initiative de la révision de la Constitution appartient concurremment au Président de la République, sur proposition du Premier Ministre et aux membres du Parlement.

Art. 89 lid 2 Constitution 1958: Le Projet ou la proposition de révision doit être voté par les deux assemblèes en termes identiques.

Grondwetswijzigingen behoeven in Frankrijk, evenals in Nederland en Duitsland, de goedkeuring van beide parlementskamers. Art. 89 Grondwet stelt dat grondwetswijzigingen 'en termes identiques' aangenomen moeten worden door de beide parlementskamers. Van een 'dernier mot' voor de Assemblée nationale kan dan ook nooit sprake zijn, waar de wijziging van de grondwet in het geding is.

Grondwetswijzigingen kunnen geīnitieerd worden door de President van de Republiek, de Premier en de leden van beide parlementskamers. " Senatoren hebben vanaf 1958 in ruime mate gebruik gemaakt van dit recht. Niet minder dan 148 voorstellen tot aanpassing van de vigerende grondwet werden tot medio 1998 gedeponeerd bij het Bureau van de Sénat. Niet én(1) wijzigingsvoorstel werd in die veertig jaar door de regering op de agenda van de Assemblée Nationale gezet. ${ }^{78}$

Het wetgevingstraject is bij grondwetswijzigingsvoorstellen in principe hetzelfde als bij gewone wetten, zij het met dien verstande dat het in geen enkel stadium van het traject voor grondwetswijziging mogelijk is een Commission Mixte Paritaire samen te doen stellen. De ratio hiervan is gelegen in het voorkomen van situaties die het gecodificeerde beginsel van 'aanname in identieke bewoordingen' van voorstellen tot wijziging van de Grondwet in beide parlementskamers, waarop art. 89 Constitution 1958 duidelijk doelt, uit zouden kunnen hollen. Enigszins in tegenspraak met deze constatering is overigens wel het gegeven dat de regering in één of beide parlementskamers naar behoefte de 'vote bloqué' ex art. 44 lid 3 Grondwet kan verlangen. Door dit middel slechts te hanteren in de politiek weerbarstigste parlementskamer kan de regering 'termes identiques' afdwingen, zodat in ieder geval in formele zin aan de vereisten van art. 89 Constitution 1958 voldaan wordt. Tegelijkertijd dient natuurlijk wel bedacht te worden dat het 'alles of niets' van de 'vote bloqué' in de Sénat bij grondwetsvoorstellen verhoogde risico's met zich meebrengt. 'Niets' betekent immers, in tegenstelling tot hetgeen gebruikelijk is in het gewone wetgevingstraject (denk

77. Art. 89 lid 1 Constitution 1958.

78. http://www.senat. fr/presentations/ivre3/livre3 mono.html. 29-10-2001. 
bijvoorbeeld aan de 'question préalable positive'), direct het echte einde van het grondwetswijzigingsvoorstel en dus echt gewoon 'niets'.

Definitieve aanname van grondwetswijzigingen loopt via een referendum of via het Congrès. In het tweede geval komen beide parlementskamers in gezamenlijke zitting bijeen en dient het voorstel tot aanpassing van de Grondwet aangenomen te worden door een $2 / 3 \mathrm{e}$ meerderheid $^{80}$

De Sénat pleegt in voorkomende gevallen wel degelijk gebruik te maken van de vetorechten die voortvloeien uit art. 89 Grondwet. Zowel in 1984 als in 1990 werden wijzigingsvoorstellen door toedoen van de leden van het Franse Hogerhuis weggestemd. Zoals gezegd kan een definitieve uitspraak van het parlement over een grondwetswijziging natuurlijk wel omzeild worden indien de President een referendum over de kwestie uitschrijft. De praktijk heeft echter uitgewezen dat het Congrès (en daarmee de Sénat) in het hedendaagse Franse staatsbestel desondanks ontegenzeggelijk een waakhondfunctie is gaan vervullen, waar de Grondwet in het geding is. Aanpassing van de titels VIII $\mathrm{t} / \mathrm{m} \mathrm{X}$ en XVI der Grondwet in 1992, ten gevolge van het verdrag van Maastricht bijvoorbeeld, werd actief en constructief begeleid door de Sénat. ${ }^{81}$ Sinds 1959 werd de Grondwet 12 maal gewijzigd via goedkeuring door het Congrès. ${ }^{82}$

\subsubsection{Organieke wetten}

Art. 46 Constitution 1958 voorziet voor de parlementaire behandeling van organieke wetten in een procedure die afwijkt van hetgeen dienaangaande gebruikelijk is voor gewone wetten in formele zin. Interessant in het kader van dit boek zijn met name alinéa 3 en 4 van voornoemd grondwetsartikel. In alinéa 3 wordt bepaald dat de gewone procedure ex art. 45 Constitution 1958, inclusief 'urgence', Commission Mixte Paritaire en 'dernier mot' gewoon van toepassing is. De Assemblée nationale kan in finale instantie echter slechts tot aanname van de organieke wet besluiten, indien een absolute meerderheid van de leden in die zin zijn stem uitbrengt. De ongelijkheid tussen Assemblée nationale en Sénat is op dit vlak, naar de letter, dus minder groot.

Volledige gelijkheid tussen beide parlementskamers wordt betracht, waar het de behandeling van 'lois organiques relatives au Sénat' betreft. In dat geval is definitieve aanname in gelijke bewoordingen door beide parlementskamers verplicht. Wat precies verstaan dient te worden onder 'lois organiques relatives au Sénat' is verduidelijkt door de Conseil Constitutionnel, die organieke wetgevingsprojecten moet toetsen aan de grondwet, alvorens de President tot afkondiging kan overgaan. ${ }^{83}$ De Conseil stelde dat het moet gaan om wetgeving die beoogt wijzigingen aan te brengen in de wijze waarop het Franse Hogerhuis is georganiseerd en wel in dier voege dat er sprake is van: 'poser, modifier ou abroger des règles le concernant'. Aanpassingen in de wijze van samenstelling van kiescolleges valt niet

79. Daarom wordt de vote bloqué ook nauwelijks gehanteerd bij grondwetswijzigingen. In 1961 werd een voorstel tot aanpassing van de parlementaire zittingsperioden door de Sénat verworpen na inzetting van de vote bloqué.

80. Art. 89 lid 3 Constitution 1958.

81. J-E. Gicquel, 1996, a.w., p. 1075.

82. http://www.senat.fr/presentation/livre3/livre3 mono.html. 29-10-2001.

83. Conseil Constitutionnel 10 juillet 1985, nr. 85-195. 
onder die definitie, wijzigingsvoorstellen aangaande de verkiesbaarheid van parlementarièrs (voor beide parlementskamers) wél.

\subsection{De wetgevingscommissies}

Inmiddels is meermaals zichtbaar geworden dat het parlementaire commissiewerk binnen het raam van het Franse wetgevingsproces een relatief prominente plaats in pleegt te nemen. Ik beperk mij op deze plaats tot een summiere bespreking van de werkwijze der vaste en speciale wetgevingscommissies van het Franse Hogerhuis. De werkwijze van de Commission Mixte Paritaire werd reeds aan de orde gesteld. Over de werkwijze en bevoegdheden van enquêtecommissies en andersoortige onderzoekscommissies wordt gerapporteerd in het kader van de bestuurscontrole (vanaf par. 5.8).

De Sénat kent zes vaste commissies, die het reguliere werkterrein van de wetgever in principe afdekken ${ }^{84}$ ledere senator is lid van één vaste commissie. De politieke krachtsverhoudingen van de Sénat als geheel worden zo veel mogelijk gereflecteerd in de commissies. Interessant is het gegeven dat de vaste commissies voor het ontplooien van hun activiteiten niet gebonden zijn aan de officięle zittingstermijnen van de Sénat. Omdat de Franse Hogerhuiskamer tevens nooit ontbonden kan worden, betekent dit dat de vaste commissies als de enige te allen tijde activeerbare factor in het wetgevingsproces te beschouwen zijn.

De Grondwet opent in art. 43 ook de mogelijkheid tot het formeren van speciale ad-hoc senaatscommissies, indien de regering of de Sénat, op voorstel van de voorzitter dit verzoekt. Bestaat een vaste kamercommissie uit minimaal 42 en maximaal 78 leden, afhankelijk van het werkterrein van die commissie, een speciale commissie moet uit efficiency overwegingen standaard 37 leden tellen. ${ }^{85}$

Het bestaan van slechts zes vaste kamercommissies met daarnaast de mogelijkheid tot het creëren van speciale ad-hoc commissies, was bedoeld als antwoord op en ter preventie van de ongebreidelde obstructiemacht die de vele vaste kamercommissies ten tijde van de $4 \mathrm{e}$ Republiek plachten te hebben. ${ }^{86}$ In de praktijk van de 5 e Republiek worden de speciale commissies, zo blijkt, vooral ingesteld als er behoefte is aan een soort 'task force' met extra specialisme in huis om belangrijke en ingewikkelde wetgevingsprojecten (op bijvoorbeeld financieel-economisch terrein) efficiënt te begeleiden. Verder blijkt het in Parijs ook wel eens handig te zijn om een speciale commissie samen te stellen ter voorkoming van escalerende onenigheid tussen meerdere vaste commissies over bijvoorbeeld competentievraagstukken $^{87}$

Geheel anders dan bijvoorbeeld in Groot-Brittanniě en Nederland, waar het commissiewerk hoofdzakelijk plaats vindt in plenaire (inbreng)vergaderingen, wordt het feitelijke commissiewerk in het Franse Hogerhuis sterk gestuurd door één enkele senator: de rapporteur. ${ }^{88}$ Deze onderzoekt het wetsvoorstel, consulteert (al dan niet alleen) vertegenwoordigers van

84. Art. 7 Règlement du Sénat

85. Art. 10 lid 3 Règlement du Sénat.

86. J. Cluzel, Le Sénat dans la socièté française. Paris 1990, p. 109

87. Art. 17 lid I Règlement du Sénat. Het Presidium beslist uiteindelijk of een speciale commissie wordt samengesteld.

88. Art. 19 Règlement du Sénat. 
belangenorganisaties, experts, vakbonden e.d. Hij suggereert eigen amendementen, beoordeeld amendementen afkomstig vanuit regering of Assemblèe Nationale enz. Zijn uiteindelijke bevindingen worden voorgelegd c.q. verdedigd voor de voltallige commissie (het bijwonen van de commissievergaderingen is inmiddels wettelijk verplicht gesteld ${ }^{59}$ ) die haar oordeel over zowel de amendementen als het ontwerp als geheel vervolgens kan uitspreken. Uiteraard blijven zelfstandige aanpassingen van het voorstel van de rapporteur door de voltallige commissie mogelijk, doch het door hem voorgestelde raamwerk vormt daarvoor wel het uitgangspunt. ${ }^{90}$ Tenslotte wordt van de rapporteur verwacht dat hij de commissiestandpunten publickelijk toelicht en verdedigt voor de Sénat in plenaire zitting bijeen.

Een rapporteur wordt niet zo maar bij toerbeurt aangewezen vanuit het ledenbestand van de betreffende commissie, doch dient voorgedragen te worden door een meerderheid van de commissieleden. Van eminent belang voor deze keuze is niet slechts de mate van expertise waarover hij/zij beschikt, maar zeker ook de politieke kleur van de aspirant-rapporteur. Omdat alle (vaste en speciale) kamercommissies een getrouwe partijpolitieke afspiegeling plegen te herbergen van de Sénat als geheel, zal de rapporteur in de meeste gevallen (en zeker indien het politiek gevoelige teksten betreft) van centrumrechtse huize zijn. ${ }^{91}$

Vervolgens enkele opmerkingen over de rol die de vaste commissies in het Franse Hogerhuis plegen te vervullen tijdens het laatste stadium van het wetgevingstraject. In tegenstelling tot hetgeen dienaangaande te doen gebruikelijk is in bijvoorbeeld Nederland, maakt de Franse grondwetgever een onderscheid tussen het 'domaine de la loi ${ }^{\text {'92 }}$ en het 'domaine réglementaire ${ }^{, 93}$. De wettekst zoals aangenomen door het parlement ex. art. 45 Constitution 1958 bevat nog geen uitvoeringsbepalingen, aangezien deze onder het 'domaine réglementaire' plegen te vallen. Het is de taak van de regering om voornoemde bepalingen per decreet toe te voegen aan de voorliggende wet, zodat vervolgens tot publicatie en afkondiging kan worden overgegaan. $\mathrm{Nu}$ de Franse grondwetgever van 1958 de regering geen formeel afgebakende afhandelingplicht in deze heeft opgelegd, is de Sénat vanaf 1972 gaan controleren of een en ander naar behoren geschiedt. ${ }^{94}$ Naar gelang de aard van de voorliggende parlementair goedgekeurde wettekst gaat één der vaste senaatscommissies speciaal letten op de verdere gang van de procedurele afwikkeling. Met name twee aspecten plegen de speciale aandacht van de commissieleden te hebben: de afhandelingsnelheid én de vraag of de door de regering toegevoegde uitvoeringsbepalingen wel voldoende sporen met de geest van de wettekst, zoals die is aangenomen door de beide volksvertegenwoordigende organen. De afhandelingsnelheid pleegt nog wel eens problemen op te leveren. ${ }^{95}$ Naast initiatief tot regelmatige publicatie in het 'Bulletin des commissions' van de stand van zaken aangaande het afronden van wetsvoorstellen ex art. 37 Constitution 1958, pleegt eens per jaar het Presidium op de hoogte gesteld te worden. De uitoefening van deze controle-

89. Art. 15 Règlement du Sénat. De problematiek rondom de 'cumul des mandats' is hieraan natuurlijk niet vreemd.

90. Zeker niet van politiek belang ontbloot is in dit kader art. 44 al. 2 Constitution 1958. De regering kan, na aanvang van het plenaire debat in het Hogerhuis over een wetsvoorstel, de behandeling van alle amendementen die niet volledig onderworpen zijn geweest aan het onderzoek van kamercommissies verbieden.

91. J. Cluzel, Le Sénat dans la société française, a.w., p. 117-118.

92. Art. 34 Constitution 1958

93. Art.37 Constitution 1958

94. J. Mastias en J. Grangé, a.w., p. 238

95. Blijkens onder meer een circulaire van de Premier ministre, dd.1-6-1991, gericht tot zijn regering. 
taak door de Sénat, een taak die zij zich bij gebrek aan dwingende regelgeving op dit terrein zoals gezegd zelf heeft toebedeeld, blijkt zich ontwikkeld te hebben tot een weliswaar relatief marginale doch heuse check voor de Franse senaatskamer van de regeringsactiviteit rondom de toevoeging van uitvoeringsbepalingen aan wetsvoorstellen in formele zin.

\subsection{Balans wetgevingsfunctie}

Bezien vanuit het perspectief van de belangrijkste (mede)wetgevende instituties in Frankrijk kunnen de eerste 43 jaar van de 5e Republiek moeilijk gekenschetst worden als statische jaren. De door Debré c.s. uitgewerkte Grondwet van 1958 heeft, waar de output van het formele wetgevingstraject in het geding is, een 'logistieke' ordening opgeleverd, die afhankelijk van de partijpoliticke situatie van het moment relatief eenvoudig praktisch aanpasbaar blijkt te zijn. De regic daarvan is sinds 1958 ontegenzeggelijk in handen van de regering. In een staatsrechtelijke constellatie waar enerzijds de President, Premier ministre, regering en beide parlementskamers in voortdurende wisselwerking met elkaar de formeel wetgevende macht uitoefenen, terwijl anderzijds diezelfde instituties vrijwel allemaal met enige regelmat (maar lang niet altijd synchroon) een ander politiek 'jasje' aantrekken, zou

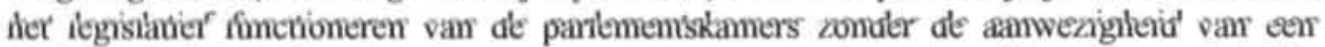
werkbare juridische bandbreedte (voor met name de regering) ook welhaast net zo dodelijk kunnen zijn geweest voor de voortgang van het wetgevingstraject, als ten tijde van de $3 \mathrm{e}$ Republiek te doen gebruikelijk.

Waar heeft de Sénat nu gestaan in dat geheel, tijdens de ruim 40 jaar van constitutioneel verankerd 'bicaméralisme inégalitaire'?

De invloed op het wetgevingsproces is onder alle omstandigheden in ieder geval in die zin geconditioneerd, dat zij afhankelijk is van regeringshandelingen. De regering stuurt het wetgevingsproces in het Palais de Luxembourg, gebruikmakend van een aantal sterke juridische wapens, zoals gezegd, vrijwel volledig. 'L'ordre du jour prioritaire, l'irrecevabilité, l'urgence, le vote bloqué en le dernier mot', zijn allemaal tactisch inzetbare sturingsinstrumenten, te hanteren wanneer de politieke situatie daarom vraagt. En die politieke situatie wijzigt regelmatig. Politiek duidelijk geisoleerd van zowel de regering, als het Lagerhuis en de President was het Franse Hogerhuis in ieder geval tussen 1962 en 1969. Tijdens die periode was de rol van de Sénat sterk defensief en werd (door vooral President de Gaulle en zijn regering) ervaren als een hindernis voor het goed functioneren van het wetgevingsapparaat. ${ }^{96}$ Als gevolg daarvan werden tussen 1963 en 1968 vrijwel de helft $(45,5 \%)$ van alle wetsvoorstellen die via een Commission Mixte Paritaire liepen uiteindelijk pas aangenomen na het 'dernier mot' ex art. 45 lid 4 van de Assemblée nationale. De regering forceerde in diezelfde periode 71 maal een 'vote bloqué' in het Hogerhuis. Zeer veelzeggend: in viervijfde deel van die gevallen had de 'vote bloqué"' verwerping van het voorstel door de Sénat tot gevolg. Ook veelzeggend: tussen 1966 en 1969 werden nog maar in totaal 12 regeringsvoorstellen tot wet eerst ingebracht bij de Sénat. Tussen 1970 en 1973 bijvoorbeeld waren dat er 55, terwijl sindsdien het Hogerhuis als medewetgevend orgaan ook kwantitatief gemeten nooit meer zo uit beeld is geweest, als tussen 1962 en 1969. 
De politieke verwijdering tussen de Sénat enerzjjs en President, regering en Assemblée anderzijds ontstond, omdat de ruraal verkozen senatoren zichzelf rekenden tot het 'midden' en niet tot de gaullisten. Vanuit die positie wenste het Hogerhuis alle wetgevingsvoorstellen kritisch te onderzoeken. Ook kon de Sénat slechts met de grootst mogelijke moeite wennen aan een aantal nieuwe procedureregels die de parlementaire invloed dienden in te dammen, de regel van 'l'ordre du jour prioritaire' voorop. In 1962 escaleerde deze situatic, die zoals gezegd zeven jaar van extreme polarisatic tot gevolg zou hebben. In 1969 uiteindelijk, werd door President de Gaulle het beruchte correctief referendum uitgeschreven, waarin (onder meer) werd voorgesteld de bevoegdheden van de Sénat sterk te reduceren. ${ }^{97}$ Het door een meerderheid van het Franse volk uitgesproken 'non' leidde vervolgens tot het aftreden van de zittende President en, belangrijker in het kader van dit boek, tot een sterke politieke opwaardering van de (mede)wetgevende activiteiten ontplooid in het Palais de Luxembourg. Het presidentschap van Pompidou staat dan ook in het teken van verbeteringen op het vlak van: 'représentativité, autorité en efficacité'. De Sénat manoeuvreert zich gaandeweg in de positie van 'chambre de réflexion'. Er werd in toenemende mate gebruik gemaakt van het amendement om wetgevingsvoorstellen te verrijken c.q. aan te passen conform de wensen van de regering. In politieke zin situeerde het Franse Hogerhuis zich duidelijk in de luwte in een mate die tot 1970 nog ondenkbaar was geweest. ${ }^{98}$

De komst van Giscard d'Estaing als President luidde de meest harmonieuze periode uit de bestaansgeschiedenis van de Sénat onder het regime van de 5e Republiek tot nu toe in. En dat zeker niet in de laatste plaats omdat ook hij, evenals de permanente meerderheid van het Hogerhuis een representant van het Frans-rurale politieke 'centrum' (UDF) was. Als gevolg van deze natuurlijke band werd door de regeringsleiders tijdens het regime van Giscard d'Estaing meermaals de facultatieve 'approbation d'une déclaration de politique générale' ex art. 49 lid 4 Grondwet aan de Sénat gevraagd én (uiteraard) verkregen. Commissions Mixte Paritaire kwamen vrijwel altijd tot overeenstemming. Art. 45 al. 4 Constitution 1958 (dernier mot) werd tijdens de periode van het presidentschap van Giscard slechts gehanteerd voor $0,8 \%$ (!) van het totale aantal wetgevingsprojecten dat het Journal Officiel wist te halen. Gebruikmaking van de 'vote bloqué' in het Hogerhuis kwam zelfs helemaal niet voor.

Al die harmonie bleek ook een keerzijde te hebben. Theoretisch aan een senaat toegeschreven kenmerken als waakzaamheid, reflectie en kwaliteitsbewaking kwamen meermaals sterk in dienst te staan van de dwang wetgevingsproducten snel richting eindstreep te loodsen. De Sénat kortom, maakte tijdens deze periode overduidelijk deel uit van de regeringscoalitie.

Vanaf het aantreden van Mitterand in 1981 veranderde de positie en werkwijze van de Sénat volledig. Tussen 1981 en 1986 en tijdens de periode 1988-1993 stond de Sénat politiek compleet geïsoleerd tegenover een linkse regering en een (in meerderheid) linkse Assemblée. Art. 45 al. 4 Constitution 1958, de juridisch duidelijkste exponent van 'inégalité' werd tijdens die perioden, zoals wij gezien hebben, veelvuldig gehanteerd. Omdat de socialistische regering 99 tijdens voornoemde perioden veelvuldig besloot om 'I'ordre du jour prioritaire' van beide parlementskamers volledig af te stemmen op de voortgang van

97. De Sénat zou slechts adviserende bevoegdheden behouden.

98. J. Mastias, le Sénat, a.w., p, 19-26.

99. Tijdens de regering Mauroy van 1981 tot 1984 maakten ook de communisten deel uit van de regering. 
haar eigen wetsvoorstellen, tevens de niet-toelaatbaarheid van senaatsamendementen ex art. 40,41 en 44 Grondwet actief onderzocht, regelmatig 'I'urgence' proclameerde, voortdurend conciliatiecommissies bijeenriep, de 'vote bloqué' eiste en de Assemblée nationale vaak het laatste woord ex art. 45 lid 4 Grondwet verleende, leek zelfs de term 'inégalité' ter kwalificering van het functioneren van het Franse tweekamerstelsel niet krachtig genoeg. ${ }^{100}$ Ook in de situatie zoals ontstaan ten gevolge van de verkiezingen voor de Assemblée nationale van 1997, is sprake van een vrijwel volledige partijpolitiek isolement van de Sénat. ${ }^{101}$ De procedurele mogelijkheden van vooral de artt. 44 al. 3 en 45 Constitution 1958, blijken sindsdien wederom frequent gehanteerd te worden door de regering ${ }^{102} \mathrm{Het}$ zij echter nogmaals gezegd, zelfs in een dergelijke partijpolitiek zo benarde positie blijft de Sénat, via met name het recht van amendement, wel gewoon actief betrokken bij vooral de vervolmaking van de politiek minder gevoelige wetsvoorstellen.

Sterk tegengesteld werd de situatie voor de Sénat als medewetgevend orgaan vooral tijdens de eerste twee perioden van 'cohabitation'. Zowel in 1986-1988 als in 1993-1995 was sprake van cen regering gebaseerd op centrumrechtse meerderheden in beide parlementskamers die geacht werd samen te werken met de socialistische President Mitterand. Met name tussen 1986 en 1988 bleek Mitterand zich sterk af te zetten tegen het beleid van de regering. Zo weigerde hij meermaals wetgevingsproducten van zijn noodzakelijke handtekening ex art. $10 \mathrm{al}$. I Constitution 1958 te voorzien. Deze situatie van 'cohabitation' had, zoals beschreven, weer een duidelijke opwaardering van de Sénat als medewetgevend orgaan tot gevolg. De staatsrechtelijke nouveauté van de 'question préalable positive' als geste richting regering en bedoeld om de door de President geëntameerde vertragingtechniek ex art. 10 lid 2 Grondwet te minimaliseren, was daar een direct uitvloeisel van. Het 'dernier mot' werd niet of nauwelijks nog gehanteerd. De 'vote bloqué' en de 'exceptions d'irrecevabilité' werden nog slechts aangewend om obstructieve amendering van de oppositionele minderheid in te dammen. De Sénat kortom, manifesteerde zich in die periode als een loyale en weinig kritische partner van de regering in het wetgevingsproces. ${ }^{103}$

Tijdens de tweede periode van cohabitation was de centrumrechtse meerderheid in de Assemblée nationale groot. Zo groot zelfs dat de regering geen strakke regie van het regelgevingproces meer nodig achtte. Er ontstond zowaar enige politieke ruimte voor dialoog aangaande de gewenste inhoud van wetgevingsproducten, resulterend in meer aandacht voor de geluiden vanuit het Palais de Luxembourg. ${ }^{104}$ Oplossingen voor meningsverschillen, ontstaan tijdens de gang van het proces werden zoveel mogelijk opgelost via de reguliere 'navette' tussen beide parlementskamers. De Sénat: 'retrouve sa voix; reconque une

100. J-E. Giquel 1996, a.w., p. 1073 e.v.

101. Weliswaar is President Chirac eveneens van centrum-rechtse (zij het gaullistische) huize, maar voor de wijze waarop het formele wetgevingstraject ten uitvoer wordt gebracht heeft dit geen gevolgen, omdat de regering Jospin zich dienaangaande ten opzichte van het staatshoofd onafhankelijk heeft weten to positioneren, waar het wetgevingstraject in het geding is.

102. Het aantal 'dernier mots' voor de Assemblée nationale steeg na installatie van de socialistische regering Jospin van vijwel nul tot ruim $30 \%$ van het totale aantal wetgevingsprodukten dat het Journal Officiel bereikte.

103. J-E. Giquel, 1996, a.w., p. 1071

104. Niet onbelangrijk was ook het gegeven dat Premier Balladur zijn oog had laten vallen op het Presidentschap. een post die in 1995 vacant zou komen. Daartoe meende hij in ieder geval de steun van het Franse 'midden'. vooral sterk vertegenwoordigd in de Senat, niet te kunnen ontberen. 
influence et un poids qu'il n'avait pas eu depuis un certain temps.' ${ }^{105}$ Als gevolg daarvan verdubbelde tijdens deze tweejarige periode ook het aantal wetgevingsinitiatieven vanuit de Sénat dat de eindstreep haalde.

\subsection{Bestuurscontrole}

\subsubsection{Inleiding}

De mate waarin de handel en wandel van een regering gecontroleerd pleegt te worden door het parlement, is vanzelfsprekend ten sterkste verbonden met de mate waarin een afhankelijkheidspositie tussen beide staatsinstituties gecreterd is. Onder het regime van de $3 \mathrm{e} \mathrm{en} 4 \mathrm{e}$ Republiek bleek een schier onafzienbare schare achtereenvolgende regeringen voor het functioneren dusdanig afhankelijk te zijn van fiattering door de parlementskamers dat in feite meestal sprake was van een: 'état de crise ministérielle quasi permanente'. Tijdens de 12 jaar van de 4e Franse Republiek traden gemiddeld ruim twee nieuwe ministersploegen per jaar aan, hetgeen ontwikkeling van ook maar enigszins consistent beleid natuurlijk onmogelijk maakte. Deze onevenwichtigheid heeft, zoals bekend, in grote mate bijgedragen tot de korte duur van de 4e Republiek. ${ }^{100}$

Het antwoord van de grondwetgever van de 5e Republiek op de geschetste situatie was dan ook om de volksvertegenwoordiging te beperken in zijn mogelijkheden tot controle van het bestuur.

\subsubsection{De politieke ministeriële verantwoordelijkheid}

In art. 20 jo artt. 49 en 50 Constitution 1958 is de politieke ministeriële verantwoordelijkheid verankerd. Art. 20 spreekt van: 'responsabilité devant le Parlement'. Uit de artt. 49 en 50 Grondwet blijkt vervolgens dat voornoemde verantwoordelijkheid slechts in de verhouding regering-Assemblée nationale voorzien kan worden van een reële sanctie via het opzeggen van het vertrouwen.. De Sénat moet zich, zoals reeds gememoreerd in par. 5.2.2 in dat kader tevreden stellen met een facultatief door de regering activeerbare goedkeuringsceremonie betreffende de algemene beleidslijnen.

Indien echter de regering, in de persoon van de Premier ministre, onder het regime van art. 49 al. 1 Constitution 1958 een 'déclaration de politique générale' pleegt af te leggen, gebeurt dit in de regel tegelijkertijd ook in de Sénat en wel door de vice-Premier.

Mocht een dergelijke verklaring voor de Assemblée nationale vergezeld gaan van de vertrouwensvraag én de Sénat tegelijkertijd niet gevraagd worden om de 'approbation' ex art. 49 al. 4, dan is iedere vorm van discussie of debat omtrent de regeringsverklaring in het Hogerhuis niet toegestaan. ${ }^{107}$ Indien de vertrouwensvraag niet wordt opgeworpen in het Lagerhuis is discussie tussen de (vice) minister en senatoren wel mogelijk. Mocht art. 49 al. 4 Constitution 1958 geactiveerd worden, dan is een openbaar debat gevolgd door stemming verplicht. ${ }^{108}$ Sinds 1958 werd 214 maal een 'déclaration de politique générale afgelegd.

105. R. Monory, (senaatsvoorzitter) Journal Officiel, Débats 1993 p. 6787 en 1994 p. 8018.

106. Zie hoofdstuk 2, par. 2.3.3.

107. Art.39 lid 1 Règlement du Sénat.

108. Art. 39 lid 2 Règlement du Sénat. 
Deze ging 28 maal vergezeld van de vertrouwensvraag voor de Assemblée nationale. De goedkeuring van het Franse Hogerhuis ex art. 49 al. 4 Constitution werd tot nu toe 12 maal gevraagd én verkregen. ${ }^{109}$ Zoals reeds gememoreerd gebeurde dit, ten gevolge van een permanente centrumrechtse politieke meerderheid in de Sénat, vrijwel exclusief indien de regeringsmacht werd uitgeoefend door politieke geestverwanten en succes in ieder geval verzekerd was. Slechts ten tijde van de socialistische minderheidsregering Rocard werd op deze regel een uitzondering gevormd. De twee gevallen waarin hij om bijval vanuit het Hogerhuis vroeg (en kreeg), betroffen onderwerpen van buitenlands beleid die dienden te steunen op een hoog parlementair consensusgehalte: de Franse politiek aangaande ontwikkeling van Oost-Europa na de val van de Berlijnse Muur en de Midden-Oosten-politiek.

Omdat 'approbation' ex art. 49 al. 4 Constitution 1958 nog nooit tot een afwijzend oordeel in het Hogerhuis heeft geleid, valt niet met zekerheid te zeggen dat de regering in het voorkomende geval niet zou terugtreden. Hoe dit ook zij, een gesanctioneerde, naar believen door de volksvertegenwoordigers activeerbare vertrouwensrelatie tussen regering en Sénat bestaat onder het regime van de Grondwet der 5e Republiek zelfs niet in theoretische zin. Het initiatief tot formele beleidsbeoordeling door de Sénat zal in het Franse staatsbestel immers altijd vanuit de regering moeten komen; een premisse die erg slecht verenigbaar lijkt te zijn met het wezen van de ministeriële verantwoordelijkheid. Uiteraard zal dit thema ook in het volgende hoofdstuk, dat het functioneren van de Nederlandse Eerste Kamer tot onderwerp heeft, onderwerp van bespreking uit maken.

\subsubsection{Het vragenrecht}

In het Palais de Luxembourg blijkt onder het regime van de 5e Republiek zeer vruchtbare grond aanwezig te zijn geweest voor de kwantitatieve ontwikkeling van het parlementaire vragenrecht. In 1971 werden nog geen 1000 vragen per jaar afgevuurd op de regering. In 1997 waren het er meer dan 8000 terwijl in 1998, 1999 en 2000 het aantal van 7000 vragen ruimschoots overschreden werd. ${ }^{110}$

Het vragenrecht heeft op verschillende manieren gestalte gekregen. De grootste groep vormen de schriftelijke vragen. Daarnaast is er de mogelijkheid tot het stellen van mondelinge vragen mét en zonder debat. Tenslotte onderscheidt men tegenwoordig binnen het Franse parlementsrecht nog de vragen betreffende actuele onderwerpen, te stellen tijdens het tweewekelijkse openbare vragenuurtje en de vragen over specifiek Europese onderwerpen.

Aan schriftelijke vragen die uitsluitend door individuele senatoren aan individuele bewindslieden gesteld mogen worden, zijn in materiele zin in principe geen voorwaarden verbonden, met dien verstande dat aantijgingen tegen met name genoemde derden uit den boze zijn. "'I Schriftelijke vragen worden gepubliceerd in een 'annexe' van het 'Journal officiēl'. Het eveneens aldaar gepubliceerde antwoord volgt in principe binnen één kalendermaand. Een minister kan zich te allen tijde beroepen op het staatsbelang indien beantwoording vanuit regeringsoogpunt vermeden dient te worden. ${ }^{112}$

109. http:/www.senat.fr/presentation/livre4/ivre4/ html, 13-12-1999.

110. http://www. senat fr/airs-cgi/questions.cgi, 21-4-2001.

111. Art. 74 lid 1 Règlement du Sènat.

112. Art. 75 lid 2 Règlement du Sénat. 
Het kwalitatieve belang van de geschreven vraag als controle-instrument richting regering is ook in Frankrijk (evenals overigens in Groot-Brittannie) gering ${ }^{113}$ Vermeldenswaard is in dit kader hooguit dat door de 'chambre rurale' regelmatig aandacht wordt gevraagd voor specifieke problemen van lokale en regionale aard, die anders volledig aan de aandacht van de centrale overheid zouden ontsnappen. ${ }^{114}$

Slechts $4,3 \%$ van alle vragen afkomstig uit het Franse Hogerhuis zijn mondelinge vragen. De meeste hiervan zijn zgn. 'question orale sans débat'. Qua vorm en inhoud worden aan deze vragen geen andere vereisten gesteld dan aan de schriftelijke vragen. Omdat mondelinge vragen alleen de kwalificatie 'mondeling' kunnen blijven behouden indien zij ook mondeling beantwoord worden, zijn twee zittingen per maand ingeruimd voor de beantwoording inclusief repliek door de vragenstellers en duplick door de aangesproken ministers. De agenda valt onder het beheer van het Presidium. ${ }^{115}$ Van een stortvloed aan naast elkaar en op zichzelf staande monologen pleegt overigens geen substantiele invloed uit te gaan ${ }^{116}$ Op verzock van minimaal 30 senatoren kan een mondelinge vraag zonder debat getransformeerd worden in een vraag mét debat." Het recht tot het stellen van 'questions orales avec débat' is onder het regime van de 5e Republiek een recht van interpellatic geworden. Door middel van het reglement van orde van de Sénat wordt de gang van zaken strak geregisseerd. Slechts diegenen die vooraf bij het Presidium spreektijd hebben aangevraagd mogen (maximaal 10 minuten) het woord voeren. ${ }^{118}$ De tijdslimiet kan door het Presidium naar believen ingekort worden. ${ }^{119}$ De datum voor de interpellatie wordt eveneens door het Presidium (in samenspraak met de regering) vastgesteld. De Sénat kan hierop wel enige invloed uitoefenen indien daartoe bij minimaal dertig senatoren behoefte bestaat. ${ }^{120}$ Voor 'questions orales avec débat portant sur des sujets européens' ex artt. 83 bis en 83 ter $\mathrm{RdS}$, bestaat in grote lijnen een identiek regime.

Het belang van de interpellatie als controlemiddel voor de Sénat is in de loop van de jaren, ondanks de introductie van het debat over Europa georiënteerde onderwerpen in 1991 sterk afgenomen, zoals duidelijk blijkt uit tabel 5.5.

De effectiviteit van het debat als uitvloeisel van mondelinge vragen wordt vooral door het formele verbod op stemmingen in de vorm van moties c.q. resoluties negatief beïnvloed. Parlementariërs pleegden in dat verband te spreken van 'messes sans communion". ${ }^{21}$ Resteren nog de 'questions d'actualité'. In navolging van het Britse House of Commonsmodel heeft de Sénat in 1982 besloten tot instelling van een dergelijk vragenuur. Twee maal per maand mogen de senatoren op individuele basis vragen stellen aan leden van de

113. J. Mastias, A Problem of Identity: The French Sénat, a.w., p. 182-183.

114. J.Cluzel, Le Sénat dans la société française, Paris 1990, p. 127-129.

115. Art. 77 lid 2 Règlement du Sénat.

116. J.Mastias et J. Grangé, a.w., p. 235.

117. Art. 78 lid 5 Règlement du Sénat. Hierin wijkt het reglement van orde van de Sénat af van het reglement van orde van de Assemblée nationale, waarin de mogelijkheid tot transformatie geheel ontbreekt.

118. Art. 82 lid 1 Règlement du Sénat.

119. Art. 29 bis Règlement du Sénat.

120. Art. 80 lid 2 Règlement du Sénat bepaalt dat de datum voor een debat op verzoek van minimal dertig senatoren vervroegd kan worden tot het moment dat de in behandeling zijnde onderwerpen van de 'ordre du jour prioritaire' zijn afgehandeld.

121. J. Mastias en J.Grangé, a.w., p.236. Tevens: J. Mastias, A Problem of Identity: The French Senate, a.w., p. 183-184. 
regering. De TV is daarbij present. De grootte van de politieke partijen wordt gewogen om te bepalen met welke frequentie vragen gesteld mogen worden door individuele representanten. Per uitzending worden maximaal 11 vragen gesteld. De vragensteller en de minister hebben ieder twee en een halve minuut spreektijd ter beschikking.

Het moge duidelijk zijn dat ook deze vorm van uitoefening van het parlementair vragenrecht geen bijzonder probaat middel van bestuurscontrole kan zijn. Politieke profilering lijkt hier van veel groter belang te zijn.

Tabel 5.5

\begin{tabular}{|c|c|c|c|c|}
\hline Periode & Question écrites & $\begin{array}{l}\text { Question orale } \\
\text { sans débat }\end{array}$ & $\begin{array}{l}\text { Question orale } \\
\text { avec débat }\end{array}$ & $\begin{array}{l}\text { Question orale } \\
\text { avec débat sur } \\
\text { sujets européens }\end{array}$ \\
\hline 1981 & 5244 & 214 & 42 & \\
\hline 1982 & 6011 & 140 & 39 & \\
\hline 1983 & 5179 & 136 & 47 & \\
\hline 1984 & 6420 & 135 & 89 & \\
\hline 1985 & 6417 & 158 & 76 & \\
\hline 1986 & 5111 & 145 & 30 & \\
\hline 1987 & 5168 & 142 & 46 & \\
\hline 1988 & 4415 & 53 & 10 & \\
\hline 1989 & 4802 & 126 & 34 & \\
\hline 1990 & 5414 & 108 & 16 & \\
\hline 1991 & 6168 & 112 & 22 & 3 \\
\hline 1992 & 4931 & 128 & 11 & 6 \\
\hline 1993 & 6381 & 91 & 10 & 6 \\
\hline 1994 & 5339 & 94 & 10 & 4 \\
\hline 1995 & 4034 & 58 & 5 & 3 \\
\hline 1996 & 5724 & 286 & 7 & 3 \\
\hline 1997 & 7927 & 273 & 2 & \\
\hline 1998 & 7282 & 264 & 8 & \\
\hline 1999 & 6801 & 262 & 11 & \\
\hline
\end{tabular}

Bron: http://cubitus. senat,friairs-cgi/questions.cgi, 14 december 1999

\subsubsection{Vaste kamercommissies}

De vaste kamercommissies van het Franse Hogerhuis ontplooien naast de reeds besproken wetgevingstaken zeker ook substantiěle activiteiten op het terrein van de bestuurscontrole: 'Indépendemment des autres dispositions les concernant, les commissions permanentes assurent l'information du Sénat pour lui permettre d'exercer, conformément á la Constitution son contrôle sur la politique du gouvernement . $^{123}$

Om te beginnen maken alle vaste commissies ruimschoots gebruik van de rechten tot het horen van ministers. Formele politiek-beleidsmatige begrenzingen betreffende de door de 
Sénat exploiteerbare terreinen zijn er nauwelijks. Mocht de informatie verkregen via hoorzittingen niet toerijkend bevonden worden, dan kunnen een of meerdere vaste senaatscommissies vervolgens besluiten tot het formeren van een 'mission d'information ${ }^{\text {'124 }}$, zeg maar een officięle sub-commissie die, nauwelijks gehinderd door formele beperkingen, nader onderzoek gaat verrichten naar het functioneren van de regering op een zo nauwkeurig mogelijk afgebakend beleidsterrein. Deze wijze van bestuurscontrole door de Sénat heeft de laatste twee decennia sterk aan populariteit gewonnen, niet in de laatste plaats omdat op deze wijze relatief eenvoudig meerdere senaatscommissies tegelijk kunnen participeren. In 1986 bijvoorbeeld werd een 'mission commune d'information' gelanceerd over telecommunicatie, waarbij alle zes vaste commissies betrokken waren. De grootste charme van deze wijze van werken schuilt voor de senatoren in de handelingsvrijheid. Geen tijdslimiet en geen strak juridisch kader. Onderzoek naar de implementatie van de Schengenakkoorden bijvoorbeeld duurde ruim twee jaar en leverde veel politiek gevoelige en derhalve publicitair belangrijke informatie op over drugstransporten tussen de lidstaten. ${ }^{125}$

Speciale faciliteiten ter controle van het regeringsbeleid heeft de 'commission des Finances'. De parlementaire budgetbewaking wordt getffectueerd door de rapporteurs van voornoemde commissie in beide Kamers. Deze rapporteurs kunnen te allen tijde de informatic opvragen die op enigerlei wijze gelieerd is met de overheidsfinanciēn. ${ }^{126}$ Dit betekent dat naast technische aspecten zeker ook politieke aspecten van bepaalde budgettair gelieerde beleidskeuzes onderwerp van onderzoek door rapporteurs uit het Hogerhuis uit zullen maken. Vooral tijdens die perioden dat de kleur van de politieke meerderheden der beide parlementskamers niet overeenkomt, komen partijpolitiek gestuurde controle-aktiviteiten door de rapporteurs van de 'commission des Finances' van de Sénat frequent voor. Veel effect gaat er als regel overigens niet van uit. ${ }^{127}$

\subsubsection{Het recht van enquête}

In de optiek van de Franse grondwetgever van 1958 diende het door beide parlementskamers uit te oefenen recht van enquête formeel strak ingekaderd te worden, opdat misbruik maken van dit recht door het parlement uit politiek opportunisme nauwelijks nog mogelijk zou kunnen zijn. Het 'parlementarisme' ten tijde van de 3e en 4e Republiek is daaraan vanzelfsprekend niet vreemd geweest. De ordonnance waarin het parlementair enquêterecht werd uitgewerkt verbood de vorming van enquêtecommissies in geval 'la gestion d'un service publique ou l'examen de faits particulièrement graves' tevens aanleiding gaf tot enige vorm van gerechtelijk onderzoek. ${ }^{128}$ Mocht een parlementskamer reeds besloten hebben tot installatie van een enquêtecommissie en wordt vervolgens pas een gerechtelijk vooronderzoek opgestart, dan dient de onderzoekscommissie in de regel per direct ontbonden te worden. Dit alles uiteraard met de bedoeling de onafhankelijkheid van de vervolgende autoriteiten zo optimaal mogelijk te kunnen garanderen. In de loop van de jaren is echter gebleken dat opstarten van een gerechtelijk vooronderzoek én installatie van

124. Art. 21 Règlement du Sénat.

125. http://www.senat. fr/presentation/livre4/livre44.html, 13-12-1999.

126. Paragraphe IV de I'article 164 de T'ordonnance du 31 décembre 1958.

127. J. Cluzel, a.w., p. 120 e.v.

128. Ordonnance nr. 58-1100, dd. 17-11-1958, art. 6. 
een parlementaire enquêtecommissie onder omstandigheden allerminst onmogelijk hoeft te zijn. De ramp met de olietanker 'Amoco Cadiz' voor de kust van Bretagne in 1978 bijvoorbeeld, vormde voor de Sénat de aanleiding voor het formeren van een 'commission d'enquête, die vervolgens voortvarend te werk ging, terwijl het Franse openbaar ministerie toch reeds een vooronderzoek bleek te hebben opgestart.

Tot 1991 kende het Franse staatsbestel twee verschillende mogelijkheden tot vorming van enquêtecommissies. Allereerst was daar de 'commission de contrôle', die zich met name pleegde te concentreren op onderzoek betreffende het beleid van overheidsinstellingen. ${ }^{129}$ De 'commision d'enquête' had tot taak serieuze feiten van algemenere aard te onderzoeken. Vanaf de wetswijziging van 1991 wordt echter geen onderscheid meer gehanteerd en kent de wet nog slechts de 'commission d'enquête', die bevoegd is om onderzoek te verrichten op alle voornoemde terreinen. ${ }^{130}$ Een onderzoek mag maximaal zes maanden in beslag nemen, waarna een eindrapport voorgelegd dient te worden aan de parlementskamer die tot instelling van de enquêtecommissie heeft besloten.

De commissies (maximaal 21 leden) worden samengesteld op basis van evenredigheid, hetgeen impliceert dat de bestaande partijpolitieke verhoudingen gerespecteerd worden. ${ }^{131}$

De bevoegdheden van de parlementaire enquêtecommissies zijn aanzienlijk. In principe dient alle denkbare informatie waaraan de commissie behoefte heeft verstrekt te worden. Uitzondering op deze regel kan slechts gemaakt worden voor overheidsdocumenten 'd'un caractère secret et concernant la Défense nationale, les Affaires étrangère et la Sécurité intérieure ou extérieure'. Dagvaarding behoort tot de mogelijkheden. Personen die in de optiek van de commissie gehoord dienen te worden, kunnen daartoe gedwongen worden. Het horen van getuigen (al dan niet onder ede) behoort eveneens tot het arsenaal dat de enquêtecommissie ter beschikking staat. ${ }^{132}$ Het zal in het licht van hetgeen reeds gememoreerd is over de relatief sterke politisering van de Franse parlementaire instituties nauwelijks bevreemding wekken dat de inzet van het recht van enquête door de Sénat ten tijde van divergerende meerderheden in de beide parlementskamers frequenter gehanteerd wordt dan wanneer Assemblée natonale, regering en Sénat partijpolitiek op een lijn zitten. Het is zelfs meerdere keren voorgekomen dat de Assemblée nationale en de Sénat (ieder vanuit het eigen politieke gezichtsveld) tegelijkertijd een 'commission d'enquête' installeerden om onderzoek te doen naar hetzelfde onderwerp. ${ }^{133}$ Tijdens de politiek 'heftige' periode 19811985 werden evenveel onderzoeken geëntameerd door het Franse Hogerhuis als tijdens de 14 jaar die daaraan vooraf gingen. ${ }^{134}$ Hier valt te denken aan onderzock naar de nationalisatie van ondernemingen, het beleid van de SNCF (Spoorwegen) en de wijze waarop de posterijen functioneerden.

129. Een redelijke vermaardheid kregen dergelijke onderzoekscommissies niet in de laatste plaats omdat de onderzoeksobjecten veelal in de overzeese gebiedsdelen gesitueerd waren, hetgeen onder meer het ontstaan van de benaming 'commission touristique' tot gevolg had.

130. Loi nr. 91-698 du 20 juillet 1991.

131. Art. 11 lid 1 et 2 Reglement du Sénat.

132. Loi $77-807$ du 19 juillet 1977

133. J. Mastias, A Problem of Identity: The French Sénat, a.w., p. 184.

134. Mastias en J. Grangé, a.w., p.236 en 237. Overigens betrof het hier naast onderzoeken van een 'commission d'enquète' ook onderzoeken van diverse 'commissions de contröle', alsmede éen 'mission d'information' en én 'groupe d'étude'. 
Ook heden ten dage maakt de Franse senaatskamer in het kader van de bestuurscontrole nog steeds met regelmaat gebruik van het recht van enquête. In de periode 1998-2000 werd een vijftal onderzoeken afgerond over de veiligheidspolitiek aangaande Corsica, het onderwijsbeleid, het energiebeleid, het asielbeleid en de infrastructuur in relatie tot de ontwikkelingen in de communicatietechnologie. ${ }^{135}$ De politicke lading van de enquêterapporten is in de loop der jaren wel minder geworden ter faveure van de zuivere informatievergaring. ${ }^{136}$ Onder het regime van de 5e Republiek is, zeker indien dit afgezet wordt tegen bijvoorbeeld het volledige onbenut laten van het recht van enquête door de Nederlandse Eerste Kamer, met zekere regelmaat door de Sénat gebruik gemaakt van het parlementaire recht op zelfstandig onderzoek. Sinds 1958 werd 54 maal een Commission d'enquête en 13 maal een Commission de controle door het Franse Hogerhuis in het leven geroepen. ${ }^{137}$ Het effect van de enquêtes is over het algemeen beperkt gebleven. Debet daaraan is zeker niet in de laatste plaats het gegeven geweest, dat het middel door de Franse senaatskamer wellicht iets te vaak is ingezet om de zittende regering in verlegenheid te brengen ${ }^{138}$

\subsubsection{Délégations}

Evenals het Britse House of Lords is de Franse Sénat zich naast haar taak als bestuurscontroleur sinds een drietal decennia ook meer en meer gaan toeleggen op vormen van gespecialiseerde informatieverschaffing aan parlement en regering, gecombineerd met permanent toezicht op de gang der ontwikkelingen aangaande een aantal complexere (beleids) terreinen die de Franse overheid als belangrijk kwalificeert. Dit alles wordt geëffectueerd via zgn. 'delegations' van afgevaardigden, materieel nauwelijks te onderscheiden van de vaste kamercommissies ex art. 43 Grondwet. Het grote verschil zit in het gegeven dat de delegaties niet rechtstreeks ingrijpen in het wetgevingsproces. Maar daarover zo dadelijk meer.

Veruit de meest prestigieuze permanente afvaardiging is de naar Brits voorbeeld opgestarte 'délégation du Sénat pour l'union Européene'. Deze is ingesteld in $1979^{139}$ en sindsdien voortdurend actiever geworden. Na aanname van de Europese Acte in 1987 werd dan ook besloten het aantal leden van de delegatie te verdubbelen ${ }^{140}$. Het Verdrag van Maastricht heeft tot gevolg gehad dat de permanente senaatsafvaardiging voor de Europese Unie zich ook diende te gaan concentreren op de ontwikkelingen vallend onder de tweede en derde pijler van de EU. ${ }^{141}$ De hoofddoelstelling van de delegatie is sindsdien als volgt gecodificeerd: 'suivre les travaux conduits par les instititions de l'Union européene'. Zowel de vaste kamercommissies als de regering kunnen gebruik maken van de opgebouwde expertise. Het spreekt vanzelf dat aan dergelijke expertise met name ook vanuit regeringskringen grote behoefte bestaat in een tijdperk dat aanpassing van nationale wetgeving aan door de Gemeenschap uitgevaardigde richtlijnen en andere vormen van regelgeving voortdurend terugkerende realiteit is geworden. Speciale aandacht verdient in dat kader art. 88 lid 4

135. http://cubitus.senat. fr/commission/enquete/index.html. dd. 21-3-2001.

136. J. Mastias, A Problem of Identity: The French Sénat, a.w., p. 184.

137. http://cubitus.senat.fr/commission/enquete/index.html. 21-3-2001.

138. J. Mastias, A Problem of Identity: The French Sénat, a.w., p. 184.

139. Loi nr. 79-564 du 6 juillet 1979.

140. Loi nr. $90-385$ du 10 mai 1990 . Het aantal ging van 18 naar 36 .

141. Loi nr. 94-476 du 10 juin 1994. 
Grondwet, toegevoegd als gevolg van de grondwetsherziening van 1992: 'Le Gouvernement soumet à l'Assemblée nationale et au Sénat, dès leur transmission au Conseil de l'Union européenne, les propositions d'actes des Communautés européenne et de l'Union européenne comportant des disposition de nature législative'.

De Franse wetgever heeft ter nadere concretisering van de bedoelingen van dit grondwetsartikel cen belangrijke taak toebedeeld aan een 'délégation pour l'Union'. Voorstellen tot besluitvorming van wetgevende aard vanuit de Gemeenschap dienen door de Franse regering bij het Bureau van de Sénat gedeponeerd te worden, waarna de 'délégation du Sénat pour les Communautés européennes' deze bekijkt en indien noodzakelijk verder bestudeert. $^{142}$ Als direct gevolg van deze studie kunnen concept voorstellen neergelegd worden bij een der vaste senaatscommissies, die beziet of overname van de ideeën neergelegd in voornoemde concepten wenselijk is. Mocht de vaste senaatscommissie inderdaad menen dat de voorstellen van de delegatie hout snijden, dan worden de resoluties geformaliseerd. ${ }^{143}$ Dit laatste kan overigens ook nog door de Sénat in plenaire zitting besloten worden. Aangenomen resoluties betreffende voorstellen van wetgevende aard vanuit de EG en EU worden tenslotte voorgelegd aan de regering en de Assemblée nationale. ${ }^{144}$

Tabel 5.6

\begin{tabular}{|l|c|c|c|c|c|c|c|c|c|}
\hline & $I 992$ & $I 993$ & 1994 & $I 995$ & 1996 & 1997 & 1998 & 1999 & 2000 \\
\hline $\begin{array}{l}\text { Voorstellen van } \\
\text { wetgevende } \\
\text { aard EU }\end{array}$ & 40 & 143 & 171 & 206 & 201 & 231 & 206 & 181 & 253 \\
\hline $\begin{array}{l}\text { Concept- } \\
\text { resoluties } \\
\text { delegation }\end{array}$ & - & 19 & 20 & 16 & 16 & 5 & 9 & 15 & 15 \\
\hline $\begin{array}{l}\text { Gedeponeerd } \\
\text { bij de Sénat }\end{array}$ & - & 18 & 27 & 16 & 19 & 9 & 13 & 16 & 14 \\
\hline $\begin{array}{l}\text { Aangenomen } \\
\text { door de Sénat }\end{array}$ & - & 7 & 13 & 9 & 13 & 3 & 9 & 12 & 4 \\
\hline \begin{tabular}{l} 
Plenair \\
\hline Via vaste
\end{tabular} & - & 3 & 5 & 5 & 4 & 1 & 1 & 2 & 1 \\
\hline commissic & - & 8 & 4 & 9 & 2 & 8 & 10 & 3 \\
\hline
\end{tabular}

Bron: http://cubitus.senat.fn'europe/dpue-bilan.html, I november 2001

Uit bovenstaande gegevens kan in ieder geval de conclusie getrokken worden dat de Sénat via de 'délégation pour l'Union européenne' in relatief constante mate enige invloed probeert uit te oefenen op de uiteindelijke regelgevende besluitvorming van de Raad van Ministers.

Opdat de senaatsdelegatie voor Europese aangelegenheden zo optimaal mogelijk kan functioneren vergaart zij (via de regering) alle beschikbare informatie over ontwikkelingen

142. Art. 73bis Règlement du Sènat.

143. Art. 73 bis- 8 Règlement du Sénat.

144. Art. 73bis-11 Reglement du Senat. 
binnen alle drie de pijlers van de EU. Per jaar komt de delegatie gemiddeld ongeveer 30 maal bij elkaar. Er worden zeer regelmatig hoorzittingen georganiseerd om door ministers en ambtenaren op de hoogte te worden gebracht van EU-gerelateerde ontwikkelingen. Per jaar verschijnen een redelijk aantal door de delegatie samengestelde 'rapports d'information' over een veelheid aan Europese onderwerpen variërend van de invoering van de euro $^{145}$ tot de toepassing van het subsidiariteitsbeginsel. ${ }^{146}$ In totaal werden sinds 1990114 rapporten gepubliceerd. ${ }^{\text {977 }}$ Evenals in Groot-Brittanniê kunnen ook in Frankrijk de uitkomsten van dit soort semi-zelfstandige onderzoekingen vanuit de gelederen der senaat een zekere impact hebben op toekomstig regeringsbeleid. Daarvoor is wel van groot belang dat de uitkomsten zorgvuldig geformuleerd zijn en niet-partijgebonden tot stand blijken te zijn gekomen. Over het algemeen blijkt aan die eisen tegenwoordig goed voldaan te kunnen worden. ${ }^{148}$

De 'délégation pour l'Union européenne' is zeker niet het enige nieuwe parlementaire onderzoeksorgaan dat gecreeerd werd tijdens de laatste drie decennia. Als typisch Frans kan men de stichting in 1979 van een 'délégation parlementaire pour les problèmes démographiques' karakteriseren. Omdat de groei van de Franse bevolking al decennia lang structureel achterbleef bij de ontwikkelingen dienaangaande in andere politick toonaangevende West-Europese landen, wenste beide parlementskamers regelmatig op de hoogte gehouden te worden van alle beleidsontwikkelingen die samenhang vertoonden met c.q. invloed uitoefenden op de problematiek van de bevolkingsaanwas. Pas nadat begin 90er-jaren was gebleken dat de programma's ter stimulering van de geboorteaanwas structureel vruchten af gingen werpen, heeft deze delegation haar onderzoeks-en contrôle-aktiviteiten opgeschort. Omdat de Franse parlementskamers begin 80er jaren tot de conclusie kwamen dat zij met enige regelmaat over te weinig informatie en know-how beschikten om tot verantwoorde besluitvorming over te kunnen gaan betreffende zaken van specifiek wetenschappelijke en technische aard, werd besloten een 'office parlementaire d'évaluation des choix scientifiques et technologiques' te creëeren. ${ }^{149}$ Het 'office' werkt ten behoeve van beide parlementskamers gezamenlijk. De samenstelling is dienovereenkomstig paritair, rekening houdend met de partijpolitieke verhoudingen van het moment in zowel de Assemblée nationale als de Sénat. ${ }^{150}$ Het hoofddoel van het 'office' zoals vastgesteld door de wetgever is: 'd'informer le Parlement des conséquences des choix de caractère scientifique et technologique afin notamment d'éclairer ses décisions'. De expertise van het 'office' wordt met enige regelmaat ingeroepen door met name de vaste kamercommissies en in iets mindere mate door de bureau's van de Assemblée nationale en de Sénat. Van belang tijdens het afgelopen decennium bleken onder andere een drietal rapporten over de veiligheidsaspecten bij kerncentrales, een rapport over de ontwikkeling van de informatiemaatschappij en een onderzoek naar het stimuleren van research-programma's te zijn geweest. ${ }^{151}$

145. Rapport nr. 388, 27 mai 1999.

146. Rapport nr. 46, 23 octobre 1996.

147. http://www.senat. fr/europe/rap90-96.html alsmede http://www.senat.fr/europe/rap.html, dd. 29-3-2000.

148. J. Mastias, A Problem of Identity: The French Sénat, a.w., p. 183-185.

149. Loi $\mathrm{nr} .83-606$ du 9 juillet 1983.

150. In de praktijk hebben acht leden uit ieder der parlementskamers ambtshalve zitting. Omdat de samenstelling partijpolitiek volledig dient te sporen met de samenstelling van beide parlementskamers, worden bovenop de zestien permanente leden naar behoefte tijdelijke leden benoemd.

151. http:/www.senat. fr/presentation/livre4/livre46.html, 13-12-1999. 


\subsection{Balans bestuurscontrole}

Ook in Frankrijk dient de portee van bestuurscontrole door de senaatskamer niet overschat te worden. Politieke ministeriële verantwoordelijkheid blijkt in de relatie regering-Sénat in feite niet sanctioneerbaar te zijn. Een vorm van algemeen vertrouwen in het regeringsbeleid kán, uitsluitend op verzoek van de regering zelf, uitgesproken worden door het Hogerhuis. Van het vragenrecht, zeker het schriftelijk vragenrecht, wordt door de senatoren in Frankrijk vrij veel gebruik gemaakt. Ter signalering van een waar scala aan hedendaagse (regionale) problemen een probaat middel, doch ter controle van het handelen van de centrale overheid weinig effectief.

Zeker niet onbelangrijk daarentegen lijken in het kader van de bestuurscontrole de diverse wijzen van informatieverkrijging te zijn. Via de 'mission d'information', de commission d'enquête maar tegenwoordig vooral de permanente 'délégations' wordt op grote schaal relevante informatie verzameld én gepubliceerd. Informatie die posterieur (semi-)overheidshandelen kritisch becommentarieert of anterieur relevante (o.a. Europeesrechtelijke) ontwikkelingslijnen schetst. Naar mate de (in meerderheid altijd centrumrechtse) Sénat beter weerstand kan bieden aan de neiging om partijgebonden onderzoek te verrichten, blijkt voor de door de Franse senatoren op een aantal specifieke beleidsterreinen opgebouwde expertise ook meer belangstelling te bestaan vanuit regeringskringen. 


\section{Nederland, wetgeving en bestuurscontrole}

\subsection{Inleiding}

De laatste jaren is in Nederiand veel onderzoek verricht naar positie en functioneren van de Eerste Kamer. In 1998 verscheen cen dissertatie die met name de geschiedenis van de Nederlandse senaatskamer tot onderwerp had.' In $2000 \mathrm{kwam}$ daar nog een tweede dissertatie bij, waarin de specifiek staatsrechtelijke positie van de Eerste Kamer uitvoerig beschreven werd. ${ }^{2}$ Een rechtsvergelijkend onderzoek, waarin het functioneren van een viertal West Europese senaatskamers (waaronder de Eerste Kamer) centraal staat, kan dan natururlijk mooi als sluitstuk van een samenhangende trilogie beschouwd worden. Daar komt bij dat in dit onderzock de staatsrechtelijke positie van de senaatskamer natuurlijk niet los geweekt kan worden van de politicke praktijk. Als wij praten over het functioneren van senaatskamers zijn staatsrecht en politiek immers onder alle omstandigheden onverbrekelijk met elkaar verbonden. Tegelijkertijd moet in dat kader echter ook opgemerkt worden dat voortdurende herhaling van zetten in dit derde proefschrift dat de Nederlandse senaatskamer (mede) tot onderwerp heeft, zo veel mogelijk voorkomen dient te worden. Het is die wetenschap die mij vanzelfsprekend noopt om de beschrijving van de wijze waarop de Nederlandse Eerste Kamer uitvoering pleegt te geven aan haar medewetgevend en bestuurscontrolerend takenpakket bondig te houden.

Een beschrijving van de wijze waarop de Nederlandse senaatskamer pleegt te functioneren in het kader van het wetgevingsproces in formele zin heeft een geheel ander karakter dan de beschrijving van de wijze waarop het House of Lords, de Sénat en de Bundesrat participeren in het legislatieve proces. De reden ligt voor de hand: als enige van de vier senaatskamers die tot onderwerp van deze studie gemaakt zijn, krijgt de Eerste Kamer pas de mogelijkheid om zich te buigen over het wetgevingsproduct in wording nadat het wetgevingsproces in materiêle zin al afgerond is. Zij mag dan vervolgens, althans naar de letter, slechts het geheel aannemen of verwerpen. Dienaangaande laat art. 85 jo art.81 Grondwet geen ruimte voor twijfel. De parlementaire praktijk blijkt tegenwoordig echter toch iets minder rigide ingekleurd te worden. Af en toe slaagt de Nederlandse senaatskamer er in aan (vorm en/of inhoud) van een wettekst te 'knabbelen', zonder dat dit verwerping tot gevolg heeft.

Dit proces van 'knabbelen' zal door mij, nadat de positie van de Nederlandse senaatskamer in het legislatieve proces globaal geduid is, als eerste beschreven worden. Vooral de novelle, maar ook de toezegging, de motie en de intrekking zullen aan de orde gesteld worden. Nadat vervolgens eerst enige noodzakelijke opmerkingen over het functioneren van het commissiestelsel gemaakt zijn, wordt de aandacht verplaatst naar het recht tot verwerpen van alle wetsvoorstellen in formele zin zélf. Hoe functioneert dit recht? In het kader van de beschouwingen uit hoofdstuk 3 werd reeds kort stilgestaan bij de vraag in hoeverre er in de praktijk

1. B. van den Braak, De Eerste Kamer, Geschiedenis, samenstelling en betekenis 1815-1995, Den Haag 1998.

2. F. de Vries, De staatsrechtelijke positie van de Eerste Kamer, dissertatie, Serie monografieên Nederlands Parlementsrecht nr. 9, Deventer 2000. 
sprake lijkt te zijn van zowel een juridisch/theoretisch aanwezige als een politiek/praktisch effectueerbare vertrouwensrelatie tussen regering en Eerste Kamer. Deze kwestie blijkt alleszins van belang te kunnen zijn voor de wijze waarop het vetorecht in handen van de Eerste Kamer functioneert. Een bespreking van de wijze waarop deze vertrouwensregel in Nederland in de relatie tussen senaatskamer en regering 'aanwezig' is, fungeert daarom als brug naar een slotbeschouwing over het hedendaagse politick-praktische medewetgevend functioneren van de Nederlandse senaatskamer. In de laatste paragraaf van dit hoofdstuk tenslotte, zal aandacht besteed worden aan de wijze waarop de Eerste Kamer invulling blijkt te geven aan het bestuurscontrolerend takenpakket.

\subsection{Achteraan in de rij}

De staatsrechtelijke positie van waanit de Nederlandse Senaat moet manoeuvreren in het formele wetgevingsproces wijkt in vergelijking tot de situatie dienaangaande in zowel Frankrijk, Duitsland als Groot-Brittanniè zoals gezegd substantieel af. Wetsvoorstellen kunnen in Nederland nooit en te nimmer geïnitieerd worden vanuit de senaatskamer. Artikel 82 Grondwet laat daarover geen onduidelijkheid bestaan: 'Voorstellen van wet kunnen worden ingediend door of vanwege de Koning en door de Tweede Kamer der Staten-Generaal'. Weliswaar is in de 'Proeve van een nieuwe Grondwet' ook gespeeld met de gedachte het recht van initiatief aan de Eerste Kamer toe te kennen, doch nader uitgewerkt en uiteindelijk geconcretiseerd is dit voorstel nooit. ${ }^{3}$

De impact van het formele gemis van een recht van initiatief voor de Eerste Kamer wordt echter overtroffen door het gemis van een recht van amendement. Amendering van wetgevingsvoorstellen behoort immers evenmin tot het instrumentarium dat de Eerste Kamer bij de wetgevingswerkzaamheden mag hanteren. ${ }^{4}$ Tijdens de debatten rondom de grondwetsherziening van 1840 werd onder andere aan dat thema al de volgende fraaie, kernachtige en daarom sindsdien voortdurend geciteerde passage uit een regeringsantwoord gewijd: 'De Eerste Kamer is niet een uit eigen beweging handelend, zij is slechts een onderzoekend en oordelend lid der wetgevende magt. De Eerste Kamer is niet ingesteld om artikel voor artikel de wetten te onderzoeken, maar om de groote beginselen te handhaven, om te waken tegen overijling en dwaling, om aan driften heilzame palen te stellen en den Troon tot een bolwerk te strekken'.

Zelfs nadat in het kader van de belangrijke grondwetsherziening van 1917 (algemeen kiesrecht) de vereisten voor het lidmaatschap van de twee Nederlandse parlementskamers gelijkgesteld waren, is voornoemd uitgangspunt aangaande een verbod tot hantering van het recht van amendement door de Eerste Kamer niet veranderd. Dat is opmerkelijk te noemen, omdat de Nederlandse senaatskamer als gevolg van voornoemde grondwetsherziening wel definitief op zoek moest naar een formeel nieuwe taakstelling. De Vries schetst deze belangrijke fase als volgt: 'In beide kamers werd vanaf dat moment op precies dezelfde manier en in dezelfde mate invulling gegeven aan de grondwettelijk verankerde vertegenwoordigingsopdracht. De oordeelsvorming van de Eerste Kamer kon derhalve niet langer gericht zijn tegen de besluit-

3. Proeve van een nieuwe Grondwet, Ministerie van Binnenlandse Zaken, Den Haag 1966, art. 57.

4. Art. 84 lid 1 jo art. 85 Grondwet.

5. Handelingen 1839-1840, bijlage XVIII. 
vorming door de Tweede Kamer. Zij ging een zelfstandig karakter dragen. Het fundament voor de heroverwegende taak van de Eerste Kamer was gelegd. De 'chambre de réflection' was geboren'. ${ }^{6}$ Hoewel gedeeltelijk correct behoeft deze visie van de Vries toch enige nadere nuancering. De Eerste Kamer is, althans op het terrein van de (mede)wetgeving, bij gebreke van de rechten van initiatief en amendement, immers nooit formeel in staat gesteld om op dezelfde wijze als de Tweede Kamer invulling te geven aan de door de grondwetgever verstrekte vertegenwoordigingsopdracht.

$\mathrm{Na} 1917$ functioneerde weliswaar een herzieningskamer die kon bogen op een vrij stevig kiezersmandaat (zij het zwakker dan het kiezersmandaat van de Tweede Kamer), doch tegelijkertijd kon vastgesteld worden dat de Eerste Kamer deugdelijke instrumenten ter herziening van voorstellen tot wetgeving in formele zin grotendeels moest ontberen. Een hoogst ongelukkige situatie voor een 'chambre de réflexion', zo lijkt toch ook de Vries te concluderen: 'De kamer is gedwongen haar heroverwegende rol te vervullen op basis van (beperkte) bevoegdheden die veeleer passen bij een kamer die de Tweede Kamer in de teugels moct houden, dan bij een huis dat aan het wetgevingsproces iets zou moeten toevoegen'.' Een situatie, die de Eerste Kamer in de loop de jaren dan ook heeft aangezet tot het (beperkt) creěren en hanteren van andere 'middelen' dan het recht van amendement ter eventuele (particle) bijsturing van voorliggende voorstellen tot wet. Middelen die tot gemecnschappelijk doel hebben, de heroverwegingtaak van de Nederlandse senaatskamer in voorkomende gevallen toch iets minder robuust te laten functioneren, dan mogelijk is via het allesomvattende ' ja' of 'neen' ex art. 85 jo 81 Grondwet.

Dat heroverweging van de voorstellen tot wet in formele zin geen sinecure is, werd al duidelijk tijdens de bespreking van de Britse en Franse bicamerale wetgevingspraktijk. En ook het takenpakket voor de Nederlandse senaatskamer in deze is indrukwekkend: specifieke aandacht voor aspecten van rechtstatelijkheid, toetsing aan rechtsbeginselen, toetsing aan de constitutie, controle op juridisch-technische aspecten, consistentie, relatie tot het internationale recht, meer specifiek strijdigheid met verdragsteksten, maatschappelijk draagvlak, uitvoerbaarheid. ${ }^{8}$ In geval de Eerste Kamer op basis van een of meerdere van deze toetscriteria op legislatieve omissies stuit, lijkt actie natuurlijk geboden. Maar welke?

In de nu volgende paragrafen zal kort beschreven op welke wijze en in welke mate de Nederlandse senaatskamer in de parlementaire praktijk eventuele bijsturing in 'finale instantie' van voorstellen tot wet in formele zin handen en voeten blijkt te (kunnen) geven.

6. F. de Vries, Het Nederiandse tweekamerstelsel: over de plaats van de Eerste Kamer, NJB 26-10-2001, p. 1928.

7. Idem.

8. Zie o.a. H. Kummeling. Preadvies, De Nederlandse Eerste Kamer, Zwolle 1992, p.58 en B. van den Braak, De Eerste Kamer, Geschiedenis, samenstelling en betekenis 1815-1995, Den Haag 1998, p. 451. B. de Gaay Fortman, Parlement en wetgeving, in: W.F. de Gaay Fortman (red), Problemen van wetgeving, Deventer 1982, p.60; De Vries, NJB 2001, a.w., p. 1829. 


\subsection{Bijsturingsinstrumenten}

\subsubsection{De Novelle}

Het gegeven dat via de Nederlandse Grondwet alleen de Tweede Kamer een recht van amendement toekomt, heeft ontegenzeggelijk invloed gehad op de ontwikkeling via de politieke praktijk aan de overzijde van het Binnenhof van een nouveauté die luistert naar de benaming 'novelle'. ${ }^{9}$ Wat is een novelle? Stel dat de Eerste Kamer niet geheel tevreden is over een of meerdere specifieke onderdelen van een wetsvoorstel, zoals aangenomen door de Tweede Kamer. Die onvrede kan zowel juridisch-dogmatisch als politiek-inhoudelijk van aard zijn. In beide gevallen is het natuurlijk goed denkbaar dat de Senaat het wetsvoorstel wenst te wijzigen en totale verwerping niet opportuun acht. In de Nederlandse parlementaire praktijk is voor dat probleem, bij afwezigheid van een recht van amendement, door de politiek zelf een oplossing ontwikkeld. De Eerste Kamer claimt sinds 1967 van de vorige eeuw namelijk de mogelijkheid, onder aanhouding (en impliciete dreiging van verwerping) van een wetsvoorstel dat partieel gewijzigd moet worden in de optiek der senatoren, om de indiener informeel te verzocken een voorstel tot wetswijziging in te dienen. Indien de bewindsman/vrouw een dergelijke 'verzoek' gestand wenst te doen, doorloopt het door de regering ingediende wijzigingsvoorstel vervolgens het volledige wetgevingstraject en wordt, aangekomen bij de Eerste Kamer, gelijktijdig met het aangehouden oorspronkelijke (gedeeltelijk aan te passen) wetsvoorstel aangenomen. ${ }^{10}$

Naast deze 'zware vorm' waarin het instrument novelle door de senaatskamer gehanteerd wordt, blijkt er in de Nederlandse parlementaire praktijk ook gebruik gemaakt te worden van een lichtere variant. Het is aan het Haagse Binnenhof namelijk ook mogelijk gebleken dat de senaatskamer het onderhavige, partieel bekritiseerde wetsvoorstel gewoon aanvaardt, waarna bekendmaking en inwerkingtreding vervolgens uit blijven totdat het wijzigingsvoorstel eveneens in werking kan treden. Binnen de Nederlandse staatsrechtelijke doctrine is geen eensgezindheid over de reikwijdte van het begrip 'novelle'. Een aantal schrijvers meent dat slechts de zware vorm onder de definitie dient te vallen, omdat (ten gevolge van de aanhouding) slechts in dat geval sprake zal zijn van een formeel afwijkende wetgevingsprocedure. ${ }^{11}$ Mijn insteek aangaande de reikwijdte van het begrip novelle is minder formalistisch, resultaatgerichter van aard. In beide gevallen initieert de regering, als een rechtstreeks gevolg van de aandrang daartoe vanuit de Eerste Kamer, een wetswijzigingsvoorstel, dat tegelijkertijd met het gewraakte oorspronkelijke voorstel tot wet in werking zal moeten treden. Een wetswijziging daarenboven die rechtstreeks in relatie staat tot het oorspronkelijke wetsvoorstel zoals aangeboden aan de Nederlandse senaatskamer.

Een elegante oplossing trouwens die 'novelle', zo lijkt het, nu het formeel de indiener van het wetsvoorstel is en niet de Senaat, die het initiatief tot wetswijziging neemt. Grondwettelijke bezwaren worden omzeild en de Eerste Kamer kan via deze vondst enige bijsturing van wetsvoorstellen realiseren. Bijsturing die qua praktisch politiek resultaat hoe dan ook bijzonder

9. H. Bevers, Nieuws over de novelle, Tijdschrift voor beleidswetenschappen en publickrecht 1989, p.391-408.

10. A.W. Heringa e.a., De Nederlandse Grondwet, Zwolle 1983, p. 141-143.

11. Zie onder andere: F, de Vries, De staatsrechtelijke positie van de Eerste Kamer, dissertatie, Deventer 2000. p. 187-189. 
veel overeenkomst vertoont met de neerslag van succesvolle amendementen (vanuit de Tweede Kamer). Dien ten gevolge valt dan ook niet te ontkennen dat de novellepraktijk op enigszins gespannen voet staat met art. 85 Grondwet ('... die het voorstel overweegt zoals het door de Tweede Kamer aan haar is gezonden'). Het wetsontwerp tot wijziging van de Machtigingswet in 1974 gaf al eens aanleiding tot pittige discussies over dit onderwerp, uiteindelijk uitmondend in een advies van de Raad van State. Dit college billijkte de ontstane praktijk, maar benadrukte tegelijkertijd dat het bevorderen van novelles tijdens het wetgevingsproces wel uitzondering moest blijven. ${ }^{12}$ Van een verkapt recht van amendement was volgens de Raad van State geen sprake. ${ }^{13}$ Hoe juridisch correct deze visie ook moge zijn, in de politicke praktijk is uiteraard wel degelijk sprake van onvervalste amendering van een wetsvoorstel.

\subsubsection{Novellepraktijk}

Novelles blijken, geheel in de geest van het advies van de Raad van State, inderdaad vaak politiek niet geladen juridisch-technische aspecten van wetgeving te betreffen.

Sinds 1967 is in $\mathbf{4 3}$ gevallen met uiteindelijk succes een novelle van niet-inhoudelijke ofwel corrigerende aard bevorderd. ${ }^{14}$ Daar waar het indienen van novelles politicke spanning met regering en/of Tweede Kamer kan veroorzaken, blijkt terughoudendheid over het algemeen in de rede te liggen. In een beperkt aantal gevallen echter ( 23 maal tussen $1974 \mathrm{en} 2001^{15}$ ) heeft de Nederlandse Senaat tot nu toe via de novelleconstructie met succes inhoudelijk invloed uit weten te oefenen op voorliggende wetsontwerpen. Deze novellevorm is natuurlijk met name interessant, omdat uitoefening ervan het intrinsieke spanningsveld tussen enerzijds de formele afwezigheid van een recht van amendement voor de Eerste Kamer en anderzijds een praktijk van wetsaanpassing van inhoudelijke aard door de Eerste Kamer omwille van politieke opportuniteit, behoorlijk kan oprekken. Tijdens het laatste decennium wist de Eerste Kamer in precies tien gevallen een dergelijke novelle door te drukken. Gemiddeld één inhoudelijke novelle per jaar dus. Van frequent gebruik kan derhalve beslist niet gesproken worden, eerder van terughoudendheid. ${ }^{16}$

Ik voeg met het doel een en ander volledig in het juiste perspectief te kunnen plaatsen nog enige supplementaire kwantitatieve gegevens toe. Van de 4439 wetsvoorstellen die de Eerste Kamer zijn gepasseerd in de periode 1983-2000, werden er 20 inhoudelijk aangepast door middel van een novelle. Anders gezegd, op $0,105 \%$ van alle voorstellen tot wet in formele zin die tijdens voornoemde periode behandeld werden, heeft de Nederlandse senaatskamer inhoudelijk invloed uit weten te oefenen via de novelleconstructie. ${ }^{17}$ Zeker niet in de laatste plaats bleek dit overigens te gebeuren wanneer de bescherming van de eigen positie in het geding was. ${ }^{18}$ Ombuiging van hoofdlijnen van wetsvoorstellen door de Eerste Kamer via de novelle blijkt in de praktijk niet voor te komen. ${ }^{19}$

12. Kamerstukken 12.723 en 12.917. Zie ook: T.H. Kerkhofs, Het recht van amendement, in: H.M. Franssen (red), Het parlement in aktic, Assen 1986, p. 96.

13. Zo ook: F. de Vries, dissertatie, a.w., p. 206 e.v. Aangezien de Eerste Kamer niet kan eisen doch slechts kan verzoeken en slechts de regering kan beslissen, zal van een verkapt recht van amendement zijns inziens nooit sprake kunnen zijn.

14. http://www.eerstekamer.nl/cgi-bin/pdesns.cgi?user $=\% 26$ dir $=/ 9202000.6-11-2001$.

15. Idem.

16. In die zin ook: F. de Vries, dissertatic, a.w., p. 203.

17. Kamerstukken Eerste Kamer 2000-2001 26976, nr. 175a.

18. Zoals bij de introductie van Planologische Kernbeslissingen in het kader van de wijziging van de Wet op de 
De novellepraktijk is, zoals gezegd, ontstaan in $19677^{20}$ De eerste novelle betrof een aanvulling van het Wetboek van strafvordering. Tussen 1967 en september 2001 werd de novelle 66 maal in stelling gebracht. ${ }^{21}$ Slechts in 46 gevallen echter, kon het initiatief tot het indienen van een wijzigingsvoorstel tenuggevoerd worden tot specifieke legislatieve actie vanuit de Nederlandse senaatskamer. In de overige 20 gevallen bleek de regering én niet de Eerste Kamer tevens materieel de initiatiefnemer te zijn. Ook de regering namelijk, blijkt de novelle af en toe als een politiek-strategisch juridisch instrument te hanteren ter nadere modellering van voorliggende wetsontwerpen. Een bekend geval deed zich voor ten tijde van het kabinet Den Uyl. De regering poogde onwelgevallige plooien (lees: onwelgevallige amendering door de Tweede Kamer) in een voorstel tot wet dat het grondwater tot onderwerp had, glad te strijken via het indienen van een novelle. ${ }^{22}$ Deze novelle werd vervolgens overigens dusdanig grondig geamendeerd door de Tweede Kamer, dat het door de regering beoogde effect volledig te niet werd gedaan.

Tevens is het reeds meerdere malen voorgekomen dat novelles het directe gevolg zijn van een proces dat omschreven zou kunnen worden als een 'logistiek bepaald een-tweetje' tussen regering en Eerste Kamer. Deze uitspraak vraagt uiteraard om nadere toelichting. Tussen de behandeling van een voorstel tot wet in de Tweede Kamer en de Eerste Kamer kan de nodige tijd verstrijken. Totaal anders dan in Groot-Brittanniě, waar zoals wij gezien hebben ieder wetsvoorstel dat op het einde van het parlementaire jaar nog geen 'Royal Assent' heeft verkregen van rechtswege vervalt, kan een wetsvoorstel afkomstig van de formele wetgever in Nederland na afronding van de behandeling in de Tweede Kamer (meerdere jaren) vertraging oplopen zonder dat hierdoor het wetgevingsproces aangaande dat specifieke voorstel definitief afgebroken hoeft te worden. Indien nu in een reeds door de Tweede Kamer afgerond wetsvoorstel onvolkomenheden worden aangetroffen die het gevolg zijn van bijvoorbeeld veranderende maatschappelijke ontwikkelingen of breed gedragen veranderende beleidsvisies, kan het voor de regering handig zijn, indien noodzakelijk geachte aanpassingen kunnen geschieden via de weg van de novelle. ${ }^{23}$ De Eerste Kamer blijkt zich in deze veelal redelijk coöperatief op te stellen. Dat kan, zo heeft de praktijk inmiddels geleerd, zo ver gaan dat aanpassingen betreffende verschillende wetsvoorstellen op verzoek van de regering ondergebracht worden in hetzelfde wijzigingsvoorstel. ${ }^{24}$ Maar ook indien na aanname van het wetsvoorstel door de Tweede Kamer toch nog allerhande technische wijzigingen noodzakelijk worden geacht door de regering, blijkt de novelle af en toe van grote praktische waarde. Juridisch-technische aanpassingen zijn via de novellevorm immers goed uitvoerbaar. ${ }^{25}$

Het is interessant om in dit kader ook nog te wijzen op een Nederlandse wetgevingsnouveauté die in de parlementaire praktijk van het nog prille nieuwe millennium het levenslicht heeft gezien: de veegwet. Tijdens de behandeling van de complexe belastingherziening 2001 is door de regering voorafgaande aan de behandeling van die wet in de Eerste Kamer reeds

ruimtelijke ordening.

19. F. de Vries, dissertatie, a.w., p. 204-205.

20. Wetsvoorstellen $\mathrm{nr} .7979$ en 8054.

21. http:/www.eerstekamer, $n$ l/cgi-bin/pdesns.egi?user $=\% 26$ dir $=/ 9202000,6-11-2001$.

22. Wetsvoorstel nr. 13705.

23. Zie uitgebreid: F. de Vries, dissertatie, a.w., p. 191-193.

24. Het betrof wijzigingsvoorstellen aangaande de Auteurswet 1912 (wetsvoorstellen $23247 \mathrm{en} \mathrm{23812)}$

25. Eerste Kamer 1984-1985, 16.538. Maar liefst 83 foutjes in het wetsontwerp Wet Gemeenschappelijke Regelingen werden via de novelle weggepoetst. 
besloten een zgn. 'veegwet' op te stellen. In die 'vervolmakingswet' zouden de ontbrekende puntjes definitief op de i kunnen worden gezet. Omdat het besluit tot opstelling van de veegwet genomen werd in een stadium van het wetsproces waarin de senatoren formeel nog niet aan zet waren geweest, kon de veegwet beschouwd worden als een nauwelijks verholen uitnodiging aan hun adres om de belastingplannen als het ware 'amenderend' te verrijken met in de Eerste Kamer aanwezige fiscale expertise, een uitnodiging waarvan ook gebruik is gemaakt. ${ }^{26}$

De wijze waarop het recht van amendement 'via' het House of Lords en de Sénat ter nadere correctie, aanpassing of verbetering van voorliggende wetsvoorstellen op verzoek van de regering gehanteerd pleegt te worden en de wijze waarop dezelfde doelen 'via' de novelleconstructie sporadisch nagestreefd blijken te kunnen worden door de Nederlandse regering. vertoont overeenkomst. In die zin omvat de Nederlandse novellepraktijk onmiskenbaar trekjes van het te Westminster en in het Palais de Luxembourg gehanteerde recht van amendement, zij het kwantitatief in hoge mate begrensd. Een en ander neemt echter niet weg dat de novelle ook voor Nederlandse bewindslieden soms als een bijzonder handig legislatief werktuig beschouwd mag worden.

Het middel kan politiek-strategisch nuttig zijn als wisselgeld, indien bijvoorbeeld één der coalitiepartners in de Eerste Kamer blijft tegenstribbelen. Uiteraard wordt een verzoek vanuit de Nederlandse senaatskamer tot het indienen van een inhoudelijke novelle lang niet altijd gehonoreerd door de regering. In een dergelijk geval zal de Eerste Kamer, een eventueel 'onaanvaardbaar' vanuit de geledingen der regering daargelaten, natuurlijk sneller opteren voor verwerping van het wetsvoorstel. ${ }^{27}$ Waar wij eerder zagen dat er opvallende parallellen te trekken zijn tussen het afdwingen van technische novelles door de Eerste Kamer en de wijze waarop het recht van amendement door vooral de Britse senaatskamer gehanteerd pleegt te worden, dringt zich hier een sterke parallel op met de gang van zaken rondom de totstandkoming van formele wetgeving in de Bondsrepubliek. Bij onze oosterburen bekijkt de Bundesrat tijdens de 'zweite Durchgang' (zie par. 7.3 e.v) van wetsvoorstellen namelijk áltijd indringend of regering en Bundestag wel in voldoende mate rekening hebben gehouden met de wijzigingssuggesties zoals door de Bundesrat tijdens de 'erste Durchgang' geopperd. Indien dit niet het geval is én het betreft een wetsvoorstel dat 'zustimmungsbedürftig' is, dan zal de benodigde toestemming niet snel meer gegeven worden.

\subsubsection{Toezegging}

Naast de novelle in een zware en een lichte variant is sinds de zeventiger jaren van de vorige eeuw, zij het sporadisch, ook een met de novelle verwante parlementaire praktijk ontstaan die luistert naar de term 'toezegging'. De toezegging is in feite een afgeleide van de novelle, zij het minder stellig en te effectueren in de 'nabije toekomst'. Het betekent echter wel dat een Minister of staatssecretaris aangeeft de werking van een (onderdeel van een) wet te zullen bijsturen op een wijze die tegemoet komt aan de wensen die (vaak in relatie tot de vraag of het voorstel tot wet wel gesteund zou worden) blijken te leven in de Eerste Kamer. Zo wilde de senaat dat het Nederlandse parlement invloed zou kunnen behouden op de invulling van het zgn: 'arbeidsmarktcriterium' ter bepaling van het maximale aantal studenten dat zich in zou

26. Veegwet Wet inkomstenbelasting 2001.

27. In die zin ook: F. de Vries, dissertatie, a.w., p. 201. 
mogen schrijven voor bepaalde studies ${ }^{28}$ Van recenter datum is onder andere een toezegging van de regering in relatie tot de door de Eerste Kamer gevreesde verslechterende positie van WAO'ers na inwerkingtreding van de Nabestaandenwet. ${ }^{29}$ Deze wet zou al snel na inwerkingtreding geetvalueerd en eventueel bijgesteld kunnen worden. Een interessant fenomeen die toezegging, met name omdat hierin door de regering op een relatief eenvoudige wijze het minimaal noodzakelijke 'wisselgeld' verpakt kan worden dat noodzakelijk blijkt ter voorkoming van nodeloze spanning in de relatie Eerste Kamer-regering rondom de herziening van voorstellen tot wet. Toezeggingen kunnen in feite plaats vinden in iedere gewenste vorm. De belofte tot nader onderzoek of evaluatie, het bevorderen van aanpassingen, bijstellingen enz. ${ }^{30}$ Zolang de Eerste Kamer zich maar tevreden stelt met de belofte van regeringswege dat de geopperde bezwaren in de praktijk niet op zullen treden, dan wel per omgaande gecorrigeerd zullen kunnen worden. In ruil ziet de Eerste Kamer vervolgens af van verdere aanhouding dan wel verwerping van het gewraakte voorstel.

Een voorbeeld. Tijdens de parlementaire behandeling vlak voor het zomerreces van 2001, van een wetsvoorstel dat een aanpassing van de procedure tot benoeming van de burgemeester en de Commissaris van de Koningin tot onderwerp had, bleek dat de VVD-fractie (een der coalitiepartijen) problemen had met een onderdeeltje van de wet in de door de regering voorgestelde vorm. ${ }^{31}$ Onder omstandigheden (bijvoorbeeld na een gemeentelijke herindeling) zou de gemeenteraad uiteindelijk toch ook een aanbeveling waarop slechts de naam van één burgemeesterskandidaat prijkte aan de minister kunnen voorleggen. En dat mocht nu toch echt niet volgens de VVD-senatoren. Een aanbeveling voor benoeming van een burgemeester zou, absolute overmachtsituaties uitgezonderd, altijd meervoudig moeten zijn. In eerste termijn meende de VVD-fractie bij monde van dhr. Luijten dat slechts een inhoudelijke novelle uitkomst zou kunnen bieden. De minister zag het probleem niet zo en wist het in tweede termijn in ieder geval al te reduceren tot een kwestie van 'technische aard'. Voorafgaande aan de derde termijn heeft de minister uiteindelijk een brief aan de Eerste Kamer gestuurd waarin hij toezegde bereid te zijn tot het doorvoeren van een wetstechnische aanpassing indien daaraan behoefte zou bestaan. Een dergelijke technische wijziging zou dan meegenomen kunnen worden 'in een volgende wijziging van de Gemeentewet'. ${ }^{32}$ Waarna wetsvoorstel 25444 uiteindelijk dan toch gewoon in de voorliggende vorm door de Eerste Kamer aangenomen werd.

Naast (en in relatie tot) de novelle en de toezegging blijkt ook de motie voor de Eerste Kamer aanknopingspunten te bieden voor enige beìnvloeding van het Nederlandse wetgevingproduct in wording. "De moties die werden ingediend bij de behandeling van wetsvoorstellen zijn in toenemende mate gaan functioneren als een middel om het gebrek aan mogelijkheden van de Eerste Kamer om in het wetgevingsproces sturend op te treden, te compenseren', ${ }^{33}$

28. Machtigingswet inschrijving studenten (18163).

29. Handelingen Eerste Kamer 1995-1996, p. 971-973.

30. Voor een deugdelijk overzicht zij verwezen naar F. de Vries, dissertatie, a.w., p. 246-251.

31. Aanpassing procedure benoeming burgemeester en commissaris van de Koningin (25444).

32. Eerste Kamer 2000-2001, 25444, nr. 11f, p. 3.

33. F. de Vries, dissertatie, a.w. p. 235. 


\subsubsection{Motie}

Het Reglement van Orde van de Eerste Kamer voorziet via art. 93 in de mogelijkheid tot het indienen van moties. Deze moeten op schrift gesteld zijn en door tenminste vier senatoren ondersteund worden. Moties kunnen tevens ingediend worden namens wetgevingscommissies. Voorwaarde is wel dat de betreffende motic gesteund wordt door de meerderheid van de commissieleden.

Af en toe spreekt de Eerste Kamer zich via een motie nog wel eens uit over de eigen positic. De dwingende motie van afkeuring, waarmee de vertrouwensregel via ongeschreven recht ten volle geactiveerd wordt, komt, in verband met het politieke primaat van de Tweede Kamer, in de relatie Senaat-regering in de praktijk niet meer voor (zie ook par. 6.5.1).

\begin{tabular}{|c|c|c|c|}
\hline Zittingsjaar & Aantal wetten & Aantal zittingen & Aantal moties* \\
\hline $1980-81$ & 377 & 39 & 7 \\
\hline $1981-82$ & 471 & 31 & 6 \\
\hline $1982-83$ & 288 & 41 & 5 \\
\hline $1983-84$ & 286 & 38 & 6 \\
\hline $1984-85$ & 317 & 41 & 4 \\
\hline $1985-86$ & 184 & 37 & 9 \\
\hline $1986-87$ & 199 & 39 & 14 \\
\hline $1987-88$ & 193 & 36 & 1 \\
\hline $1988-89$ & 197 & 37 & 8 \\
\hline $1989-90$ & 212 & 34 & 5 \\
\hline $1990-91$ & 281 & 37 & 10 \\
\hline $1991-92$ & 272 & 35 & 7 \\
\hline $1992-93$ & 278 & 37 & 4 \\
\hline $1993-94$ & 332 & 40 & 6 \\
\hline $1994-95$ & 311 & 37 & 13 \\
\hline $1995-96$ & 255 & 40 & 5 \\
\hline $1996-97$ & 304 & 38 & 3 \\
\hline $1997-98$ & 351 & 37 & 57 \\
\hline
\end{tabular}

Bronnen: Handelingen Eerste Kamer 1997-98, Statistieken Eerste Kamer, p. 668 en Statistisch Jaarboek 2000, Centraal Bureau voor de Statistiek, Heerlen 2000, p. 412.

- Het betreft hier zowel moties in het kader van de wetgevende bevoegdheden als moties in het kader van de bestuurscontrole.

Van het indienen van moties waarin door de Eerste Kamer aangedrongen wordt op aanpassing van een wetsontwerp, wordt ook wel gesuggereerd dat het verkapt amendementsrecht betreft. Hantering van het middel door de Senaat impliceert uiteraard geen formele dwang. Maar nu het de Eerste Kamer toch al zo zeer aan juridische machtsmiddelen ter sturing van het wetgevingsproces in formele zin ontbreekt, is de motie als beïnvloedingsinstrument in het politieke debat rondom wetsvoorstellen toch af en toe een bescheiden rol gaan spelen. Met 


\section{Hoofdstuk 6}

name vanaf de zeventiger jaren is een zekere toename van het gebruik van de politiek-inhoudelijke motie door de Nederlandse senaatskamer geconstateerd. ${ }^{34}$

Tussen oktober 1998 en oktober 2001 werden door de Eerste Kamer 18 moties aangenomen ${ }^{35}$ De invloed die van de (inhoudelijke) motie uit kan gaan op het algehele wetgevingsproces dient niet overtrokken te worden. In een sporadisch geval worden via het instrument van de motie daadwerkelijk concrete toezeggingen aan een minister of staatssecretaris ontlokt, dan wel indirect een bijdrage geleverd tot volledige intrekking van het onderhavige wetsvoorstel. ${ }^{36}$ In de regel zal het belang van de wetgevinggerelateerde motie voor de Eerste Kamer echter niet groter zijn dan dat van een 'ontluchtingsventiel' voor met name de oppositiepartijen. ${ }^{37}$ Onvrede kan formeel geuit worden, waarna weer overgegaan wordt tot de orde van de dag. $\mathrm{Nu}$ en dan zal het middel van de motie mede dienen om een aarzelende coalitiepartner definitief over de streep te trekken. ${ }^{38}$ Ook in kwantitatieve zin blijft het belang van de motie ter (bij)sturing van het wetgevingsproces door de Eerste Kamer bijzonder marginaal. Ter vergelijking: in 1996-97 werden in de Nederlandse senaatskamer drie moties aangenomen en in de Tweede Kamer 371. Een jaar later nam de Eerste Kamer geen enkele motie aan, tegen 342 door de Tweede Kamer.

\subsubsection{Intrekking}

Tenslotte nog een kort woord over de intrekking. Indien de regering wijzigingvoorstellen vanuit het parlement niet wenst te billijken behoort intrekking van het wetsvoorstel tot aan het moment van de eindstemming in de Eerste Kamer tot de mogelijkheden (art. 86 Grondwet) ${ }^{39}$ De Vries constateerde dat regelmatiger dan voorheen inhoudelijke bezwaren van de Eerste Kamer ten grondslag plegen te liggen aan een besluit tot intrekking. Daarbij blijkt de band met de bevoegdheid tot verwerping ex art 85 Grondwet vaker goed zichtbaar te zijn. ${ }^{40}$ Tijdens de behandeling in de Eerste Kamer zijn tussen 1945 en mei 2001 in totaal 32 voorstellen tot wet daadwerkelijk ingetrokken. ${ }^{41}$ Dat betekent dat nog geen $0,3 \%$ van het aantal wetsontwerpen dat tijdens die periode aan de Eerste Kamer werd voorgelegd uiteindelijk is ingetrokken. ${ }^{42}$ In hoofdzaak betrof het dan redenen van inhoudelijke aard. In enkele gevallen bleek een wetsontwerp inmiddels te zijn achterhaald door de ontwikkelingen, of overbodig te zijn geworden in verband met de indiening van een volgend wetsvoorstel. De intrekking heeft regelmatig het

34. Zie: F. de Vries, dissertatie, a.w., p. 237 e.v voor een overzicht van de belangrijkste moties van politiekinhoudelijke aard die door de Eerste Kamer tijdens de laatste drie decennia van de vorige eeuw werden ingediend.

35. http://www. eerstekamer.nl. 8-11-2001.

36. Onder andere wetsvoorstellen 21399,21450 en 22226.

37. F. de Vries, dissertatic, a.w. p. 238-246.

38. Idem, p. 246.

39. G. Visscher, Parlementaire invloed op wetgeving. 's-Gravenhage 1994, p. 409v. Uit dit onderzoek naar invloed vanuit de volksvertegenwoordiging op wetgeving bleek dat ongeveer 4 procent van alle wetsvoorstel. len voortijdig wordt ingetrokken. Hoogst zelden gebeurd dit pas tijdens de behandeling van een voorstel in de Eerste Kamer.

Zie G. Visscher, Parlementaire invloed op wetgeving, 's-Gravenhage 1994, p. 409 e.v.

40. De Vries, dissertatie, a.w., p. 217-219.

41. http:/www.eerstekamer.nl. 11-5-2001.

42. Eerste Kamer 2000-2001 26976, nr. 175a, p. 4. 
karakter van een 'verzoenend gebaar in de richting van tegenstribbelende (regerings-)fracties'. Via de intrekking kan zo snel een nieuw, aangepast voorstel ingediend worden. ${ }^{3}$

Tussentijds samenvattend, blijkt dat de Eerste Kamer via de novelle in al haar vormen (zwaar, licht, inhoudelijk dan wel technisch) almede via de toezegging, de motie en de intrekking, zij het zowel kwalitatief als kwantitatief ontegenzeggelijk in de marge, enige invloed van bijsturende aard op het Nederlandse wetgevingsproduct in wording uit weet uit te oefenen. ${ }^{44}$

De ontwikkeling van deze middelen tot bijsturing is slechts mogelijk gebleken in de wetenschap dat de Eerste Kamer in laatste instantie altijd nog beschikt over de ultieme stok achter de deur: het absoluut vetorecht.

Alvorens de bespreking van de wijze waarop het vetorecht in de Nederlandse bicamerale praktijk blijkt te functioneren ter hand te pakken, moeten echter eerst nog enige opmerkingen over het wetgevingsproces in de Eerste Kamer in het algemeen en de commissiefase in het bijzonder worden gemaakt.

\subsection{Het commissiestelsel}

In het wetgevingsproces is, zoals gezegd, pas een taak ingeruimd voor de Senaat ná afronding van het volledige wetgevingstraject door de Tweede Kamer. Dit geldt zowel voor regeringsvoorstellen tot wetgeving in formele zin, als voor initiatiefwetsvoorstellen vanuit de Tweede Kamer. In de Eerste Kamer doorloopt het wetsvoorstel vervolgens allereerst de gangbare parlementaire procedures via voorbereidend onderzoek in de vaste of bijzondere commissies ${ }^{45}$.

De 75 Nederlandse deeltijdsenatoren blijken tegenwoordig formeel actief te zijn in niet minder dan 21 kamercommissies. ${ }^{46}$ Grotendeels bestrijken deze commissies dezelfde beleidsterreinen als de ministeries. De Kamervoorzitter bepaalt het aantal leden van een commissie, met inachtneming van de getalsverhouding tussen de fracties en tevens met de bepaling dat elk der fracties in iedere commissie vertegenwoordigd kan zijn. ${ }^{47}$ De Kamervoorzitter bepaalt eveneens aan welke commissie het onderzoek van een voorstel wordt toevertrouwd. ${ }^{48}$

Het gegeven dat de commissie partijpolitiek zo breed mogelijk samengesteld wordt, heeft onder meer tot gevolg dat de vergaderingen puur naar de letter beschouwd mogen worden als materieel centrale momenten in het wetgevingsproces. Immers, binnen de commissie wordt niet alleen het beschikbare optimum aan specialismen bij elkaar gebracht, maar kan dankzij de brede samenstelling in voorkomende gevallen ook nog eens partijpolitieke consensus bereikt worden. Deze constellatie kan een commissie die zich kritisch positioneert, tot een

43. F. de Vries, dissertatie, a.w., p. 217.

44. Deze lijst wordt door Jurgens nog aangevuld met enige extra beinvloedingsmiddelen van niet formele aard, zoals het uitlokken van interpretatieve besluiten over de betekenis van bepalingen in wetsvoorstellen, het afdwingen dat delen van wetsvoorstellen (nog) geen kracht van wet krijgen, het afdwingen van inhoudelijk debat achteraf en tijdrekken via de commissiefase. Zie: E. Jurgens, Boekbeschouwingen, RM Themis 2001/ 9, p. 289.

45. Art. 32 e.v. Reglement van Orde van de Eerste Kamer der Staten-Generaal.

46. http: //www.eerstekamer.nl. 9-11-2001.

47. Art. 36 Reglement van Orde van de Eerste Kamer der Staten-Generaal.

48. Art. 41 Reglement van Orde van de Eerste Kamer der Staten-Generaal. 
belangrijke gesprekspartner van de regering maken tijdens deze fase van het wetgevingsproces.

Het belang van het werk der vaste senaatscommissies in Nederland moet waar het wetgevingsproces in het geding is, zoveel is inmiddels al wel duidelijk, niet overtrokken worden. Omdat de Eerste Kamer uiteindelijk slechts 'ja' of 'nee' mag zeggen tegen het wetsvoorstel in zijn geheel, spreckt het vanzelf dat de specialisten in de vaste kamercommissies zich niet snel zullen verliezen in al te gedetailleerd onderzoek. Desondanks wordt zo nu en dan vanuit een senaatscommissie nog wel eens een kamerbrede en derhalve krachtige motie ingediend. Bijvoorbeeld in een poging ongewenste amendering van een wetsvoorstel door de Tweede Kamer te neutraliseren. ${ }^{49}$ Dergelijke gerichte politieke actie vanuit de senaatscommissie blijft echter betrekkelijk uitzonderlijk.

Met die commissievergaderingen van de Nederlandse senaatskamer blijkt in de parlementaire praktijk trouwens iets zeer opmerkelijks aan de hand te zijn. In hoofdzaak bestaan ze eigenlijk slechts op papier. Daar bedoel ik mee, dat deze vergaderingen, hoge uitzonderingen daargelaten, of gewoon niet plaatsvinden, of schriftelijk afgehandeld worden. De ingewikkelder c.q. politick gevoeliger wetsontwerpen daargelaten, heeft de Eerste Kamer, bij gebreke van een recht van amendement, als regel blijkbaar nauwelijks behoefte aan de wettelijk verplichte extra (commissie) vergaderingen tussen fractieberaad en plenaire zitting. Hagelstein formuleerde het in een voetnoot enigszins eufemistisch als volgt: 'Commissievergaderingen nemen niet veel tijd in beslag. Op de dinsdagen welke de Kamer vergadert worden de commissievergaderingen als regel gehouden in of rond de theepauze van de plenaire vergadering'. ${ }^{50}$ Inhoudelijk wordt de wettelijk verplichte commissiebemoeienis van de Eerste Kamer rondom het wetgevingsproces meestal afgewerkt via een procedure die luistert naar de veelbelovende benaming 'inbrengvergadering'. Dat zijn bijeenkomsten die (naar alle waarschijnlijkheid vanwege de 'verschriftelijking' van deze procedure ex art. 44-46 RvoEK) een besloten karakter hebben. ${ }^{51}$ Een en ander komt erop neer dat per fractie schriftelijke opmerkingen met betrekking tot voorstellen tot wet bij de griffie gedeponeerd kunnen worden. De griffier bundelt de binnengekomen reacties en sluist het geheel vervolgens door naar de commissievoorzitter die bekijkt of nadere bespreking c.q. schriftelijke uitwisseling noodzakelijk is. Zo niet dan volgt vaststelling 'bij de thee'.

Zoveel over de feitelijke 'werkwijze' van de Eerste Kamercommissies. Vervolgens enige korte complementaire opmerkingen van formelere aard. Nadat (indien noodzakelijk geacht) een voorlopig verslag, de Memorie van Antwoord door de minister en een schriftelijk eindverslag uitgebracht zijn, volgt openbare behandeling. ${ }^{52}$ Tenslotte moet de Nederlandse Senaat plenair stemmen over het wetsvoorstel. ${ }^{53}$ De formele Grondwettelijke keuze: alles of niets. Nederland is het enige onderzocksland waar de Senaat over het ultieme machtsmiddel beschikt om alle wetgevingsvoorstellen in formele zin in zijn geheel te verwerpen, zonder enige vorm van terugzendplicht. ${ }^{54}$

49. F. de Vries, dissertatic, a.w., p. 231.

50. G. Hagelstein, De parlementaire commissies, Serie monografieên Nederlands Pariementsrecht nr. 6, p. 374, noot 79 .

51. Klemmende redenen voor deze beslotenheid zijn er nauwelijks te geven, aldus ook G.H. Hagelstein, De parlementaire commissies, Groningen 1991, p. 371.

52. Art. 71 Reglement van Orde van de Eerste Kamer der Staten Generaal.

53. Art. 105ev. Reglement van Orde van de Eerste Kamer der Staten Generaal.

54. Art. 85 Grondwet. 
Een kanttekening is echter op zijn plaats. Men dient zich te realiseren dat alleen al om praktische redenen niet eenvoudig een wetsvoorstel verworpen zal worden, waarover reeds (veelal via amendementen uitgewerkte) overeenstemming bestaat tussen regering en de Tweede Kamer. Soms maanden, maar meestal jaren van ambtelijke voorbereiding, bespreking in de ministerraad, advisering door de Raad van State, besprekingen op commissieniveau in de Tweede Kamer alsmede amendering en parlementaire behandeling in openbare vergadering aldaar zouden dan immers in één klap totaal te niet gedaan kunnen worden. Daar komt bij dat de leden van beide Nederlandse parlementskamers gerekruteerd én gekozen plegen te worden vanuit dezelfde politieke groeperingen. Vanuit die wetenschap zullen senatoren die namens de coalitiepartijen zitting hebben in de Eerste Kamer voorstellen tot regelgeving afkomstig uit de schoot van 'hun' regering natuurlijk niet licht verwerpen. ${ }^{55}$

\subsection{Verwerping}

Feit blijft echter dat de Nederlandse Senaat als ultiem machtsmiddel formeel de mogelijkheid heeft wetsvoorstellen van regering en Tweede Kamer definitief te blokkeren. De belangrijkste oorzaken voor het gegeven dat van dit wapen slechts zelden gebruik gemaakt wordt, hangen samen met de status van wetgevingsheroverweger die de Senaat vanaf 1848 en zeker vanaf 1917 steeds duidelijker ten deel is gevallen. Het politiek primaat kwam, zoals wij gezien hebben, bij de rechtstreeks gekozen Tweede Kamer te liggen en de band tussen Regering en Tweede Kamer werd steeds nauwer. Met de Luxemburgse kwestie van 1867 werd de vertrouwensregel definitief gevestigd tussen Tweede Kamer en regering. Vanaf 1917 werd de formatie van nieuwe regeringen na verkiezingen onder het regime van een kiesstelsel van evenredige vertegenwoordiging langzaam maar zeker ondenkbaar zonder coalitiebesprekingen tussen politieke partijen uit de Tweede Kamer. Daar kwam nog bij dat vooral de laatste decennia de relatie Tweede Kamer-regering via voortdurende politieke opwaardering van het regeerakkoord innig is geworden.

Vanuit haar positie als niet-rechtstreeks gekozen volksvertegenwoordigend orgaan zonder het politieke primaat, maar wel acterend in een democratisch systeem van checks and balances, moet de Nederlandse Senaat zijn in theorie verstrekkende en derhalve 'botte' machtsmiddel van totale verwerping dan ook subtiel en met de nodige terughoudendheid zien te hanteren.

De praktijk van heroverweging door de Eerste Kamer laat zien dat van die terughoudendheid tot nu toe ontegenzeggelijk sprake is geweest. ${ }^{56}$ In de periode 1945 tot mei 2001 werden door de Eerste Kamer in totaal 47 wetsvoorstellen daadwerkelijk verworpen. ${ }^{57}$ Minder dan één voorstel per jaar derhalve en minder dan $0,3 \%$ van het totaal aantal wetsontwerpen dat de Eerste Kamer tijdens voornoemde periode passeerde.

Nuancering van de wijze waarop door de Nederlandse Senaat invulling wordt gegeven aan de grondwettelijke mogelijkheid tot verwerping van wetsvoorstellen, is mogelijk via bestudering van de onderliggende motieven. Waren die vooral van politieke of van juridische aard?

Visscher constateert in zijn onderzoek over de periode 1963-1986 dat: 'voor alles duidelijk wordt, dat de Eerste Kamer als politieke factor in het wetgevingsproces niet beperkt blijft tot

55. In die zin ook: F. de Vries, dissertatie, a.w., p. 182-184.

56. Zie hiertoe uitgebreid: G. Visscher, Parlementaire invloed op wetgeving, Den Haag 1994, p. 597 e.v.

57. http://www.eerstekamer.nl/,11-5-2001. 
het toetsen van voorstellen aan min of meer concrete normen zoals rechtmatigheid of doelmatigheid dan wel normen van behoorlijke wetgeving ${ }^{58}$ De heroverweging van wetgevingsvoorstellen geĩnitieerd door de regering en reeds aangenomen door de Tweede Kamer lijkt dus ook politiek gestuurd. ${ }^{59}$

Nadere duiding door Visscher van de motieven die een rol gespeeld hebben bij verwerping van de wetsvoorstellen leert ons vervolgens dat in de meeste gevallen 'niet zozeer sprake was van een toetsing aan de normen van recht- en doelmatigheid, maar van een beleidsmatige afweging c.q. beoordeling. Als politieke actor beoordeelde de Senaat of de voordelen van een specifiek voorstel wel zwaarder wogen dan de nadelen', ${ }^{60}$ Daadwerkelijke hantering van het machtsmiddel der verwerping door de Eerste Kamer (dan wel dreigen met verwerping ter afdwinging van een of meerdere novelles) kwam zelden voor en dan nog in hoofdzaak bij wetsontwerpen met een 'relatief geringe maatschappelijke of politieke lading, ${ }^{61}$ maar was dan wel in hoofdzaak politiek/beleidsmatig geinspireerd. In dat kader kunnen vooral de bescherming van de eigen constitutionele positie (bijvoorbeeld grondwetswijzigingsvoorstellen met betrekking tot de inrichting en samenstelling van de Staten-Generaal ${ }^{62}$, de ontwerp-Comptabiliteitswet $^{63}$ en het medebeslissingsrecht bij PKB-procedures ${ }^{64}$ ) en het beschermen van gemeentelijke herindelingsbelangen (bijvoorbeeld de gemeentelijke grenscorrecties tussen Blaricum en Huizen, de herindeling van de Bommelerwaard en de herindeling van de Midden-Betuwe ${ }^{65}$ ) als regelmatig terugkerend onderliggend motief genoemd worden. ${ }^{66}$ In min of meer gelijksoortige bewoordingen liet de Vries zich uit bij zijn onderzoek over de periode 1956-2000 ${ }^{67}$ Op de onderliggende motieven tot verwerping kom ik verderop (par. 6.5.2) terug.

Voorlopige conclusie? De Eerste Kamer is een (weliswaar indirect) gekozen volksvertegenwoordigend orgaan dat zich bij de zeldzame gebruikmaking van het haar als heroverweger van wetsvoorstellen tockomende machtsmiddel tot verwerping van wetsvoorstellen vooral laat leiden door politiek/beleidsmatige motieven.

Voorwaar geen vreemd of opmerkelijk gegeven voor een volksvertegenwoordigend medewetgevend orgaan! Tegelijkertijd wel een gegeven dat in de praktijk regelmatig aanleiding blijkt te geven tot politiek-staatsrechtelijke onduidelijkheden, niet in de laatste plaats omdat hier per saldo de reikwijdte van de ministeriële verantwoordelijkheid, meer in het bijzonder in de verhouding regering-en senaat mede in het geding blijkt te kúnnen zijn.

58. G. Visscher, a.w., p. 602 .

59. Zo ook: B. van den Braak, a.w., p. 448 en F, de Vries, dissertatic, a w., p. 258

60. G. Visscher, a.w., p. 603.

61. G. Visscher, a.w., p. 598.

62. Handelingen Tweede Kamer 1976-77, Bijlage 14.222.

63. Handelingen Eerste Kamer 1971-72, p. 181 e.v.

64. Eerste Kamer 1984-85, 14889 .

65. Handelingen Tweede Kamer 1984-85, Bijlage 18.618.

66. G.Visscher, a.w., p. 393 e.v en 612 e.v.

67. F.de Vries, dissertatic, a, w., p. 123 e.v. 


\subsubsection{Het veto en de vertrouwensregel}

De verhouding tussen Tweede Kamer en regering wordt beheerst door het vertrouwensregel Daarover bestaat natuurlijk geen enkele twijfel. Wordt echter ook de verhouding regeringEerste Kamer bepaald door deze regel? In het verre verleden is eenmalig een voltallig kabinet

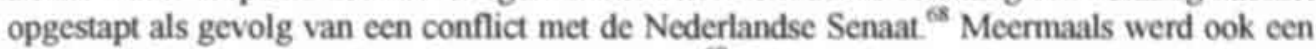
minister of staatssecretaris tot heengaan aangezet. ${ }^{69}$ Tijdens de na-oorlogse periode is de vertrouwensregel nooit door de Eerste Kamer formeel geactiveerd, maar werd wel door de regering zelf in totaal vier maal gedreigd met cen 'onaanvaardbaar' ${ }^{70}$ In 1999 tenslotte, tijdens de 'nacht van Wiegel' leidde het niet aanvaarden in tweede lezing van een voorstel tot herziening van de Grondwet door de Eerste Kamer met de vereiste tweederde meerderheid zelfs tot een heus kabinetscrisisje. Dit alles kan niet anders dan tot de conclusie leiden dat in ieder geval sprake is van enige vorm van vertrouwensrelatie tussen regering en Eerste Kamer. Of en zo ja door wie, de uit die vertrouwensrelatie voortvloeiende vertrouwensregel geactiveerd zou mogen worden, daarover wordt echter nog steeds met enige regelmaat gebakkeleid."

Tijdens de grondwetsherziening van 1983 werden (nadat afschaffing van de Nederlandse senaatskamer geen haalbare kaart bleek te zijn) pogingen ondemomen om wijzigingen aan te brengen in de bevoegdheden die de Eerste Kamer toe zouden moeten komen als medewetgevend orgaan. Gedacht werd daarbij vooral aan het verlenen van een terugzendrecht van wetsvoorstellen naar de Tweede Kamer, gecombineerd met een suspensief veto. ${ }^{72}$ In het kader van de discussies die daarover gevoerd werden speelde vanzelfsprekend de vertrouwensregel een belangrijke rol. De regering was bij monde van Minister Wiegel van oordeel: 'dat die regel in beginsel ook voor de Eerste Kamer bestaat, maar dat de Eerste Kamer door het niet toepassen daarvan blijk heeft gegeven van de reserve die zij passend acht voor haar positie in het hanteren van haar bevoegdheden'. Vanuit de PvdA (van Thijn) werd gesuggereerd dat die terughoudendheid geen staatsrechtelijke norm zou zijn, doch simpelweg praktijk. ${ }^{73}$ Een praktijk die gewijzigd zou kunnen worden op het moment dat dit politiek opportuun blijkt te zijn. Wat daar (vooralsnog) ook van zij, geconstateerd kan op deze plaats in ieder geval al worden dat de werking en reikwijdte van de vertrouwensrelatie in de relatie regering-Eerste Kamer in de optiek van politici niet eenduidig bepaalbaar blijken te zijn.

De grondwetsherziening van 1983 werd, zoals bekend, afgerond zonder doorvoering van wijzigingen in het bevoegdhedenpakket van de Eerste Kamer. In de periode die volgde bleek sprake te zijn van een (voor Nederlandse begrippen) bijzonder assertieve Senaat, die actieve hantering van de haar toekomende geschreven en ongeschreven constitutionele rechten tot 'norm' leek te gaan verheffen, daarmee, zo op het eerste oog, impliciet aangevend dat de hierboven gememoreerde visie van van Thijn betreffende de vermeende terughoudendheid van de

68. Er werd toen voor ontbinding gekozen, omdat bekend was dat een nieuw te kiezen Eerste Kamer een regeringsgezinde partijpolitieke meerderheid zou krijgen, terwijl van een dergelijke meerderheid tot dat moment geen sprake was.

69. Zie hiertoe: J.Vis, Van 'Menagerie du Roi' tot politiek college, De Eerste Kamer van 1849 tot 1887, in: A. Postma e.a., Aan deze zijde van het Binnenhof, Den Haag 1990, p. 163-211.

70. Openlijk gebeurde dat in 1949 (Grenscorrectiewet), 1972 (verhoging collegegelden) en 1989 (wijziging AAW). Achter de groene gordijnen van de Eerste Kamer werd in 1988 door de toenmalige Minister van Onderwijs gedreigd met de kabinetskwestie in verband met de Harmonisatiewet.

71. Onder andere F. de Vries, NJB 2001, a.w., p. 1832-1833.

72. Handelingen II $1979-1980,14.222$, p. 2718 e.v.

73. Handelingen Tweede Kamer 1979-1980, 14.222, p. 2101. 
Eerste Kamer wellicht zo gek nog niet was. Wat was er aan de hand? Allereerst viel op dat in de tachtiger jaren relatief vaak wetsvoorstellen door de Senaat werden verworpen. Vanaf de laatste wereldoorlog tot 2001 werden in totaal slechts 47 wetsvoorstellen verworpen (zoals gezegd gemiddeld minder dan één voorstel per jaar). In de jaren 1986 en 1987 werden in totaal echter 8 voorstellen verworpen, waarbij in alle gevallen politieke overwegingen een centrale rol speelden. ${ }^{74}$ Daarnaast liepen ook in het openbare debat tussen Eerste Kamer en regering de spanningen regelmatig hoog op. ${ }^{75}$ Ten gevolge van de wijzigingen in het kiesstelsel na de jongste uitgebreide grondwetsherziening wist de Eerste Kamer zich democratisch beter gelegitimeerd, hetgeen een rol kan hebben gespeeld bij de veranderende opstelling van de senaat. Vooral het gegeven dat zij pal na de verkiezingen voor provinciale staten op alleszins begrijpelijke gronden meende te kunnen bogen op een actuelere afspiegeling van de kiezersgunst bleck tijdens die jaren cen storend element op te leveren in de verhouding tussen Eerste Kamer en regering.

Eveneens belangrijk lijkt het Harmoniesatiewet-debâcle geweest te zijn. ${ }^{76}$ De toenmalige Minister van Onderwijs Deetman had om hem moverende redenen van beleidsmatige aard behoorlijke haast met definitieve aanname van dat wetsvoorstel. Omdat de Senaat toch omwille van de rechtszekerheid enigszins tegenstribbelde, ging de minister zelfs zo ver, buiten de openbaarheid de vertrouwenskwestie te stellen. Na de snelle aanname van het wetsvoorstel die daarop vanzelfsprekend volgde (Indien een lid van de Nederlandse regering in de Eerste Kamer het 'onaanvaardbaar' uitspreekt, laat de senaatskamer haar bezwaren tegen een voorliggend wetsontwerp per definitie vallen. Deze 'actie' kan binnen het Nederlandse staatsrecht welhaast beschouwd worden als een conventie.) vertoonde de wet wel serieuze rechtstatelijke gebreken. Zelfs de Hoge Raad sprak zich uiteindelijk uit over deze kwestie. Het hoogste Nederlandse rechtscollege gaf aan dat de wet in wezen strijdig was met het rechtszekerheidsbeginsel. $^{77}$ De Eerste Kamer, kwam daarmee als wetgevingherzieningskamer in een wel héél twijfelachtig daglicht te staan. Immers, het heette toch bij uitstek de taak van de Nederlandse Senaat te zijn, op stapel staande wetgeving in formele zin te toetsen aan rechtstatelijke aspecten.

De geest leek vervolgens uit de fles. Nog in hetzelfde jaar dat de Hoge Raad het Harmonisatiewet-arrest wees, meende de regering bij monde van Minister Kok van Financièn wederom (zij het deze keer in het openbaar) genoodzaakt te zijn het 'onaanvaardbaar' uit te spreken. Het betrof wijzigingen in de AAW-regeling die geen uitstel gedoogden in verband met de naderende jaarwisseling. De Eerste Kamer meende van haar kant dat 'financiële haast' een slechte raadgever was en dat eerst rechtsongelijkheid bevorderende onderdelen uit het wetgevingsvoorstel gehaald dienden te worden. Het machtswoord trotseren gebeurde uiteraard echter wederom niet: 'Er moet wel iets zeer uitzonderlijks aan de hand zijn, zouden wij deze

74. Initiatiefvoorstel Van der Burg/Stoffelen m.b.t. enquèterecht (19029), Verhaal van bijstandskosten (18813), Invoering openbaar kartelregister (16555), gemeentelijke herindelingen Bommelerwaard (19055) en Midden-Betuwe (19138), Onderwijsvoorrangswet (18775), Goedkeuring oprichting Europese culturele stichting (17852), Verticale prijsbinding en minimumprijzen (19361).

75. Vermaard geworden zijn vooral de aanvaringen tussen de (voorzitter van de) Christen-Democratische fractie Kaland en Minister President Lubbers.

76. Meent ook Kummeling, De Eerste Kamer, Chambre de Révolution?, NJB 1990, p. 263.

77. HR 14-4-1989, NJ 1989, p. 469. 
verantwoordelijkheid willen nemen. Nu het politicke primaat niet aan ons tockomt, zjn wij bereid voor het machtswoord te buigen'. ${ }^{78}$

Wel werd in de maanden die volgden menig debat gewijd aan de manoeuvreernimte die de Senaat toe behoorde te komen. CDA-fractievoorzitter Kaland opperde dat de Eerste Kamer zich nooit formeel aan het regeerakkoord had gebonden en dat hij ook materieel weinig binding met dit beleidsconvenant aanwezig achtte, nu de Senaat in formatiebesprekingen op geen enkele wijze partij bleek te zijn. Kaland wenste slechts overtuigd te worden door inhoudelijke argumenten. De Minister President gaf daarop te kennen dat de Eerste Kamer zich zjns inziens eerst en vooral zou moeten richten op het toetsen van de rechtmatigheid en doelmatigheid van wetgeving. ${ }^{79}$ Het maken van politieke afwegingen door de Senaat diende daarbij zijns inziens zo veel mogelijk vermeden te worden.

Het was met name de grote christen-democratische fractie, nota bene afkomstig uit de gelederen van de regeringscoalitie, die het vuurtje aangaande de positie van de Eerste Kamer in haar verhouding tot de regering voortdurend opstookte. In 1991 werd door de CDA-fractic van de Eerste Kamer zelfs tijdelijk de werking van art. 85 Grondwet gebnuskeerd, toen geweigerd werd om een wetsvoorstel over ziektekostenverzekering in de voorliggende (door de Tweede Kamer goedgekeurde) vorm überhaupt in behandeling te nemen. ${ }^{\mathrm{BO}}$

$\mathrm{Na}$ die laatste ferme protestdemonstratie heeft de Eerste Kamer nog wel gedebatteerd over haar positionering, maar de geest is zijn fles toch onmiskenbaar weer op gaan zoeken. ${ }^{81} \mathrm{De}$ aloude heroverweging vanuit politieke terughoudendheid is vervolgens weer gewoon het vrijwel Kamerbreed omarmde credo gaan worden.

Ook binnen de rechtswetenschap wordt, mede ten gevolge van de beschreven parlementaire praktijken, nog steeds met enige regelmaat gediscussieerd over de positionering van de Senaat ten opzichte van regering en Tweede Kamer. ${ }^{82}$ Eensgezindheid lijkt in ieder geval te bestaan over het gegeven dat de Senaat een politiek orgaan is. Maar moet de bandbreedte waarbinnen de Eerste Kamer al dan niet 'politiek gevoelig wetgevingsgedrag' mag ontplooien afgebakend worden op grond van praktische overwegingen of dogmatiek. Kummeling heeft zich, mijns inziens terecht, in zijn preadvies vooral laten leiden door het eerste. Er is zijns inziens 'veel te zeggen voor de stelling dat er een vertrouwensrelatie bestaat tussen Eerste Kamer en kabinet, maar dat de daaraan ten grondslag liggende vertrouwensregel slechts eenzijdig, namelijk door de regering geactiveerd mag worden', ${ }^{83}$ Immers zo vervolgt hij 'nu het politieke primaat blijkens bevoegdheden en staatkundige praktijk zo nadrukkelijk bij de Tweede Kamer berust en om die reden bij de kabinetsformatie slechts het vertrouwen van de Tweede Kamer wordt gezocht, behoort het niet tot de taken van de Eerste Kamer een kabinet c.q. individuele bewindslieden op grond van een zelfstandig politiek oordeel naar huis te sturen. Aan een senaat

78. Aldus fractievoorzitter Kaland van het CDA tijdens de vergadering van de Eerste Kamer dd. 28-12-1989. Handelingen Eerste Kamer 1989-1990, p. 7 e.v.

79. Handelingen Eerste Kamer 1989-1990, p. 355 e.v.

80. Handelingen Eerste Kamer 1991-1992, p. 195 e.v.

81. Zie 0.a Handelingen Eerste Kamer 1991-1992, p. 1383 e.v.

82. Zie o.a. H. Kummeling, a.w. ; F. de Vries, dissertatic, a.w;; F. de Vries NJB 2001, a.w; B. van den Braak, a.w.; G. Visscher, a.w.; H. Kummeling en P. Bovend'Eert, Vam Raalte's Het Nederlands Parlement, Deventer 2000.

83. H.R. Kummeling. De Nederlandse Eerste Kamer, Preadvies, Den Haag 1992, p. 23. 
die functioneent als kamer van heroverweging komt cen dergelijke bevoegdheid niet toe'.84 De Vries blijkt het op dit punt oneens te zijn met de stellingname van Kummeling. Hij meent dat 'de veronderstelling van een slechts eenzijdig activeerbare vertrouwensrelatie blijk geeft van een fundamentele miskenning van de betekenis van de vertrouwensregel' ${ }^{85}$ Die is, zo stelt de Vries, namelijk niet in ons staatsbestel terecht gekomen als strategisch instrument voor de regering, doch ter bepaling van de afhankelijkheidsrelatie van de regering richting Staten-Generaal inclusief Eerste Kamer. 'De werkzaamheden van de Eerste Kamer zouden slagkracht ontberen indien de vertrouwensregel niet zou gelden'.

Wellicht is deze visie in principieel staatsrechtelijke zin ook anno 2000 nog verdedigbaar, iedere relatie tot de moderne Nederlandse parlementaire praktijk is hier echter zoek. In het kader van het rechtsvergelijkende hoofdstuk 8 zal ik dit nader uitwerken.

Het activeren van de vertrouwensregel door de Nederlandse Senaat via bijvoorbeeld het aannemen van een motie van wantrouwen of het verwerpen van een wetsvoorstel waaraan het 'onaanvaardbaar' van de regering is gekoppeld, zou in twee opzichten ook voor problemen zorgen die binnen het vigerende juridische raamwerk feitelijk niet oplosbaar zijn. Allereerst is daar het praktische gegeven dat Provinciale Staten niet ontbonden kunnen worden, zodat per saldo de situatie ook na ontbinding van de Eerste Kamer ten gevolge van cen vertrouwensconflict en de daar op volgende verkiczing van nieuwe senatoren door de leden van Provinciale Staten partijpolitick ongewijzigd zou blijven. Het is hooguit denkbaar dat in een dergelijke situatie enige personele wijzigingen in de kieslijsten aangebracht zouden worden. Minister-President Lubbers maakte (als politiek pressiemiddel) toespelingen in die richting tijdens het vermaarde debat tussen hem en CDA-fractievoorzitter Kaland in 1990, waar de politieker opstelling van de Eerste Kamer ter discussie stond. ${ }^{86}$

Van serieuzere aard echter zijn de problemen die zouden ontstaan in de relatie tussen Eerste en Tweede Kamer bij activering van de vertrouwensregel door de Nederlandse Senaat. Immers, de Nederlandse regering leunt tegenwoordig als vanzelfsprekend sterk op de Tweede Kamer. Krachtige partijpolitieke organisatie en uitgewerkte regeerakkoorden staan daarvoor duidelijk garant. Fundamentele onwerkbaarheid, op basis van het gegeven dat het politieke primaat van de Tweede Kamer terzijde geschoven zou worden, met alle gevolgen van dien voor de voortgang van de wetgevingstaak van Staten-Generaal en regering, lijkt bij activering van de vertrouwensregel door de senaatskamer in de gegeven situatie allerminst ondenkbaar. Het ontstaan van een ook maar enigszins vergelijkbare situatie behoort in Frankrijk, GrootBrittanniě en zelfs de Bondsrepubliek Duitsland zowel formeel als materieel dan ook tot de onmogelijkheden. Politieke confrontaties tussen de senaat en de regering, culminerend in een negatief vertrouwensvotum zijn in voornoemde landen zo goed als uitgesloten.

Dit alles gezegd hebbende nog een (voorlopig) afsluitende opmerking over de gelding van de vertrouwensregel in de relatie tussen de Nederlandse regering en de Eerste Kamer. Hoewel ik. zoals inmiddels duidelijke moge zijn, de door Kummeling in zijn preadvies geformuleerde insteck verre prefereer, zou ik toch een kleine doch mijns inziens niet onbelangrijke nuancering in zijn stelling willen suggereren: 'dat de (...) vertrouwensregel slechts eenzijdig. namelijk door de regering geactiveerd mag worden', zou gewijzigd moeten worden in: 'zal worden'. Een dergelijke formulering ondervangt grotendeels het door de Vries geopperde

84. Idem.

85. F. de Vries, dissertatic, a.w., p. 171

86. Er werd door de toenmalige voorzitter van de Eerste Kamer gesproken over 'moord op kiaarlichte dag' 
principieel staatsrechtelijke bezwaar (strikt naar de letter behoort activering van de vertrouwensregel door zowel regering als Eerste Kamer dan immers wel tot de mogelijkheden) en sluit tegelijkertijd naadloos aan bij de inmiddels toch wel zeer bestendige praktijk. In hoofdstuk $8 \mathrm{zal}$ deze materie in rechtsvergelijkend perspectief overigens nog nader uitgewerkt worden.

\subsubsection{Nogmaals het vetorecht}

De Nederlandse wetgevingspraktijk rondom mogelijke verwerping van voorstellen tot wet, waar wij ons nu iets gedetailleerder over zullen buigen, toont aan dat de Eerste Kamer zuivere en open conflictsituaties welhaast per definitie pleegt te vermijden.

Het uitgebreide onderzoek van Visscher naar parlementaire invloed op wetgeving laat, zoals reeds werd beschreven, goed zien dat verwerping van wetsvoorstellen door de Eerste Kamer een zeldzaamheid is. Een beeld dat in 2000 door de Vries nog eens werd bevestigd. ${ }^{87}$ Onderliggende motieven bij verwerping ex art. 85 jo 81 Grondwet bleken, aldus Visscher, meestal van politiek/beleidsmatige aard. Het betrof daarbij, zoals gememoreerd, in veel gevallen echter voorstellen die ó van relatief geringe betekenis werden geacht (de helft van de gevallen), of (direct dan wel indirect) het belang van de Eerste Kamer zelf tot onderwerp hadden. ${ }^{\text {sh }}$ Verworpen wetsvoorstellen niet vallend in een van beide categorieèn hadden regelmatig specifieke voorstellen tot gemeentelijke herindeling tot onderwerp, traditioneel een beleidsterrein waarop de Eerste Kamer meer speelnuimte blijkt te krijgen. ${ }^{89}$

Verwerpingen door de Eerste Kamer maakten (in de door Visscher onder de loep genomen periode) minder dan één procent uit van het totaal aantal wetsontwerpen dat uiteindelijk het Staatsblad wist te bereiken. Vertraging van wetgeving door middel van het inzetten van de zware novellevariant kwam nog minder voor. ${ }^{90}$ De overige 2498 onderzochte wetsvoorstellen werden gewoon aangenomen. Ruim de helft daarvan als hamerstuk. Bekijken wij het stemgedrag, dan blijkt partijpolitieke binding de bepalende factor bij uitstek te zijn geweest. Zowel de senatoren uit die partijen die de coalitie vormden als de senatoren uit de oppositiepartijen, vertoonden (zonder zichtbare afwijkingen) vrijwel standaard hetzelfde stemgedrag als de collega's aan gene zijde van het Binnenhof. ${ }^{9 !}$

Visscher komt na kwalitatieve en kwantitatieve beoordeling van de onderzochte wetsvoorstellen tot de eindconclusie dat de Eerste Kamer in wezen 'substantiële structurele invloed slechts via de blokkade van een zeer beperkt aantal voorstellen heeft uitgeoefend'. ${ }^{92}$ Vertraging bleek nog het voornaamste soort invloed te zijn dat de Senaat uitoefende. 'Anders dan in de Tweede Kamer resulteerde deze vertraging normaal gesproken evenwel niet in inhoudelijke veranderingen vande regeringsvoorstellen'. ${ }^{3}$

87. F. de Vries, dissertatic, a.w., p. 185 ,

88. G. Visscher, a.w., p. 602 e.v.; F. de Vries, dissertatie, a.w., p. 123 e.v.

89. G. Visscher, a.w., idem en F. de Vries, dissertatic, a.w., p. 148 e.v. Het betrof de opheffing van de gemeente Diepenveen (10962), de aanpassing van de gemeentegrens tussen Blaricum en Huizen (18618), de herindeling van de Bommelerwaard (19055), de herindeling van de Midden-Betuwe (19138) en de herindeling van de gemeenten Boekel, Veghel en Uden (25116).

90. Zie G. Vischer, a.w., p. 773 en B. van den Braak, a.w., p. 287.

91. G. Visscher, a.w., p. 390 e.v.

92. G. Visscher, a.w., p. 773.

93. Idem. 
Uitsplitsing van het pakket wetsvoorstellen dat sinds 1950 door de Nederlandse senaatskamer is verworpen in voorstellen tot wijziging van de grondwet en overige voorstellen, levert nog enige interessante additionele informatie op. Van de 45 wetsvoorstellen die tijdens voornoemde periode door een veto van de Eerste Kamer getroffen werden, hadden er niet minder dan 15 ( oftewel eenderde deel) een voorstel tot grondwetswijziging als onderwerp. ${ }^{94}$

Hieruit zou de conclusie getrokken kunnen worden dat de Nederlandse senaatskamer zich blijkbaar met verve kwijt van haar taak als beschermer van de Grondwet. Bestudering van de onderwerpen die in het geding waren leert echter dat het in de meeste gevallen óf zaken van ondergeschikt belang betrof, zoals de vervanging van volksvertegenwoordigers bij zwangerschap (23.798) of ( en met name) voorstellen die direct of indirect de eigen staatsrechtelijke positic van de Eerste Kamer zouden kunnen beïnvloeden c.q. aantasten, zoals het voorzitteschap van de Verenigde Vergadering (16.640)en de vervroeging van Prinsjesdag (11.302). Als regel neemt de Eerste Kamer voorstellen tot wijziging van de Grondwet gewoon over. ${ }^{95}$

Wat leert de beschreven informatie over de wijze waarop de Eerste Kamer haar taken als medewetgevend volksvertegenwoordigend orgaan uitvoert ons nu in feite? De Nederlandse Senaat heeft bij het heroverwegingsproces formeel 'slechts' het relatief ineffectieve middel der verwerping ter beschikking. Weinig effectief omdat enerzijds totale verwerping van wetsvoorstellen met politiek gewicht een onhaalbare kaart blijkt te zijn en het anderzijds evenmin goed denkbaar is dat in het Nederlandse staatsbestel door de Senaat (via met name de novelleconstructie) veel inhoudelijk gesleuteld mag worden aan wetsvoorstellen. In het speciale geval dat wetsvoorstellen desondanks toch door de Nederlandse Senaat verworpen werden, was het politieke gewicht van het voorstel, de zeer zeldzame uitzondering daargelaten, niet dusdanig dat daardoor een serieus conflict met regering en Tweede Kamer kon ontstaan. ${ }^{96}$

Voor het overige 'kefte' de heroverwegende Senaat, vanuit de haar toebedeelde positie soms wel eens hoorbaar, maar bleef braaf in de pas lopen met de politieke geestverwanten uit de Tweede Kamer. Beleidsmatige bemoeienis met wetsvoorstellen van enig politiek gewicht blijkt de regering (daartoe gelegitimeerd door de Tweede Kamer) nu eenmaal niet op prijs te stellen en soms zelfs 'onaanvaardbaar' te vinden. De beschreven perikelen rondom de invoering van de Harmonisatiewet maar zeker ook, recentelijker de kwestie van het hoger beroep in de asielprocedure mogen daarvoor onder meer tot pijnlijk voorbeeld dienen. Laatstgenoemde kwestie zou rechtsongelijkheid in het leven roepen, omdat asielzoekers het recht op een onafhankelijk rechterlijk oordeel in twee instanties ontnomen werd. De regering deed bij monde van de Minister van Justitie wel enige vage toezeggingen, maar wenste toch dat het wetsvoorstel voor het overige onverkort door de Eerste Kamer aangenomen zou worden. Senator De Boer sprak van een 'kosmetische schaamlap' die niet kon verdoezelen dat het hart van de Senaat werd geraakt. ${ }^{97}$ Ook de aanname van de Algemene nabestaandenwet op de valreep van $1995^{98}$ en de Wet herstructurering Varkenshouderij ging met grote onvrede in het senatoren-

94. http:/www, eerstekamer.nl. 28-11-2001.

95. Zo ook: F, de Vries, dissertatie, a,w, p. 142

96. De nacht van Wiegel. waarin het grondwetherzieningsvoorstel tot invoering van een correctief referendum werd weggestemd was zo'n uitzondering.

97. Handelingen Eerste Kamer, 22.735, p. 786 e.v. In de inmiddels in werking getreden Vreemdelingenwet 2000 is overigens tegemoet gekomen aan de bezwaren betreffende (de onmogelijkheid van) hoger beroep in de asielprocedure.

98. Handelingen Eerste Kamer 1995-96, 24169. p. 516 c.v. 
corps gepaard. De wijze waarop gepoogd werd wettelijk het quotum aan varkens in Nederland te reguleren was juridisch sterk aanvechtbaar, zo meende een grote groep senatoren. Toch werd het ontwerp aangenomen. De meerderheid van de PvdA-fractie verschool zich daarbij achter het argument dat het 'duivelse dilemma van (ongeamendeerd) voor- of tegenstemmen' in wezen geen keuze was.

Als de Eerste Kamer vanuit haar eigen visie echt onvoldoende vertrouwen heeft in (de kwaliteit van) de beleidsuitingen die onder de wetgevingshamer komen, kan dat in de Nederlandse wetgevingheroverwegingspraktijk uiteindelijk blijkbaar slechts zelden een doorslaggevende rol spelen, het formeel zo machtige wapen van art. 81 jo art. 85 Grondwet ten spijt.

\subsection{Belang}

In het licht van de voorgaande constatering lijkt de vraag naar het belang van de Nederlandse senaatskamer als medewetgevend orgaan dan ook zeker gesteld te mogen worden. Een vrijwel kamerbrede, majeure en voortdurend tenugkerende klacht van de Nederlandse senatoren betreft het gegeven dat met hun expertise zo weinig gedaan kan worden. Modificeren en modelleren van wetsvoorstellen door de Eerste Kamer is formeel immers uit den boze in het Nederlandse staatsbestel. Het door de Tweede Kamer reeds aangenomen eindmodel staat er al. Amendering door de Nederlandse senaatskamer is niet geoorloofd. De zeldzaam voorkomende novelle of toezegging daargelaten is alles of niets gewoon de enige keuze. Toch wordt jaar in jaar uit, decennium in decennium uit, zowel vanuit de Nederlandse politiek ${ }^{99}$ als de wetenschap ${ }^{100}$ bij voortduring gewezen op zin en noodzaak van het takenpakket dat aan de 'Kamer van Heroverweging' wordt toegedicht. En dit lijstje, ik herhaal het nog maar eens, mag er zijn: specifieke aandacht voor aspecten van rechtstatelijkheid, toetsing aan de constitutie, controle op juridisch-technische aspecten, consistentie, overgangsrecht, relatie tot het internationale recht, maatschappelijk draagvlak, doelmatigheidstoetsing, uitvoerbaarheid en uiteraard een inhoudelijk beleidsmatige toetsing vanuit politieke overtuiging. Dit alles zijn bepaald geen onbelangrijke taken in een tijd dat raamwetgeving in combinatie met grootschalige delegatie van wetgevende bevoegdheid aan de regering de norm is geworden en de internationalisering ook de Nederlandse nationale wetgever in formele zin definitief in de greep heeft gekregen.

Kosten en baten afwegend van de inspanningen die de Eerste Kamer zich pleegt te getroosten in het kader van het wetgevingsproces lijkt het begrijpelijk dat de Nederlandse senator gevoelens van frustratie vaak maar moeilijk kan onderdrukken. Het laatste woord hebben mét vetorecht en toch in veruit de meeste gevallen nauwelijks noemenswaardige invloed uit kunnen oefenen op vorm en inhoud van het eindproduct. Anders dan de collega's uit zowel Frankrijk, Groot-Brittannië als de Bondsrepubliek Duitsland is hij/zij op geen enkele wijze reëel betrokken bij de totstandkoming van een wet in formele zin. Niet bij de voorbereiding naar Duits model, maar ook niet bij de nadere vormgeving via eventuele amendering naar Frans of Brits model. Nederlandse senatoren zullen zich vrijwel standaard tevreden moeten stellen met

99. Archief Eerste Kamer, agenda College van Senioren, januari 1996 en B. de Gaay Fortman, Parlement en wetgeving uit: W.F. de Gaay Fortman, Problemen van wetgeving, Deventer 1982, p. 60 e.v.

100. Onder andere: F. de Vries, NJB 2001, a.w., p. 1829; H. Kummeling. Preadvies, De Nederlandse Eerste Kamer, Zwolle 1992, p. 58. 
kruimels Met het beamen van een Minister of staatssecretaris dat accenten uit bepaalde passages van een voorliggende tekst wellicht ook anders geìnterpreteerd kunnen worden. Met de toezegging dat de werking van een wet na verloop van tijd onderwerp van evaluatie uit zal maken. Met moties waarin de onvrede over onderdelen van voorliggende wetsontwerpen voorafgaande aan aanname nog geventileerd kan worden. Of met een verwijzing naar de Handelingen van de Eerste Kamer, die in voorkomende gevallen immers altijd nog geraadpleegd kunnen worden door een steeds actiever wordende nationale rechter. ${ }^{101}$

\subsubsection{Terugzending}

Omdat de Nederlandse senaatskamer als medewetgever formeel in het geheel niet kan beschikken over instrumenten ter bijsturing, terwijl de praktische behoefte daaraan (getuige ook het ontstaan van de novellepraktijk) in de loop der tijd ontegenzeggelijk groter geworden is, wordt de roep om aanpassingen op dat vlak sinds de jaren tachtig van de twintigste eeuw in steeds bredere kring uitgedragen. ${ }^{102}$ Begin 2000 heeft de regering als uitvloeisel van het regecrakkoord een notitie over de positie van de Eerste Kamer aan de Tweede Kamer gestuurd. Hierin werd onder meer een poging ondernomen, een eventueel recht voor de Eerste Kamer om wetsvoorstellen in formele zin na 'heroverweging' terug te kunnen sturen naar de Tweede Kamer nader vorm te geven. ${ }^{103}$ De Nederlandse senaatskamer zou, aldus de Minister, geen recht van amendement dienen te krijgen, doch de mogelijkheid om een wetsvoorstel integraal terug te kunnen sturen naar de Tweede Kamer voor herbeoordeling door deze politiek belangrijkste parlementskamer 'met inachtneming van de opmerkingen van de Eerste Kamer'. ${ }^{104} \mathrm{De}$ grote vraag is dan vervolgens natuurlijk hoe een en ander verder vorm moet krijgen. Behoudt de Eerste Kamer het vetorecht na terugzending? Gaan de stemverhoudingen ter aanname c.q. verwerping aangepast worden? Wordt terugzending verplicht indien de senaatskamer niet tot aanname van het wetsvoorstel wil overgaan?

De regering formuleerde in de notitie een drietal opties. Deze waren met name gebaseerd op de gedachte van een terugzendplicht ${ }^{105}$ richting Tweede Kamer in geval van verwerping van een wetsvoorstel via gewone meerderheid. Definitieve verwerping zou nog slechts mogelijk blijven bij een tweederde meerderheid. Na terugzending zou dan geopteerd kunnen worden voor of facultatieve amendering en afhandeling door de Tweede Kamer, of behandeling in verenigde vergadering van beide parlementskamers. Daarnaast wordt nog de mogelijkheid open gelaten dat de Eerste Kamer een teruggezonden en vervolgens eventueel door de Tweede Kamer geamendeerd voorstel ten tweede male zou mogen heroverwegen. In dat geval zou verwerping echter eveneens slechts mogelijk zijn middels een gekwalificeerde tweederde meerderheid. ${ }^{106}$

Tijdens de eerste officièle ronde van het debat dat in de Eerste Kamer aan dit thema gewijd werd $^{107}$. gaf de Minister aan terugzending van wetsvoorstellen naar de Tweede Kamer in

101. Zie ook: J.M. Polak, De Eerste Kamer en de interpretatie van wetten, NJB 9-9-1986, p. 876.

102. Zie 0.a., E.C.M. Jügens, Een recht van renvooi!, Namens 1989, afl. 8, p. 37. Eveneens: H. Kummeling. Preadvies, a.w. p. $38 v$ en F. de Vries, dissertatie, a.w., p. 374 e.v.

103. Kamerstukken II 1999-2000, 26976, nr. I

104. Idem, p. 15 .

105. Zie ook: W, Witteveen, a.w, p. 932

106. Kamerstukken II 1999-2000, 26976, nr. 1. p. 16-17.

107. Handelingen Eerste Kamer nr. 5, 6-11-2001, p. 176-207. 
principe als een zinvol alternatief voor de bestaande novellepraktijk te kunnen beschouwen, vooropgesteld dat de Tweede Kamer vervolgens wel het laatste woord krijgt: 'we moeten geen verhouding ondermeester versus bovenmeester krijgen', aldus de minister. ${ }^{108}$ De Eerste Kamer gaf alvast in meerderheid aan in dát idee niets te zien. Tijdens een tweede ronde gaf de Eerste Kamer in meerderheid aan alles gewoon bij het oude te willen laten. Een motie Jurgens, waarin voorgesteld werd ter finale afdoening door de Tweede Kamer tenugzending van wetsvoorstellen voorzien van wijzigingssuggesties vanuit de Eerste Kamer mogelijk te maken, werd niet voldoende gesteund. ${ }^{109}$ En daarmee is de cirkel dan naar het zich laat aanzien weer eens rond. De Nederlandse parlementaire geschiedenis heeft inmiddels meermaals overtuigend aangetoond dat aanpassingen van de Nederlandse 'rigid constitution' waar de wijze van functioneren van het tweekamerstelsel en meer concreet wijziging van de (machts) positie van de Eerste Kamer in het geding is, gevoeglijk tot de onmogelijkheden gerekend mag worden. Terugzending van wetsvoorstellen door de Eerste Kamer aan de Tweede Kamer $^{110}$ heeft, zo lijkt het, dan ook nog lang geen plaatsje verworven in het contemporaine Nederlandse staatsrecht. Ik kom op deze kwestie in het kader van het rechtsvergelijkende hoofdstuk 8 overigens nog terug.

\subsection{Bestuurscontrole}

\subsubsection{Inleiding}

Hoewel de wetgevingstaken van de Senaat en de taken in het kader van de bestuurscontrole evidente samenhang vertonen, getuige onder meer de ontbindingsperikelen (zie par. 3.3.2) en de jaarlijks terugkerende begrotingsbehandeling in samenhang met het budgetrecht, worden deze twee deelterreinen van de Senaat traditioneel veelal gescheiden besproken. Een traditie waar ook hier niet geheel van af gestapt zal worden. Dit betekent dat in dit gedeelte allereerst als overgang tussen wetgeving en bestuurscontrole de rechten van de Senaat betreffende de jaarlijkse rijksbegroting besproken zullen worden. Daarna worden achtereenvolgens de interpellatie, het individueel vragenrecht, de motie, en het enquêterecht kort aan de orde gesteld.

\subsubsection{Budgetrecht}

Ook voor begrotingswetten geldt het alles-of-niets-principe. Amendering is niet mogelijk. De departementale begrotingsvoorstellen worden niet gelijktijdig aan de Senaat aangeboden. ${ }^{11}$ Formeel dient de volledige Rijksbegroting voor aanvang van het nieuwe kalenderjaar door beide Kamers zijn aangenomen.

Voornoemde constellatie van feitelijkheden heeft tot gevolg gehad dat de jaarlijkse behandeling van de afzonderlijke begrotingsvoorstellen in de Eerste Kamer curieus pleegt te verlopen. Deze voorstellen kúnnen de gewone route volgen via de departementale commissies, inclusief

108. Idem, p, 5-201.

109. Handelingen Eerste Kamer 2001-2002, p. 863.

110. Vooral Jurgens heeft namens de PvdA de afgelopen decennia al meermaals invoering van enige vorm van terugzendrecht bepleit.

111. H.G. Warmelink, Parlement en begroting. Serie monografieên Nederlands Parlementsrecht, Groningen 1993, p.189 e.v. 
voorlopig verslag en eindverslag. Indien deze weg gevolgd wordt, zal in de regel de betreffende begrotingswet vervolgens zonder stemming aanvaard worden aangezien "de Eerste Kamer niet de mogelijkheid heeft om wijzigingen aan te brengen in de begroting en evenmin tegen afzonderlijke begrotingsartikelen kan stemmen', terwijl ook het indienen van moties slechts hoogst zelden pleegt te gebeuren. ${ }^{112}$

Ook echter kan geopteerd worden voor de administratieve afdoening oftewel 'vereenvoudigde behandeling' ex art. 54 RvOEK: Indien een voorstel zonder beraadslaging en zonder stemming in de Tweede Kamer werd aanvaard, kan de commissie aan wie het voorstel in de Senaat is toevertrouwd eindverslag uitbrengen zonder het houden van zelfs maar een inbrengvergadering. Dit betekent dat na opstelling van een eindverslag het betreffende begrotingsvoorstel direct goedgekeurd kan worden. Deze wijze van werken brengt uiteraard een aanzienlijke tijdsbesparing met zich mee en daaraan blijkt grote behoefte te bestaan. Weliswaar heeft art. 18 van de Comptabiliteitswet $1976^{113}$ aangaande de eindejaarstijdsdruk enige verlichting bewerkstelligd, doch (gedeeltelijke) administratieve afdoening is jaar in jaar uit noodzakelijk, zoniet vanzelfsprekend betreffende een aanzienlijk aantal begrotingsvoorstellen ${ }^{114}$ Het blijft, ondanks de hier geschetste praktijk overigens alleszins mogelijk dat aan de rijksbegrotingsvoorstellen achteraf nog beleidsdebatten gewijd zullen worden. Deze zijn dan uiteraard per definitie zonder consequenties voor de reeds aangenomen voorstellen. In de praktijk wordt tegenwoordig meestal van het houden van dergelijke debatten 'après la lettre' afgezien in verband met een chronisch overbelaste agenda.

In feite kan door dit alles het historisch recht der rechten van het parlement, het budgetrecht, als controle-instrument voor de Nederlandse Senaat vrijwel niets meer betekenen. ${ }^{115} \mathrm{Nu}$ de behandeling van de begrotingsvoorstellen anno 2000 minimaal gedeeltelijk nog slechts pro forma geschiedt in een van het amendementsrecht verstoken Eerste Kamer, lijkt het recht van verlenen van financiele autorisatie voor zover het de tweede Nederlandse parlementskamer aangaat, toch wel erg ver uitgehold te zijn.

\subsubsection{Interpellatie}

Ingevolge artikel 139 RvOEK heeft ook de Eerste Kamer het recht over onderwerpen 'vreemd aan de orde van de dag' inlichtingen te vragen aan bewindslieden. Dit verzoek tot interpelleren dat door ieder lid van de Senaat kan worden uitgeoefend, wordt gericht aan de Eerste Kamer zelf. Art. 139 RvOEK is een uitwerking van de in art. $68 \mathrm{Gw}$ beschreven inlichtingenplicht voor bewindslieden richting parlementskamers. Uit dit Grondwetsartikel blijkt dat voornoemde plicht slechts begrensd wordt door 'strijd met het belang van de staat'. Het recht van interpellatie maakt het voor (individuele leden van) de Eerste Kamer mogelijk via het openbare debat informatie in te winnen c.q. uit te wisselen aangaande de visie van ministers en staatssecretarissen betreffende ieder denkbaar politiek en/of maatschappelijk

112. H.G. Warmelink, a.w., p. 195.

113. Maximaal 1/3e van de budgetten die het voorgaande jaar beschikbaar waren via de departementale begrotingspost, kunnen door de minister ook voor het nieuwe begrotingsjaar gevorderd worden, indien vóór I januari de raak nog niet rond is.

114. H.G. Warmelink, a.w., p. 197.

115. De Vries spreckt in zijn dissertatie in dit kader (p. 295) mijns inziens terecht van 'rituele dansen die weinig inhoudelijke betekenis hebben'. 
onderwerp dat van belang wordt geacht. Tevens kan de Kamer via deze weg proberen de regering te overtuigen van de (on)zinnigheid van actie op bepaalde beleidsterreinen.

Zelfs indien een meerderheid van de Kamer zich formeel zou uitspreken tegen het verstrekken van inlichtingen door een Minister aan bepaalde individuele kamerleden, moet de gevraagde informatie toch aangeleverd worden. Art. 68 Grondwet laat daarover sinds de grondwetsherziening van 1987 geen enkele onduidelijkheid meer bestaan. Vooral voor leden afkomstig uit oppositionele politieke partijen is het interpellatierecht dan ook een bijzonder functioneel parlementair recht gebleken. Dit te meer, daar Nederlandse bewindslieden zich in de praktijk slechts uiterst moeizaam achter het begrenzingscriterium 'belang van de staat' blijken te kunnen verschuilen. ${ }^{116}$ Voor de Nederlandse senaatskamer is dit laatste in de praktijk natuurlijk niet van belang. In die parlementaire praktijk wordt van het recht van interpellatie slechts hoogst zelden gebruik gemaakt door de leden van de Eerste Kamer. ${ }^{17}$ En als er dan toch sprake van is, blijkt dat tegenwoordig met name te gebeuren in het kader van een soort zelfevaluatie. Zo vormde de positionering binnen het staatsbestel van de Eerste Kamer in 1990 de aanleiding voor een van die zeldzame gelegenheden. ${ }^{118}$ De rol van de Eerste Kamer bij wetgeving was het onderwerp van de interpellatie de Boer uit 1996. Wederom de rol van de Eerste Kamer, maar nu in relatie tot de 'nacht van Wiegel', vormde voor senator Schuurman in 1999 de aanleiding voor een tweede interpellatie waaraan zijn naam verbonden zal blijven.

\subsubsection{Vragenrecht}

Naast het recht van interpellatie biedt art. 140 RvOEK aan Nederlandse senatoren de mogelijkheid schriftelijke vragen te stellen aan bewindslieden. In het geval van de schriftelijke vraag ex art. 140 RvOEK bekijkt de Voorzitter eerst marginaal of tegen doorzending aan de minister 'overwegend bezwaar bestaat wegens vorm en inhoud' (art. 140 lid 2 RvOEK). Bij die 'marginale toetsing' door de voorzitter wordt gekeken of de vragen niet al eerder in de Tweede Kamer zijn gesteld, niet al te zeer particuliere belangen dienen van het lid dat vragen stelt, dat zij geen onwelvoeglijke taal bevatten, dat de plicht tot geheimhouden niet geschonden wordt en dat het onderwerp in kwestie niet zeer kort geleden of binnenkort toch in de Kamer aan de orde gekomen is dan wel komt.

De tegenwoordig in art. 140 RvOEK geformuleerde eis, dat vragen schriftelijk gesteld moeten worden, heeft sinds de formele introductie in 1918 twee maal aanleiding gegeven tot bespiegelingen over dit onderwerp. 'Daar de Kamer op ongeregelde tijden bijeenkomt, de Ministers daardoor nodeloos uit hun werk worden gehaald en de praktijk in de Tweede Kamer geleerd heeft, dat van deze bevoegdheid (het stellen van mondelinge vragen, EK) hoogst zelden gebruik gemaakt wordt' meenden de indieners van het voorstel tot aanvulling van het Reglement van Orde ter regeling van het vragenrecht dat het hanteren van een mondeling vragenrecht niet zinvol was. ${ }^{119}$ De Eerste Kamer had hoegenaamd geen problemen met het voorstel 'aangezien deze Kamer zooveel minder bijeen is dan de andere en de groote meerderheid van de leden buiten 's-Gravenhage verblijf houdt'. ${ }^{120}$ In 1967 werd toegevoegd dat de vragen

\footnotetext{
116. G. Visscher, a.w., p. 92-94. Een beroep op het belang van de staat dient door de betreffende minister of staatssecretaris sinds 1985 in de ministerraad gemeld en zonodig verantwoord te worden.

117. Vanaf 1963 in totaal 8 maal.

118. Interpellatie Schuurman.

119. Bijlage Handelingen Eerste Kamer 1917-1918, nr. 161, p. 2.

120. Bijlage Handelingen Eerste Kamer 1917-1918, nr. 161a.
} 
schriftelijk gesteld moesten worden. De mogelijkheid tot mondelinge beantwoording van schriftelijke vragen werd niet wenselijk geacht, doch bleek tijdens de grondwetsherziening van 1983 opnieuw onderwerp van discussie te worden. Een voorstel om het recht tot mondelinge beantwoording van schriftelijke vragen op te nemen in het Reglement van Orde van de Eerste Kamer kon bogen op vrijwel kamerbrede sympathie, doch werd uiteindelijk niet doorgezet. ${ }^{121}$ Duidelijk was wel geworden dat het de Eerste Kamer in principe volkomen vrij zou staan, om op de door haar gewenste manier invulling te geven aan de wijze waarop het in de Grondwet verankerde recht tot het verkrijgen van inlichtingen via schriftelijke vragen vorm dient te krijgen. ${ }^{122}$

Uitoefening van het vragenrecht geschiedt ten behoeve van verschillende doeleinden. De belangrijkste functie is natuurlijk beïnvloeding van het regeringsbeleid, maar ook het signaleren van maatschappelijke misstanden, de ombudsmanfunctie ten behoeve van de politieke achterban en informatievoorziening door de regering zijn medebepalend voor de populariteit van het individueel vragenrecht. ${ }^{123}$

Postma signaleerde in zijn onderzock naar het interpellatie- en vragenrecht, dat vooral leden van oppositiepartijen graag gebruik plegen te maken van het schriftelijk vragenrecht om op die wijze inzage te verkrijgen in beleidsdirectieven waarvan zij, als oppositiegroepering, normaliter verstoken blijven. ${ }^{124}$

Van het schriftelijk vragenrecht wordt logischerwijze iets sneller gebruik gemaakt door de leden van de Eerste Kamer dan van het interpellatierecht. Het stellen van schriftelijke vragen past naar de letter immers goed bij het profiel van de Nederlandse senator. Deze is als parttime volksvertegenwoordiger in de regel slechts één dag in de week werkzaam voor de Eerste Kamer en moet het werk verrichten zonder noemenswaardige ambtelijke ondersteuning. Voeg daarbij dat de fracties in de Eerste Kamer kleiner zijn dan in de Tweede Kamer en het wordt duidelijk dat de schriftelijke vraag een bijzonder praktisch middel kan zijn om toch enig inzicht te kunnen verkrijgen in de handel en wandel van de regering.

Naar de effectiviteit van het middel in de relatie Eerste Kamer-regering is nooit onderzoek verricht, maar feit is wel dat er in absolute zin opvallend weinig vragen worden gesteld. De behoefte om zaken via de formele (schriftelijke) vraag onder de aandacht van de regering te brengen, leeft bij de Nederlandse senatoren blijkbaar nauwelijks. Om het kwantitatief in perspectief te plaatsen: tussen januari 1999 en november 2001 werden door de Nederlandse senaatskamer in totaal 55 schriftelijke vragen gesteld. Tijdens diezelfde periode werden door zowel de leden van de Franse Sénat als het Britse House of Lords meer dan 15000 kwesties schriftelijke onder de aandacht van de respectievelijke regeringen gebracht, uiteraard gepaard gaande met een verzoek om antwoord.

\subsubsection{Recht van enquête}

Sinds 1887 heeft de Eerste Kamer (naast de Tweede Kamer) het recht van enquête. Dat recht kan ook in verenigde vergadering worden uitgeoefend (art. 70 Grondwet.). Het behelst de

121. Zie hiervoor o.a De Gaay Fortman: Handelingen Eerste Kamer 1982-1983, p. 1147 e,v.

122. A Postma, Het interpellatie- en vragenrecht van de Eerste en Tweede Kamer, Serie monografieèn Nederlands Pariementsrecht, Groningen 1985, p. 47.

123. G. Visscher, Het vragenrecht, in: Het parlement in aktie, a.w., p. 239-241.

124. A. Postma, Het interpellatierecht van de Eerste- en Tweede Kamer, a.w. p. 67. 
mogelijkheid om zelfstandig op onderzoek uit te gaan. Kwesties van grote maatschappelijke, economische of sociale importantie waarover dienovereenkomstige beroering is ontstaan en onduidelijkheid blijft bestaan, kunnen een parlementskamer van de Staten-Generaal doen besluiten tot het instellen van een enquête. ${ }^{125}$ Een dergelijk besluit moet genomen worden met meerderheid van stemmen. Vervolgens wordt een commissie benoemd die de uitvoering op zich zal nemen (art. 131 RvOEK). De commissie kan getuigen en deskundigen oproepen en ondervragen (art 133 RvOEK). Vanaf het moment dat het via aanname van een initiatiefwetsvoorstel mogelijk was geworden ook ministers in het openbaar en onder ede te gaan horen, werd de parlementaire enquête in Nederland een populair controlemiddel. ${ }^{126}$

Over het verlenen van het recht van enquête aan gekwalificeerde minderheden is regelmatig discussie gevoerd. In het kader van de grondwetsherziening 1983 werd door de Tweede Kamer via een amendement Faber naar Duits voorbeeld de mogelijkheid geopperd het initiatief tot een enquête toe te kennen aan een parlementaire minderheid van 1/5 deel der leden. Dan zou het voor regeringsgezinde meerderheden onmogelijk worden enquêtevoorstellen vanuit de oppositie te blokkeren. De Raad van State meende echter dat dan het parlementaire stelsel aangetast zou kunnen worden. Zij voorzag 'onwerkbare situaties' en 'weinig verheffende verschillen'. ${ }^{127}$ Ook werd opgemerkt dat 'een veelvuldig gebnuik van dit relatief gemakkelijk hanteerbaar gemaakte wapen de parlementaire werkzaamheden onevenredig zou belasten'. Mede ten gevolge van dat advies besloot de Eerste Kamer in tweede lezing het voorstel af te wijzen. Markant genoeg heeft bij deze afwijzing het enige enquêtevoorstel dat ooit door leden van de Eerste Kamer is ingediend een belangrijke rol gespeeld. Het enquêtevoorstel Mol/ $\mathrm{Trip} / \mathrm{Vis}{ }^{128}$ dat de problematiek rondom kernafval-opwerkingswetgeving zou betreffen vond geen genade in de ogen van het CDA. Vooral fractievoorzitter Kaland zag er niets in en sprak zelfs van een politieke blunder. ${ }^{129}$ Het CDA had in eerste lezing wel ingestemd met het minderheidsrecht tot het initiëren van enquêtes, maar zag nu, nog vóór de tweede lezing, dat de consequenties ook in eigen huis goed voelbaar zouden kunnen worden. Het grondwetsherzieningsvoorstel betreffende het minderheidsrecht op enquête verkreeg in tweede lezing niet eens een gewone meerderheid. ${ }^{130}$

In 1986 is nogmaals een poging gewaagd vanuit de Tweede Kamer. Nu ging het om 1/3 van het aantal leden. Ook deze keer strandde het voorstel uiteindelijk in de Eerste Kamer. ${ }^{131}$

Hoewel de door de Tweede Kamer geïnitieerde parlementaire enquête sinds de tachtiger jaren in Nederland een effectief en derhalve frequenter gehanteerd parlementair onderzoeksmiddel is gebleken, heeft de Eerste Kamer haar initiatieven in deze vooralsnog beperkt tot het afgewezen voorstel van Mol, Trip en Vis.

In 2000 is door de Raad van Senioren van de Eerste Kamer echter de bereidheid uitgesproken toch maar eens gebruik te gaan maken van het enquête-instrument als middel ter controle. ${ }^{132}$ Dit besluit werd vooral ingegeven door de overtuiging dat een al te monistische verhouding

125. A.H.M. Dölle, Het recht van parlementaire enquête, Serie monografieên Nederlands Parlementsrecht, Groningen 1985 .

126. A. Kappeijne van de Coppello, Het recht van enquête, in: Het parlement in aktic, a.w., p. 65-66.

127. Handelingen Tweede Kamer 1981, 16.938A.

128. Eerste Kamer 1980-1081, bijlage II 15.920, nr. 149b, Handelingen p. 1089-1098.

129. Handelingen Eerste Kamer 1980-1981, p. 1091.

130. Handelingen Eerste Kamer 1981-1982, p. 443-444.

131. Handelingen Eerste Kamer 1985-1986, p. 960.

132. Zie Volkskrant 2-11-2000, p. 7. 
tussen regering en Tweede Kamer betreffende de gang van zaken voor een aantal beleidsterreinen die aan nadere parlementaire controle onderworpen zouden moeten worden (bijvoorbeeld de mislukte steunoperaties aan Fokker of het leveren van soldaten voor een VN-missie in Srebrenica) ongewenste leemten in de bestuurscontrole tot gevolg kan hebben. In de loop van 2000 werd door het CDA het voorstel gelanceerd om de Eerste Kamer een enquête te laten houden over de problemen in de zorgsector. Tot op heden (november 2001) is dienaangaande echter geen verdere actie ondernomen.

\subsection{Balans}

Lijphart constateerde in zijn onderzoek 'Patterns of Democracy' (par. 1.3) dat in Nederland een betrekkelijk krachtig tweekamerstelsel kan functioneren. Hij baseerde deze conclusie op het gegeven dat de Eerste Kamer deugdelijk democratisch gelegitimeerd is en beschikt over aanzienlijke constitutionele rechten, het absoluut vetorecht voorop. ${ }^{133}$

Theorie en praktijk lopen waar het functioneren van de Eerste Kamer in het geding is, echter ontegenzeggelijk uitcen. Zeer goed zichtbaar wordt dat, waar de bestuurscontrolerende taakstelling van de Nederlandse senaatskamer in het geding is. Bij het budgetrecht, het enquêterecht en het vragenrecht. Allemaal fraai in de Grondwet dan wel organieke wetten, respectievelijk Reglement van Orde uitgewerkte rechten die zich in de praktijk niet ( enquête) of slechts in de marge (begroting, interpellatie en vragenrecht) onderscheiden van een lege huls. Deze betrekkelijk wrange constatering is natuurlijk niet nieuw. De belangrijkste oorzaak ligt voor de hand. De Nederlandse deeltijdsenator, heeft in de meeste gevallen ook nog een hoofdberoep te vervullen. Daar komt bij dat het formeel niet geringe takenpakket van de leden der Eerste Kamer verricht moet worden zonder noemenswaardige ambtelijke ondersteuning. Dus moeten er keuzes gemaakt worden. En aangezien de voortgang van het formele wetgevingsproces in de nog nauwelijks geprivatiseerde verzorgingsstaat die Nederland ook in de 2 le eeuw nog altijd is, hoe dan ook prioriteit moet hebben, valt de keuze voor de Eerste Kamer als vanzelfsprekend bovenal op wetgevingsheroverweging: op beoordeling van de juridische kwaliteit van regelgevingvoorstellen, van de doelmatigheid, de uitvoerbaarheid, de verenigbaarheid met verdragen enz. Vanzelfsprekend omdat ook de 'handtekening' van de Eerste Kamer nu eenmaal steeds weer opnieuw grondwettelijk vereist is, alvorens een nieuwe wet of wetswijziging het Staatsblad kan bereiken. De vanzelfsprekendheid wordt echter minder indien de wettelijk beschikbare instrumentaria ter heroverweging van het legislatieve product in wording goed tegen het licht worden gehouden. Dan blijkt dat een absoluut vetorecht dat slechts het wetsvoorstel in zijn geheel kan treffen ongeschikt is ter bijsturing van regelgevingvoorstellen. Juridische instrumenten die gedeeltelijke bijsturing via inhoudelijke dan wel technische toevoegingen wél mogelijk maken (tenugzending naar Duits voorbeeld of een recht van amendement naar Brits of Frans voorbeeld) ontbreken opmerkelijk genoeg volledig in het Nederlandse geschreven recht. Het gegeven dat de portee van het commissiewerk in de Nederlandse senaatskamer zo miniem is, moet ook in dat licht beoordeeld worden.

Toch kan de Eerste Kamer sinds enige decennia via de in de parlementaire praktijk ontstane constructies van de 'novelle' en de 'toezegging' af en toe ( zij het in minder dan $1 \%$ van de

133. A. Lijphart, Patterns of Democracy. Yale University Press, New Haven 1999, p. 205-213. 
gevallen) ook in materiele zin enige bijsturende invloed uit oefenen op de op stapel staande voorstellen tot wetgeving in formele zin. Tenminste als het er politick niet echt om spant, getuige onder meer de voorbeelden van de Harmonisatiewet, AAW en Herstructurering Varkenshouderij.

De maximaal toelaatbare actieradius van de heroverwegende Nederlandse senaatskamer blijkt al sinds de invoering van het algemeen kiesrecht in hoofdraak bepaald via partijpolitieke lijnen geregisseerd vanuit de regeringscoalitic. Gedragen door degelijk gefundeerde politiekstaatsrechtelijke noties als 'het primaat van de Tweede Kamer' en de 'terughoudendheid van de Eerste Kamer' is de bijzonder beperkte actieradius die het functioneren van de Nederlandse senaatskamer in het kader van de wetgevingsheroverweging zo typeert, als het ware geinstitutionaliseerd. En in geval van calamiteiten kan de regering of een individuele minister altijd nog de vertrouwensregel activeren om een tegenstribbelende Eerste Kamer terecht te wijzen.

'Strong bicameralism' tenslotte, zou de Nederlandse senaatkamer formeel ook uit kunnen stralen waar het bewaken van de constitutie in het geding is. Vooral nu tegenwoordig een tweederde meerderheid voor de coalitiepartners in de Eerste Kamer geen voortdurende vanzelfsprekendheid meer is. De hoogst zeldzame uitzondering daargelaten blijkt de Eerste Kamer in de praktijk slechts grondwetswijzigingen van ondergeschikte betekenis en (vooral) grondwetwijzigingsvoorstellen de eigen positie betreffende te verwerpen. 



\title{
Hoofdstuk 7
}

\section{Bondsrepubliek Duitsland, wetgeving en bestuurscontrole}

\author{
Durch den Bundesrat wirken die Lander bei der Gesetzgebung und Venvaltung des Bundes \\ mit.'
}

\subsection{Inleiding}

Uit de strekking van hetgeen in de hoofdstukken 2 en 3 van dit boek reeds kon worden opgemerkt over ontstaan, benoemingsstelsel en organisatie van de Duitse Bundesrat, bleek al meermaals dat iedere vorm van duiding van het fenomeen Bundesrat als 'Zweite Kammer' van een parlementair staatsbestel samenhang zal vertonen met de federale staatsvorm van de Bondsrepubliek Duitsland: 'Im Schnittpunkt zwischen Bund und Ländern, Foderalismus und Parlamentarismus, Legislative und Executive, Parteienstaat und bürokratischem Sachverband ist der Bundesrat teil all dieser Kräfte und Prinzipien und ist zugleich den hinter ihnen liegenden Schubkräften ausgesetzt' ?

Vanzelfsprekend draagt deze constatering in zowel formele als materièle zin tevens implicaties met zich mee voor de wijze van totstandkoming van de Bondsduitse legislatieve output. In welke mate bijvoorbeeld zal binnen de Duitse bondsstaatconstructie sprake (kunnen) zijn van onafhankelijk van de Bond functionerende Lănder, die via de Bundesrat hun eigen inbreng kunnen hebben in het wetgevingsproces van de Bond als geheel? Vanuit welk federatief staatsmodel wordt het centrale begrip 'mitwirken' uit art. 50 GG in de praktijk nader uitgewerkt, in een systeem waar de Bundesrat de brug vormt tussen elementen van federale en parlementaire regeringssystemen? De vraag naar de staatstheoretische verhouding tussen het federatieve element en het eenheidselement zal, met name natuurlijk omdat specifiek de medewetgevende functie van de Bundesrat daarbij in het geding is, dan ook allereerst aan de orde moeten komen, alvorens over gegaan zal kunnen worden tot een beschrijving van de wijze waarop de Bundesrat in de praktijk tegenwoordig vorm pleegt te geven aan zijn legislatieve bevoegdheden. Bij dit alles mag ook niet uit het oog verloren worden welke dwingende rol het partijpolitieke element kan spelen in een federaal/parlementair politiekstaatsrechtelijk krachtenveld als het Bondsduitse. Tijdens de (uitvoerig te bespreken) problematiek betreffende de ontwikkeling van het partiële legislatieve vetorecht dat de Duitse senaatskamer grondwettelijk toekomt bijvoorbeeld, zal het partijpolitieke element grondig belicht worden.

Daar komt, specifiek met het oog op dit comparatief onderzoek, nog bij dat een vergelijking van de rol die de Bundesrat speelt in het Duits federale wetgevingsproces, met de rol die de Eerste Kamer, de Sénat en het House of Lords ('tweede' parlementskamers functionerend binnen niet-federatieve staatsinstellingen) ter uitwerking van de legislatieve taakstelling plegen te vervullen, al snel gekwalificeerd zou kunnen worden als een gekunstelde poging tot vergelijking van wellicht in het geheel niet te vergelijken grootheden. Enige

1. Art. $50 \mathrm{GG}$.

2. R. Dolzer, und M. Sachs, Das parlamentarische Regierungssystem und der Bundesrat- Entwicklungsstand und Reformbedarf, Berlin 1999, p. 9. 
verheldering dienaangaande is dan ook zeker geboden. Mijn aandacht zal in dit hoofdstuk derhalve eerst uitgaan naar een meer specifieke duiding van het in de Bondsrepubliek Duitsland gepraktiseerde federatieve staatsmodel, voor zover relevant in het kader van mijn onderzoek naar het functioneren van senaatskamers in een viertal West-Europese democratieèn. Daarop aansluitend zal ik dan een these formuleren als antwoord op de vraag of de feitelijke politiekstaatsrechtelijke positie van de Bundesrat, die als 'tweede' Duitse wetgevingskamer functioneert binnen een federatief staatsverband een vergelijking met de positie van de drie genoemde zusterinstellingen, zoals bekend functionerend binnen even zovele eenheidsstaten, in de weg staat. Het vervolg van dit hoofdstuk zal gecentreerd worden rondom de gang van Bondsduitse regelgevingprocessen. Eerst en vooral natuurlijk voorstellen voor wetgeving in formele zin geïnitieerd vanuit de Bondsregering. Regelgevingvoorstellen gebaseerd op delegatie van wetgeving en de besluitvorming aangaande intern werkende Bondsduitse beleidsregels zullen in de marge eveneens besproken worden. De uitgebreide aandacht voor de wijze waarop de Bundesrat uitvoering geeft aan haar medewetgevende taakstelling wordt gerechtvaardigd vanuit het gegeven dat de Bundesrat vrijwel alle beschikbare tijd blijkt te investeren in activiteiten die verband houden met de gang van Bondsduitse regelgevingvoorstellen in de meest brede zin des woords.

De wijze waarop en de mate waarin partijpolitieke invloeden zich manifesteren tijdens voornoemde regelgevingprocessen zullen natuurlijk eveneens onderwerp van bespreking uitmaken. De partijpolitieke invloed zal belicht worden vanuit beide bases, het Land én de Bond, waarbij de Bundesrat als spil fungeert. De mate waarin het uiteindelijke succes van regelgevingvoorstellen afhankelijk gesteld wordt van expliciete toestemming door de Bundesrat, alsmede de werking van de Bondsduitse conciliatiecommissie, de 'Vermittlungsausschuss' vergen én krijgen extra aandacht in dit hoofdstuk. Datzelfde geldt voor de positie die de Bundesrat op basis van het nieuwe grondwetsartikel 23 in de Bondsduitse staatsrechtelijke constellatie in kan gaan nemen met betrekking tot EU-gelieerde regelgevingvoorstellen.

De bestuurscontrole door de Bundesrat tenslotte zal in kwantitatief opzicht relatief onderbedeeld worden in dit hoofdstuk, eenvoudig omdat de Bondsduitse tweede kamer die klassiek-parlementaire taak grotendeels over blijkt te laten aan de Bundestag.

\subsection{De Duitse Bondsstaat}

Vanzelfsprekend is zowel in de doctrine als in de rechtspraak regelmatig aandacht uitgegaan naar het beantwoorden van de vraag welke federatieve staatsvorm nu model staat voor de politiekstaatsrechtelijke praktijk zoals die in de Bondsrepubliek Duitsland vorm heeft gekregen sinds 1949.

In eerste instantie leek het er even op alsof geopteerd zou zijn voor het zgn. 'Dreistaatenmodell'. Dit theoretisch model, dat reeds in 1925 door Kelsen op schrift werd gesteld, gaat ervan uit dat de staatsmacht binnen de Bondsrepubliek Duitsland verdeeld wordt over 'Länder, Bund en Gesamtstaat'. De macht van de Lănder blijft in dat model beperkt tot het eigen territorium. De Bund bestrijkt het gehele Duitse territorium. De Gesamtstaat ten- 
slotte kan zich manifesteren als een optelsom van Bund en Lănder. De Bundesrat zou in dit model functioneren als orgaan ter behartiging van de belangen en ontwikkeling van de Gesamtstaat. ${ }^{3}$ Het Bundesverfassungsgericht leek zich in eerste instantie even te laten leiden door het 'Dreistaatenmodell', 'Het model bleek echter al snel te weinig verklaringskracht te bezitten voor de wijze waarop de verschillende staatsrechtelijk gefundeerde instituties en organen zich ten behoeve van de ontwikkeling van de Bondsrepubliek Duitsland ten opzichte van elkaar bleken te manifesteren. ${ }^{5}$ In plaats van een open dualistisch federalisme ging zich namelijk al direct vanaf 1949 een systeem met vele sterk unitaristische tendensen manifesteren. Het concept van gescheiden huishoudens in de staatsrechtelijke relatie Bund-Lănder bleek al snel te evolueren tot een concept van vermenging.

Bijzonder interessant is ook het in 1962 door Hesse ontwikkelde 'Einheitsstaatsmodell'. Dit model is met name zo interessant omdat voor de ontwikkeling ervan de daadwerkelijke constitutionele praktijk in de naoorlogse Bondsrepubliek het uitgangspunt gevormd heeft. Hesse signaleerde sinds het ontstaan van de Bondsrepubliek in 1949 namelijk cen voortdurende tendens tot verdergaand unitarisme op zowel maatschappelijk, partijpolitiek als ook staatsrechtelijk vlak. De zich snel ontwikkelende verzorgingsstaat en de centrale rol die daarin alleen al uit doelmatigheidsoverwegingen wel weggelegd móest zijn voor de uitvoerende macht, had zijns inziens tot gevolg dat de centrale overheid en de overheden der Länder in steeds toenemende mate tot elkaar veroordeeld werden. In wezen zijn, het 'unitaristischen Bundesstaat'-model indachtig, de in casu relevante verschillen tussen federatie en eenheidsstaat, aldus Hesse, dan ook grotendeels terug te voeren tot dat extra element van horizontale machtenscheiding waarmee rekening dient te worden gehouden tijdens het wetgevingsproces. Een extra, via het instituut Bundesrat te concretiseren element, dat aan de verdere uitbouw van zowel het democratieprincipe als het rechtsstaatprincipe in de Bondsrepubliek Duitsland nog één dimensie toevoegt.' In dit model kan, waar het functioneren van de Bundesrat als tweede parlementskamer in het geding is, relatief eenvoudig aansluiting gezocht worden bij tweekamerstelsels functionerend in de drie eenheidsstaten die in dit boek ook onder de loep worden genomen.

Dan is er het 'Zweistaatenmodell' dat tegenwoordig althans gedeeltelijk de heersende leer lijkt te vertegenwoordigen. ${ }^{8}$ In dit model worden 'Bund' en 'Länder' onderscheiden.

Slechts de 'Bund' is echt soeverein. De niet soevereine 'Länder' worden wel expliciet door de 'Bund' erkend als binnen de Bondsrepubliek functionerende staatsrechtelijk entiteiten.' Binnen dit model ligt het accent voor het functioneren van de Bundesrat iets sterker dan in het 'Einheitsstaatsmodell' op het tevens behartigen van regionale belangen der Lănder in het kader van het wetgevingsproces op bondsniveau.

3. H. Kelsen, Allgemeine Staatrechtslehre, Neudruck Bad Homburg 1966. Ook H. Nawiasky, Allgemeine Staatslehre, Band 3: Staatrechtslehre, Einsiedeln 1956.

4. BverfGE 6, 309.

5. D. Hanf, Bundesstaat ohne Bundesrat?, Die Mitwirkung der Glieder und die Rolle zweiter Kammern in evolutiven und devolutiven Bundesstaaten. Eine rechtsvergleichende Untersuchung, Baden-Baden 1999, p. 66-76.

6. K. Hesse, Der unitarische Bundesstaat, Karlsnuhe 1962.

7. K. Hesse, a.w., p. 27 e.v.

8. D. Hanf, a.w., p. 68.

9. K. Stern, Das Staatsrecht der Bundesrepublik Deutschland, Band I, München 1984, p. 489 c.v. 
Tenslotte is er het 'Kombinationsmodell' van Bleckmann. In dit omvangrijke model wordt een poging ondernomen de centrale elementen uit de drie reeds besproken modellen met elkaar te verenigen. ${ }^{10}$ In het 'Kombinationsmodell' worden de Länder beschouwd als Staten. De Duitse soevereiniteit ligt niet uitsluitend bij de Bond als geheel. De soevereiniteit is namelijk splitsbaar in oppergezag (Bond) en 'Untergewalt', dat de eigen huishouding van het Land omvat. De Bundesrat is hier het orgaan bij uitstek dat tot taak heeft zowel de grondwettelijk verankerde 'soevereine rechten de eigen huishouding betreffende' voor de Länder te beschermen als mee te werken aan de ontwikkeling van de Bondsrepubliek als geheel. ${ }^{11}$

\subsubsection{Bondsstaat en Bundesrat}

Wat leert deze korte conceptuele excursie ons over de positie van de Bundesrat in relatie tot 'Bund' en 'Länder'? In de Bondrepubliek Duitsland kan, mede ten gevolge van de sociaal-economische ontwikkelingen in de naoorlogse verzorgingstaat een steeds manifester wordende constitutionele ontwikkeling richting 'unitarischen Beteiligungsfoderalismus ${ }^{\prime 2}$ waargenomen worden. Een ontwikkeling die de positie die Bond en Land in staatsrechtelijke zin ten opzichte van elkaar in nemen, aan voortdurende veranderingen onderhevig maakte. Veranderingen in het legislatieve bevoegdhedenpakket van zowel Bond als Lănder met aanzienlijke repercussies voor de benadering van voornoemde dogmatiek. Veranderingen die met name ook de plaatsbepaling van de Bundesrat, die binnen dat verschuivende concept een complexe centrale tweeledige taakstelling te vervullen heeft, niet ongemoeid kan laten. Enerzijds immers, moet het eigen 'semi-soevereine' belang van de Lānder in Berlijn gediend worden. Anderzijds moet, gelegitimeerd door en vanuit de Länder, een extra element ingebracht worden bij de deelname aan de 'gesamtstaatlichen demokratischen Willensbildung'. Een element dat door de grondwetgever zelfs als dusdanig elementair voor het voortbestaan van de Duitse Bondsstaat wordt beschouwd, dat het valt onder de 'Ewigketsgarantie'-bescherming van art. $79 \mathrm{Abs} .3 \mathrm{GG}{ }^{13} \mathrm{Bij}$ dit alles dient ook nog verdisconteerd te worden, dat de uitbouw van het concept van een 'unitarischen Beteiligungsfoderalismus' in de Bondsrepubliek Duitsland nooit los beschouwd mag en kán worden van ontwikkelingen die zich blijken te manifesteren binnen het partijpolitieke krachtenveld.

Zoveel over de theorie. Laten wij de aandacht verleggen naar de praktijk. Wanneer nu blijkt dat met name het coöperatieve element aangaande de Bondsduitse 'Willensbildung' op de voorgrond treedt, waar de participatie van de Bundesrat bij het legislatieve proces op Bondsniveau in het geding is, lijkt een vergelijking van het functioneren van bicamerale stelsels in de eenheidsstaten Frankrijk, Groot-Brittanniě en Nederland met het Bonds-

10. A. Bleckmann, Staatsrecht I, Staatsorganisationsrecht, Grundlagen, Staatszielbestimmungen und Staatsorganisationsrecht des Bundes, Köln 1993, p. 1469 e.v.

11. Idem, p. 1487.

12. D. Hanf, a.w., p. 73.

13. Art. 79 Abs. 3 GG: 'Eine Ánderung dieses Grundgesetzes, durch welche die Gliederung des Bundes in Lander. die grundsatzliche Mitwirkung der Lander bei der Gesetzgebung oder die in den Artikeln 1 und 20 niedergelegten Grundsatze beruhrt werden, ist unzulassig: 
duitse federale tweekamermodel alleszins verantwoord. Het verschil wordt dan, voor zover de medewetgevende werkzaamheden in het geding zijn, immers grosso modo teruggebracht tot die grotere legitimerende werking. welke de Bundesrat vanzelfsprekend blijft ontlenen aan zijn staatsrechtelijke band met de Duitse 'regio's'.

De vraag in hoeverre het zwaartepunt der activiteiten van de 'Zweite Kammer' in de Bondsrepubliek Duitsland gaandeweg ook daadwerkelijk richting 'gesamtstaatlichen demokratischen Willensbildung' is verschoven, zal echter pas met voldoende nauwkeurigheid beantwoord kunnen worden nadat in kaart is gebracht op welke wijze de Bundesrat in de praktijk gebruik pleegt te maken van zijn constitutioneel verankerde medewetgevende rechten (daaronder begrepen de rechten tot 'Zustimmung' en 'Einspruch'), waar het wetgevingsproces op Bondsniveau in het geding is.

\subsection{Wetgevingstraject}

\subsection{Erste Durchgang}

Art. 76 Abs. 2 GG: Vorlagen der Bundesnegienang sind zunachst dem Bundesrat zuzuleiten. Der Bundesrat ist berechtigt innerhalb von sechs Wochen zu diesen Vorlagen Stellung zu nehmen (...).

Ook in de Bondsrepubliek komen veruit de meeste wetsvoorstellen anno 2000 als vanzelfsprekend voort uit de koker van de regering. Nieuwe beleidsplannen worden op de departementen van de federale ministeries uitgewerkt tot wetsvoorstellen. Vervolgens gebeurt er echter iets opmerkelijks. Ieder nieuw wetsvoorstel afkomstig van de regering moet in alle gevallen eerst naar de Bundesrat gestuurd worden. Dit, de Lănder vertegenwoordigend, orgaan krijgt in de meeste gevallen vervolgens zes weken de tijd om stelling te nemen tegen het voorstel tot wet. Geeft de regering formeel aan 'haast' te hebben met de voortgang van het wetgevingsproces in een concreet geval, dan kan de termijn verkort worden tot drie weken. ${ }^{14} \mathrm{Na}$ die zes of drie weken moet het wetsvoorstel verzonden worden naar de Bundestag en dit volledig onafhankelijk van de vraag of de Bundesrat zijn standpunt met betrekking tot de voorliggende voorstellen al heeft kunnen bepalen. Mocht dit laatste nog niet gelukt zijn, dan wordt de formele standpuntbepaling van de Duitse senaatskamer zo spoedig mogelijk nadien aangereikt aan de Bundestag. De door de Bundestag te verrichten werkzaamheden rondom het wetsontwerp in kwestie worden uiteraard echter niet opgeschort in afwachting van die formele reactie van de senaatskamer. Wel moet vermeld worden, dat de Bundesrat sinds de grondwetsherziening van 1994 de mogelijkheid ter beschikking gekregen heeft om de termijn van zes weken ter stellingname ex. art. 76 Abs. 2 GG, op basis van 'wichtigem Grunde, insbesondere mit Rücksicht auf den Umfang einer Vorlage' met drie weken te laten verlengen. ${ }^{15}$ In geval van 'eilbedürftigkeit' ex art. 76 Abs. 2 GG zal de termijn in een dergelijk geval dus gewoon weer zes weken $(6+3-3=6)$ bedragen. Met art. 76 Abs. 2 GG heeft de Bundesrat een juridisch wapen in handen

14. Art. 76 Abs. 2 GG.

15. Art.76 Abs. 3 GG. 
gekregen dat een tegenwicht kan vormen tegen te veelvuldig voorkomende 'haast' van regeringswege. ${ }^{16}$ De gemiddelde termijn van zes weken is overigens in praktische zin relaticf krap bemeten. Het lijkt nauwelijks voorstelbaar dat de Länder binnen die termijn verantwoord stelling kunnen nemen ten opzichte van complexe wetsvoorstellen, wetstechnische verbeteringen kunnen aanbrengen, bestuursrechtelijke ervaringen in de voorstellen kunnen incorporeren, financiële consequenties voor de Länder zichtbaar kunnen maken enz. Zeker indien de partijpolitieke verhoudingen dit toelaten, blijkt de Bundesrat in de praktijk dan ook al tijdens het ontwerpstadium op de Bondsministeries op de hoogte gesteld te worden van de prille plannen, zodat de formele zesweken termijn in wezen beduidend langer kan zijn.'

De Bundesrat pleegt in ruime mate gebruik te maken van het hierboven beschreven recht om als eerste parlementskamer een formeel standpunt te mogen bepalen met betrekking tot wetsvoorstellen van de Bondsregering. Sterker nog; deze 'erste Durchgang' blijkt door de Duitse senaatskamer beschouwd te worden als cen van de belangrijkste fases uit het volledige wetgevingsproces, eenvoudig omdat de mogelijkheden tot beìnvloeding en sturing tijdens dit vroege stadium allerminst gering plegen te zijn. ${ }^{18}$ Niets ligt immers al definitief vast. Met name Nederlandse senatoren zullen, hun eigen medewetgevende beïnvloedingsmogelijkheden tijdens het allerlaatste stadium van het wetgevingsproces indachtig, de waarde van de Duitse 'erste Durchgang' waarschijnlijk volmondig onderschrijven. Daar komt nog een opmerkelijk gegeven bij dat samenhangt met de staatsrechtelijke structuur van de Bondsrepubliek. Zoals beschreven in hoofdstuk 3 (3.5.1) bestaat de Bundesrat uitsluitend uit afgevaardigden van de regeringen der afzonderlijke Lănder. Dit gegeven impliceert dat nieuwe Bondsregeringsvoorstellen tot wet die ex art. 76 Abs.2 ter politiek/ juridische standpuntbepaling voorgelegd worden aan de Bundesrat, in feite eerst ter hand gesteld worden van het bestuursondersteunend overheidsapparaat in de respectievelijke Lảnder. De gevolgen dáárvan zijn niet licht te overschatten.

De bestuursorganisatie van de Bondsrepubliek Duitsland is zodanig ingericht dat de uitvoering van regelgevingbesluiten afkomstig uit zowel Bond als Länder grotendeels in handen van de Länder ligt. Daartoe beschikken de Länder over een professionele ambtelijke organisatic. Logisch uitvloeisel hiervan is dan weer dat het bestuursondersteunend overheidsapparaat van de Lănder met name ook tijdens de 'erste Durchgang' van nieuwe wetsontwerpen gebruik kan en zal maken van haar aanzienlijke bestuurs- en beleidstechnische know-how: 'Die Verwaltungserfahrung, die in den Ländern bei der Anwendung der Bundesgesetze gewonnen wird, soll über den Bundesrat für die Gesetzgebung des Bundes nutzbar gemacht werden', Want 'das Leben mit der Vielzahl der Fälle die von der Verwaltung gelöst werden müssen, ist erfahrungsgemäss immer sehr viel erfinderischer als

16. Dat de nieuwe regeling van Art. 76 Abs. 2 Satz 3 beslist geen dode letter hoeft te zijn, bleek tijdens de zeventiger jaren. De SPD-FDP coalitie in Bonn verklaande in die tijd zeer regelmatig wetsvoorstellen 'eilbedurftig', Ierwij! uit de betreffende rechtregel toch duidelijk af te lezen viel dat de termijn die de Bundesrat ter beschikking kreeg voor een eerste stellingname, slechts 'ausnahmsweise' ingekort zou mogen worden.

17. D. Wyduckel, Der Bundesrat als Zweite Kammer, Die Offentiche Verwaltung 1989, p. 185.

18. G. Ziller und G-B. Oschatz, Der Bundesrat, Dosseldorf 1998, p. 28 
die Phantasie des Gesetzgebers. ${ }^{19}$ Op deze wijze lijkt derhalve juridisch-beleidsmatig sturend via het ambtelijk apparaat van de Lander, door de Duitse senaatskamer aanmerkelijke directe invloed uitgeoefend te kunnen worden op inhoud en vormgeving van het legislatieve product.

De derde oorzaak tenslotte ter verklaring van het aanzienlijke belang van de 'erste Durchgang' voor de positie van de Bundesrat als medewetgever ligt op het partijpolitieke vlak. Hoewel zoals bekend anders georganiseerd dan bij de Bundestag kan ook de Bundesrat in feite relatief eenvoudig uitgetekend worden via partijpolitieke scheidslijnen. Zittende regeringen van Länder die dezelfde politieke kleur in hun vaandel blijken te dragen, weten elkaar ook in de 'zweite Kammer' goed te vinden. Standpuntbepaling met betrekking tot frisse door de Bondsregering gelanceerde wetsvoorstellen door de Bundesrat(smeerderheid) hoeft dan ook beslist allerminst als stelregel politiek-neutraal te geschieden. Integendeel, niet voor niets wordt de 'erste Durchgang' in de Duitse staatsrechtelijke literatuur met enige regelmaat ook wel aangehaald als de 'politischen Durchgang' ${ }^{20}$

Alvorens mijn relaas over bevoegdheden en positie van de Bundesrat in het Duitse wetgevingsproces op Bondsniveau voort te zetten, acht ik het in het licht van laatstgenoemde constateringen noodzakelijk op deze plaats enige additionele opmerkingen te maken over de wijze waarop het partijpolitieke element zich in de Bondsrepubliek Duitsland in de verhouding regering-Bundestag-Bundesrat voor met name de senaatskamer heeft ontwikkeld sinds 1949.

\subsubsection{Partijpolitieke structuren}

De Bundesrat onderscheidt zich duidelijk van de Eerste Kamer, de Franse Sénat en zelfs het House of Lords, waar de partijpolitieke samenwerkingsverbanden in het geding zijn. Het semi-formele begrip 'partijfractie' blijkt als logisch uitvloeisel van de in 1949 gekozen Bundesratstructuur (op Bondsduits niveau) volledig te ontbreken. De bepalende actoren waar de partijpolitieke verhoudingen in de Duitse senaatskamer in het geding zijn, kunnen slechts (voortdurend wisselende) afgevaardigden van de Landsregeringen zijn. Deze regeringsafgevaardigden hebben daarenboven geen andere keuze dan zich ten behoeve van hun taken in de Bundesrat in eerste instantie te groeperen als Land. Immers, art. 51 Abs. 3 Satz 2 GG eist eenstemmigheid per Land in de Duitse senaatskamer. Dit betekent dat in al die gevallen dat Landsregeringen de vrucht zijn van coalitievorming, hetgeen tegenwoordig in vrijwel het gehele territorium van de Bondsrepubliek bij voortduring het geval pleegt te zijn, partijpolitieke afstemming per Land onomkoombaar is. Een zekere 'parteipolitischen entschärfung ${ }^{21}$ kán het gevolg van deze gang van zaken zijn (zie par. 7.3.2.1). Naast partijpolitieke afstemming per Land, is het sinds het begin van de zeventiger jaren in de Duitse constellatie ook zeer gangbare praktijk geworden dat vrij nauwkeurige partijpolitieke afstemming tussen de politieke geestverwanten in de 16 Länder plaats vindt met het oog op de (politieke) opstelling in de Bundesrat. Zeker indien sprake is van diverge-

19. G. Ziller und G-B. Oschatz, a.w., p. 28-29.

20. H. Laufer und U. Münch, Das foderative System der Bundesrepublik Deutschland, München 1998, p. 168

21. G. Ziller und G-B. Oschatz, a.w., p. 119. 
rende partijpolitieke meerderheden in Bundestag en Bundesrat, blijkt er van 'parteipolitischen entschärfung' dan ook in mindere mate sprake te zijn. ${ }^{22}$ Ik kom op dit thema nog meerdere keren terug.

\subsubsection{Partijpolitiek, het Land en de Bundesrat}

Het maken van coalitieafspraken waar het stemgedrag van een Land in de Bundesrat in het geding was, werd in feite pas een issue nadat begin zeventiger jaren een sterke polarisatie in de politieke verhoudingen op Bondsniveau op ging treden. Als gevolg van de studentenopstanden die in het voorjaar van 1968 onder meer in Duitsland en Frankrijk plaats gevonden hadden, werden de 'Grosse Koalition'-partners van weleer, de Sociaal-Democraten en Christen-Democraten in de Bondsrepubliek in ideologische zin sterk uit elkaar gedreven. Die ontwikkeling bleek tevens gevolgen te hebben voor de opstelling van de Bundesrat in het legislatieve proces. Ook in dit tot dan toe zo pragmatisch-zakelijk opererende medewetgevende orgaan ${ }^{23}$ werd in navolging van de Bundestag namelijk steeds openlijker partijpolitiek gepredikt.

Er bleek in de Duitse staatsrechtelijke literatuur opmerkelijk genoeg toch nog de nodige discussie gevoerd te moeten worden over de vraag of de Bundesrat überhaupt wel voorwerp van partijpolitieke aktiviteit uit zou mogen maken. ${ }^{24}$ De uitkomst van die discussie kon echter hoe dan ook niet anders dan op voorhand vast staan: 'dass aufgrund der verfassungsrechtlichen Stellung der Parteien einerseits und der dem Bundesrat vom Grundgesetz zugewiesenen Funktion anderseits ein Agieren der Landesregierungen bzw. der diese tragenden Parteien im Bundesrat unter parteipolitischen Gesichtspunkten zulässig ist' ${ }^{25}$

Dat wetende, nu even cen noodzakelijke zijsprong naar enige aspecten van kiestechnische aard met relevantie voor het (partijpolitiek gefundeerde) stemgedrag van de Bundesratsleden.

De onderhandelingen die ten grondslag liggen aan het bereiken van politieke overeenstemming tussen coalitiepartners uit een Land van de Bondsrepubliek Duitsland over het te volgen stemgedrag in de Bundesrat zijn geen sinecure. Strikt juridisch heeft ieder land drie mogelijkheden ter beschikking waar het stemgedrag in de Bundesrat in het geding is: vóor, tegen of onthouding. Ten gevolge van het grondwettelijk vereiste dat de Bundesrat zijn besluiten moet nemen met 'mindestens der Mehrheit seiner Stimmen' ${ }^{26}$ zijn onthoudingen in materieel juridische (en derhalve politieke) zin echter te beschouwen als tegenstemmen. Omdat eenstemmigheid per Land vereist is én de keuze zich in politieke zin dus slechts tot 'ja' of 'neen' kan beperken ${ }^{27}$, worden in de regel gedetailleerde afspraken ('die

22. Ch. Gramm, Gewaltenverschicbungen im Bundesstaat, Zu Moglichkeiten und Grenzen der Verfassungsrechtsdogmatik, Archiv des offentlichem Rechts 1999, p. 213-216.

23. Zie daartoe: A. Pfitzer. Der Bundesrat, Mitwirkung der Lander im Bund,Heidelberg 1987.

24. H. Klein. Der Bundesrat der Bundesrepublik Deutschland, die 'Zweite Kammer', in: Archiv des offentlichen Rechts 1983, p. 358

25. Idem, p. 83.

26. Art. 52 Abs. 3 Satz $1 \mathrm{GG}$.

27. K. Reuter. Praxishandbuch Bundesrat, Verfassungsrechtliche Grundlagen, Kommentar zur Geschaftsordnung. Praxis des Bundesrates, Heidelberg 1991, p. 271-272. 
Bundesratsklausel') overeengekomen tussen de coalitiepartners die de Landsregering vormen. Voor de meeste Duitse Lănder komen die afspraken er op neer dat met betrekking tot het stemgedrag voor iedere afzonderlijke stemming volledige overeenstemming tussen de coalitiepartners over de uiteindelijke keuze vereist is. Wordt die overeenstemming niet bereikt, dan volgt stemonthouding. ${ }^{28}$ Om politieke spanningen zo veel mogelijk te vermijden manifesteert zich daarbij in de meeste Länder in de regel een politick spel van geven en nemen, in het Duits omschreven als 'entscharfen'. Het kan echter ook anders lopen. In Rheinland-Pfalz bijvoorbeeld bleken de sinds 1996 bestaande partijpolitieke verhoudingen ten gevolge van de hierboven beschreven gang van zaken rondom de Bundesratclausule juist aanleiding te geven tot het ontstaan van extra spanningen tussen de coalitiepartners. Daar trad een SPD-FDP coalitie aan, in de wetenschap dat de regeringsscepter in Bonn gezwaaid werd door een CDU/CSU-FDP coalitie. De FDP van Rheinland-Pfalz werd hierdoor met een partijpolitiek dilemma opgezadeld dat zich met name manifesteerde rondom stemmingen in de Bundesrat. Indien immers de regeringsleden van coalitiepartners SPD en FDP uit Rheinland-Pfalz geen overeenstemming zouden weten te bereiken over een gezamenlijke handelswijze in de senaatskamer, zou normaliter slechts stemonthouding het gevolg kunnen zijn. Omdat dit, zoals gezegd, een juridisch 'neen' betekent, zou de FDP via een 'automatische' stemonthouding wél een nuttige bijdrage kunnen leveren ter voorkoming van 'Einspruch' tegen wetsontwerpen afkomstig van de politieke broeders in de Bondsregering, doch slechts in negatief sanctionerende zin actief zijn, waar het de mogelijke verlening van 'Zustimmung' voor wetsontwerpen afkomstig van de Bondsregering betreft. ${ }^{29}$ Gezien het (politieke) gewicht dat met name de wetsontwerpen waarvoor tevens formele toestemming van de Bundesrat vereist is, plegen te hebben (zie hierna), werd in Rheinland-Pfalz in 1996 dan ook gekozen voor een nieuwe en zeer markante variant van de 'Bundesratsklausel'. Onderwerpen vastgelegd in het regeerakkoord worden conform die afspraken behandeld in de Bundesrat. Over alle andere onderwerpen kan worden onderhandeld, waarbij tussen 'Zustimmungs'- en 'Einspruchsgesetzentwurfen' een strikte scheiding aangebracht dient te worden. Indien overeenstemming niet bereikt kan worden over het te entameren stemgedrag in de senaatskamer beslist het lot tussen een gezamenlijk 'ja' en een gezamenlijk 'neen'. De 'verliezende' coalitiepartij bepaalt dan automatisch de te volgen stemstrategie bij de eerstvolgende stemming in de Bundesrat waarvoor geen gezamenlijk standpunt bepaald kon worden. ${ }^{30}$ Deze gang van zaken, die als de 'Mainzer Bundesratsklausel' al snel een eigen leven is gaan leiden, zorgt er in ieder geval voor dat het zuiver partijpolitieke gebruik van het middel der stemonthouding niet meer mogelijk is. De Ministerpresident van Rheinland-Pfalz was zelf de mening toegedaan dat 'Verfassungsgeschichte' geschreven werd. ${ }^{31}$ Wat daar ook van zij, de 'Mainzer Bundesratsklausel' maakt wel manifest dat partijpolitieke verhoudingen in relatie tot de wijze van

28. S. Jutzi, Losentscheid im Gesetzgebungsverfahren, Zum neuen 'Wechselstimmverfahren' nach der Mainzer Bundesratklausel in der Koalitionsvereinbarung von SPD und FDP. Zeitschrift für Rechtspolitik 1996, p. 381.

29. Voor een uitgebreide verhandeling over werking en belang van de Zustimmungs- en Einspruchgesetze zij verwezen naar par. 7.3.4.1 e.v.

30. S. Jutzi, S., a.w., p. 380-381.

31. Allgemeine Zeitung Mainz, 27 april 1996. 
functioneren van de Bundesrat, niet in de laatste plaats ten gevolge van de constitutionele plicht tot eenstemmigheid per Land in de Bundesrat, zowel op Lands- als Bondsniveau een rol van betekenis spelen.

\subsubsection{Partijpolitiek, de Bond en de Bundesrat}

Tijdens de eerste twintig jaar van de BRD leek het er sterk op dat partijpolitiek in de Bundesrat hooguit een bescheiden rol zou spelen ${ }^{32}$ Grote coalities tussen Christen-Democraten en Sociaal-Democraten hadden, zoals reeds eerder gememoreerd, permanente meerderheden in zowel Bundestag als Bundesrat tot gevolg. De discussies over wetsvoorstellen in de Duitse senaatskamer hadden in die tijd een overwegend juridisch-technisch karakter, waarbij de competentieverdeling tussen Bond en Lănder natuurlijk regelmatig een rol van grote betekenis speelde (zie daartoe met name par. 7.3.6.1 en par. 7.3.6.2 met betrekking tot de 'Zustimmungsbedürftigkeit').

Vanaf het aantreden van de sociaal-liberale regering Brandt/Scheel in 1969 begon die situatie echter te veranderen. In 1969 was nog sprake geweest van een nipte sociaal-liberale meerderheid in de Bundesrat. Iedere volgende Landtagsverkiezing betekende echter een afbrokkeling van invloed voor de politieke geestverwanten van de regeringspartijen uit Bonn in de betreffende parlementen. Dit had tot logisch gevolg dat vanaf 1972 tot het aantreden van de eerste regering Kohl in 1982 de Duitse senaatskamer politiek gedomineerd kon worden door oppositionele groeperingen van Christen-Democratische huize. Daar kwam bij, het zij nogmaals onder de aandacht gebracht, dat de zeventiger jaren in de Bondsrepubliek (evenals overigens in Nederland) gekenmerkt werden door relatief heftige polarisering van het politieke leven. Polarisering die ook door drong in de Duitse parlementskamers.

Dit alles nu bleck zijn uitwerking niet te missen op de partijpolitieke organisatiestructuur zoals die ten behoeve van Bundesratleden binnen de (grond)wettelijke contouren placht te bestaan. Tot de zeventiger jaren werd door (vooral op de juridische inhoud van wetsvoorstellen gefocuste) senatoren nauwelijks enige behoefte aan politieke afstemming ervaren. Er kon, zo was de heersende mening, in een atmosfeer van politieke luwte door de leden van de Bundesrat vooral constructief gewerkt worden aan (verbetering van) wetgevingsoutput. ${ }^{33}$ Dat beeld veranderde vervolgens echter snel en definitief. Regeringsafgevaardigden van Länder gedomineerd door de Christen Democraten ('A-Länder') gingen zich evenals hun politieke opponenten uit de door de SPD gedomineerde zgn 'B-Länder' organiseren. Voorbespreking en coördinerering van voorstellen die tijdens de eerstvolgende Bundesratvergadering aan de orde gesteld zouden gaan worden werd norm. Daarbij werden ook regelmatig geestverwante Bundestagafgevaardigden uitgenodigd. Zelfs iets dat opvallende gelijkenis vertoonde met het Britse 'Whipping' deed zijn intrede. ${ }^{34}$

32. G. Konow, Der Bundesrat und das Gleichgewicht zwischen Bund und Landem, Anmerkungen zur und aus det Arbeit des Bundesrates von 1958 bis 1988, in: Vierzig Jahre Bundesrat, Baden-Baden 1989, p. 244 e.v; tevens: G. Ziller und G.B. Oschatz, a.w., p. 119.

33. A. Pfitzer, Der Bundesrat, Heidelberg 1995, p 54 e.v

34. G. Ziller und G-B. Oschatz, a.w., p. 120-121. 
Tussen 1982 en 1990 kwamen de partijpolitieke meerderheden in Bundestag en Bundesrat weer overeen. De Christen-Democratie regeerde de Bondsrepubliek tijdens die jaren, daarbij nauwelijks gehinderd door oppositionele krachten. Dit had onmiskenbaar depolariserende gevolgen, hetgeen de coöperatie tussen beide organen in het kader van het legislatieve proces ten goede kwam. De regering Kohl bleek regelmatig handig gebruik te kunnen maken van de gememoreerde, inmiddels semi-geformaliseerde samenwerkingsverbanden tussen A-Lănder en B-Lănder onderling. Potentięle conflictstof tussen Bundesrat en Bondsregering over vorm en/of inhoud van wetsvoorstellen kon op deze wijze via kleine concessies al tijdens 'voorbesprekingen' efficiënt uitgeplooid worden. ${ }^{35}$

Vanaf 1990 is het partijpolitieke plaatje in de Bondsrepubliek snel veel complexer geworden. De Groenen wonnen sterk aan invloed, maar veel belangrijker nog. het territorium van de voormalige DDR ging, in de vorm van vijf nieuwe Länder deel uit maken van de Bondsrepubliek. De aloude opsplitsing van de Bundesrat in A en B Lander werd daarmee snel grotendeels geschiedenis. Regelmatig bleken de senatoren uit het voormalige Oost-Duitsland hun krachten op basis van zuiver economische motieven te bundelen. Ook anderszins bleek er in de nu uit 16 Lănder samengestelde Bundesrat met enige regelmaat sprake te zijn van ad-hoc coalitieverbanden, die via de partijpolitieke scheidslijnen niet te verklaren waren.

Samenvattend kan gesteld worden dat de legislatieve besluitvormingsprocessen in de Bundesrat anno 2000 minder exclusief dan tijdens de zeventiger jaren gedomineerd worden door de partijpolitiek. Diverse regionale belangen, maar zeker ook de belangen van het Land ten opzichte van het belang van de Bond, kunnen in voorkomende gevallen tijdelijk blijkbaar meer gewicht in de senatoriale overwegingsschaal leggen. ${ }^{36}$ Het bepalen van een verdeelsleutel voor Bond en Lănder betreffende de belastinginkomsten bijvoorbeeld, geschiedt om voor de hand liggende redenen in de regel niet via partijpolitieke scheidslijnen. Nu zichtbaar is gemaakt dat partijpolitieke verhoudingen onmiskenbaar een rol van wisselende betekenis kunnen vervullen bij de door de Bundesrat in het kader van het wetgevingsproces uit te voeren werkzaamheden, wordt de aandacht weer verlegd naar het belang van de 'erste Durchgang' tijdens het wetgevingstraject, alsmede meer in het bijzonder naar de wijze waarop de regering op Bondsniveau lastige dan wel onwelgevallige stellingname ex art. 76 Abs. 2 GG kan omzeilen.

\subsubsection{Nogmaals de 'erste Durchgang'}

In staatsrechtelijke zin is het momentum van de 'ersten Durchgang' vanuit de optiek der Duitse senatoren met name nauwelijks te overschatten, omdat de leden van de Bundesrat in tegenstelling tot de collegae uit het House of Lords (vgl. 'first reading'!) of de Sénat Français niet kunnen beschikken over een formeel recht van amendement. De impact van dit gegeven is vanzelfsprekend aanzienlijk. Indien immers de leden van de Bondsduitse tweede parlementskamer in meerderheid van mening zouden zijn dat in een regeringsvoorstel tot wet substantiële aanpassingen van bijvoorbeeld wetsdogmatische, wetstech- 
nische of beleidsmatige aard, dan wel belangrijke andersoortige koerswijzigingen doorgevoerd zouden dienen te worden, valt verre te prefereren, dat tijdens een pril wetgevingsstadium suggesties in die richting reeds naar voren gebracht zullen worden. Tijdens iedere volgende wetgevingsfase zal de lopende machinerie immers al minder flexibel kunnen anticiperen op nieuw in te brengen wetwijzigingsvoorstellen. Het Nederlandse bicamerale wetgevingsstelsel moge daarvoor tot sprekend voorbeeld dienen.

De vanzelfsprekendheid waarmee hier geschreven wordt over het doorvoeren van 'substanticle aanpassingen' door de Bundesrat tijdens de 'erste Durchgang' is overigens wel degelijk bevochten tijdens de beginjaren van de na-oorlogse Bondsrepubliek. Konrad Adenauer, de cerste na-oorlogse Kanselier meende dat drie weken meer dan genoeg zou zijn voor: 'Stellungname zu den Grundlinien einer vorgeschlagenen gesetzlichen Regelung'. 'Gesetztechnische Kleinarbeit' zou zijns inziens vooral vermeden moeten worden. ${ }^{37}$

\subsubsection{Omzeilen}

Over enige procedurele gevolgen die de fase van de 'erste Durchgang' in politieke zin kan hebben, moeten op deze plaats nog additionele opmerkingen gemaakt worden. Tijdens de achterliggende halve eeuw is namelijk regelmatig gebleken dat de Bondsregering om haar moverende redenen pogingen in het werk heeft gesteld om de uit art. 76 Abs. 2 GG voortvloeiende verplichting zo veel mogelijk te kunnen omzeilen. De achterliggende gedachte daarbij was veelal een logische: het voorkomen van politiek onwelgevallig en derhalve hinderlijk commentaar betreffende regeringsvoorstellen tot wet: 'Dieser erste Durchgang zwingt die Bundesregierung praktisch zu erneuter Beschlussfassung über strittige Punkte und beeinflusst hăufig die politische Auseinandersetzung in den Beratungen der Vorlage durch den Bundestag'.

Vooral ten tijde van divergerende partijpolitieke meerderheden in de Bundestag en Bundesrat, blijkt de Bondsregering met enige regelmaat juridische wegen te willen bewandelen die in wezen slechts tot doel lijken te hebben om de Bundesrat tijdens de eerste fase van het wetgevingsproces zo veel mogelijk buiten spel te kunnen houden. Daartoe wordt handig gebruik gemaakt van het recht van initiatief dat in de Duitse staatsrechtelijke constellatie toekomt aan zowel de regering als beide parlementskamers. Politiek gevoelige voorstellen tot wet afkomstig uit de koker van de regering, kunnen, zo is de redenering. net zo goed, maar dan formeel onder de noemer van initiatiefwetsvoorstel ${ }^{38}$ ingediend worden door Bundestagsleden afkomstig uit fracties die de regering steunen. De Bundesrat $\mathrm{zal}$, indien die procedure gevolgd wordt, de voorstellen tot wet dan namelijk pas in een later stadium van het wetgevingsproces voor de eerste maal onder ogen kunnen krijgen. Formele stellingname door de Duitse senaatskamer ex art. 76 Abs.2 GG vervalt dan volledig. Ook is het mogelijk dat een voorstel tot wet dat materieel afkomstig is van de regering tegelijkertijd beide procedures doorloopt ('Paralleleinbringung'). Het officièle argument dat in dergelijke gevallen ter verklaring gehanteerd pleegt te worden vanuit regerings- 
kringen is de door de agenda afgedwongen 'tijdsdruk, ${ }^{39}$ In dat kader moet hier wellicht nog opgemerkt worden dat alle wetgevingsvoorstellen die niet formeel tot wet verheven zijn aan het einde van een kabinetsperiode van rechtswege vervallen.

In praktische zin betekent het initièren van regeringsvoorstellen via de Bundestag, dat zowel de visie van de Bundesrat als de reacties daarop vanuit de regering, tijdens het commissiewerk in de Bundestag eenvoudigweg ontbreken. Een dergelijke gang van zaken kan als een verarming beschouwd worden, omdat zowel de reeds gememoreerde wetstechnische expertise als de enorme bestuurspraktische uitvoeringservaring die via de Länder in de Bundesrat aanwezig is, niet aangewend kunnen worden, in een stadium van het wetgevingsproces waarin het uit praktisch oogpunt extra zinvol lijkt om daarvan nu juist wél gebruik te maken.

Principieler van aard zijn twee andersoortige bezwaren. Allereerst kan er geen misverstand over bestaan dat de grondwetgever in het wetgevingsproces op Bondsniveau nauwe samenwerking tussen regering, Bundestag én Bundesrat beoogde. Zeker in al die gevallen waar nieuwe regelgeving door de Laander ten uitvoer zal moeten worden gebracht, is dat ook niet meer dan evident. Het via verkapt Bundestaginitiatief buitenspel zetten van de Bundesrat tijdens de 'erste Durchgang' lijkt dan ook al snel beschouwd te kunnen worden als minachting van de grondwetgever in deze. ${ }^{40}$ Aan de uiteindelijke redactie van art. 76 Abs. 2. GG ligt tevens het gedachtengoed van 'checks and balances' op bondsniveau in de relatie Bund-Länder ten grondslag. In een politiek/staatsrechtelijke constellatie waar regering en Bundestag sterke monistische verbondenheid vertonen, kan de mogelijkheid tot stellingname door de (door de Länder afgevaardigde) Bundesratsleden betreffende regeringsvoorstellen tot wet enig noodzakelijk geacht tegenwicht vormen. ${ }^{41}$

\subsubsection{Zweite Durchgang}

De door de Duitse doctrine unaniem als invloedrijk gekwalificeerde positie die de Bundesrat tegenwoordig inneemt in de Duitse politiek/staatsrechtelijke constellatie op Bondsniveau, hangt ten nauwste samen met de wijze waarop en de mate waarin de Bondsduitse senaatskamer gebruik pleegt te maken van de haar grondwettelijk toebedeelde medewetgevende bevoegdheden.

Constitutioneel uitgangspunt voor de wijze waarop wetgevingsbesluiten ten behoeve van de Bondsrepubliek als geheel tot stand dienen te komen vormt art. 77 GG. Daarin komt vooraleerst tot uitdrukking dat de Bundestag toonaangevend is, waar de legislatieve besluitvorming in het geding is. De Bundestag beslist over een voorstel tot wet en vervolgens wordt de voorlopige wettekst via de voorzitter van de Bundestag verzonden naar de Bundesrat. ${ }^{42}$ De Duitse senaatskamer kan daarna het volledige voorstel bestuderen. Hierbij zal er vanzelfsprekend nauwkeurig op gelet worden of suggesties van zowel dogmatische,

39. G. Ziller, Zum Spannungsverhältnis zwischen Bundestag und Bundesrat im Gesetzgebungsverfahren, in: D. Wiltke und B. Schulte, Der Bundesrat, Die staatsrechtliche Entwicklung des foderalen Verfassungsorgans, Darmstad 1992, p. 332 e.v.

40. G. Ziller und G-B. Oschatz, a.w., p. 30 e.v.

41. G. Ziller, a.w., p. 333.

42. Art. 77 Abs. 1 GG. 
beleidsmatige als technisch-uitvoerende aard, die de Bundesrat tijdens de 'erste Durchgang' aan de regeringsvoorstellen meende te moeten toevoegen, ook daadwerkelijk onderdeel van de voorliggende wet zijn gaan uitmaken. Extra aandacht zal de Duitse senaatskamer tevens hebben voor in de wettekst geīncorporeerde amendementen afkomstig uit de gelederen van de Bundestag. Uitgebreide aandacht tenslotte, zal ook uitgaan naar initiatiefwetsvoorstellen gelanceerd door leden van de Bundestag. Niet alleen betreft het dan immers wetteksten die de Bundesrat nog niet eerder kon bestuderen, doch tevens kán het in het geval van wetgevingsinitiatief door leden van de Bundestag wetsvoorstellen betreffen die tot dan toe bewust zo veel mogelijk aan beìnvloeding en sturing door afgevaardigden van de Bundesrat onttrokken werden. ${ }^{43}$

\subsubsection{Einspruch}

Indien Bundesratleden zich niet kunnen verenigen met (gedeelten uit) de voorliggende wettekst, beschikken zij niet over de formele mogelijkheid tot amendering, maar wél over de mogelijkheid tot het bijeenroepen (binnen drie weken) van een conciliatiecommissie, de zgn. 'Vermittlungsauschuss'. Het besluit moet wel genomen worden met minimaal een gewone meerderheid van de 69 maximaal uit te brengen stemmen ${ }^{44}$ Indien deze commissie, die paritair samengesteld is uit 16 leden van zowel de Bundestag als de Bundesrat, bij gewone meerderheid van stemmen een compromisvoorstel lanceert dat (al dan niet partieel) afwijkt van het oorspronkelijke, reeds door de Bundestag goedgekeurde voorstel, moet de Bundestag over dat nieuwe voorstel een oordeel vellen. ${ }^{45}$ Mocht de Bundestag uiteindelijk toch tot de formele slotsom komen, dat de door de 'Vermittlungsausschuss' voorgestelde aanpassingen ongewenst zijn, dan rest voor de senaatskamer nog altijd de mogelijkheid tegen (de redactie van) de betreffende wet verzet aan te tekenen. ${ }^{46}$ Deze 'Einspruch' kan door de Bundestag echter zonder nadere motivering afgewezen worden. Wel eist de grondwetgever dat het terzijde schuiven van de 'Einspruch' geschiedt bij meerderheid van het aantal leden dat zitting heeft in de Bundestag. ${ }^{47}$ Indien het Bundesratbesluit tot 'Einspruch' gedragen wordt door een tweederde meerderheid van het aantal senaatsleden, ontstaat voor de Bundestag automatisch de formele plicht een afwijzing eveneens te laten steunen op minimaal tweederde van de uitgebrachte stemmen, terwijl dit stemmenaantal nooit minder mag zijn dan de helft van het aantal leden dat zitting heeft in de Bundestag. ${ }^{48}$ Gezien het gegeven dat ook in de Bondsrepubliek Duitsland regeringen tegenwoordig eigenlijk nooit meer beschikken over een tweederde meerderheid in de Bun-

\footnotetext{
43. G. Ziller und G-B. Oschatz, a.w., p. 32.

44. Art. 77 Abs. 2 Satz 1.

45. Art. 77 Abs. 2 Satz 5 GG.

46. Art. 77 Abs. 3 Satz 1 GG, 'Soweit zu einem Gesetze die Zustimmung des Bundesrates nicht erforderlich ist, kann der Bundesrat, wenn das Verfahren nach Abs. 2 (Vermittlungsausschuss: EK) beendigt ist gegen ein vom Bundestage beschlossenes Gesetz binnen zwei Wochen Einspruch einlegen'.

47. Art. 77 Abs. 4 Satz 1 GG.

48. Art. 77 Abs. 4 Satz 2 GG.
} 
destag. vertoont deze laatste mogelijkheid matericel veel overeenkomst met cen absoluut vetorecht voor de Bundesrat. ${ }^{49}$

Wellicht ten overvloede zij op deze plaats wel nog expliciet vermeld, dat het starten van de hier beschreven procedurele mogelijkheid tot 'Einspruch' (ten behoeve van de mogelijkheden tot uitoefening van de medewetgevende, herzienende, corrigerende functies van de Bundesrat in de Duitse Grondwet terecht gekomen) afhankelijk gesteld is van het voordien bijeenroepen van de 'Vermittlungsausschuss'. ${ }^{50}$ De (juridische of politieke) aard van het eventueel door deze commissie geformuleerde compromisvoorstel speelt daarbij geen rol.

De globaal uitgetekende 'Einspruch'-procedure in 'zweiten Durchgang' werd, waar de participatie van de Bundesrat in het geding is, door de grondwetgever van 1949 beschouwd als de nieuwe standaardprocedure voor regelgeving bij wet op Bondsniveau. De functionele, via de Lãnder gelegitimeerde, wetgeving-herzieningskamer zou zich in het na-oorlogse federale wetgevingssysteem in de meeste gevallen voldoende kunnen laten gelden door middel van het recht op 'Einspruch', zo was de redenering. ${ }^{51}$ In de Bondsduitse wetgevingspraktijk echter, lijkt dit suspensieve vetorecht, afgaande op de kwantitatieve gegevens geen al grote rol te vervullen (zie tabel 7,1).

Tabel 7.1

\begin{tabular}{|c|c|c|}
\hline Einspruch des Bundesrates & Anzahl der Einsprüche & $\begin{array}{c}\text { Einspruch vom Bundestag } \\
\text { zurückgewiesen }\end{array}$ \\
\hline $1949-1953$ & 1 & - \\
\hline $1953-1957$ & 1 & 1 \\
\hline $1957-1961$ & 3 & 1 \\
\hline $1961-1965$ & - & - \\
\hline $1965-1969$ & - & - \\
\hline $1969-1972$ & 1 & 4 \\
\hline $1972-1976$ & 5 & 5 \\
\hline $1976-1980$ & 7 & 6 \\
\hline $1980-1983$ & 7 & - \\
\hline $1983-1887$ & - & 4 \\
\hline $1987-1990$ & 1 & 12 \\
\hline $1990-1994$ & 5 & - \\
\hline $1998-1998$ & 13 & - \\
\hline
\end{tabular}

Bronnen: Handbuch des Bundesrates für das Geschaftsjahr 1999/2000, Baden-Baden 2000, p. 297-298; http://www.bundesrat.de/PDund F/index.html. 21 november 2001.

49. H. Klein, Der Bundesrat der Bundesrepublik Deutschland-die 'Zweite Kammer', in: Archiv des ôffentlichen Rechts, Tubingen 1983, p. 349.

50. Art. 77 Abs. 3 Satz 1 GG: 'Soweit zu einem Gesetze die Zustimmung des Bundesrates nicht erforderlich ist, kann der Bundesrat, wenn das Verfahren nach Abs. 2 (Vermittlungsausschuss; EK) beendigt ist gegen ein vom Bundestage beschlossenes Gesetz binnen zwei Wochen Einspruch einlegen'.

51. R. Dolzer, Das pariamentarische Regierungssystem und der Bundesrat- Entwicklungsstand und Reformbedarf. Berlin 1999, p. 14-15. 
Slechts in 44 gevallen (op een totaal van 5541 door beide parlementskamers behandelde wetsvoorstellen) werd formeel gebruik gemaakt van het recht op 'Einspruch'. Het nettoresultaat van deze beperkte inzet van het suspensief veto was, vanuit de optiek van de Bundesrat, relatief mager, temeer daar de Bundestag in $80 \%$ van de gevallen het verzet vervolgens terzijde kon schuiven. Anders gezegd, de Bundesrat wist bij $0,0016 \%$ van alle wetsvoorstellen via de 'Einspruch'-procedure tastbare wijzigingen af te dwingen. Het middel zal slechts effectief kunnen zijn indien de Bondsregering niet kan bogen op een solide meerderheid in de Bundestag óf indien de Bundesrat bij machte blijkt om verzet ex art. 77 Abs. 3 aan te tekenen via een tweederde meerderheid van zijn leden. Dergelijke situaties hebben zich in de Bondsduitse parlementaire praktijk nauwelijks voorgedaan. ${ }^{52}$ Succesvolle 'Einspruch' via de (voor de Bundestag) onneembare horde van een tweederde meerderheid kon tussen 1949 en 2001 in vier gevallen opgetekend worden. ${ }^{53}$

Uit bovenstaande tabel lijkt wel relatief overtuigend naar voren te komen dat de Bundesrat zich ter daadwerkelijke hantering van het recht op formeel verzet met name laat leiden door partijpolitieke motieven. De enige perioden immers dat in ieder geval zo nu en dan de mogelijkheden tot 'Einspruch' ex art. 77 Abs. 3 GG feitelijk gepraktiseerd werden, vielen samen met de perioden van divergerende partijpolitieke meerderheden in Bundestag en Bundesrat.

Bleck het praktische nut van het recht op verzet niet al te groot aangeslagen te moeten worden; een geheel ander verhaal moet verteld worden over de wettelijke 'Zustimmungs'mogelijkheden die de Bundesrat kan exploiteren.

\subsubsection{Zustimmung}

De Bundesrat heeft via het beschreven recht van 'Einspruch' ex art. 77 Abs. 3 zoals wij gezien hebben het wapen van het suspensieve veto tot zijn beschikking. ${ }^{54}$ De grondwetgever was echter van mening dat met betrekking tot bepaalde wetsvoorstellen, die in de Grondwet expliciet én limitatief opgesomd werden, ${ }^{55}$ de Bundesrat als vertegenwoordiger van de belangen der Länder op Bondsniveau, over een absoluut veto diende te beschikken. Voor de totstandkoming van wetgeving waarvoor de 'Zustimmung' van de Bundesrat een grondwettelijk vereiste is, zou de overeenstemming betreffende inhoud en redactie van voorliggende wetsvoorstellen uiteindelijk altijd totaal moeten zijn. De Bundesrat wordt in deze derhalve gelijk geschakeld met de Bundestag.

De te volgen procedure voor wetsvoorstellen die zonder formele toestemming van de Bundesrat niet tot stand kunnen komen is globaal als volgt: na initiěring door de regering en stellingname door de Bundesrat, wordt het wetsvoorstel voorgelegd aan de Bundestag. Deze 'eerste' parlementskamer onderzoekt het voorstel volledig via vaste (en eventueel

52. R. Dolzer und M. Sachs, a.w., p. 56.

53. En wel met betrekking tot het Preisgesetz, het Landwirtschaftzathlungsgesetz 1959. het Beweissicherungsgesetz, almede een wetswijziging aangaande het Strassenverkehrsgesetz.

54. R. Dolzer und M. Sachs, a.w., p. 15.

55. Voor een volledige catalogus van alle grondwetsartikelen die de noodzaak tot 'Zustimmung' van de Bundesrat bij wetgevingsvoorstellen voorschrijven, 47 in totaal, zij verwezen naar noot 63 van dit hoofdstuk. 
bijzondere) commissies. Tijdens de tweede lezing kunnen amendementen voorgesteld worden. $\mathrm{Na}$ afloop van de derde en laatste lezing wordt gestemd over de wijzigingsvoorstellen en uiteindelijk over het gehele product. Vervolgens wordt het wetsvoorstel doorgestuurd naar de Bundesrat. Daar gaat het door de Bundestag goedgekeurde voorstel direct ter behandeling naar een van de 17 vaste commissies. Indien de complexiteit daarom vraagt kunnen ad-hoc 'Sonderausschusse' gecrečerd worden. ${ }^{56}$

\subsubsection{Wetgevingscommissies}

Even een zijsprong. Hoewel reeds kort opgemerkt in hoofdstuk 3, hecht ik er aan nogmaals onder de aandacht te brengen dat voor de bemanning van Bundesratcommissies een speciaal regime geldt. Als uitzondering op de hoofdregel van art. 51 GG waarin bepaald wordt dat slechts leden van de Landsregeringen lid van de BR kunnen zijn, staat in art. 52 lid 4 GG beschreven: 'Den Ausschüssen des Bundesrates können andere Mitglieder oder Beauftragte der Regierungen der Länder angehören'. In commissies kunnen ook gevolmachtigden van de regering zitting hebben, die als zodanig benoemd worden door de regeringen van de Länder. In de praktijk zijn dit veelal ter zake kundige ambtenaren, die zelfs geen inwoner hoeven te zijn van het Land waarvoor zij als gevolmachtigde optreden. ${ }^{57}$ De vaste commissies blijken veel gebruik te maken van gespecialiseerde ambtenaren De 'Finanzausschuss' bijvoorbeeld wordt er door gedomineerd. Maar ook in vele andere commissies die bij voortduring behoefte hebben aan gespecialiseerde inbreng (o.a. Agrarausschuss, Wirtschafsausschuss) zijn ambtenaren als regel sterk vertegenwoordigd. Er zijn overigens tevens vaste Bundesratcommissies waarin de ambtenarij nauwelijks een rol van betekenis vervult. De 'Ausschuss für Auswärtige Angelegenheiten' bijvoorbeeld, is vrijwel altijd exclusief samengesteld uit regeringsleiders van de 16 Duitse Lănder. ${ }^{58}$ Om de 'ordenliche Mitgliedschaft' te verkrijgen volstaat formele benoeming als zodanig door de Landsregering. Dergelijke commissieleden bezitten tevens stemrecht. ${ }^{59}$ Beceindigd wordt het lidmaatschap van de commissies door het simpelweg op te geven, of door een besluit van die strekking afgegeven door de Landsregering.

Uit oogpunt van vertegenwoordigende democratie zijn de implicaties van dit gegeven opmerkelijk. Voorstellen tot wet, gelanceerd door de Bondsregering en uitgewerkt op de departementen te Berlijn, worden uit naam van de Bundesrat gecheckt (en zo nodig voorzien van suggesties ter wijziging c.q. aanvulling) door werknemers van de departementen der Länder. De parlementen der Länder kunnen slechts vanaf de zijlijn toekijken en in voorkomende gevallen bewindslieden ter verantwoording proberen te roepen. In de Duitse staatsrechtelijke literatuur wordt in dit kader wel gesproken van 'Exekutivfóderalismus' of (minder eerbiedig) 'Parlament der Oberregierungsräte'. ${ }^{\text {. }}$

56. $\$ 11$ Abs. 1 GOBR.

57. K. Reuter, Praxishandbuch Bundesrat, a.w, p. 365-368.

58. G. Ziller und G-B, Oschatz, a.w., p. 71.

59. $\S 11$ GOBR.

60. Ch. Gramm, Gewaltenverschiebungen im Bundesstaat, in: Archiv des öffentlichen Rechts 1999, p. 217. 
Vanuit de commissies worden de noodzakelijk geachte aanbevelingen overgebracht aan het Bundesratsplenum dat natuurlijk wel de formele eindverantwoordelijkheid voor het wetgevingsproduct blijft dragen.

\subsubsection{Nogmaals Zustimmung}

Dan weer terug naar de 'Zustimmungs'-problematiek. Welke soort wetsvoorstellen zijn met name 'zustimmungsbedürftig'? Ten eerste (vanzelfsprekend) de grondwetswijzigingen. De grondwetgever vereist dat verandering van die regels uit de Grondwet die aangepast mogen worden ${ }^{61}$, slechts kan geschieden indien daartoe in zowel de Bundestag als de Bundesrat een tweederde meerderheid van het aantal leden toestemming verleent. ${ }^{62}$ In die zin worden soortgelijke besluitvormingsstructuren gehanteerd als in vrijwel alle parlementaire democratieën met bicamerale stelsels, die beschikken over een geschreven constitutie. De in theorie forse drempel heeft niet kunnen voorkomen dat sinds 1949 in de Bondsrepubliek Duitsland maar liefst 43 grondwetswijzigingen doorgevoerd konden worden. Zeer vele van deze grondwetswijzigingen hadden een verdere uitbreiding tot gevolg van het aantal beleidsterreinen waarvoor de Bundesrat in geval van toekomstige regelgeving zou kunnen beschikken over een absoluut blokkaderecht. ${ }^{63}$

De Bundesrat is zijn vetorecht in deze echter niet gaan gebruiken ter blokkade van grondwetswijzigingsvoorstellen, doch veeleer als sturingsinstrument. Ten gevolge van de grondwetswijzigingen zijn vele bevoegdheden die oorspronkelijk bij de Lănder ondergebracht waren, naar de Bond verschoven. Hierdoor werd de potentiële machtspositie van de Bondsorganen inclusief de Bundesrat duidelijk versterkt. De Bundesrat heeft nooit, via bijvoorbeeld hantering van het vetorecht, aangegeven ongelukkig te zijn met deze ontwikkeling. ${ }^{64}$

Sinds de ratificatie van het Verdrag van Maastricht speelt de 'Zustimmung' van de Bundesrat ook een belangrijke rol in relatie tot het afstaan van soevereiniteitsrechten van de in de Bondsrepubliek opgenomen Länder aan supranationale instellingen van de Europese Unie. ${ }^{65}$ Hierop kom ik nog uitgebreid terug (par. 7.4.2).

In de tweede plaats behoeven wetsvoorstellen die van invloed zijn op de financiěle huishouding van de Länder de formele toestemming van de Bundesrat. Te denken valt aan

61. Zie art. 79 Abs. $3 \mathrm{GQ}$ voor de grondwettelijk verankerde regelingen en rechten die nooit gewijzigd zullen kunnen worden.

62. Art. 79 Abs. 2 GG.

63. Oorspronkelijk was 'Zustimmung' vereist op grond van een of meerdere onderdelen van de volgende grondwetsartikelen: Art. 29 Abs. 7:37 Abs. 1; 59 Abs. 2; 77 Abs. 2; 79 Abs. 2;80 Abs. 2; 81 Abs. 1; 81 Abs. $2 ; 84$ Abs. 1, 84 Abs. $2 ; 84$ Abs. 3; 84 Abs, 5; 85 Abs. 1; 85 Abs, 2; 87 Abs. 2; 105 Abs, 3; 106 Abs. 3; 106 Abs. 4 ; 107; 108 Abs. $3 ; 108$ Abs. $6 ; 119 ; 130$ Abs. $1 ; 132$ Abs. $4 ; 134$ Abs. $4 ; 135$ Abs. 5 GG.

Sindsdien zijn daar bijgekomen: Art. 16a Abs. 2; $16 \mathrm{abs}$. 3; 23 Abs. 1; 23 Abs. 7; 53 a Abs. 1; 74 Abs. 2: $74 a$ Abs. 2; 74a Abs, 3; 87 b Abs. 3; 87e; 87d Abs, 2, 87e Abs. 5; 87f Abs. 1:91a Abs. 2; 104a Abs. 3; 104a Abs. 4; 104a Abs.5; 106 Abs. 5; 106a; 115a Abs. 1; 115 e Abs. 1; 115 c Abs. 3; 115d Abs. 2; 1151 Abs. 1; 1151 Abs. 2; 120a Abs. 1, 143a Abs. 3; 143b Abs. 2 GG.

64. H. Laufer und U. Manch, aw, p. 170-171.

65. Art. 23 Abs. 1 Satz 2 GG. 
regelingen die de verdeling van belastinggelden over Bond en Länder vastleggen ${ }^{66}$ of regelingen die het aandeel aan inkomstenbelasting bepalen dat ten goede komt aan de gemeenten. ${ }^{6}$

In de derde plaats kunnen ook wetsvoorstellen die van invloed zijn op het 'bestuurlijk handelen' van de Länder slecht kracht van wet krijgen na formele goedkeuring door zowel Bundestag als Bundesrat. ${ }^{68}$

Vooral van deze laatste categorie 'zustimmungsbedürftige' regels is, zoals in de nu volgende paragraaf uiteen gezet zal worden, een nauwelijks te overschatten invloed uitgegaan op de verhouding tussen de Bondsregering. Bundestag en Bundesrat, waar de totstandkoming van regelgeving op Bondsniveau in het geding is.

\subsubsection{Art. 84 en 85 GG}

De reikwijdte van art. 85 Abs. 1 GG en met name van art. 84 Abs. 1 GG bleek veel groter te zijn, dan oorspronkelijk voorzien. Al in 1953 werd in de Duitse staatsrechtelijke literatuur geconstateerd dat dit laatste grondwetsartikel het 'grosse Einfallstor' bleek te zijn, voor het uitdijen van de mogelijkheden tot praktiseren van het vetorecht door de Bundesrat. ${ }^{69}$ In een bijzinnetje van art, 84 GG (evenals overigens art. $85 \mathrm{GG}$ ) bleek veel politieke ruimte schuil te gaan: 'Führen die Länder die Bundesgesetze als eigene Angelegenheit aus, so regeln sie die Einrichtung der Behörden und das Verwaltungsverfahren, soweit nicht Bundesgesetze mit Zustimmung des Bundesrates etwas anderes bestimmen.'

Als er derhalve Bondswetgeving geïnitieerd wordt waarin ook het 'Verwaltungsverfahren' van de Länder aan bod komt, kunnen dergelijke voorstellen slechts kracht van wet krijgen na formele toestemming van de Bundesrat. Ter beantwoording van de sindsdien voortdurend terugkerende ultieme vraag, of 'Zustimmung' in casu al dan niet een vereiste zou moeten zijn, speelden met name éen interpretatiekwestie en een tweetal theses een doorslaggevende rol.

De interpretatiekwestie betrof uiteraard vooral het begrip 'Verwaltungsverfahren'. In de rechtelijke beslissing aangaande het 'Vierten Rentenversicherungs Änderungsgezets', een arrest dat in meerdere opzichten belangrijk is gebleken voor de staatsrechtelijke plaatsbepaling van de Bundesrat als federale medewetgever ten opzichte van Bundestag en Bondsregering, is uitgemaakt dat wetsvoorstellen de formele toestemming van de Bondsduitse senaatskamer behoeven indien de voorgestelde regeling 'sich zwar auf die Regelung materiell-rechtlicher Fragen beschränkt, in diesem Bereich jedoch Neuerungen in Kraft setzt, die den nicht ausdrücklich geänderten Vorschriften über das Verwaltungsverfahren eine wesentlich andere Bedeutung und Tragweite verleihen' ${ }^{70}$

In de eerste these die een grote rol is gaan spelen in het Bondsduitse wetgevingsspel werd verondersteld dat ieder wetsvoorstel waarin ook maar in één enkele paragraaf een voorschrift opgenomen werd, die het bestuurlijk handelen van de Lănder tot onderwerp had,

66. Art. 105 Abs. 3 GG.

67. Art. 106 Abs. 5 Satz 2 GG.

68. Art. 84 Abs. 1 GG en Art. 85 Abs. 1 GG.

69. H. Schneider, Die Zustimung des Bundesrates zu Gesetzen, Deutsches Verwaltungsblatt 1953, p. $257-261$.

70. BVerfGE 37,363 (383f). 
het gehele wetsvoorstel 'zustimmungsbedürftig' maakte. ${ }^{71}$ Deze zgn. 'Einheitstheorie' is al betrekkelijk snel de heersende leer geworden. ${ }^{72}$ De Bundesrat wist uiteraard goed garen te spinnen bij de praktische uitwerking van deze theorie. In toenemende mate konden voorstellen tot wet afkomstig van de Bondsregering door de Bundesrat op grond van de 'Einheitstheorie' praktisch beschouwd worden als 'Zustimmungsbedürftig'. Dit knelde vanzelfsprekend met name indien de partijpolitieke meerderheid in de senaatskamer uit oppositionele groeperingen samengesteld bleek te zijn, zoals dit tussen 1972 en 1982 voortdurend het geval was. In 1976 liep de politieke discussie over de reikwijdte van de 'Einheits'-praktijk hoog op. De toenmalige Bondskanselier Schmidt verklaarde in de Bondsdag serieus te overwegen beperking van 'Bundesgesetze auf das materielle Recht, auf gesellschafts-, wirtschafts- und aussenpolitisch relevante Fragen' in de toekomst tot nieuwe wetgevingsstandaard te willen verheffen. ${ }^{73}$ In de praktijk zou dit dan betekenen dat wetgeving gesplitst zou gaan worden in een materieelrechtelijk gedeelte dat geen toestemming van de Bundesrat zou behoeven en een procesrechtelijk gedeelte dat die toestemming wél behoeft. De rechtspraak bleck deze opvatting in principe te kunnen billijken. ${ }^{74}$ Zelfs indien splitsing van wetgevingsvoorstellen expliciet zou geschieden met het vooropgezette doel om de eis van 'Zustimmung' door de Bundesrat in casu te kunnen vervangen door 'Einspruch', zou dat geen ontoelaatbare omzeiling van de wetgevingsrechten van de Bundesrat hoeven te betekenen. De toelaatbaarheidsgrens is blijkbaar wél bereikt waar inherente samenhang tussen materieel en formeel bestuursrechtelijke regels tot gevolg zal hebben dat toepasbaarheid van de betreffende wet onmogelijk wordt: 'Ist das Verwaltungsverfahren mit dem materiellen Regelungsgehalt untrennbar verknüpft, dann ist eine rein materielle Regelung notwendigerweise auch ein Regelung des Verwaltungsverfahrens. ${ }^{75}$ Deze eventuele 'untrennbare verknüpfung' tussen materiële en formele rechtsregels bleek voor de wetgevingsjuristen van de regering Schmidt inderdaad in de praktijk veelal een niet of nauwelijks te ontwarren Gordiaanse knoop op te leveren. Regeringscoalities die zich geconfronteerd zagen met een in meerderheid 'oppositionele' Bundesrat hebben deze weg ter indamming van het medebeslissingsrecht van de Duitse 'Zweite Kammer' dan ook niet al te lang bewandeld. ${ }^{76}$ Tegenwoordig wordt van de splitsingsmogelijkheid sporadisch gebruik gemaakt. Dit gebeurt vooral omdat de Bondsregering ook nog wel eens van zich af wenst te bijten in tijden dat oppositionele meerderheden de werkzaamheden in de Bundesrat zelfbewust blijken te domineren.

Resumerend betekent dit alles dat wetsvoorstellen die niet splitsbaar blijken te zijn als eenheid behandeld zullen moeten worden en derhalve ook aan een vetorecht van de Bundesrat onderworpen kunnen worden indien (wijziging van) het bestuurlijk handelen van de Länder op enigerlei wijze in het betreffende wets(wijzigings)voorstel aan bod komt.

71.

72.

73. Verhandlungen des Deutschen Bundestages, 7e Wahlperiode, 19-2-1976

74. DVBI. 1978, S. 318 (319ft). Het Bundesverfassungsgericht had in de veelgeciteerde uitspraak BVerfGE 37. 363 ook al door laten schemeren, een dergelijke praktijk te zullen billijken.

75. G. Ziller, Zum Spannungsverhaltnis zwischen Bundestag und Bundesrat, a.w., p. 342.

76. Idem.

77. Ch. Gramm, a.w., p. 223-224. 
In de tweede these werd gesteld dat iedere wijziging van een Bondswet die oorspronkelijk tot stand gekomen is via 'Zustimmung' door de Bundesrat te allen tijde wederom door diezelfde Duitse senaatskamer goedgekeurd zal moeten worden, zelfs indien slechts wijzigingen worden doorgevoerd die als zodanig geen formele toestemming van de Bundesrat zouden behoeven. ${ }^{78}$ In geval de vraag naar de reikwijdte van toestemming door de Bundesrat een voorstel betreft dat zowel materieelrechtelijke als formeel bestuursrechtelijke regels bevat, is door de rechtspraak in eerste instantie beslist dat die toestemming bij aanpassingvoorstellen betreffende oorspronkelijk 'Zustimmungsbedürftige' wetgeving dán vereist is, indien direct of indirect tevens in die wettekst vervatte voorschriften van formeel bestuursrechtelijke aard een 'wesentlich andere Bedeutung und Tragweite' blijken te krijgen. ${ }^{79}$ In een recentere uitspraak is hierop door het Bundesverfassungsgericht nog een niet onbelangrijke nadere verfijning aangebracht; een verfijning waardoor de reikwijdte van de 'Zustimmungsbedürftigkeit' per saldo verder toeneemt. En wel indien: 'Ānderung materiell-rechtlicher Normen eine grundlegende Umgestaltung der Rechtsqualităt der dem Bund durch früheres Gesetz übertragen Aufgabe bewirkt und dadurch der Bestimmung über die Verwaltungszuständigkeit des Bundes inhaltlich eine wesentlich andere Bedeutung und Tragweite verleiht, die von der früher erteilten Zustimmung ersichtlig nicht mehr umfasst wird'. ${ }^{80}$ Hier ligt het accent meer op mogelijke onderliggende bevoegdheidsverschuivingen in het federale bestuurssysteem.

In feite doet zich sinds 1949 een voortdurende verschuiving van bevoegdheden van de Lănder richting Bond voor. In het licht daarvan kan deze laatste uitspraak zeker ook geìnterpreteerd worden. Ter 'compensatie' voor eventueel verlies aan eigen bestuursbevoegdheden voor de Lảnder, zo lijkt het, krijgt de Bundesrat, het medewetgevend orgaan dat de Länder op Bondsniveau vertegenwoordigt, via vernuiming van het vetorecht meer mogelijkheden tot beïnvloeding van de besluitvorming aangaande wetgevingsproducten aangereikt. $^{81}$. Uiteraard is in dit hoofdstuk het laatste woord over dat uitruilproces nog niet geschreven.

Ter complementering moet hier nog enige aandacht besteed worden aan het begrip 'Einrichtung der Behörden' dat in zowel art. 84 Abs. 1 GG (bestuurlijk handelen van de Lănder ter uitvoering van hogere regelgeving) als in art. 85 Abs. 1 GG (bestuurlijk handelen van de Länder ter uitvoering van eigen regelgeving) in relatie tot de eventuele 'Zustimmungsbedürftigkeit' van nieuwe wetgeving door de Bundesrat opgenomen is. Het Bundesverfassungsgericht meende in deze: 'Die Einrichtung von Landesbehörden regelt das Bundesgesetz nicht nur wenn es neue Landesbehörden schafft, sondern auch, wenn es den näheren Aufgabekreis einer Behörde festlegt. ${ }^{, 82}$ Deze uitspraak betekent dat ook indien slechts een nadere wettelijke duiding van competentievoorschriften beoogd zou worden, toestemming van de Bundesrat vereist zou zijn. Wel wordt toegevoegd dat de nieuwe

\footnotetext{
78. H. Schneider, a.w., p. 287.

79. BVerfGE 37,363 (383).

80. BVerfGE 48,127 (180f).

81. H-J Blanke, Der Bundesrat im Verfassungsgefüge des GG, Jura 1995, p. 62.

82. BVerfGE 75, 108 (150)
} 


\section{Hoofdstuk 7}

regeling 'rechtstreeks' en 'kwalitatief van invloed moet zijn op het werkterrein dat door de overheden van de Länder bestreken wordt. ${ }^{83}$

Laten wij. nu vastgesteld is op welke wijze de reikwijdte van de 'Zustimmungsbedürftigkeit' van wetgevingsvoorstellen door de Bundesrat bepaald c.q. opgerekt kan worden, nader in ogenschouw nemen welke ontwikkelingen zich op het Bondsduitse wetgevingsterrein in kwantitatieve zin voor hebben gedaan:

Tabel 7.2:

\begin{tabular}{|c|c|c|c|c|}
\hline & $\begin{array}{l}\text { Einspruch- } \\
\text { gesetze } \\
\text { Verkündigt }\end{array}$ & $\begin{array}{l}\text { Zustimmungs- } \\
\text { gesetze } \\
\text { Verkündigt }\end{array}$ & $\begin{array}{l}\text { Verkündigte } \\
\text { Gesetze } \\
\text { Total }\end{array}$ & $\begin{array}{l}\text { Versagung } \\
\text { der } \\
\text { Zustimmung }\end{array}$ \\
\hline $1949-1953$ & 317 & $228(41,8 \%)$ & 545 & 12 \\
\hline $1953-1957$ & 256 & $254(49,8 \%)$ & 510 & 11 \\
\hline $1957-1961$ & 188 & $236(55,7 \%)$ & 424 & 4 \\
\hline $1961-1965$ & 198 & $227(53,4 \%)$ & 425 & 7 \\
\hline $1965-1969$ & 229 & $224(49,4 \%)$ & 453 & 10 \\
\hline $1969-1972$ & 161 & $172(51,7 \%)$ & 333 & 3 \\
\hline $1972-1976$ & 237 & $269(53,2 \%)$ & 506 & 19 \\
\hline $1976-1980$ & 157 & $182(53,7 \%)$ & 339 & 15 \\
\hline $1980-1983$ & 65 & $71(52,2 \%)$ & 136 & 6 \\
\hline $1983-1987$ & 128 & $192(60,0 \%)$ & 320 & - \\
\hline $1987-1990$ & 164 & $202(55,2 \%)$ & 366 & 1 \\
\hline $1990-1994$ & 211 & $282(57,2 \%)$ & 493 & 21 \\
\hline $1994-1998$ & 223 & $328(59,5 \%)$ & 551 & 22 \\
\hline $1998-2001$ & 133 & $149(52,8 \%)$ & 282 & 17 \\
\hline
\end{tabular}

Bronnen: Handbuch des Bundesnates für das Geschaftsjahr 1999/2000, Baden-Baden 2000, p. 297-298; http://www. bundesrat.de/PDund F/index.html. 21 november 2001

Uit bovenstaande tabel kunnen een aantal interessante feiten worden gedestilleerd. Allereerst blijkt duidelijk dat Zustimmung door de Bundesrat bij wetgeving op Bondsniveau al vanaf het prille begin eerder regel dan uitzondering geweest is. Al vanaf 1953 bleek minimaal de helft van alle nieuwe wetgeving afhankelijk gesteld te worden van formele toestemming door de Duitse senaatskamer ('mitwirken'!). Direct nadat de wetgevingsmachine van de nieuwe naoorlogse Bondsrepublick Duitland op stoom gekomen was, bleek dat het recht van 'Einspruch', het suspensieve vetorecht niet in een mate tot wasdom kon komen als door de grondwetgever van 1949 nog beoogd en verondersteld was. ${ }^{84}$ De snelheid waarmee dat duidelijk werd was opmerkelijk te noemen. Ontwikkelingen die significant van invloed blijken te zijn op de (gecodificeerde) staatsrechtelijke verhoudingen in

83. BVerfGE 55, 274 (337f) als minderheidsopinie :BVerfGE 75, 108 (150f),

84. P. Lerche, Zustimmungsgesetze, in: Vierzig Jahre Bundesrat, Baden-Baden 1989, p. 184-186. 
een federaal systeem, plegen zich in de regel stap voor stap te manifesteren via de weg van de geleidelijkheid. ${ }^{85}$

Sinds de vijftiger jaren van de twintigste eeuw is, zo blijkt uit de tabel, het aantal wetsvoorstellen dat blijkbaar 'Zustimmungsbedürftig' bleek te zijn alleen maar toegenomen. In het licht van hetgeen daarover reeds te berde is gebracht, zal die constatering nauwelijks verwondering kunnen wekken. De gehele ontwikkeling is in staatsrechtelijke zin terug te voeren tot verschuivingen in het Bondsduitse federale systeem. In feite is, zo heeft vijftig jaar pariementaire geschiedenis ons geleerd, voortdurend sprake geweest van een min of meer pragmatische uitwisseling. Dit behoeft nadere uitleg. De federale regering heeft via cen scala aan grondwetswijzigingen en andersoortige wetsvoorstellen steeds meer bevoegdheden ten koste van de Länder naar zich toe weten te trekken. Dit werd vooral mogelijk gemaakt door het in de Duitse grondwet verankerde systeem der 'Konkurrierende Gesetzgebung' ${ }^{86}$ Voor al die wetgevingsterreinen die volgens de grondwet ressorteren onder de vlag van de concurrerende wetgeving kunnen de Länder zelfstandig tot regelgeving overgaan, tenzij de Bond ter wille van 'die Herstellung gleichwertiger Lebensverhăltnisse im Bundesgebiet oder die Wahrung der Rechts- oder Wirtschaftseinheit im gesamtstaatlichem Interesse ${ }^{, 87}$ besluit zelf wetgeving te entameren. Dit laatste nu is op een dergelijk grote schaal gebeurd dat de Länder hier zo te zeggen vrijwel volledig 'weggeconcurreerd' zijn.

$\mathrm{Er}$ is echter meer aan de hand geweest. Een voorbeeld kan verhelderend werken. De lijst aan beleidsterreinen waarop concurrerende wetgevingsbevoegdheden tussen Bond en Lănder door de grondwetgever toelaatbaar werd geacht, is via o.a. het na grondwetswijziging toegevoegde art. 74a GG nog verder uitgebreid. ${ }^{88}$ Lid 2 van dat grondwetsartikel is in het kader van dit relaas vooral interessant: 'Bundesgesetze nach Absatz 1 bedürfen der Zustimmung des Bundesrates'. Blijkbaar meende de Bondsduitse wetgever dat een aanzienlijke bevoegdhedenverschuiving in het federale systeem vanuit de Länder richting Bond verantwoord was. Een verschuiving die zelfs doorgetrokken mocht worden tot het niveau waarop de ambtelijke salarisschalen ('ein föderales Nervenzentrum') vastsgesteld worden. Als doekje voor het bloeden stond daar voor de Lănder echter tegenover dat wetsvoorstellen op de beleidsterreinen die art. 74a GG bestrijkt, nog slechts kracht van wet kunnen krijgen middels formele toestemming door de Bundesrat. Bevoegdhedenverlies bij de Länder werd ingeruild voor een door de tweede (door afgevaardigden van de regeringen der Länder bemande) parlementskamer uit te oefenen toestemmingsrecht. ${ }^{89}$

Dit inruilen heeft zich bepaald niet beperkt tot art. 74a GG. Tijdens vijftig jaar Bondsduitse federale geschiedenis zijn bevoegdheden tot specifieke regelgeving op grote schaal

85. P. Lerche, a.w., p. 186.

86. Art. 72 GG.

87. Art. 72 Abs. 2 GG

88. Dit grondwetsartikel geeft richtlijnen over de wijze waarop regelgeving betreffende salariëring en andersoortige voorzieningen ten behoeve van openbare diensten ter hand genomen dient te worden.

89. P. Lerche, a.w, p. 186-187. 
van het Land op de Bond overgegaan en vrijwel altijd is dit gepaard gegaan met een verruiming van de 'Zustimmungsbedürftigkeit'.

In dat licht bezien is het nauwelijks opvallend te noemen dat de toestemmingsquote sinds de 10e naoorlogse kabinetsperiode (1983-1987) zelfs op is gaan schuiven naar $60 \%$ van het totaal aantal wetten. Voeg daarbij dat tijdens het laatste kabinet Kohl (1994-1998) maar liefst $90 \%$ van alle politiek gevoelige wetsvoorstellen slechts tot wet verheven bleek te kunnen worden na formele 'Zustimmung' door de (door oppositionele partijen gedomineerde) Bundesrat ${ }^{91}$ en het wordt duidelijk dat niet slechts de staatsrechtelijke doch ook de politieke discussie over het aan de Duitse senaatskamer toekomende vetorecht momenteel een hoge actualiteitswaarde bezit. In dat kader wordt ook wel gesproken over het 'Problem der faktische Grosse Koalition'. ${ }^{92}$ De Bondsregering moet over het gros der politiek zwaarwichtig geachte wetsvoorstellen niet slechts tot overeenstemming komen met de coalitiepartners in de Bundestag, maar evenzo met een Bundesratsmeerderheid. Die meerderheid in de 'zweite Kammer' is tegenwoordig echter slechts te verkrijgen via de partijen die in de Bundestag oppositie moeten voeren. De Bondsregering kortom, moet tot overeenstemming zien te komen met vrijwel alle politieke partijen die zitting hebben in de Bondsduitse parlementskamers: 'Der Handlungsspiefraum der Regierung geht im allparteienfoderalismus' gegen null, ${ }^{93}$

Tenslotte nog enige opmerkingen over de in bovenstaande tabel afgedrukte gegevens betreffende díe wetsvoorstellen die ten gevolge van het de Bundesrat toekomende vetorecht uiteindelijk sneuvelden. Allereerst valt op dat in kwantitatieve zin slechts een beperkt aantal wetsvoorstellen uiteindelijk de eindstreep niet gehaald heeft ten gevolge van het niet verlenen van toestemming door de Bundesrat. In de periode tot 1969 kwam hantering van het vetorecht door de Duitse senaatskamer meestal nog voort uit confrontaties tussen Bondsbelangen en regionale Landsbelangen van bijvoorbeeld financiēle aard of uit de tegenstelling tussen industriële belangen en agrarische belangen. De 23 gesneuvelde wetsvoorstellen tussen 1949 en 1957 zijn dan ook te verklaren vanuit die achtergrond. ${ }^{94}$ Daarentegen lijken zeker ook partijpolitieke oorzaken aanwijsbaar te zijn ter verklaring voor het vergelijkenderwijze toch redelijk substantiële aantal 'Zustimmungsversagungen' tijdens de perioden 1972-1980 en 1990-1998. Tijdens beide perioden immers is bij voortduring sprake geweest van divergerende partijpolitieke meerderheden in beide Bondsduitse parlementskamers. De Bundesrat vervulde zeker tijdens voornoemde perioden duidelijker dan anders niet slechts een functionele medewetgevende rol, doch manifesteerde zich evencens als politieke oppositie: 'In der Willensbildung des Bundesrats stand oder steht nicht mehr das einzelne Land, sondern die bundespolitisch orientierte Mehrheitsbildung und der Bezug zur politischen Gesamtleitung des Bundes im Vordergrund' ${ }^{95}$ Hoewel deze sterkere politieke rol voor de Bundesrat niet was beoogd door de grondwetgever van 1949

90. R. Dolzer, a.w., p. 15, G. Konow, Gleichgewicht zwischen Bund und Làndern, a.w., p. 245-247.

91. R. Dolzer, a.w., p. 15.

92. Ch. Gramm, a.w., p. 214-215.

93. Idem, p. 214.

94. G. Ziller und G-B.Oschatz, a.w., p. 119-120.

95. R. Dolzer, a.w., p. 13. 
(die niet opteerde voor de Senaatvariant, doch voor de Bundesratvariant), hoeft zij anderzijds ook geen onoverkomelijke problemen op te leveren. Een zekere mate van partijpolitiek gevoed dualisme hoeft immers ook in de bicamerale verhoudingen van de moderne Bondsrepubliek allerminst als systeemvijandelijk te worden beschouwd. Dit wordt pas anders indien dualisme plaats zou maken voor 'systemwidrige Obstruktion' door de Bundesrat, ${ }^{96}$ iets dat in praktische zin relatief eenvoudig ensceneerbaar lijkt te zijn voor een medewetgevend orgaan in het bezit van verregaande mogelijkheden tot hantering van een vetorecht.

In die zin neemt de Bundesrat uit politiek-strategisch oogpunt een hoogst markante plaats in tussen enerzijds de Nederlandse Eerste Kamer (volledig absoluut vetorecht zonder conciliatiemogelijkheid) en de Franse Sénat (geen vetorecht, maar wel conciliatie via de Commission Mixte Paritaire). Een plaats die uit oogpunt van zeggenschap vruchtbaar lijkt te zijn.

Indien tijdens een periode van divergerende partijpolitieke meerderheden in Bundesrat en Bundestag slechts ongeveer $4 \%$ van de wetgevingsvoorstellen uiteindelijk de eindstreep niet blijkt te halen, omdat de Bundesrat gebruik heeft gemaakt van het vetorecht, kan, met recht van spreken, gewezen worden op het gegeven dat een dergelijke 'versagungs'-quote eigenlijk relatief bescheiden is. Ter vergelijking: in Frankrijk weigert de senaatskamer ten tijde van getalsmatige dominantie door oppositionele partijpolitieke meerderheden bij ongeveer $30 \%$ van de gelanceerde voorstellen tot wet uiteindelijk de instemming (waarna de Assemblée nationale wel nog het laatste woord kan krijgen).

De verklaring voor het gegeven dat slechts weinig wetsvoorstellen uiteindelijk toch blijken te sneuvelen op grond van een absoluut veto, uitgeoefend door de Bundesrat, lijkt voort te vloeien uit een aantal elkaar over en weer beïnvloedende factoren. Enerzijds is daar het politieke gegeven van een absoluut vetorecht voor de Bundesrat voor zo'n $60 \%$ van alle wetgevingsvoorstellen. Vervolgens moet verdisconteerd worden dat een eigenlijk recht van amendement de Duitse senaatskamer staatsrechtelijk niet toekomt. Deze twee feiten culmineren zowel (al) tijdens de 'erste Durchgang' als (vooral) tijdens de conciliatieprocedure die in het Bondsduitse wetgevingstraject is ingebouwd via de 'Vermittlungsausschuss'procedure

\subsubsection{Vermittlungsausschuss}

De 'Vermittlungsausschuss' is een gezamenlijk orgaan van Bundestag en Bundesrat. Art. 77 Abs. 2 bepaalt dat deze commissie tot taak heeft te bemiddelen tussen beide Bondsduitse parlementskamers, indien verschillen van inzicht over (tekstgedeelten van) voorliggende wetsvoorstellen niet oplosbaar blijken te zijn in de loop van het reguliere wetgevingstraject. Indien de Bundesrat 'Einspruch' ex art. 77 Abs. 3 wil laten aantekenen tegen een daarvoor in aanmerking komend wetsvoorstel, dan is voorafgaande behandeling van dat voorstel in de conciliatiecommissie, zoals reeds eerder aangeduid, verplicht. In geval van

96. R. Dolzer, a.w., p. 20

97. Zie hoofdstuk 5, par. 5.3.5.1 en par. 5.3.5.2. 
'Zustimmungsbedürftigkeit ex art. 77 Abs. 2 kúnnen zowel de Bundesrat als ook de Bondsregering en Bundestag verzoeken om behandeling in de 'Vermittlungsausschuss'. De samenstelling van de commissie vertoont veel overeenkomst met de samenstelling van de Franse Commission Mixte Paritaire. Uit Bundestag en Bundesrat (per land één afgevaardigde) hebben een gelijk aantal vertegenwoordigers zitting, hetgeen betekent dat de Duitse conciliatiecommissie wordt bemand door 32 leden. ${ }^{99}$ In partijpolitieke zin vormt de samenstelling van de commissie zoveel mogelijk een afspiegeling van de geldende verhoudingen dienaangaande in de Bundestag en de Bundesrat. ${ }^{100}$ De afgevaardigden vanuit zowel Bundestag als Bundesrat kunnen nooit (formeel) gebonden worden aan instructies van buitenaf. In die zin verschilt de gang van zaken in de 'Vermittlungsausschuss' dan ook aanmerkelijk van hetgeen voor afgevaardigden vanuit de Länder ('einheitliche Stimmabgabe')gebruikelijk is bij stemmingen in de Bundesrat. De voorzittershamer wisselt iedere drie maanden tussen cen Bundesrats- en een Bundestagsafgevaardigde. ${ }^{101}$

Doel van de commissie (what's in a name!) is, zoals gezegd, het vervullen van een bermiddelende rol in geval de visies van Bundesrat en Bundestag betreffende (onderdelen van) voorstellen tot wet niet volledig blijken te sporen. Gemeenschappelijke inspanningen moeten ertoc leiden dat politieke meningsverschillen omgezet worden in voor beide parlementskamers acceptabele compromissen. Het eindproduct van de 'Vermittlungsausschuss' kan nooit méér zjjn dan een censgezind wijzigingsvoorstel. De definitieve beslissing over de levensvatbaarheid van het voorliggende wetsvoorstel inclusief door de commissie gesuggereerde wijzigingsvoorstellen, ligt vervolgens bij Bundestag én Bundesrat. Dit is temeer van belang, daar het immers goed mogelijk is, dat de 'Vermittlungsausschuss' tijdens bepaalde perioden, ten gevolge van electorale verschuivingen bij Landtagsverkiezingen, gedomineerd blijkt te worden door groeperingen die door Bondsregering en Bundestagsmeerderheid als oppositioneel beschouwd dienen te worden.

Vanzelfsprekend is het eveneens mogelijk, dat de bemiddelingscommissie er gewoon niet uitkomt en het wetsvoorstel in oorspronkelijke of beperkt aangepaste vorm terugstuurt naar de Bundesrat. Deze moet, afhankelijk van de aard van het wetsvoorstel, vervolgens besluiten om al dan niet over te gaan tot integrale 'Zustimmung' ex art. 77 Abs. 2 GG, dan wel 'Einspruch' ex art. 77 Abs. 3.

Indien de 'Vermittlungsauschuss' het wél cens is geworden over een geamendeerde nieuwe versie van een voorstel tot wet, moet vervolgens allereerst de Bundestag een standpunt bepalen over het voorliggende compromis. ${ }^{102}$ Stemt de Bundestag in met dat eindprodukt van de 'Vermittlungsausschuss', dan is vervolgens de Bundesrat aan de beurt. In geval een van beide parlementskamers het compromis van de commissie afwijst, moet uiteindelijk onvermijdelijk door zowel Bundestag als Bundesrat een definitief besluit genomen worden

98. Het is tevens goed mogelijk dat de Vermittlungsausschuss meerdere malen bijeen geroepen wordt ter bespreking van hetzelfde wetsvoorstel. Deze commissie kan namelijk achtereenvolgens en in willekeurige volgorde door zowel Bundestag, als Bundesrat, als Bundesregierung bijeengeroepen worden.

99. Art. 1 Gemeinsame Geschaftsordnung fur den Ausschuss nach art. 77 des Grundgezetses.

100 H. Laufer und U. Manch, a.w., p. 177,178 .

101. Art. 2 Gemeinsame Geschalfsordnung fur den Ausschuss nach art 77 des Grundgezetses.

102. Art. 10 Abs. 2 Gemeinsame Geschaftsondnung des Bundestages und des Bunderrates fur den Ausschuss nach Artikel 77 des Grundgesetzes. 
over het oorspronkelijke voorstel tot wet. Ik schrijf hier bewust 'uiteindelijk' omdat, wanneer geen overeenstemming blijkt te kunnen worden bereikt over 'Zustimmungsbedürtige' wetsvoorstellen die ter tafel liggen, zowel de Bondsregering als de Bundestag het recht hebben om de 'Vermittlungsausschuss' nogmaals bijeen te roepen ter deliberatie over dezelfde voorstellen. ${ }^{103}$

Laten wij eens kijken welke praktische rol de 'Vermittlungsausschuss' tot nu toe in de Bondsduitse parlementaire wetgevingspraktijk heeft kunnen spelen:

Tabel 7.3

\begin{tabular}{|l|r|r|r|r|r|}
\hline $\begin{array}{l}\text { Vermittlungs } \\
\text { ausschuss }\end{array}$ & Anrufung & $\begin{array}{l}\text { durch den } \\
\text { Bundesrat }\end{array}$ & $\begin{array}{l}\text { durch die } \\
\text { Bundes- } \\
\text { regierung }\end{array}$ & $\begin{array}{l}\text { durch den } \\
\text { Bundestag }\end{array}$ & $\begin{array}{l}\text { Verkündete } \\
\text { Gesetze }\end{array}$ \\
\hline $1949-1953$ & 75 & 70 & 3 & 2 & 63 \\
\hline $1953-1957$ & 65 & 59 & 3 & 3 & 56 \\
\hline $1957-1961$ & 49 & 46 & 3 & - & 47 \\
\hline $1961-1965$ & 39 & 34 & 3 & 2 & 35 \\
\hline $1965-1969$ & 39 & 34 & 4 & 1 & 30 \\
\hline $1969-1972$ & 33 & 31 & 2 & - & 31 \\
\hline $1972-1976$ & 104 & 96 & 7 & 1 & 89 \\
\hline $1976-1980$ & 77 & 69 & 7 & 1 & 57 \\
\hline $1980-1983$ & 20 & 17 & 3 & - & 17 \\
\hline $1983-1987$ & 6 & 6 & - & - & 6 \\
\hline $1987-1990$ & 13 & 13 & - & - & 11 \\
\hline $1990-1994$ & 85 & 71 & 14 & - & 71 \\
\hline $1994-1998$ & 92 & 74 & 10 & 8 & 73 \\
\hline $1998-2001$ & 33 & 26 & 6 & 1 & 73 \\
\hline Totaal & 730 & 646 & 65 & 19 & 614 \\
\hline
\end{tabular}

Bronnen: Handbuch des Bundesrates für das Geschaftsjahr 1999/2000, Baden-Baden 2000. p. 297-298; http://www.bundesrat.de/PDund F/index.html. 21 nocember 2001

Uit bovenstaande gegevens kan opgemaakt worden dat de 'Vermittlungsausschuss' al vanaf 1949 beschouwd mag worden als een niet onbelangrijke schakel in het wetgevingsproces op Bondsniveau. Bijna elf procent $(10.8 \%)$ van alle wetten die op Bondsduits niveau tussen 1949 en 2001 tot stand gebracht werden, liepen via de 'Vermittlungsausschuss'. In veruit de meeste gevallen blijkt de commissie samen gekomen te zijn op verzoek van de Bundesrat. Over het praktische nut van de commissie kan nauwelijks nog twijfel bestaan. Van de in totaal 730 wetsvoorstellen die geheel of gedeeltelijk door de 'Vermittlungsausschuss' onder de loep genomen werden, haalden er 646 , of $84 \%$ uiteindelijk in aangepaste vorm de eindstreep. Voorwaar geen slecht resultaat. Belangrijke motor achter dit succes is natuurlijk het gegeven dat Bundestag en Bundesrat via met name de 'Zustim-

103. Voor wetsvoorstellen waartegen door de Bundesrat via 'Einspruch' slechts een opschortend veto uitgesproken kan worden, is een dergelijke gang van zaken natuurlijk nict opportuun. 
mungsbedürftigkeit' in combinatie met de juridische mogelijkheden tot het suggereren van aanpassingsvoorstellen als het ware tot elkaar veroordeeld zijn. 'Geen overeenstemming, dan ook geen wetgeving'! Vertegenwoordigers van Franse oppositiepartijen in de 'Commission Mixte Paritaire' zouden ongetwijfeld watertanden, indien hen dergelijke mogelijkheden aangereikt konden worden. Men dient zich wel met klem te realiseren dat de leden van de Bundesrat in tegenstelling tot de leden van de Franse Sénat niet beschikken over een recht van amendement. Dit impliceert onder meer ook dat de Bundesrat ná de 'Erste Durchgang' een voorliggend wetsvoorstel slechts in zijn geheel 'à la de Eerste Kamer' mag beoordelen, tenzij besloten wordt de Vermittlungsausschuss in te schakelen. In dat geval kunnen de vertegenwoordigers in die commissie wél weer wijzigingsvoorstellen lanceren. Dat een dergelijk gezamenlijke eindbod van vertegenwoordigers uit Bundestag en Bundesrat in de beschreven politiek/staatsrechtelijke constellatie in de meeste gevallen voldoende politieke gewicht in de schaal legt om met succes de eindstreep te kunnen halen, lijkt vervolgens logisch.

De geconstateerde relatie tussen de legislatieve succesquote en de 'veroordeling tot elkaar' van Bundesrat en Bundestag is overigens ook in kwantitatieve zin vrij goed te onderbouwen: in de periode 1972-1976 was niet alleen sprake van een sterke mate van politieke polarisatie tussen de regerende SPD/FDP-coalitie Schmidt/Genscher en een krachtige Christen-Democratische oppositie, maar tegelijkertijd bleek die oppositie in de Bundesrat ook over een constante meerderheid te beschikken. Dit had tot gevolg dat het wetgevingsproces tijdens die periode maar liefst 104 maal via de 'Vermittlungsausschuss' liep; een record. De periode 1987-1990 liet het spiegelbeeld zien. Een Christen-Democratische regering Kohl en een vrij zwakke SPD-oppositie in combinatie met een riante meerderheid voor de Christen-Democraten in zowel Bundestag als Bundesrat. Gevolg: de 'Vermittlungsausschuss' werd slechts 13 maal bijeen geroepen. Tot zover volmaakt logische ontwikkelingen. Een parallel met de gang van zaken rondom het inschakelen van de Franse 'Commission Mixte Paritaire' zou in zoverre dan ook eenvoudig te trekken zijn. ${ }^{104}$ Kijken wij echter naar de mate waarin bemiddeling door de speciale wetgevingscommissie succesvol was, dan zijn de verschillen tussen de beide Duitse regeerperiodes hooguit marginaal. Tussen 1972 en 1976 bleek bemiddeling door de 'Vermittlungsausschuss in $85,5 \%$ van de gevallen succesvol te zijn geweest. Voor de periode $1987-1990$ was dat $84,6 \%$.

Tenslotte nog een ander sprekend voorbeeld. In 1979 werden in het kader van Europese belastingharmonisatie nieuwe wetsvoorstellen gelanceerd. In die voorstellen werden onder meer de begrippen 'Inland' en 'Ausland' nader gedefinieerd. 'Inland' was volgens de Bundesratmeerderheid het territorium van het Duitse Rijk op 31 december 1937. De Bondsregering was van mening dat een definitie gehanteerd diende te worden die in directe relatie stond tot de bestaande politiek/volkenrechtelijke realiteit. Bondsregering en Bundestag(smeerderheid) hielden voet bij stuk. Op verzoek van de Bundesrat werd de Vermittlungsausschuss bij elkaar geroepen. Deze kwam met een eindvoorstel dat voor de Bundesrat niet acceptabel was. Omdat het hier een 'zustimmungsbedürftig' wetsvoorstel betrof 
maakte vervolgens de Bondsregering gebruik van haar recht om de Vermittlungsausschuss wederom bijeen te roepen. De commissie bleef grosso modo bij haar oorspronkelijke voorstel. Logisch gevolg hiervan was natuurlijk een hernieuwde afwijzing door de Bundesrat. Nu maakte de Bundestag, als werkelijk allerlaatste mogelijkheid óók nog eens gebruik van het recht ex art. 77 Abs. 2 Satz 4 om de Vermittlungsausschuss op te roepen. De (door afgevaardigden van de oppositiepartijen gedomineerde) conciliatiecommissie besloot nu ineens in al haar wijsheid de woorden 'Inland' en 'Ausland' te vervangen door respectievelijk 'Erhebungsgebiet' en 'Aussengebiet', waarna de Bundesrat besloot tot definitieve toestemming en de wet afgekondigd kon worden. ${ }^{105}$

Het in de Bondsrepubliek Duitsland vigerende wetgevingbemiddelingsysteem, waarvan de doelmatigheid inmiddels wel is aangetoond, wordt desondanks in twee opzichten serieus bekritiseerd. Ten eerste wordt gesteld dat de politieke invloed die van de 32-koppige, in die hoedanigheid niet rechtstreeks democratisch gelegitimeerde commissieleden uit gaat op het wetgevingsproduct onevenredig groot is. Weliswaar heeft de regering via de partijpoliticke meerderheid in de Bundestag formeel het laatste woord, maar in feite blijft de keuze voor de politiek belangrijkste parlementskamer beperkt tot aanname (Zustimmungl) van het bemiddelingsvoorstel of intrekking van het gehele wetsontwerp. Deze praktische gang van zaken bezorgde de 'Vermittlungsausschuss' onder meer de weinig chique titulatuur 'Obergesetzgeber' dan wel 'Dunkelkammer der Gesetzgebung'. ${ }^{106}$

In de tweede plaats wordt het als problematisch ervaren dat de Bundesrat via de 'Vermittlungsausschuss' soms méér lijkt te doen dan ex art. 50 GG 'meewerken' bij de totstandkoming van wetgeving op Bondsniveau. Vooral ten tijde van divergerende meerderheden in Bundestag en Bundesrat kan 'meewerken' zeker ook een niet geringe mate aan politieke sturing van het wetgevingbemiddelingsproces in de 'Vermittlungsausschuss' inhouden. $^{107}$

Tijdens de nadagen van de Sociaal-Liberale coalitie onder Helmut Schmidt bijvoorbeeld, leidde een dergelijke gang van zaken tot een flink conflict. De Bundesrat die gedomineerd werd door de Christen-Democraten, stemde tegen een regeringsvoorstel tot wet waarin de opbouw van de begroting in de relatie Bund-Länder centraal stond. De 'Vermittlungsausschuss' die vervolgens bijeen geroepen werd, beperkte zich niet tot bemiddeling betreffende de voorliggende stukken, doch reikte ook alvast oplossingen aan voor een aantal bijbehorende legislatieve deelproblemen, waarover de Bundestag nog niet cens een eerste eigen oordeel had geveld. De Bundestag meende dan ook dat de conciliatiecommissie zijn boekje te buiten was gegaan. Het wetgevingsproces moet een openbaar parlementair proces zijn en blijven. ${ }^{108}$ Voorkoken van oplossingen achter de deuren waar de Vermittlungsausschuss vergadert, zou staatsrechtelijk niet door de beugel kunnen. Het Bundesverfassungsgericht bleek het weliswaar met dat principe eens te zijn, doch oordeelde in casu de gang van zaken niet ongrondwettelijk. ${ }^{109}$

105. F. Vogel, Der Vermittlungsausschuss, in: Vierzig Jahre Bundesrat, Baden-Baden 1989, p. 213-225.

106. G. Ziller und G-B. Oschatz, a.w., p. 33.

107. H. Laufer und U. Münch, a.w., p. 181

108. D. Posser, Der Vermittlungsausschuss, in: Vierzig Jahre Bundesrat, Baden-Baden 1989, p. 210

109. BverfGE 72, 175, 187-193. 
Zoveel over de gang van zaken betreffende het nationaal Bondsduitse legislatieve proces. Een bespreking van de wijze waarop en de intensiteit waarmee de Duitse Bundesrat gebruik pleegt te maken van de hem/haar toekomende legislatieve vetorechten kan echter niet afgerond worden, alvorens specifiek aandacht is besteed aan de ontwikkelingen dienaangaande in de relatie Bondsrepubliek Duitsland- Europese Unie.

\subsection{De Bundesrat in Europa}

De gestage toename van supranationale bevoegdheden voor organen van achtereenvolgens EEG, EG en EU had en heeft vanzelfsprekend niet slechts gevolgen voor de Bondsrepublick als geheel, doch evenzeer, zoniet pregnanter voor de onderdelen van de federatie, de Länder. Het trekken van een parallel met ontwikkelingen op legislatief terrein in de verhouding Bond-Länder lijkt hier alleszins verantwoord. In het "coöperatief federale Duitse staatsverband' lijkt sinds de vijftiger jaren namelijk niet alleen sprake geweest te zijn van cen voortdurende bevoegdhedenoverdracht van Land naar Bond (via met name de pragmatisch unitaristische invulling die door de Bondsregering gegeven werd aan de artt. 74 en 74a GG), doch tevens van Land naar 'Brussel'. Wij hebben gezien dat de afdracht van bevoegdheden van de Länder aan de Bond in veel gevallen uitgewisseld werd tegen extra zeggenschap voor de Bundesrat bij de aanname van het Bondsduitse legislatieve eindproduct. Het kan nauwelijks verwondering wekken dat de Länder (via onder andere de Bundesrat) reeds vanaf het ontstaan van EGKS, EURATOM en EEG ook betrokken hebben willen raken bij de besluitvorming aangaande nieuwe Europese regelingen. Immers, zo was de redenering, partiële afdracht van soevereiniteit ten behoeve van bepaalde beleidsterreinen zou op het vlak van de uitvoering met name voelbaar worden in de Länder. Derhalve zou 'gesetzliche Sicherung für die Mitwirkung der Lănder in Angelegenheiten der europăischen Integration' verzekerd moeten worden.

Ontwikkelingen in die richting verliepen vooraleerst langzaam. De mate van invloed die de Länder tijdens de zestiger en zeventiger jaren via de Bundesrat op de besluitvorming in Brussel uit wisten te oefenen is hooguit als marginaal te kwalificeren. In eerste instantie namelijk, had de Duitse regering richting Bundestag en Bundesrat slechts een informatieplicht betreffende de benadering van allerhande internationaalrechtelijke aangelegenheden, waaronder EEG-aangelegenheden. ${ }^{11}$ De Bundesrat mocht dan stelling nemen tegen de voorgestelde EEG-regeling, doch de verantwoordelijke Bondsduitse minister was, geheel conform de letter van de Duitse grondwet, vrij om in de Raad van Ministers voornoemde stellingname te negeren. De centrale grondwetsbepaling voorzag in die tijd namelijk in de mogelijkheid tot overdracht van soevereine rechten door de Bond aan 'zwischenstaatliche Einrichtungen', zónder dat hiervoor nadere toestemming van de Lănder vereist was. ${ }^{112}$ Dat ging pas geleidelijk veranderen na de aanname van de Europese Akte in I986. Voornoemd grondwetsartikel (Art. $24 \mathrm{GG}$ ) bleef weliswaar ongewijzigd bestaan, doch

110. G. Ziller und G-B Oschatz, a.w., p. 42.

111. Art 53 Satz 3 GO.

112. Art. 24 Satz I GG. 
Bondsduitse ratificatiewetgeving betreffende de Europese Akte voorzag in de plicht voor de Bondsregering om minder vrijblijvend dan voorheen rekening te houden met de standpuntbepaling van de Länder waar expliciet nieuwe EU-regels in het geding waren die qua beleidsterrein 'ganz oder teilweise in die ausschliessliche Gesetzgebungszuständigkeit der Länder fallen oder deren wesentliche Interessen berühren'. ${ }^{113}$ De Bondsregering mocht de standpuntbepaling van de Lănder over aangelegenheden die in voornoemde categorie thuis hoorden uitsluitend nog terzijde schuiven indien 'zwingenden integrations- und aussenpolitischen Gründen' daartoe aanleiding gaven, ${ }^{114}$ een open uitnodiging voor regelmatig terugkerende (steeds) politiek getinte interpretatiedebatten.

De grote doorbraak voor de Länder (en de Bundesrat in functie van het de Länder vertegenwoordigend orgaan op Bondsniveau) kwam tot stand ten gevolge van het Verdrag van Maastricht. Via dat verdrag zou de subsidiariteitsgedachte een prominente plaats gaan krijgen: 'Op gebieden die niet onder haar exclusieve bevoegdheid vallen, treedt de Gemeenschap overeenkomstig het subsidiariteitsbeginsel, slechts op indien en voor zover de doelstellingen van het overwogen optreden niet voldoende door de Lid-Staten kunnen worden verwezenlijkt (...).' ${ }^{115}$ Hoewel hier natuurlijk eerst en vooral de relatic EU-nationale staat bedoeld was, maakten de Duitse Länder in een poging om voornoemd subsidiariteitsbeginsel door te laten trekken tot de relatie EU-'regio' bijzonder handig gebruik van een zich tezelfdertijd aandienend politiek momentum. Een en ander ging als volgt in zijn werk: het Verdrag van Maastricht voorzag onder andere ook in de oprichting van een (in Duitsland te vestigen!) Europese Centrale Bank. Zonder grondwetswijziging ${ }^{116}$ zou dit vanuit Duits oogpunt bezien fraaie perspectief nooit meer dan fictie kunnen worden. En voor een dergelijke grondwetswijziging was een tweederde meerderheid in zowel Bundestag als Bundesrat vereist. De regeringen van de Duitse Länder, tevens broedplaats voor de leden van de Bundesrat, wisten deze troef ten volle te benutten. In ruil voor coóperatie vanuit de Lănder bij de uiteindelijke ratificatie van het Verdrag van Maastricht (inclusief $E C B$ ), werd een nieuw Duits grondwetsartikel uitonderhandeld, waarin verregaande bevoegdheden tot medewerking van de Lănder en de Bundesrat bij EU- aangelegenheden opgenomen werden, het 'Europa-Artikel 23 GG'.117

\subsubsection{Art. 23 GG}

De geest waarmee de Duitse 'unitaristisch-coöperatieve' federatie in de 21 e eeuw de Europese Unie dient te gaan benaderen blijkt duidelijk uit Abs. 1 Satz 1 van art. 23 GG: 'Zur Verwirklichung eines vereinten Europas wirkt die Bundesrepublik Deutschland bei der Entwicklung der Europäischen Union mit die demokratischen, rechtstaatlichen, sozialen und foderativen Grundsătzen und dem Grundsatz der Subsidiarităt verplichtet ist und einen diesem Grundgesetz im wesentlichen vergleichbaren Grundrechtsschutz gewähr-

113. Art. 2 Gesetz zur Ratifikation der Einheitlichen Europāischen Akten.

114. H. Laufer und U. Manch, a.w., p. 294.

115. Art. 5 EG-Verdrag.

116. Art. 88 Satz 2 GG (oud).

117. H. Laufer und U. Münch, a.w., p. 317. 
leistet'. De wijze waarop de Duitse Bondswetgever verwerkelijking van dit streven formeel gestalte zal moeten geven is in het kader van dit boek ook bepaald niet oninteressant: 'Der Bund kann hierzu durch Gesetz mit Zustimmung des Bundesrates Hoheitsrechte übertragen'. ${ }^{118}$ In Abs. 1 Satz 3 tenslotte, wordt ook nog eens expliciet aangegeven dat het afstaan van soevereine rechten ten faveure van de EU altijd dient te geschieden via de procedure van art. 79 Abs. 2: 'Ein solches Gesetz bedarf der Zustimmung von Zwei Dritteln der Mitglieder des Bundestages und zwei Dritteln des Bundesrates'.

Felle debatten over de 'Zustimmungsbedürftigkeit' door de Bundesrat hoeven hieromtrent vanzelfsprekend dus nooit gevoerd te worden.

Debatten over de vraag of een gekwalificeerde tweederde meerderheid in beide Bondsduitse parlementskamers voor iedere EU-verdragswijziging noodzakelijk wordt, echter wél. Centraal in die discussie staat de vraag in welke mate de in het geding zijnde verdragsaanpassingen tevens enige (verdere) overdracht van soevereiniteit impliceren. De Bondsregering was de mening toegedaan dat volstaan zou kunnen worden met toestemming van beide Kamers via gewone meerderheid van stemmen, indien: 'Änderungen des Union-Vertrages zu ratifizieren sind, die von ihrem Gewicht her der Gründung der Europäischen Union nicht vergleichbar sind und insoweit nicht die Geschaftsgrundlagen dieses Vertrages betreffen'. ${ }^{119}$ In de Duitse staatsrechtelijke literatuur werd geopperd dat wellicht onderscheid gemaakt zou moeten gaan worden tussen overdracht van soevereiniteitsrecht aan de EU zonder consequenties voor de materiële inhoud van de Duitse Grondwet en overdracht van soevereiniteitsrechten die dat wél hebben. ${ }^{120}$ Volgens vaste rechtspraak van het Bundesverfassungsgericht moet echter iedere overdracht van soevereiniteitsrechten beschouwd worden als een materièle wijziging van de Grondwet. ${ }^{121}$

Omdat de ontwikkeling van het EU-recht bij voortduring als dynamisch te kwalificeren zal blijven, lijkt de door de Duitse wetgever te bewandelen weg weinig doelmatig te zijn. Immers ook iedere relatief onbeduidende wijziging van een EU-verdragstekst die op welke wijze dan ook gelieerd is aan over te dragen dan wel reeds overgedragen soevereiniteitsrechten, inclusief wijzigingen waarbij in materiële zin in feite niets verandert, moet in de Bondsrepubliek lopen via de zware grondwetswijzigingprocedure ex art. 79 Abs. 2 GG.

Hoewel de praktijk minder weerbarstig blijkt dan de letter zou doen vermoeden, ${ }^{122}$ betekende de invoering van art. $23 \mathrm{Abs} .1$ hoe dan ook grote politieke winst voor de Bundesrat ten opzichte van regering en Bundestagsmeerderheid, waar bemoeienis met de relatie BRD-EU in het kader van supranationale besluitvormingsprocessen in het geding is, nu immers altijd toestemming van de Bundesrat vereist blijkt te zijn. In veel gevallen zelfs een tweederde meerderheid.

118. Art. 23 Abs. 1 Satz 2 GG.

119. Begrandung des Regienungsentwurfs zu Art. 23, BT-Drs. 12/3338, S. 7.

120. G-B Oschatz und H. Risse, Die Bundesregienung an der Kette der Länder?, Die Offentiche Verwaltung jun 1995. p. 439.

121. BVerfGE $58,1,36$

122. Indien er getwijfeld wordt over de vraag of in casu wel soevereiniteitsrechten in het geding zijn, terwijl tegelijkertijd grote partijpolitieke consensus bestaat over de noodzaak tot ratificatie van bepaalde verdragswijzigingen, blijkt in de Bondsduitse wetgevingspraktijk afhandeling als gewone wet ex art. $77 \mathrm{Abs} .2$ zeker niet ongebruikelijk te zijn. 
Het Bondsduitse 'Europa-artikel' 23 GG heeft echter nog veel meer in petto voor de Bundesrat. Het tweede lid van dit grondwetsartikel beschrijft de onderlinge verhouding tussen de drie belangrijkste Bondsduitse wetgevingsorganen, de regering, de Bundestag en de Bundesrat betreffende EU-aangelegenheden: 'In Angelegenheiten der Europäischen Union wirken der Bundestag und durch die Bundesrat die Länder mit'. Glashelder blijkt uit deze bepaling wederom welk een legitimerende kracht vanuit de onderdelen der Duitse federatie uit kan gaan op de actieradius en daardoor het functioneren van de Bundesrat. Ter concretisering van voornoemde regel is de Bondsregering verplicht om zowel de Bundestag als de Bundesrat altijd zo snel mogelijk de noodzakelijke informatie over EU-aangelegenheden te verschaffen. ${ }^{123}$

Informatie verkrijgen is echter hooguit de eerste stap richting volwaardig 'mitwirken'. Participatie impliceert naast informatievergaring immers tevens de mogelijkheid tot standpuntbepaling en de mogelijkheid dit standpunt met enig politiek gewicht uit te kunnen dragen. In de leden $4 \mathrm{t} / \mathrm{m} 6$ van art. $23 \mathrm{GG}$ worden hiertoe de noodzakelijk geachte grondwettelijke aanzetten gegeven, zij het dat de betreffende delen van het 'Europa-artikel' niet uit blijken te blinken in helderheid van formulering. Allereerst wordt in art. 23 Abs. 4 gesteld dat de Bundesrat ingeschakeld moet worden: 'soweit er an einer entsprechenden innerstaatlichen Massnahme mitzuwirken hätte oder soweit die Länder innerstaatlich zustăndig wăren'. Mocht duidelijk zijn dat hiervan sprake is, dan moet, aldus de Duitse grondwetgever, vervolgens worden vastgesteld tot wiens competentie de inhoud van de in het geding zijnde EU-maatregel gerekend dient te worden. Is dat de Bond als geheel, dan hoeft de Bondsregering stellingname van de Bundesrat betreffende de in het geding zijnde EU-maatregel slechts te 'berücksichtigen'. ${ }^{124}$ Valt de materie die in de EU-maatregel uitgewerkt wordt tevens onder de wetgevingscompetentie van de Länder op een wijze waardoor hun 'Behördeneinrichtung und ihre Verwaltungsverfahren schwerpunktmässig betroffen sind', dan dient stellingname door de Bundesrat 'massgeblich berücksichtigt' te worden door de Bondsregering. ${ }^{125}$ In het geval tenslotte, dat uitsluitend de wetgevingscompetentie van de Länder in het geding is, voorziet de grondwet in vertegenwoordiging vanuit die Länder in Brussel. ${ }^{126}$ Het moge duidelijk zijn dat nauwkeurige interpretatie van deze in art. 23 GG geformuleerde rechtsbegrippen niet eenvoudig zal zijn. Mede met het oog op die constatering heeft de Duitse Bondswetgever een speciale procedure ter oplossing van conflicten ontwikkeld. Deze procedure voorziet in geval Bondsregering en Bundesrat in een concreet geval ten gevolge van competentie-onduidelijkheden van mening verschillen over de interpretatie van voornoemde rechtsregels, in formeel overleg tussen afgevaardigden vanuit beide organen. ${ }^{127}$ Mocht dat formele overleg niets opleveren dan voorziet de regeling vervolgens nog in een facultatieve afstemmingsmogelijkheid door de Bundesrat. Wordt de Bundesratsvisie blijkens het resultaat van de stemming gesteund door

123. Art. 23 Abs, 2 Satz 2 GG. De informatieplicht is verder uitgewerkt in het 'Gesetz aber die Zusammenarbeit von Bund und Landern in Angelegenheiten der Europalischen Union (EUZBLG).

124. Art. 23 Abs. 5 Satz 1 GG.

125. Art. 23 Abs. 5 Satz 2 GG.

126. Art. 23 Abs. 6 GG

127. Art. 5 Abs. 2 EUZBLG. 
minimaal tweederde deel van haar leden, dan móet de visie van de 'zweite Kammer' met betrekking tot de in het geding zijnde EU-problematiek 'massgeblich' verdisconteerd worden. ${ }^{128}$

Hoewel deze procedure op het eerste gezicht slechts strategisch voordeel voor de Bundesrat op lijkt te leveren, kan dat in de praktijk toch eenvoudig anders uitvallen. Gekwalificeerde tweederde meerderheden blijken gezien de contemporaine partijpolitieke verhoudingen nauwelijks nog haalbaar. En mocht de stemming niet de vereiste tweederde meerderheid opleveren, dan heeft de Bondsregering vervolgens wél de handen vrij. ${ }^{129}$

Aan dit alles kan nog toegevoegd worden dat er een regelmatige check plaats dient te vinden om te achterhalen in hoeverre de Bondsregering als vertegenwoordiger voor de Bondsrepubliek in Brussel de stellingname van de Bundesrat, indien daartoe aangemaand, 'massgeblig' blijkt te 'berücksichtigen'. ${ }^{130}$ In ieder geval impliceren de EU-gelieerde werkzaamheden voor de Bundesrat een aanmerkelijke én permanente opwaartse bijstelling van de werkdruk. Uitgedrukt in cijfers: tot september 1999 heeft de Bundesrat als orgaan ter vertegenwoordiging van de Länderbelangen niet minder dan 7206 EG/EU-voorstellen kunnen bespreken.

\subsubsection{Europakammer}

In het kader van de bespreking van de relatie Bundesrat-EU dienen nog enige complementaire opmerkingen gemaakt te worden over de eveneens grondwettelijk verankerde mogelijkheid voor de Bundesrat tot het installeren van een 'Europakammer': 'Für Angelegenheiten der Europäischen Union kann der Bundesrat eine Europakammer bilden, deren Beschlüsse als Beschlüsse des Bundesrates gelten'. ${ }^{132}$ Dankzij de instelling van dit orgaan kan de Bundesrat in voorkomende gevallen steeds adequaat reageren op regelgevingontwikkelingen vanuit Brussel. Wanneer zoveel haast geboden is dat de eerstvolgende bijeenkomst van de Bundesrat niet afgewacht kan worden, neemt de 'Europakammer' zelfstandig besluiten. ${ }^{133}$ Deze besluiten kunnen dan vervolgens als richtinggevend beschouwd worden voor de verantwoordelijke Bondsduitse minister tijdens (voortzetting van de) onderhandelingen in de Raad van Ministers. Ook indien op verzoek van de Bondsregering, (een van) de Länder of een parlementscommissie verzocht is om vertrouwelijke behandeling van een bepaald EU-voorstel, voorziet de Geschäfsordnung van de Bundesrat in mogelijke behandeling door de 'Europakammer' in plaats van bespreking tijdens de reguliere Bundesratsbijeenkomst. ${ }^{134}$

128. Idem.

129. G-B. Oschatz und H. Risse, a.w., p. 443.

130. Idem.

131. O. Ziller und G-B. Oschatz, a.w., p. 41.

132. Art 52 Abs. 3a GG.

133. $\$ 45$ d onder 2 Geschalfsordnung des Bundesrates.

134. $\$ 45$ d onder 3 Geschafsordnung des Bundesrates. 
Het praktische belang van de 'Europakammer' is tot nu toe vrij beperkt gebleven. Tot september 1999 werden slechts 16 EU-voorstellen in dit orgaan en zijn voorloper (Kammer für Vorlagen der Europäischen Gemeinschaften) besproken. ${ }^{135}$

Bekijken wij het totale plaatje van het 'Europa-artikel' $23 \mathrm{GG}$ in relatie tot de positie die de Bundesrat ten opzichte van de Bondsregering in kan nemen, dan moet toch geconcludeerd worden, dat de zeggenschap van de Bundesrat per saldo duidelijk toeneemt. Evenals dat het geval was rondom de totstandkoming van nieuwe wetgeving ex art. 74 en 74 a GG (Konkurrierende Gesetzgebung), vindt ook hier als het ware weer de uitruil plaats tussen afdracht van bevoegdheid door de Länder en toename van (mede)zeggenschap voor de Bundesrat bij de Bondsduitse positionering, in dit geval inzake EU-regelingen. De basis voor deze ontwikkeling wordt gevormd door het aloude (in federatieve verbanden evenmin te veronachtzamen) democratieprincipe dat ook bij de ontwikkeling van supranationale EU-politiek voor de Bondsrepubliek vanzelfsprekend uitgangspunt dient te blijven. Het Bundesverfassungsgericht heeft zich daarover nog eens ondubbelzinnig uitgesproken in het 'Maastricht'-arrest. ${ }^{136}$

\subsection{Gedelegeerde wetgeving en beleidsregels}

De Bundesrat heeft van de grondwetgever ook ten aanzien van gedelegeerde wetgeving en beleidsregels een prominente plaats in de besluitvorming toegewezen gekregen.

Allereerst de wetgevingsdelegatie. Via art. 80 GG zijn zowel de Bondsregering, de individuele ministers als de regeringen van de Lănder gemachtigd tot het uitvaardigen van gedelegeerde, op wetgeving in formele zin terug te voeren regels. Het kader dient aangegeven te worden door de wet in formele zin. ${ }^{137}$ In lid 2 van art. 80 GG wordt vervolgens aangegeven voor welke beleidsterreinen regelgeving op grond van delegatie slechts rechtskracht kan krijgen na toestemming daarvoor van de Bundesrat. Het venijn zit hier in de staart: '(...) sowie Rechtsverordnungen auf Grund von Bundesgesetzen, die der Zustimmung des Bundesrates bedürfen oder die von den Ländern in Auftrage des Bundes oder als eigene angelegenheit ausgeführt werden'. In de praktijk betekent dit, dat vrijwel alle regels die tot stand komen op grond van wetgevingsdelegatie tevens aan de Bundesrat voorgelegd worden. Voor de Bundestag is in dit geheel geen enkele rol weggelegd.

Procedurele voortschriften rondom de behandeling van gedelegeerde regels door de Bundesrat zijn er nauwelijks. Er is geen wettelijke termijn die in acht genomen moet worden. De Bundesrat kan instemmen met het voorliggende ontwerp, kan dit verwerpen, dan wel kan wijzigingsvoorstellen suggereren. Conciliatie via een 'Vermittlungsausschuss' naar het voorbeeld van art. 77 Abs. 3 GG past uiteraard niet in deze procedure. Het vetorecht van de Bundesrat is hier dan ook absoluut.

In een federatie zoals de BRD die gekenmerkt wordt door sterk unitaristische tendensen, spelen door de Bondsregering uitgevaardigde, door de Länder uit te voeren beleidsregels

135. Handbuch des Bundesrates für das Geschäsjahr 1999/2000, Baden-Baden 2000, p. 298.

136. BVerfGE 89, 155 (190f).

137. Art. 80 Abs. 1 Satz 2 GG. 
een rol van grote betekenis. De basisprincipes betreffende 'Bundesauftragverwaltung durch die Länder' zijn ook terug te vinden in de Grondwet. ${ }^{138}$ De grondwet beoogt dat de Länderregeringen bindende aanwijzingen vanuit Berlijn slechts via formele toestemming door de Bundesrat tot stand kunnen komen. ${ }^{139}$ Ook hier wordt weer zichtbaar dat vermindering van zelfstandige bevoegdheden voor de Länder gecompenseerd wordt via deelname van de Bundesrat aan de totstandkoming van de relevante regelgeving.

$\mathrm{Nu}$ zowel delegatie van wetgeving als ook de behoefte tot het uitvaardigen van beleidsregels door de Bondsregering onder druk der voortdurende sociaal-economische ontwikkelingen een enorme vlucht heeft genomen, is het alleen al daarom niet van belang ontbloot nader te bekijken hoe de Bundesrat in de praktijk om pleegt te gaan met zijn politiekstaatsrechtelijke machtspositie in deze.

Tabel 7.4

\begin{tabular}{|l|c|c|c|c|}
\hline & $\begin{array}{l}\text { Rechts- } \\
\text { verordnungen } \\
\text { vom Bundesrat } \\
\text { beraten }\end{array}$ & $\begin{array}{l}\text { Zustimmung } \\
\text { vom Bundesrat } \\
\text { versagt }\end{array}$ & $\begin{array}{l}\text { Verwaltungs- } \\
\text { vorschriften } \\
\text { vom Bundesrat } \\
\text { beraten }\end{array}$ & $\begin{array}{l}\text { Zustimmung } \\
\text { vom Bundesrat } \\
\text { versagt }\end{array}$ \\
\hline $1949-1953$ & 426 & 6 & 110 & 2 \\
\hline $1953-1957$ & 579 & 12 & 66 & 1 \\
\hline $1957-1961$ & 471 & 9 & 58 & - \\
\hline $1961-1965$ & 550 & 2 & 72 & - \\
\hline $1965-1969$ & 525 & 2 & 62 & - \\
\hline $1969-1972$ & 471 & 2 & 60 & - \\
\hline $1972-1976$ & 680 & - & 81 & - \\
\hline $1976-1980$ & 554 & 2 & 78 & - \\
\hline $1980-1983$ & 298 & 5 & 45 & - \\
\hline $1983-1987$ & 448 & 2 & 71 & - \\
\hline $1987-1990$ & 546 & 1 & 61 & 1 \\
\hline $1990-1994$ & 639 & 1 & 47 & - \\
\hline $1994-1998$ & 619 & 5 & 69 & - \\
\hline $1998-2001$ & 346 & - & 39 & - \\
\hline
\end{tabular}

Bronnen: Handbuch des Bundesnates fur das Geschaftsjahr 1999/2000, Baden-Baden 2000. p. 297-298; http://www.bundesrat.de PDund F/index.html. 21 november 2001

Op het terrein van zowel gedelegeerde wetgeving als ook op het terrein van de beleidsvoorschriften is sprake van een permanent coöperatief proces waar de medebeslissende rol van de Bundesrat in het geding is. De Bundesrat blijkt het druk te hebben met de voortdurende toestroom van vooral regels op grond van delegatie. ${ }^{140}$ Formele toestemming volgt

140. W. Patzelt. The Very Federal House: The German Bundesrat, in: Senates. Bicameralism in the contemporary World, Ohio State University Press 1999, p. 81. 
in de regel uiteindelijk echter welhaast standaard, óók ten tijde van partijpolitieke onbalans in de verhouding Bundesrat-Bundestag. Doelmatigheidsoverwegingen lijken hier te prevaleren boven partijpolitiek. Het gegeven dat de werkzaamheden rondom gedelegeerde wetgeving en beleidsregels zich grotendeels voltrekken in door ter zake kundige ambtenaren ('Landesministerialbürokratien') bevolkte vaste kamercommissies, is daar zeker niet vreemd aan zijn. ${ }^{141}$ Die doelmatige tevens op de uitvoering gerichte benadering van de Bundesrat heeft overigens ook tot gevolg dat de regering voorafgaande aan de formele goedkeuring door de Bundesrat vaak nog zal moeten sleutelen aan voorliggende 'Rechtsverordnungen': 'In der Regel macht der Bundesrat Änderungsauflagen. Nur wenn diese von der Bundesregierung oder dem zustãndigen Bundesminister akzeptiert werden, wird die Rechtsverordnung rechtswirksam'. 142

Ter afsluiting van de bespreking van de uitgebreide lijst aan werkzaamheden op het punt van regelgeving en beleidsregels die de Bundesrat in de Bondsrepubliek Duitsland vervult, mogen enige opmerkingen over de werking van het recht van wetgevingsinitiatief natuurlijk niet ontbreken.

\subsection{Recht van initiatief}

Art. 76 Abs. 1 GG: Gesetzvorlagen werden beim Bundestage durch die Bundesregierung, aus der mitte des Bundestages oder durch den Bundesrat eingebracht.

Evenals de Franse Sénat en het Britse House of Lords, komt ook de Duitse Bundesrat het wetgevingsinitiatief toe. De te volgen procedure wijkt vanzelfsprekend af van de reeds besproken standaardwetgevingsprocedure, aangezien de Bundesrat bij eigen wetgevingsinitiatief natuurlijk niet geroepen is tot eerste stellingname ex art. 76 Abs. 2 GG. In geval van wetgevingsinitiatief door de Bundesrat heeft de Bondsregering ex art. 76 Abs. $3 \mathrm{GG}$ recht op een 'Erste Durchgang', alvorens het wetsvoorstel doorgestuurd dient te worden naar de Bundestag. Deze 'Erste Durchgang' is procedureel verder een zuivere copie van de beschreven gang van zaken bij regeringsvoorstellen tot wet ex art. 76 Abs. 2 GG (termijnen enz.). Nadat de Bondsregering een eerste standpunt heeft kunnen bepalen, wordt het voorstel doorgestuurd naar de Bundestag, waarna de reguliere weg via vaste kamercommissies gevolgd wordt. Omdat een wetgevingsinitiatief, zeker indien afkomstig uit de gelederen der Bundesrat, op de wetgevingsagenda geen hoge prioriteit pleegt te hebben, komt het met enige regelmaat voor dat dergelijke voorstellen op het einde van cen kabinetsperiode nog niet afgerond zijn. Dit heeft tot gevolg dat voornoemde voorstellen formeel vervallen.

Laten wij verdere bespreking van het recht van initiatief voor de Duitse Bundesrat illustreren met een aantal relevante kwantitatieve gegevens: 
Tabel 7.5

\begin{tabular}{|c|c|c|c|}
\hline & $\begin{array}{l}\text { Vom Bundesrat } \\
\text { als Gesetzentwurf } \\
\text { beschlossen }\end{array}$ & $\begin{array}{l}\text { Von der Bundes- } \\
\text { regierung dem } \\
\text { Bundestag zugeleitet* }\end{array}$ & Verkündete Gesetze \\
\hline $1949-1953$ & 29 & 20 & $12(60 \%)$ \\
\hline $1953-1957$ & 16 & 11 & $8(73 \%)$ \\
\hline $1957-1961$ & 5 & 5 & $2(40 \%)$ \\
\hline $1961-1965$ & 8 & 8 & $3(38 \%)$ \\
\hline $1965-1969$ & 14 & 14 & $9(64 \%)$ \\
\hline $1969-1972$ & 27 & 24 & $13(54 \%)$ \\
\hline $1972-1976$ & 75 & 73 & $18(25 \%)$ \\
\hline $1976-1980$ & 53 & 52 & $9(25 \%)$ \\
\hline $1980-1983$ & 38 & 38 & $32(54 \%)$ \\
\hline $1983-1987$ & 61 & 59 & $15(32 \%)$ \\
\hline $1987-1990$ & 51 & 47 & $27(28 \%)$ \\
\hline $1990-1994$ & 108 & 96 & $37(25 \%)$ \\
\hline $1994-1998$ & 147 & 144 & $12(18 \%)$ \\
\hline $1998-2001$ & 71 & 68 & $15 \%$ \\
\hline
\end{tabular}

Bronnen: Handbuch des Bundesrates für das Geschafsjahr 1999/2000, Baden-Baden 2000; http://www.bundesrat.de/PDund F/index.html. 21 november 2001

•Het aantal voorstellen in kolom 3 ligt lager dan in kolom 2 omdat tegen het einde van vrijwel iedere kabinetsperiode onder tijdsdruk prioriteiten gesteld moeten worden door de wetgever. Daardoor blijkt dan de afhandeling van met name de wetgevingsinitiatieven uit de parlementskamers nogal eens in de knel te kumnen komen.

De drijfveer voor hantering van het recht van initiatief door de Bundesrat is sinds 1949 in grote lijnen tweeèrlei geweest. Enerzijds uiteraard behartiging van specifieke belangen van de Länder op Bondsniveau. Beslist dient in dit kader namelijk niet vergeten te worden dat ten gevolge van de beschreven exodus aan zelfstandige wetgevende competentie voor de Länder (op vrijwel alle denkbare beleidsterreinen heeft de Bond op basis van de artt. 74 en 74a GG immers de legislatieve bevoegdheden resoluut richting Berlijn gesluisd) nog slechts het initiatiefrecht van de Bundesrat rest om specifieke Länderbelangen op Bondsniveau in regelgeving omgezet te kunnen krijgen. Gedeeltelijk kan de gestage toename van het aantal wetgevingsinitiatieven vanuit de Bundesrat tussen 1949 en 1998 dan ook op basis van voornoemde ontwikkeling verklaard worden. ${ }^{143}$

Voor het overige echter lijkt het toegenomen aantal wetgevingsinitiatieven vanuit de Bundesrat mede verklaard te worden vanuit partijpolitieke motieven. In bovenstaande tabel is goed zichtbaar dat het aantal wetgevingsinitiatieven dat door leden van de Bundesrat gelanceerd werd, een significante toename vertoonde vanaf het moment dat de partijpolitieke meerderheid in de Bundestag waarop de Bondsregering steunde, moest gaan samenwerken met oppositionele meerderheden in de Bundesrat. Zowel in de periode 1969-1982 als de 
periode 1991-1998 deed deze situatie zich voor. In versterkte mate werd de Bundesrat tijdens voornoemde perioden door de partijen die in de Bundestag oppositie voerden beschouwd als 'bundespolitische Bühne'. ${ }^{144}$ De kwantitatieve gegevens wijzen ontegenzeggelijk in die richting. Immers, terwijl het aantal wetgevingsinitiatieven tijdens perioden van divergerende partijpolitieke meerderheden in Bundestag en Bundesrat een behoorlijke toename vertoonde, bleek de uiteindelijke succesquote voor die 'schaduwkabinetachtige' initiatieven steken onder de $30 \%$. Afgezet tegen de ruim $50 \%$ tijdens perioden van partijpolitieke détente tussen de beide Bondsduitse parlementskamers is dat opvallend laag. Anderzijds, geheel onbetekenend wordt het recht van initiatief in handen van de Duitse senaatskamer blijkbaar nooit. ${ }^{145}$

Tenslotte dient hier nog opgemerkt te worden, dat Bundesratmeerderheden zich de laatste jaren ook voor het lanceren van wetgevingsinitiatieven regelmatig regionaal plegen te groeperen. De regeringen van de Länder uit vroegere oostduitse gebiedsdelen blijken elkaar goed te kunnen vinden als 'oostduitse' belangen in het geding zijn. ${ }^{146}$

\subsection{Bestuurscontrole}

De door de grondwetgever van 1949 grondig doordachte organisatiestructuur voor de Duitse Bundesrat leent zich niet bijzonder voor het stelselmatig uitoefenen van bestuurscontrolerende taken. Het beperkte aantal plenaire sessies, de 'Einheitliche Stimmabgabe', de wisselende vertegenwoordiging per beleidsonderwerp per Land. Allemaal factoren die zinvolle controle van het bestuurlijk handelen op Bondsniveau niet tot cen cenvoudige opgave maken.

Het zal in dat licht gezien dan ook nauwelijks verwondering wekken dat een instrumentarium dat de Bundesrat ten dienste kan staan ter controle van de Bondsregering, afgezien van de reeds besproken middelen die aangewend kunnen worden in het kader van het legislatieve proces op Bondsniveau, vrijwel afwezig is.

De grondwetgever van 1949 heeft gemeend dat in de relatie Bundesrat-Bondsregering op geen enkele wijze geopteerd zou moeten worden voor een sanctioneerbare vertrouwensrelatie. Binnen de geldende Bondsduitse verhoudingen is dan ook slechts de Bundestag staatsrechtelijk gelegitimeerd tot het aannemen van een zgn. constructieve motie van wantrouwen. ${ }^{147}$ Slechts de Bundestag kan de Bondskanselier bij meerderheid van stemmen tot aftreden dwingen, maar alleen indien tegelijkertijd een nieuwe Kanselier gekozen wordt. Op de samenstelling van de Bondsregering kan de Bundesrat evenmin invloed uitoefenen. Wat wel bestaat in het Duitse staatsrecht is zoiets als een niet-sanctioneerbare verantwoordingsrelatie van de Bondsregering richting Bundesrat. Deze specifieke grondwettelijk

146. G. Ziller und G-B. Oschatz, a.w., p. 27.

147. Art. $67 \mathrm{GG}$ 
verankerde verantwoordingsrelatie beperkt zich echter tot het terrein van de financiële huishouding van de Bond. ${ }^{148}$

Maar er is meer: 'die Mitglieder der Bundesregierung haben das Recht und auf Verlangen die Pflicht an den Verhandlungen des Bundesrates und seiner Ausschūsse teilzunehmen. Sie müssen jederzeit gehört werden. Der Bundesrat ist von der Bundesregierung über die Führung der Geschăfte auf dem laufenden zu halten'. ${ }^{49}$ Met name de laatste volzin van voornoemd grondwetsartikel is bijzonder interessant te noemen. 'Auf dem Laufenden zu halten' impliceert immers voortdurende informatieplicht vanuit de Bondsregering richting Bundesrat. Ook over zaken waar de Bundesrat nog helemaal geen weet van heeft. Politiek allerminst oninteressant derhalve. In de Duitse staatsrechtelijke literatuur wordt deze plicht dan ook omschreven als 'Kardinalnorm des parlementarischen Kontaktes zwischen dem zentralen Bundesexekutivorgan und dem foderativen Organ'. 150

De informatieplicht ex art. 53 GG is op geen enkele wijze aan beperkingen onderhevig, zodat de Bundesrat in principe van alle regeringsaangelegenheden permanent op de hoogte gebracht zou moeten worden. Omdat het hier natuurlijk veelvuldig tevens vertrouwelijke, zoniet geheime informatie kan betreffen, is voortdurende informatievoorziening van de Bondsregering richting Bundesratplenum weinig zinvol gebleken. In de praktijk is men dan ook al snel andere wegen gaan bewandelen. Informatic-uitwisseling tussen Bondsregering en Bundesrat blijkt sinds jaar en dag vooral te verlopen via de vaste commissies van de Bundesrat. Deze gremia lenen zich daarvoor dankzij de doelmatige Bondsduitse organisatiestructuur ook uitstekend. In de commissies hebben immers naast ambtenaren vaak tevens vooraanstaande leden van de regeringen (regeringsleiders en ministers) der respectievelijke Länder zitting, waardoor de lijnen niet langer hoeven te worden dan strikt noodzakelijk wordt geacht. Dit geldt zeker voor de politiek zwaardere commissies. Zo is er bijvoorbeeld een vruchtbare traditie van systematische informatie-uitwisseling ontstaan in de commissies 'Auswărtige Angelegenheiten' en 'Verteidigung'. De verantwoordelijke Bondsministers plegen in die commissies tijdens de reguliere zittingen op semi-structurele basis ten overstaan van de collega's uit de Länder kond te doen van de relevante ontwikkelingen. ${ }^{151}$ Daarnaast pleegt voor informatieverstrekking aan de Bundesrat door leden van de Bondsregering in de praktijk ook frequent gebruik gemaakt te worden van de Ständige Beirat. Deze institutie belegt iedere week direct na afloop van de reguliere vergadering van de Bondsregering een bijeenkomst. Het is gebruikelijk dat de gevolmachtigden uit de zestien Länder die in dit gremium zitting hebben tijdens die wekelijkse sessies door de 'Chef des Bundeskanzleramtes' bijgepraat worden over de besluiten die door de Bondsregering genomen zijn. ${ }^{152}$

Als juridisch sluitstuk voor de informatieplicht ex art. 53 Satz 3 GG kan Satz I van datzelfde artikel beschouwd worden. Leden van de Bondsregering kunnen door de Bundesrat (dwingend) opgeroepen worden om voor de Bundesrat of een uit de Bundesrat voort-

148. Art. 114 Abs, $1 \mathrm{GG}$.

149. Art. $53 \mathrm{GG}$.

150. K. Reuter. Praxishandbuch Bundesrat, a.w., p. 300.

151. G. Ziller und G-B. Oschatz, a.w., p. 99.

152. G. Ziller und G-B. Oschatz, a.W., p. 68 
komende commissie te verschijnen. Op deze wijze zal, indien de noodzaak daartoe aanwezig mocht zijn, tekst en uitleg gegeven kunnen worden over specifieke c.q. onduidelijke aspecten van regeringsbeleid. Dit 'Zitierrecht' kan, in potentie ten tijde van divergerende partijpolitieke meerderheden in Bundestag en Bundesrat, natuurlijk al snel een stevige politieke lading krijgen. ${ }^{153}$ De parlementaire praktijk heeft echter uitgewezen dat formele dwang op basis van art. 53 Satz 1 GG nooit nodig is. Een verzoek vanuit de Bundesrat gericht aan een bewindsman uit Berlijn om de Bundesrat op de hoogte te brengen over de 'Bundesgeschăfte' blijkt als regel gewoon gehonoreerd te worden. 154

Desondanks moet de totale reikwijdte van de informatieplicht die de Bondsregering ex art. 53 GG heeft ten opzichte van de Bundesrat toch niet al te nuim worden ingeschat. In de praktijk blijkt de Duitse tweede parlementskamer echt niet 'unaufgefordert, umfassend, rechtzeitig und regelmăssig' geìnformeerd te worden, een situatie die de Bundesrat ook gewoon blijkt te accepteren. ${ }^{153}$ De informatie die wél doorkomt via met name de 'politischen Ausschüssen', de Ständige Beirat' en de ministerięle overlegrondes wordt als regel blijkbaar als voldoende ervaren.

Samenvattend zou, strikt formeel, gesteld kunnen worden dat de Bondsregering grondwettelijk verplicht wordt tot voortdurende informatieverschaffing aan de Bundesrat, terwijl tegelijkertijd van een politiek-staatsrechtelijk afdwingbare vertrouwensrelatie geen sprake is.

Lezer dezes heeft inmiddels echter kunnen constateren dat de Bondsregering en de Bundesrat rondom het politiek zwaarwichtige wetgevingsproces in hoge mate van elkaar afhankelijk plegen te zijn. Het medebeslissingsrecht door de Bundesrat betreffende zo'n $60 \%$ van de wetsvoorstellen, de regels op basis van wetgevingsdelegatie én de beleidsregels vanuit Berlijn hebben als welhaast vanzelfsprekende consequentie een vrij grote mate van vervlechting en politieke afhankelijkheid bewerkstelligd tussen de regering en de (uit leden van de Länderregeringen samengestelde) Duitse 'Zweite Kammer'. Dientengevolge blijkt de plicht tot informatieverschaffing c.q het recht op informatieverkrijging over het algemeen zakelijk en weinig gepolariseerd vorm te krijgen.

\subsubsection{Vragenrecht}

Uit art. 53 GG kan ook de Bondsduitse variant van een vragenrecht voor de tweede parlementskamer worden afgeleid. 'Auf dem laufenden halten' impliceent immers ook verzoeken om additionele informatie. Het vragenrecht voor de leden van de Bundesrat is in 1966 nader uitgewerkt in de Geschäfsordnung. ${ }^{136}$ Tot die tijd was het voor individuele leden niet mogelijk vragen tot de Bondsregering te richten. ${ }^{157}$ Momenteel voorziet lid 1 van $\S 19$ van de Geschäfsordnung des Bundesrates (GOBR) in de formele mogelijkheid voor

153. K. Reuter, Praxishandbuch Bundesrat, a.w., p. 302.

154. K. Reuter, Praxishandbuch Bundesrat, a.w., p. 298.

155. K. Reuter, Praxishandbuch Bundesrat, a.w. p. 309.

156. $\$ 19$ Geschaftsordnung des Bundesrates.

157. G. Ziller und G-B. Oschatz, a.w., p. 101. 
ieder individucel lid van de Bundesrat vragen te stellen aan (leden van) de Bondsregering over zaken die niet vreemd zijn aan de orde van de dag.

Daarnaast heeft ieder der 16 Länder de mogelijkheid vragen te stellen aan de regering die wél vreemd zijn aan de orde van de dag. ${ }^{158}$ Van dit sinds 1966 in het Duitse staatsrecht verankerde zogenaamde 'selbständigen Fragenrecht' blijkt in de parlementaire praktijk nauwelijks gebruik gemaakt te worden. Gemiddeld minder dan één vraag per drie jaar. ${ }^{\text {is }}$ De vragen werden merendeels gesteld namens individuele Länder. Hoewel de Bondsregering meende niet rechtens verplicht te zijn tot het beantwoorden van vragen ex $\S 19$ Abs. 2 GOBR, in geval deze niet door de Bundesrat als geheel werden overgenomen, is toch in alle gevallen 'aus Courtoisie' besloten de vragensteller zo optimaal mogelijk te bedienen. 180

In de praktijk wordt zoals gezegd door de leden van de Bundesrat slechts zeer sporadisch gebruik gemaakt van het hun toekomende vragenrecht. In de meeste gevallen hebben de gestelde vragen betrekking op wetsvoorstellen die in behandeling zijn. Vragenuurtjes naar Brits voorbeeld over actuele thema's of regionale problemen komen vrijwel niet voor tijdens zittingen van de Bundesrat. Het politieke debat dat rondom 'Grosse Anfragen, Kleine Anfragen, Aktuelle Stunden en Fragenstunden' duidelijk een prominente plaats inneemt tijdens de zittingen van de Bundestag, heeft zich in de andersoortige politieke cultuur die het Bundesratgebeuren kenmerkt nooit écht kunnen manifesteren.

Onderzoek in de vorm van parlementaire enquête's, in welke variant dan ook uit te voeren door of namens de Duitse Bundesrat, heeft geen plaats gekregen in het naoorlogse Bondsduitse staatsrecht.

\subsection{Balans}

De keuze die de Duitse grondwetgever in 1949 bij de besluitvorming aangaande de instelling van een senaatskamer op Bondsniveau gemaakt heeft ten faveure van een Bundesratsvariant, blijkt verregaande implicaties te hebben voor de wijze waarop deze 'zweite Kammer' functioneert. Zowel federale, parlementaire als politieke krachten bepaalden en bepalen in voortdurende interactie met elkaar de handelswijze van de Bundesrat. Daarenboven heeft ook de hechte personele band tussen de Bundesrat en de regeringen der Länder inclusief het daaronder ressorterend ambtelijk apparaat grote gevolgen voor de wijze waarop de Bondsduitse senaatskamer zich manifesteert.

Centraal element waar het functioneren van de Duitse Bundesrat in het geding is, vormt zonder enige twijfel de grondwettelijk voorgeprogrammeerde dwang tot het bereiken van compromissen bij de legislatieve arbeid.

'Mitwirken' bij de totstandkoming van regelgeving ten behoeve van de Bondsrepubliek als geheel, een wettelijke vereiste dat de Bundesrat door de grondwetgever via art. $50 \mathrm{GG}$ werd opgelegd, blijkt inderdaad letterlijk genomen te kunnen worden. Voor het merendeel

160. K. Reuter, Praxishandbuch Bundesrat, a.w., p. 415; ook: G. Ziller und G-B.Oschatz, a.w., p. 101. 
van de voorstellen tot wet in formele zin, alsmede alle regelgeving die gebaseerd is op delegatie, is tegenwoordig officiele toestemming van de Bundesrat vereist. Ook op het steeds verder uitdijende terrein van de EU-regelgeving loopt iedere overdracht van soevereiniteitrechten sinds het in werking treden van het nieuwe art. 23 GG, via de weg van voorafgaande toestemming door de Bundesrat.

De Bundesrat heeft de invloedrijke positie in het wetgevingsproces op Bondsduits niveau weten te bemachtigen als onderdeel van een voortdurend uitruilproces tussen Bond en Länder. Ter compensatie van verlies aan zeggenschap voor de Länder betreffende (voorheen) eigen aangelegenheden, kregen de regeringen van de 'zelfstandige' onderdelen der Duitse federatie via de Bundesrat de mogelijkheid bij voortduring substantiele invloed uit te gaan oefenen op de totstandkoming van nieuwe wetgeving op Bondsniveau: 'Die Mitwirkung der Lănder an der Willensbildung des Bundes ermöglicht somit eine fóderal erträgliche Zentralisierung in Form der Unitarisierung.' ${ }^{161}$

'Mitwirken' wordt echter ook sterk gestimuleerd door de wijze waarop de wetgevingsprocedures in de naoorlogse Bondsrepubliek vorm hebben gekregen. Wetgevingsvoorstellen lopen via de Bondsregering (initiatief), De Bundesrat (erste Durchgang), de Bundestag (amendering en voorlopige aanname), wederom de Bundesrat (Zustimmung of Einspruch) en vervolgens al naar gelang de politieke uitkomst van werkzaamheden tot dan toe, nog de Vermittlungsausschuss en wederom Bundestag en Bundesrat. Dit alles in de wetenschap dat de meeste wetsvoorstellen met enig politiek gewicht niet tot stand kúnnen komen, zonder de medewerking van zowel Bondsregering als Bundestag en Bundesrat. Hierdoor is vanzelfsprekend een permanent spel van geven en nemen gaan ontstaan. Voor de Bundesrat betekent dit vooral, dat tijdens de 'erste Durchgang' reeds aangegeven kan worden, waar wijzigingen van het wetsvoorstel zinvol, zo niet noodzakelijk geacht worden, mede met het oog op uiteindelijke 'Zustimmung'. Ook in de 'Vermittlungsausschuss' kan 'amendering' van onderdelen van voorliggende wetsvoorstellen door Bundesratafgevaardigden als een alleszins reële en derhalve frequent benutte optic beschouwd worden. Daarmee ben ik bij een derde factor gekomen die het 'Mitwirken' ex art. 50 GG ontegenzeggelijk structureel blijkt te stimuleren c. q. te conditioneren: de Bundesratsleden moeten afkomstig zijn uit de gelederen der Landsregeringen. Het feitelijke juridisch-inhoudelijke wetgevingswerk wordt grotendeels voor hen gedaan door het ambtelijk apparaat van de Länder. Dit betekent dat er al vanaf het moment van de 'erste Durchgang' sprake zal zijn van duidelijk zichtbare lijnen tussen de 'Ministerialbürokratie' van de Bondsregering en de Lănder. Deze directe verbindingslijnen tussen de executieve van Bond en Länder plegen in de regel de nodige 'politische entschärfung' tot gevolg te hebben.

Resteert de vraag op welke wijze het 'Mitwirken' door de Bundesrat ex art. 50 GG gestuurd wordt door de partijpolitiek. Hoewel binnen de Bondsrepubliek in zowel politicke als staatsrechtelijke kringen momenteel veel gepraat en geschreven wordt over een te invloedrijke Bundesrat, waar het legislatieve proces in het geding is, blijkt in de praktijk slechts een zeer beperkt aantal wetsvoorstellen de eindstreep uiteindelijk niet te halen. Anders gezegd, de Bundesrat benut zijn politieke macht ook in geval van divergerende 
partijpolitieke meerderheden in de Bondsduitse parlementskamers niet ter destructie, niet ter obstructie, doch ter verfijning van de constructie. Dit kan zo functioneren omdat de Bondsregering en de Bundestag(smeerderheid) niet om de Bundesrat heen kunnen, terwijl de 'zweite Kammer' zijnerzijds minstens zo afhankelijk is van de beide andere wetgevingsorganen. Natuurlijk wordt het politieke spel rondom wetgevingsvoorstellen gecompliceerder en minder transparant indien de Bundestagsoppositie over een meerderheid beschikt in de Bundesrat, maar behoort dat nu juist niet tot de essenties van een parlementair stelsel waarin bicameralisme ten stelligste grondwettelijk verankerd is?

Enige korte opmerkingen over de bestuurscontrolerende taak van de Bundesrat ter afsluiting. De Bundesrat blijkt alle aandacht te concentreren op de legislatieve arbeid. Controle van het Bondsbestuur blijft beperkt tot algemene informatie-uitwisseling en een sporadische kamervraag. Een recht van enquête ontbreekt, terwijl ook anderszins geen zelfstandig beleidscontrolerend onderzoek door de Bundesrat wordt verricht. De mogelijkheid tot het uitspreken van een formeel vertrouwensvotum door de Bundesrat heeft in het naoorlogse Duitse staatsrecht geen plaats gekregen.

Dat de controlerende taak in de Bondsrepubliek, althans buiten het wetgevingsproces, vrijwel volledig weg valt voor de 'zweite Kammer', hangt natuurlijk samen met het gegeven dat de Bundesrat niet bestaat uit semi-permanent zetelende volksvertegenwoordigers, doch uit (wisselende) afgevaardigden vanuit de executieve der 16 Länder. In het rechtsvergelijkende hoofdstuk dat nu volgt zal ik hierop nog terugkomen. 


\section{Hoofdstuk 8}

\section{Vergelijkende beschouwingen}

\subsection{Kies- en benoemingsstelsels}

\subsubsection{Inleiding}

In het derde hoofdstuk van dit boek hebben wij gezien dat de wijze waarop de senaatskamer in de vier onderzoekslanden gekozen dan wel benoemd pleegt te worden enorme onderlinge verschillen vertoont. De meeste Britse Lords worden voor het leven benoemd. Slechts de 26 in het Britse Hogerhuis benoemde bisschoppen vormen op deze regel een uitzondering. Zij treden terug als zij zeventig jaar geworden zijn. De leden van de Duitse Bundesrat worden benoemd vanuit de regering der deelstaten, hetgeen uiteraard vanzelf impliceert dat die benoeming slechts tijdelijk kan zijn. De senatoren uit Nederland en Frankrijk hebben hun zetels in de tweede nationale parlementskamer bemachtigd via reguliere verkiezingsrondes, die recht geven op een zittingstermijn van vier respectievelijk negen jaar in de nationale senaatskamer. Als direct gevolg van de verschillende benoemings/verkiezingssystemen, zo hebben wij kunnen constateren, vertoont de mate van democratische legitimatie tussen de vier senaatskamers enorme verschillen. Relatief groot is deze legitimatie, zeker sinds de grondwetsherziening van 1983, in Nederland nu daar vierjaarlijks de gehele Eerste Kamer als uitvloeisel van Provinciale Statenverkiezingen ververst pleegt te worden. Nagenoeg afwezig is de democratische legitimatie voor het Hogerhuiswerk nog steeds in Groot-Brittanniè. Zeker de indirect gekozen leden van de Franse Sénat, maar ook de benoemde leden van de Duitse Bundesrat weten zich via de regio's in redelijke mate democratisch gelegitimeerd, zo hebben wij kunnen constateren. Van substantičle disproportionaliteit tussen de partijpolitieke samenstelling van de senaatkamer en de nationale demografie is (ten gevolge van het gehanteerde kiesstelsel) tegenwoordig nog slechts sprake in Frankrijk. Sinds de verplichte exodus van het gros der Heriditary Peers uit het House of Lords ten gevolge van de inwerkingtreding van de House of Lords Bill 1999 en de daarmee gepaard gaande benoemingen van een groot aantal Labourgezinde hogerhuisleden ('Tony-Cronies') sporen de partijpolitieke verhoudingen in het House of Lords immers ook redelijk met de nationale verhoudingen dienaangaande. In ieder geval zijn automatische absolute meerderheden voor één der dominerende politieke stromingen (naar Frans model) in het Hogerhuis van Groot-Brittannië anno 2001 geschiedenis. Zeker indien de voorstellen van de 'Wakeham Commission', in november 2001 door de regering Blair nader vorm gegeven in een White Paper ( benoeming van $80 \%$ der senatoren naar rato vanuit de zittende politieke stromingen via een onafhankelijke benoemingscommissie, gecombineerd met gefaseerde verkiezing van de overige $20 \%$ ) gerealiseerd zullen worden.

De keuze voor een rechtsvergelijkend onderzoek dat het functioneren van de senaatskamers van Frankrijk, Groot-Brittannië, Duitsland en Nederland tot onderwerp heeft, blijkt, gezien de diversiteit aan gehanteerde stelsels, met name met het oog op de vertegenwoordigingsgedachte bepaald geen ongelukkige te zijn geweest. Laat ik op dit punt de derde onderzocksvraag, zoals geformuleerd in hoofdstuk 1 nogmaals in herinnering brengen: 
'Kunnen deugdelijk democratisch gelegitimeerde senaatskamers hun medewetgevende en bestuurscontrolerende taken effectiever uitoefenen, dan senaatskamers die niet of slechts indirect democratisch gelegitimeerd zijn?'

Voor het onderzoek betekent dat concreet, dat in de nu volgende paragrafen vergeleken dient te worden op welke manier en in welke mate van de wijze van verkiezing c.q. benoeming der senatoren in de vier onderzoekslanden invloed uitgaat op de wijze waarop de 'vertegenwoordigende' senaatskamers van diezelfde landen uitvoering geven aan hun medewetgevende en bestuurscontrolerende taakstelling. Welke invloed gaat van de keuze voor een benoemings/ verkiezingssysteem uit op de partijpolitieke verhoudingen, zowel binnen de senaatskamer als ten opzichte van de volkskamer?

Enige normatieve elementen zullen in de slotconclusie uiteindelijk tevens onderdeel uitmaken van dit hoofdstuk: kan cen senaatskamer, de medewetgevende 'tweede' parlementskamer om goed te kunnen functioneren beter het volk als geheel vertegenwoordigen (Nederland), of is het wellicht te verkiezen dat er een duidelijke legitimerende verbinding tussen senaat en regio bestaat (Frankrijk, Duitsland)? Moet de senaat om als parlementskamer te kunnen functioneren wel (voldoende) democratisch gelegitimeerd zijn, of kan vertegenwoordiging van kennis, ervaring en expertise bij afwezigheid van enige vorm van democratische legitimatie (GrootBrittannie) eveneens volstaan?

\subsubsection{Kiezen}

In Nederland en Frankrijk is de samenstelling van de senaat zoals wij gezien hebben een uitvloeisel van algemene verkiezingen. In Nederland zijn deze verkiezingen in hun uitwerking echter hooguit met de grootst mogelijke terughoudendheid te beschouwen als indirecte verkiezingen. Weliswaar zijn het de Provinciale Staten die de senatoren kiezen, doch in wezen zijn de Statenleden, waar de verkiezing voor de Eerste Kamer in het geding is, nauwelijks méér dan pro forma kiesmannen die de wensen van het electoraat in het ene kiesdistrict Nederland concretiseren. Zeker nu sinds 1983 ook nog eens de gehele Eerste Kamer vierjaarlijks in zijn totaliteit ververst pleegt te worden na Provinciale Statenverkiezingen op basis van evenredige vertegenwoordiging blijkt de term 'indirect', hoewel formeel correct, in feite niet langer erg gelukkig gekozen te zijn. De verkiezingen voor de Franse Sénat daarentegen zijn zeer zeker te classificeren als indirect. Ieder departement is immers een kiesdistrict en per departement worden (afhankelijk van onder meer het inwonersaantal) een variërend aantal senatoren gekozen door een kiescollege afkomstig uit meerdere regionale overheidsorganen, waaronder de gemeenteraden. Daar komt bij dat per driejaarlijkse verkiezingsronde slechts $1 / 3 \mathrm{e}$ deel der senaatszetels vacant is, met alle logische gevolgen van dien voor de continuiteit van de werkzaamheden van de Franse 'Chambre de Réflexion', Indien bijvoorbeeld senatoren met een bepaald relevant specialisme gekozen worden, betekent dit, dat de Sénat als geheel (herverkiezing daargelaten) daar negen jaar lang profijt van kan hebben.

Ook in partijpolitieke zin is sprake van een opmerkelijk verschil tussen de kiesstelsels van Frankrijk en Nederland. In Frankrijk kunnen als direct gevolg van het complexe (zie par. 3.4.1) verkiezingssysteem voor senatoren (door de socialist Jospin gekaraktariseerd als 'anomalie') slechts marginale wijzigingen optreden in de geldende partijpolitieke verhou- 
dingen. Ruraal centrumrechts zal onder het huidige kiesregime altijd de grootste en derhalve toonaangevende politieke groepering in het Palais de Luxembourg blijven. In Nederland daarentegen worden veranderingen in de kiezersvoorkeuren ( via provinciale staten) direct en volledig verwerkt in de nieuwe zetelverdeling voor de Eerste Kamer. De partijpolitieke verhoudingen in de Nederlandse senaatskamer verschillen derhalve niet wezenlijk van de verhoudingen dienaangaande in de Tweede Kamer. Wel zal een nieuw aantredende ploeg Nederlandse senatoren in partijpolitieke zin tijdelijk kunnen bogen op een recenter kiezersmandaat, hetgeen de politieke assertiviteit van de Eerste Kamer in ieder geval niet nadelig zal beinvloeden.

\subsubsection{Benoemen}

De senaatskamers van de Bondsrepubliek Duitsland en Groot-Brittanniě worden zoals wij gezien hebben niet samengesteld via verkiezingen doch door middel van een benoemingssysteem (zie met name hoofdstuk 3). In Groot-Brittannie is die benoeming (Lords Spiritual uitgezonderd) vooralsnog nog steeds 'for Life', In Duitsland daarentegen is deze tijdelijk en zeer onbepaald, variërend van eenmalig op afroep tot decennia lang (bijvoorbeeld een lang zittende regeringsleider van een der Duitse deelstaten). De Duitse senatoren kunnen als leden van de Länderregeringen in tegenstelling tot hun Britse collega's in ieder geval bogen op een indirecte vorm van democratische legitimatie. De Britse Lords moeten iedere reelle vorm van democratische legitimering voorshands nog altijd volledig ontberen.

Partijpolitiek blijkt het Britse systeem stabiliserend uit te werken. Onlangs zijn de (tot dan toe altijd al stabiele) partijpolitieke verhoudingen in het Hogerhuis ten gevolge van de 'House of Lords Bill 1999' sterk gewijzigd. Dat neemt, zoals reeds zijdelings opgemerkt in de inleiding. echter niet weg dat nu de meeste Hereditary Peers van het parlementaire toneel verdwenen zijn onder gelijktijdige benoeming van een grote groep Life Peers (van voornamelijk Labourhuize), wederom met de nodige nauwkeurigheid vastgesteld kan worden hoe de partijpolitieke verhoudingen liggen. En aangezien de samenstelling van het House of Lords voor het eerst in de Britse parlementaire geschiedenis in partijpolitieke zin als redelijk uitgebalanceerd gekwalificeerd mág worden, zijn de belangrijkste politieke groeperingen tevreden en lijkt een nieuwe Brits parlementaire conventie alleszins te kunnen gaan ontstaan. Ook de jongste regeringsvoorstellen wijzen in die richting: 'Its political membership should be broadly representative of the main parties relative voting strengths'.

De partijpolitieke verhoudingen in de Bondsrepubliek zijn minder stabiel van aard, ondanks het gegeven dat ook de Bundesrat niet via (in)directe algemene verkiezingen, doch via benoeming wordt samengesteld. Iedere verkiezingsronde voor een nieuw parlement van een Duits Land kan, in ieder geval in theorie, namelijk een verschuiving van de (meestal op coalitie-afspraken berustende) partijpolitieke verhoudingen in de Lander en daarmee in de Bundesrat tot gevolg hebben. Het overall-beeld dienaangaande is in de Bondsrepubliek vrij complex. Medio 1999 bijvoorbeeld was de Bondsregering samengesteld uit een coalitie tussen SPD en Grünen. De regeringen in de 16 Duitse Lănder (en uit dier voege dus ook de Bundesrat-afvaardigingen) waren op dat moment gebaseerd op een waar scala aan coalitieverhoudingen: 
Hoofdstuk 8

Tabel 8.1

\begin{tabular}{|l|c|l|}
\hline Land & $\begin{array}{l}\text { Stemmen in de } \\
\text { Bundesrat }\end{array}$ & Regeringspartijen \\
\hline Baden-Würtenberg & 6 & CDU/FDP \\
\hline Bayern & 6 & CSU \\
\hline Berlin & 4 & CDU/SPD \\
\hline Brandenburg & 4 & SPD/CDU \\
\hline Bremen & 3 & SPD/CDU \\
\hline Hamburg & 3 & SPD/GAL \\
\hline Hessen & 5 & CDU/FDP \\
\hline Mecklenburg-Vorpommern & 3 & SPD/PDS \\
\hline Niedersachsen & 6 & SPD \\
\hline Nordrhein-Westfalen & 6 & SPD/B 90/Grüne \\
\hline Rheinland-Pfalz & 4 & SPD/FDP \\
\hline Saarland & 3 & CDU \\
\hline Sachsen & 4 & CDU \\
\hline Sachsen-Anhalt & 4 & SPD \\
\hline Schleswig-Holtein & 4 & SPD/B 90/Grüne \\
\hline Thisingew & 4 & CDU \\
\hline
\end{tabular}

Bron: http:/www,bundesrat.de/aktuellStimmen.html, 27 maart 2001

\subsubsection{Partijpolitieke stabiliteit}

Indien de stabiliteit c.q. volatiliteit van de partijpoliticke verhoudingen in de senaatskamers van de vier onderzoekslanden onderling vergeleken wordt, kan geconstateerd worden dat het benoemingssysteem voor het House of Lords in potentie de hoogste mate van stabiliteit én continulteit blijkt te kunnen garanderen. $\mathrm{Na}$ de aanpassingen ten gevolge van de House of Lords Bill 1999 én de benoeming (voor het leven) van een kleine tweehonderd nieuwe Hogerhuisleden door Tony Blair is de partijpolitieke balans in het Britse Hogerhuis, zoals wij gezien hebben, in evenwicht. Zowel Labour als de Conservatieven lijken zich inmiddels verenigd te hebben achter het idee dat de krachtverhouding tussen beiden in het Hogerhuis structureel in balans moet zijn en blijven. De stabiliserende en 'oliënde' functie van een getalsmatig niet onaanzienlijke groep politiek onafhankelijke Cross-Benchers moet daarbij evenmin onderschat worden. De politiek-staatsrechtelijke discussies rondom de hervorming van het House of Lords sinds 1999 in ogenschouw nemend, lijkt het allerminst onaannemelijk, dat de huidige situatie rondom benoeming/verkiezing van Britse Hogerhuisleden dan ook niet fundamenteel zal wijzigen. ${ }^{3}$ Een door de grootste politieke partijen (al dan niet via de Prime Minister) gedomineerd benoemingsbeleid, eventueel aangevuld met gefaseerde verkiezing van een beperkt aantal Britse senatoren zal, naar het zich laat aanzien, ook in de toekomst garant staan voor de gewenste stabiliteit.

Goede tweede op de fictieve lijn stabiel-volatiel is de Sénat Français. Een plotselinge en forse omslag in de kiezersvoorkeuren (een fenomeen dat in het hedendaagse Frankrijk opvallend

3. D. Shell and P. Giddings, The Future of Parliament, Reform of the Second Chamber. The Hansard Society for Parliamentary Govemment, London 1999. 
regelmatig opgeld doet: 1981, 1985, 1987, 1991, 1997) kan ten gevolge van het geldende verkiezingsregime voor de Franse senaatskamer (zie hoofdstuk 3) immers hooguit marginale veranderingen voor de zetelverdeling in het Palais de Luxembourg tot gevolg hebben.

Ook in personele zin doet de stabiliteit in de Sénat nauwelijks onder voor het House of Lords. Franse senatoren worden voor negen jaar gekozen en plegen dankzij de sterke banden met het departement (cumul des mandats) frequent voor herverkiezing in aanmerking te komen. Senatoren die 18 of 27 jaar een zetel bezet houden in het Palais de Luxembourg zijn geen uitzondering. Ook voor Frankrijk geldt derhalve: stabiliteit én continuiteit.

Vervolgens Nederland. Sinds de grondwetswijziging van 1983 zal iedere omslag in de kiezersvoorkeuren ten tijde van Provinciale Statenverkiezingen vrijwel direct én volledig vertaald worden in de partijpolitieke samenstelling van de Eerste Kamer. Een maal per vier jaar behoort een complete 'swing' in theorie derhalve tot de mogelijkheden. De hoge mate aan potentiele volatiliteit in de partijpolitieke verhoudingen die het gevolg van het gehanteerde kiesstelsel is, blijkt door de Nederlandse regering in toenemende mate als hinderlijk te worden ervaren. ${ }^{4}$ Sinds ten gevolge van de grondwetswijziging van 1983 het systeem van driejaarlijkse verkiezing van slechts de helft der zittende senatoren vaarwel werd gezegd, is iedere structurele relatie tussen kiesstelsel en continuiteit verdwenen. Tot nu toe is het echter nog nooit zo ver gekomen, dat de Nederlandse senaatskamer getalsmatig werd gedomineerd door de politicke partijen die tezelfdertijd oppositie voerden in de Tweede Kamer, zij het dat marges bijzonder krap geworden zijn. Zeker voor het doorvoeren van een eventuele grondwetswijziging ( tweederde meerderheid in beide parlementskamers) zal een kabinet in de Eerste Kamer tegenwoordig sneller aangewezen kunnen raken op ondersteuning vanuit oppositionele kringen. ${ }^{5}$

Vierde in de rij is de Duitse Bundesrat. Omdat in de regel maar in één of twee Länder tegelijkertijd parlementsverkiezingen plaatsvinden, zal de partijpolitieke samenstelling van de Bundesrat weliswaar slechts geleidelijk kunnen wijzigen, doch binnen een periode van vier jaar moeten in alle zestien Lånder minstens één maal Landtagsverkiezingen hebben plaatsgevonden, zodat de politieke machtsverhoudingen binnen de Bundesrat wel voortdurend kúnnen wijzigen. En die partijpolitieke verhoudingen in de Bundesrat, zo blijkt al sinds 1972, ontwikkelen zich graag 'oppositioneel' ten opzichte van de coalitieverhoudingen in de Bundestag. Een regel die zowel op blijkt te gaan voor centrum-rechtse (CDU/FDP onder Kohl) als centrum-linkse (SPD/FDP onder Helmut Schmitt en SPD-Grünen onder Schröder) regeringscoalities. $^{6}$

\subsubsection{Partijpolitieke stabiliteit in relatie tot de eerste parlementskamer}

Nu de mate van partijpolitieke stabiliteit als direct gevolg van de gehanteerde benoemings/ verkiezingswijze voor senatoren in kaart is gebracht, moet natuurlijk bekeken worden wat dit alles voor gevolgen heeft voor de werkrelatie met de andere nationale parlementskamer.

Deze vraag blijkt, zoals wij in de hoofdstukken $3 \mathrm{t} / \mathrm{m} 6$ hebben kunnen constateren, in politiek-staatsrechtelijke kringen van drie van de vier onderzoekslanden de nodige actualiteitswaarde te bezitten. Zowel in Frankrijk als in Groot-Brittanniē en Nederland wordt de

Tweede Kamer 1999-2000, 26976, nr. 2.

Vanaf medio 1999 bijvoorbeeld is dit voor het kabinet Kok Il ook het geval.

6. W. Patzelt, The Very Federal House: The German Bundesrat, in: Senates, Bicameralism in the Contemporary World, Ohio State University Press 1999, p. 84-87. 
laatste jaren regelmatig fundamentele discussie gevoerd over dit thema. Heeft eventuele vergroting van de democratische legitimatie niet tot gevolg dat de senaatskamer zich zelfbewuster en meer rivaliserend op gaat stellen bij de uitoefening van de medewetgevende en controlerende taken (Groot-Brittanniě en Nederland)? Mag een kiesstelsel bepaalde politieke groeperingen in de senaatskamer bij voortduring sterk bevoordelen met alle gevolgen van dien voor de mogelijkheden tot samenwerking met de andere parlementskamer (Frankrijk)? Voor de partijpolitick meest stabiele senaatskamer van de vier, het House of Lords, geldt dat de stabiliteit ook duidelijk uitstraalt naar de legislatieve werkrelatie met het House of Commons. De partijpolitieke krachtsverhoudingen zijn volkomen helder. Er kan daarenboven sinds medio 1999 structureel geen sprake meer zijn van partijpolitieke onbalans.

In hoofdstuk 4 werd aangetoond dat de loyaliteit ten opzichte van het officiele regeringsstandpunt betreffende wetgevingsvraagstukken van zowel Peers van Labourhuize als de Peers die lid zijn van de Conservatieve Partij hooguit in uitzonderlijke situaties (bijvoorbeeld ten tijde van de behandeling van het Poll Tax-wetsvoorstel) ernstig op de proef gesteld zal worden. Ook van het House of Lords als geheel (inclusief Cross Bench en onafhankelijken derhalve) kan daarenboven gesteld worden dat ten opzichte van het House of Commons sprake is van redelijk stabiele op duidelijke ondergeschiktheid gebaseerde semi-onafhankelijke bicamerale werkverhoudingen. Mede als gevolg van het permanente democratisch deficit wordt, zoals wij gezien hebben, nu immers al ruim een halve eeuw lang de Salisbury Doctrine gehanteerd om de relatie met het House of Commons op het legislatieve terrein af te bakenen. Een doctrine die inhoudt dat bij regeringsvoorstellen tot wet die een uitwerking blijken te zijn van voornemens uit het laatste verkiezingsmanifest (in de regel de politiek zwaarwichtiger onderwerpen) het Hogerhuis per definitie niet zal volharden, indien de meningen tussen beide parlementskamers uiteen blijken te lopen.

Dat desondanks in Groot-Brittannié met name eind twintigste eeuw een diepgaande discussie gevoerd werd over het doorvoeren van flinke aanpassingen in het tot dan toe geldende benoemingsregime voor leden van het Hogerhuis (par. 3.2.2 en 3.2.3), hangt uiteraard in hoofdzaak samen met het democratisch deficit dat inherent is aan een systeem van benoemingen, zoals dat nog steeds gehanteerd wordt in Groot-Brittanniè. Ik werk deze problematiek zo dadelijk (par. 8.1.6) verder uit.

Het is zonder meer markant én tekenend te noemen dat de Royal Commission die advies uit moest brengen over de wenselijke vorm van een nieuw (en beter legitimerend) benoemings' verkiezingssysteem ten behoeve van het Britse Hogerhuis niet verder wenste te gaan dan verkiezing van slechts $35 \%$ van het aantal Hogerhuisleden naast benoeming van de overige $65 \%$. zij het dat ook de zittingstermijn van de benoemde leden gelimiteerd zou moeten worden tot 15 jaar. Zeg maar, gegarandeerd behoud van de bestaande, op onderschikking ten opzichte van regering en House of Commons gebaseerde verhoudingen, gedrapeerd met een toefje contemporaine democratische legitimatie. Continuiteit en stabiliteit in de bicamerale legislatieve werkverhouding kunnen, zo meent de Royal Commission, beter gegarandeerd worden indien zowel staatsrechtelijk als politiek sprake is en blijft van een structureel ondergeschikte relatie ten opzichte van het House of Commons: 'The House of Commons should continue to be the pre-eminent chamber of Parliament and should remain the principal forum for the

7. A House for the future, Report of the Royal Commission on the Reform of the House of Lords, January 2000, p. 180 e,v. 
resolution of political differences. Nothing should be construed as seeking to undermine the House of Commons as the final political authority under our constitution' 8 . Een opvatting dic de huidige regering Blair blijkt te delen met de commissie: 'The House of Lords should remain subject to the pre-eminence of the House of Commons in discharging its functions:?

In de Franse Sénat, de senaatskamer die, zoals gezegd ná het House of Lords kan bogen op de meest stabiele partijpolitieke verhoudingen, is de situatie volledig tegengesteld. Stabiele partijpolitieke verhoudingen in het Palais de Luxembourg, zo blijkt sinds 1958 bij voortduring uit de medewetgevende gedragslijn van de Franse Sénat, dragen geen enkele garantie in zich voor het bewerkstelligen van semi-constante uitgebalanceerde werkverhoudingen met de Assemblée Nationale, naar Brits model. ${ }^{10}$ Sleutelbegrip ter verklaring van dit verschil is, zoals reeds eerder betoogd werd, de sterkere (nurale) democratische legitimatie voor de Sénat. Zeker in de Franse politieke cultuur, waarin al sinds 1795 keer op keer onder vele regimes gekokketteerd pleegt te worden met een streven naar het 'parlementarisme parfait', kan het belang van de vertegenwoordigingsgedachte niet eenvoudig overgewaardeerd worden. Daar komt bij. dat ten gevolge van het gehanteerde kiesstelsel sprake is van sterke formele én informele banden tussen de senatoren en het departement dat zij vertegenwoordigen in de Sénat. Gevolg: zelfbewuste politici van (in hoofdzaak) centrumrechtse conservatief-rurale huize die actief en constructief kunnen en zullen meewerken aan de totstandkoming van nieuwe wetgeving in formele zin indien de regering is samengesteld uit politieke geestverwanten (zoals bijvoorbeeld ten tijde van Giscard d'Estaing). Daarentegen zijn zij even zo goed in staat zijn tot regelmatige tegenwerking van de regering in het legislatieve proces (bijvoorbeeld tussen 1983 en 1985, maar ook weer vanaf 1997) indien deze steunt op een meerderheid in de Assemblée nationale bestaande uit partijpolitieke opponenten.

In 1999 is door de socialistische regering Jospin een poging ondernomen om het kiesregime aangepast te krijgen in dier voege dat het ongelijke stemgewicht ten faveure van het platteland zou verminderen. Deze poging is door ingrijpen van de Conseil Constitutionnel slechts zeer ten dele gelukt." Ten gevolge van de aanname van de 'Loi relative à I' élections des Sénateurs' kunnen sinds 2000 in iets meer departementen dan voorheen senatoren gekozen worden op basis van een systeem van evenredige vertegenwoordiging. De centrumrechtse dominantie in de Franse senaatskamer blijft vooralsnog echter ongebroken: 'Le Sénat restera le miroir de la France nurale', 12

Vervolgens Nederland. Achttien jaar na de laatste substantiële grondwetsherziening begrijpen eigenlijk nog slechts weinigen in politiek en staatsrechtelijk Nederland waarom in 1983 besloten werd om af te stappen van indirecte verkiezing der senaatsleden in twee driejaarlijkse tranches ten faveure van vierjaarlijkse indirecte verkiezing der gehele populatie ineens. 'Uitvoeringstechnische bezwaren' samenhangend met de indeling in provincies blijken de belangrijkste reden te hebben gevormd. ${ }^{13}$ De mogelijke politiek-strategische gevolgen van de grondwetswijziging zijn na 1983 al snel zichtbaar geworden. De kans op divergerende meer-

LCD White Paper, The House of Lords, Completing the Reform, 7-11-2001, nr. II

10. J. Mastias, The French Sénat, in: Senates, Bicameralism in the contemporary World, Ohio State University 1999, p. 182-187.

11. Décision $2000-432$ DC, 6 Juni 2000 .

12. Le Monde, 8-7-2000, p. 9.

13. Kamerstukken II 1976-1977, 14223 , nr. 3, p. 5-7 
derheden in de beide Nederlandse parlementskamers is, zo meent de regering, aanmerkelijk toegenomen ${ }^{14}$ en daarmee de 'angst' dat de Eerste Kamer zich, regelmatig steunend op een recenter kiezersmandaat, assertiever zou kunnen gaan opstellen in haar relatie tot de Tweede Kamer en de regering. Vooralsnog blijkt de soep echter bij lange na niet zo heet geconsumeerd te worden. De bicamerale politieke verhoudingen worden in Nederland immers al num honderdvijftig jaar lang sterk bepaald door terughoudendheid van de zijde van de Eerste Kamer. Een attitude die gegroeid is vanuit een nog steeds onveranderde bicamerale staatsrechtelijke organisatie in Nederland; een organisatie die in rechtsvergelijkende zin ontegenzeggelijk als markant te kwalificeren is. Met de toename van de politieke assertiviteit van de Eerste Kamer als gevolg van de inwerkingtreding van een nieuw kiesregime valt het in ieder geval wel mee. Het afgelopen decennium werd, éen enkel voorval (de Nacht van Wiegel) daargelaten, ontegenzeggelijk niet gekarakteriseerd door extra assertiviteit van de Nederlandse senaatskamer. Vanzelfsprekend zal ik deze problematiek in het kader van de rechtsvergelijkende bespreking der medewetgevende taken (par. 8.2.5.3) verder uitwerken.

De Bundesrat (als laatste senaatskamer op de partijpolitieke lijn stabiel-volatiel) is, waar de consequenties van het benoemingssysteem voor de legislatieve werkrelatie met de andere parlementskamer in rechtsvergelijkende zin in het geding zijn, als direct uitvloeisel van de federatieve staatsvorm die de Bondsrepubliek kenmerkt, tot op zekere hoogte een ietwat vreemde eend in de bijt. Het benoemingssysteem voorziet immers in afvaardiging vanuit de Länderregeringen. Anders gezegd: de tweede Bondsduitse parlementskamer is exclusief samengesteld uit vertegenwoordigers afkomstig uit de uitvoerende macht der Länder. Zoals reeds werd beschreven in par. 7.3.2.2, heeft dit onder meer tot consequentie dat naast partijpoliticke Bondsbelangen en regionale banden ook regionale dwarsverbanden ('A-Länder' versus 'B-Länder' en de Oost-West tegenstelling) sneller van invloed zullen zijn op de politieke werkrelatie met de Bundestag. Ländergrens overschrijdende partijpolitiek is ondanks voornoemde invloeden echter ook in de werkrelatie tussen Bundestag en Bundesrat toch altijd de dominerende factor gebleken. ${ }^{15}$ Dusdanig dominant zelfs, dat de Bondsduitse 'zweite Kammer' in de Duitse politicologische literatuur ook wel als 'zweite Regienung' betiteld wordt. $^{16}$

Wat zijn wij tot nu toe in vergelijkende zin te weten gekomen over de relatie tussen de mate van partijpoliticke stabiliteit in de senaatskamer in de vier landen als gevolg van het gehanteerde benoemings/verkiezingssysteem en de wijze waarop de samenwerking met de andere wetgevende parlementskamer in die landen pleegt te verlopen? Dat partijpolitieke stabiliteit en continuteit als gevolg van het benoemings/verkiezingssysteem stabiliserend uit kán (Groot-Brittanniě) maar niet hoeft (Frankrijk) te werken op de werkrelatie met de andere parlementskamer. Daarenboven blijkt in Nederland in de werkrelatie tussen Tweede en Eerste Kamer duidelijk sprake te zijn van een hoge mate aan zowel stabiliteit als continuiteit, terwijl het kiesstelsel juist instabiliteit bevorderend zou moeten uitwerken. Blijkbaar is partijpolitieke stabiliteit voor de wijze waarop de senaatskamer samenwerkt met de volkskamer geen gegeven dat geisoleerd bekeken kan worden.

14. Sinds 1999 steunt de regering Kok II in de Eerste Kamer nog siechts op een meerderheid van én enkele zetel. Een tot dan toe ongekend smalle marge waar de partijpoliticke verhoudingen in de Nederlandse senaatskamer in het geding zijn.

15. W. Patzelt, a.w, p. 60 e.v,

16. Idem, p. 84. 
Wél kan geconstateerd worden dat nationale partijpolitieke verhoudingen zoals die gelden ten gevolge van het gehanteerde kies/benoemingssysteem voor het medewetgevende functioneren van de senaatskamer in zowel London, Parijs, Berlijn als Den Haag, zij het op een verre van uniforme wijze, een significante rol in de werkrelatie met de andere parlementskamer plegen te vervullen. Vooral voor Frankrijk (structurele centrumrechtse meerderheden) en de Bondsrepubliek (een scala aan wisselende, meest 'oppositionele' coalitieverbanden) is die conclusic, mede ten gevolge van de sterke formele banden met de regio, onomkoombaar.

Alvorens de relatic tussen het kies/benoemingsstelsel en de wijze waarop senaatskamers 'vertegenwoordigend' kunnen functioneren verder rechtsvergelijkend uit te gaan werken, moet op deze plaats eerst echter nog een essentièle zijstap gemaakt worden. De keuze voor een bepaald kies/benoemingssysteem draagt namelijk hoe dan ook tevens serieuze implicaties in zich voor de wijze waarop de senaatskamer in de vier onderzoekslanden in sociaal-demografische zin samengesteld kan worden. Anders gezegd, een senaatskamer met een structureel sterke vertegenwoordiging uit bijvoorbeeld vakbondskringen zal een andersoortige werkrelatie onderhouden met de regering dan een tweede parlementskamer die (daartoe gelegitimeerd via het gehanteerde benoemings/verkiezingssysteem) een zeer gemêleerde samenstelling vertoont.

\subsubsection{Samenstelling}

De meest verregaande mogelijkheden tot differentiatie bij de sociaal-demografische samenstelling van de senaatskamer liggen verankerd in het Britse benoemingssysteem. De PrimeMinister is aan geen enkele rechtsregel onderworpen, waar de keuze voor senatoren uit bepaalde beroepsgroepen in het geding is. Life Peers kunnen afkomstig zijn uit alle geledingen van de Britse samenleving. In de praktijk blijken bij de benoeming slechts een beperkt aantal conventies in acht genomen te worden. De belangrijkste betreft de regelmatig terugkerende benoeming van een behoorlijk aantal voormalige Lagerhuisleden tot Life Peer. Dit gebeurt uiteraard omdat zowel de regering(spartij) als de oppositie te allen tijde behoefte heeft aan een aantal politiek inhoudsdeskundige 'waakhonden' in de andere wetgevingskamer. Verder wordt er sinds de inwerkingtreding van de House of Lords Bill 1999 voor gewaakt dat de partijpolitieke verhouding tussen met name Labour, Conservatives en Cross Bench in evenwicht blijft. Los van voornoemde conventies is de Prime Minister echter vrij in het benocmingsbeleid. Gevolg: het House of Lords laat zich qua samenstelling kenmerken door een waaier aan specifieke expertise. De (voor het leven benoemde) Lords zijn afkomstig uit alle mogelijke beroepsgroepen en maatschappelijke groeperingen. Naast de groep voormalige MP's zijn dat o.a mensen afkomstig uit de zakenwereld, financiën, de vakbond, het onderwijs, allerhande academici, kunstenaars, medici, politie, lokale overheden enz. enz. ${ }^{17}$ De gemiddelde leeftijd komt voor de leden van de Britse senaatskamer vanzelfsprekend relatief hoog te liggen, aangezien zij voor het leven benoemd worden. De hoge gemiddelde leeftijd voor de groep 'working Peers' hangt echter ook samen met het gegeven dat zij grotendeels geselecteerd plegen te worden uit diegenen die inmiddels in de nadagen van hun maatschappelijke carrière zijn aanbeland (en dus tijd hebben voor het semi-vrijwillige Hogerhuis werk).

Volledig tegengesteld is het beeld in dat andere land waar de senatoren benoemd worden, de Bondsrepubliek. De Bundesrat is immers exclusief samengesteld uit (wisselende) leden van 
de 'Länderregieringen', beroepspolitici die als onderdeel van de uitvoerende macht in de bloei van hun (sterk partijpolitiek gestuurde) carrière zijn. Het leidt geen twijfel dat ten gevolge van dit gegeven zowel de beroepsmatige samenstelling van de Bundesrat als geheel, als de werkattitude van de individuele leden der Duitse 'tweede kamer', sterk afwijkt van hetgeen gebruikelijk is te Westminster.

De grotere waaier aan langdurige expertise die inherent is gebleken aan de Britse benoemingsmethode kan natuurlijk evenmin zonder gevolgen blijven voor de wijze waarop de medewetgevende taken verricht plegen te worden. In ieder geval is de kans dat de medewetgevende taakstelling van de Britse senaatskamer zich sneller zal beperken tot 'herbeoordeling in de luwte' alleen al als een direct uitvloeisel van de wijze van samenstelling beduidend hoger in te schatten dan voor de Bundesrat.

De Franse constitutic van 1958 voorziet voor de Sénat, zoals wij gezien hebben, eerst en vooral in een vertegenwoordigende taakstelling ten behoeve van 'collectivités territoriales'. 18 Voor het te hanteren kiesstelsel heeft dit tot gevolg dat deze Franse regio's daarin het centrale element dienden te vormen. De consequenties voor de samenstelling van de Sénat van die keuze van de grondwetgever zijn aanzienlijk gebleken. Veel landbouwers, artsen, juristen en leraren die als partijpolitiek loyale burgemeester van kleinere Franse gemeenten tevens gekozen worden in het Franse Hogerhuis. Deze senatoren zijn dus vaak tegelijkertijd lid van de tweede Franse parlementskamer, burgemeester van een kleinere Franse gemeente én parttime notaris of deeltijd schoolhoofd. Dat deze Franse duizendpoot uit bijvoorbeeld Charix le Haut of Larnagol sur Lot aan zijn functie van parlementariër/medewetgever een aanzienlijk andere invulling geeft, dan zijn semi-gepensioneerde Britse collega die zijn/haar expertise als voormalig jurist/econoom/vakbondsman/grootgrondbezitter/politicus ten volle ten behoeve van het parlementaire revisiewerk in kan zetten, ligt voor de hand.

Een vergelijking van het type senator dat het Franse kiesstelsel voortbrengt met het soort afgevaardigde dat ten gevolge van het in de Bondsrepubliek gehanteerde benoemingssysteem functioneert in de Bundesrat, blijkt ook allerminst oninteressant te zijn. Beide danken hun benoeming aan een sterke formele band met de regio, in de Britse staatsrechtelijke literatuur ook wel omschreven als 'Constitutional glue'. "Iedere verdere vergelijking loopt echter mank. De Duitse senator is bovenal prominent lid van de uitvoerende macht van eeri der 16 Länder, qua inwonertal variërend van 1 tot 18 miljoen inwoners. De Franse senator is bovenal tandarts, ondernemer, advocaat of boer én burgemeester van een kleine tot middelgrote Franse gemeente.

Tenslotte de Nederlandse senator. Deze is voor verkiezing sterk afhankelijk van kandidaatstelling via de politieke partijen. Deze partijen schuiven een scala aan types naar voren: oud, maar zeker tegenwoordig ook jong, mensen uit het onderwijs, het bedrijfsleven, de semioverheid, zelfstandigen, voormalig Tweede Kamerleden en bewindslieden en zelfs tijdelijk te 'parkeren' aspirant-leden voor toekomstige regeringscoalities. Het gros der Nederlandse senatoren blijkt evenals de Duitse en Franse collega's nog in de bloei van de maatschappelijke carrière te zitten. Een maatschappelijke carrière die voor de meeste leden van de Eerste Kamer in tegenstelling tot de collega's van Bundesrat en Sénat echter als regel weinig rakvlakken in zich pleegt te dragen met het werk in de politieke arena. Voeg daarbij dat de

18. Art. 24 Constitution 1958

19. M. Docherty, and N. Ryder, Constitutional Law, What should we do with the second chamber?, in: The Law Teacher 2000, p. 358 e.v. 
Nederlandse senator slechts 35 tot 40 dinsdagen per jaar beschikbaar hoeft te hebben ten behoeve van diens parlementaire taken en het moge duidelijk zijn dat de uitgangspositie in deze voor de werkrelatie met de eerste parlementskamer in Nederland als redelijk unick te kwalificeren is.

Ook de leden van de Bundesrat hoeven weliswaar slechts acte de présence te geven tijdens commissievergaderingen en een beperkt aantal plenaire zittingen, doch zij kunnen ter voorbereiding en ondersteuning voortdurend gebruikmaken van cen goed gekwalificeerd ambtelijk apparaat. Indien de leden van de Bundesrat zuivere volksvertegenwoordigers en geen leden van de regionale uitvoerende macht zouden zijn geweest, hadden zij evenals de collegasenatoren te Parijs, Londen en Den Haag niet de beschikking kunnen hebben over een dergelijk groot en goed gekwalificeerd ambtelijk apparat. Dat dit gegeven een serieuze impact heeft op de grondigheid waarmee de veelal complexe medewetgevende taakstelling door de senaatskamer ter hand kan worden genomen is evident. Omdat ten gevolge van het gehanteerde benoemingssysteem inhoudsdeskundige ambtenaren namens de Bundesrat structureel in de gelegenheid gesteld worden om belangrijke (juridische) know how toe te voegen aan de op stapel staande wetgevingsproducten, heeft dit vanzelfsprekend tevens grote gevolgen voor de werkrelatie met de Bundestag. Ter vergelijking: de Nederlandse senatoren kunnen ten opzichte van de Tweede Kamer slechts hun eigen expertise in de strijd gooien ter vervolmaking c.q. revisie van het legislatieve product.

Voor de leden van het Franse maar vooral het Britse Hogerhuis geldt dat het parlementaire werk in principe nagenoeg als een voltijdse bezigheid beschouwd dient te worden. De Britse Prime Minister laat in zijn/haar benoemingsbeleid tegenwoordig zeker ook meewegen in hoeverre de nieuwe Life Peer in staat blijkt om tijd vrij te maken voor de werkzaamheden in het Britse Hogerhuis. In de praktijk blijkt de dagelijkse opkomst voor het Hogerhuiswerk in Westminster sinds de inwerkingtreding van de House of Lords Bill 1999 rondom de $50 \%$ te circuleren. ${ }^{20} \mathrm{De}$ Franse senator haalt die aanwezigheidsquote niet, ten gevolge van de "cumul des mandats'-problematiek. ${ }^{21}$ Je kunt tenslotte maar op een plaats tegelijk zijn (zie par. 3.4.3).

\subsubsection{Verkiezing/benoeming en vertegenwoordiging}

En dan nu terug naar de vertegenwoordigingsgedachte als basis voor parlementair bicameralisme. De mate waarin sprake blijkt te zijn van 'democratische gefundeerde vertegenwoordiging' ten gevolge van de keuze voor benoeming dan wel (in)directe verkiezing der senatoren speelt bij dit alles natuurlijk ook een rol. Bicameralisme impliceent verhoudingen tussen de beide parlementskamers variërend van ideaaltypische 'rivaliteit' tot ideaaltypische 'assistentie'. ${ }^{22}$ 'Rivaliteit' doelt hier op de (on)mogelijkheid tot het geheel of gedeeltelijk kunnen afdwingen van eigen politiek-beleidsmatige accenten door de senaatskamer. 'Assistentie' impliceert in de parlementaire wetgevingspraktijk eerst en vooral rechtmatigheidscorrectie. Daarbij wordt met name gedoeld op juridisch-dogmatische en juridisch-technische verbeteringen van het wetgevingsproduct in wording. Daarnaast vallen ook 'verrijkende' sug-

20. http:/www, parliament the-stationery-office,co.uk/pa/ld199900/ldbrief/10402.htm, 9-4-2001

21. F. Chevalier, Le Senateur Français 1875-1995. Essai sur le recrutement at la représentativité des membres de la seconde chambre, Paris 1996, p. 295 e.v

22. M. Docherty and N. Ryder, a.w. p. 368-370. 


\section{Hoofdstuk 8}

gesties tot verbetering van de kwaliteit der wetteksten van doelmatige, maatschappelijk wenselijke politick-bicameraal non controversięle aard onder het kopje 'assistentie'.

Tot het takenpakket dat tegenwoordig in theorie toegeschreven pleegt te worden aan de senaatskamer behoren zoals wij gezien hebben de bestrijding van te sterk monistische tendensen in de verhouding regering-volkskamer, alsmede in algemenere zin het verzorgen van een gedegen 'check' op het regeringsbeleid. Beide taken vallen uiteraard onder het kopje 'rivaliteit'. Daarnaast wordt van de tweede wetgevingskamer echter ook verwacht, dat het wetgevingsproduct politiek en/of juridisch heroverwogen, verbeterd, aangepast wordt; 'rivaliteit' en/of 'assistentie' derhalve.

Naar mate de vertegenwoordiging door de senaatskamer ten gevolge van het gehanteerde benoemings/verkiezingssysteem berust op een minder deugdelijk democratisch fundament, zo heet het, zou ook minder nuimte geclaimd kunnen worden voor de ten uitvoerlegging door de 'tweede' parlementskamer van rivaliteitstaken: 'Während Erste Kammern gleichsam natürlich demokratisch legitimiert sind, uber 'one man, one vote' den Souverăn, das Volk, repräsentieren, ist die legitimatorische und repräsentatorische Ausgangslage Zweite Kammern differenzierter und diffiziler. Hieraus ergeben sich: erstens ein hăufig prekăre Existenz, zweitens Konsequenzen für ihre Funktionszuweisung und drittens ein Anhaltspunkt, wanum Zweite Kammern sowohl in Debatten um die politisch-institutionelle Anpassung an gesellschaftliche Modernisienungsprozesse häufig nicht einmal am Rande bericksichtigt werden, als aucb is Konfliktsituationen kaum je von der Öffentlichkeit als kompetenter Ansprechpartner gesehen werden. ${ }^{23}$

Vooral Groot-Brittannie blijkt uitstekend in dit kader te passen. Afwezigheid van deugdelijke vertegenwoordigende (democratische) legitimatie wordt in het Verenigd Koninkrijk door het House of Lords weliswaar gecompenseerd met een hoge mate van 'assistentie' bij de (legislatieve) arbeid die door het House of Commons verricht moet worden, maar daar ligt dan ook direct de grens.

Pogingen tot verfijning en aanpassing van het vigerende benoemingssysteem hebben, zoals wij meermaals hebben mogen optekenen, echter wel de nodige actualiteitswaarde. Of dit essentiele veranderingen op zal leveren valt vooralsnog te betwijfelen. Blijkens de staatsrechtdoctrine lijkt men in Groot-Brittanniè impliciet tot de conclusie gekomen te zijn, dat de taken van de tweede Britse parlementskamer slechts 'assisterend' van aard dienen te blijven, ten opzichte van regering en House of Commons. ${ }^{24}$ Daarvan uitgaande lijkt een toekomstige Britse senaatskamer die grotendeels benoemd en voor ongeveer $1 / 3 \mathrm{e}$ tot $1 / 5 \mathrm{e}$ deel gekozen wordt, de meeste kans te maken. ${ }^{25}$ Het opmerkelijke van de Britse aanpak zit zonder enige twijfel in de vanzelfsprekende 'onderschikking', Krachtige democratische legitimatie voor de senaatskamer, gebaseerd op uitsluitend de uitslag van reguliere algemene verkiezingsrondes, wordt afgewezen omdat dit rivaliserende nevenschikking tussen Commons en Lords tot gevolg zou kunnen hebben: 'We envisage a helpful rather low grade role for the second chamber, which

23. S. Schüttemeyer, und R. Sturm, Zweite Kammern in westlichen Demokratien, Zeitschrift fur Parlamentsfragen 1992, p. 518

24. Zie 0.a.:M. Russell, Reforming the House of Lords, Oxford 2000, p. 260-294; D. Shell. The Future of the Second Chamber. The Political Quarterly 1999, p. 390-397.

25. Ook in het door de regering Blair in november 2001 uitgebracht White Paper 'Completing the Reform' wordt in die richting gedacht. 
would operate so as to assist the Commons and the Government'. ${ }^{26}$ En ook: 'Whatever method is used to compose the chamber, it should be one that adds value to the representativeness of Parliament without displacing the primacy of the Commons as the chamber through which governments are made and unmade'. 27

De uitwerking van de Franse bicamerale verhoudingen, zoals die ten gevolge van het gehanteerde verkiezingsstelsel voor de Sénat gelden, blijkt in beduidend mindere mate ideaaltypisch verklaarbaar te zijn. Hoewel in principe sprake is van een degelijke (en expliciet constitutioneel vereiste) vorm van democratische legitimatie, is de Sénat juist ten gevolge van de wijze waarop rondom dat kiesstelsel een partijpolitieke organisatie functioneert, zoals wij gezien hebben, slechts met de nodige reserve te beschouwen als een het gehéle Franse volk vertegenwoordigend parlementair orgaan. Daarvoor is de bevoordeling van centrumrechts als direct gevolg van het gehanteerde kiesstelsel eenvoudig te ver doorgeschoten. Van zuivere vertegenwoordiging van de 'collectivités territoriales' is echter evenmin sprake. Vooral de 'collectivités nurale' blijken immers via de partijpolitiek deugdelijk én permanent vertegenwoordigd te worden in de tweede Franse parlementskamer. Dientengevolge blijkt de werkrelatie tussen Assemblée Nationale, regering en Sénat afhankelijk van de politieke kleur der regering sterker 'assisterend' dan wel 'rivaliserend' van aard te zijn. De krachtige Franse traditie van 'parlementarisme' en de daarmee samenhangende cultuur van voortdurende politieke strijd tussen regering en parlement speelt bij dit alles eveneens onmiskenbaar een rol van betekenis.

In de Bondsrepubliek vertegenwoordigen de leden van de Bundesrat de Bondsbelangen namens de onderdelen van de federatie, de Länder. De grondwetgever van 1949 gaf, door te opteren voor het Bundesratsmodel in plaats van voor het Senaatsmodel, te kennen dat de tweede Bondsduitse parlementskamer vooral 'assisterend' actief zou moeten worden. ${ }^{28}$ De praktijk is, zoals wij in het vorige hoofdstuk gezien hebben, echter al snel een andere geworden. Vanaf het moment dat SPD/FDP-coalities regeringsverantwoordelijkheid op Bondsniveau gingen dragen, politiseerden de verhoudingen tussen Bundestag en Bundesrat in snel tempo. Het benoemingssysteem vanuit de uitvoerende macht der Länder liet daarvoor ook voldoende nuimte en mogelijkheden, zodat de Duitse 'zweite Kammer' nu toch al weer drie decennia lang niet slechts blijkt te assisteren bij de vervolmaking van het nationale legislatieve product, doch daarenboven ook voortdurend sterke beleidsinhoudelijke activiteiten ontplooit, waar de wetgeving op Bondsniveau in het geding is. Ondanks de slechts indirecte democratische legitimatie lijkt de Bundesrat binnen de Bondsduitse politiek/staatsrechtelijke constellatie goed in staat om te fungeren als 'kompetenter Ansprechpartner'.

De meest opmerkelijke positie wordt echter ingenomen door de Nederlandse Eerste Kamer. Welhaast perfect democratisch gelegitimeerd, het Nederlandse volk in zijn geheel vertegenwoordigend via de gehanteerde verkiezingsmethode en tevens gekenmerkt door cen degelijke partijpolitieke organisatie, zou verwacht mogen worden dat de Nederlandse senaatskamer bij voortduring substantiêle bicamerale activiteiten van zowel rivaliserende als assisterende aard weet te ontplooien. Het tegendeel lijkt, althans in vergelijking tot betgeen zich in Londen, Parijs en Berlijn dienaangaande afspeelt, echter het geval te zijn.

26. M. Docherty, and N. Ryder, aw, p. 381.

27. D. Shell, and P. Giddings, The future of Parliament, Reform of the Second Chamber. The Hansard Society, London 1999, p. 20.

28. Zie daartoe par. 2.5.6. 
Een dergelijke uitspraak schreeuwt natuurlijk om nadere onderbouwing en verklaring. Daartoe zal in de nu volgende paragrafen in rechtsvergelijkende zin dan wel eerst een brug geslagen moeten worden naar de twee centrale terreinen waarop de 'Chambres de réflexion' hun centrale parlementaire activiteiten plegen te ontplooien: de medewetgeving en de bestuurscontrole.

\subsection{Wetgeving}

\subsubsection{Inleiding}

Het op enigerlei wijze behulpzaam zijn bij de totstandkoming van nieuwe nationale regelgevingvoorstellen is voor de senaatskamer van ieder der vier onderzoekslanden ontegenzeggelijk te beschouwen als de hoofdtaak bij uitstek. ${ }^{29}$ Het kan dan ook nauwelijks verwondering wekken dat de meeste beschikbare tijd besteed pleegt te worden aan activiteiten samenhangend met de vervolmaking van het legislatieve product. Concreet betekent dit aan de ene kant dat de Britse Lords en de Franse senatoren anno 2000 gemiddeld ruim $60 \%$ van hun 'Hogerhuistijd' spenderen aan direct wetgevingsgelieerde activiteiten, terwijl aan de andere kant de Bundesrat maar vooral de Eerste Kamer zelfs praktisch álle beschikbare tijd aan wetgevingswerkzaamheden besteden. Voor de Bundesrat hoeft deze laatste constatering uiteraard nauwelijks verwondering te wekken, aangezien dit de Länder vertegenwoordigende medewetgevende orgaan op het terrein van de bestuurscontrole behalve de informatieplicht (voor de Bondsregering) ex art. 53 GG, in feite geen bevoegdheden van betekenis bezit. De Nederlandse Eerste Kamer daarentegen bezit wel degelijk een aantal formele, goed met andere senaatskamers vergelijkbare bevoegdheden die controle van het regeringshandelen handen en voeten behoren te geven.

De mate waarin de senaatskamer actief dient te participeren in het totstandkomingproces van nieuwe regelgevingvoorstellen blijkt per land enorme verschillen te vertonen. In de Bondsrepubliek wordt de Bundesrat als regel al tijdens het voorbereidende stadium van een wetsvoorstel (op ambtelijk niveau) actief betrokken. Tijdens de allereerste officiële fase van de parlementaire behandeling is, zoals wij gezien hebben, betrokkenheid van de Bundesrat bij het wetgevingsproces via de 'erste Durchgang' zelfs constitutioneel verankerd. De Bondsduitse senatoren krijgen dan drie tot negen weken de tijd om (met behulp van het ambtelijk apparaat der Länder) een standpunt te bepalen betreffende alle wetsvoorstellen in formele zin. Voorstellen die in dat prille stadium in de Bundestag nog in het geheel niet op de agenda hebben gestaan. In Frankrijk en Groot-Brittanniê kán actieve inbreng vanuit de senaatskamer bij de parlementaire wetgevingsprocedure uitgesteld worden tot het moment dat de Assemblée nationale respectievelijk het House of Commons hun werkzaamheden rondom een wetsvoorstel (in cerste lijn) afgerond hebben; noodzakelijk is dit echter allerminst. De Nederlandse Eerste Kamer mag hoe dan ook pas in actie komen nadat een voorstel tot wet volledig is afgerond door de Tweede Kamer.

29. Blijkens een weinig objectief doch alleszins onderhoudend artikel in bet NRC-maandblad van juni 2001 wordt in dit kader door de Nederlandse Eerste Kamer namelijk gesproken over 'core business': G. van Westerloo, Het fluisteren der senatoren, in: M, maandblad van NRC Handelsblad, juni 2001, p. 6-20. 
Hoewel alle vier de senaatskamers (mede)wetgeving als hoofddoelstelling mogen beschouwen, blijkt de wijze waarop deze constitutionele taakstelling per staat uitgewerkt wordt op het eerste gezicht al enorme verschillen te vertonen. In deze paragraaf worden die verschillen verder uitgewerkt en geanalyseerd. Eerst wordt aandacht besteed aan het belang van het beheer van de wetgevingsagenda. Vervolgens wordt de gebruikmaking van het recht van initiatief door de respectievelijke senaatskamers vergeleken. Vanzelfsprekend zal in rechtsvergelijkende zin tevens aandacht besteed worden aan de commissiefase. Tenslotte zal in dit gedeelte uitgebreid stil gestaan worden bij de werking van het juridische beinvloedingsinstrumentarium dat de vier senaatskamers (al dan niet) ter beschikking hebben gekregen ter vervulling van de medewetgevende taakstelling.

\subsubsection{De wetgevingsagenda}

Allereerst is daar het beheer van de wetgevingsagenda en de daarmee samenhangende mogelijkheden tot uitoefening van het recht van initiatief. Welke staatsorganen kunnen invloed doen gelden op de volgorde én het tempo waarmee wetgevingsvoorstellen in de senaatskamer behandeld zullen worden? Het politiek-strategisch belang dat beheer van de wetgevingsagenda met zich mee pleegt te brengen is nauwelijks te overschatten. Dit blijkt met name in staatsinstellingen waar het beheer van de wetgevingsagenda volledig in handen van de regering is. Frankrijk levert daarvan het bijzonder zichtbare bewijs. De Franse regering heeft immers, zoals wij hebben gezien, het exclusieve recht om bij voorrang te bepalen welke wetsvoorstellen in welke volgorde behandeld worden in de Franse senaatskamer. Dit exclusieve recht beperkt zich niet slechts tot regeringsvoorstellen, doch omvat tevens initiatiefvoorstellen uit de parlementskamers, inclusief amendementen en sous-amendementen. ${ }^{30}$ Verdisconteren wij bij dit alles ook nog eens dat de Franse regering tevens een zeer indrukwekkende juridische 'trukendoos' ter nadere sturing van het wetgevingsproces (dernier mot, vote bloqué, exception d'irrecevabilité enz.) ter beschikking heeft, en het moge duidelijk zijn waar de regic van het wetgevingsproces in formele zin in Frankrijk geconcentreerd is. De Sénat rest, voor zover beïnvloeding van de wetgevingsagenda het thema is, in feite slechts de mogelijkheid tot het ontwikkelen van enige tijdrekkende activiteiten via onder meer de uitoefening van het recht van amendement. ${ }^{31}$

Ook in Groot-Brittannię, de Bondsrepubliek en Nederland heeft de nationale regering anno 2000 natuurlijk een meer of minder dikke vinger in de pap, waar het beheer van de wetgevingsagenda in het geding is. Strikte scheiding van wetgeving en uitvoering tussen parlement en regering naar VS-voorbeeld komt in onze onderzoekslanden in het geheel nict voor. De Nederlandse regering blijkt in haar wetgevingsrelatie tot de Eerste Kamer een overheersende invloed op de inhoud wetgevingsagenda uit te oefenen. Zelfs de Franse verhoudingen dienaangaande staan daarbij in de schaduw. De oorzaak is echter een geheel andere, veel minder complexe, vrijwel zuiver formeelrechtelijke: De Nederlandse senaatskamer is de enige van de vier die pas in actie mag komen indien het wetgevingsproces in materiele zin al zo goed als volledig afgerond is. ${ }^{32}$ Omdat de Eerste Kamer daarenboven ook nog eens de rechten van

30. Art. 29 lid 3 Règlement du Sénat.

31. O.a: Art. 32 lid 2 Règlement du Sénat, Art. 36 lid 2 Réglement du Sénat en art. 42 lid 8 Règlement du Senat.

32. Art.85 Grondwet. 
initiatief en amendement moet ontberen, is uitoefening van wezenlijke invloed op de inhoud van de wetgevingsagenda uiteraard op voorhand volledig illusoir.

In Groot-Brittannie is het evenals in Frankrijk formeel mogelijk dat de regering nieuwe voorstellen tot wet eerst lanceert in de senaatskamer. Zowel overwegingen van politieke als van logistieke aard (al hetgeen dat de Lords al hebben gedaan ter verfijning van politiek niet controversiele wetgevingsvoorstellen hoeven de Commons immers niet meer te doen) kunnen daaraan ten grondslag liggen. Óf een wetsvoorstel eerst in het House of Lords c.q. de Sénat onderwerp van parlementair onderzoek zal gaan uitmaken kan in beide landen echter beschouwd worden als een exclusief prerogatief van de regering. In die zin kan van enige substantičle invloed op de wetgevingsagenda door de senaatskamer dan ook zeker geen sprake zijn.

Een vergelijking tussen de manier waarop de Franse Sénat en het Britse House of Lords al dan niet materièle invloed op de wetgevingsagenda uit kunnen oefenen, blijkt met name interessant omdat daardoor het enorme verschil in politicke cultuur tussen Parijs en Londen zo treffend geillustreerd kan worden. Terwijl inhoudelijke sturing van de wetgevingsagenda door de senatoren uit het Palais de Luxembourg gevoeglijk als een grondwettelijk verankerde, juridisch vrijwel volledig dichtgetimmerde onmogelijkheid kan worden beschouwd (l'ordre du jour prioritaire $)^{33}$, blijkt de invloed van het Britse Hogerhuis op de samenstelling en voortgang van de wetgevingsagenda vooral sterk ingeperkt te worden via het o zo Britse proces van regulier overleg via 'the Usual Channels': 'The House of Lords gives no formal preference to Government business in its standing orders, and maintains an ancient tradition of equality. However, the conduct of business must be arranged in advance, by informal but effective means: ${ }^{34}$ Zonder terug te kunnen of hoeven vallen op allerhande procedurele regels naar Frans voorbeeld blijkt de Britse regering onafhankelijk van de politieke kleur van het moment de wetgevingsagenda in het Britse Hogerhuis te kunnen beheren, 'provided that they are perceived to do so in the best interest of the House, and discuss the arrangements with those concerned in advance'. ${ }^{35}$ De kracht van de conventie, zijnde een der wezenskenmerken die de werking van het Britse parlementaire recht mede bepaalt, strekt zich in Westminster blijkbaar ook vrijwel volledig uit over de partijpolitieke verhoudingen. Dat formeel-juridische betutteling aangaande het beheer van de wetgevingsagenda in het Britse rechtssysteem achterwege is gebleven is in rechtsvergelijkende zin des te opmerkelijker indien men ook nog eens verdisconteert dat alle wetgevingsvoorstellen in formele zin die bij de sluiting van ieder afzonderlijk parlementair jaar nog geen 'Royal Assent' hebben gekregen van rechtswege zullen komen te vervallen. Het kost in dat licht gezien natuurlijk weinig voorstellingsvermogen om vervolgens tot de conclusie te komen dat met name de Britse regering in feite erg gebaat zou zijn bij een strakke wetgevingsagenda. Het in par, 4.4.6 van dit boek uitgewerkte voorbeeld over de voortgang van de 'European Parliamentary Elections Bill' spreekt dienaangaande boekdelen. Voor de gemiddelde Franse senator, geschoold in het sterke historische besef dat 'parlementarisme' er toe doet, moet het welhaast onbegrijpelijk zijn, dat de Britse collega's iedere wezenlijke invloed op samenstelling en voortgang van de wetgevingsagenda als het ware vrijwillig (juridische instrumenten zijn er immers niet voorhanden) afstaan aan de regering van de dag.

33. Art. 48 lid I Constitution 1958.

34. J. Griffith and M. Ryle, Parliament, Functions, Practice and Procedures, London 1989, p. 468.

35. J. Griffith and M. Ryle, a.w., p. 468. 
Van de vier senaatskamers die in dit boek voorwerp van onderzoek zijn geweest, oefent de Bundesrat ontegenzeggelijk de meeste invloed uit op de inhoud en voortgang van de wetgevingsagenda. De belangrijkste oorzaak ligt voor de hand. De Bondsduitse grondwetgever heeft immers bepaald, dat de Bundesrat reeds tijdens de beginfase van het wetgevingsproces een inhoudelijk standpunt over de meeste voorstellen tot wet in formele zin mag bepalen. ${ }^{36}$ Hier is overigens sprake van een bevoegdheid, géén plicht. Een bevoegdheid waar door de Bundesrat 'fast immer' gebruik van gemaakt pleegt te worden. ${ }^{37}$ De tijdspanne waarbinnen de Bundesrat, via het hun ter beschikking staande ambtelijk apparaat der Lănder deze 'erste Durchgang' moet afronden kan, zoals wij reeds eerder memoreerden, afhankelijk van het soort wetsvoorstel en de mate van 'Eilbedürftigkeit' variëren van drie tot negen weken. De Bundesrat heeft ter vaststelling van de exacte termijn een duidelijke stem in het geheel.

Het Bondsduitse wetgevingstraject wordt sterk gekenmerkt door zigzag-bewegingen tussen de Bundestag en de Bundesrat tijdens zowel de eerste als de tweede 'Durchgang' van álle wetgevingsvoorstellen in formele zin. Dat gegeven gecombineerd met de grondwettelijk verankerde mogelijkheid/plicht tot conciliatie aan het einde van het wetgevingstraject heeft tot gevolg dat de invloed van de Duitse senaatskamer op de wetgevingsagenda niet anders dan relatief groot kan zijn. In die zin steekt de gang van zaken in de Bondsrepubliek rondom het politiek-strategisch zo belangrijke beheer van de wetgevingsagenda vooral schril af tegen de vrijwel zuivere lijdzaamheid die door de Eerste Kamer in Nederland dienaangaande ten toon gespreid moet worden.

Tijdens bovenstaande bespreking van het belang van het beheer van de wetgevingsagenda in rechtsvergelijkend perspectief werd reeds meerdere malen gewezen op de rol die het recht van initiatief in dat kader in enkele landen kan spelen. Wetgevingsinitiatief vanuit de senaatskamer kán immers de nodige impact hebben op zowel volgorde als tijdspanne waarbinnen wetsvoorstellen afgehandeld plegen te worden. Over de werking van het wetgevingsinitiatief zoals uitgeoefend door de senaatskamer moet in rechtsvergelijkende zin dan ook nog een aantal aanvullende opmerkingen gemaakt worden.

\subsubsection{Recht van initiatief}

De Britse, Franse en Duitse senatoren bezitten het recht van initiatief. De leden van de Nederlandse Eerste Kamer moeten het volledig stellen zonder de mogelijkheid tot het lanceren van eigen wetgevingsvoorstellen.

Hoewel het wetgevingsinitiatief in functie van de modellering van de moderne naoorlogse verzorgingsstaatgedachte tegenwoordig met name wordt uitgeoefend door de regering, blijken tot op de dag van vandaag toch ook nog steeds met enige regelmaat voorstellen vanuit senaatskamers de eindstreep te kunnen halen. In de Bondsrepubliek ligt de succesquote voor wetgevingsinitiatief vanuit de senaatskamer de laatste jaren met bijna $6 \%$ relatief hoog ${ }^{38}$ De Britse Lords moeten zich tevreden stellen met de helft van voornoemd percentage. Tijdens de parlementaire sessies van 1997-98 en 1998-99 bleef het aantal wetsvoorstellen afkomstig van Hogerhuisleden dat 'Royal Assent' verkreeg steken op $3 \%{ }^{39}$ In Frankrijk tenslotte blijkt de

37. G. Ziller und G-B. Oschatz, Der Bundesrat, Dusseldorf 1998. p. 28

38. http://www. bundesrat. de PDundF/zahlenspiegel. html, 23-04-01

39. http//www. parliament the-stationery-office,co.uk/pa/ld199899//dpbstat9906.htm, 23-04-01 
laatste jaren nim $4 \%$ van de wetgevingsinitiatieven vanuit het Palais de Luxembourg uiteindelijk de status van wet te hebben verkregen. ${ }^{40}$

In Groot-Brittannie is sterker dan elders vooral de factor tijd bepalend voor de vraag of wetgevingsinitiatief vanuit het House of Lords kans van slagen heeft. Partijpolitieke overwegingen spelen als regel slechts een ondergeschikte rol. De (reeds meermaals gememoreerde) tijdspanne van één parlementair jaar waarbinnen ieder voorstel tot wet in formele zin in Groot-Brittanniê op straffe van formele vervallenverklaring kracht van wet moet krijgen, blijkt de dominerende factor bij uitstek te zijn. Niet zo zeer voor het Hogerhuis overigens, doch voor het Lagerhuis. Iedere minuut die in het House of Commons besteed wordt aan initiatiefwetsvoorstellen vanuit het Hogerhuis, blijkt tegenwoordig welhaast letterlijk beschouwd te kunnen worden als een minuut te veel (met als gevolg dat ieder amendement het vanzelfsprekende einde van het initiatiefwetsvoorstel zal betekenen). Vooral tijdens het laatste gedeelte van het parlementaire jaar (tussen Pasen en eind oktober) is voornoemd uitgangspunt bij voortduring bestendige politieke praktijk gebleken. Ten gevolge van dit alles zal succesvol wetgevingsinitiatief vanuit het Hogerhuis slechts politiek niet controversiêle niet al te complexe onderwerpen kunnen betreffen: 'most successful private members' bills introduce minor changes, possibly removing anomalies in earlier legislation, or introducing small alterations recommended by committees of inquiry', ${ }^{41}$ Op deze plaats moet aangaande de wijze warop het recht van initiatief witgeoefend door het Britse Hogerhwis pleegt te functioneren wel nog met klem gewag gemaakt worden van de maatschappelijke impact die formeel niet succesvolle wetgevingsinitiatieven vanuit het House of Lords zo af en toe op de Britse samenleving als geheel kunnen hebben. Controversiële onderwerpen als bijvoorbeeld abortus provocatus en het verbod van besnijdenis bij vrouwen werden eerst als Private Member Bill geìntroduceerd. Het maatschappelijke debat dat van deze formeel 'vruchteloze' pogingen tot regelgeving het gevolg was, effende uiteindelijk in beide gevallen wel de weg voor daadwerkelijke codificatie via regulier regeringsinitiatief. ${ }^{42}$

Waar de Brits bicamerale verhoudingen rondom het wetgevingsinitiatief vanuit het Hogerhuis in het geding zijn, kan uiteindelijk echter geconcludeerd worden dat de senatoriale activiteiten een vrijwel exclusief 'assisterend' karakter blijken te hebben. Voor meer dan dat ontbreekt zoals wij gezien hebben eenvoudig de noodzakelijke nuimte in de tijd.

Voornoemde conclusie lijkt voor de praktische gang van zaken rondom het wetgevingsinitiatief in de Bundesrat en de Sénat Français zeker niet zonder meer zo eenduidig getrokken te kunnen worden.

Voor de Bondsrepubliek geldt dat inkaderen van de wijze waarop door de senaatskamer gebruikgemaakt wordt van het recht van wetgevingsinitiatief uiteraard eerst en vooral beoordeeld moet worden in relatie tot de constitutioneel voor 'eeuwig' verankerde federatieve staatsstructuur. Tijdens ruim vijftig jaar Bondsduitse wetgevingsgeschiedenis heeft de Bond de Länder zoals wij gezien hebben vrijwel buitenspel weten te zetten op de 'concurrerende' materièle wetgevingsterreinen ex art. 74 en 74 a GG. Dit kon gebeuren op basis van een aantal door de Duitse grondwetgever geattribueerde concurrerende wetgevingsbevoegdheden waarbij de Bond vrij eenvoudig formeel voorrang mocht claimen ter effectuering van die wetge-

40. http://www.senat. fr/presentation/livre2/livre227.html, 30-11-1999.

41. D. Shell, The House of Lords, London 1992, p. 154.

42. Prohibition of Female Circumcision Bill 1985; Human Fertilisation and Embryology Bill 1990. 
vingsbevoegdheden. ${ }^{43}$ Als uitvloeisel van deze gang van zaken restte de Länder nog slechts het recht van initiatief om te pogen specifieke 'regionale' wensen op Bondsniveau in wetgeving omgezet te krijgen. Een recht waarvan vooral ten tijde van divergerende partijpoliticke meerderheden in Bundestag en Bundesrat vrij frequent gebruik gemaakt wordt. 'Der Bundesrat als bundespolitische Bühne' is sinds 1969 langzamerhand een begrip geworden. 'Gerade in jūngster Zeit hat sich erwiesen, dass auf der Ebene der Ministerpräsidenten oder in Fachministerkonferenzen wichtige Entscheidungen getroffen wurden, die dann auf dem Wege der Bundesratsinitiative in das Gesetzgebungsverfahren mündeten', ${ }^{44}$ Ook ad-hoc Bundesratcoalities bestaande uit bijvoorbeeld de voormalige DDR-Lănder of de (qua aantal inwoners) kleinere Duitse Länder hebben tegenwoordig het strategische nut van het recht van initiatief als politiek instrument ontdekt. ${ }^{45}$

Op dit punt aangekomen kan een kwantitatieve vergelijking van de succesquote voor het recht van initiatief tussen Bundesrat en Sénat interessante feitelijkheden opleveren:

Tabel 8.2

\begin{tabular}{|l|l|l|l|l|}
\hline Periode van: & \multicolumn{3}{|l|}{ Aantal ingediende } & \multicolumn{2}{l|}{$\begin{array}{l}\text { Aantal initiatiefwetsontwerpen } \\
\text { tot wet verheven }\end{array}$} \\
\hline & Sénat & Bundesrat & Sénat & Bundesrat \\
\hline $\begin{array}{l}\text { Partijpolitieke } \\
\text { divergentie I* }\end{array}$ & $637(100 \%)$ & $166(100 \%)$ & $19(3 \%)$ & $44(27 \%)$ \\
\hline $\begin{array}{l}\text { Partijpolitieke } \\
\text { coherentie ** }\end{array}$ & $108(100 \%)$ & $112(100 \%)$ & $9(8 \%)$ & $47(42 \%)$ \\
\hline $\begin{array}{l}\text { Partijpolitieke } \\
\text { divergentie II } \\
* * *\end{array}$ & $447(100 \%)$ & $255(100 \%)$ & $23(5 \%)$ & $64(25 \%)$ \\
\hline
\end{tabular}

* Frankrijk: 1981-1986; Duitsland: 1972-1983

** Frankrijk: 1986-1988; Duitsland: 1983-1990

*** Frankrijk: 1988-1993; Duitsland: 1990-1998

Uit bovenstaande tabel wordt goed zichtbaar dat een door de senaatskamer uit te oefenen recht van initiatief zowel in de Bondsrepubliek als in Frankrijk beter blijkt te gedijen tijdens perioden van partijpolitieke coherentie tussen (meerderheden van) de twee nationale parlementskamers. Een constatering die natuurlijk nauwelijks opmerkelijk te noemen is. Beduidend interessanter daarentegen is het gegeven dat de succesquote voor het initiatiefrecht tijdens zowel perioden van partijpolitieke détente als perioden van polarisatie voor de Bundesrat procentueel vele malen hoger uitvalt dan voor de Franse senaatskamer. Een verklaring van dit fenomeen zou gevonden kunnen worden in de federale staatsstructuur van de Bondsrepubliek, die behartiging van specifieke 'Lănderbelangen' door de uit afgevaardigden van de Länderregeringen samengestelde Bondsduitse senaatskamer immers tot iets vanzelfsprekends maakt. Echt overtuigen doet deze verklaring echter niet. Ook de Franse

43. Op basis van de artt. 74 en 74 a GG wist de Bond immers op nagenoeg alle beleidsterreinen waar zowel de Bond als de Lânder de formele bevoegdheid tot regelgeving toekwam ('konkurrierenden Gesetzgebung') het wetgevingsinitiatief definitief naar zich toe te trekken.

44. G. Ziller und G-B. Oschatz, a.w., p. 25.

45. G. Ziller und G-B. Oschatz, a.w., p. 27. 
senatoren worden formeel geacht het belang van de regio's mede te behartigen. En ook zij werken als regel ('cumul des mandats') vanuit een sterke materiële band met het departement waarvoor zij afgevaardigd worden. Er moet dus meer aan de hand zijn. Ik kom hier zo dadelijk (par, 8.2.5.3) op terug.

Vooralsnog is in ieder geval duidelijk dat in de Franse bicamerale constellatie succesvolle hantering van het recht van initiatief door de Sénat ook anno 2001 nog altijd sterk afhankelijk is van de partijpolitieke verhoudingen van het moment in de Assembleé nationale. Is de regeringscoalitie van centrumrechtse huize dan behoort sporadische succesvolle hantering door de Franse senaatskamer van het recht van initiatief alleszins tot de reële mogelijkheden. Is de regeringscoalitie niet van centrumrechtse huize, dan bestaat het recht van initiatief voor de Franse Sénat in feite vrijwel uitsluitend op papier. De Franse regering kan, daartoe gemachtigd via de grondwet, eenvoudig weigeren om een politiek onwelgevallig initiatiefwetsvoorstel afkomstig van de Sénat in te schrijven in de wetgevingsagenda van de Assemblée nationale. De legislatieve bemocienis van het Franse Hogerhuis via het recht van initiatief kan dan ook gevoeglijk gekarakteriseerd worden als 'sterk assisterend' van aard. Rivaliserende wetgevingsactiviteiten blijken door de regering grotendeels effectief uitgebannen te (kunnen) worden.

De Bondsduitse situatie rondom de werking van het recht van initiatief voor de Bundesrat samensautend kaw daacentegew echter allerwinst als orijwel wislbitend 'sterk assisterend' functioneren' gekenschetst worden. De Bundesrat weet het recht van initiatief tevens regelmatig handig en zelfbewust in wisselende politieke settings te hanteren ter verwezenlijking van een aantal eigen 'regionale' belangen.

De bulk aan wetgevingsproducten komt echter niet tot stand via uitoefening van het recht van initiatief door een der parlementskamers, doch via regeringsinitiatief. Het is dan ook met name van belang te vergelijken op welke wijze de senaatskamers uit de vier onderzoekslanden materiële invloed blijken uit te kunnen oefenen op de totstandkoming van dat product.

Allereerst de commissiefase.

\subsubsection{Commissie algemeen en organisatiestructuur}

Een vergelijking van de wijze waarop de respectievelijke senaatskamers van Frankrijk, Nederland, Duitsland en Groot-Brittannië vorm geven aan de hen constitutioneel toegekende medewetgevende taken, kan onmogelijk getrokken worden zonder de nodige aandacht te besteden aan het functioneren van het commissiestelsel in voornoemde landen. De wijze waarop het wetgevingsgelieerde commissiewerk vorm pleegt te krijgen wordt naast en in combinatie met de mate waarin parlementskamers zich weten te specialiseren, beschouwd als cen van de belangrijke institutionele factoren ter bepaling van de mate waarin parlementaire invloed op het wetgevingsproces uitgeoefend wordt. ${ }^{46}$

Behalve het House of Lords werken de senaatskamers die in dit boek onderwerp van onderzoek hebben uitgemaakt ten behoeve van de reguliere wetgevingsgelieerde activiteiten normaliter met vaste commissies. Deze commissies worden grofweg onderscheiden via de gangbare departementale indelingen, zij het dat de differentiatie in de Bundesrat (16 vaste

46. P. Norton. The Legislative Powers of Parliament, in: The evolving role of Parliament in Europe, p. 15-32, Antwerpen 1994 . 
kamercommissies) en de Eerste Kamer (21 vaste kamercommissies) veel verder doorgevoerd blijkt te zijn dan in de Franse Sénat (6 vaste kamercommissies).

De vaste kamercommissies van de Bundesrat worden structureel gekenmerkt door een bijzonder hoge graad van specialisatie. Niet alleen wordt per beleidsterrein als regel de zittende minister uit ieder der 16 Länder afgevaardigd, maar daarenboven voorziet het Duitse recht ook nog eens ruimschoots in de mogelijkheid het inhoudelijke commissiewerk (via bijvoorbeeld het instellen van subcommissies ex $\$ 39 \mathrm{Abs}$. 4 GOBR) af te laten handelen door gespecialiseerde ambtenaren uit de Lånder. In de praktijk betekent dit dat met name het technische, juridische, niet-politieke deel van het wetgevingswerk in naam van de Bundesratsleden gedaan pleegt te worden door ambtenaren. Zo is de inbreng van gespecialiseerde ambtenaren in de 'Finanzausschuss' altijd groot, terwijl de sterk politieke 'Ausschuss für Auswertige Angelegenheiten' (waarin de 16 regeringsleiders der Duitse Länder als regel zélf hun Land plegen te vertegenwoordigen) functioneert zonder substantièle inbreng van ambtenaren. De geconstateerde hoge specialisatiegraad van de Bundesratcommissies wordt daarenboven voortdurend bewaakt door de 'Ausschussbüros', permanent functionerende secretariaten die tot hoofdtaak hebben 'den Vorsitzenden bei der Vorbereitung und Leitung der Ausschusssitzungen zu unterstützen', ${ }^{47}$ Qua professionaliteit en algemene expertisegraad (via vooral de inbreng van de 'vaste' ambtelijke staf der Länder) kunnen de vaste kamercommissies van de Bundesrat dan ook niet anders dan sterk af steken tegen hetgeen zich dienaangaande manifesteert in het Palais de Luxembourg en op het Haagse Binnenhof. De Franse en Nederlandse senatoren moeten het 'in commissie', om het eens relatief plat uit te drukken, zelf maar uitzoeken. Vooral in Nederland lijkt daarmee op papier een ernstig probleem geschapen te zijn, aangezien de voor slechts een periode van vier jaar gekozen Nederlandse senatoren (hoofdzakelijk in andere sectoren van de samenleving werkzame) deeltijdpolitici zijn, die niet meer dan 35 tot 40 dinsdagen per jaar bijeen komen ter behandeling (inclusief commissievergaderingen) en afhandeling van (onder meer) álle voorstellen tot wet in formele zin. De praktische oplossing voor dit probleem luistert naar de naam 'inbrengvergadering'. De commissiefase in de Nederlandse senaatskamer bestaat als regel slechts uit een facultatieve schriftelijke ronde die uitmondt in een formeel vast te stellen eindverslag. Anders gezegd, commissievergaderingen van de 21 vaste Nederlandse senaatscommissies vinden in feite (vrijwel) niet plaats.

De Franse senatoren (met een kiezersmandaat voor negen jaar) hebben een pragmatische oplossing gekozen om het geconstateerde tekort aan aanwezige expertise in de commissies zoveel mogelijk te kunnen ondervangen. Ieder der 321 senatoren kan slechts lid zijn van éen der zes vaste commissies, zodat de nodige specifieke expertise kan worden opgebouwd. Daarenboven benoemt de voltallige commissie voor ieder wetsontwerp dat ter tafel komt een 'rapporteur' die zich voorafgaande aan de plenaire commissiesessies volledig zal verdiepen in het wetsontwerp onder de hamer. De rapporteur (al naargelang de complexiteit van het onderwerp bijgestaan door een of meerdere collega-senatoren) onderzoekt het wetsvoorstel, consulteert experts, belangenorganisaties e.d. en bestudeert en suggereert wijzigings- en aanpassingsvoorstellen. De neerslag van al deze activiteiten vormt onderwerp van bespreking tijdens de plenaire vergaderingen (met verplichte aanwezigheid) van de kamercommissies. Dit alles maakt de rapporteur tot een inhoudsdeskundig en invloedrijk individu. 
De leden van het Britse Hogerhuis tenslotte werken niet met vaste kamercommissies, maar benaderen de commissiewerkzaamheden op geheel eigen wijze. Omdat de leden van het House of Lords voor het leven worden benoemd, de werkzaamheden in principe de gehele werkweek in beslag nemen en de parlementaire werkzaamheden daarenboven ook nog eens vervuld worden op semi-vrijwillige basis, kan in feite niet van tevoren worden ingeschat hoeveel van de ruim 700 Lords op een willekeurige dag acte de présence zullen geven. Hierop anticiperend wordt in het Britse Hogerhuis in de meeste gevallen geopteerd voor de 'Committee of the whole House'-constructie. Iedere aanwezige Lord kan participeren in het commissiewerk van die dag. In de praktijk betekent dit dat het commissiewerk in het Britse Hogerhuis sterk gedomineerd kan worden door leden van de regering (die immers ook deel uitmaken van het House of Lords). Deze hoofdregel wordt met name dan gebroken indien wetsontwerpen ter tafel komen betreffende beleidsterreinen waarop een of meerdere Lords in de loop der jaren wezenlijke expertise hebben weten op te bouwen. In die gevallen kan de inbreng van Britse senatoren in het commissiewerk behoorlijk groot worden. Niet voor niets heeft een substantiele uitbouw van de in het House of Lords aanwezige 'expertise' het fundament onder het bestaansrecht voor een tweede parlementskamer in Groot-Brittannië de laatste decennia aanmerkelijk weten te verstevigen. Ik kom hier nog uitgebreid op tenug. Overigens moet volledigheidshalve nog gewag gemaakt worden van het fenomeen 'Select Committee'. Omdat diepgaander onderzoek via de procedure van de plenaire commissievergadering natuurlijk uitgesloten is, bestaat in de Britse senaatskamer veel sterker dan in de senaatskamers van de overige drie onderzoekslanden regelmatig behoefte aan het instellen van bijzondere kamercommissies, zgn. 'Select Committees'. Dergelijk onderzoek betreft dan vooral niet gecompliceerde regeringsvoorstellen die wél nog enig nader snuffelwerk vereisen, alsmede (veel belangrijker) bijzonder gevoelige maatschappelijke thema's.

Wat leert dit alles ons nu tot dusverre over de gang van zaken rondom de reguliere commissiewerkzaamheden zoals die in het kader van het wetgevingsproces door de vier senaatskamers uitgevoerd worden? In ieder geval dat in het ene geval (de Bondsrepubliek) veel meer tijd, mankracht en expertise geinvesteerd wordt in de commissiefase(s) dan in het andere geval, waar de commissiefase vrijwel non-existent is (Nederland). Ook blijkt geconcludeerd te kunnen worden dat in Groot-Brittannië grondig commissie onderzoek van een willekeurig wetsvoorstel veel sterker dan in Frankrijk (rapporteur) en zeker de Bondsrepubliek (ambtelijk apparaat) afhankelijk blijft van min of meer toevallig aanwezige expertise in de senaatskamer. Van het House of Lords kan dienaangaande tegenwoordig overigens wel het een en ander verwacht worden. De Life Peers zitten niet vast aan een kiezersmandaat van vier of negen jaar. Daamaast hebben zij ook nog eens veel meer tijd ter beschikking voor het parlementaire werk in het algemeen en het commissiewerk in het bijzonder dan hun collega's uit Frankrijk en Nederland.

\subsubsection{Taakstelling senaatscommissies}

De geconstateerde grote verschillen in aanpak van het parlementaire commissiewerk door de senaatskamers in de vier onderzockslanden, kan natuurlijk niet los van de te verwezenlijken taakstelling per staat besproken worden.

Het systeem van vaste kamercommissies zoals dat in de Bondsrepubliek functioneert ten behoeve van de senaatskamer, onderscheidt zich vooral door het gegeven dat ieder voorstel tot wet (in formele zin) niet éen doch tweemaal tijdens achtereenvolgende fases van het wet- 
gevingsproces voorwerp van onderzoek door een senaatscommissie uit zal maken (waarbij eventuele inschakeling van de Vermittlungsausschuss zelfs nog buiten beschouwing blijft). Tijdens de 'erste Durchgang' ${ }^{48}$ formuleent de commissie desgewenst ten behoeve van het Bundesratsplenum uitgewerkte 'Ändenungsemphfelungen'. Tijdens de 'zweite Durchgang' wordt door de commissie allereerst nauwkeurig onderzocht wat regering en Bundestag met voomoemde 'Emphfelungen' (mede met het oog op het belang van de 'uitvoerende' Linder) gedaan hebben, om vervolgens de door de Bundesrat gewenste definitieve vorm van het wetsvoorstel compleet voor te bereiden. De wijzigingsvoorstellen die de vaste kamercommissies kunnen suggereren tijdens met name de 'erste Durchgang' staan formeel niet als amendementen te boek. In materiele zin zijn voornoemde 'Emphfelungen' dat echter ontegenzeggelijk wél. In die zin ligt een vergelijking betreffende de uitvoering van de taakstelling door vaste commissies van Sénat en het House of Lords, senaatskamers die beschikken over een formeel recht van amendement, zeer voor de hand. Het bespreken van (door regering of eerste parlementskamer) noodzakelijk geachte wijzigingsvoorstellen en het voorbespreken van nieuwe wijzigingssuggesties namens het House of Lords of de Sénat vormen ook voor de vaste kamercommissies in Groot-Brittanniê en Frankrijk de hoofdmoot van de werkzaamheden. Belangrijk verschil met de Bondsrepubliek is dan ook dat een wetsvoorstel in formele zin in Frankrijk en Groot-Brittannie als regel slechts een maal in zijn geheel voorwerp van voorbereidend onderzoek voor de vaste kamercommissie zal uitmaken.

De taakstelling van de vaste kamercommissies der Nederlandse Eerste Kamer wijkt sterk af van het beschreven beeld. Vrijwel volledig gespeend van de materiele mogelijkheid tot het ontwikkelen van 'amenderende' activiteiten (in de vorm van sporadische novelles, toezeggingen of amenderende moties) en volledig gespeend van de formele mogelijkheid tot amenderen, blijft al met al onduidelijk op welke wijze de commissiefase voor de Nederlandse senaatskamer naast de fractievergaderingen en de plenaire bijeenkomsten nog veel wezenlijke toegevoegde waarde in het kader van het wetgevingheroverwegingsproces op kan leveren. En daarmee is ook cenvoudig verklaard waarom uitsluitend in de Nederlandse staatsrechtelijke constellatie nooit een commissiesysteem 'gericht op specialisatic en aandacht voor details ${ }^{* 49}$. naar Frans, Duits of Brits voorbeeld tot ontwikkeling is kunnen komen.

Wat heeft de rechtsvergelijkende verkenning van de mogelijkheden tot beinnvloeding van wetgevingsvoorstellen in formele zin door de vier senaatskamers ons tot dusverre opgeleverd? Het beheer van de wetgevingsagenda is een prerogatief van de nationale regeringen. Senaatskamers kunnen (Frankrijk) of willen (Groot-Brittanniē) als regel weinig invloed uitoefenen op samenstelling en voortgang van die agenda. In één geval (Nederland) is zelfs sprake van een vrijwel $100 \%$ lijdzame verhouding, zij het dat het tempo waarin voorstellen tot wet worden afgedaan, natuurlijk tot op zekere hoogte een zaak voor de Eerste Kamer zelf blijft. Indien de regering de datum voor inwerkingtreding al een wetsvoorstel heeft opgenomen (bijvoorbeeld 1 januari) ligt de regie ook hier toch ontegenzeggelijk bij de regering.

Slechts de Bundesrat praat op structurele basis mee, waar de vaststelling van de wetgevingsagenda in het geding is.

48. Omdat voor de "erste Durchgang slechts een gelimiteerde tijdspanne van gemiddeld zes weken voorhanden is pleegt het commissiewerk vaak al opgestart te worden op een moment dat het onderhavige wetsvooritel nog bij de Bundestag in behandeling is.

49. F. de Vries, de staatsrechtelijke positie van de Eerste Kamer, dissertatie, Groningen 2000, p. 233. 
Ook het recht van initiatief blijkt vooral in de Bondsrepubliek Duitsland met enige regelmaat succesvol gehanteerd te kunnen worden door (wisselende meerderheidscoalities in) de senaatskamer. De Sénat en het House of Lords zijn in de parlementaire praktijk volledig afhankelijk van de welwillendheid van de regering van het moment (en de partijpolitieke meerderheid van Assemblée nationale c.q. House of Commons). De Nederlandse Eerste Kamer ontbeert de mogelijkheid tot wetgevingsinitiatief volledig.

De mate waarin de vier senaatskamers in staat gesteld worden om invloed op het wetgevingsproduct in wording uit te oefenen via de commissiewerkzaamheden in ogenschouw nemend, springt wederom de Bundesrat er in meest positieve zin uit. Vanuit de zekerheid van voortdurend aanwezige (juridische) wetgevingsexpertise (ambtelijk apparaat) mogen de Duitse senatoren ieder wetsontwerp in formele zin tijdens het wetgevingsproces twee maal in commissieverband volledig tegen het heroverwegingslicht houden. De Franse senatoren creeren expertise via de noeste arbeid van hun rapporteurs. De diepgang van het Britse commissiewerk is (naast de regeringsinbreng) afhankelijk van toevallig aanwezige expertise in het Hogerhuis, waardoor voorstellen op het ene beleidsterrein meer aandacht krijgen dan andere.

De Nederlandse Eerste Kamer bezit ook hier wederom de minst gunstige uitgangspositie met het $o$ g op beinvloeding van het wetgevingsproduct. Omdat de vijfenzeventig deeltijdsenatoren weinig tijd en mankracht kunnen genereren voor het ontwikkelen van 'duurzame' expertise, maar vooral omdat zij in feite geen instrumenten ter beschikking hebben ter inhoudelijke bijstelling van voorstellen tot wet, blijkt de commissiefase in de Eerste Kamer zich, uitzonderingen daargelaten, te beperken tot formeel-schriftelijke inbrengvergaderingen. Wel is de commissiefase in de Nederlandse senaatskamer soms handig om de 'neuzen'van de verschillende fracties op één lijn te krijgen, wanneer de Eerste Kamer de regering onder druk wil gaan zetten.

Bicameralisme, het woord indiceert het al, is qualitate qua gebaseerd op een dualistische conceptie van de politieke organisatie. ${ }^{50}$ Tot op zekere hoogte met uitzondering van de Duitse Bundesrat, heeft het er tot zover echter alle schijn van dat de medewetgevende taakstelling van de vier senaatskamers die in dit boek onderwerp van onderzoek uitmaken anno 2001 in hoofdzaak sterk (in hoofdzaak juridisch) 'assisterend' ingevuld wordt. Met die constatering in het achterhoofd gaan wij nu de werking en effectiviteit van de centrale staatsrechtelijk verankerde instrumenten voor de senaatskamers ter beìnvloeding van het wetgevingsproduct vergelijken.

\subsubsection{Juridische beinvloedingsinstrumenten}

\subsubsection{Vetorecht}

Het formeel machtigste wapen in handen van een senaatskamer met het oog op beïnvloeding van wetgevingsvoorstellen is het absolute vetorecht. Geen overeenstemming tussen beide parlementskamers, dan ook geen wetgeving. 'Bicameralisme parfait'. De Nederlandse Eerste Kamer bezit als enige van de vier onderzochte senaatskamer een absoluut vetorecht met betrekking tot alle voorstellen tot wet in formele zin die aan de senaatskamer voorgelegd worden. Het trekken van een parallel met de gang van zaken in de Bondsrepubliek ligt hier voor de hand, nu de Bundesrat immers ook de beschikking heeft over een absoluut vetorecht 
aangaande bepaalde voorstellen tot wet, met dien verstande dat in de Duitse senaatskamer tegenwoordig ongeveer $60 \%$ van de wetsvoorstellen getroffen kunnen worden door die definitieve toestemmingsweigering. De Duitse grondwetgever van 1949 heeft via zowel de mogelijkheid tot interpretatie van de artt. 84 en 85 GG ('soweit nicht Bundesgesetze mit $\mathrm{Zu}$ stimmung des Bundesrates etwas anders bestimmen') als de mogelijkheid tot invulling van concurrerende wetgevingsbevoegdheden ex. art 74 en 74 a GG de groei van het aantal ' $\mathrm{Zu}$ stimmungsbedürftige' wetsvoorstellen sterk gestimuleerd. Op beleidsterreinen waar de grondwetgever via concurrerende wetgevingsbevoegdheden open had gelaten of de Bond dan wel de Länder tot nadere regelgeving over zouden moeten gaan, hebben de Länder in de loop der jaren veel terrein prijs moeten geven. Dit voortdurende verlies aan wetgevende competenties werd echter vrijwel standaard gecompenseerd via toekenning van een absoluut vetorecht aan de parlementaire vertegenwoordiging van de Länder op Bondsniveau, de Bundesrat, betreffende alle toekomstige wetgevingsvoorstellen in formele zin op het bewuste beleidsterrein.

De parallel tussen de Eerste Kamer en de Bundesrat aangaande de praktische werking van het legislatieve bevoegdhedenpakket zou nog iets verder doorgetrokken kunnen worden. Beide senaatskamers ontberen immers formeel het recht van amendement. Achter de term 'formeel' blijkt in deze echter een wereld van verschil schuil te gaan. De Bundesrat bestudeert een wetsvoorstel als standaard twee maal in zijn geheel. De fase van de 'erste Durchgang' staat volledig haaks op hetgeen dienaangaande in Nederland gebruikelijk is. Tijdens cen fase van het wetgevingsproces dat nog niets definitief vast ligt, de Bundestag nog geen oordeel heeft kunnen vellen dan wel amendementen heeft kunnen toevoegen, kan de Duitse senaatskamer zijn visie over zowel het geheel als de onderdelen van het voorstel al etaleren. De waarde van een absoluut vetorecht komt, indien te combineren met de mogelijkheid tot formele kennisname van wetsvoorstellen tijdens een eerdere fase van het wetgevingsproces in strategische zin natururlijk ook in een volledig ander daglicht te staan. Als uitvloeisel van die cerdere bestuderingfase kunnen en zullen door een senaatskamer op structurele basis 'suggesties' van niet slechts (juridisch-technische en dogmatisch) 'assisterende', doch ook van (politick-beleidsmatig) 'rivaliserende' aard aan het wetsvoorstel in wording toegevoegd worden, in de wetenschap (voor álle partijen) dat tegen het einde van het traject nog altijd een veto kan worden uitgesproken. Dergelijke 'suggesties' zijn qua kracht niet van formele amendementen te onderscheiden. Sterker nog, amendementen afkomstig van bijvoorbeeld het House of Lords of de Sénat français (waarover dadelijk meer) kunnen door zowel de Britse als de Franse regering terzijde geschoven kunnen worden, zonder al te grote consequenties voor de levensvatbaarheid van een wetsvoorstel. De Duitse Bondsregering zal zich wel twee keer bedenken alvorens door de Bundesrat gelanceerde wijzigingsvoorstellen terzijde te schuiven.

De mogelijkheden voor de Nederlandse senatoren blijken schril af te steken tegen hetgeen hierboven geschreven werd over de Bondsduitse wetgevingspraktijk. Een zeer sporadische novelle van technische of inhoudelijke aard dan wel toezegging daargelaten beschikt de Eerste Kamer ook in de wetgevingspraktijk eenvoudigweg niet over instrumenten die op amendering lijkende bijsturing van wetgevingsvoorstellen tot gevolg zouden kunnen hebben. Het absoluut vetorecht is voor dat doel te enen male ongeschikt. Anders gezegd, de Nederlandse senaatskamer beschikt waar de heroverweging van wetgeving in formele zin in het geding is in feite slechts over beīnvloedingsmogelijkheden van sterk 'rivaliserende' aard. Blijkbaar heeft de Nederlandse grondwetgever het niet nodig geacht om de Eerste Kamer juridische instrumenten aan te reiken om Tweede Kamer en regering (tevens) te kunnen 


\section{Hoofdstuk 8}

'assisteren' in het kader van de wetgevingheroverweging. Men zou in deze tot de conclusie kunnen komen dat de Nederlandse grondwetgever de dualistische conceptie die in theorie immers inherent aan bicameralisme is, consequent trouw is gebleven. Een snelle blik in de Nederlandse parlementaire geschiedenis leert dat die redenering slechts dan op kan gaan, indien voor de praktische uitwerking van voomoemde dualistische conceptie niet de verhouding tussen regering en (partijpolitieke meerderheid van de) Tweede Kamer enerzijds en de heroverwegende Eerste Kamer centraal zou staan, doch veeleer de inmiddels werkelijk volledig achterhaalde verhouding regering/Eerste Kamer versus Tweede Kamer. ${ }^{51}$ De huidige Nederlandse staatsrechtelijke verhoudingen (wel vetorecht, geen recht van amendement en initiatief) bestaan immers al sinds de grondwetsherziening van 1848 en waren uitsluitend bedoeld om de regering (lees: Koning) af te kunnen schermen tegen onwelgevallige (lees: rivaliserende) wetgevingsproducten afkomstig uit de Twééde Kamer. Met consequente verzekering door de grondwetgever dat het bicamerale gedachtegoed dualistisch rivaliserend gepraktiseerd zou moeten worden, heeft ruim 150 jaar radiostilte van de kant van diezelfde grondwetgever waar eventuele introductie van 'assisterende' legislatieve instrumenten ten behoeve van een heroverwegende Eerste Kamer in het geding was, dan ook überhaupt niets van doen. Ik kom hier zo dadelijk nogmaals op terug (par. 8.2.5.3).

De gevolgen van de gang van zaken rondom hantering van een vetorecht tussentijds samenvattend, blijkt het er in de kern op neer te komen dat van een absoluut vetorecht voor de senaatskamer een 'natuurlijke' preventieve werking uit kan gaan, indien dit recht gecombineerd kan worden met de mogelijkheid tot formele bemoeienis tijdens een eerder stadium van het wetgevingsproces. Bestudering van de Bundestag's Plenarprotokolle bevestigden deze veronderstelling ondubbelzinnig. Veranderingsvoorstellen gelanceerd door de Bundesrat tijdens de 'erste Durchgang' blijken als regel 'weitgehend gefolgt' te worden door de Bundestag, ook indien de voorstellen van de Bundesrat van 'niet-assisterende' (lees: politicke) aard

$\mathrm{zijn}^{52}$ In een bicameraal wetgevingssysteem als het Nederlandse, waar het vetorecht slechts geisoleerd gehanteerd mag worden aan het einde van de rit, is preventief sleutelen aan voorstellen tot wet op basis van wensen uit de senaatskamer uiteraard per definitie uitgesloten.

De hamvraag is echter nog niet gesteld. In welke mate en met welk effect wordt het vetorecht in de bicamerale parlementaire praktijk nu ook werkelijk ingezet door Bundesrat en Eerste Kamer? Een voldoende gefundeerd antwoord op die vraag kan onmogelijk geformuleerd worden zonder daar de (afwezigheid van een) conflictenregeling ter beslechting van geschillen op het terrein van wetgevingsontwikkeling tussen beide parlementskamers bij te betrekken. Ik verwijs voor een antwoord op voornoemde vraag dan ook naar de slotoverwegingen in par. 8.2.5.3.

\subsubsection{Recht van amendement}

De leden van het Britse en Franse Hogerhuis hebben weliswaar niet de beschikking over een absoluut vetorecht in al dan niet afgezwakte vorm indien zij wetgevingsvoorstellen willen bijstellen dan wel tegenhouden, maar daar staat tegenover dat beide senaatskamers wel gebruik kunnen maken van een recht van amendement. Dit is een recht dat zowel door het

51. J. Vis, Van 'ménagerie du Roi' tot politick college, De Eerste Kamer van 1849 tot 1887, in: Aan deze zijde van het Binnenhof, 's-Gravenhage 1990, p. 188-206.

52. Deutsche Bundestag DIP Plenarprotokolle, http://dip.bundestag de/cgi-bin/dipwww nofr/continue, 28-62001. 
House of Lords als door de Sénat frequent gehanteerd blijkt te worden. Het gemiddeld aantal amendementen dat door de Britse Hogerhuisleden per parlementair jaar formeel wordt ingediend lag tussen 1981 en 1999 op ongeveer duizend. Sinds de inwerkingtreding van de House of Lords Bill 1999 die gepaard ging met de benoeming van vele nieuwe Life Peers, is dat gemiddelde opgeschroefd tot het astronomische aantal van gemiddeld ruim 9000 . Of daarmee een nieuwe trend gezet is, moet natuurlijk nog afgewacht worden. De Franse collega's uit het Palais de Luxembourg zijn op het terrein der wetgevingsamendering al langer zeer actief. Per jaar stellen zij sinds 1981 gemiddeld nuim 4500 amendementen van zowel technische als inhoudelijke aard voor.

In hoeverre de voorgestelde amendementen uiteindelijk ook geincorporeerd blijken te worden in de definitieve wettekst is afhankelijk van meerdere op elkaar inwerkende procedurele, politiek-culturele en zuiver partijpolitieke factoren. Laten wij allereerst de Franse praktijk rondom hantering van het recht van amendement door de senaatskamer bekijken.

Ervan uitgaande dat een 'projet de loi' reeds door de Assemblée nationale is behandeld en aangenomen, hetgeen in Frankrijk in de regel als de meest voor de hand liggende gang van zaken wordt beschouwd, moet de Sénat de voorliggende wettekst aannemen 'en vue de l'adoption d'un texte identique'. ${ }^{53}$ Meent de Sénat in meerderheid dat aan dat vereiste voorshands niet voldaan kan worden, dan zal het recht van amendement in stelling gebracht worden. Ik gebruik bewust de term 'in stelling gebracht' omdat het door de Sénat uit te oefenen recht van amendement in de Franse politieke constellatie van oudsher naast legislatief correctie-instrument tevens van grote betekenis is gebleken als politick-strategisch beinvloedingsinstrument in een parlementair spel van checks and balances. Afhankelijk van de politieke verhoudingen van het moment in het semi-presidentiěle Franse stelsel (o.a. cohabitation) is het recht van amendement zowel door oppositionele politieke minderheden als door meerderheden uit de (permanent centrumrechts georiènteerde) Sénat frequent ingezet als legislatief vertragingswapen richting regering en Assemblée nationale. Hoezeer in Frankrijk rekening wordt gehouden met mogelijke hantering van het recht van amendement door een parlementskamer als politiek obstructiewapen, blijkt uit het gegeven dat de (grond)wetgever een waar scala aan juridische instrumenten aan de regering ter hand heeft gesteld (zoals ook o.a. het reeds besproken beheer van de wetgevingsagenda, maar ook de vote bloqué) om dreigende vertragings- c.q. omvormingseffecten tijdens het wetgevingstraject door middel van excessief gebruik van het recht van amendement zo veel mogelijk te kunnen pareren. Art. 40 Grondwet (acceptatie van amendementen wordt afhankelijk gesteld van de financiele gevolgen), art. 41 Grondwet (afbakening van het werkterrein van de wetgever in formele zin) en art. 44 lid 2 Grondwet (acceptatie van amendementen kan afhankelijk gesteld worden van voorafgaande bespreking in de vaste kamercommissies), alsmede de art. 44 lid $2^{54}$ en 48 lid $3^{55}$ Règlement du Sénat beogen de mogelijkheden tot onwelgevallige gebruikmaking van het recht van amendement in te dammen. Deze wetsartikelen blijken, met name ten tijde van divergerende partijpolitieke meerderheden (een situatie die sinds 1981 meer regel dan uitzondering blijkt te zijn), ook allerminst als dode letters beschouwd te worden. In een aantal

53. Art. 45 lid 1 Constitution 1958

54. Mogelijkheid tot het stopzetten van de wetgevingsprocedure indien een wetsvoorstel, danwel een gedeelte van een wetsvoorstel in strijd of tegenspraak lijkt te zijn met de grondwet, een organicke wet of een verdrag.

55. Niet toelaatbaarheid van amendementen die op geen enkele wijze in verband blijken te staan met de wettekst die in behandeling is 
gevallen worden, zoals beschreven in hoofdstuk 5, met gebruikmaking van art. 41 Grondwet, art. 44 lid 2 Grondwet en art. 44 lid 2 Règlement du Sénat zelfs grotere cohorten gebundelde amendementen afkomstig vanuit het Franse Hogerhuis door de regering buiten de verdere discussies rondom wetsvoorstellen gehouden. Politick rivaliserende bemoeienis van de kant van een oppositionele Sénat met het wetgevingsproduct wordt door de regering niet getolereerd. Slechts voor juridisch-assisterende activiteiten blijft blijkbaar wel altijd enige nimte aanwezig. Tijdens de jaren van sterke politieke polarisatie tussen regering en Assemblée enerzijds en Sénat anderzijds (met name $1981 \mathrm{t} / \mathrm{m} 1985$ en vanaf 1997) vond namelijk nog altijd ongeveer een kwart van de amendementen die werden ingediend door leden van het Hogerhuis hun weg naar de definitieve wettekst. Het betrof dan wel inderdaad nagenoeg uitsluitend amendementen van technische apolitieke aard, waarin de regering zich zonder meer wist en weet te vinden.

In het kader van het op partijpolitieke rivaliteit gebaseerde 'parlementaristische' relaas over de werking van het Franse tweekamerstelsel dient volledigheidshalve ook nog gewag gemaakt te worden van enig 'assisterend' senaatsgedrag optima forma dat eveneens deel uitmaakt van de moderne wetgevingspraktijk. Indien de partijpolitieke meerderheid van zowel Assemblée nationale als Sénat van centrumrechtse huize is en oppositionele minderheden in het Hogerhuis desondanks hun amenderend 'mondje' wensen te roeren met betrekking tot een voorstel tot wet, kan het proclameren van de 'question préalable positive' ex art. 44 lid 3 Règlement du Sénat voornoemde oppositie in één klap monddood maken. De Sénat bestrijdt daartoe gewoon in meerderheid formeel de opportuniteit van een voorliggend wetsvoorstel voorafgaande aan de plenaire behandeling en die behandeling zal niet meer plaatsvinden. Dit betekent dan geenszins dat het wetsvoorstel in kwestie in de prullenbak verdwijnt. Integendeel. De regering krijgt op die wijze namelijk de mogelijkheid tot verdere succesvolle en efficiënte afhandeling van het wetsvoorstel op een presenteerblaadje aangereikt.

Nauwelijks vergelijkbaar met de beschreven gang van zaken in Frankrijk is de bicamerale wetgevingspraktijk te Westminster. Uiteraard wordt ook in Groot-Brittannië het recht van amendement voor zowel de regeringspartij als de oppositie uit beide parlementskamers tot op bepaalde hoogte ingezet voor het bereiken van zuiver politieke doelen. De lat blijkt daarbij echter bij lange na niet zo hoog te liggen als in Frankrijk.

Gemiddeld genomen werd tot 1999 per parlementair jaar iets minder dan de helft van alle ingediende wetsvoorstellen door de Lords van amendementen voorzien. De laatste jaren is dat percentage toegenomen. Tenug bij het House of Commons wordt vervolgens bekeken of de door het Hogerhuis voorgestelde wetwijzigingsvoorstellen ook dáár in de voorliggende tekst geïncorporeerd kunnen worden. Wordt incorporatie om politieke of andersoortige redenen volgens de regering en het House of Commons niet wenselijk geacht, dan pleegt het Britse Hogerhuis als regel niet te persisteren waar het de aanname van door hen voorgestelde amendementen betreft, een attitude die normaliter los staat van de partijpolitieke verhoudingen van het moment. Indien de voorliggende wetsontwerpen de vrucht van beleidsprerogatieven uit het verkiezingsmanifest van de zittende regeringspartij blijken te zijn, wordt het beschreven gedragspatroon van politieke tenughoudendheid bij de uitoefening van het recht van amendement zoals wij gezien hebben volledig geregisseerd via de Salisbury Doctrine. Aangezien het House of Lords ten gevolge van de Acts of Parliament van 1911 en 1949 niet meer kon beschikken over een vetorecht betreffende wetgevingsvoorstellen en haar positie ook anderszins (gebrek aan democratische legitimatie) in feite sterk ondergeschikt was 
geworden aan het House of Commons, heeft zij halverwege de twintigste eeuw besloten regering en Commons bij de ten uitvoerlegging van de centrale verkiezingsbeloften niet meer wezenlijk te hinderen. Tegenwoordig heet het nog steeds dat 'the present House exemplifies a rather fine sense of just how awkward it can be without causing serious and significant problems to either Conservative or Labour governments'. ${ }^{56}$ De gang van zaken rondom de aanname van de 'European Parliamentary Elections Bill', zoals beschreven in hoofdstuk 4 van dit boek, markeert dienaangaande de uiterste grens.

Voor het House of Lords blijkt het accent bij het hanteren van een amendementsrecht dan ook veeleer te liggen op het vlak van de juridisch inhoudelijke kwaliteitsverbetering. Daarbij dient zeker niet uit het oog verloren te worden dat als uitvloeisel van de formeel monistische Britse structuur ook in de senaatskamer altijd leden van de zittende regering prominent zitting zullen hebben. Amendementen afkomstig uit het Britse Hogerhuis plegen mede vanuit die achtergrond frequenter dan in het Palais de Luxembourg de neerslag te zijn van actief en constructief meedenken met de regering en diens automatische meerderheid in het House of Commons, los van politieke kleur.

Wat leert ons dit alles zo ver? Een wetgevingcheck uit te voeren door de senaatskamer, blijkt in alle vier de onderzockslanden op duidelijk te onderscheiden wijzen te geschieden. Indien een zekere mate van dualisme voor de praktische tenuitvoerlegging van het bicamerale gedachtegoed inzake wetgevingsontwikkeling als vanzelfsprekende norm beschouwd zou moeten worden, lijken de Bundesrat en de Sénat, naar het zich tot nu toe laat aanzien, beter te voldoen dan het House of Lords en de Eerste Kamer. Vooral het House of Lords lijkt zich vrijwel volledig geschikt te hebben in een 'assisterende' rol waar heroverweging van wetsvoorstellen in het geding is.

De neiging om partijpolitieke rivaliteit via amendementen om te zetten in daden blijft vooral in de Franse parlementaire omgeving onverkort aanwezig. doch de Franse regering blijkt te kunnen beschikken over een indrukwekkend arsenaal aan staatsrechtelijke instrumenten waardoor zij bijzonder adequaat in staat gesteld wordt om voornoemde neiging professioneel te kanaliseren.

Definitief beoordelen in hoeverre de vier senaatskamers in vergelijkende zin in staat zijn zinvol uitvoering te geven aan hun heroverwegende taken op het terrein van de wetgeving. kan uiteraard echter pas indien tevens de werking van de respectievelijke conflictenregelingen in het geheel verdisconteerd wordt.

\subsubsection{Conflictenregeling}

Zowel de Franse als de Duitse Grondwetgever hebben 'grondig' werk gemaakt van het ontwerpen van een regeling die er in voorziet patstellingen tussen beide parlementskamers op het vlak van de wetgevingsontwikkeling tot een oplossing te brengen. In Groot-Brittanniê is relatief eenvoudig een politieke oplossing gezocht en gevonden op het moment dat voornoemde problematiek manifest werd. Het Nederlandse tweekamerstelsel blijkt nog altijd te kunnen functioneren zonder een conflictenregeling.

Laat ik allereerst aandacht besteden aan de handelswijze rondom wetgevingsconflicten in Parijs en Berlijn. 


\section{Hoofdstuk 8}

De Franse grondwetgever van de 5e Republiek heeft, enerzijds doordrongen van het historisch gegeven dat het recht van amendement een plaats heeft in de wortels van de Franse 'parlementaristische' democratie, doch zich anderzijds ook ten volle bewust van het gegeven dat wetgevingsprocessen maar beter voltooid kunnen worden $^{57}$, een duidelijk uitgewerkte conflictenregeling in de Grondwet verankerd. Art. 45 lid 1 Constitution 1958 stelt dat de Franse parlementskamers wetgeving slechts tot stand kunnen brengen via aanname van een identieke wettekst. Indien er onenigheid blijft bestaan over het wetsvoorstel als geheel of gedeelten daanuit, treedt de 'navette' in werking. De wettekst circuleert in dat geval normaliter tot twee maal tussen de Assemblée nationale en de Sénat opdat gepoogd kan worden volledige toestemming te bereiken. Daarna kan een conciliatiecommissie in het leven geroepen worden. In het geval de regering formeel aangeeft haast te hebben met definitieve aanname van het wetsvoorstel ('I'urgence' ex art. 45 lid 2 Constitution 1958) wordt deze 'Commission Mixte Paritaire' na minimaal één lezing in beide parlementskamers al samengesteld. Het eindproduct van een 'Commission Mixte Paritaire' kan vele vormen aannemen. Het voorstel zoals aangenomen door de Assemblée nationale kan integraal overgenomen worden. Hetzelfde geldt vanzelfsprekend ook voor het oorspronkelijke senaatsvoorstel. Zeker is in ieder geval dat eventuele amendementen afkomstig uit de koker van de "Commission Mixte Paritaire' slechts onderdeel van een eindvoorstel uit kunnen maken, indien deze geaccordeerd zijn door de regering. ${ }^{58}$

Als de Commission Mixte Paritaire, waarin een gelijk aantal afgevaardigden uit beide parlementskamers conform de geldende partijpolitieke verhoudingen zitting pleegt te hebben, er ook niet uit komt, mag uiteindelijk de (regeringsgezinde meerderheid van de) Assemblée nationale op verzoek van de regering definitief beslissen via 'le dernier mot' ex art. 45 lid 4 Constitution 1958. De Sénat kan in dat laatste geval als medewetgevend orgaan verder dus volledig buitenspel worden gezet. Het gecombineerde gebnik van conciliatie en 'le dernier mot' blijkt in de Franse wetgevingspraktijk, zij het afhankelijk van de partijpolitieke verhoudingen van het moment, een spilfunctie te kunnen vervullen. Met name wanneer conflicten tussen beide parlementskamers direct te herleiden zijn tot het gegeven dat sprake is van divergerende partijpolitieke meerderheden, een situatie die sinds 1981 meer regel dan uitzondering blijkt te zijn, ${ }^{59}$ wordt voornoemde procedure regelmatig gevolgd. Van alle wetgevingsvoorstellen die tijdens de vijfjarige periode tussen 1981 en 1986 de eindstreep haalden, liep niet minder dan $40 \%$ via 'le dernier mot'. Tijdens de tweede periode dat de in hoofdzaak centrumrechtse Sénat zich geconfronteerd zag met een door socialisten gedomineerde Assemblée nationale (1988-1993) kon $29 \%$ van de wetgevingsvoorstellen slechts tot wet verheven worden na gebruikmaking van de procedure ex art. 45 lid 4 Constitution 1956. Ook tijdens de huidige regering Jospin wordt tot $30 \%$ van alle Franse wetgeving in formele zin afgehandeld op de beschreven wijze. Ter vergelijking: in de zes jaar dat tussen 1981 en 2001 sprake was van grote partijpolitieke congruentie tussen beide Franse parlementskamers werd slechts 1,1\% van alle wetgeving in formele zin afgedwongen via de gewraakte procedure. ${ }^{60}$ In die jaren

57. De IVe Republick was immers onder meer gestrand omdat opeenvolgende regeringen niet of nauwelijks in staat bleken in samenwerking met het parlement regeigeving tot stand te brengen.

58. Art. 45 lid 3 Constitution 1958.

59. Hiervan was sprake ten tijde van de regeringen Mauroy (1981-1984, Fabius (1984-1986), Rocard (19881991), Cresson (1991-1992), Bérégovoy (1992-1993) en Jospin (1997-2002).

60. Senat Français, http:/www. fr/presentation/live3/livre39.html, 30-11-2000. 
werd het recht van amendement in de Franse Sénat in sterke mate 'assisterend' aangewend ter precisering en verbetering van voorstellen tot wet. Ter illustratie: tijdens het cerste jaar dat de centrumrechtse regering Balladur zaken mocht doen met een centrumrechtse meerderheid in beide parlementskamers werden er 2733 amendementen door de Sénat voorgesteld en aangenomen. Van deze amendementen werden er niet minder dan $2349(86 \%)$ zonder verdere discussie opgenomen in de definitieve wetteksten. ${ }^{61}$

Het grote belang van het activeren van conciliaticcommissies blijkt voor de Franse regering niet zo zeer gestoeld te zijn op enige vorm van bicameraal gedachtegoed, doch veeleer op cen als zodanig ervaren noodzaak om (door de regering niet als constructief ervaren) wetgevingsbemoeienis van oppositionele groeperingen in de Sénat te kanaliseren.

Of deze conclusie ook op kan gaan in de Bondsrepublick Duitsiand waar conciliatie tussen Bundestag en Bundesrat via de 'Vermittlungsausschuss' eveneens een gangbare procedure is geworden, valt nog te bezien. De Duitse bemiddelingscommissie die evenals de 'Commission Mixte Paritaire' is samengesteld uit een gelijk aantal leden van beide parlementskamers (op Bondsniveau) moét geconsulteerd worden indien door de Bundesrat 'Einspnuch' tegen een wetsvoorstel ex art. 77 Abs. 2 GG aangetekend wordt. Indien het wetsvoorstel valt onder de categorie die getroffen kan worden door een absoluut veto van de Bundesrat (zoals aangegeven is dit tegenwoordig bij ongeveer $60 \%$ van de voorstellen het geval) mág de 'Vermittlungsausschuss' in actie komen. Hiertoe kan niet (zoals in Frankrijk) slechts de regering het initiatief nemen. Ook de Bundestag en de Bundesrat zijn daartoe onafhankelijk van elkaar gerechtigd. De definitieve beslissing over de levensvatbaarheid van een voorliggend eindvoorstel uit de koker van de 'Vermittlungsausschuss' kan in de Bondsrepubliek door de regering niet exclusief in handen van de Bundestag worden gelegd. Een equivalent van 'le dernier mot' is in het Duitse staatsrecht met betrekking tot 'zustimmungsbedürftige' wetsvoorstellen onbekend. Een dergelijke beslissing ligt in handen van Bundestag én Bundesrat. Sinds 1949 blijkt $10,8 \%$ van alle wetten die op Bondsniveau tot stand werden gebracht via de 'Vermittlungsausschuss' te zijn gelopen. ${ }^{62}$ Van de inmiddels ruim 750 wetsvoorstellen die geheel of gedeeltelijk door de Bondsduitse conciliatiecommissie onder de loep werden genomen, haalde $84 \%$ uiteindelijk in aangepaste vorm de eindstreep. De belangrijkste motor achter dit Bondsduitse bicamerale wetgevingssucces is het gegeven dat Bundestag en Bundesrat via met name de 'Zustimmungsbedürftigkeit' voor het gros der wetgevingsvoorstellen als het ware tot elkaar veroordeeld zijn. De reeds eerder geconstateerde preventieve werking die van het eventueel door de Bundesrat uit te oefenen absoluut vetorecht uit kan gaan op de wil tot samenwerken, speelt ook tijdens de formele conciliatiefase ontegenzeggelijk wederom een rol van betekenis. Iedere vergelijking met de Franse situatie loopt op dit punt dan ook mank. Collegasenatoren die als vertegenwoordigers van de Sénat zitting hebben in de 'Commission Mixte Paritaire' zullen immers altijd moeten werken aan legislatieve compromissen in de wetenschap dat de Assemblée nationale ná conciliatie nog altijd 'le dernier mot' kan krijgen van de partijpolitieke geestverwanten in de regering.

Het verband tussen de legislatieve succesquote van de Duitse conciliatieprocedure en de 'veroordeling tot elkaar' is relatief duidelijk te onderbouwen met kwantitatieve gegevens. De gehele periode tussen 1949 en 2001 overziend, blijkt dat tussen 1972 en 1976 de meeste

62. http $: /$ www bundesrat de PdundF/index html, 18-2-2001. 
behoefte aan conciliatie via de 'Vermittlungsausschuss' bestond (104x). Dit leek ook allerminst vreemd, aangezien in die jaren niet alleen sprake was van sterke partijpolitieke polarisatie tussen de regerende SPD/FDP-coalitie Schmidt/Genscher enerzijds en de CDU/CSUoppositie anderzijds, doch daarenboven die christendemocratische oppositiepartijen in de Bundesrat ook nog eens over een permanente meerderheid beschikten. De periode 1987-1990 liet het spiegelbeeld zien. Een krachtige CDU/CSU/FDP-regering onder Helmut Kohl tegenover een vrij zwakke SPD-oppositie in combinatie met een riante meerderheid voor de Christen Democraten in zowel Bundestag als Bundesrat. Gevolg: de 'Vermittlungsausschuss' werd slechts 13 maal bijeen geroepen. Tot zover volmaakt logische ontwikkelingen die perfect sporen met de gang van zaken zoals beschreven met betrekking tot de 'Commission Mixte Paritaire'. Kijken wij echter naar de mate waarin bemiddeling door de Duitse conciliatiecommissie tijdens de beide genoemde kabinetsperioden succesvol was, dan blijkt van enig significant verschil geen sprake meer te zijn. Tussen 1972 en 1976 was bemiddeling door de 'Vermittlungsausschuss' in $85,5 \%$ van de gevallen succesvol. Voor de periode 1987-1990 was dat $84,6 \%$. Onthullende gegevens. Gegevens die aantonen dat de werking van de bicamerale wetgevingsmachinerie in de Bondsrepubliek beduidend minder sterk dan in Frankrijk afhankelijk blijkt te zijn van de partijpolitieke verhoudingen van het moment.

'Die Tatsache dass der Bundesrat bei zustimmungsbedürftigen Gesetzen nicht überstimmt werden kann, hat wesentlich dazu beigetragen, dass ihm im politischen Kräftefeld bei der Gesetzgebung eine gewichtige Stellung zukommt ${ }^{63}{ }^{63}$ Rivaliserend bicameralisme pur sang. In de periode 1949-1999 werden er van de 5401 'Zustimmungsbedürftige' voorstellen tot wet die beide Bondsduitse parlementskamers passeerden 133 (2,4\%) door een absoluut veto van de Bundesrat getroffen. Vooral de eerste acht jaar na de hereniging van de BRD en DDR werd de 'Zustimmung' relatief frequent (in totaal 43 maal) geweigerd door de Bundesrat. ${ }^{64} \mathrm{Al}$ met al blijkt de Bundesrat het ultieme legislatieve machtsmiddel ex art. 77 GG echter niet vaak te (hoeven) hanteren: 'In den meisten Fällen kommt es schon deshalb nicht zur Verweigenung der Zustimmung, weil die Bundesregienung bereits bei Ausarbeitung der Vorlage und später dann der Bundestag bei seinen Beratungen der starken Position des Bundesrates Rechnung tragen. Wenn ein Gesetz zustimmungsbedürftig ist, wird der Bundestag schon von vornherein geneigt sein, den vom Bundesrat vorgebrachten Wünschen nachzukommen, um die Zustimmung des anderen Hauses nicht in frage zu stellen', ${ }^{65}$

Waarmee wij zijn aangekomen in Nederland. De Eerste Kamer is, zoals gezegd, gerechtigd álle wetgevingsvoorstellen in formele zin met een absoluut veto te treffen. In de praktijk gebeurt dit ook in Nederland echter nauwelijks. Zelfs de toch bescheiden Bondsduitse 'Verweigerungsquote' van $2,4 \%$ is nog beduidend hoger dan de Nederlandse. In Nederland werden tussen 1945 en mei 2001 in totaal 47 wetsvoorstellen getroffen door een absoluut veto van de senaatskamer, hetgeen neer komt op een percentage van nog geen $0,3 \%$. Terwijl de verklaring voor het lage percentage in de Bondsrepubliek ontegenzeggelijk schuil gaat in de werking van de hierboven beschreven 'systemgewollte Dualităt', ${ }^{66}$ moet de oorzaak in Nederland juist gezocht worden in een vrijwel totale áfwezigheid van inhoudelijk dualisme tussen de Eerste

63. G. Ziller, und G-B. Oschatz, a.w., p. 39.

64. http://www. bundesrat.de/PDundF/zahlenspiegel.html, 7-7-2001.

65. G. Ziller und G-B Oschatz, a.w., p. 38.

66. R. Dolzer und M. Sachs, Das parlamentarische Regienungssystem und der Bundesrat, Entwicklungsstand und Reformbedarf, Berlin 1999, p. 20. 
Kamer enerzijds en regering/Tweede Kamer anderzijds. De afwezigheid van een formele regeling (als alternatief voor het definitief wegstemmen van een voorstel) ter oplossing van conflicten tussen beide partijen over vorm en/of inhoud van voorliggende wetteksten blijkt in Nederland het centrale element te zijn. Alles of niets, dat is de enige keuze die de Eerste Kamer heeft. Geen amendering, geen conciliatie. In 'semi-formele'b' zin wordt slechts de mogelijkheid tot het 'bevorderen' van een novelle in zeldzame gevallen gedoogd.

Dat de Eerste Kamer vrijwel nooit gebruik kan maken van het absoluut vetorecht heeft een tweetal hoofdoorzaken. De eerste oorzaak schuilt in het gegeven dat in de regel jaren van noeste wetgevingsarbeid op departementen, bij de Raad van State en in de Tweede Kamer vooraf plegen te gaan aan het moment waarop de Eerste Kamer 'op gene dinsdag' het wetsvoorstel aangereikt krijgt, waarna op grond van art. 85 jo 81 Grondwet in principe slechts tot definitieve integrale aanname dan wel definitieve integrale verwerping besloten kan worden. Het volmaakte spiegelbeeld derhalve van de Bondsduitse situatic. Daarbij kan gevoegd worden dat een wetgevingsvoorstel in formele zin tegenwoordig vrijwel nergens meer (en dus ook niet in Nederland) beschouwd zal kunnen worden als een zuiver op zichzelf staand product. In de regel is de samenhang met een scala aan andere overheidsregelingen, afspraken, nota's en andersoortige beleidsuitingen ronduit groot te noemen. Onder die omstandigheden 'op gene dinsdag' als kamer van heroverweging definitief 'neen' zeggen tegen een regeringsvoorstel tot wet is geen eenvoudige opgave. ${ }^{68}$ Dan moet het wetgevingsvoorstel toch wel echt 'rammelen'.

De tweede oorzaak is van partijpoliticke aard. Druk vanuit de Nederlandse regering via de fracties der coalitiegenoten op basis van politieke argumentatie, ultima ratio soms zelfs culminerend in het opwerpen van het 'onaanvaardbaar' door de Minister staat, zo heeft de geschiedenis duidelijk uitgewezen, garant voor een verder niet-persisterende attitude der Eerste Kamer-leden waar het vetorecht in het geding is. Het belang van een stevige mate aan partijdiscipline moet in dat kader ook bepaald niet uitgevlakt worden.

Tijdens de laatste zittingen van de Eerste Kamer vóór het zomerreces van 2001 werd weer eens fraai geètaleerd hoe de machtsverhouding tussen regering en senaatskamer inzake aanname van voorstellen tot wet in formele zin in elkaar zit. Voorstellen voor een tijdelijk correctief referendum, een burgemeestersreferendum en herindeling van groot Den Haag oogsten veel kritiek in de Eerste Kamer. Het leek, afgaande op de plenair gespuide kritiek ondenkbaar dat alle drie de voorstellen het zouden kunnen halen. Stevige druk vanuit vooral de VVD-top (met name de VVD-fractie in de Eerste Kamer lag dwars) én de regering. gecombineerd met een minimale 'novelle-achtige' toezegging van de Minister inzake het burgemeestersreferendum bleken uiteindelijk echter al voldoende om de voorstellen aangenomen te krijgen. ${ }^{69}$

De Nederlandse staatsrechtelijke constellatie rondom de werking van een tweekamerstelsel inzake wetgevingsheroverweging overziend (absoluut vetorecht voor de Eerste Kamer betreffende alle wetsvoorstellen in formele zin gecombineerd met de afwezigheid van zowel een recht van amendement voor de senaatskamer als een conflictenregeling), kan slechts gecon-

67. In de marge spelen daarnaast (zie hoofdstuk 6) een aantal beinvioedingsmechanismen van meer informele aard een rol, zoals de toezegging, het vervolgdebat, dreigen toestemming te onthouden aan EU-besluiten e.d.

68. In die zin ook: E. Jurgens, Boekbeschouwingen, De staatsrechtelijke positie van de Eerste Kamer, Themis 2001, p. 287-288.

69. Handelingen Eerste Kamer 2000-2001, 25444, p. 1531-1552, p. 1585-1603, p. 1612-1628, p. 1669-1672 en p. 1691 . 
cludeerd worden dat ook het Nederlandse bicameralisme formeel gekenmerkt wordt door enige vorm van: 'systemgewollte Dualitat', zij het een opvallend weinig doelmatige. Regelmatige actie van rivaliserende aard vanuit de Eerste Kamer is zoals wij gezien hebben 'not done'. Hondervijttig jaar van Nederlandse bicamerale wetgevingspraktijk hebben dat ruimschoots aangetoond. Indien toch zo nu en dan een wetsvoorstel door toedoen van de Eerste Kamer naar de prullenbak wordt verwezen, betreft het al gauw thema's met slechts regionaal belang (herindelingen e.d.) of thema's die het eigen belang van de Eerste Kamer op enigerlei wijze raken.

Enige praktische nimte tot 'assistentie' bij de vervolmaking van het wetgevingsproduct naar zowel Frans, Duits als Brits voorbeeld, is de Nederlandse senatoren vreemd genoeg nooit verleend door de Grondwetgever. Des te opmerkelijker is het dat zowel vanuit de Nederlandse politiek als de wetenschap desondanks toch nog altijd steevast gewezen blijft worden op zin en noodzaak van een blijkbaar op papier bestaand takenpakket voor de Eerste Kamer dat duidelijk juist sterk 'assisterend' van aard is. Rechtmatigheidtoetsing, specifieke aandacht voor aspecten van rechtstatelijkheid, toetsing aan de constitutie, controle op juridisch-technische aspecten, consistentie, relatie tot het internationale recht, maatschappelijk draagvlak enz. Wetsvoorstellen zullen in voorkomende gevallen wellicht grondig en kritisch onderzocht worden met het oog op al deze zaken, maar vervolgens moet toch als regel gewoon standaard volledig ongewijzigde aanname van de voorliggende wettekst volgen.

Deze Nederlandse, al met al toch zo goed als inhoudsloze variant van bicamerale 'Systemgewollte dualităt' is, voor zover betrekking hebbend op de medewetgevende taakstelling van de Eerste Kamer, uitsluitend te verklaren vanuit een staatsrechtelijke anomalie en wel een anomalie die nog stamt uit de tijd van Thorbecke: Koning en Eerste Kamer versus Tweede Kamer. Dat anno 2001, nuim 150 jaar later en vanuit een meer dan volledig veranderde politiek-maatschappelijke realiteit toch nog steeds op dezelfde, vanuit rechtsvergelijkend perspectief bekeken nagenoeg zinloze wijze gewerkt moet worden, vindt zijn oorzaak eveneens in de Grondwet. Iedere wijziging behoeft een gekwalificeerde tweederde meerderheid in beide parlementskamers. En de Eerste Kamer houdt niet erg van grondwetswijzigingen, zo heeft de Nederlandse parlementaire geschiedenis inmiddels wel aangetoond, zeker wanneer die wijzigingen de Eerste Kamer zélf kunnen betreffen.

Tenslotte de Britse methode om conflicten tussen de parlementskamers met betrekking tot voorstellen tot wetgeving in formele zin op te lossen. Daarover kunnen wij kort zijn. Het House of Commons heeft alle troeven in handen. 'Money Bills' behoren in feite tot het exclusieve domein van het Britse Lagerhuis terwijl de overige voorstellen (inclusief bijvoorbeeld een voorstel tot afschaffing van het Britse Hogerhuis) tot wet slechts maximaal éen jaar door het House of Lords tegengehouden kunnen worden. Vanuit die wetenschap beperken de Britse senatoren zich, uitzonderlijke gevallen (European Parliamentary Elections Bill) daargelaten, dan ook vrijwel uitsluitend tot zuiver assisterend medewetgevend gedrag via met name adequate hantering van het recht van amendement. Daarbij blijken zij. zeker op een aantal specifieke beleidsterreinen waaronder bijvoorbeeld EU-regelgeving, een hoge mate aan expertise ontwikkeld te hebben.

Daarover echter zo dadelijk meer in het derde gedeelte van dit rechtsvergelijkende hoofdstuk, dat de bestuurscontrole door senaatkamers tot onderwerp zal hebben. 


\subsubsection{Samemvattend}

De belangrijkste bevindingen uit de voorgaande rechtsvergelijkende paragrafen alvast kort samenvattend, kan gesteld worden dat heroverweging van wetsvoorstellen door de senaatskamer anno 2001 grotendeels plaats blijkt te vinden onder regie van de regering. De vier senaatskamers die hun heroverwegende taken in theorie uitvoeren vanuit een dualistische conceptie blijken in de parlementaire praktijk vooral 'assisterende' juridisch-technische en juridisch-dogmatische activiteiten te ontplooien. Slechts voor de Nederlandse situatie kan deze conclusie niet getrokken worden, nu aan de Eerste Kamer de instrumenten om effectief 'assisterend' actief te kunnen worden eenvoudig formeel ontzegd zijn en zij ook in de parlementaire praktijk de noodzakelijke ruimte daartoe nagenoeg volledig ontbeert.

Politicke 'rivaliserende' activiteiten vanuit de heroverwegende senaatskamer worden consequent de kop in gednukt (Frankrijk) of gewoon niet gedoogd (Groot-Brittanniè en Nederland). Uitsluitend in de Bondsrepubliek is de senaatskamer bij machte om bij de wetgevingsheroverweging zowel politiek-beleidsmatige 'rivaliserende' als juridisch-dogmatische en juridisch-technisch 'assisterende' overwegingen een rol te laten spelen. Het is zeker niet exclusief de federatieve structuur van de Bondsrepubliek waardoor voornoemd verschil in praktische werking is veroorzaakt. Dat is evenzeer een bijzonder goed doordacht systeem van op elkaar inwerkende rechtsregels rondom de Bondsduitse wetgevingsprocedure vanaf de 'erste Durchgang', via sterk geprofessionaliseerde vaste kamercommissies en een 'zweite Durchgang' tot en met de eventuele eindstemming over een advies van de 'Vermittlungsausschuss'.

Van een sterke relatie tussen een deugdelijke democratische legitimatie voor de senaatskamer enerzijds en beìnvloedend medewetgevend functioneren van diezelfde senaatskamer anderzijds, blijkt geen sprake te zijn. De democratisch zeer deugdelijk gelegitimeerde Eerste Kamer staat materieel medewetgevend immers vrijwel buitenspel, terwijl het totaal niet democratisch gelegitimeerde House of Lords in assisterende zin tegenwoordig relatief stevig aan de legislatieve weg mee blijkt te kunnen timmeren. Factoren als 'tijd' en (langdurig aanwezige en zich daardoor verder ontwikkelende) 'expertise' spelen daarbij een belangrijke rol.

\subsection{Bestuurscontrole}

\subsubsection{Inleiding}

Zoals wij in de vorige paragraaf gezien hebben ligt het accent met betrekking tot de praktische invulling van het takenpakket van de senaatskamer relatief sterk op het vlak van de wetgevingsheroverweging. In een land als Nederland blijkt de senaat in de praktijk zelfs vrijwel alle beschikbare tijd te spenderen aan een check van het wetgevingsproduct in wording. Bicameralisme, zo wil de theorievorming rondom dit thema, impliceert echter méér dan zuivere wetgevingsheroverweging. ${ }^{70}$ De senaatskamer maakt immers onlosmakelijk deel uit van het nationale parlement en het parlement als geheel zou in de moderne parlementaire democratie

70. Zie daartoc o.a: S.C. Patterson and A. Mughan, Senates, Bicameralism in the contemporary World, Ohio State University 1999: M. Russell, Reforming the House of Lords, Lessons from Overseas, Oxford 2000; J. Mastias et J. Grangé, Les Secondes Chambres du Parlement en Europe Occidentale, Paris 1987, H.W, Blom, Bicameralisme, Tweekamerstelsels vroeger en nu, Handelingen van de Internationale Conferentie ter gelegenheid van het 175-jarig bestaan van de Eerste Kamer der Staten-Generaal, Den Haag 1992. 
eerst en vooral ook het regeringsbeleid in al haar uitingsvormen moeten controleren, 'Checks and Balances'. Daar stuiten wij echter op een praktisch probleem dat implicaties zou kunnen hebben voor het controlerend functioneren van senaatskamers. De vanzelfsprekende contemporaine partijpolitieke verwevenheid tussen zittende regeringen enerzijds en een 'entscheidungsfahige' meerderheid van de eerste nationale parlementskamer anderzijds, blijkt de onafhankelijkheid van voornoemde controle in alle vier de onderzoekslanden tegenwoordig namelijk serieus onder druk te zetten. Strakke partijdiscipline regeert immers in zowel de Bundestag, het House of Commons, de Assemblée nationale als de Tweede Kamer tegenwoordig nagenoeg absoluut, met alle logische gevolgen voor de onafhankelijkheid van de bestuurscontrole van dien. Voor zover de verhouding regering-eerste parlementskamer dan nict ook al reeds staatsrechtelijk-theoretisch monistisch gefundeerd was (Groot-Brittanie), is voornoemde verhouding in politiek-praktische zin in ieder der vier landen heden ten dage ontegenzeggelijk als zodanig te classificeren. Waarmee zeker in theorie numte geschapen wordt voor een tweede, partijpolitick minder strak opererende parlementskamer om een rol te spelen in dit spel van checks and balances: "The most fundamental and simple justification for the existence of a second chamber is that it acts to prevent the excessive concentration of power in the hands of a single institutional actor and compensates for the apparent deficiencies elsewhere in the system. In theory, second chambers do this by checking the power of an ascendant chamber whilst providing the legislature as a whole with a additional tier or extra dimension to offset the power of the executive'?

In deze laatste paragraaf van dit rechtsvergelijkend hoofdstuk zal met name aandacht besteed worden aan die activiteiten van de senaatskamers in de vier onderzoekslanden die niet onder de noemer van medewetgeving plegen te vallen; activiteiten die grotendeels gevangen kunnen worden onder de noemer 'bestuurscontrole'. Zowel vertrek- en eindpunt als centraal thema voor de bespreking van de bestuurscontrolerende taakstelling door de senaatskamer vormt de reikwijdte van de ministeriële verantwoordelijkheid in de verhouding regering-senaat. Daarbij zal de aan- of afwezigheid van een al dan niet functionerende vertrouwensregel als mogelijk sluitstuk voor die ministerielle verantwoordelijkheid uiteraard prominent meegenomen worden. Als onderdeel van die bespreking wordt eveneens aandacht besteed aan de belangrijkste activiteiten die de senaatskamers van de vier onderzoekslanden plegen te ontplooien om vanuit een heden ten dage vanzelfsprekend sterk monistisch getinte politieke werkomgeving toch handen en voeten te kunnen geven aan de bestuurscontrolerende taakstelling.

\subsubsection{Ministeriele verantwoordelijkheid}

In het kader van dit boek is vanzelfsprekend vooral van belang te bepalen in hoeverre het leerstuk van de ministerièle verantwoordelijkheid praktische gelding blijkt te hebben in de relatie regering-senaatskamer. Ter beantwoording van die vraag acht ik het bepaald zinvol allereerst te vergelijken in hoeverre regeringshandelen door de respectievelijke senaatskamers uiteindelijk als uitvloeisel van de werking der politieke ministeriele verantwoordelijkheid daadwerkelijk gesanctioneerd blijkt te kunnen worden. Anders gezegd: in hoeverre verschillen de reikwijdte en de gelding van de vertrouwensregel in de relatie regering-senaatskamer per onderzoeksland? Deze verschillen blijken substantieel te zijn. Ook op dit terrein is de ene

71. P. Carmichael, and A. Baker, Second Chambers, A Comparative Perspective, in: The House of Lords, Its Parliamentary and Judicial Roles, Oxford 1999, p. 71-72. 
senaatskamer absoluut de andere niet. De Bundesrat en het House of Lords moeten hun bestuurscontrolerende taken onder de paraplu van de politicke ministericle verantwoordelijkheid uitvoeren zonder de mogelijkheid te hebben regeringshandelen op enigerlei wijze formeel te sanctioneren. In feite geldt vrijwel hetzelfde voor de Franse Sénat. Weliswaar omvat het Franse staatsrecht sinds 1958 tevens de mogelijkheid voor de senaatskamer tot het uitspreken van een formele 'approbation d'une déclaration de politique générale', ${ }^{12}$ doch over deze instemming of goedkeuring kan door de Sénat uitsluitend vergaderd en gestemd worden indien de Premier Ministre expliciet daarom verzocht heeft. Slechts hij kan het initiatief nemen tot het opstarten van de procedure die moet leiden tot het al dan niet uitspreken door de Sénat van formeel vertrouwen aangaande de voorgelegde beleidskeuzes. Vrijwel een halve eeuw van parlementaire geschiedenis onder het regime van de Vijfde Republiek heeft genoegzaam aangetoond dat een dergelijk formeel verzoek ex art. 49 lid 4 Constitution 1958 slechts dán door de Franse regeringsleider aan de Sénat gericht zal worden indien hij volkomen zeker is dat de uitkomst positief zal zijn. In de regel betekent dit dat slechts om senatoriale 'approbation' wordt gevraagd indien de partijpolitieke kleur van regering en senaatsmeerderheid in overeenstemming is. De allerminst oninteressante vraag op welke wijze een Franse regeringsleider zou reageren indien de Sénat desgevraagd zou weigeren het vertrouwen ex art. 49 lid 4 Constitution 1958 uit te spreken blijft daarmee (vooralsnog) helaas onbeantwoord.

Nederland is het enige van de vier onderzoekslanden waar geen enkele formeel-staatsrechtelijke drempel is opgeworpen ter inperking van de werking van de vertrouwensregel in de relatie regering-senaatskamer. Deze vertrouwensregel geldt theoretisch dan ook 'in volle omvang in het verkeer tussen de Eerste Kamer en de benoemde leden van de regering', zoals de Vries terecht stelt in zijn recente dissertatie over de staatsrechtelijke positie van de Eerste Kamer. ${ }^{73}$ Zijn motivering: "het onverkort veronderstellen van een ongeschreven vertrouwensrelatie tussen de Eerste Kamer en de benoemde leden van de regering is noodzakelijk om de Eerste Kamer met vnucht een rol te kunnen laten spelen als medewetgevend orgaan en controleur van de regering. Zonder deze ongeschreven constitutionele stok achter de deur zouden de werkzaamheden slagkracht ontberen. Dat nu is vanuit het belang van een krachtige parlementaire democratie niet wenselijk' ${ }^{74}$

Deze motivering spoort mijns inziens in het geheel niet met de parlementaire praktijk. Terzijde zij allereerst al opgemerkt dat indien voomoemde motivering daadwerkelijk steekhoudend zou zijn, dat het beleidscontrolerend functioneren van andere senaatskamers zoals de Bundesrat, het House of Lords en ook de Sénat Français al gauw in een apart, minder daadkrachtig daglicht zou zetten. Immers, deze eveneens vanuit een parlementair stelsel functionerende senaatskamers moeten het bij de uitvoering van hun medewetgevende en bestuurscontrolerende taakstelling toch ontegenzeggelijk stellen zonder dit sluitstuk van de ministerięle verantwoordelijkheid, de in volle omvang geldende vertrouwensregel.

Op dit punt aangekomen acht ik het wel wenselijk cen duidelijk onderscheid te maken tussen de taakstelling van de senaatskamer 'als medewetgevend orgaan en controleur van de regering'. Allereerst besteed ik aandacht aan de medewetgevende taakstelling van de senaatskamer in het licht van de ministeriêle verantwoordelijkheid.

\footnotetext{
72. Art. 49 lid 4 Constitution 1958.

73. F. de Vries, dissertatic, a.w., p. 370.

74. Idem, p. 371.
} 
Daarbij expliciet verwijzend naar hetgeen reeds opgemerkt is over het medewetgevende functioneren der vier senaatskamers, zij op deze plaats nogmaals opgemerkt dat de 'rivaliserende' slagkracht van de senaat vanuit haar rol van medewetgever vooral bepaald blijkt te worden door de mate waarin een effectief juridisch beìnvloedingsinstrumentarium aan de tweede parlementskamer ter beschikking is gesteld (schoolvoorbeeld: Bondsrepubliek Duitsland). Verder kon op geen enkele wijze aangetoond worden dat de aanwezigheid van een in volle omvang activeerbare vertrouwensregel de medewetgevende slagkracht van de senaatskamer effectief ten goede kan komen. In tegendeel. De activeerbare vertrouwensregel blijkt in het kader van het legislatieve proces zoals gezegd slechts in Nederland staatsrechtelijke realiteit te zijn en dus gehanteerd te kunnen worden in de relatie regering-senaat. Weliswaar heeft de parlementaire praktijk in Nederland inderdaad onomstotelijk uitgewezen dat van een activering van de vertrouwensregel in de relatie Eerste Kamer-regering ook tegenwoordig nog sporadisch sprake blijkt te zijn, doch de vraag die daarbij dan wel tegelijkertijd gesteld moet worden is natuurlijk: 'wie activeert eigenlijk die vertrouwensregel?' En dan blijkt dat dit oorspronkelijke parlementaire recht, 'de ultieme stok achter de deur', in de relatie regeringEerste Kamer uitsluitend nog geactiveerd pleegt te worden door (leden van) de regering, via het uitspreken van een 'onaanvaardbaar', ${ }^{75}$ Met name eind tachtiger jaren van de vorige eeuw hebben leden van de kabinetten Lubbers II en Lubbers III meer dan eens aangegeven initiatieven tot wetaanpassingen of voorstellen tot integrale intrekking van (reeds door de Tweede Kamer goedgekeurde) voorstellen, opgeworpen vanuit de Eerste Kamer niet te willen accepteren. Dreigen met hantering van het vetorecht door de Nederlandse senaatskamer werd beantwoord met de geformaliseerde dreiging ('onaanvaardbaar') vanuit de regering de betreffende ministerspost wegens klaarblijkelijk gebrek aan vertrouwen in de Eerste Kamer ter beschikking te zullen stellen, indien de senatoren in meerderheid voet bij stuk zouden hou$\operatorname{den}^{76}$ De Eerste Kamer is gegeven de contemporaine politieke realiteit op het Binnenhof vervolgens standaard de partij gebleken die zich volledig schikte, hoe dubieus de kwaliteit van het wetgevingsprodukt-onder-de- hamer wellicht ook was, getuige onder meer de benuchte problematick rondom het doordrukken van de Harmonisatiewet.

In algemene termen gegoten betekent dit dat de mogelijkheid voor de Nederlandse senaatskamer om een door de regering geìnitieerd legislatief product te controleren in de parlementaire praktijk eerder ingeperkt dan vernuimd kunnen worden via de werking van de vertrouwensregel. Het contrast tussen staatsrechtelijke theorie en politieke praktijk kan haast niet groter uitvallen dan op dit punt gebeurt. De 'ultieme stok achter de deur' voor de heroverwegende Nederlandse senaatskamer is verworden tot een welhaast exclusief prerogatief van de regering. waardoor de slagkracht van de Nederlandse senaatskamer op het vlak van de wetgevingsheroverweging niet vergroot doch juist verkleind wordt. Het sluitstuk van de ministericle verantwoordelijkheid is in deze specifieke verhouding geen ultieme stok doch een degelijk keurslijf geworden voor de formeel tot wetgevingscontrole bevoegde partij.

En dan nu specifiek aandacht voor de bestuurscontrolerende taakstelling van de senaat in relatie tot het leerstuk van de politicke ministerięle verantwoordelijkheid. De senaat is mijns inziens wel degelijk ook in staat 'met (enige) vnucht' een rol te spelen als controleur van de

75. In hoofdstuk 5 is uitgebreid aandacht besteed aan het gegeven dat de Nederlandse senaatskamer zelf nooit het initiatief neemt tot activering van de vertrouwensregel.

76. Bijvoorbeeld in 1989 rondom de AAW-kwestie of in 1988, zij het niet in het openbaar, rondom de aanname van de Harmonisatiewet. 
regering, vanuit een structuur waarin de staatsrechtelijke mogelijkheid tot activering van de vertrouwensregel ontbreekt.

Onder deze stelling, die ik nader zal toelichten, gaat echter een vraag schuil die ik daaraan voorafgaande beantwoord: kan de senaat haar rol als controleur van de regering slechts dan met de noodzakelijke 'slagkracht' uitoefenen indien dit onder alle omstandigheden strikt binnen de kaders der ministeriēle verantwoordelijkheid gebeurt? Mocht dit namelijk niet of slechts ten dele zo zijn, dan komt het belang c.q. de noodzaak van een sanctioneerbare verantwoordelijkheidsrelatie in de verhouding regering-senaatskamer daarmee vanzelfsprekend in een ander daglicht te staan.

Met die wetenschap in het achterhoofd zullen wij ons daar waar de bestuurscontrolerende taakstelling door de senaat in het geding is, dan ook niet direct storten op een praktische invuloefening van de werking van het parlementaire rechtenpakket ter bepaling van de reele reikwijdte en effectiviteit van de ministeriele verantwoordelijkheid in de parlementaire politieke setting. Eerst zal, zij het natuurlijk wel in het licht van de ministerièle verantwoordelijkheid, gerubriceerd moeten worden op welke wijze de vier senaatskamers die onderwerp van onderzoek zijn geweest in het kader van dit boek, de tijd die overblijft voor parlementaire werkzaamheden na aftrek van de zuiver wetgevingsgebonden activiteiten, blijken te besteden. Om te beginnen kan natuurlijk in de meeste landen ook het aloude budgetrecht nog een rol spelen in het kader van de bestuurscontrole door de senaatkamer. Vervolgens het reguliere commissiewerk in de vaste commissies, die als een permanent forum voor beleidscontrole door de parlementskamers beschouwd kunnen worden. Dan is er het debat in verscheidene uitingsvormen, variërend van de snelle interpellatie tot het grondige Britse 'general debate'. Vervolgens dient gewag gemaakt te worden van het zelfstandige onderzock. Ook hier blijkt numschoots gevarieerd te kunnen worden op het thema. Naast een uitwerking van het enquêterecht blijkt immers met name in Groot-Brittanniě (Investigative Select Committees) en Frankrijk (délegation du Sénat) door de respectievelijke senaatkamers ook anderszins veel tijd besteed te worden aan onderzoek. Tevens blijken de senaatskamers standaard energie te steken in het stellen van (mondelinge en schriftelijke) vragen en het indienen van moties.

Deze lijst aan activiteiten overziend, kunnen de meeste actieterreinen zonder twijfel direct genubriceerd worden onder de "paraplu" van de ministeriële verantwoordelijkheid. Het vragenrecht in al haar vormen, het recht van enquête, hantering van de motie, verwijzen naar het budgetrecht, dit alles functioneent binnen het parlementaire stelsel op basis van het gegeven dat de regering voor al 'haar' (gebrek aan) daden ter verantwoording kan worden geroepen door het parlement en dus ook door de senaatskamer.

\subsubsection{Ministeriele verantwoordelijkheid?}

Mag deze conclusie echter ook getrokken worden in relatie tot activiteiten als het zelfstandig onderzoek door de Franse Sénat en het Britse House of Lords of het Britse 'General Debate'? Het Britse House of Lords is, zoals wij gerien hebben in hoofdstuk 4, is de afgelopen 25 jaar steeds meer energie gaan steken in het entameren en uitvoeren van zelfstandig onderzoek via de installatie van een aantal 'Select Committees'. Vermaard én hooglijk gewaardeerd werden tijdens die kwart eeuw met name de werkzaamheden van de 'European Communities Com-

77. D.J. Elzinga, De politicke ministerięle verantwoordelijkheid, in: Ministerięle verantwoordelijkheid in Nederland, Zwolle 1994, p. 35. 
mittee: 'The European Communities Committee has built up a strong reputation as an effective instrument of parliamentary scnunity'. ${ }^{78}$ En iets verderop: 'its terms of reference and the way in which it has developed mean that it operates very like an investigatory committee by ranging widely over EU policy and producing reports which are both highly regarded and not infrequently influential in London and Brussels'. ${ }^{9}$ Maar ook op andere beleidsterreinen (o.a.: Delegated Powers Scrutiny Committee, Science and Technology, Economic Affairs, Monetary Policy en Constitution ${ }^{80}$ ) werd het House of Lords actief via de instelling van (al dan niet tijdelijke) Select Committees. Het Britse Hogerhuis kan deze werkzaamheden op eigen initiatief oppakken, omdat de Britse senatoren in tegenstelling tot de collega's in het House of Commons 'tijd' ter beschikking hebben. Daarnaast moeten wij ons realiseren dat een onderwerp als 'Europe' (vooral bij de Conservatives) binnen het House of Commons politiek dusdanig gevoelig pleegt te liggen, dat effectief parlementair onderzoek op semi-permanente basis naar het reilen en zeilen van 'Brussels' vanuit het Lagerhuis (althans tot nu toe) nooit een haalbare kaart is gebleken. De neerslag van het zelfstandige onderzoek door Britse senaatscommissies kan vervolgens, indien de uitkomsten daartoe aanleiding geven, voorwerp van uitgebreide discussie zijn in het plenum van het Hogerhuis (waar ook leden van de zittende regering deel van uitmaken), opdat eventuele toekomstige formele advisering richting regering zoveel mogelijk uitgekristalliseerd plaats zal kunnen vinden. De kwaliteit van dergelijke debatten wordt aller wegen als hoogstaand gekwalificeerd, niet in de laatste plaats omdat aan die debatten deel wordt genomen door voor het leven benoemde 'ouwe rotten' (Life Peers) die participeren vanuit opgebouwde expertise en belangstelling. Ter illustratie: het komt zelfs met enige regelmaat voor dat Hogerhuisdebatten waarin interessante juridische kwesties aan de orde worden gesteld, bijgewoond worden door (al dan niet gepensioneerde) leden van het hoogste Britse rechtscollege, de Law Lords.

Sterk vergelijkbaar met de werkzaamheden van voornoemde Britse Select Committees zijn de activiteiten van de zgn. Franse 'délégations' voortkomend uit de tweede parlementskamer. Medio 2001 bleken een vijftal 'delegations' uit naam van de Franse Sénat actief te zijn. De bekendste: 'le délégation du Sénat pour l'union Européenne'. De hoofddoelstelling: 'suivre les travaux conduits par les institutions de L'Union Européenne'. In concreto is deze doelstelling niet alleen ingekleurd via het produceren van een voortdurende stroom rapporten over een scala aan EU-gerelateerde onderwerpen, doch tevens via de permanente bestudering door de Sénat van de regelgevingsvoorstellen die het Palais de Luxembourg vanuit Brussel (via de Franse regering) bereiken. Sinds 1990 zijn alleen al door deze 'délégation' niet minder dan 114 rapporten over Europese onderwerpen gepubliceerd. Andere 'délégations' die onderzoek verrichten uit naam van de Franse Sénat hebben onder meer de duurzame ontwikkeling van het Franse grondgebied ${ }^{81}$ en de gelijkberechtiging van man en vrouw tot onderwerp. ${ }^{82}$ In zijn algemeenheid blijkt ook aangaande het nut van het semi-zelfstandig onderzoek dat deze 'délégations' vanuit de Franse Sénat uitvoeren, geconcludeerd te worden dat 'their balance sheet is

78. P. Carmichael and B. Dickson, The House of Lords, Its Parliamentary and Judicial Roles, Oxford 1999, p. 21.

79. Idem.

80. Zie voor een complete lijst van 'Select Committee reports' van het House of Lords: http:/ www.parliament, the-stationery-office.co.uk/pa/ld/dselect.htm. 6-9-2001.

81. Art. 10 Loi d'orientation nr. $99-533$ du 25 juin 1999 pour l'aménagement et le développement durable du territoire.

82. Loi nr. $99-585$ du 12 juillet 1999. 
positive and the reports produced, clearly reflect Senate initiative and thoughtfulness', 83 Tevens kan op deze plaats nog gewag gemaakt worden van het 'office parlementaire d'évaluation des choix scientifiques et technologiques'. Ook dit bureau (waarin leden van beide Franse parlementskamers zitting hebben) blijkt informatieverstrekking aan het parlement over ontwikkelingen en aangelegenheden die van belang (kunnen) zijn voor tockomstige (inter) nationale beleidsontwikkeling tot voornaamste doelstelling te hebben. ${ }^{84}$ Betreffende al dit semi-zelfstandig onderzoek, waar afvaardigingen vanuit zowel de Britse als Franse senaatskamer tegenwoordig blijkbaar zo veel tijd en energie in plegen te steken, moeten nu een tweetal samenhangende vragen beantwoord worden: kunnen dergelijke activiteiten ook rec̈le betekenis hebben, waar de bestuurscontrolerende taakstelling van de senaatskamer in het geding is en zo ja, vallen deze (naar het zich ontegenzeggelijk laat aanzien) langzamerhand behoorlijk uitgroeiende activiteiten van de tweede parlementskamer daarmee dan vervolgens ook automatisch onder de 'paraplu' van het stelsel der ministerięle verantwoordelijkheid?

Het antwoord op de eerste vraag is in wezen simpel: kennis is imvloed. Indien de regering beleidsbeslissingen moet gaan nemen c.q. omzetten in regelgevingvoorstellen op terreinen waar de senaat grote expertise heeft opgebouwd, raakt de tweede pariementskamer welhaast automatisch betrokken. Zowel de Britse als de Franse praktijk tonen onomwonden aan, dat de regering sterk gaat leunen op de kennis van het House of Lords maar zeker ook de Sénat, indien knopen doorgehakt moeten worden op dergelijke beleidsterreinen.

Hoogst interessant, en daarmee alvast een voorlopige brug bouwend naar de beantwoording van vraag twee, is het gegeven dat parlementaire controle door bijvoorbeeld de Britse senaatskamer enerzijds en beleidsvorming door de regering anderzijds, rondom o.a. EU-onderwerpen of thema's betreffende 'Wetenschap en Technologie' onmogelijk nog los van elkaar benoemd zullen kunnen worden. De mijns inziens terechte constatering dat de ministerièle verantwoordelijkheid in de relatie regering-parlement een permanent proces is en derhalve niet slechts ná beleidsvaststelling door de regering, doch ook voorafgaande aan die beleidsvaststelling uitgeoefend kan worden, ${ }^{85}$ past goed in dit plaatje.

Alvorens deze problematiek echter definitief te duiden, is het op deze plaats noodzakelijk een beeld te schetsen van de mate waarin de vier senaatskamers nog effectief 'werk' blijkt te (kunnen) maken van de 'traditionele' bestuurscontrolerende rechten die zij bezitten.

\subsubsection{Vragenrecht}

Het recht voor de senaatskamer om vragen te stellen aan de regering van de dag komt in de vier onderzoekslanden voor in verscheidene vormen. De grootste variatie treffen wij aan in Westminster: starred questions, unstarred questions, Private notice questions, Questions for Written Answer. In alle vier de staatsinstellingen is ruimte gecreëerd voor het stellen van zowel mondelinge als schriftelijke vragen. Behandeling van mondelinge kamervragen kán in zowel Groot-Brittanniě, Nederland als Frankrijk geschiedden in de vorm van een debat of interpellatie.

83. J. Mastias, A Problem of Identity: The French Senat, in: S.C. Patterson and A. Mughan, Senates, Bicameralism in the contemporary World, Ohio State University 1999, p. 185.

84. Loi nr. 83-606 du 9 juillet 1983

85. M. Scheltema en H. Lubberdink. Ministerięle verantwoordelijkheid en parlementaire controle, in: Parlementaire controle en democratie in de verzorgingsstaat (Bundel staatsrechtconferentie 1980) Utrecht 1980, p. $1-18$. 
De parlementaire praktijk heeft voor alle vier de senaatskamers uitgewezen dat van het vragenrecht geen substantièle bestuurscontrolerende invloed uit blijkt te gaan. Van het recht tot het stellen van schriftelijke vragen wordt door de senaatskamers in Londen en Parijs weliswaar veelvuldig gebruik gemaakt, doch invloed gaat er ook daar hoegenaamd niet van uit, eenvoudig omdat ieder afzonderlijk detailvraagje los staat van de overige schriftelijke vragen en als zodanig volledig uit het zicht verdwijnt.

Binnen het Bondsduitse staatsrecht is de schriftelijke vraag aan de regering in de functie van controlemiddel voor de Bundesrat nooit tot ontwikkeling gekomen. Een zelfde conclusie kan in feite ook voor de Eerste Kamer getrokken worden. Ter vergelijking: de leden van het House of Lords en de Sénat knuipen ieder jaar meer dan 5000 keer in de pen om de regering om opheldering of informatie te vragen. Het absolute topjaar voor de Eerste Kamer op dat terrein blijkt reeds 30 jaar tenug te liggen. In het jaar 1971-1972 werden namelijk niet minder dan 197 schriftelijke vragen geformuleerd door de senatoren. De laatste jaren zweeft het gemiddelde in Nederland rondom de 18 schriftelijke vragen per jaar. ${ }^{86}$ De onderwerpen variëren van thema's als de muskusratbestrijding en de erkenning van het (mooie, EK) Limburgs als streektaal tot het Russisch lidmaatschap van de Raad van Europa.

Het praktische belang van de mondelinge vragen blijkt in de politieke arena's die de Britse en Franse senaatskamer qualitate qua hoe dan ook zijn, overigens evenmin als substantieel gekwalificeerd te kunnen worden. Ik herhaal in dit kader graag een tweetal treffende citaten uit vorige hoofdstukken: 'mere shadow-boxing' (House of Lords) en 'messes sans communion' (Sénat). De Nederlandse Eerste Kamer hanteert het mondelinge vragenrecht niet, wel af en toe het min of meer vergelijkbare interpellatierecht. Voornoemde citaten ter typering van de Britse en Franse praktijk waar het belang van het mondelinge vragenrecht in het geding was, zouden in feite eveneens gebruikt kunnen worden om het belang van het recht van interpellatie voor de Nederlandse senaatskamer te duiden. Zeven keer werd er door de Nederlandse senatoren geỉnterpelleerd sinds 1982. Deze interpellaties hadden vaak de positie van de eigen parlementskamer tot onderwerp. De Vries constateerde daarenboven terecht dat de vier meest recente interpellaties gekenmerkt werden door 'stoom afblazen van politiek ongenoegen over het optreden van de regering ${ }^{+8}$ ?

Ook in de Bondsrepubliek tenslotte ontbreekt een relatief fijnmazige vragenrecht in de relatie senaatskamer-regering nagenoeg volledig. ${ }^{88}$ Daar staat tegenover dat de Bondsregering wel grondwettelijk verplicht is om de Bundesrat voortdurend 'auf dem laufenden zu halten' aangaande 'die Fühnung der Geschäfte'. ${ }^{89}$ Deze algemene regel, waarin ook een plicht tot beantwoording van Bundesratsvragen schuil gaat, blijkt (via zowel commissievergaderingen, Ständige Beirat, als de plenaire Bundesrats en Bundestagsvergaderingen) in de parlementaire praktijk wél een behoorlijke impact te hebben. ${ }^{90}$ De verklaring van dit relatieve succes ligt voor de hand: beide Bondsduitse parlementskamers en de Bondsregering zijn, zoals reeds meermaals werd betoogd, in het kader van de medewetgevende taakstelling van senaats-

86. http:/www.ecrstekamer.nl/egi-bin pdesns,cgi?user, 4-9-2001.

87. F. de Vries, dissertatic, a.w., p. 310.

88. Weliswaar is in $\$ 19$ GOBR de mogelijkheid tot het stellen van vragen gecodificeerd, doch praktische betekenis heeft dit tot nog toe nooit gekregen.

89. Art. $53 \mathrm{GG}$.

90. Onder andere W.J. Patzelt. The German Bundesrat, in: Senates, Bicameralism in the contemporary World, Ohio 1999, p.83-84; G. Ziller und G-B. Oschatz, a.w., p. 98-102. 
kamers, permanent in sterke mate tot elkaar veroordeeld. De Bondsregering blijkt zich dientengevolge dan ook niet te kunnen of willen veroorloven om met de wensen van de senaatskamer op het terrein van de informatieverschaffing lichtvaardig om te gaan. Ik kom hier in de volgende paragraaf nog op terug.

\subsubsection{Bestuurscontrolerend commissiewerk}

Naast de reeds besproken werkzaamheden van de 'Select Committees' in het House of Lords en de werkzaamheden van de 'Délégations' in de Franse senaatskamer, wordt ook door vaste senaatscommissies uit de onderzoekslanden de nodige bestuurscontrolerende arbeid verricht. Vooral de Franse Sénat moet in dit kader genoemd worden. Art. 22 lid I van het Règlement du Sénat verschaft de Franse senatoren de benodigde basis om via de vaste commissies hoorzittingen te organiseren en nader bestuurscontrolerend onderzock ('le mission d'information ex art. 21 Règlement du Sénat) te entameren. Van deze bevoegdheden wordt de laatste decennia frequent gebruik gemaakt. ${ }^{91}$ Momenteel (september 2001) lopen een zestal 'zocktochten naar informatie'. De onderwerpen varièren van het nationale kankerbestrijdingsbeleid tot het disfunctioneren van de 'Bibliothethèque Nationale de la France', Met name het gegeven dat de eindrapporten openbaar worden, met alle eventuele politiek-publicitaire gevolgen van dien, maakt dat van de 'missions d'information' ontegenzeggelijk invloed uit kan gaan op de regering. De regels van het (in Frankrijk vanouds gepolariseerde) partijpolitieke spel bepalen echter uiteindelijk in hoeverre van wezenlijke impact gesproken kan worden. De mogelijkheid tot het formuleren van consequenties in de vorm van bijvoorbeeld moties of andersoortige 'stokken achter de deur' kent het Franse staatsrecht in ieder geval niet toe aan ontevreden parlementariërs uit de senaatskamer.

Ook in de Bondsrepubliek is sprake van regelmatige informatievergaring door de senaatskamer via de vaste commissiesvergaderingen. Daar gebeurt dat, zoals reeds eerder aangestipt, onder de vigeur van art. 53 GG. Zeker in de Bondsduitse constellatie blijkt deze vorm van bestuurscontrole goed te functioneren. Een belangrijke oorzaak hiervoor gaat schuil in het gegeven dat de uitwisseling van informatie in de vaste Bundesratscommissies plaats vindt tussen specialisten van de uitvoerende macht der Länder enerzijds en specialisten van de uitvoerende macht op Bondsniveau anderzijds. ${ }^{92}$

\subsubsection{Het recht van enquête}

Formeel kunnen slechts de Sénat Français en de Eerste Kamer het enquêterecht uitoefenen. De Nederlandse senaatskamer blijkt in de praktijk echter nooit gebruik te maken van dit parlementair recht. De Franse senatoren doen dit wel en met name gevoed vanuit politicke overwegingen: 'le Sénat en a fait, naturellement, un large usage pendant sa période d'opposition politique pour requérir contre le Gouvernement'. ${ }^{93} \mathrm{Nu}$ dergelijke perioden zich sinds 1981 in Frankrijk voortdurend aan elkaar blijken te rijgen, wordt het controlemiddel dat de enquête formeel pleegt te zijn dan ook veel gehanteerd. Tussen 1960 en 2000 maar liefst 54 maal, waarvan 45 vanaf 1981, zijnde het moment waarop de centrumrechtse Sénat zich duidelijk sterk oppositioneel ging profileren ten opzichte van regelmatig terugkerende rege-

91. Http://cubitus senat fr/commission/mission/index html, 6-9-2001

92. G Ziller und G-B. Oschatz, a.w., p. 99

93. J. Mastias et J. Grangè, a.w., p. 236 
ringen van (hoofdzakelijk) socialistische signatuur. De (socialistische) meerderheid van de Assemblée nationale is zelfs nu en dan in staat gebleken tezelfdertijd een parallel enquêteonderzoek op te starten waarin exact dezelfde materie op de agenda werd geplaatst. De waarde van het controlemiddel erodeerde daardoor sterk. ${ }^{94}$

\subsubsection{De senaat en de werking van de politieke ministeriele verantwoordelijkheid}

Dan nu terug naar mijn oorspronkelijke betoog. Het plaatje zit mijns inziens als volgt in elkaar: het belang van bicameralisme heeft, zoals ook Blondel nim een decennium geleden constateerde ${ }^{95}$, ten gevolge van de allesoverheersende dominantie van de partijpolitiek in de moderne parlementaire stelsels, sterk aan belang ingeboet. Van oudsher was het de bedoeling dat ook de senaatskamers het regeringsbeleid aan een extra 'check' onderwierpen onder de paraplu van de ministeriële verantwoordelijkheid. De tweede parlementskamer ontbeert echter reèle juridische sanctiemiddelen die beleidscontrole echt effectief kunnen maken (vooral Groot-Brittannie en Frankrijk) en/of wordt klein gehouden via de gangbare democratische meerderheidsregels vanuit een strakke partijpolitieke organisatie (met name in Frankrijk en Nederland). Gegoten in terminologie die reeds eerder door mij gehanteerd werd: 'rivaliserend' gedrag vanuit de senaatskamer in het kader van krachtdadige bestuurscontrole onder de

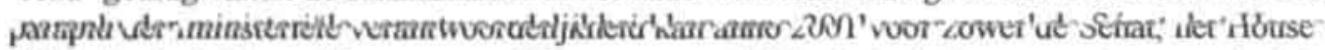
of Lords als de Eerste Kamer nauwelijks nog een politiek-strategisch speerpunt vormen in het kader van een voortdurende zoektocht naar ' werkbaar evenwicht', alle inspanningen die met name de Franse senaatskamer zich op dit punt nog regelmatig blijkt te getroosten ten spijt. Vooral in Groot-Brittannië en in iets mindere mate in Frankrijk is de senaatskamer zich daarentegen sterk toe gaan leggen op zelfstandige onderzoeksactiviteiten van sterk 'assisterende' aard die, zeker in eerste instantie, los van (eventueel toekomstig) regeringsbeleid uitgevoerd worden. Belangwekkend is vervolgens natuurlijk wel het gegeven dat de beide senaatskamers juist dankzij hun 'assisterend' zelfstandige onderzoek in staat zijn gebleken enige extra inhoud te geven aan hun bestuurscontrolerende taakstelling, bijvoorbeeld indien EU-gerelateerde beleidsvisies of thema's rondom wetenschap en techniek onderwerp van parlementaire bespreking uit gaan maken in Londen of Parijs.

Geconstateerd kon worden dat rondom de bestuurscontrolerende taakstelling van de senaatskamer van Groot-Brittanniě en Frankrijk steeds duidelijker gehandeld wordt in termen van 'assistentie' en zeker niet uitsluitend in termen van 'rivalisering'. Het oorspronkelijke bicamerale concept van een effectieve extra 'check' op het regeringsbeleid vanuit rivalisering is grotendeels achterhaald ('shadow-boxing') en blijkt dan ook bijstelling te behoeven. Strakke partijpoliticke banden vanuit een al dan niet geformaliseerd monistisch kader blijken zeker in Groot-Brittannié, Frankrijk en Nederland het manco aan 'rivaliserende' slagkracht van de senaatskamer heden ten dage grotendeels te bepalen. Ook de eventuele aanwezigheid van een ten volle activeerbare vertrouwensregel doet daaraan onder de gegeven omstandigheden niets af. De (in vergelijking tot de praktijk in de andere onderzoekslanden) nagenoeg volledige afwezigheid van ook maar enigszins effectieve bestuurscontrolerende activiteiten van de Eerste Kamer toont dat duidelijk aan.

95. J. Blondel, Comparative Government, London 1990, p. 243 c.v. 
Traditionele bestuurscontrolerende instrumenten onder de paraplu van de ministerièle verantwoordelijkheid als het vragenrecht en het recht van enquête blijken in handen van senaatskamers dan ook nauwelijks nog effect te sorteren. Een uitzondering moet hier natuurlijk wel gemaakt worden voor de Bondsrepublick. De Bundesrat wordt immers door de Bondsregering over het algemeen goed 'auf dem laufenden' gehouden. Dit vindt zijn oorzaak, zoals wij inmiddels wel weten, in het gegeven dat de Bondsduitse senaatskamer en de Bondsregering op het terrein van de (Bonds)wetgeving veel sterker dan in de andere landen structureel tot elkaar veroordeeld zijn. Niet vergeten dient in dat kader te worden dat beleidsuitvoering dient te geschieden door de overheden uit de zestien Länder. Alleen al uit praktisch oogpunt is het dan ook vanzelfsprekend dat de Bondsregering diezelfde 'uitvoerende' overheden tevens zoveel mogelijk informeert over de beleidsontwikkeling.

\subsection{Beantwoording onderzoeksvragen}

Waarmee ik dan uiteindelijk beland ben bij de beantwoording van de centrale onderzocksvragen die ik geformuleerd heb.

Hoewel Lijphart in 'Patterns of Democracy' op formeel juiste gronden concludeert (zie par. 1.3) dat deugdelijke democratische legitimatie voorwaarde is voor een volksvertegenwoordigende 'tweede kamer' om krachtig optreden door diezelfde kamer in het kader van parlementair bicameralisme te kunnen bewerkstelligen, blijkt deze conclusie waar het praktische parlementaire functioneren van de Duitse Bundesrat, het Britse House of Lords, de Franse Sénat en de Nederlandse Eerste Kamer in het geding is, ontegenzeggelijk genuanceerd te moeten worden. Wil een senaatskamer met vrucht politiek 'rivaliserende' parlementaire activiteiten ontplooien, dan blijkt reèle democratische legitimatie inderdaad een eerste vereiste te zijn. $Z_{0}$ is het vooral de totale áfwezigheid van democratische legitimatie die bijvoorbeeld de afwezigheid van 'rivaliserende' daadkracht van het House of Lords in hoge mate blijkt te verklaren. Het functioneren van de Britse senaatskamer wordt met name sterk gestuurd vanuit de behoefte om vooral maar niet in conflict te komen met het rechtstreeks gekozen House of Commons. De Salisbury Doctrine spreekt dienaangaande boekdelen.

Indien de senaatskamer zich echter beperkt tot medewetgevende c.q. onderzoekende activiteiten die niet als 'politiek-rivaliserend' doch als (regering en volkskamer) 'assisterend' gekwalificeerd kunnen worden, blijkt de mate waarin de senaatskamer tenug kan vallen op een anno 2001 als legitiem ervaren mandaat van de kiezer, althans in de vier landen die voorwerp van onderzoek zijn geweest, niet van wezenlijk invloed te zijn op de effectiviteit van de taakuitoefening. De voor het leven benoemde Britse Lords kunnen dan beslist minimaal wedijveren met hun democratisch beter gelegitimeerde collega's te Berlijn en Parijs en Den Haag. Laat ik ter beantwoording van de vraag of aan het functioneren van de vier senaatskamers, zoals die in verscheidene vormen in op westerse leest geschoeide democratische samenlevingen binnen Europa naast de volkskamer vorm hebben gekregen, nog toegevoegde waarde toegekend wordt, de in par. 1.3 beschreven onderzoeksresultaten van Lijphart aangaande 'strong bicameralism' tot uitgangspunt nemen.

Lijphart formuleerde een conceptie rondom het al dan niet krachtdadig politieke functioneren van tweekamerstelsels gebaseerd op de theoretische aan- of afwezigheid van symmetrie en 
incongruentie der beide parlementskamers. Zijn onderzoekingen (voorzover relevant in het kader van dit betoog) leverden het volgende staatje van sterk naar zwak op:

Strong bicameralism:

Medium-strength bicameralism:

Medium-strength bicameralism:

Between medium-strength and

weak bicameralism:

\section{Germany}

Netherlands

France

\section{United Kingdom}

De uitkomsten van mijn vergelijkende onderzoekingen naar het praktisch medewetgevend en bestuurscontrolerend functioneren van de vier senaatskamers blijken een enigszins afwijkende volgorde op te leveren:

\author{
Duitsland: \\ Frankrijk: \\ Groot-Brittannie: \\ Nederland:
}

\author{
Effectieve rivaliteit en effectieve assistentie \\ Ineffectieve rivaliteit en effectieve assistentie \\ Geen rivaliteit en effectieve assistentie \\ Geen rivaliteit en (vrijwel) geen assistentie
}

'Rivaliteit' doelt hier dus (zie par. 8.1.6) op de (on)mogelijkheid tot het geheel of gedeeltelijk kunnen afdwingen van eigen politick-beleidsmatige accenten door de senaatskamer. 'Assistentie' impliceert in de parlementaire wetgevingspraktijk eerst en vooral rechtmatigheidscorrectic. Daarbij wordt met name gedoeld op juridisch-dogmatische en juridisch-technische verbeteringen van het wetgevingsproduct in wording. Daarnaast vallen ook 'verrijkende' suggesties tot verbetering van de kwaliteit der wetteksten van doelmatige, maatschappelijk wenselijke politick-bicameraal non controversièle aard onder het kopje 'assistentie'.

Beide rubriceringen in ogenschouw nemend, blijkt slechts sprake te zijn van één duidelijke dissonantie: de 'afwaardering' van de Nederlandse Eerste Kamer. Daarbij zal ik zo dadelijk uitvoerig stil staan.

Het Bondsduitse tweekamerstelsel is inderdaad krachtig. De extra legitimerende werking vanuit de constitutioneel federatief verankerde regio (Laander) speelt daarbij zeker een rol, maar het zijn toch zeker ook andere factoren die het krachtdadig functioneren van de Bundesrat mede verklaren. Vooral het staatsrechtelijke gegeven dat alle voorstellen tot wet in formele zin beide Bondsduitse parlementskamers tijdens het reguliere wetgevingstraject twee maal moeten passeren speelt een belangrijke rol. Dat gegeven, gecombineerd met de wetenschap dat grondig legislatief commissiewerk door (met name) gespecialiseerde ambtenaren uit de (de Bondswetgeving uitvoerende) Länder gegarandeerd is én de meeste wetsvoorstellen uiteindelijk 'Zustimmung' van de Bundesrat behoeven, blijkt permanente invloed op het wetgevingsproces van zowel rivaliserende als assisterende aard te garanderen.

Het relatief succesvolle functioneren van de Duitse senaatskamer in beleidsmatig-politiek 'rivaliserende' zin (checks and balances), blijkt wel op zichzelf te staan. De Sénat, het House of Lords en de Eerste Kamer komen daar niet of nauwelijks aan toe.

Beslist niet op zichzelf staat de portee van de assisterende werkzaamheden in de Bundesrat. Ook de Sénat en het House of Lords blijken, vanuit de wetenschap dat zij in geval van conflict met respectievelijk de Asemblée nationale en het House of Commons uiteindelijk altijd 
het onderspit zullen moeten delven, goed in staat om de regering en de eerste parlementskamer effectief en zinvol te ondersteunen via vooral hantering van het recht van amendement. De partijpolitieke verhoudingen van het moment spelen in Frankrijk ontegenzeggelijk een rol van betekenis in dit geheel. De bij voortduring behoorlijk gepolariseerde politieke verhoudingen in het Franse parlement hebben voor de (in meerderheid ten gevolge van het kiesregime altijd) centrumrechtse Sénat tot gevolg, dat beduidend effectiever medewetgevend 'geassisteerd' pleegt te worden indien ook de nationale regering van centrumrechtse huize is. In de praktijk kan dat dan zelfs betekenen dat wetgevingsvoorstellen in feite volledig panklaar gemaakt worden door de tweede parlementskamer, zodat de Assemblée nationale van de uiteindelijke formele aanname van de 'texte identique' bij wijze van spreken een hamerstuk zou kunnen maken. Ook de regering Blair blijkt zich tegenwoordig met enige regelmaat te bedienen van de senaatskamer om politiek minder controversiele voorstellen tot wet alvast volledig uit te werken. Zeer sprekend is ook de Franse wetgevingspraktijk rondom het stellen van de 'question préalable positive' door de Sénat, waarmee de Franse Hogerhuiskamer zich ter versnelling van het wetgevingsproces vrijwillig buitenspel kan laten zetten.

Meestentijds is de laatste decennia in Frankrijk echter geen sprake van partijpoliticke coherentie tussen regering en Sénat. Maar zelfs dan blijkt toch altijd een substantieel deel van de wetgevingsproductie 'verrijkt' te kunnen worden ten gevolge van amenderende bemocienis vanuit de senaatskamer.

De Britse senaatskamer heeft de afgelopen twee decennia als het ware hernieuwd bestaansrecht afgedwongen via zeer effectief assisterend gedrag. Per definitie in de schaduw van het House of Commons ( en derhalve relatief los van politieke kleur) wordt de verwezenlijking van het regeringsbeleid gedegen ondersteund door het House of Lords. Belangrijkste instrumenten daartoe zoals gezegd, het recht van amendement en het zelfstandig onderzock via de Select Committees.

Hetgeen expertise tot een centraal element in het geheel maakt. De mogelijkheden tot het opbouwen en in stand houden van de noodzakelijke expertise in de senaatskamer blijkt vooral binnen de constitutionele kaders van Duitsland en Groot-Brittanniè goed mogelijk. In Duitsland vanuit het permanente ambtelijk apparaat der Länder dat het gros der vaste kamercommissies bemant. In het Verenigd Koninkrijk via de benoeming van senatoren 'For Life'. Ook de Franse Sénat echter, kan dankzij cen kiezersmandaat voor haar senatoren van minimaal negen jaar en een doelmatige organisatie van de commissiewerkzaamheden terugvallen op de nodige expertise. Omdat ieder der 321 Franse senatoren slechts lid mag zijn van één vaste commissie, het legislatieve veldwerk door terzake kundige 'rapporteurs' wordt verricht en de commissievergaderingen verplicht gesteld zijn, blijkt ook het Franse tweekamerstelsel in 'assisterende' zin bij voortduring vruchten af te kunnen werpen. Daarnaast timmert de Sénat tevens aan de weg. waar het verrichten van onderzoek in het geding is. Dit gebeurt frequent via hantering van het recht van enquête. Ook genereert de Franse senaatskamer (via de 'délégations') evenals het House of Lords ( via de 'Select Committees' en het 'General Debate') de nodige exclusieve expertise op belangrijke en modeme beleidsterreinen (EU, wetenschap en techniek) die de voortdurende aandacht van de regering wel moeten hebben.

En dan tenslotte de Nederlandse senaatskamer. Ondanks de zo krachtdadige positie 'op papier' (met name de goede democratische legitimatie en het absolute vetorecht voor álle voorstellen tot wet in formele zin) valt de draagwijdte van zowel het medewetgevend als het bestuurscontrolerend functioneren van de Eerste Kamer vrijwel volledig in het niet bij het- 
geen dienaangaande gebeurt te Londen, Parijs en Berlijn. 'Rivaliserend' gedrag van de Eerste Kamer wordt in Den Haag bij afwezigheid van een formele conflictenregeling al sinds jaar en dag zo goed als onaanvaardbaar geacht. De Nederlandse senaatskamer etaleert hier dan ook vrijwel standaard vanzelfsprekende terughoudendheid. En 'assistentie' is, althans op het terrein van de medewetgeving, zo goed als onmogelijk. Bij gebreke van een recht van amendement kan hooguit zo nu en dan een novelle of toezegging boven komen drijven. Het mag dan ook nauwelijks verwondering wekken dat de commissiefase tijdens het wetgevingstraject in de senaatskamer, een fase die als een van de belangrijkste institutionele factoren ter bepaling van de mate van parlementaire invloed op het wetgevingsproces kan worden beschouwd, in de Nederlandse senaatskamer onmiskenbaar een betrekkelijk zieltogend bestaan lijdt. Tijdens gemiddeld één dag in de week moeten maximaal 75 deeltijdsenatoren, naast alle andere verplichtingen, niet minder dan 21 commissies draaiende houden. Ga er maar eens aan staan.

Voor activiteiten van rivaliserende of assisterende aard via het entameren van onderzoek door commissies vanuit de Eerste Kamer bestaan géén formele drempels. Hier lijkt vooral het gebrek aan tijd en mankracht de doorslaggevende rol te spelen. In ieder geval is het recht van enquête nu toch al nuim een eeuw lang door de Nederlandse senaatskamer nooit gehanteerd. En voor het opbouwen van extra expertise via wegen die de Britse Select Committees en de Franse Délégations bewandelen lijkt evenmin ruimte in tijd en mankracht aanwezig.

In de kern samenvattend: toegevoegde waarde hebben de senaatskamers, met uitzondering van de Nederlandse, anno 2001 ontegenzeggelijk met name in het kader van de wetgevingsassistentic. Daarnaast manifesteren de Britse en Franse senaatskamer zich vanuit opgebouwde expertise ook steeds effectiever in assisterende zin via onderzoeksrapporten aangaande een aantal centrale beleidsterreinen (bijvoorbeeld rondom de EU), waarop het regelmatig entameren van nieuwe regelgevingvoorstellen een vanzelfsprekendheid geworden is.

Ter afsluiting nog een, strikt genomen, buiten de kaders van dit vergelijkend onderzoek vallend obiter dictum:

\subsection{De Eerste Kamer}

En hoe moet het dan verder met de Nederlandse senaatskamer? Afgezet tegen hetgeen de Bundesrat, de Sénat en het House of Lords als tweede parlementskamer blijken te kunnen bewerkstelligen, lijken de inspanningen van de Eerste Kamer zonder al te veel terughoudendheid gekarakteriseerd te kunnen worden als rituele dansen. Afschaffing ligt dan ook zeker in de rede. Een constitutionele rechter zal nuimschoots in staat zijn de gaatjes die daardoor ontstaan te dichten.

$\mathrm{U}$ en ik weten echter dat afschaffing geen reële optie is. Zesentwintig eensgezinde senatoren volstaan daartoe al. En de parlementaire geschiedenis heeft regelmatig aangetoond dat de eensgezindheid onder de Nederlandse senatoren met name groot is, indien de eigen positie in het geding blijkt te zijn. Laat ik daarom, in de hoop dat wellicht ooit in het Nederlandse parlement communis opinio zal ontstaan over de noodzaak tot structurele aanpassing van het vigerende, vrijwel nutteloze tweekamerstelsel, opbouwend eindigen. 
Een tweede parlementskamer kan, dat heeft dit onderzoek wel duidelijk gemaakt, veel meer doen dan wetgeving toetsen op de juridische merites. Dit impliceert dat de Eerste Kamer, indien daartoe de noodzakelijke voorwaarden zouden worden geschapen, ook mér kan betekenen in het kader van wetgeving en bestuurscontrole dan een constitutionele kamer.

Introductie van de mogelijkheid tot terugzending van wetsvoorstellen naar de Tweede Kamer zal ontegenzeggelijk leiden tot verbetering van het integrale wetgevingsproduct. Tenugzending dient, de Britse en Franse praktijk indachtig. mijns inziens wel slechts mogelijk te worden vanuit een 'assisterende' conceptie. Een kiesstelsel waarbij per drie, vier of vijf jaar slechts $1 / 3$ e deel of de helft van de senaatskamer ververst wordt, valt verre te prefereren. Dan kan aanwezige c.q. op te bouwen expertise immers veel beter tot zijn recht komen dan in het huidige systeem. Verder moet het heroverwegingswerk verdeeld kunnen worden over meer senatoren die minimaal twee volledige dagen per week in die hoedanigheid actief zouden moeten zijn. Het is een illusie om te veronderstellen dat 75 senatoren in het tijdsbestek van gemiddeld één dag per week de job adequaat kunnen klaren. De Eerste Kamer zou in ieder geval uitgebreid moeten worden tot een omvang die overname in enigerlei vorm van een praktisch functionerend commissiestelsel (als bijvoorbeeld het Franse) mogelijk maakt. Ambtelijke ondersteuning van enige omvang (ten behoeve bijvoorbeeld van rapporteurs) lijkt daarvoor eveneens noodzakelijk.

Vanuit die randvoorwaarden zou ook de Nederlandse senaatskamer mijns inziens een nuttige bijdrage kunnen leveren aan het tegenwoordig volledig door de partijpolitiek gedomineerde proces waarin wetgeving in formele zin in de moderne West Europese democratic tot stand moet worden gebracht. Een bijdrage die mede met het oog op die laatste constatering dan ook met name verscholen moet gaan in daadwerkelijk implementeerbare kwaliteitsargumenten en inhoud, naar Brits voorbeeld. Dit kan eenvoudig geschiedden via enige vorm van terugzendrecht. Implementering van 'verrijkingsvoorstellen' vanuit de Eerste Kamer in voorstellen tot wet dient mijns inziens te geschieden vanuit een afweging tussen (in de Tweede Kamer aanwezige) politieke ruimte enerzijds en de kracht van voornoemde kwaliteitssuggesties anderzijds. Een definitief vetorecht in handen van een toekomstige Nederlandse senaatskamer zie ik vanuit die perceptie dan ook zeker niet langer als een absolute voorwaarde voor het zinvol kunnen functioneren van de kamer van heroverweging. In tegendeel. Een opschortend vetorecht met een beperkte tijdsduur naar Brits voorbeeld zal mijns inziens ruimschoots voldoen. Behalve tot aanname of integrale verwerping ( als politiek signaal) kan besloten worden tot terugzending. Aan die tenugzending kunnen door de Eerste Kamer 'opmerkingen', 'verrijkingsvoorstellen' of gewoon amendementen (want dat zijn het immers in materiele zin) gekoppeld worden. Op die wijze kunnen vanuit de wetgevingscommissies suggesties over rechtmatigheid, rechtstatelijkheid, doelmatigheid enz. als het ware 'Iegaal' én functioneel richting Tweede Kamer gesluisd worden. De verrijkingsvoorstellen zullen zowel het geheel als het juridisch-technische detail kunnen betreffen. $\mathrm{Zij}$ zullen materieel in de meeste gevallen niet substantieel hoeven te verschillen van hetgeen momenteel in de sporadische inhoudelijke en technische novelles teruggevonden kan worden. Het surplus ten opzichte van de huidige praktijk zit hem ontegenzeggelijk in het gegeven dat bij uitoefening van een terugzendrecht door de senatoren geen terughoudendheid betracht hoeft te worden. In de Kamer van Heroverweging aanwezige expertise hoeft dan niet meer grotendeels verloren te gaan. Ook de Nederlandse senaatskamer, de tweede parlementskamer, kan dan eindelijk een reële bijdrage gaan leveren aan de totstandkoming van zo goed mogelijke wetgeving in formele zin. Kiest 


\section{Hoofdstuk 8}

de Eerste Kamer in meerderheid niet voor aanname, noch voor verwerping, doch voor tenugzending van cen wetsvoorstel, voorzien van noodzakelijk geachte aanpassingsproposities, dan is na terugzending de wetgevingstaak van de tweede parlementskamer tot een einde gekomen. De Tweede Kamer kan het teruggezonden ontwerp tijdens deze tweede behandelingsronde, rekening houdend met de (al dan niet tevens al politiek signaal bedoelde) verrijkingsvoorstellen vanuit de Eerste Kamer opnieuw amenderen, maar is daartoe formeel geenszins gehouden.

Als de kracht van het kwaliteitsargument het uiteindelijk niet blijkt te kunnen winnen in de door de regeringspartijen gedomineerde partijpolitieke arena van de Tweede Kamer, moet de Eerste Kamer maar terugtreden. Vooral de Britse maar ook de Franse bicamerale wetgevingspraktijk toont echter aan, dat kwaliteit vaak écht wel overtuigen zal.

Een uitzondering tenslotte, dient wellicht gemaakt te worden voor de rol die de Nederlandse senaatskamer speelt bij grondwetswijzigingen. Een tweede parlementskamer kan onmiskenbaar een functie vervullen als 'bewaker van de constitutie'. Het geldende regime rondom de besluitvorming bij grondwetswijzigingen behoeft in essentie dan ook niet gewijzigd te worden, hetgeen impliceert dat twee lezingen in beide parlementskamers en een tweederde meerderheid tijdens de tweede lezing in eveneens beide kamers noodzakelijk zou moeten blijven, zolang in Nederland nog geopteerd wordt voor het handhaven van een tweekamerstelsel.

voor ilet ovenge zou de ivederianase senaatskamer ook eens ujd kunnen gaan steken in mietwetgevende activiteiten. Een senaatskamer is bij uitstek een geschikt forum om parlementaire enquêtes te houden. Stimulering van zelfstandig onderzoek en het daaraan te koppelen opbouwen van 'eigen' expertiseterreinen naar Brits en Frans voorbeeld zal ook zeker vruchten afwerpen. Het zij nogmaals gezegd, anno 2001 is het ondenkbaar geworden dat het Britse House of Lords niet betrokken raakt bij de uitwerking van voorstellen tot regelgeving op een scala aan beleidsterreinen.

Hetgeen mij bij mijn allerlaatste opmerking brengt. Die benamingen voor onze parlementskamers mogen nu toch echt wel eens omgedraaid gaan worden. Tenminste als zij beide blijven voortbestaan. In zowel Londen, Parijs als Berlijn valt slechts met de grootst mogelijke moeite uit te leggen hoe het toch kan zijn dat twee bij ons een staat en een twee. 


\section{Summary}

The core question of this study is whether senatorial chambers offer sufficient value in addition to lower houses of parliament to justify their continuing existence. The question arises with some regularity in many West European states that still have a bi-cameral parliamentary system. More in particular, the study investigates whether the British House of Lords, the French Sénat, the Dutch Eerste Kamer and the German Bundesrat are still considered to have substantial added value with respect to the legislative process as well as control of executive action. As background to this principal question, a comparative study is made of the extent to which those senatorial chambers which are directly democratically legitimised (as in France), exercise their duties with regard to co-legislation and control of executive action more effectively than senatorial chambers which are not (as in the United Kingdom) or merely indirectly democratically legitimised (as in the Netheriands and Germany).

With regard to activities that are the domain of the upper houses as co-legislators and controllers of executive action, use is made of a conception derived from British literature. In this conception, 'bi-cameralism' implies the relation between the two chambers, in which the upper house ideal-typically plays either a 'rivalling' or an 'assisting' role. 'Rivalry' is here to be taken to mean the (im)possibility for the upper house to wholly or partially enforce its own politico-policy accents. 'Assistance' in parliamentary legislative practice implies first and foremost correction as to lawfulness, in particular improvements of a legal-dogmatic and legal-technical nature. Suggestions for improving the effectiveness and social desirability of legislative texts as well as their politico-bi-cameral and non-controversial nature are also placed under the heading 'assistance'.

There are substantial differences between the four upper houses with regard to democratic legitimisation, composition and organisation. The members of the British and German upper houses (over 700 and 69 members, respectively) are appointed rather than elected. In the United Kingdom, they are appointed 'for Life' through the head of government; in Germany indirectly for an indeterminate period of time from the incumbent governments of the sixteen Lander. The members of the Dutch upper house, 75 in total, are elected indirectly through a system of proportional representation. Finally, the members of the French Sénat (321) are elected through a system made up of elements of both proportional representation and majority voting. As a result, in the case of the British upper house, democratic legitimisation is virtually absent with regard to co-legislation and control of executive action, whereas the Bundesrat has been indirectly legitimised through the Lander administrations. For the Sénat and the Dutch upper house, the Eerste Kamer, democratic legitimisation, at least in theory, may be regarded as a significant Leitmotiv. It was found that the partypolitical relations within the respective upper houses are also influenced by the system employed: election or appointment. Until the coming into effect of the House of Lords Act 1999, the British upper house was dominated quantitatively by the Conservatives. After the majority of the Hereditary Peers had been sent off that year, the Labour government started to appoint additional Life Peers of a non-Conservative persuasion at an accelerated pace. This created a more balanced image in a party-political sense. No longer is it possible for one of the major British political movements to automatically have an absolute majority in the House of Lords. Such a conclusion can definitely not be drawn for the political move- 
ments represented in the Sénat, in spite of the fact that French senators are elected rather than appointed through free and secret ballots. Even a sudden substantial change in preference of the electorate, a phenomenon occurring with remarkable regularity in contemporary France, may only effect marginal changes in seat distribution in the Palais de Luxembourg. This is a consequence of the distinctive electoral regime for the French upper house. A number of mutually reinforcing rules in electoral legislation cause rural France to be structurally over-represented in the upper house. Consequently, since 1958, the centre-right has dominated the Sénat uninternuptedly.

The degree of party-political stability of the House of Lords and the Sénat can never be equalled by the Eerste Kamer and the Bundesrat. In the Netherlands, virtually every change in electoral preference on the occasion of the quadrennial elections for provincial administrations has a direct and full impact on the composition of the upper house. The partypolitical composition of the Bundesrat is affected by the separate elections for each of the sixteen Lander parliaments. Since 1972, in the majority of cases, the party-political relations in the Bundesrat have developed 'opposite to' coalition relations in the Bundestag. In the Dutch Eerste Kamer, finally, the opposition parties in the lower house have never had a majority of the seats since the introduction of general suffrage.

The most important duty of the four upper houses is co-legislation. Large differences in legislative practice have been found. Managing the legislative timetable is the prerogative of national governments. As a rule, the lower houses have (as in France) or wish to have (as in the United Kingdom) little influence on the composition and progress of the agenda. In the case of the Netherlands, a fully passive attitude was found. Only the Bundesrat exerts influence on a structural basis, where the legislative agenda is concerned.

In the Federal Republic of Germany, furthermore, the right of initiative is also successfully exercised on a regular basis by the (varying majority coalitions in the) upper house. In parliamentary practice, the Sénat and the House of Lords are fully dependent on the good will of the government of the day and, of course, the party-political majority in the Assemblée nationale and the House of Commons, respectively. The Dutch Eerste Kamer has no right of legislative initiative.

With regard to the extent to which the four upper houses are given the opportunity to exert genuine influence on legislative products through the very important committee phase, again the Bundesrat comes out on top. As a result of the certainty of continuous legislative expertise offered by the public servants of the Lander, German senators have two opportunities through committees to review bills in the course of the regular legislative process. French senators gain expertise though an organisation specially geared for that purpose. Each senator holds a nine-year mandate. He/she can only sit on a single permanent committee and the bills must be thoroughly prepared and monitored by rapporteurs. Aside from the input offered on a permanent basis by the government, the thoroughness of the work by the British committees strongly depends on the expertise that happens to be available in the House of Lords at that moment, so that bills in one policy area may be paid more attention than those in others. Strength in numbers and especially the appointment of hundreds of new Life Peers indisputably have enhanced the intensity with which committee work is done in the House of Lords.

The Dutch Eerste Kamer also enjoys the least favourable position where influence on legislative products is concerned. Inasmuch as the $\mathbf{7 5}$ part-time senators under a four-year 
mandate are not able to generate much time and manpower to develop 'lasting' expertise, but especially because they have, in effect, no instruments at their disposal to amend the substance of bills, the committee stage of the Eerste Kamer can be readily left out.

The main instruments available to the upper houses for the purpose of amending bills are the right of veto and the right of amendment, sometimes combined with forms of dispute settlement in order to definitively resolve any conflicts with the lower house. A suspensory veto right has proved to be of little practical value to the senate in amending bills. Both the House of Lords and the Bundesrat use the instrument sparingly. Of more interest is the absolute right of veto. The Bundesrat and the Eerste Kamer have such a right, in the case of the Bundesrat applying to $65 \%$ of bills. An absolute right of veto has shown to generate a large preventative effect if combined with the power of intervention during preceding stages in the legislative process This assumption was borne out unequivocally as a result of studying the Bundestag's Plenarprotokolle. It was found that amendment proposals introduced by the Bundesrat during the 'erste Durchgang' were most likely to be adopted by the Bundestag, even where such Bundesrat's proposals were of a non-'assisting' (read: political) nature. In a bi-cameral legislative system, such as that of the Netherlands, where the right of veto will be exercised in rare cases at the end of the legislative process, preventative 'tinkering' with bills based on senatorial wishes is precluded by definition. However, even in the ultimate stage of the Dutch legislative process, when the upper house is entitled to scrutinise and assess the final product, no legal basis exists for 'tinkering'. Apart from the odd 'crumb', through the novelle construction, it does not happen. An across-the-board 'yes' or 'no' are the only options for Dutch senators. Placed at the end of a complex and time-consuming legislative process, and relatively closely coached by the government coalition of the day, the answer is readily 'yes', even where, occasionally, it is perfectly clear in advance that the bill is in complete breach of the rule-of-law principle.

The Sénat and the House of Lords have a right of amendment, which is exercised on a large scale. In French legislative practice, depending on the party-political relations of the day, the right of amendment is found to be deployed as a 'rivalling' instrument to slow down the process of bills that are unwelcome. The French constitutional legislator, however, has provided the government with a number of legal means to reduce the effectiveness of 'rivalling' behaviour to virtually zero. The right of amendment of either house has proved more significant as an instrument of 'assistance'. Improvement of the quality of bills is paramount in this respect. The House of Lords in particular, but also the Sénat, spend a lot of time and energy on this. The fact that the House of Lords puts that much energy into legislative activities of an 'assisting' nature has also something to do with dispute resolution as operative in the United Kingdom. If the House of Commons and the House of Lords continue to disagree on the final draft of a bill, the latter may be 'overruled' in the end pursuant to the Parliament Acts 1911 and 1949. In France, a Commission Mixte Paritaire, which is a conciliation commission consisting of members of both houses, will be established in case of dispute, before the Assemble nationale, with the cooperation of the government, renders a final judgment on (the wording of) the bill. Also in Germany, where the Bundesrat has been given powers closely resembling a right of amendment to modify legislative products, disputes over the wording of bills may ultimately be entrusted to a conciliation commission (Vermittlungsausschuss). The Bundesrat has the power to still withhold its consent (Zustimmung) afterwards in approximately 65 per cent of bills, in 
which case the bill is consigned to the dustbin. In sharp contrast with the Bundesrat, the House of Lords and the Sénat may eventually be sidelined.

The above entails that, in practice, the review of legislative proposals conducted by the four upper houses under study largely takes place under the guidance of the government. In theory, they exercise their legislative duties on the basis of a dualistic conception; in practice, however, they engage in activities that are mainly of an 'assisting' nature. This is different for the Netherlands only, since the Dutch upper house has been denied any instruments, in the form of a right of amendment or a derived right, to effectively render 'assistance' and lacks almost totally the necessary room to act in parliamentary practice.

Politically 'rivalling' activities by the upper house within the context of the legislative process are consistently nipped in the bud (France) or simply not tolerated (United Kingdom and the Netherlands). Only in the Federal Republic of Germany is the senate capable of playing a 'rivalling' role in a polico-policy sense as well as an 'assisting' role where legal-dogmatic and legal-technical considerations are concerned. It is not so much the federal structure of the Bundesrepublik that has caused the difference in practical operation. It is rather a very well thought-out system of interrelated legal rules governing federal legislative procedure starting with the first Durchgang, through strongly professionalised permanent committees and the second Durchgang, to, where applicable, the final vote on the outcome of the Vermittlungsausschuss.

There is no evidence of a strong relation between proper democratic legitimisation of the upper house and co-legislative influence exerted by that same house. The duly democratically legitimised Dutch upper house has virtually no role to play as co-legislator, whereas it was found that the House of Lords, which has no democratic legitimisation whatsoever, is now a comparatively serious 'assisting' legislative partner. Time and lasting -hence further advancing-expertise are major factors in this respect.

Although the four senatorial houses spend most of their time by far on co-legislative duties, they also perform others. The majority of these can be simply brought under the heading 'control of executive action'. As yet, additional control of government policy by upper houses, under the umbrella of ministerial responsibility, has proved of little effect. The House of Lords and the Sénat have been found to lack workable sanctioning instruments to render such policy control effective. Moreover, they are kept harmless by a rigid partypolitical organisation via the usual democratic majority rules. This is also observed in the Netherlands. As a result, the Dutch upper house spends almost no time controlling executive action. This attitude of great restraint adopted by the Eerste Kamer in relation to parliamentary scrutiny of executive action is especially remarkable, since only in the Netherlands the relation senate-government is formally based on confidence (vertrouwensregel).

Expressed in the terminology used here, this implies that, in the year 2001, 'rivalling' behaviour by the upper houses in relation to vigorous control of executive action, under the umbrella of ministerial responsibility, has nearly ceased to be a politico-strategic spearhead in the continuous search for a workable balance, in either the Senat, the House of Lords and the Eerste Kamer. This in spite of all the efforts to this effect still taken on a regular basis by the French upper house in particular. In the United Kingdom and to a lesser degree in France, the resulting 'deficit' in the set of controlling duties of the upper houses has been somewhat taken up by independent investigative activities of a strongly 'assisting' nature. To achieve this, the House of Lords and the Sénat had to start operating outside the tradi- 
tional boundaries of ministerial responsibility. Independent information gathering by the upper house is often, certainly in the beginning, fully divorced from (possible future) government policy. Precisely because of the 'assisting' nature of their independent investigations, for which they had to extend their duties beyond the traditional boundaries of ministerial responsibility, these two upper houses have proved capable of adding some substance to control of executive action within traditional boundaries. An example would be EU-related policy views or topics relating to science and technology becoming part of the parliamentary debate in London or Paris.

It can be concluded that also where control of executive action is concerned the upper houses of the United Kingdom and France act increasingly in terms of 'assistance' and certainly not exclusively in terms of 'rivalry'. For the most part, the original bi-cameral concept of an effective additional check of government policy from a perspective of 'rivalry' is obsolete and needs to be modified. It was found that close party-political ties, be it within a monist context or otherwise, in large part determine the lack of 'rivalling' impact, especially in the United Kingdom, France and the Netherlands. The possible existence of a confidence rule that can be made fully operational, is not going to counteract this effect. The near complete absence of any form of effective control by the Dutch Eerste Kamer of executive action, as opposed to practices in the other countries under investigation, clearly demonstrates this.

Such traditional control instruments, under the umbrella of ministerial responsibility, as the right to pose questions (vragenrecht) or the right of parliamentary inquiry (enquête), have been found to be of no effect in the hands of the upper houses with the exception of the Bundesrat, of course. In general, the Bundesrat is kept abreast of things by the federal government. This is due to the fact that the federal upper house and the federal government are strongly interdependent, much more so than is the case in the other countries, where legislation is concerned. It must be borne in mind in this respect that it is the sixteen Lander that must implement policies. It is therefore logical, solely from a practical angle, that the German federal government optimally informs these 'executive' authorities on policy development.

In the year 2001, the senatorial chambers, with the exception of the Dutch upper house, continue to offer added value, particularly in the area of legislative 'assistance'. In addition to this, the British and French upper houses manifest themselves more and more effectively in an 'assisting' capacity through investigative reports on a number of core policy areas, for instance with regard to the EU. As a result, regular initiation of new legislative proposals has become a matter of course.

In view of the above, it seems therefore reasonable to abolish the now virtually meaningless Dutch upper house. A constitutional court will be well able to fill in the resulting gaps. Should abolition prove not to be feasible politically, then the following essential adjustments to the current system should be introduced:

The number of senators should be increased. They should spend more than the odd day a week on parliamentary work. The electoral mandate must be extended in duration, so that more expertise can be gained. A certain degree of assistance by public servants is needed. These preconditions will make it more feasible to effectively give meaning to the operation of a committee system. In that event, the Dutch upper house could engage in co-legislative activities in an almost purely 'assisting' capacity modelled on the British example. The 
right of veto, which has proved to be completely meaningless, may be exchanged, to this end, for a right of veto of a suspensory nature of limited duration (as a political signal) in combination with a right of recommittal (terugzendrecht). In a substantive sense, such right of recommittal will provide the Dutch upper house with a right of amendment that can be exercised without restraint. Ultimately, it will have to be the first house, i.e. the lower house, as the weightiest chamber, which, through the power of amendment, determines whether or not amendments proposed by the upper house will be incorporated in the definitive legislative product. British and French bi-cameral legislative practice, incidentally, has demonstrated that well-argued amendment proposals from the senate have proved to be very persuasive. The regime governing constitutional amendments does not need to be revised so long as the Netherlands maintains a bi-cameral system.

The Dutch upper house should also spend time, in future, on non-legislative activities. An upper house that operates on the basis of a conception that is mainly of an 'assisting' nature is excellently suited to conduct parliamentary enquiries (enquêtes). Furthermore, it will prove conducive to conducting independent investigations and building the necessary areas of expertise based on the British and French examples. 


\section{Geraadpleegde literatuur}

Akkermans, P.W.C. (red)

De Grondwet, een artikelsgewijs commentaar, tweede druk, Tjeenk Willink Zwolle 1992 Albrecht, $\mathrm{M}$.

De invloed van het kiesstelsel op de samenstelling van de volksvertegenwoordiging en op de vorming van de regering, Arbeiderspers Amsterdam 1960

Archer, $\mathrm{P}$.

The House of Lords, Past, Present and Future, in: The Political Quarterly 1999, p. 396-403 Arnim, $\mathrm{H}-\mathrm{H}$.

Die Verfassung hinter der Verfassung, Zeitschrift fur Rechtspolitik 1999, p. 326335

Ashworth, V.

Le controle de constitutionnalité des lois par le Sénat du Second Empire, in. Revue du Droit Public et de la Science Politique en France et a l'Étranger 1994، p. 40-51 Avril, P.

Les innovations sénatoriales, in: Pouvoirs nr.44 1988, p. 111-123

Avril, P. et Gicquel, J.

Droit pariementaire, Montchrestien Paris 1996

Badura, B.

Staatsrecht, Systematische Erlăuterung des Grundgesetzes fur die Bundesrepublik Deutschland, C.H. Beck'sche Verlagsbuchhandlung, Munchen 1996

Baguenard, J.

Le Sénat, Presses Universitaires de France Paris 1990

Baldwin, N.

The House of Lords and the Labour Government 1974-1979, in: Journal of Legislative Studies 1995 , p. 218-242

Baldwin, $\mathrm{N}$.

The Membership of the House, in: D. Shell and D. Beamish (eds), The House of Lords at Work, Oxford Claredon Press 1993, p. 39-55

Baldwin, N.

The Membership and Work of the House of Lords, in: P. Carmichael and B. Dickson (eds),The House of Lords, Its Parliamentary and Judicial Roles, Hart Publishing Oxford 1999. p. 29-51

Beamish, D. and Shell, D.

The House of Lords at Work, A Study based on the 1988-1989 Session, Clarendon Press

Oxford 1993

Beatty, A.

Why the Case for Parliamentary Reform in Britain is so weak, in: The Journal of Legislative Studies 1998, p. 1-16

Bécane, J-C.

Le règlement du Sénat: A la recherche du temps maîtrisé, in: Pouvoirs nr. 44 1988, p. 79-86

Beekelaar, G.A.M.

Tussen twee revolutiejaren, De Eerste Kamer van 1830 tot 1848, in: A. Postrma e.a. (red), Aan deze zijde van het Binnenhof, SDU 's-Gravenhage 1990, p. 83-138

Bevers, $\mathrm{H}$.

Nieuws over de novelle, Tijdschrift voor beleidswetenschappen en publiekrecht 1989.

p. 391408 . 
Blanke, H-J.

Der Bundesrat im Verfassungsgefuge des Grundgesetzes, in: Jura 1995, Heft 2, p. 5766 Blom, H.W.

Bicameralism, History - theory - problems, in: H.W. Blom e.a. (red), Bicameralisme. Tweekamerstelsel vroeger en nu. Handelingen van de Internationale Conferentie ter gelegenheid van het 175-jarig bestaan van de Eerste Kamer der Staten-Generaal, Den Haag 1992, p. 19-34 Blom, H.W.

Ethos and interests, Arguments for representational differentiation in a changing society, in: H.W. Blom e.a. (red), Bicameralisme, Tweekamerstelsel vroeger en nu, Handelingen van de Internationale Conferentie ter gelegenheid van het 175 -jarig bestaan van de Eerste Kamer der Staten-Generaal, Den Haag 1992, p. 147-155

Blondel, J.

Comparative Government, Sage London 1990

Bogdanor, V.

The problem of the upper house, in: H.W. Blom e.a. (red), Bicameralisme, Tweekamerstelsel vroeger en nu, Handelingen van de Internationale Conferentie ter gelegenheid van het 175 jarig bestaan van de Eerste Kamer der Staten-Generaal, Den Haag 1992, p. 411422

Bogdanor, V.

Reform of the House of Lords: A Sceptical View, in: The Political Quarterly 1999, p. $375-381$

Bos, W.

Der Bundesrat als Träger der auswärtigen Gewalt, Tubingen 1977

Borthwick, R.

Delegated Legislation, in: D. Beamish and D. Shell (eds). The House of Lords at Work, Oxford University Press 1993, p. 137-165

Borthwick, R.

Debates and Questions, in: D. Beamish and D. Shell (eds),The House of Lords at Work,

Oxford University Press 1993, p. 210-246

Bown, F.

Influencing the House of Lords: the Role of the Lords Spiritual 1979-1987, in: Political Studies 1994, p. 105-119

Braak, van den, $B$.

De Eerste Kamer, Geschiedenis, samenstelling en betekenis 1815-1995, Sdu Den Haag 1998

Brazier, R.

Constitutional Practice, Clarendon Press Oxford 1990, p. 195-223

Brazier, R.

The Second Chamber: Paradoxes and Plans, in: P. Carmichael and B. Dickson (eds), The

House of Lords, Its Parliamentary and Judicial Roles, Hart Publishing Oxford 1999, p. 54-65

Britz, G.

Zustimmungsbedorftigkeit von Bundesgesetzen und die Verwaltungsorganisationshoheit der Lander, Probleme der Anwendung von Art. 84 Abs. 1 und Art. 85 Abs. 1 GG, in: Die Öfentliche Verwaltung 1998, p. 636642

Bromhead, P.A.

The House of Lords and Contemporary Politics, Routledge\& Kegan London 1958

Bromhead, P.A. and Shell, D.

The Lords and their House, in: Parliamentary Affairs 1967, p. 337-349 


\section{Brown, A}

Parliament 1377-1422, in: R. Davies and J. Denton (eds), The English Parliament in the Middle Ages, Collins London 1984

Bundesrat

Vierzig Jahre Bundesrat, Tagungsband zum wissenschaftlichen Symposium in der Evangelischen Akademie Tutzing, Baden-Baden 1989

Burkens, M.C. en Schagen, van, J.A.

De Bondsrepubliek Duitsland, in: L. Prakke en C.A.J.M. Kortmann (red), Het staatsrecht van de landen van de Europese Unie, Deventer 1998, p. 111-173

Busch, E.

Die Stimmenverteilung im Bundesrat, Ein verfassungsgeschichtlicher Vergleich, in: Zeitschrift fur Gesetzgebung 1990, p. 307332

Camby, J-P et Servent, P.

Le travail parlementaire sous la cinquième Republique, Montchrestien Paris 1992

Camby, J.P.

La saisine du Conseil constitutionnel ou l'impossible retrait, in: Revue du Droit Public et de la Science Politique en France et a I' Étranger 1997, p. 5-12

Carmichael,P. and Baker, A.

Second Chambers, A Comparative Perspective, in: P. Carmichael and B. Dickson (red). The House of Lords, Its Parliamentary and Judicial Roles, Hart Publishing Oxford 1999, p. 67-90 Chaussebourg, A.

Les groupes parlementaires du Sénat, in: Pouvoirs 1988 nr. 44, p. 69-77

Chazelle, $R$.

Le Sénat et le Droit Parlementaire Coutumier, in: Chroniques Constitutionnelles 1988. p. 711-733.

Chevalier, $\mathrm{F}$.

Le Sénateur francais 1975-1995, Essai sur le recrutement et la représentativité des membres de la seconde chambre, Science Politique Paris 1989

Chevallier, J-J.

Histoire des institutions et des régimes politiques de la France de 1789 à nos jours, Editions Dalloz, Paris 1991

Cluzel, J.

Le Sénat dans la société française, Economica, Paris 1990

Cohendet, M-A.

La Cohabitation, Leçons d'une expérience, Presses Universitaires de France Paris 1993

Couwenberg, S.W.

Bicameralism - historical background, alternative conceptions and current relevance, in: H.W. Blom e.a. (red), Bicameralisme. Tweekamerstelsel vroeger en nu. Handelingen van de Internationale Conferentie ter gelegenheid van bet 175-jarig bestaan van de Eerste Kamer der Staten-Generaal, Den Haag 1992, p. 139-146

Cowley, P.and Melhuish, D.

Peers' Careers: Ministers in the House of Lords, 1964-95, in: Political Studies 1997, p. 21-35 Cramer, $\mathrm{N}$.

De Eerste Kamer na 1917 in heroverweging, in: A. Postma e.a. (red), Aan deze zijde van het Binnenhof, SDU 's-Gravenhage 1990, p. 283-344

Cromwell, $\mathrm{V}$,

Peers and personal networks: the link between the two Houses of Parliament since the mid- 


\section{Geraadpleegde literatuur}

nineteenth century, in: : H.W. Blom e.a. (red), Bicameralisme, Tweekamerstelsels vroeger en $\mathrm{nu}$, Handelingen van de Internationale Conferentie ter gelegenheid van het 175-jarig bestaan van de Eerste Kamer der Staten-Generaal, Den Haag 1992, p. 383395

De Smith, $\mathrm{S}$. and Brazier, $\mathrm{R}$.

Constitutional and Administrative law, Penguin Books London 1998

Delcamps, A.

Le Sénat et la décentralisation, Economica Paris 1991

Dolle, A.H.M.

Het recht van parlementaire enquête, Serie monografieèn Nederlands Parlementsrecht nr.3,

Wolters Noordhoff Groningen 1985

Drewry, G. and Brock, J.

Government Legislation: An Overview, in : D. Beamish and D. Shell (eds), The House of

Lords at Work, Oxford University Press 1993, p. 61-96

Dreyfus-Schmidt, $M$.

Le Métier de sénateur, in: Pouvoirs 1988 nr. 44, p. 59-68

Elzinga. D.J. en Wisse, C.

De parlementaire fracties, Serie monografieèn Nederlands Parlementsrecht nr. 5, Wolters

Noordhoff Groningen 1988

Elzinga, D.J.

De politieke ministeriële verantwoordelijkheid, in: D.J. Elzinga (red), Ministeriële verantwoordelijkheid in Nederland, Tjeenk Willink, Zwolle 1994, p. 3149

Fabritius, G.

Der Bundesrat: Transmissionsriemen fur die Unitarisierung der Bundesrepublik?, in:

Zeitschrift fur Parlamentsfragen 1976, p. 448-460

Finer, $\mathrm{S}$.

Comparative Government, An introduction to the study of politics, Penguin Books

Harmondsworth 1985

Franklin, $\mathrm{M}$. and Norton, $\mathrm{P}$.

Parliamentary Questions, Clarendon Press Oxford 1993

Friedrich, $\mathrm{M}$.

Bundesrat und Landesparlamente, in: Zeitschrift fur parlamentsfragen 1975, p. 48-76

Fröchling, $\mathrm{H}$.

Der Bundesrat in der Koordinierungspraxis von Bund und Landern, zur Rolle des Bundesrates im kooperativen Föderalismus, Becksmann Freiburg 1972

Fromme, $\mathrm{F}$,

Die beide "Kammern" im Widerstreit, Gegensātzliche Mehrheiten in Bundestag und Bundes-

rat, in: D. Wiltke und B. Schulte (red), Der Bundesrat, Darmstadt 1990, p. 381-401

Gaay Fortman, de, W.F.

Problemen van wetgeving, Kluwer Deventer 1982

Gallagher, $\mathrm{M}$.

Electoral Systems and Voting Behavior, in: M. Rhodes (ed). Developements in West

European Politics, Macmillan Press, London 1997, p. 114-130

Georges, P.

Droit Public, Economica Paris 1992

Gicquel, J-E.

Droit Constitutionnel et Institutions Politiques, Editions Montchrestien Paris 1995, p. $421-489$ 
Gicquel, J-E.

Le Sénat sous la seconde cohabitation, in: Revue du Droit Public et de la Science Politique en France et à l'Étranger 1996, p. 1069-1094

Gicquel, J-E.

La lutte contre l'abus du droit d'amendement au Sénat, in: Revue du Droit Public et de la

Science Politique en France et a l'Étranger 1997, p. 1351-1374

Giddings, P. and Drewry, G.

The House of Lords and the European Community: The Evolution of Arrangements for

Scrunity, Macmillan London 1995

Goguel, F.

Du Sénat de la Ille à celui de la Ve, in: Pouvoirs 1988 nr. 44 , p. 5-14

Grangé, J.

Lefficacité normative du Sénat, in: Revue Française de Science Politique 1984, p. 955-987

Grangé, J.

Le système d'election des sénateurs et ses effets., in Pouvoirs 1988 nr. 44, p. 35-57

Grangé, J.

Les déformations de la représentation des collectivités territoriales et de la population au

Sénat, in: Revue Française de Science Politique 1990, p. 5-45

Grangé, J. et Mastias, J.

Le Sénat francais comparé aux autres deuxièmes Chambres européennes, in: Pouvoirs 1988 nr. 44, p. $131-140$

Gramm, Ch.

Gewaltenverschiebungen im Bundesstaat, Zu Moglichkeiten und Grenzen der

Verfassungsrechtsdogmatik, in: Archiv des offentlichen Rechts 1999, p. 212236

Grantham, C.

Select Committees, in: D. Beamish and D. Shell (eds), The House of Lords at Work, Oxford University Press 1993, p. 281-307

Griffith, J. and Ryle, M.

Parliament, Functions, Practice and Procedures, Sweet \& Maxwell, London 1989

Guchet, Y.

La Ve République, Economica Paris 1994

Hagelstein, G.H.

Correcties van fouten in wetsvoorstellen, in: Tijdschrift voor Openbaar Bestuur 1985 , p. $334-338$.

Hagelstein, G.H.

De parlementaire commissies, Serie monografieen Nederlands parlementsrecht nr. 6, Wolters Noordhoff Groningen 1991

Hagelstein, G.H

De Eerste Kamer roert zich, reactie, in: Nederlands Juristenblad 1986, nr. 2, p. $51-52$

Hainkel, A.

Die Organisation des Bundesrates, Schäuble Berlin 1991

Hancock, D.

Politics in Western Europe, London 1998

Hanf, D.

Bundesstaat ohne Bundesrat?, Die Mitwirkung der Glieder und die Rolle zweiter Kammern in evolutiven und devolutiven Bundesstaaten, Eine rechtsvergleichende Untersuchung, Nomos Verlagsgesellschaft Baden-Baden 1999 


\section{Geraadpleegde literatuur}

Hanikel, A.

Die Organisation des Bundesrates, Schảuble Rheinfelden 1991

Harrison, M. e.a.

De Gaulle to Mitterand, Presidential Power in France, Hurst \& Company, London 1993

Heringa, A.W.

Ministeriele verantwoordelijkheid en parlementaire controle, in: P.P.T. Bovend'Eert e.a. (red), Grensverleggend staatsrecht, Kluwer Deventer 2001, p. 155173.

Heringa, A.W. en Zwart, T.

De Nederlandse Grondwet, Tjeenk Willink Zwolle 1991

Hofmann $\mathrm{H}$. und Meyer-Tesschendorf, $\mathrm{K}$.

Der Europa-Artikel 23 GG in der staatlichen Praxis, in: Zeitschrift fur Gesetzgebung 1997, p. 8186

Hood Phillips', O.

Constitutional and Administrative Law, Sweet \& Maxwell London 1987

Jekewitz, J.

Die Stimmenverteilung im Bundesrat nach dem Einigungsvertrag, in: Recht und Politik 1991, Heft 1, p. 97-109

Jekewitz, J.

Schonzeit fur Rehe als Machtprobe zwischen Bundesregierung und Bundesrat, in: Zeitschrift fur Rechtspolitik 1995, p. 248251

Jones, G.W.

A Forgotten Right Discovered, in: Parliamentary Affairs 1967, p. 363372

Jurgens, E.C.M.

Een recht van renvooi!, in: Namens 1989, nr. 8, p. 27

Jurgens, E.C.M

De mythe van Meerenberg. Over de betrekkelijke legitimatie die uitgaat van medewetgeving door de Staten-Generaal, in: Nederlands Juristenblad 1993, p. 13811386

Jurgens, E.C.M.

Senaat moet uitvoering van wetten controleren, in: NRC Handelsblad 2 januari 1996

Jurgens, E.C.M.

Mr.F. de Vries, De staatsrechtelijke positie van de Eerste Kamer, Boekbeschouwing, in: RM Themis 2001, p. 287289

Jutzi, S

Losentscheid im Gesetzgebungsverfahren, Zum neuen "Wechselstimmverfahren" nach der

Mainzer Bundesratsklausel in der Koalitionsvereinbarung von SPD und FDP, in: Zeitschrift fur Rechtspolitik 1996, p. 380385

Kalberg, F.A.J.T.

De staatsrechtelijke positie van de Eerste Kamer der Staten-Generaal, in: Tijdschrift voor Openbaar Bestuur 1990, p. $302-306$, p. $333-338$ en p. $364-366$

Kan, J.M. (red)

Een nieuwe Grondwet?, Beschouwingen naar aanleiding van het eindrapport van de

Commissie Cals-Donner, Tjeenk Willink Zwolle 1971

Kerkhofs, T.H

Het recht van amendement, in: H.M. Franssen (red), Het parlement in aktie, van Gorcum Assen 1986 
Klein, $\mathrm{H}$.

Der Bundesrat der Bundesrepublik Deutschland, die "Zweite Kammer", in: Archiv des offentlichen Rechts 1983, p. 329370

Knies, W.

Der Bundesrat: Zusammensetzung und aufgaben, in: Die Offentliche Verwaltung 30, 1977

Knippenberg, E.T.C.

Refelecties over de positie van de Eerste Kamer heroverwogen, in: Nederlands Juristenblad 2000 , p. 934-936

Knippenberg, E.T.C.

La Bouche qui dit Oui, De Nederlandse senaat in internationaal perspectief, Bestuurskunde 2000 , p. $364-376$

Konig, $\mathrm{T}$.

Politikverflechtungsfalle oder Parteienblockade?, Das Potential fur politischen Wandel im deutschen Zweikammersystem, in: Staatswissenschaft und Staatspraxis 1997, p. 135-161

Konow, G.

Uberlegungen zum Sitz des Bundesrates, in: Zeitschrift fur Rechtspolitik 1996, p. 161163

Kortmann, C.A.J.M.

Constitutioneel Recht, Kluwer Deventer 1997, p. 199-230

Kortmann, C.A.J.M.

De Franse Republiek, in: L. Prakke en C.A.J.M. Kortmann (red), Het staatsrecht van de landen van de Europese Unie, Kluwer Deventer 1998, p. 223-297

Koschnick, $\mathrm{H}$.

Der Bundesrat zwischen Landerinteressen, gesamtstaatlicher Verantwortung und Parteipolitik, in: Vierzig Jahre Bundesrat, Baden-Baden 1989, p. 81-94

Kummeling, H.R.B.M.

De Eerste Kamer: Chambre de Révolution, in: Nederlands Juristenblad 1990, p. 262-266

Kummeling, H.R.B.M.

De Nederlandse Eerste Kamer, preadvies, de Vereniging voor de vergelijkende studie van het recht van Belgiê en Nederland, Tjeenk Willink Zwolle 1992

Kummeling, H.R.B.M. en Bovend'Eert, P.

Van Raalte's Het Nederlandse parlement, Kluwer Deventer 2000

Laar, van, Th. J.

De positie van de Eerste Kamer, Regelmaat 2000, p. 145146

Laband, $\mathrm{P}$.

Der Bundesrat, Deutsche Juristen Zeitung 1911, p. 1-17

Lammers, $\mathrm{H}-\mathrm{H}$.

Der Reichsrat, in: Staatsund Selbstverwaltung 3, 1921-1922, p. 182-196

Lang, $R$.

Die Mitwirkungsrechte des Bundesrates und des Bundestages in Angelegenheiten der Europâischen Union gemâss Art. 23 Abs. 2 bis 7 GG, Duncker und Humbolt Berlin 1997

Laski, J.

The Problem of a Second Chamber, in: Studies in Law and Politics 1932, p. 104124

Laufer, $\mathrm{H}$.

Der Bundesrat: Eine Untersuchung aber Zusammensetzung. Arbeitsweise, politische Rolle und Reformprobleme, Bundeszentrale fur politische Bildung. Bonn 1972

Laufer, $\mathrm{H}$. und Monch, $\mathrm{U}$.

Das foderative System der Bundesrepublik Deutschland, Leske und Budrich Augsburg 1998 


\section{Geraadpleegde literatuur}

\section{Leonard, D.}

Replacing the Lords, in: The Political Quarterly 1995, p. $287-298$

Lijphart, A.

Democracies, patterns of Majoritarian and consensus Government in Twenty-One Countries, Yale University Press New Haven 1984

Lijphart, A. en Grofman, B.

Choosing an electoral system, Issues and Alternatives, Praeger New York 1984

Lijphart, A.

Electoral Systems and Party Systems, A study of Twenty-Seven Democracies 1945-1990,

Oxford University Press 1994

Lijphart, A.

Patterns of Democracy, Government Forms and Performance in Thirty-Six Countries, Yale

University Press New Haven 1999

Limberger, $\mathrm{G}$.

Die Kompetenzen des Bundesrates und ihre Inanspruchnahme: Eine empirische Untersuchung. Duncker und Humbolt Berlin 1982

Lohse, V

Die EG-Kammer des Bundesrates, ein Novum im deutschen parlamentarischen System, in:

Deutsche Verwaltungspraxis 1989 nr. 2, p. 3338

Longford, F.

A History of the House of Lords, Collins London 1988

Luchaire, F. et Conac, G.

La Constitution de la République française, Economica Paris 1987

Marichy, J-P.

La deuxième chambre dans la vie politique française depuis 1875, Librairie Générale de Droit de Jurisprudence, Paris 1969

Mastias, J.

Le Sénat de la Ve République: Réforme et Renouveau, Economica Paris 1980

Mastias, J. et Grangé, J.

Les Secondes Chambres du Parlement en Europe Occidentale, Economica Paris 1987

Mastias, J.

Histoir de tentations du Sénat de la Ve République, in: Pouvoirs 1988 nr. 44, p. 15-34

Mastias, J.

A Problem of Identity: The French Sénat, in: S. Patterson \& A. Mughan (eds), Senates,

Bicameralism in the contemporary World, Ohio State University Press, Columbus 1999, p. 162198

Maus, D.

Le Sénat, l'Assemblée nationale et le Gouvernement, in: Pouvoirs 1988 nr. 44, p. 119-130

Maus, D.

Le Parlement sous la Ve République, Presses Universitaires de France, Paris 1996

May, E.

Parliamentary Practice, Twenty-second Edition, Butterworths London 1997

Mclean, 1 .

Mr Asquith's Unfinished Business, in: The Political Quarterly 1999, p. 382-389

Meny, $Y$.

Government and Politics in Western Europe, Oxford University Press 1998 
Miers, D. and Brock, J.

Government Legislation: Case-Studies, in: D. Beamish and D. Shell (eds). The House of Lords at Work, Claredon Press Oxford 1993, p. 97-136

Miers, D and Page, A.

Legislation, Sweet \& Maxwell London 1982

Mitchell, J. and Davies, A.

Reforming the Lords, Institute of Public Policy Research London 1993

Morgan, J.

The House of Lords and the Labour Government 1964-70, Clarendon Press Oxford 1975

Mughan, A. and Swarts, J.

The Coming of Parliamentary Television: The Lords and the Senate Compared, in: Political

Studies 1997 , p. $36-48$

Natzler, D. and Millar, D.

Private Members' Bills, in: The House of Lords at Work, Clarendon Press Oxford 1993. p. $166-190$

Niemann, $\mathrm{H}$.

Die bundesstaatliche Bedeutung des Bundesrates unter besonderer Berocksichtigung der

Funktion des Vermittlungsausschusses, Gottingen 1978

Nohlen, D.

Wahlrecht und Parteiensystem, Augsburg 1989

Norris, P. and Lovenduski, J.

Political Recruitment: Gender, Race and Class in the British Parliament, Cambridge

University Press 1995

Norton, $\mathrm{P}$.

Does Parliament Matter?, Contemporary Political Studies, Harvester Wheatsheaf London 1993

Norton, $\mathrm{P}$.

The Legislative Powers of Parliament, in: The evolving role of Parliaments in Europe, Antwerpen 1994, p. 1532

Nuna, $R$.

The House of Lords in the Parliament of Mary I, a omen, London 1953

Oschatz, G-B, und Risse, $\mathrm{H}$.

Bemerkungen zum Gesetzinitiativrecht des Bundesrates, in: Zeitschrift fur Gesetzgebung 1989, p. 316331

Oschatz, G-B. und Risse, $\mathrm{H}$.

Bundesrat und Europaische Gemeinschaften, in: Die Offentliche Verwaltung 1989, p. 509519

Oschatz, G-B. und Risse, $\mathrm{H}$.

Die Bundesregierung an der Kette der Lànder?, Zur europapolitischen Mitwirkung des

Bundesrates, in: Die Offentliche Verwaltung 1995, p. 437-452

Oud, P.J.

Honderd Jaren, Een eeuw van staatkundige vormgeving in Nederland 1840-1940, Van

Gorcum Assen 1987

Patzelt, W.

The Very Federal House: The German Bundesrat, in: S. Patterson \& A. Mughan (eds),

Senates, Bicameralism in the contemporary World, Ohio State University Press, Columbus 1999 , p. 5992 
Pfitzer, A

Der Bundesrat: Mitwirkung der Lander im Bund, Huthig Heidelberg 1995

Polak, J.M.

De Eerste Kamer en de interpretatie van wetten, in: NJB 1986, p. 876

Posser, D.

Der Vermittlungsausschuss, in: Vierzig Jahre Bundesrat, Nomos Verlagsgesellschaft, BadenBaden 1989, p. 203213

Postma, A.

Het interpellatieen vragenrecht van de Eerste en Tweede Kamer, Serie monografieèn

Nederlands Parlementrecht nr. 2, Wolters Noordhoff Groningen 1985

Postma, A. en Strak, A.

De Reglementen van Orde van de Eerste Kamer der Staten-Generaal, Sdu 's-Gravenhage 1989

Postma, A.

De Eerste Kamer vergeleken met zusterinstellingen in het buitenland, in: A. Postma e.a., Aan deze zijde van het Binnenhof, Sdu 's-Gravenhage 1990, p. 409-442

Postma, A

De rol van de Eerste Kamer bij de formele wetgeving, Regelmaat 2000,p. 106114

Pour mieux connaître le Sénat, http://www.senat.fr, 30-11-2001

Prakke, L.

Van links naar rechts, De Eerste Kamer van 1849 tot 1887, in: A. Postma e.a. (red), Aan deze zijde van het Binnenhof, Sdu 's-Gravenhage 1990, p. 227-266

Prakke, L.

Het Verenigd Koninkrijk van Groot-Brittannié en Noord-Ierland, in: L. Prakke en C.A.J.M.

Kortmann (red), Het staatsrecht van de landen van de Europese Unie, Kluwer Deventer 1998, p. 793-867

Puttnam, D

A Democratic and Expert House, in: The Political Quarterly 1999, p. 368-381

Report of the Constitutional Commission on options for a new Second Chamber, Chairman Lord Mackay of Clashfern, Westminster April 1999

Report of the Royal Commission on the Reform of the House of Lords, Chairman Lord

Wakeham, Westminster January 2000

Reuter, $\mathrm{K}$.

Der Bundesrat als Parlament der Länderregieringen, Parlamentsrecht und Parlamentspraxis in der Bundesrepublik Deutschland, De Gruyter Berlin 1989

Reuter, K.

Praxishandbuch Bundesrat, Verfassungsrechtliche Grundlagen, Kommentar zur Geschaftsordnung, Praxis des Bundesrates, Muller Juristischer Verlag Heidelberg, 1991

Richard, I. and Welfare, D.

Unfinished Business, Vintage London 1999

Riddell, $\mathrm{P}$.

The Second Chamber: In Search of a Complementary Role, in: The Political Quarterly 1999. p. $404-410$

Rush, M.

Parliament and the Public, Longman London 1986 
Rush, M.

The House of Lords: The Political Context, in: P. Carmichael and B. Dickson (eds), The House of Lords, Its Parliamentary and Judicial Roles, Oxford 1999, p. 7-28

Russell, M.

Second Chambers Overseas, in: The Political Quarterly 1999. p. 411-418

Russell, M.

Reforming the House of Lords, Lessons from Overseas, Oxford University Press 2000

Ruwe, De, Th.

De Eerste Kamer der Staten-Generaal, Gebr. Janssen Nijmegen 1957

Sauvel, T.

L'Empereur et le Conseil d' Etat statuant au contentieux, in: Revue du Droit Public et de la

Science Politique en France et à l'étranger 1973, p. 1383-1402

Scheltema, M. en Lubberdink, H.G.

Ministeriele verantwoordelijkheid en parlementaire Controle, in: Parlementaire controle en democratie in de verzorgingsstaat, Staatsrechtcongres 1980, Ars Aequi Libri 1980, p. I-18

Schenke, W-R.

Gesetzgebung zwischen Parlamentarismus und Foderalismus, in: Parlamentsrecht und

Parlamentspraxis in der Bundesrepublik Deutschland, De Gruyter Berlin 1989, p. 1485-1521

Schepper, $\mathrm{H}$

De Eerste Kamer in het Verenigd Koninkrijk der Nederlanden, in: A. Postma e.a. (red), Aan deze zijde van het Binnenhof, Sdu 's-Gravenhage 1990, p. 15-58

Schmidt-Bleibtreu, B.

Kommentar zum Grundgesetz, Luchterhand, Berlin 1995

Schneider, $\mathrm{H}$.

Die Zustimmung des Bundesrates zu Gesetzen, in: D. Wiltke und B. Schulte (red), Der

Bundesrat, , Die staatsrechtliche Entwicklung des foderalen Verfassungorgans,

Wissenschaftliche Buchgesellschaft Darmstadt 1990, p. 283-300

Schneider, H-P. und Zeh, W.

Parlamentsrecht und Parlamentspraxis in der Bundesrepublik Deutschland, De Gruyter, Berlin 1989

Scholl, U.

Der Bundesrat in der deutschen Verfassungsentwicklung, Reichsverfassung von 1871 und

Grundgesetz, Duncker und Humblot Berlin 1982

Scholtz, R.

Die Gemeinsame Verfassungskommission von Bundestag und Bundesrat, in: Zeitschrift fur Gesetzgebung 1994 nr. 1, p. 134

Schormann, M.

Die Umgehung des Bundesrates im sog. "Ersten Durchgang" einer Gesetzesvorlage, in:

Archiv des offentichen Rechts, Tubingen 1990, p. 45-63

Schattemeyer, S. und Sturm, R.

Wozu Zweite Kammern?, Repräsentation und Funktionalitat Zweiter Kammern in westlichen Demokratien, in: Zeitschrift fur Parlamentsfragen 1992, p. 517536

Seydel, M.

Der Deutsche Bundesrath, in: D. Wilke und B. Schulte (red), Der Bundesrat, Die staatsrechtliche Entwicklung des foderalen Verfassungorgans, Wissenschaftliche Buchgesellschaft Darmstadt 1990 , p. $5-40$ 


\section{Geraadpleegde literatuur}

Shell, D.

The House of Lords, Harvester Wheatsheaf, London 1992

Shell, D. The House of Lords and the Thatcher Government, in: Parliamentary Affairs 1985, p. 16-32

Shell, D. The House of Lords in Context, in: D. Beamish and D. Shell (eds), The House of Lords at Work, Claredon Press Oxford 1993, p. 1-33

Shell, D. Questions in the House of Lords, in: M. Franklin and P. Norton (eds), Parliamentary Questions, Oxford University Press1993, p. 150-175

Shell, D. The European Communities Committee, in: D. Beamish and D. Shell (eds), The House of Lords at Work, Claredon Press Oxford 1993, p. 247-281

Shell, D. The House of Lords: Time for a Change, in: Parliamentary Affairs 1994, p. 721737

Shell, D. The Second Chamber Question, in: The Journal of Legislative Studies 1998, p. 17-32

Shell, D. and Giddings, P.

The Future of Parliament, Reform of the Second Chamber. The Hansard Society for

Parliamentary Government, London 1999

Shell, D.

The Future of the Second Chamber, in: The Political Quarteriy 1999, p. 390-396

Shell, D. To Revise and Deliberate: The British House of Lords, in: S. Patterson \& A. Mughan, Senates (eds), Bicameralism in the contemporary World, Ohio State University Press,

Columbus 1999, p. 199224

Smith, E.A.

The House of Lords in British Politics \& Society 1815-1911, Collins London 1992

Sommer, K-L.

Der Bundesrat als aussenpolitische Kontrollinstanz in den Anfangsjahren der Bundesrepublik Deutschland, in: Zeitschrift fur Parlamentsfragen 1992, p. 537556

Sousse, $\mathrm{M}$.

Le bicaméralisme: bilan et perspectives, in: Revue du Droit Public et de la Science Politique en France et à l' Etranger 1997, p. 13231350

Stevens, A.

The Government and politics of France, Longman London 1996

Strickrodt, G.

Das Bundesratsmandat, Gebunden und frei, in: Die Offentliche Verwaltung 1949, p. 321-324

Tardan, A.

Le rôle législatif du Sénat, in: Pouvoirs 1988 nr. 4, p. 97-113

Thompson, B.

Textbook on Constitutional \& Administrative Law, Blackstone London 1993

Tsebelis, G. and Money, J.

Bicameral Negotiations: The Navette System in France, in: British Journal of Political Science nr. 25, p. 101-129

Tyrie, A.

Reforming the House of Lords: A Conservative Approach, Conservative Policy Forum 1998

Verhey, L.F.M.

Parlementaire controle en scrutiny of administration: de betekenis van de Britse Select

Committees, in: P.P.T. Bovend'Eert e.a. (red), Grensverleggend staatsrecht, Kluwer Deventer 2001, p. 299322

Vermeer, A.R.

Alleen gespecialiseende Eerste Kamer heeft nut, in: Namens 1987, nr. 2, p. 93-97 
Videlin, J-C

La mission d'information parlementaire, in: Revue francaise de Droit Constitutionnel 1999. p. $699-723$

Vincent, $\mathrm{J}$.

The House of Lords, in: Parliamentary Affairs 1966, p. 475-485

Vis, J.J.

De ontbinding van het parlement, Serie monografieên Nederlands Parlementsrecht nr, 4, Wolters Noordhoff Groningen 1987

Vis, J.J.

Van ménagerie du Roi tot politiek college, De Eerste Kamer van 1849 tot 1887, in: A. Postma e.a. (red), Aan deze zijde van het Binnenhof, Sdu 's-Gravenhage 1990, p. 163-210

Visscher, G.

Parlementaire invloed op wetgeving. Inventarisatie en analyse van de invloed van de beide Kamers der Staten-Generaal op de wetgevende activiteiten van de kabinetten Marijnen tot en met Lubbers I, Sdu 's-Gravenhage 1994

Visscher, G.

De Tweede Kamer als eindredacteur, in: Regelmaat 2000, p. 95105

Vogel, F.

Der Vermittlungsausschuss, in: Vierzig Jahre Bundesrat, Nomos Verlagsgesellschaft, BadenBaden 1989, p. 213-225

Volkmar Heyen, E.

Der Bundesrat, Ein Rat der autonomen Kabinette?, in: Der Staat 1982, p. 191202

Vries, de, F.

De politieke verantwoordelijkheid en het functioneren van de Eerste Kamer, in: D.J. Elzinga, Ministeriele verantwoordelijkheid in Nederland, Zwolle 1994

Vries, de, F.

De staatsrechtelijke positie van de Eerste Kamer, Serie monografieén Nederlands

Parlementsrecht nr. 9, Kluwer Deventer 2000

Vries, de, F.

Het Nederlandse tweekamerstelsel: over de plaats en taak van de Eerste Kamer, in NJB 2001. p. 18271834

Warmelink, $\mathrm{H}$.

Parlement en begroting, Serie monografieên nr. 7, Wolters Noordhoff Groningen 1993

Wasowics, $\mathrm{M}$.

Les changements des attributions de la chambre haute des parlements en Europe aux XIXe et au début du XXe siècle, in: H.W. Blom e.a. (red), Tweekamerstelsels vroeger en nu, Handelingen van de Internationale Conferentie ter gelegenheid van het 175-jarig bestaan van de Eerste Kamer der Staten-Generaal, Den Haag 1992, p. 131-146

Weber, Y

La Crise du Bicaméralisme, in: Revue du Droit Public et de la Science Politique en France et à l'Etranger 1988, p. 571606

Welfare, D.

An Anachronism with Relevance: The Revival of the House of Lords in the 1980s and Its

Defence of Local Government, in: Parliamentary Affairs 1992, p. 205-219

Westerloo, van, G.

Het Fluisteren der senatoren, in: M, maandblad van NRC Handelsblad, juni 2001, p. 6-20 
Wilke, D. und Schulte, B. (red)

Der Bundesrat: die staatrechtliche Entwicklung des foderalen Verfassungsorgans, Wissenschaftliche Buchgesellschaft Darmstadt 1990

Witteveen, W.

Retour afzender: over de terugzendplicht, in: Nederlands Juristenblad 2000, p. 932-933

Wright, V.

The President and the Prime Minister: subordination, conflict, symbioses or reciprocal paratism?, in: M. Harrison e.a., De Gaulle to Mitterand, Presidential Power in France, London 1993, p. 101

Wyduckel, D.

Der Bundesrat als Zweite Kammer, Zur verfassungsrechtlichen Stellung des Bundesrats in Gesetzgebungsverfahren, in: Die Offentliche Verwaltung 1989, p. 181192

Ziller, G.

Zum Spannungsverhaltnis zwischen Bundestag und Bundesrat im Gesetzgebungsverfahren, in: D. Wiltke und B. Schulte (red), Der Bundesrat, Wissenschaftliche Buchgesellschaft Darmstadt 1990, p. 325-351

Ziller, G. und Oschatz, G-B.

Der Bundesrat, Droste Verlag Dosseldorf 1998 


\section{Curriculum vitae}

Erik Knippenberg werd geboren op 25 april 1952 te Geleen. Aldaar doorliep hij op het lyceum St. Michiel de middelbare school. Na eerst een jaar MO-Engels gevolgd te hebben aan de Katholieke Leergangen te Tilburg, heeft hij aan de Rijkspedagogische Academie te Maastricht het diploma Volledig Bevoegd Onderwijzer behaald.

In 1983 werd de overstap naar het recht gemaakt. Na afronding van de studie Nederlands Recht aan de Universiteit Maastricht (in die jaren nog Rijksuniversiteit Limburg) medio 1987, is hij als wetenschappelijk medewerker actief geworden ten behoeve van de werkgroep lokale politiek, een onderzoeksgroep die verbonden was aan de faculteit der rechtsgeleerdheid van de Universiteit Maastricht.

Bij die faculteit is Erik Knippenberg tot op heden werkzaam gebleven. Tussen $1990 \mathrm{en}$ 1999 als docent. Onderwijsinnovatic en dan met name het mede opzetten en implementeren van de reguliere programma-evaluatie stond tijdens die jaren naast onderwijsuitvoering centraal.

Begin 2000 werd de overstap gemaakt naar de capaciteitsgroep publiekrecht, waar hij sindsdien werkzaam is in de functie van universitair docent staats- en bestuursrecht. 
In dit boek wordt in rechtsvergelijkende zin ingegaan op de vraag in hoeverre de senaat, de tweede nationale parlementskamer, nog voldoende meerwaarde vertegenwoordigt ten opzichte van de eerste parlementskamer, om het bestaansrecht van de senaatskamer te rechtvaardigen. Daartoe wordt de wijze van functioneren van het Britse House of Lords, de Sénat Français, de Nederlandse Eerste Kamer en de Bondsduitse Bundesrat onderling vergeleken, waarbij onderscheid gemaakt wordt tussen de medewetgevende en bestuurscontrolerende taakstelling.

Daarnaast wordt rechtsvergelijkend onderzocht in hoeverre direct democratisch gelegitimeerde senaatskamers hun medewetgevende en bestuurscontrolerende taken effectiever uit kunnen oefenen dan senaatskamers die niet of slechts indirect democratisch gelegitimeerd zijn.

Erik Knippenberg (1952) is als universitair docent staats- en bestuursrecht verbonden aan de capaciteitsgroep Publiekrecht van de Universiteit Maastricht. 